UNIVERSIDADE DE SÃO PAULO - USP

ESCOLA DE ENGENHARIA DE SÃO CARLOS - EESC

EDILINCON MARTINS DE ALBUQUERQUE

Avaliação do tratamento combinado de lixiviado de aterro sanitário e esgoto sanitário em sistema de lodos ativados

VERSÃO DEFINITIVA

São Carlos

2012 
Página intencionalmente deixada em branco 
EDILINCON MARTINS DE ALBUQUERQUE

\title{
Avaliação do tratamento combinado de lixiviado de aterro sanitário e esgoto sanitário em sistema de lodos ativados
}

\begin{abstract}
Dissertação apresentada ao Programa de PósGraduação em Engenharia Hidráulica e Saneamento da Escola de Engenharia de São Carlos da Universidade de São Paulo para obtenção do título de Mestre em Ciências (Engenharia Hidráulica e Saneamento).
\end{abstract}

Orientador: Prof.Tit. Jurandyr Povinelli

São Carlos 
AUTORIZO A REPRODUÇÃO E DIVULGAÇÃO TOTAL OU PARCIAL DESTE TRABALHO, POR QUALQUER MEIO CONVENCIONAL OU ELETRÔNICO, PARA FINS DE ESTUDO E PESQUISA, DESDE QUE CITADA A FONTE.

Ficha catalográfica preparada pela Seção de Tratamento da Informação do Serviço de Biblioteca - EESC/USP

Albuquerque, Edilincon Martins de.
Avaliação do tratamento combinado de lixiviado de
aterro sanitário e esgoto sanitário em sistema de lodos
ativados. I Edilincon Martins de Albuquerqu ; orientador
Jurandyr Povinelii. São Carlos, 2012.
Dissertação - Mestrado (Programa de Pós-Graduação em
Engenharia Hidráulica e Saneamento)-- Escola de
Engenharia de São Carlos da Universidade de São Paulo,
2012.
1. Tratamento consorciado. 2. Air Stripping. 3. Reator
anaeróbio compartimentado (RAC). 4. Remoção de
nitrogênio. 5. Microbiologia de lodos ativados. I.
Título.




\section{FOLHA DE JULGAMENTO}

Candidato: Engenheiro EDILINCON MARTINS ALBUQUERQUE.

Título da dissertação: "Avaliação do tratamento combinado de lixiviado de aterro sanitário e esgoto sanitário em sistema de lodos ativos".

Data da defesa: 05/06/2012

\section{Comissão Julgadora:}

Prof. Titular Jurandyr Povinelli (Orientador)

(Escola de Engenharia de São Carlos/EESC)

\section{Drª . Eloisa Pozzi}

(Escola de Engenharia de São Carlos/EESC)

Prof. Dr. Marcus Cesar Avezum Alves de Castro

(Universidade Estadual Paulista "Júlio de Mesquita Filho"/UNESP-campus de Rio Claro)

Coordenador do Programa de Pós-Graduação em Engenharia Hidráulica e Saneamento:

Prof. Titular Edson Cezar Wendland

Suplente do Presidente da Comissão de Pós-Graduação em Exercício:

Prof. Titular Denis Vinicius Coury
Resultado:
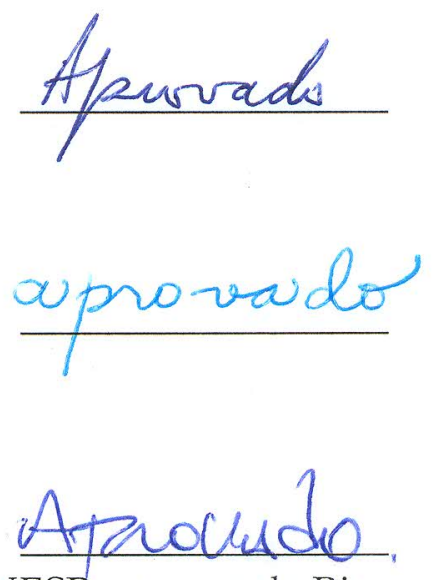
Dedico este trabalho aos meus pais Edimar Rufino de Albuquerque e Eliete Martins de Albuquerque por todo amor, ensinamento, esforço e dedicação nessa caminhada. Sem eles, jamais teria conseguido chegar até aqui. 


\section{AGRADECIMENTOS}

À Deus que tem derramado bênção sem medidas sobre a minha vida mostrando sempre o seu imenso amor.

Ao Prof. Jurandyr Povinelli por me acolher como seu orientando, pela orientação, pelos importantes conhecimentos e ensinamentos transmitidos durante a realização deste trabalho.

Aos meus pais Edimar Rufino de Albuquerque e Eliete Martins de Albuquerque, que, apesar da distância, sempre estiveram presentes e se esforçaram para me proporcionar todo o necessário à realização deste sonho.

Aos meus irmãos Keliane Martins de Albuquerque e Edifranklin Martins de Albuquerque, que, apesar da distância, sempre me deram apoio e torceram pelo meu sucesso.

Ao grande companheiro e amigo Alex Trindade pelo apoio, paciência e incentivo nessa importante etapa da minha vida.

À Eloiza Pozzi pela co-orientação, amizade, apoio, incentivo e colaboração durante o desenvolvimento deste trabalho.

Ao Prof. Luiz Daniel e à Profa. Maria Bernadete A. Varesche pelas valiosas sugestões e observações feitas no exame de qualificação e disponibilização dos equipamentos para realização dos exames de microscopia óptica.

Ao Prof. Marcos Cezar de Castro Avezum pelas valiosas sugestões e colaboração feitas na defesa do mestrado.

À Profa. Maria Olímpia por permitir o uso das instalações do Laboratório de Química Ambiental do IQSC e à técnica Diva por todo apoio durante as análises físico-químicas de uma das etapas desta pesquisa.

Aos técnicos do laboratório de saneamento: Júlio César Trofino, Paulo Fragiá como, Natália e Maria Aparecida P. Viudes (Cidinha), pelos ensinamentos e pela amizade. 
Aos professores, funcionários e colegas do Departamento de Hidráulica e Saneamento, em especial à Profa. Lyda Sabogal e à Profa. Márcia Zamariolli Damianovic e às funcionárias Sá, Rose e Pavi, pela ajuda preciosa e pela disponibilidade durante todo o mestrado.

Ao técnico Roberto C. Bérgamo, pela amizade e disponibilidade durante a construção e adaptação dos reatores utilizados nesta pesquisa.

Aos amigos Djalma Ferraz, Gabriela Palhuzi e Irene Souza, pela grande amizade, carinho e pelo auxilio valioso. Sempre dispostos a ajudar nos momentos em que precisei de apoio.

Às colegas Ludimila Turetta e Fernanda Ferraz, por terem me prestado todo o apoio e auxílio durante a fase inicial do meu trabalho de pesquisa.

Aos professores da UFAM, Annunziata Donadio Chateaubriand, Ellen Barbosa de Andrade e João Bosco Ladislau, que sempre me incentivaram e torceram por esta grande conquista.

À Prefeitura Municipal de São Carlos por permitir acesso ao aterro sanitário municipal.

À Faber Castell por permitir a coleta do inóculo e aos funcionários Maciel e Adriano pela disponibilidade e auxilio durante as coletas.

Ao CNPq pela concessão da bolsa de estudos (Processo No 147812/2010-0).

À Fundação de Amparo à Pesquisa de São Paulo (FAPESP) pelo auxilio financeiro (Processo N²010/51955-2).

À todos que contribuíram direta ou indiretamente para realização deste trabalho. 


\section{RESUMO}

ALBUQUERQUE, E. M. Avaliação do tratamento combinado de lixiviado de aterro sanitário e esgoto sanitário em sistema de lodos ativados. 2012. 276p. Dissertação (Mestrado) - Escola de Engenharia de São Carlos, Universidade de São Paulo, São Carlos-SP.

Um dos principais resíduos gerados nos aterros é o lixiviado, que possui elevada concentração de matéria orgânica biodegradável e refratária e de matéria inorgânica, como nitrogênio amoniacal e metais pesados. O tratamento combinado de lixiviado com esgoto sanitário tem sido utilizado em algumas estações de tratamento de esgoto (ETE) brasileiras. No entanto, o processo ainda sofre vários questionamentos e incertezas, especialmente sobre os efeitos da adição do lixiviado sobre o sistema de tratamento. Nesse contexto, o presente trabalho visou avaliar a eficiência do tratamento combinado de lixiviado/esgoto em sistema de lodos ativados, em diferentes condições. Na primeira etapa desta pesquisa, foram realizados experimentos de tratabilidade em escala de bancada (regime de batelada) utilizando as proporções volumétricas de $0 \%$ (controle), 0,2\%, $2 \%$ e $5 \%$ de lixiviado em diferentes condições experimentais. Dentre eles, o Experimento 2 (lixiviado pré-tratado por alcalinização e air stripping) se mostrou mais viável tecnicamente, alcançando eficiências de remoção da DBO, da DQO e do COD acima de 97, 82, 60\%, respectivamente, até a proporção de $2 \%$ de lixiviado pré-tratado. Na segunda etapa da pesquisa, foi avaliada a tratabilidade utilizando reatores em escala piloto (regime contínuo) tratando esgoto sanitário com 2\% (P1) e 0\% (P2-controle) de lixiviado pré-tratado, com relação microrganismo-alimento de 0,22 kgDBO/kgSSV.dia, tempo de detenção hidráulica de 24 horas e idade do lodo de 20 dias. Os resultados indicaram viabilidade do tratamento nas condições estudadas com $2 \%$ de lixiviado prétratado, cujas eficiências médias de remoção da DBO, da DQO, do COD foram de 93, 84 e 60\%, respectivamente. Esta pesquisa foi desenvolvida com apoio financeiro (Processo No 2010/51955-2) da Fundação de Amparo à Pesquisa de São Paulo (FAPESP).

Palavras-chave: Lixiviado de aterro sanitário. Tratamento consorciado. Air Stripping. Reator Anaeróbio Compartimentado (RAC). Microbiologia de lodos ativados. 


\begin{abstract}
ALBUQUERQUE, E. M. Evaluation of combined treatment of landfill leachate and sewage in activated sludge. 2012. 276p. Dissertation (Master) - Escola de Engenharia de São Carlos, Universidade de São Paulo, São Carlos-SP.
\end{abstract}

The leachate is one of the main wastes generated in landfills, it has a high concentration of biodegradable and refractory organic matter and inorganic matter, such as ammonia and heavy metals. The combined treatment of leachate with sewage has been used in various sewage treatment plants in Brazil. However, there are still many questions and uncertainties about the process, especially the effects of adding leachate on the treatment system. In this context, this study aimed at evaluating the efficiency of combined treatment of leachate/sewage in activated sludge under different conditions. In the first stage of this research, treatability experiments were carried out in a bench scale (SBR) using the volumetric proportions of $0 \%$ (control), $0.2 \%, 2 \%$ and $5 \%$ leachate under different experimental conditions. The Experiment 2 (leachate pretreated by alkalinization and air stripping) was more technically feasible, achieving efficiencies of removal of BOD, COD and DOC above 97, 82, 60\%, respectively, until the proportion of $2 \%$ pre-treated leachate. In the second stage of the research was evaluated the treatability using pilot-scale reactors (continuous flow) for sewage treatment with $2 \%$ (P1) and $0 \%$ (P2-control) leachate pretreated. The operational parameters adopted were foodmicroorganism rate of $0.22 \mathrm{kgDBO} / \mathrm{kgSSV} . \mathrm{d}$, hydraulic retention time of 24 hours and the sludge retention time of 20 days. The results indicated the viability of the combined treatment with $2 \%$ leached pretreated, whose average efficiency of removing BOD, COD, DOC were 93, 84 and 60\% respectively. This research was developed with financial support (case No. 2010/2-51955) of Fundação de Amparo à Pesquisa de São Paulo (FAPESP).

Keywords: Landfill leachate, Combined Treatment. Air Stripping. Anaerobic Baflled Reactor (ABR). Microbiology of activated sludge system. 


\section{LISTA DE FIGURAS}

Figura 3.1 - Sequências metabólicas e grupos envolvidos na digestão anaeróbia dos resíduos sólidos. Bouallagui et al. (2004) ...

Figura 3.2 - Esquema das unidades da etapa biológica do sistema de lodos ativados

Figura 3.3 - Reator biológico com recirculação de lodo (sistema de lodos ativados).

Figura 3.4 - Redução da DBO em função da idade do lodo e da relação A/M ou taxa de aplicação em sistema de lodos ativados. Acqua Engenharia (2010).

Figura 3.5 - Modelo estrutural de multi-camadas de flocos de lodo ativado. (Sheng et al.,2006)46

Figura 3.6 - Predomínio relativo de microrganismos versus idade do lodo e relação A/M (Jenkis et al., 2003.

Figura 4.1 - Fluxograma ilustrativo das etapas experimentais desenvolvidas durante a pesquisa60

Figura 4.2- Fotografia aérea do Aterro Sanitário de São Carlos (2009) adaptada de Vega Engenharia apud Ferreira (2010)

Figura 4.3 - Poço de acúmulo e sucção do esgoto sanitário da rede pública utilizado nos experimentos: (1) grade grossa; (2) cesto cilíndrico de chapa moeda.

Figura 4.4 - Bombas centrífugas autoescorvantes instaladas para sucção e recalque do esgoto sanitário para alimentação dos reatores.

Figura 4.5 - Reator Anaeróbio Compartimentado (RAC): (1) compartimento de entrada do esgoto; (2) interior das 3 primeiras câmaras; (3) interior da câmara com decantador de placas....64

Figura 4.6 - Corte longitudinal do Reator Anaeróbio Compartimentado (RAC). FONTE: (Povinelli, 1999).

Figura 4.7 - Serviço de manutenção e limpeza do Reator Anaeróbio compartimentado (RAC) e

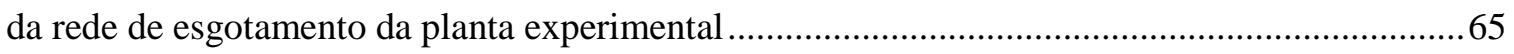

Figura 4.8 - Reservatório com agitador mecanizado para alcalinização do lixiviado. 66

Figura 4.9 - Torre de air stripping (1) torres de recolhimento (2 e 3), sendo a, b, c e d os pontos de amostragem. Fonte: Ferraz (2011).

Figura 4.10 - Instalação experimental do sistema de remoção e recolhimento de amônia: (1) torre de air stripping; (2) torres de absorção; (3) reservatório para armazenamento do lixiviado; (4) compressor de ar; (5) rotâmetro; (6): bomba dosadora.

Figura 4.11 - Reator aeróbio utilizado durante a adaptação dos microrganismos aeróbios esgoto sanitário ou efluente anaeróbio sob aeração constante. Adaptado de Turetta (2011) . .70 
Figura 4.12- Corte esquemático do reator de lodos ativados em escala de bancada. Fonte: Adaptado de Turetta (2011).

Figura 4.13- Perspectiva do reator de lodos ativados em escala de bancada

Figura 4.14 - (1) Célula de aeração com 4 reatores de 10 L cada e (2) unidades de sedimentação, utilizada nos experimentos em escala de bancada (Etapa 3)

Figura 4.15 - Planta e Perfil esquemático do reator de lodos ativados em escala piloto 76

Figura 4.16 - Reator de lodos ativados em escala piloto: (1) tanque de aeração; (2) decantador justaposto; e (3) câmara para coleta do efluente. .76

Figura 4.17 - Decantador secundário: (a) lodo sedimentado; (b) lodo suspendido pela aeração intermitente.

Figura 4.18 - Sistema de lodos ativados: (1) Tanque de equalização; (2) Tanques de mistura e alimentação; (3) Bombas de alimentação dos reatores; (4) Bombas de retorno do lodo; (5) Tanques de aeração; (6) Agitadores mecanizados; (7) Aeradores; (8) Decantadores secundários.79

Figura 4.19 - Microscópio ótico Olympus, modelo DP-72 utilizado nos exames de microscopia durante o experimento em escala piloto.

Figura 4.20 - pHmetro Qualxtron QX 1500 e Oxímetro Digimed DM-4P utilizados nas medições e $\mathrm{pH}$ e OD, respectivamente

Figura 4.21 - Aparelhagem utilizada nos testes de determinação da Taxa de Consumo de Oxigênio (TCO) e Coeficiente Global de Transferência de Oxigênio $\left(\mathrm{K}_{\mathrm{L}} \mathrm{a}\right)$ no experimento em escala piloto (Etapa 4). .84

Figura 5.1 - Lixiviado bruto (a), lixiviado alcalinizado a pH 11 (b), lixiviado alcalinizado a pH 12,5 (c).

Figura 5.2 - Microscopia de campo claro da microfauna do lodo (inóculo) do sistema de lodos ativados da indústria Faber Castell: aspecto geral do floco - 50x (a); metazoário rotífero semelhante à Philodinavus sp.- 100x (b); metazoários rizópodes semelhantes a Arcella sp. e Euglypha sp.- 200x (c); protozoário ciliado fixo semelhante à Vorticella sp. - 200x (d). .93

Figura 5.3 - Variação da DQO bruta nos experimentos de bancada (regime de batelada) nas proporções de 0 (controle); 0,2; 2 e 5\% de lixiviado. .95

Figura 5.4 - Variação da DQO solúvel nos experimentos de bancada (regime de batelada) nas proporções de 0 (controle); 0,2; 2 e 5\% de lixiviado. .96

Figura 5.5 - Eficiência média de remoção da DQO bruta nos experimentos de bancada para as proporções de 0 (controle); 0,2; 2 e 5\% de lixiviado em diferentes condições: E1-lixiviado mais esgoto; E2-lixiviado pré-tratado mais esgoto; E3-lixiviado pré-tratado mais efluente anaeróbio; E4-lixiviado mais efluente anaeróbio. 105

Figura 5.6 - Eficiência média de remoção da DQO solúvel nos experimentos de bancada para as proporções de 0 (controle); 0,2; 2 e 5\% de lixiviado em diferentes condições: E1-lixiviado mais 
esgoto; E2-lixiviado pré-tratado mais esgoto; E3-lixiviado pré-tratado mais efluente anaeróbio; E4-lixiviado mais efluente anaeróbio 106

Figura 5.7 - Eficiência média de remoção da DBO nos experimentos de bancada para as proporções de 0 (controle); 0,2; 2 e 5\% de lixiviado em diferentes condições: E1-lixiviado mais esgoto; E2-lixiviado pré-tratado mais esgoto; E3-lixiviado pré-tratado mais efluente anaeróbio; E4-lixiviado mais efluente anaeróbio 110

Figura 5.8 - Eficiência média de remoção do COD nos experimentos de bancada para as proporções de 0 (controle); 0,2; 2 e 5\% de lixiviado em diferentes condições: E1-lixiviado mais esgoto; E2-lixiviado pré-tratado mais esgoto; E3-lixiviado pré-tratado mais efluente anaeróbio; E4-lixiviado mais efluente anaeróbio.

Figura 5.9 - Variação do COD nos experimentos de bancada (regime intermitente) nas proporções de 0 (controle); 0,2; 2 e 5\% de lixiviado.

Figura 5.10 - Variação nas formas de Nitrogênio no Experimento 1 de bancada nas proporções de 0 (controle); 0,2; 2 e 5\% de lixiviado. 122

Figura 5.11 - Variação nas formas de Nitrogênio no Experimento 2 de bancada nas proporções de 0 (controle); 0,2; 2 e $5 \%$ de lixiviado. 123

Figura 5.12 - Variação nas formas de Nitrogênio no Experimento 3 de bancada nas proporções de 0 (controle); 0,2; 2 e 5\% de lixiviado.

Figura 5.13 - Variação nas formas de Nitrogênio no Experimento 4 de bancada nas proporções de 0 (controle); 0,2; 2 e $5 \%$ de lixiviado. 125

Figura 5.14 - Variação da concentração de SST no tanque de aeração nos experimentos de bancada nas proporções de 0 (controle); 0,2; 2 e 5\% de lixiviado.

Figura 5.15 - Variação da concentração de SSV no tanque de aeração nos experimentos de bancada nas proporções de 0 (controle); 0,2; 2 e 5\% de lixiviado. 128

Figura 5.16 - Variação dos valores de IVL no tanque de aeração nos experimentos de bancada nas proporções de 0 (controle); 0,2; 2 e 5\% de lixiviado.

Figura 5.17 - Concentração de metais $(\mathrm{Pb}, \mathrm{Ni}, \mathrm{Cr})$ no lodo dos experimentos de bancada nas proporções de 0 (controle); 0,2; 2 e $5 \%$ de lixiviado.

Figura 5.18 - Concentração de metais $(\mathrm{Zn}, \mathrm{Mn}, \mathrm{Cu})$ no lodo dos experimentos de bancada nas proporções de 0 (controle); 0,2; 2 e 5\% de lixiviado. 134

Figura 5.19 - Concentração de metais (Fe) no lodo dos experimentos de bancada nas proporções de 0 (controle); 0,2; 2 e 5\% de lixiviado. 135

Figura 5.20 - Concentração de metais (Cd) no lodo dos experimentos de bancada nas proporções de 0 (controle); 0,2; 2 e 5\% de lixiviado. 136

Figura 5.21 - Caracterização da composição da microfauna em R1E1 (0\% - Experimento 1) do sistema de lodos ativados em escala de bancada. (a) Estrutura física do floco. (b)Metazoário 
rotífero semelhante à Epiphanes sp.. Ciliados fixos semelhantes à: (c)Epistylis sp. e (d)Opercularia sp.. Aumentos originais 50x, (a); 100x, (b); 300x, (c) e 100x, (d).

Figura 5.22 - Caracterização da composição da microfauna em R2E1 (0,2\% - Experimento 1) do sistema de lodos ativados em escala de bancada. Ciliados fixos semelhantes à: (a)Podophrya sp. e (b)Vorticella sp.; (c) Rizópodes semelhantes a Euglypha sp.. (d)Estrutura física do floco. Aumentos originais 100x, (a); 200x, (b); 75x, (c) e 50x, (d). 140

Figura 5.23 - Caracterização da composição da microfauna em R3E1 (2\% - Experimento 1) do sistema de lodos ativados em escala de bancada. Colônia de ciliados fixos semelhantes à: (a) e (b)Vorticella sp.; (a) Metazoário rotífero semelhante a Epiphanes sp.; (c) Estrutura física do floco; (d) Bactérias filamentosas. Aumentos originais 100x, (a) e (b); 50x, (c) e 75x, (d)..........141

Figura 5.24 - Caracterização da composição da microfauna em R4E1 (5\% - Experimento 1) do sistema de lodos ativados em escala de bancada. Rizópodes semelhantes à: (a) Euglypha sp. e (b) Arcella sp.; (c) Estrutura física do floco; (d) Bactérias filamentosas. Aumentos originais 100x, (a) e (b); 50x, (c) e 75x, (d). 142

Figura 5.25 - Caracterização da composição da microfauna em R1E2 (0\% - Experimento 2) do sistema de lodos ativados em escala de bancada. Colônias de ciliados fixos semelhantes à: (a) Epistylis sp. e (b) Vorticella sp.; (c) Bactérias coloniais Zoogloea Ramigera; (d) Rizópodes semelhantes a Arcella sp. e rotífero. Aumentos originais 100x, (a); 200x, (b); 100x, (c) e (d)...145

Figura 5.26 - Caracterização da composição da microfauna em R2E2 (0,2\% - Experimento 2) do sistema de lodos ativados em escala de bancada. Colônias de ciliados fixos semelhantes à: (a) Vorticella sp. e (b) Epistylis sp.; (c) Rizópodes semelhantes a Arcella sp. e rotífero; (d) Estrutura geral do floco. Aumentos originais 200x, (a); 100x, (b) e (c); 50x, (d). 146

Figura 5.27 - Caracterização da composição da microfauna em R2E2 (0,2\% - Experimento 2) do sistema de lodos ativados em escala de bancada. Colônias de ciliados fixos semelhantes à: (a) Vorticella sp. e (b) Opercularia sp.; (c) Rizópodes semelhantes a Arcella sp. e bactérias coloniais semelhantes à Zoogloea ramigera; (d) Estrutura geral do floco. Aumentos originais 200x, (a); 100x, (b) e (c); 50x, (d).

Figura 5.29 - Caracterização da composição da microfauna em R1E3 (controle - Experimento 3) do sistema de lodos ativados em escala de bancada. Colônias de ciliados fixos semelhantes à: (a) Epistylis sp.; (b) Rizópodes semelhantes à Euglypha sp.; (c) Bactérias filamentosas (d) Estrutura geral do floco. Aumentos originais 100x, (a); 200x, (b) e (c); 50x, (d). 151

Figura 5.30 - Caracterização da composição da microfauna em R2E3 (controle - Experimento 3) do sistema de lodos ativados em escala de bancada. (a) Bactérias filamentosas semelhantes à Beggiatoa sp.; (b) Colônias de ciliados fixos semelhantes à Epistylis sp.; (c) Rizópodes semelhantes à Arcella sp.; (d) Estrutura geral do floco. Aumentos originais 100x, (a) e (b); 200x, (c); 50x, (d).

Figura 5.31 - Caracterização da composição da microfauna em R3E3 (controle - Experimento 3) do sistema de lodos ativados em escala de bancada. (a) Colônias de ciliados fixos semelhantes à Epistylis sp. e (b) à Opercularia sp.; (c) Rizópodes semelhantes à Arcella sp. e Euglypha sp.; (d) Estrutura geral do floco. Aumentos originais 200x, (a), (b) e (c); 50x, (d). 153 
Figura 5.32 - Caracterização da composição da microfauna em R3E3 (controle - Experimento 3) do sistema de lodos ativados em escala de bancada. (a) Bactérias filamentosas; (b) Colônias de ciliados fixos semelhantes à Epistylis sp.; (c) Rizópodes semelhantes à Euglypha sp.; (d) Estrutura geral do floco. Aumentos originais 200x, (a); 100x, (b); 200x, (c); 50x, (d). 154

Figura 5.33 - Caracterização da composição da microfauna em R1E4 (controle - Experimento 4) do sistema de lodos ativados em escala de bancada. (a) e (b) Colônias de ciliados fixos semelhantes à Epistylis sp. e Vorticella sp.; (c) Rizópodes semelhantes à Euglypha sp. e à Arcella sp.; (d) Estrutura geral do floco. Aumentos originais 100x, (a); 200x, (b) e (c); 50x, (d). 157

Figura 5.34 - Caracterização da composição da microfauna em R2E4 (controle - Experimento 4) do sistema de lodos ativados em escala de bancada. (a) e (b) Colônias de ciliados fixos semelhantes à Vorticella sp.; (a), (b) e (c) Rizópodes semelhantes à Arcella sp. e à Euglypha sp.; (d) Estrutura geral do floco. Aumentos originais 100x, (a); 200x, (b) e (c); 50x, (d). 158

Figura 5.35 - Caracterização da composição da microfauna em R3E4 (controle - Experimento 4) do sistema de lodos ativados em escala de bancada. (a) Colônias de ciliados fixos semelhantes à Vorticella sp.; Rizópodes semelhantes à: (a), (b) Arcella sp. e (c) Euglypha sp.; (d) Estrutura geral do floco. Aumentos originais 100x, (a), (b) e (c); 50x, (d).

Figura 5.36 - Caracterização da composição da microfauna em R4E4 (controle - Experimento 4) do sistema de lodos ativados em escala de bancada. (a) e (b) Colônias de ciliados fixos semelhantes à Opercularia sp.; (c) Rizópodes rotíferos semelhantes à Epiphanes sp. ; (d) Estrutura geral do floco. Aumentos originais 100x, (a), (b) e (c); 50x, (d) .................................160

Figura 5.37 - Comportamento dos valores da DQO bruta no afluente e efluente e eficiência média de remoção no reator tratando esgoto sanitário com 165

Figura 5.38 - Comportamento dos valores da DQO bruta no afluente e efluente e eficiência média de remoção no reator tratando esgoto sanitário com $0 \%$ de lixiviado pré-tratado (P2controle) do experimento em escala piloto 166

Figura 5.39 - Gráfico Boxplot das eficiências de remoção da DQO bruta e medidas estatísticas dos reatores de lodos ativados tratando esgoto sanitário com 2\% (P1) e 0\% (P2-controle) de lixiviado pré-tratado do experimento em escala piloto.

Figura 5.40 - Comportamento dos valores da DQO solúvel no afluente e efluente e eficiências de remoção no reator tratando esgoto sanitário com 2\% de lixiviado pré-tratado (P1) do experimento em escala piloto. 169

Figura 5.41 - Comportamento dos valores da DQO solúvel no afluente e efluente e eficiências de remoção no reator tratando esgoto sanitário com $0 \%$ de lixiviado (P2-controle) do experimento em escala piloto. 170

Figura 5.42 - Gráfico Boxplot das eficiências de remoção da DQO solúvel e medidas estatísticas dos reatores de lodos ativados tratando esgoto sanitário e 2\% (P1) e 0\% (P2-controle) de lixiviado pré-tratado do experimento em escala piloto. 171 
Figura 5.43 - Comportamento dos valores da DBO no afluente e efluente e eficiências de remoção no reator tratando esgoto sanitário com $2 \%$ de lixiviado pré-tratado (P1) do experimento em escala piloto.

Figura 5.44 - Comportamento dos valores da DBO no afluente e efluente e eficiências de remoção no reator tratando esgoto sanitário com $0 \%$ de lixiviado (P2-controle) do experimento em escala piloto.

Figura 5.45 - Gráfico Boxplot das eficiências de remoção da DBO e medidas estatísticas dos reatores de lodos ativados tratando esgoto sanitário com 2\% (P1) e 0\% (P2-controle) de lixiviado pré-tratado do experimento em escala piloto. 174

Figura 5.46 - Comportamento dos valores do COD no afluente e efluente e eficiências de remoção no reator tratando esgoto sanitário com 2\% de lixiviado pré-tratado (P1) do experimento em escala piloto. 176

Figura 5.47 - Comportamento dos valores do COD no afluente e efluente e eficiências de remoção no reator tratando esgoto sanitário com $0 \%$ de lixiviado (P2-controle) do experimento em escala piloto. 176

Figura 5.48 - Gráfico Boxplot das eficiências de remoção do COD e medidas estatísticas dos reatores de lodos ativados tratando esgoto sanitário e 2\% (P1) e 0\% (P2-controle) de lixiviado pré-tratado do experimento em escala piloto. 178

Figura 5.50 - Comportamento da eficiência de remoção de NAT nos reatores tratando esgoto sanitário com 2\% (P1) e 0\% (P2-controle) de lixiviado pré-tratado do experimento em escala piloto 179

Figura 5.50 - Comportamento da eficiência de remoção de NTK nos reatores tratando esgoto com 2\% (P1) e 0\% (P2-controle) de lixiviado pré-tratado do experimento em escala piloto ......179

Figura 5.51 - Valores das concentrações afluente e efluente de $\mathrm{NAT}$ e efluente de $\mathrm{NO}_{3}{ }^{-}$no reator tratando esgoto sanitário com 2\% (P1) de lixiviado pré-tratado do experimento em escala piloto

Figura 5.52 - Valores das concentrações afluente e efluente de NAT e efluente de $\mathrm{NO}_{3}{ }^{-}$no reator tratando esgoto sanitário com $0 \%$ (P2-controle) de lixiviado pré-tratado do experimento em escala piloto 181

Figura 5.53 - Reator de lodos ativados, destacando a flotação de aglomerados de lodo na superfície do decantador na fase de adaptação durante o experimento em escala piloto. 183

Figura 5.54 - Variação da eficiência de remoção de N-total nos reatores tratando esgoto sanitário com 2\% (P1) e $0 \%$ (P2-controle) de lixiviado pré-tratado no experimento em escala piloto. 184

Figura 5.55 - Variação da concentração de SST no tanque de aeração dos reatores tratando esgoto sanitário com 2\% (P1) e 0\% (P2-controle) de lixiviado pré-tratado no experimento em escala piloto. 186 
Figura 5.56 - Variação da relação SSV/SST no tanque de aeração dos reatores tratando esgoto sanitário com 2\% (P1) e 0\% (P2-controle) de lixiviado pré-tratado no experimento em escala piloto

Figura 5.58 - Testes de sedimentabilidade com amostras do tanque de aeração dos reatores tratando esgoto sanitário com 2\% (P1) e 0\% (P2-controle) de lixiviado pré-tratado no experimento em escala piloto 188

Figura 5.59 - Gráfico Boxplot dos valores de IVL e medidas estatísticas dos reatores de lodos ativados tratando esgoto sanitário e $2 \%$ (P1) e $0 \%$ (P2-controle) de lixiviado pré-tratado do experimento em escala piloto

Figura 5.60 - Variação da relação A/M em função da DQO solúvel e da DBO nos reatores tratando esgoto sanitário com 2\% (P1) e 0\%(P2-controle) de lixiviado pré-tratado do experimento em escala piloto. 190

Figura 5.61 - Comportamento das concentrações de SST no afluente e efluente e eficiências de remoção no reator tratando esgoto sanitário com 2\% (P1) de lixiviado pré-tratado do experimento em escala piloto. 191

Figura 5.62 - Comportamento das concentrações de SST no afluente e efluente e eficiências de remoção no reator tratando esgoto sanitário com $0 \%$ (P2-controle) de lixiviado pré-tratado do experimento em escala piloto. 192

Figura 5.63 - Comportamento das concentrações de ST no afluente e efluente e eficiências de remoção no reator tratando esgoto sanitário com 2\% (P1) de lixiviado pré-tratado do experimento em escala piloto

Figura 5.64 - Comportamento das concentrações de ST no afluente e efluente e eficiências de remoção no reator no reator tratando esgoto sanitário com 0\% (P2-controle) de lixiviado prétratado do experimento em escala piloto

Figura 5.65 - Concentração de metais (Zn, Mn, Cu), em termos da massa seca de lodo (ST) dos reatores tratando esgoto sanitário com 2\% (P1) e 0\% (P2) de lixiviado pré-tratado do experimento em escala piloto..... 196

Figura 5.66 - Concentração de metais ( $\mathrm{Pb}, \mathrm{Ni}, \mathrm{Cd}, \mathrm{Cr})$ em termos da massa seca de lodo (ST) dos reatores tratando esgoto sanitário com 2\% (P1) e 0\% (P2-controle) de lixiviado pré-tratado do experimento em escala piloto

Figura 5.67 - Concentração de ferro (Fe) em termos da massa seca de lodo (ST) dos reatores tratando esgoto sanitário com $2 \%$ (P1) e $0 \%$ (P2-controle) de lixiviado pré-tratado do experimento em escala piloto. 198

Figura 5.68 - Variação dos valores da Taxa Específica de Consumo de Oxigênio (TCO) da biomassa dos reatores tratando esgoto sanitário com 2\% (P1) e 0\% (P2-controle) de lixiviado prétratado do experimento em escala piloto 199

Figura 5.69 - Variação dos valores Coeficiente Global de Transferência de Oxigênio $\left(K_{L} a\right)$ a $20^{\circ}$ C, na massa líquida dos reatores tratando esgoto sanitário com 2\% (P1) e 0\% (P2-controle) de lixiviado pré-tratado do experimento em escala piloto. 201 
Figura 5.70 - Imagens panorâmicas da estrutura geral do floco de lodos ativados do reator com 2\% de lixiviado pré-tratado (P1) ao longo da operação. Aumento original 100x.

Figura 5.71 - Caracterização da composição da microfauna no reator com $2 \%$ de lixiviado prétratado (P1) do sistema de lodos ativados em escala piloto. (a) Protozoários livre rastejantes semelhantes a Aspidisca sp. e Euplotes sp.; (b) Protozoário livre rastejante semelhante a Euplotes sp.; (c) Protozoários rizópodes semelhantes a Arcella sp e Euglypha sp. Aumentos originais 400x, (b); 200x (a), (c) e (d). 206

Figura 5.72 - Caracterização da composição da microfauna em com 2\% de lixiviado pré-tratado (P1) do sistema de lodos ativados em escala piloto. (a) Protozoários livres semelhantes a Aspidisca sp. e Litonotus sp.; (b) Protozoário livre semelhante a Paramecium sp.; Metazoários nematoides semelhantes a (c) Aelossoma sp e (d) Tardigrades sp. Aumentos originais 200x, (a) e (d); 400x (b); 100x, (c). 207

Figura 5.73 - Imagens panorâmicas da estrutura geral do floco de lodos ativados do reator com 0\% (P2-controle) de lixiviado ao longo da operação. Aumento original 100x. 209

Figura 5.74 - Caracterização da composição da microfauna do reator com 0\% (P2-controle) de lixiviado do sistema de lodos ativados em escala piloto. Protozoários ciliados fixos semelhantes à (a) Vorticella sp. e (b) Epistylis sp.; (c) Metazoários rotíferos; (d) Protozoário livre rastejante semelhante a Aspidisca sp.. Aumentos originais 200x, (a) e (b); 400x (c); 100x (d) 210

Figura 5.75 - Caracterização da composição da microfauna do reator com 0\% (P2-controle) de lixiviado do sistema de lodos ativados em escala piloto. Protozoários rizópodes semelhantes à (a) Euglypha sp. e (b) Arcella sp.; (c) Metazoários nematoides semelhantes à (c) Tadigrades sp. e Aelossoma sp.. Aumentos originais 200x, (a), (b), (c) e (d).

Figura 5.77 - Caracterização da composição da microfauna do reator com 0\% (P2-controle) de lixiviado do sistema de lodos ativados em escala piloto. Estrutura do floco com destaque nos microrganismos filamentosos. Aumentos originais 400x, (a); 100x, (b), (c) e (d).

Figura 5.78 - Concentrações de COD em termos da massa seca de lodo dos reatores tratando esgoto sanitário com 2\% (P1) e 0\% (P2-controle) de lixiviado pré-tratado do experimento em escala piloto.

Figura 5.79 - Remoção do nitrogênio amoniacal total pela torre de air stripping nos experimentos EX-1, EX-2 e EX-3, no pré-tratamento do lixiviado 216

Figura 5.80 - Eficiência de recolhimento da amônia no experimento EX-1, com vazão de 90 L/h de lixiviado alcalinizado (pH de 11,6) e 3500 L/h de ar, em solução de água à temperatura ambiente.

Figura 5.81- Eficiência de recolhimento da amônia no experimento EX-2, com vazão de 90 L/h de lixiviado alcalinizado (pH de 11,3) e $6400 \mathrm{~L} / \mathrm{h}$ de ar, em solução de água à temperatura ambiente.

Figura 5.82 - Eficiência de recolhimento da amônia no experimento EX-3, com vazão de $90 \mathrm{~L} / \mathrm{h}$ de lixiviado alcalinizado (pH de 11) e $3500 \mathrm{~L} / \mathrm{h}$ de ar, em solução de água e ácido sulfúrico 0,4 $\mathrm{mol} / \mathrm{L}$ à temperatura ambiente. 


\section{LISTA DE TABELAS}

Tabela 3.1 - Características típicas do lixiviado dos aterros brasileiros .27

Tabela 3.2 - Principais características dos sistemas de lodos ativados utilizados para o tratamento de esgotos domésticos.

Tabela 3.3 - Microrganismos indicadores das condições de depuração em condições aeróbias

Tabela 3.4 - Microrganismos protozoários indicadores das condições de depuração em sistema de lodos ativados .54

Tabela 3.5 - Microrganismos micrometazoários indicadores das condições de depuração em sistema de lodos ativados. .56

Tabela 4.1 - Experimentos relativos à operação do reator de lodos ativados em escala de bancada (Etapa 3).

Tabela 4.2 - Parâmetros monitorados, frequência dos exames e análises realizadas nos experimentos em escala de bancada (Etapa 3)

Tabela 4.3 - Parâmetros monitorados, frequência dos exames e análises realizadas nos experimentos em escala piloto (Etapa 4)

Tabela 5.1 - Características físico-químicas do esgoto sanitário e efluente anaeróbio proveniente do Reator Anaeróbio Compartimentado (RAC) utilizados nos experimentos.

Tabela 5.2 - Características físico-químicas do lixiviado bruto, alcalinizado e prétratado por air stripping utilizados nos experimentos de bancada. .88

Tabela 5.3 - Características físico-químicas do lixiviado bruto, alcalinizado e prétratado utilizados no experimento em escala piloto.

Tabela 5.4 - Caracterização microbiana e frequência da presença de protozoários e metazoários nos inóculos utilizados nos experimentos.

Tabela 5.5 - Concentração de sólidos nos inóculos utilizados nos experimentos........94

Tabela 5.6 - Eficiência média do sistema de lodos ativados em escala de bancada, tratando esgoto com 0 a 5\% de lixiviado (E1), na remoção da DQO bruta..... 
Tabela 5.7 - Eficiência média do sistema de lodos ativados em escala de bancada, tratando esgoto com 0 a 5\% de lixiviado (E1), na remoção da DQO solúvel.

Tabela 5.8 - Eficiência média do sistema de lodos ativados em escala de bancada, tratando esgoto com 0 a 5\% de lixiviado pré-tratado (E2), na remoção da DQO bruta 98

Tabela 5.9 - Eficiência média do sistema de lodos ativados em escala de bancada, tratando esgoto com 0 a 5\% de lixiviado pré-tratado (E2), na remoção da DQO solúvel

Tabela 5.10 - Eficiência média do sistema de lodos ativados em escala de bancada, tratando efluente anaeróbio com 0 a 5\% de lixiviado pré-tratado (E3), na remoção da DQO solúvel 100

Tabela 5.11 - Eficiência média do sistema de lodos ativados em escala de bancada, tratando efluente anaeróbio com 0 a 5\% de lixiviado (E4), na remoção da DQO bruta

Tabela 5.12 - Eficiência média do sistema de lodos ativados em escala de bancada, tratando efluente anaeróbio com 0 a 5\% de lixiviado (E4), na remoção da DQO solúvel

Tabela 5.13 - Eficiência média do sistema de lodos ativados em escala de bancada, tratando esgoto com 0 a 5\% de lixiviado (E1), na remoção da DBO. 107

Tabela 5.14 - Eficiência média do sistema de lodos ativados em escala de bancada, tratando esgoto com 0 a 5\% de lixiviado pré-tratado (E2), na remoção da DBO..... 108

Tabela 5.15 - Eficiência média do sistema de lodos ativados em escala de bancada, tratando efluente anaeróbio com 0 a 5\% de lixiviado pré-tratado (E2), na remoção da DBO. 109

Tabela 5.16 - Eficiência média do sistema de lodos ativados em escala de bancada, tratando efluente anaeróbio com 0 a 5\% de lixiviado (E4), na remoção da DBO 109

Tabela 5.17 - Eficiência média do sistema de lodos ativados em escala de bancada, tratando esgoto com 0 a 5\% de lixiviado (E1), na remoção da COD

Tabela 5.18 - Eficiência média do sistema de lodos ativados em escala de bancada, tratando esgoto com 0 a 5\% de lixiviado pré-tratado (E2), na remoção da COD........112

Tabela 5.19 - Eficiência média do sistema de lodos ativados em escala de bancada, efluente anaeróbio com 0 a 5\% de lixiviado pré-tratado (E3), na remoção da COD. .113

Tabela 5.20 - Eficiência média do sistema de lodos ativados em escala de bancada, efluente anaeróbio com 0 a 5\% de lixiviado (E4), na remoção da COD. 
Tabela 5.21 - Eficiência média do sistema de lodos ativados em escala de bancada, tratando esgoto com 0 a 5\% de lixiviado (E1), na remoção de nitrogênio.

Tabela 5.22 - Eficiência média do sistema de lodos ativados em escala de bancada, tratando esgoto com 0 a 5\% de lixiviado pré-tratado (E2), na remoção de nitrogênio.

Tabela 5.23 - Eficiência média do sistema de lodos ativados em escala de bancada, tratando efluente anaeróbio com 0 a 5\% de lixiviado pré-tratado (E3), na remoção de nitrogênio

Tabela 5.24 - Eficiência média do sistema de lodos ativados em escala de bancada, tratando efluente anaeróbio com 0 a 5\% de lixiviado (E4), na remoção de nitrogênio

Tabela 5.25 - Frequência dos microrganismos observados no sistema de lodos ativados em escala de bancada ao longo do Experimento 1. 138

Tabela 5.26 - Frequência dos microrganismos observados no sistema de lodos ativados em escala de bancada ao longo do Experimento 2

Tabela 5.27 - Frequência dos microrganismos observados no sistema de lodos ativados em escala de bancada ao longo do Experimento 3 150

Tabela 5.28 - Frequência dos microrganismos observados no sistema de lodos ativados em escala de bancada ao longo do Experimento 4 156

Tabela 5.29 - Condições operacionais e resultados do experimento com reatores de lodos ativados em escala piloto tratando esgoto com $2 \%$ (P1) e $0 \%$ (P2-controle) de lixiviado pré-tratado. 164

Tabela 5.30 - Frequência de microrganismos observados no reator com 2\% de lixiviado pré-tratado (P1) do experimento em escala piloto. 203

Tabela 5.31 - Frequência de microrganismos observados no reator com $0 \%$ de lixiviado (P2-controle) do experimento em escala piloto. 208

Tabela 5.33 - Condições operacionais e resultados das torres de remoção e de recolhimento de amônia avaliadas nos experimentos. 


\section{LISTA DE ABREVIATURAS E SÍMBOLOS}

ABNT Associação Brasileira de Normas Técnicas

ABRELPE Associação Brasileira de Empresas de Limpeza Pública e Resíduos Especiais

A/M Alimento-microrganismo

AI Alcalinidade Intermediária

AT Alcalinidade total

CONAMA Conselho Nacional de Meio Ambiente

COD Carbono Orgânico Dissolvido

CT Coliformes Termotolerantes

C.V. $\quad$ Coeficiente de variação

DBO DBO Demanda bioquímica de oxigênio

DQO DQO Demanda química de oxigênio

EESC Escola de Engenharia de São Carlos

EPS Substâncias poliméricas extracelulares

ETE Estação de Tratamento de Esgoto

ES Esgoto Sanitário

IBGE Instituto Brasileiro de Geografia e Estatística

IQSC Instituto de Química de São Carlos

IVL Índice Volumétrico do lodo

LIX Lixiviado

LPB Laboratório de Processos biológicos

LATAR Laboratório de Tratamento Avançado e Reúso de Água

MG Minas Gerais

N Nitrogênio

NAT Nitrogênio Amoniacal total

ND Não detectável 


\begin{tabular}{|c|c|}
\hline $\mathrm{NO}_{3}$ & Nitrato \\
\hline $\mathrm{NO}_{2}^{-}$ & Nitrito \\
\hline NTK & Nitrogênio total Kjeldahl \\
\hline OD & Oxigênio Dissolvido \\
\hline $\mathrm{P}$ & Fósforo \\
\hline PROSAB & Programa de pesquisas de Saneamento Básico \\
\hline RAC & Reator Anaeróbio Compartimentado \\
\hline RJ & Rio de Janeiro \\
\hline RS & Rio Grande do Sul \\
\hline RSU & Resíduos Sólidos Urbanos \\
\hline SBR & Sequential Batch Reactor \\
\hline SHS & Departamento de Hidráulica e Saneamento \\
\hline SP & São Paulo \\
\hline ST & Sólidos Totais \\
\hline STF & Sólidos totais fixos \\
\hline STV & Sólidos totais voláteis \\
\hline SST & Sólidos suspensos totais \\
\hline SSF & Sólidos suspensos fixos \\
\hline SSV & Sólidos suspensos voláteis \\
\hline $\mathrm{TDH}$ & Tempo de detenção hidráulica \\
\hline TCO & Taxa de Consumo de Oxigênio \\
\hline UASB & Upflow Anaerobic Sludge Blanket \\
\hline USP & Universidade de São Paulo \\
\hline USEPA & Environmental Protection Agency \\
\hline
\end{tabular}




\section{SUMÁRIO}

1. INTRODUÇÃO ................................................................................................................... 23

2. OBJETIVOS................................................................................................................... 25

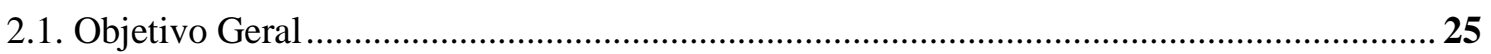

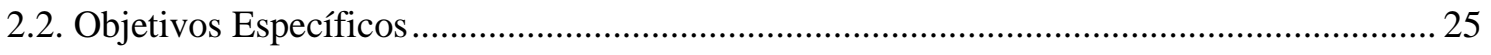

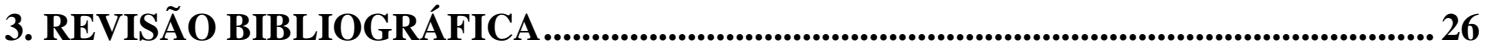

3.1. Geração e disposição de resíduos sólidos em aterros sanitários........................................... 26

3.2. Conceituação, geração e caracterização de lixiviado de aterro sanitário ............................... 28

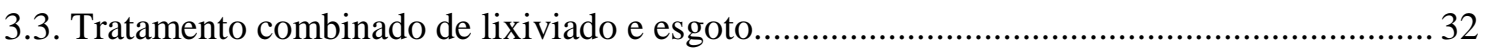

3.4. Pré-tratamento do lixiviado por air stripping visando à remoção e recolhimento de amônia38

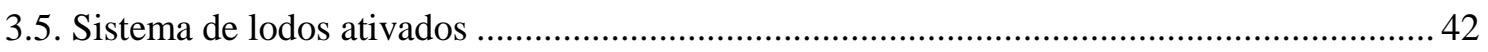

3.5.1. Fatores que interferem no processo de lodos ativados ....................................... 44

3.5.2. Variáveis envolvidas no controle operacional do processo de lodos ativados ..... 48

3.5.3. Microbiologia do processo de lodos ativados......................................................... 51

3.5.4. Sistema de lodos ativados como pós-tratamento de efluentes............................... 58

3.5.5. Remoção de nitrogênio em sistema de lodos ativados .......................................... 60

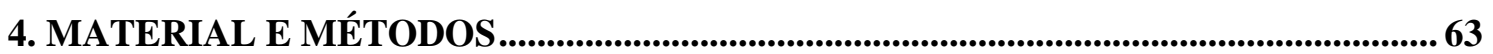

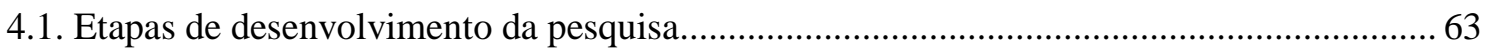

4.2. Etapa 1: Coleta e caracterização das águas residuárias e dos inóculos .................................. 64

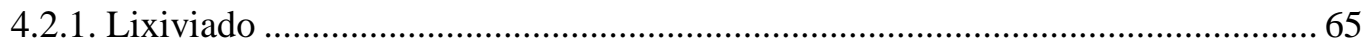

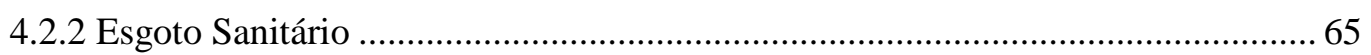

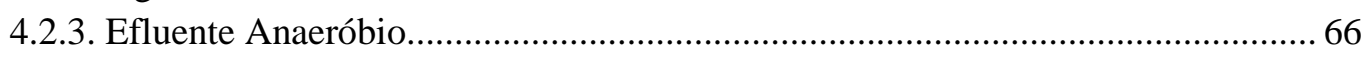

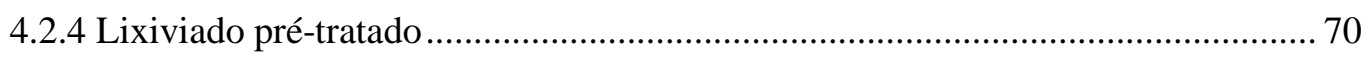

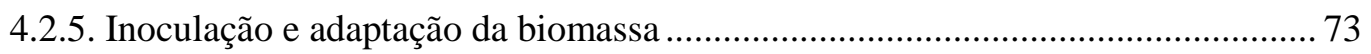

4.3. Etapa 3 - Experimentos de tratabilidade em escala de bancada (operação em batelada) .... 74

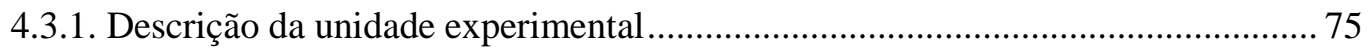

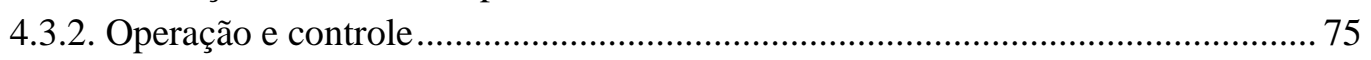

4.4. Etapa 4 - Experimentos de tratabilidade em escala piloto (operação em regime contínuo) 79

4.4.1. Descrição da unidade experimental......................................................................... 79

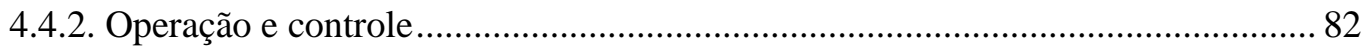

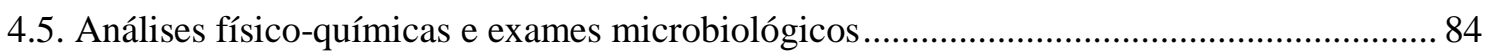

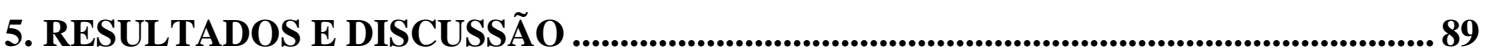

5.1. Caraterização das águas residuária utilizadas nos experimentos .......................................... 89

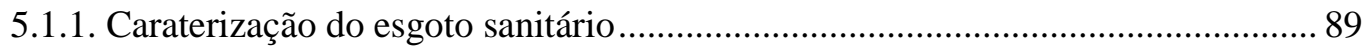

5.1.2. Caraterização dos lixiviados utilizados nos experimentos .................................... 91

5.2. Caraterísticas dos inóculos utilizados nos experimentos .................................................... 95 
5.3. Resultados das análises físico-químicas dos experimentos de tratabilidade em escala de

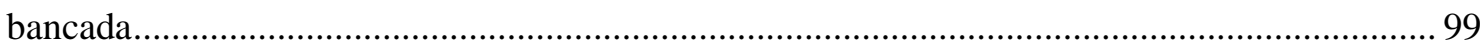

5.3.1. Considerações iniciais sobre os experimentos......................................................... 99

5.3.2. Demanda Química de Oxigênio-DQO ........................................................... 100

5.3.3. Demanda Bioquímica de Oxigênio-DBO............................................................ 107

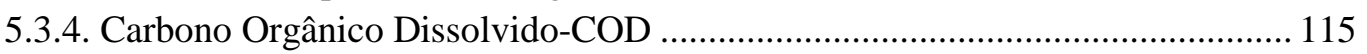

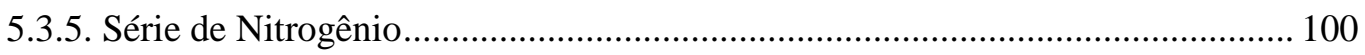

5.3.6. Concentração de sólidos nos reatores............................................................ 125

5.4. Resultados do monitoramento microbiológico dos experimentos em escala de bancada .. 141

5.4.1. Resultados do monitoramento microbiológico por microscopia óptica ............... 141

5.5. Resultados das análises físico-químicas do experimento de tratabilidade em escala piloto167

5.5.1. Considerações iniciais sobre o experimento......................................................... 167

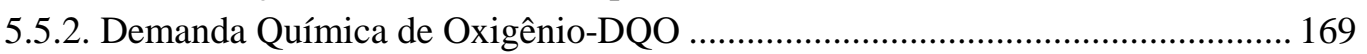

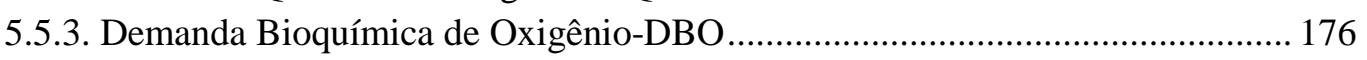

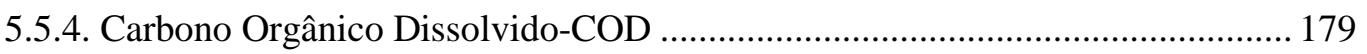

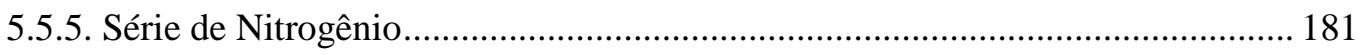

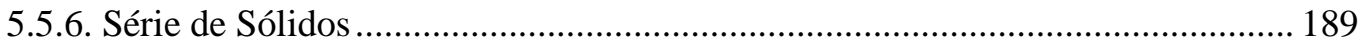

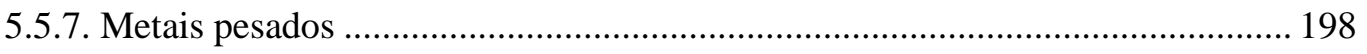

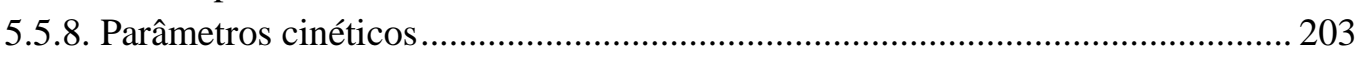

5.6. Resultados do monitoramento microbiológico do experimento em escala piloto................ 206

5.6.1. Resultados do monitoramento microbiológico por microscopia óptica ............... 206

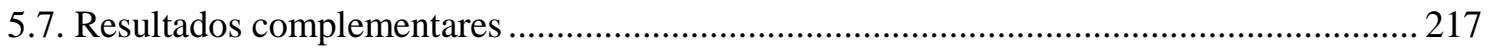

5.7.1. Avaliação do acúmulo de carbono orgânico no lodo ........................................... 217

5.7.2. Resultados dos experimentos de remoção de amônia por air stripping............... 219

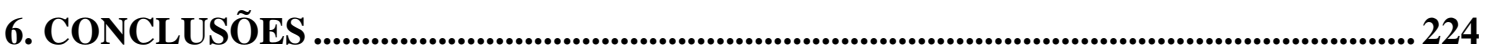

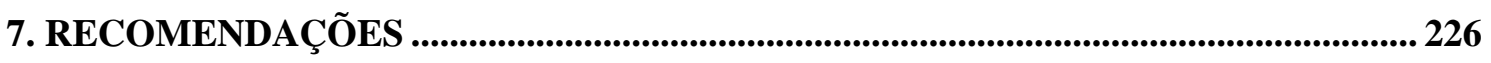

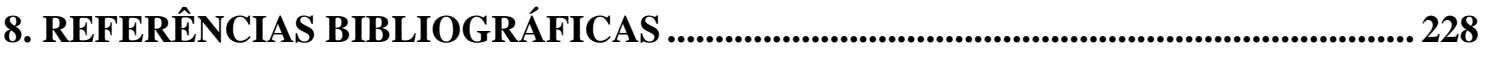

Apêndice A - Monitoramento físico-químico dos experimentos em escala de bancada.. 241

Apêndice B - Monitoramento físico-químico do experimento em escala piloto ................. 261 


\section{INTRODUÇÃO}

Apesar de haver grandes tendências de reduzir ou extinguir o uso de aterros sanitários como forma de disposição final de resíduos sólidos nos países desenvolvidos, como os EUA e países europeus, no Brasil os aterros ainda serão adotados por muito tempo, devido principalmente à maior viabilidade técnica e econômica, quando comparada a outras alternativas, e por recomendação da legislação brasileira (Lei 12.305/10 - Política Nacional dos Resíduos Sólidos), que proíbe a manutenção de lixões no país e prevê um prazo para substituição dos lixões por aterros sanitários

Segundo estatísticas dos últimos dez anos divulgadas pelo governo federal, o aterro sanitário é o método de disposição final de resíduos sólidos urbanos que mais vem sendo adotado no Brasil. Segundo a Pesquisa Nacional de Saneamento Básico de 2008, o Brasil produz diariamente cerca de 260000 toneladas de resíduos sólidos, dos quais 64\%, em peso, são dispostos em "aterro sanitário". (IBGE, 2008; SNIS, 2009).

O lixiviado é um dos principais resíduos gerados nos aterros sanitários: trata-se de um efluente potencialmente poluidor, principalmente devido às elevadas concentrações de nitrogênio amoniacal, presença de matéria orgânica biodegradável e refratária. Caso não seja coletado, transportado e tratado adequadamente pode causar impactos ambientais como a poluição dos recursos hídricos e problemas de saúde pública (Bocchiglieri, 2010).

O lixiviado de aterro sanitário vem sendo largamente estudado no Brasil e no exterior, principalmente nos últimos 20 anos. Porém devido às suas características peculiares ainda não foi obtido um sistema de tratamento economicamente viável e que atenda a todos os padrões de lançamento de efluentes estabelecidos pela resolução CONAMA n 357 de 2005, alterada pelas resoluções no 397 de 2008 e nº 430 de 2011 e por outras legislações locais, havendo a necessidade de se empregar processos mistos com pré e pós-tratamento.

O tratamento combinado de lixiviado com esgoto sanitário tem sido empregado em diversos países como forma de se reduzir custos de implantação de unidades de tratamento nos aterros e custos operacionais por longo período de tempo. No Brasil, seu emprego está sendo cada vez mais difundido. Os aterros sanitários Bandeirantes, São João, Vila Albertina e Santo Amaro, em São Paulo (SP), da Extrema, em Porto Alegre (RS), Salvaterra, em Juiz de Fora (MG), CTR-BR040, em Belo Horizonte (MG) e o 
aterro do Morro do Céu, em Niterói (RJ), são exemplos brasileiros de experiências de tratamento combinado de lixiviado com esgoto sanitário (Facchin et al., 2000; Paganini et al., 2003; Ferreira et al., 2005).

No entanto, ainda há muitas incertezas sobre os efeitos causados pela adição de lixiviado em ETE, como redução da eficiência do tratamento, baixa estabilização da biomassa, sedimentação do lodo, acúmulo de metais no lodo etc. Além da incerteza de ocorrer apenas uma diluição do lixiviado no esgoto, sem efetiva degradação dos seus compostos.

Diante desse quadro, este trabalho visou avaliar a eficiência do tratamento combinado de lixiviado com esgoto sanitário em sistema de lodos ativados e suas possíveis interferências, de forma a fornecer informações que esclareçam as referidas incertezas e investigar as condições operacionais ideais do tratamento combinado de lixiviado e esgoto sanitário em sistema de lodos ativados. 


\section{OBJETIVOS}

\subsection{Objetivo Geral}

Avaliar a eficiência do tratamento combinado de esgoto sanitário com lixiviado nas proporções volumétricas de 0 a $5 \%$, sob diferentes condições, em sistemas de lodos ativados.

\subsection{Objetivos Específicos}

- Verificar o efeito da adição de lixiviado, nas proporções volumétricas de 0;0,2;2 e 5\%, ao esgoto sanitário no desempenho do sistema de lodos ativados em escala de bancada, operado em regime de batelada, e em escala piloto, operado em regime contínuo.

- Verificar a influência do uso de efluente de reator anaeróbio no desempenho do sistema de lodos ativados operando de forma consorciada com lixiviado em proporções volumétricas de $0 ; 0,2 ; 2$ e $5 \%$.

- Verificar a influência do uso de lixiviado pré-tratado por air stripping, nas proporções volumétricas de $0 ; 0,2 ; 2$ e 5\%, no desempenho do sistema de lodos ativados operando de forma consorciada com esgoto sanitário.

- Verificar os efeitos da adição de diferentes proporções de lixiviado sobre a diversidade microbiana nos reatores aeróbios em escala de bancada (regime de batelada) e em escala piloto (regime contínuo).

- Caracterizar a qualidade do lodo aeróbio do sistema de lodos ativados, verificando a sua conformidade quanto à presença de metais com os critérios estabelecidos para uso agrícola (Resolução 375/06 do CONAMA). 


\section{REVISÃO BIBLIOGRÁFICA}

\subsection{Geração e disposição de resíduos sólidos em aterros sanitários}

O problema dos resíduos sólidos, verificado em todos os centros urbanos do país, tem gerado riscos potenciais à saúde pública e ao meio ambiente. $\mathrm{O}$ acentuado crescimento populacional, do poder aquisitivo da população, o aumento da concentração urbana, o desenvolvimento industrial e tecnológico e a mudança de hábitos de consumo da população têm sido responsáveis pelo incremento da produção de resíduos e por suas variações qualitativas.

$\mathrm{O}$ atendimento da população pelos serviços de coleta de resíduos domiciliares na zona urbana está próximo da universalização. Observa-se a expansão de $79 \%$, no ano 2000, para 97,8\% em 2008 (IBGE, 2010). A coleta dos resíduos sólidos urbanos está cada vez mais privatizada, e o número de empresas filiadas à Associação Brasileira de Empresas de Limpeza Pública e Resíduos Especiais (ABRELPE) passou de 45, em 2000, para 92, em 2009, que coletaram cerca de 183 mil toneladas de lixo diariamente em 2009.

$\mathrm{Na}$ busca de soluções para os problemas associados à geração de resíduos sólidos urbanos (RSU) têm sido investigadas várias alternativas de tratamento, processamento e disposição final, com destaque para incineração, digestão anaeróbia, compostagem, reciclagem e aterro sanitário (Pinto, 2000).

O aterro sanitário é um método de disposição final de resíduos sólidos urbanos, sobre terreno natural, através do seu confinamento em camadas cobertas com material inerte, geralmente solo, dentro de critérios de engenharia e normas operacionais específicas, de modo a evitar danos ao meio ambiente e minimizar os prejuízos ou ameaças à saúde e à segurança pública. Dessa forma, os aterros sanitários proporcionam o confinamento seguro dos resíduos no menor volume possível, na medida em que esses são cobertos com camadas de solo (Tchobanoglous, Theisen \& Vigil, 1993; Bidone \& Povinelli, 1999).

Conforme a NBR 8419/1992, tais critérios e normas referem-se aos sistemas de impermeabilização da base, drenagem periférica e superficial, drenagem de fundo para a 
coleta do lixiviado e drenagem dos gases gerados durante o processo de bioestabilização da matéria orgânica.

Assim, o aterro sanitário é o método mais usual de disposição final de resíduos sólidos no Brasil, sendo a alternativa mais viável técnica e economicamente dentro da realidade brasileira. Segundo Zgajnar-Gotvanj et al. (2009), o método oferece menor custo de operação e manutenção do que outros métodos.

A disposição final dos resíduos sólidos urbanos em aterros sanitários tem aumentado ao longo dos últimos anos no país.

Segundo estatísticas da Associação Brasileira de Limpeza Pública e Resíduos Especiais (ABRELPE), de 2003 a 2009 houve um aumento percentual de 39\% da quantidade de aterros sanitários, uma redução de $13 \%$ da quantidade de aterros controlados e $67 \%$ do número de lixões no Brasil.

Enquanto no ano 2000, 17,3\% dos municípios utilizavam aterros sanitários para a destinação final, em 2008, passaram para 27,7\%. No entanto, cerca de metade dos 5.564 municípios brasileiros ainda dispõem em lixões, e o percentual de cidades que dispõem em aterros controlados permaneceu praticamente estagnado nos oito anos, 22,3\% (2000) e $22,5 \%$ (2008). A crescente redução da disposição em lixões, verificada entre os anos 2000 e 2008, deve-se ao fato de as 13 maiores cidades, com população acima de um milhão de habitantes, coletarem mais de $35 \%$ de todo o lixo urbano do país e terem seus locais de disposição final adequados (IBGE, 2010)

No entanto, é importante salientar que esses dados podem sofrer grandes distorções, uma vez que são coletados por meio de questionários aplicados pelo IBGE às entidades que prestam serviço de saneamento no país.

Em alguns países desenvolvidos, e com menor disponibilidade de área, a opção do aterro sanitário pode não ser a mais usual, como é o caso do Japão, da Itália, da França, da Nova Zelândia e da Alemanha, que utilizam bastante o processo de incineração (Persson et al., 2007; Giusti, 2009). Em outros países, esta tecnologia está sendo cada vez mais menos utilizada, devido a recomendações legislativas, como é caso da Suécia, Holanda e dos Estados Unidos (Harada et al.; Scharff et al.; Thorneloe, 2007).

No Brasil, a Lei $\mathrm{n}^{\circ}$ 12.305/2010, que instituiu a Política Nacional dos resíduos sólidos, sugere o aterro sanitário como forma de disposição final ambientalmente adequada, de acordo com normas operacionais específicas, e que proíbe a manutenção de lixões no país e prevê um prazo para substituição dos lixões por aterros sanitários dentro 
dos critérios de engenharia de modo a evitar danos ou riscos à saúde pública e à segurança e a minimizar os impactos ambientais adversos.

Ainda que os aterros sanitários sejam operados em condições adequadas, há geração de gases de efeito estufa (como metano e dióxido de carbono) e lixiviado. Este, por sua vez, é um efluente líquido de elevado caráter poluidor, devido principalmente à elevada concentração de matéria orgânica degradável e recalcitrante e amônia, substância potencialmente tóxica ao meio ambiente, e apresenta variações na composição química e na quantidade produzida (Qsaim e Chiang, 1994).

Dessa forma, embora já seja cogitada a proibição construção de aterros sanitários em muitos países desenvolvidos, os passivos ambientais continuam existindo e deverão ser controlados. No Brasil, em decorrência da legislação vigente, a técnica ainda será amplamente utilizada, os impactos continuarão existindo se não forem tomados os devidos cuidados com os poluentes gerados da decomposição dos resíduos sólidos.

\subsection{Conceituação, geração e caracterização de lixiviado de aterro sanitário}

De acordo com Silva (2005), a degradação de RSU em aterros sanitários, de maneira geral, consiste: 1) na dissolução dos elementos minerais presentes; 2) no transporte das partículas finais e do material solúvel pela água de percolação e; 3) principalmente, na conversão biológica da matéria orgânica em formas solúveis e gasosas. Silva (2005) também afirma que esta degradação em aterros sanitários convencionais ocorre em uma curta fase de degradação aeróbia, em função do oxigênio presente na massa de resíduos, seguida por uma longa fase de degradação anaeróbia.

No processo de decomposição anaeróbia ocorrem primeiramente as reações de hidrólise dão início à redução da matéria orgânica complexa a compostos solúveis menores como os ácidos graxos, açucares simples, aminoácidos e outros compostos orgânicos de peso molecular menor. Atividades adicionais tendem complementar as modificações da matéria orgânica com a conversão dos produtos solúveis da hidrólise em ácidos orgânicos, em ácidos graxos voláteis e álcoois, ácido lático, gás carbônico, hidrogênio, amônia e sulfeto de hidrogênio. Posteriormente ocorre a oxidação dos produtos gerados na fase acidogênica em substrato apropriado para as bactérias 
metanogênica. Os produtos finais desta fase são o hidrogênio, dióxido de carbono e acetato. $\mathrm{Na}$ etapa final, as bactérias metanogênicas degradam os compostos como ácido acético, metanol, hidrogênio, ácido fórmico etc. em metano e dióxido de carbono. (Mccarty, 1964; Archer, 1985; Barlaz, 1996; Chernicharo, 1997).

Um esquema representando as quarto fases da digestão anaeróbia dos resíduos sólidos está apresentado na Figura 1.1.

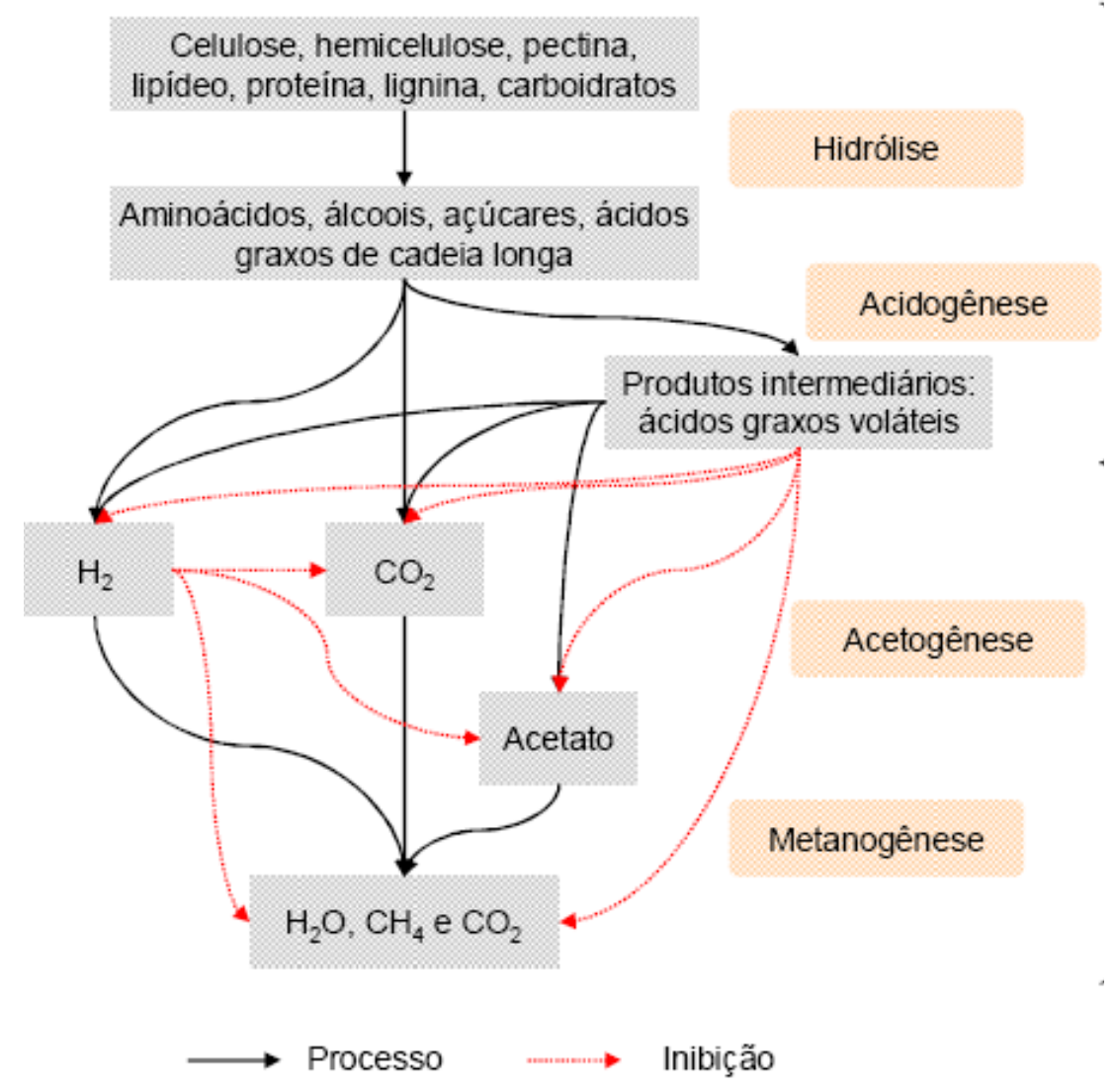

Figura 3.1 - Sequências metabólicas e grupos envolvidos na digestão anaeróbia dos resíduos sólidos. Bouallagui et al. (2004)

Durante a acidogênese, a matéria orgânica é convertida ao nitrogênio amoniacal total e ácidos voláteis de cadeia longa, por sua vez responsáveis pelos baixos valores de pH. Na chamada fase de maturação, em decorrência da escassez de nutrientes, é significativamente reduzida a atividade dos microrganismos. A concentração inicial da matéria orgânica biodegradável também é sensivelmente reduzida e a matéria remanescente é bastante refratária (Bidone e Povinelli, 1999).

A partir da combinação do líquido resultante dessa degradação anaeróbia dos resíduos sólidos, da própria água constituinte dos resíduos e da água pluvial que percola 
na massa sólida, é formado o lixiviado, que possui elevada concentração de sólidos dissolvidos extraídos durante a infiltração na massa de resíduos, de matéria orgânica (biodegradável e refratária, como as substâncias húmicas) e inorgânica, como cloreto, nitrogênio amoniacal e metais pesados, decorrentes da decomposição do lixo. (Kostova, 2006; Lange; Amaral, 2009).

Dessa forma, o processo de formação do lixiviado pode ser influenciado por diversos fatores, como hidrológicos (como regime de chuvas, infiltração, evapotranspiração, escoamento superficial, acúmulo de umidade no solo, temperatura), relativos aos resíduos sólidos (como composição e teor de umidade inicial), relativos ao tipo de disposição (como compactação, idade do aterro, solo de cobertura e profundidade do aterro). No entanto, a presença ou ausência de macronutrientes e micronutrientes ou de elementos inibidores também interferem na geração do lixiviado. (Bocchiglieri, 2005; Souto, 2009)

A composição de lixiviado de aterros municipais exibe variações temporais, locais e as concentrações de contaminantes variam em várias ordens de magnitude. Os componentes orgânicos biologicamente refratários (como substâncias húmicas), amônia e metais pesados são três problemas principais relativo ao tratamento e disposição do lixiviado (Deng; Englehardt, 2006).

Renou et al. (2008) afirmaram que as características do lixiviado de aterro sanitário geralmente podem ser representadas principalmente por parâmetros tais como: DBO, DQO, relação DBO/DQO, pH, sólidos suspensos (SS), nitrogênio amoniacal, nitrogênio total Kjeldahl (NTK) e metais pesados.

A composição do lixiviado varia em função da fase em que se encontra o aterro sanitário. Souto (2009) realizou extensa revisão bibliográfica focada em autores nacionais e construiu tabelas com características do lixiviado de aterros brasileiros.

Nas Tabela 3.1 se encontram listadas as principais características do lixiviado de aterros brasileiros na fase ácida e metanogênica.

Segundo Tchobanoglous et al (1993), aterros novos possuem lixiviados com relação DBO/DQO em torno de 0,7, enquanto em aterros antigos, esta relação se aproxima de 0,2. Já Gomes et al. (PROSAB, 2006), classificam a idade do aterro em função da relação DBO/DQO do lixiviado da seguinte maneira: uma relação DBO/DQO maior que 0,5 indica um aterro novo e instável, bem como essa relação entre 0,1 e 0,5 
indica um aterro moderadamente estável e um aterro velho e estável é indicado por uma relação DBO/DQO menor do que 0,1 .

Tabela 3.1 - Características típicas do lixiviado dos aterros brasileiros

\begin{tabular}{|c|c|c|c|c|}
\hline \multirow[b]{2}{*}{ Parâmetros } & \multicolumn{2}{|c|}{ Fase ácida } & \multicolumn{2}{|c|}{$\begin{array}{c}\text { Fase } \\
\text { metanogênica }\end{array}$} \\
\hline & Mínimo & Máximo & Mínimo & Máximo \\
\hline $\mathrm{pH}$ & 4,4 & 8,4 & 5,9 & 9,2 \\
\hline Alcalinidade Total (mg/L de $\left.\mathrm{CaCO}_{3}\right)$ & 170 & 32000 & 125 & 20200 \\
\hline Turbidez (UNT) & 100 & 540 & 0,02 & 620 \\
\hline Condutividade $(\mu \mathrm{S} / \mathrm{cm})$ & 230 & 45000 & 100 & 45000 \\
\hline $\mathrm{DBO}(\mathrm{mg} / \mathrm{L})$ & 1 & 55000 & 3 & 17200 \\
\hline DQO (mg/L) & 90 & 100000 & 20 & 35000 \\
\hline NTK (mg/L) & 1,7 & 3000 & 0,6 & 5000 \\
\hline NAT (mg/L) & 0,07 & 2000 & 0,03 & 3000 \\
\hline Nitrito (mg/L) & - & - & ND & 70 \\
\hline Nitrato $(\mathrm{mg} / \mathrm{L})$ & ND & 260 & ND & 270 \\
\hline Fósforo Total (mg/L) & ND & 45 & ND & 80 \\
\hline Cloreto $(\mathrm{mg} / \mathrm{L})$ & 275 & 4700 & 20 & 6900 \\
\hline $\mathrm{ST}(\mathrm{mg} / \mathrm{L})$ & 400 & 45000 & 200 & 29000 \\
\hline $\mathrm{STV}(\mathrm{mg} / \mathrm{L})$ & 78 & 26700 & 75 & 20700 \\
\hline $\mathrm{STF}(\mathrm{mg} / \mathrm{L})$ & 40 & 28400 & 100 & 17000 \\
\hline $\operatorname{SST}(\mathrm{mg} / \mathrm{L})$ & 10 & 7000 & 7 & 12400 \\
\hline $\mathrm{Fe}$ total $(\mathrm{mg} / \mathrm{L})$ & ND & 1400 & 0,01 & 720 \\
\hline Cd total $(\mathrm{mg} / \mathrm{L})$ & ND & 0,1 & ND & 0,6 \\
\hline $\mathrm{Cu}(\mathrm{mg} / \mathrm{L})$ & ND & 0,8 & ND & 2,9 \\
\hline $\mathrm{Cr}(\mathrm{mg} / \mathrm{L})$ & ND & 1,2 & ND & 1 \\
\hline Mn total $(\mathrm{mg} / \mathrm{L})$ & ND & 115 & ND & 30 \\
\hline $\mathrm{Ni}(\mathrm{mg} / \mathrm{L})$ & ND & 6,5 & ND & 1,4 \\
\hline $\mathrm{Zn}(\mathrm{mg} / \mathrm{L})$ & ND & 27 & ND & 35 \\
\hline $\mathrm{Pb}$ total $(\mathrm{mg} / \mathrm{L})$ & ND & 1,5 & ND & 6,7 \\
\hline CT (NMP/100ml) & 200 & $5 \times 107$ & ND & $2 \times 108$ \\
\hline
\end{tabular}

$\mathrm{ND}=$ abaixo do limite de detecção; $\mathrm{CT}=$ coliformes termotolerantes Fonte: Souto (2009)

Além de apresentarem elevadas concentrações de matéria orgânica menos biodegradável e nitrogênio amoniacal do que os esgotos domésticos, o lixiviado pode apresentar presença marcante de metais pesados com concentrações variando em função principalmente do tipo de lixo depositado no aterro. 
Urase et al. (1997) afirmam que a alta recalcitrância dos lixiviados está associada à presença de compostos de elevada massa molecular com estruturas muito complexas como é o caso das substâncias húmicas.

A carga orgânica do lixiviado, quando encontra os recursos hídricos superficiais, acarreta na sensível redução de oxigênio dissolvido, levando à instabilidade da vida dos seres aeróbios do ecossistema. Ainda, os nutrientes (nitrogênio e fósforo) podem acelerar o processo de eutrofização de corpos d'água lênticos (lagos e represas). Já as substâncias químicas presentes nos lixiviados podem ser tóxicas ou bioacumulativas na cadeia alimentar (Santos, 2010).

A composição tóxica e recalcitrante do lixiviado o torna uma grande preocupação na gestão de resíduos sólidos urbanos e, principalmente, na gestão de aterros sanitários no Brasil e no mundo. A liberação de lixiviado no solo ou diretamente nos recursos hídricos pode causar danos irreparáveis ao meio ambiente. Assim, torna-se fundamental o estudo de técnicas que visem à redução da sua geração e o seu tratamento adequado segundo parâmetros de qualidade da água determinados pela legislação ambiental.

\subsection{Tratamento combinado de lixiviado e esgoto}

O tratamento de lixiviado de aterro sanitário vem sendo estudado em vários centros de pesquisas no Brasil e, mais intensamente, no exterior. Porém dadas as características intrínsecas do resíduo, ainda não se desenvolveu um sistema de tratamento que seja economicamente viável e que ao mesmo tempo alcance eficiência suficiente para o atendimento dos padrões de lançamento. Dentre esses processos, pode-se citar: os físico-químicos, biológicos, térmicos, barreiras químicas, fitoquímicos, tecnologia de membranas entre outros.

O tratamento ideal de lixiviado de aterro sanitário, com o intuito de se reduzir os impactos negativos sobre o meio ambiente, ainda é um desafio. A complexidade e variabilidade da composição dessa água residuária tornam ainda mais difícil a tentativa de se estabelecer recomendações gerais. Os métodos apresentados na literatura mostram a grande diversidade de processos aplicados ao tratamento de lixiviado, sendo notória a necessidade de se avaliar cada caso e adotar o sistema mais adequado para cada tipo de 
lixiviado, segundo suas características e os padrões de lançamento que devem ser alcançados (Albuquerque \& Povinelli, 2011).

Observou-se também que o processo de tratamento consorciado com esgoto sanitário tem apresentado um bom desempenho, em relação aos outros processos, tanto na remoção de matéria orgânica quanto na remoção de nitrogênio amoniacal, com eficiência média de remoção, de $67 \%$ e $73 \%$, respectivamente. Dentre os sistemas revisados, o sistema de lodos ativados é o que tem proporcionado melhor desempenho no tratamento (Albuquerque \& Povinelli, 2011).

O tratamento combinado de lixiviado consiste no seu lançamento junto ao afluente de estações de tratamento de esgoto (ETEs), devendo resultar em um efluente tratado que atenda às exigências legais. Largamente utilizado nos Estados Unidos, Europa e Japão, essa prática sofre hoje questionamentos sobre as interferências que o lixiviado, em função das suas características, pode promover nos processos de tratamento, especialmente nos biológicos (Ferreira et al., 2009)

No Brasil, o tratamento combinado de lixiviado de aterros em estações de tratamento de esgoto sanitário vem sendo adotado em algumas cidades, tais como São Paulo (SP), Porto Alegre (RS), Niterói e Rio de Janeiro (RJ), Belo Horizonte e Juiz de Fora (MG) (Facchin et al., 2000; Bocchiglieri, 2005; Ferreira et al., 2007; Viana, 2007; Marques et al., 2010) .

Porém, ainda há muitas incertezas sobre os efeitos causados pela adição de lixiviado em ETE, como redução da eficiência do tratamento, baixa estabilização da biomassa, sedimentação do lodo, acúmulo de metais no lodo etc., além da incerteza de ocorrer apenas uma diluição do lixiviado no esgoto, sem efetiva degradação de seus compostos. Isso reforça a necessidade de serem desenvolvidos novos estudos a fim de se esclarecer tais incertezas, de se estabelecer adequadamente critérios para a utilização do tratamento combinando, como a proporção de diluição, condições operacionais etc. para a realidade brasileira.

Embora no Brasil não existam leis específicas em nível nacional que controlem o descarte de lixiviados de aterros sanitários, no sentido de reduzir a poluição de corpos hídricos, a USEPA estabeleceu limites para lançamentos dos lixiviados de aterros e padrões de pré-tratamento para descarga desses efluentes em sistemas públicos de tratamento de esgotos (USEPA, 2000). Em 2000, a USEPA estimava que 756 aterros de 
resíduos não-perigosos descartavam suas águas residuárias em sistemas públicos de tratamento de esgotos (USEPA, 2000).

Um argumento a favor do tratamento combinado é que o lixiviado possui elevadas concentrações de nitrogênio, enquanto que o esgoto possui elevadas concentrações de fósforo, de forma que esses nutrientes não precisam ser adicionados em plantas de tratamento biológico (Lema et al., 1988). No entanto, Heyer, Stegmann e Ehrig (1998) afirmam que a adição de lixiviado no tratamento biológico de esgoto, sem quaisquer outras mudanças no processo, poderia causar drástica redução da taxa de nitrificação resultando em toxicidade relativa à amônia.

Além disso, eventuais concentrações elevadas de metais podem inibir a atividade biológica do lodo e inviabilizar a sua utilização futura como fertilizante. Grandes volumes de lixiviado adicionados ao sistema de tratamento de esgotos podem ainda resultar em efluentes tratados com elevadas concentrações de matéria orgânica e nitrogênio amoniacal (Boyle \& Ham, 1974; Lema et al., 1988).

Outros problemas possíveis decorrentes do tratamento combinado podem ser: a corrosão de estruturas e problemas operacionais derivados da precipitação de óxidos de ferro (Cossu' apud Lema et al., 1988).

Diversos estudos buscam avaliar a viabilidade do tratamento de lixiviados de forma conjunta com esgoto doméstico. Busca-se conhecer os impactos da adição de lixiviado em diferentes proporções nos sistemas de tratamento, na qualidade do lodo e do efluente final.

Boyle \& Ham (1974) avaliaram o tratamento combinado em reatores de lodos ativados com aeração prolongada e constataram: aumento da produção de sólidos, do consumo de oxigênio e da taxa volumétrica de lodo bastante significativo acima de $10 \%$ de lixiviado; efluentes do tratamento com 10 e $20 \%$ de lixiviado, com elevadas concentrações de sólidos suspensos, DBO e DQO. Os autores recomendam a adição de lixiviado até o limite de 5\% para não impactar significativamente a qualidade do efluente.

COSSU, R. (1988) Ingegnieria Ambientale. In: LEMA, J.M.; MENDEZ, R.; BLAZQUEZ, R. Characteristics of Landfill Leachates and Alternatives for Their Treatment: A Review. Water, Air, and Soil Pollution, v.40, p. 223-250. 
Henry (1985) avaliou o tratamento combinado em ETE por lodos ativados. O autor constatou que até $2 \%$ de lixiviado, não houve alterações significativas no desempenho do sistema. De 4 a 5\% de lixiviado, o desempenho da ETE pode ser comprometido.

Kelly (1987) estudou o tratamento de lixiviado combinado com esgoto sanitário em planta piloto de lodos ativados. Obteve eficiência de remoção da DQO de 69\% com $16 \%$ de lixiviado e de $71 \%$ com $4 \%$ de lixiviado. As eficiências foram de 10 a $15 \%$ maiores na linha controle do que na linha teste. Houve um aumento da concentração de metais no lodo na linha teste, ainda que sem ultrapassar os limites estabelecidos para o uso agrícola do solo.

McBean et al. (1995) também apresentam o tratamento combinado com esgoto doméstico como uma forma bastante utilizada para se tratar lixiviados de aterros de resíduos sólidos, e reforçam a ideia de que a relação volumétrica entre o lixiviado e o esgoto não deve ultrapassar $2 \%$ para evitar problemas no tratamento.

Chang et al. (1995) estudaram o tratamento combinado em reatores de lodos ativados nas concentrações de 0,2 e 1,0\% de lixiviado. Alcançaram eficiência de remoção de DBO acima de $90 \%$, de DQO acima de $80 \%$ e redução gradativa dessas eficiências com o aumento da proporção de lixiviado de 0,$2 ; 1,0 ; 10 ; 25$ e $50 \%$.

Booth et al. (1996) avaliaram o desempenho de uma ETE por lodos ativados tratando lixiviado com esgoto sanitário na proporção média de $0,14 \%$. Os autores relatam um aumento do consumo de oxigênio na ETE em torno de $2 \%$ devido à adição do lixiviado, na produção de lodo em $2,3 \%$. As concentrações de metais no lodo se mantiveram abaixo dos limites das leis canadenses.

Diamadopoulos et al. (1997) estudaram o tratamento combinado de lixiviado com esgoto sanitário na proporção volumétrica de $10 \%$ em um reator sequencial em batelada em escala de bancada. A mistura apresentava concentração média de DBO, DQO e NTK de $430 \mathrm{mg} / \mathrm{L}, 1090 \mathrm{mg} / \mathrm{L}$ e $133 \mathrm{mg} / \mathrm{L}$ respectivamente. Segundo os autores, foram alcançadas eficiência de remoção de 70 a $98 \%$ de $\mathrm{DBO}_{5}$ e de 35 a $50 \%$ de nitrogênio total.

Chang et al. (1998) estudaram o tratamento combinado de lixiviado e esgoto sanitário em um sistema de lodos ativados de fluxo contínuo em escala de laboratório com e sem pré-tratamento físico-químico. Analisaram as diluições de 0,2;1;10;25 e $50 \%$ de lixiviado. A remoção de DBO ultrapassou 90\% e a de DQO ultrapassou 80\%, a 
qual foi mantida até a proporção de $1 \%$ de lixiviado e gradual decréscimo na remoção de orgânicos foi observado com o aumento da proporção de lixiviado de 10 a 50\%. A remoção de nitrogênio total decresceram notadamente com a adição de lixiviado entre $1 \mathrm{e}$ 10\%. A remoção de DQO foi aumentada com pré-tratamento por adsorção e a cor removida em $33 \%$ por coagulação-precipitação. Foi observada boa sedimentabilidade do lodo em todas as proporções de lixiviado e maior velocidade de sedimentação com a adição de lixiviado.

Ehrig (1998) avaliou a tratabilidade de lixiviado de forma combinada com esgoto em reatores de lodos ativados em laboratório. Foram observados valores crescentes de DBO e DQO nos efluentes finais com o aumento da proporção de lixiviado, possivelmente pela deficiência de fósforo em comparação com a adição de carga orgânica não-biodegradável. A velocidade de sedimentação do lodo aumentou com a adição de lixiviados.

Borghi et al. (2001) utilizaram reatores de lodos ativados operando em batelada para avaliar o tratamento combinado nas proporções de $0,1,2,3,5,7,5,10,15$ e $20 \%$ de lixiviado. O sistema alcançou remoções de DQO acima de $85 \%$ na proporção de $5 \%$ de lixiviado, decrescendo nas proporções superiores. A remoção de $\mathrm{N}-\mathrm{NH}_{3}$, reduziu-se gradualmente com volumes de lixiviado entre 1 e 7,5\% e manteve-se constante entre 10 e $20 \%$ de lixiviado. Os autores consideraram 10\% de volume de lixiviado como um limite prático.

Çeçen \& Çakrroğlu (2001) estudaram o tratamento combinado de lixiviado e esgoto sanitário em um sistema de lodos ativados em escala de bancada. As proporções de lixiviado variaram de 5 a 20\%. A eficiência de remoção de DQO foi de $72 \%$ e $16 \%$ nas proporções de $10 \%$ e $20 \%$, respectivamente. Quando foi realizado um tratamento prévio do esgoto com $\mathrm{FeSO}_{4}$ e polieletrólito aniônico, a remoção de matéria orgânica na proporção de $10 \%$ aumentou para $85 \%$ e na proporção de $5 \%$ aumentou para $88 \%$. Com base em tais dados, os autores recomendam que a proporção de lixiviado nunca exceda $20 \%$ do total da mistura e constataram que quando a DQO do lixiviado se aproximou de $50 \%$ da DQO total inicial, foi observado um significante decréscimo na taxa de reação, indicando efeitos de inibição.

Neczad et al. (2007) estudaram o tratamento combinado em SRB na proporção 1:9 em volume de lixiviado e esgoto, respectivamente. A eficiência de remoção de DQO 
foi de $86 \%$ quando não houve pré-tratamento do lixiviado. Porém quando o lixiviado foi pré-tratado por ultra-som, a eficiência de remoção de DQO foi de $92 \%$.

Franco (2009) avaliou o tratamento combinado de lixiviado e esgoto em uma planta piloto de lodos-ativados, instalada na ETE de Icaraí/Niterói (RJ). Os resultados indicaram eficiência de remoção média de $76 \%$ de DQO e $73 \%$ de COD na proporção de 0,5 a $1 \%$, e de $72 \%$ de DQO e $63 \%$ de COD na proporção de 2 a 2,5\% de lixiviado, sendo alcançadas remoções acima de $90 \%$ e de nitrogênio amoniacal foram alcançados valores de 80 a 97\%. Também foram operados reatores aeróbios em bancada em regime de batelada e regime contínuo. Os reatores não indicaram prejuízos ao lodo biológico em função do acréscimo de lixiviado para os percentuais de mistura 0,5 a 2,5\% de lixiviado. Problemas na sedimentabilidade do lodo biológico foram observados ao longo de todo o período de operação da planta piloto, não havendo indicação de perda de sua qualidade em função das diferentes concentrações de lixiviado na alimentação.

Marques et al. (2010) estudaram o tratamento consorciado de lixiviado de aterro sanitário e esgoto doméstico pelo processo de lodos ativados convencional através do monitoramento da ETE Arrudas, em Minas Gerais. O percentual de contribuição do lixiviado foi de 3,39\% da DQO e 5,19\% de $\mathrm{N}_{-} \mathrm{NH}_{3}$, em termos de carga. O percentual de remoção de DBO e DQO manteve valores médios acima de $90 \%$ e a remoção de nitrogênio amoniacal se manteve em valores médios acima de $75 \%$.

Santos (2010) estudou o tratamento combinado de lixiviados do Rio de Janeiro, em lagoas de estabilização para tratamento de esgoto doméstico, numa linha composta por lagoa aerada mais lagoa de sedimentação. Para as proporções de 0, 0,2, 0,5 e $2 \%$ foram alcançadas remoções de 82, 68, 66, 56\% de DQO e 77, 75, 84\% de $\mathrm{N}_{-} \mathrm{NH}_{4}$, respectivamente. Foi realizada ainda, uma estimativa da geração de esgoto e de lixiviado por uma mesma população contribuinte, alcançando-se valores entre 0,09\% e 0,13\% de volume de lixiviado em relação ao de esgoto, o que favorece a aplicação do tratamento combinado.

Turetta (2011) avaliou a tratabilidade de lixiviado do aterro sanitário de São Carlos combinado com efluente anaeróbio em reatores de lodos ativados em escala de bancada, nas proporções de 2,5; 10 e $20 \%$ de lixiviado. O reator alimentado com 2,5\% de lixiviado apresentou melhores resultados, alcançando eficiência de COT e DQO de 77 e $57 \%$, respectivamente. Os reatores alimentados com a mistura lixiviado pré-tratado com cal e efluente anaeróbio em geral apresentaram menor concentração de COT efluente que 
os reatores alimentados com lixiviado bruto, apesar da menor eficiência. A autora relatou baixas eficiências nas proporções de 10 e $20 \%$ de lixiviado, acompanhada da redução da diversidade microbiana.

\subsection{Pré-tratamento do lixiviado por air stripping visando à remoção $e$ recolhimento de amônia}

A amônia existe em solução tanto na forma iônica $\left(\mathrm{NH}_{4}{ }^{+}\right)$como na forma livre, não ionizada $\left(\mathrm{NH}_{3}\right)$, segundo a equação de equilíbrio Assim, pode-se ver que na faixa usual de $\mathrm{pH}$, próxima à neutralidade, a amônia apresenta-se praticamente toda na forma ionizada $\left(\mathrm{NH}_{4}{ }^{+}\right)$. Em pH acima de 11 praticamente toda a amônia está na sua forma livre ( $\mathrm{NH}_{3}$ ), como mostram a Reação (R-1) e Equação 1 (Metcalf e Eddy, 2003).

$$
\begin{gathered}
\mathrm{NH}_{4}^{+} \leftrightarrow \mathrm{NH}_{3}+\mathrm{H}^{+} \\
\mathrm{NH}_{3}(\%)=\frac{100}{1+\frac{\left[\mathrm{H}^{+}\right]}{K a}}
\end{gathered}
$$

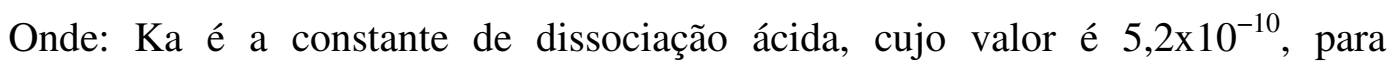
temperatura de $25^{\circ} \mathrm{C}$ e pressão de 1 atmosfera.

Nos recursos hídricos, de acordo com as condições do meio, a amônia em sua forma não ionizada $\left(\mathrm{NH}_{3}\right)$ pode ser tóxica para diversos organismos, a exemplo dos peixes, cujas taxas de crescimento e desenvolvimento podem ser afetadas. Conforme mencionado, a amônia exerce importante função nutricional, mas em excesso, juntamente com o fósforo é responsável pela eutrofização, processo que pode comprometer a qualidade dos recursos hídricos (WHO, 1986; Environment Canada, 2001).

O órgão governamental Environment Canada informa que as emissões atmosféricas da amônia têm gerado impactos ambientais, tais como formação de material particulado, acidificação e eutrofização do solo (Environment Canada, 2001).

Os lixiviados dos aterros de resíduos municipais geralmente contêm altas concentrações de componentes químicos orgânicos e inorgânicos, em especial de nitrogênio amoniacal ( superiores a $800 \mathrm{mg} / \mathrm{L}$ ), substância que mais contribui com caráter 
poluente desse efluente líquido, gerando impactos significativos caso o lixiviado seja lançado no meio ambiente (Bidone \& Povinelli, 1999; Renou et al., 2008).

Quando lançado em um corpo receptor sem prévio tratamento pode estimular a proliferação de algas e provocar o consumo de oxigênio dissolvido, prejudicando a biota do ecossistema aquático. Além disso, altas concentrações de nitrogênio amoniacal podem ser tóxicas aos microrganismos em sistemas biológicos de tratamento dessa água residuária (Turetta, 2011).

Efluentes como o lixiviado têm padrões de lançamento estabelecidos pela Resolução CONAMA 430/2011. Apesar de não ser mais exigível o padrão de nitrogênio amoniacal total para sistemas de tratamento de esgotos sanitários que recebam lixiviados, a máxima concentração permitida para efluentes de qualquer outra poluidora é de 20 mg/L. Essa Resolução atualiza aquelas de número 357/2005 e 397/2008 (Ministério do Meio Ambiente, 2011).

A concentração desses compostos nitrogenados tem uma grande variabilidade ao longo do ano, conforme elucidado por Souto (2009) e Bocchiclieri (2010). Além da vazão de esgoto sanitário afluente às ETE também estarem sujeitas a variações diárias. A avaliação de alternativas para o tratamento dos lixiviados deve considerar as grandes variações temporais locais da carga dos compostos do lixiviado e do esgoto sanitário, de modo a não comprometer a eficiência do sistema e a qualidade do efluente final.

Li e Zhao (1999) mostraram que o desempenho do processo convencional de lodos ativados pode ser significativamente afetado pela concentração elevada de nitrogênio amoniacal. A remoção de DQO decaiu de 95,1\% para 79,1\% com o aumento da concentração de nitrogênio amoniacal de 50 para $800 \mathrm{mg} / \mathrm{L}$, e observaram redução da atividade microbiana no sistema. Os resultados indicaram que a alta concentração de nitrogênio amoniacal no lixiviado necessita ser reduzida a menos de $100 \mathrm{mg} / \mathrm{L}$, por processos de pré-tratamento como air stripping ou precipitação previamente ao tratamento biológico.

Çecen \& Çakiroğlu (2001); Chen, S. et al. (2001); Del Borghi, et al. (2003) também observaram a inibição do processo de lodos ativados pela alta carga de NAT, resultando na redução da eficiência de remoção de DQO, da taxa de nitrificação e acúmulo de produtos intermediários de nitrogênio.

Estudos prévios com tratamento biológico convencional em sistema de lodos ativados indicam que sua eficiência de tratamento é bastante afetada quando o lixiviado 
contém altas concentrações de amônia livre. Shiskowski et al. (1998); Calli (2005); Wiszniowski et al. (2007) e Contrera (2008) recomendam um pré-tratamento físicoquímico do lixiviado para remoção de amônia, tais como precipitação, coagulaçãofloculação, adsorção, oxidação química e air stripping.

Em geral, a precipitação química do nitrogênio resulta na sedimentação de um precipitado de baixa solubilidade contendo íons amônio e sais, produzindo um lodo rico em nitrogênio e um efluente com alto teor de sais. (Hossaka, 2008; Li et al. 1999). Apesar da alta eficiência obtida na remoção de amônia por precipitação química por Li, et al. (1999), Zhang et al. (2009), o processo implicou na formação de sais em alta concentração, podendo comprometer o tratamento biológico posterior.

Os resultados obtidos por diversos pesquisadores mostram que são necessárias dosagens muito acima do usual para obter apenas remoções moderadas de DQO por processo de coagulação-floculação. A compilação de resultados apresentados na literatura internacional feita por Renou et al. (2008) mostrou que a eficiência máxima de remoção de DQO normalmente não ultrapassa $50 \%$, tanto com o uso de cloreto férrico como com sulfato de alumínio, mesmo na presença de auxiliares de floculação. Essas baixas eficiências também podem ser devidas ao efeito da força iônica, conforme elucidado por Souto (2009) e Ferraz (2010), dificultam a ação dos agentes de coagulantes.

Conforme Aziz et al.(2004), Kurniawan, Lo \& Chan (2006), a adsorção é efetiva para remoção de compostos não biodegradáveis do lixiviado, remove mais que $90 \%$ de DQO, porém possui baixa eficiência na remoção de amônia. No caso da adsorção em carvão ativado, uma desvantagem é que o mesmo precisa ser regenerado, o que implica na elevação dos custos (Qasin e Chiang, 1994).

Com base nos resultados discutidos, pode-se concluir que nenhum dos processos é capaz de promover uma boa remoção de amônia sem que seus custos operacionais sejam elevados, tornando-se impraticáveis em localidades com limitações econômicas.

De acordo com Souto (2009) e Ferraz (2010), mostrou-se viável a remoção de nitrogênio amoniacal total (NAT) pelo emprego de torres de air stripping, apresentando eficiências de remoção em torno de $100 \%$ em curto prazo de aeração. Quando se alcalinizou o lixiviado a pH 12, observou-se maior aceleração na remoção do NAT, acompanhada de alta remoção de cor.

Apesar da eficácia na remoção da amônia, associa-se como limitação do air stripping o lançamento do gás de arraste contendo os contaminantes extraídos da fase 
líquida, para a atmosfera, podendo causar vários impactos ambientais e problemas de saúde (Renou et al., 2008).

O uso dos chamados lavadores de gases é recomendado pela USEPA como instrumento de controle da emissão de amônia. O mecanismo de funcionamento desses lavadores é a absorção da amônia em um líquido no qual ela é solúvel (USEPA, 1995). É também comum o uso de soluções ácidas na neutralização da amônia, resultando em produtos que podem ser comercializados como fertilizantes (USEPA, 1995; Cardillo, 2002; Busca e Pistarino, 2003).

Cardillo (2002) realizou um estudo sobre a viabilidade econômica do prétratamento do lixiviado de aterros sanitários pelo uso de uma torre recheada aerada em escala piloto, com o intuito de se comercializar fosfato de amônio. O lixiviado produzido no aterro sanitário de Lara (Mauá - SP) foi submetido ao tratamento biológico, cujo custo operacional unitário é $\mathrm{R} \$ 8,52 / \mathrm{m}^{3}$ de lixiviado. De acordo com o autor, esse valor é reduzido para $\mathrm{R} \$ 2,37 / \mathrm{m}^{3}$ de lixiviado quando há a remoção prévia de amônia por air stripping e, lodo após, seu aproveitamento e comercialização como fertilizante.

Bento et al. (2009) promoveram o tratamento do lixiviado utilizando uma torre de air stripping para remoção de amônia e um reator de $4 \mathrm{~L}$ para recuperação dessa substância. O volume da torre era de 10,6 L, recheada com brita $\mathrm{n}^{\circ} 4$. Foi utilizado $1 \mathrm{~L}$ da água residuária e os resultados indicam que, no ensaio com pH 10, a eficiência da torre foi de $87 \%$ e $89 \%$ da amônia removida da fase líquida e recuperada em solução ácido clorídrico 0,2 mol/L. No ensaio com $\mathrm{pH} \mathrm{11,} \mathrm{as} \mathrm{eficiências} \mathrm{da} \mathrm{torre} \mathrm{e} \mathrm{unidade} \mathrm{de}$ recuperação foram, respectivamente, $97,5 \%$ e $87 \%$.

Ferraz (2010) avaliou a remoção de amônia em torre de air stripping de 2,25 m de altura e $15 \mathrm{~cm}$ de diâmetro. Para o recolhimento da amônia foram usados dois frascos lavadores de $6 \mathrm{~L}$, preenchidos com $4 \mathrm{~L}$ de solução de ácido sulfúrico 0,4 mol/L ou água. Os resultados obtidos indicaram remoção praticamente completa de toda a amônia contida no lixiviado. Nas diferentes condições operacionais avaliadas, a concentração de amônia remanescente no lixiviado foi igual ou inferior aos $20 \mathrm{mg} / \mathrm{L}$ determinados pela Resolução 430/2011 do CONAMA. Quanto ao recolhimento da amônia, a eficiência média obtida nos frascos lavadores próxima a $80 \%$, tanto quando utilizada a solução de ácido sulfúrico 0,4 mol/L quanto quando utilizada água. 


\subsection{Sistema de lodos ativados}

O processo de tratamento por lodos ativados foi desenvolvido na Inglaterra, em 1914, por Andern e Lockett. É chamado "lodo ativado" porque era suposta a produção de uma massa ativada de microrganismos capaz de estabilizar um resíduo por via aeróbia. $\mathrm{O}$ processo de lodos ativados consiste em promover a floculação biológica, por meio do desenvolvimento de uma cultura microbiana na forma de flocos biologicamente ativos (lodos ativados), que permanecem em contato contínuo com o substrato para adquirir sedimentabilidade suficiente e serem removidos em tanques de sedimentação (Vazzoler, 1989; Metcalf \& Eddy, 2003).

O sistema é formado por três componentes básicos: (1) reator em que os microrganismos responsáveis pelo tratamento permanecem em suspensão e aerados; (2) unidade de separação das fases líquida e sólida, geralmente em tanques de sedimentação; e (3) sistema de recirculação de lodo para promover o retorno dos sólidos removidos na unidade de separação ao reator, conforme apresentado na Figura 3.2 (Metcalf \& Eddy, 2003).

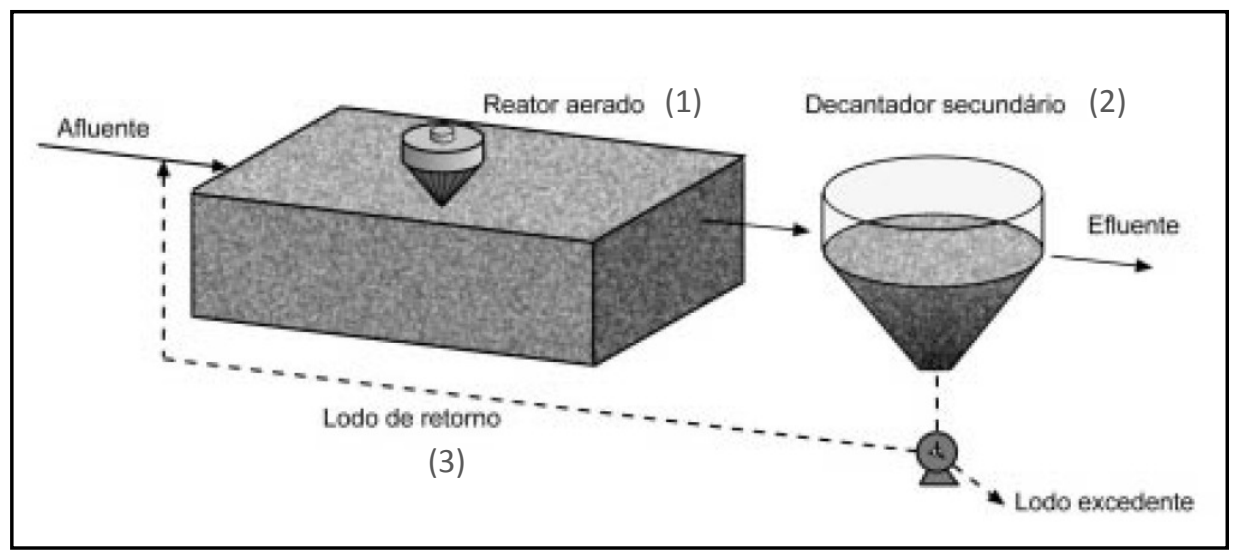

Figura 3.2 - Esquema das unidades da etapa biológica do sistema de lodos ativados.

No tanque de aeração (reator) ocorrem as reações bioquímicas de remoção da matéria orgânica e, em determinadas condições, da matéria nitrogenada. A biomassa (massa biológica) utiliza o substrato presente no esgoto bruto para se desenvolver. No decantador secundário ocorre a sedimentação dos sólidos (biomassa), permitindo que o efluente final seja clarificado. Os sólidos sedimentados no fundo do decantador 
secundário são recirculados para o reator, aumentando a concentração de biomassa no mesmo, o que é responsável pela elevada eficiência do sistema (Maciel, 2002).

O sistema de lodos ativados é amplamente utilizado, em nível mundial, para o tratamento de águas residuárias domésticas e industriais, em situações em que uma elevada qualidade do efluente é necessária e a disponibilidade de área é limitada. No entanto, o sistema de lodos ativados inclui um índice de mecanização superior ao de outros sistemas de tratamento, implicando em maiores custos de implantação, operação e manutenção, além disso, há elevada produção de lodo (Van Haandel \& Marais, 1999; Jordão \& Pessoa, 2005).

$\mathrm{Na}$ caracterização da DQO residual de efluentes de tratamento de águas residuárias, Barker et al. (1999) concluíram que a degradação aeróbia mostrou-se mais eficiente que a degradação anaeróbia, quando o afluente possuía compostos de alto peso molecular, enquanto que compostos de baixo peso molecular eram melhor tratados, sob degradação anaeróbia.

Há um grande número de alternativas de operação de lodos ativados, das quais as mais importantes são descritas sucintamente abaixo (Rojas, 2000; Von Sperling, 2002):

a) Processo Convencional: nesse sistema a idade do lodo é de 4 a 10 dias e o tempo de detenção hidráulico é de 4 a 8 horas. No sistema de lodos ativados convencional, a concentração de biomassa é bastante elevada, devido a recirculação dos sólidos sedimentares no fundo do decantador secundário, o que proporciona uma elevada eficiência na remoção de matéria orgânica, expressa em termos de DBO. O fornecimento de oxigênio é feito por aeradores mecânicos ou por ar difuso. A montante do reator há uma unidade de decantação primária, de forma a remover os sólidos sedimentáveis do esgoto bruto.

b) Processo de Aeração Prolongada: nesse sistema a idade do lodo é de 20 a 30 dias e o tempo de detenção hidráulica é de 16 a 36 horas. A biomassa permanece mais tempo no sistema. Com isto, há menos DBO disponível para as bactérias, o que faz com que elas se utilizem da matéria orgânica do próprio material celular para a sua manutenção (respiração endógena), favorecendo a ocorrência de nitrificação. Em decorrência, o lodo excedente retirado já sai estabilizado. Não se incluem usualmente unidades de decantação primária. 
c) Reator Sequiencial em Batelada: a operação do sistema é intermitente. Assim, no mesmo tanque ocorrem, em fases diferentes, as etapas de reação e sedimentação. Quando os aeradores estão desligados, os sólidos sedimentam, ocasião em que se retira o efluente. Ao se religar os aeradores, os sólidos sedimentados retornam à massa líquida, o que dispensa as elevatórias de recirculação. Não há decantadores secundários. Pode ser na modalidade convencional ou aeração prolongada.

Segundo Metcalf \& Eddy (2003), são considerações importantes no processo de lodos ativados: a seleção do tipo de reator; produção de lodo; transferência e oxigênio requerido; nutrientes requeridos; controle de organismos filamentosos; características do efluente. Quanto à alimentação, valores típicos na literatura para a relação alimentomicrorganismo $(\mathrm{A} / \mathrm{M})$ variam entre 0,05 e 1,0 .

As eficiências tipicamente obtidas no tratamento com processo de lodo ativado e suas características hidráulicas são apresentadas na Tabela 1.2.

\subsubsection{Fatores que interferem no processo de lodos ativados}

Para que sejam mantidas condições ideais à microbiota presente no reator, devem ser observadas algumas condições:

\section{- Temperatura}

Esta variável exerce grande influência no metabolismo microbiano, afetando principalmente as taxas de oxidação das matérias carbonáceas e nitrogenada. A tendência de aumento da taxa de oxidação com a elevação da temperatura mantém até uma temperatura ótima, a partir de então a taxa decresce. Portanto, a faixa de temperatura torna-se relevante, pois apresenta um caráter seletivo, podendo acarretar alterações na biomassa presente no reator. A influência da temperatura decresce com a elevação da idade do lodo (Von Sperling, 2002). Em pesquisas envolvendo variações de temperatura em sistema de lodo ativado, constataram maior eficiência na remoção de carga orgânica 
quando a temperatura foi mantida na faixa entre 25 e $35^{\circ} \mathrm{C}$ (Metcalf \& Eddy, 2003; Morais, 2005).

Tabela 3.2 - Principais características dos sistemas de lodos ativados utilizados para o tratamento de esgotos domésticos

\begin{tabular}{|c|c|c|c|c|}
\hline Item geral & Item específico & Convencional & $\begin{array}{c}\text { Aeração } \\
\text { prolongada }\end{array}$ & $\begin{array}{c}\text { Mistura } \\
\text { Completa }\end{array}$ \\
\hline $\begin{array}{l}\text { Idade do } \\
\text { lodo }\end{array}$ & Idade do lodo (d) & 4 a 15 & 18 a 30 & 5 a 15 \\
\hline $\mathrm{TDH}$ & $\mathrm{TDH}(\mathrm{h})$ & 4 a 8 & 16 a 36 & 3 a 5 \\
\hline Relação A/M & (kgDBO/dia.kgSSVTA) & 0,25 a 0,50 & 0,07 a 0,15 & 0,20 a 0,60 \\
\hline \multirow{7}{*}{$\begin{array}{l}\text { Eficiência de } \\
\text { remoção }\end{array}$} & $\mathrm{DBO}(\%)$ & 85 a 95 & 93 a 98 & 85 a 95 \\
\hline & DQO $(\%)$ & 85 a 90 & 90 a 95 & 85 a 90 \\
\hline & Sólidos suspensos (\%) & 85 a 95 & 85 a 95 & - \\
\hline & Amônia (\%) & 85 a 95 & 90 a 95 & - \\
\hline & Nitrogênio (\%) & 25 a 30 & 15 a 25 & - \\
\hline & Fósforo (\%) & 25 a 30 & 10 a 20 & - \\
\hline & Coliformes (\%) & 60 a 90 & 70 a 95 & - \\
\hline \multirow{2}{*}{$\begin{array}{l}\text { Massa de } \\
\text { lodo }\end{array}$} & $\begin{array}{l}\text { A ser tratado } \\
\text { (g ST/hab.dia) }\end{array}$ & 60 a 80 & 40 a 45 & - \\
\hline & $\begin{array}{l}\text { A ser disposto } \\
\text { (g ST/hab.dia) }\end{array}$ & 30 a 45 & 40 a 45 & - \\
\hline
\end{tabular}

Fonte: adaptado de Rojas (2000), Von Sperling (2002), Jordão \& Pessoa (2005).

TDH - Tempo de Detenção Hidráulico

A/M - Alimento/Microrganismo

\section{- $\mathbf{p H}$}

Grande parte das bactérias não apresenta condições de sobrevivência em pH acima de 9,5 e abaixo de 4,0. A situação ótima para o desenvolvimento destes microrganismos é próximo a neutralidade, entre 6,5 e 7,5 (Morais, 2005). 


\section{- Oxigênio dissolvido}

A aeração em um sistema de lodo ativado tem como funções principais suprir a demanda de oxigênio dos microrganismos aeróbios para oxidação da matéria orgânica carbonácea e de nitrogênio, a oxigenação do efluente e manter o lodo ativado em suspensão através da turbulência provocada (Van Handel \& Marais, 1999). O tamanho das bolhas é outro fator importante, quanto menor o tamanho da bolha, maior a área superficial e mais eficiente a oxigenação (Von Sperling, 2002). Em geral, a concentração de oxigênio dissolvido no tanque de aeração deve ser mantida em torno de 2,0 mg/L. Na prática, se mantém essa concentração de 2 a 4 mg/L (Metcalf \& Eddy, 2003).

\section{- Nutrientes}

Os microrganismos presentes também possuem necessidades nutricionais. O equilíbrio entre esta relação para o desenvolvimento satisfatório da biomassa é descrito como 100:5:1, respectivamente para $\left.\mathrm{DBO}_{5}: \mathrm{N}: \mathrm{P}\right)$. Para a remoção de carga orgânica, é necessário que o carbono orgânico seja o nutriente limitante, enquanto o nitrogênio e o fósforo estejam disponíveis em maior quantidade que a mínima requerida pelos microrganismos (Metcalf \& Eddy, 2003).

\section{- Substrato}

Os microrganismos que constituem o lodo são quimioheterotróficos, ou seja, utilizam como fonte de carbono os substratos existentes, através do metabolismo. $\mathrm{O}$ metabolismo bacteriano é realizado em decorrência da remoção de substrato fazendo com que quanto mais alimento for processado, maior a taxa de crescimento. A disponibilidade de alimento relaciona-se não apenas com a concentração do substrato, mas também com a biodegradabilidade em relação aos microrganismos empregados no sistema. A concentração do substrato é representada por parâmetros como: DBO, DQO e COT. A biodegradabilidade do substrato pode ser expressa de diversas formas, porém a mais usual é a relação DBO/DQO, sendo uma razão de 0,3 utilizada como um referencial mínimo de biodegradabilidade para que um determinado efluente seja submetido a um tratamento biológico (Morais, 2005). 
- Toxicidade

Segundo Fernandes (1999), águas residuárias podem conter substâncias tóxicas inibidoras do metabolismo bacteriano. A presença dessas substâncias no reator biológico pode inibir a atividade das bactérias, reduzindo a eficiência do sistema e até levá-lo ao completo colapso.

Santana (1982) e Além Sobrinho (1983) citam vários elementos que podem ser tóxicos aos sistemas de lodos ativados, tais como: metais pesados como cromo, ferro, zinco e cobre, substâncias orgânicas como fenol e formaldeído, amônia e sais orgânicos.

Estudos indicam toxicidade de várias substâncias como amônia, salinidade, metais de zinco, cromo e cobre, que em elevadas concentrações podem inibir parcialmente a atividade microbiana e causar alterações na estrutura dos flocos do lodo ativado e levar à desfloculação. (Madoni et al.,1993; Jan chuboda, 1985; Wilén et. al., 2003 e Wei et al., 2009).

A inibição de funções vitais é a maneira mais usada para avaliar efeitos tóxicos. A respiração é um parâmetro confiável para se monitorar a toxidez aguda em microrganismos (Guimarães, 1995). Para avaliação do efeito de toxicidade, a taxa de consumo de oxigênio (TCO) serve como parâmetro fundamental.

\section{- Sólidos Suspensos Voláteis}

Representa a biomassa de um sistema de lodos ativados, ou seja, a concentração de microrganismos, caracterizando, portanto a biomassa do sistema (SSV). A qualidade do inóculo está diretamente relacionada com a capacidade de depuração do efluente (Morais, 2005). Quando a degradação do efluente não é suficiente, devem-se adotar mecanismos de adaptação biológica dos microrganismos ao efluente, ou seja, realizar a aclimatação destes microrganismos (seleção no consórcio de microrganismos das espécies que melhor se adaptem ao substrato). A razão STV/ST maior que 0,6 indica elevada quantidade de matéria orgânica, favorável à utilização desses em sistema de tratamento biológico (Mendonça, 2002). 


\subsubsection{Variáveis envolvidas no controle operacional do processo de lodos ativados}

Em uma estação de tratamento de efluentes, para se obter eficiência satisfatória do processo, de forma a reduzir a variabilidade da qualidade do efluente, evitar grandes falhas e reduzir custos de operação é necessária a implementação do controle operacional (Von Sperling, 2002).

As variáveis fundamentais para o controle da operação do processo de lodos ativados são: relação alimento-microrganismo (A/M); carga orgânica volumétrica (COV); tempo de detenção hidráulica (TDH); tempo de retenção celular ou idade do lodo $\left(\theta_{\mathrm{C}}\right)$; concentração de sólidos suspensos voláteis no tanque de aeração (SSVTA); índice volumétrico do lodo (IVL), Taxa de consumo de oxigênio (TCO); e acompanhamento da floculação e da diversidade microbiana como indicadora de depuração microbiológica (Morais, 2005).

Considerando as notações apresentadas na Figura 1.3, são dadas as definições das seguintes variáveis:

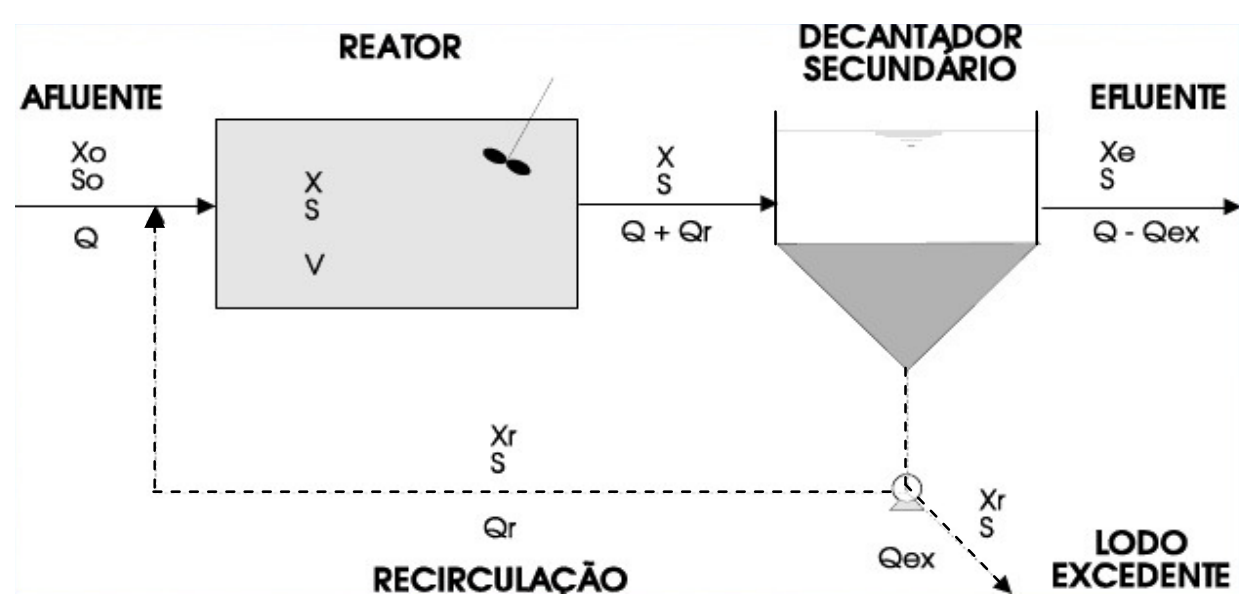

Q- vazão afluente (L/h); $\mathrm{Q}_{\mathrm{ex}}$ - vazão excedente/ de descarte (L/h); $\mathrm{S}_{0}$ - concentração de DBO afluente $\left(\mathrm{kg} / \mathrm{m}^{3}\right) ; \mathrm{V}$ - volume do reator $\left(\mathrm{m}^{3}\right) ; \mathrm{X}_{\mathrm{v}}$ - concentração de sólidos suspensos voláteis (SSVTA-g/m $\left./ \mathrm{m}^{3}\right) ; X_{\mathrm{vr}}$ - concentração de sólidos suspensos voláteis na linha de retorno (SSVR$\left.\mathrm{kg} / \mathrm{m}^{3}\right) ; X_{\mathrm{ve}}$ - concentração de sólidos suspensos voláteis no efluente $\left(\mathrm{SSV}-\mathrm{kg} / \mathrm{m}^{3}\right)$.

Figura 3.3 - Reator biológico com recirculação de lodo (sistema de lodos ativados).

Von Sperling (2002). 
- Relação Alimento/Microrganismos (A/M): Também conhecida como carga de lodo, a razão está relacionada ao conceito de que a quantidade de alimento ou substrato disponível por unidade de massa dos microrganismos está diretamente relacionada com a eficiência do sistema. Ou seja, quanto maior a relação A/M (DBO fornecida) menor será a assimilação deste substrato, porém o volume do reator é menor. Ao contrário, quando a relação A/M é baixa, maior será a necessidade de alimento, bem como a eficiência do sistema, necessitando de um volume de reator maior (Von Sperling, 2002).

$$
A / M=\frac{Q \cdot S_{0}}{V \cdot X_{V}},(\mathrm{kgDBO} / \mathrm{kgSSV} \cdot \mathrm{dia})
$$

- Carga orgânica (CO): a razão está relacionada à quantidade de alimento ou substrato disponível por unidade de tempo (dia).

$$
C O=Q \cdot S_{0},(\mathrm{kgDBO} / \mathrm{dia})
$$

- Tempo de Detenção Hidráulica (TDH): é o tempo médio que o efluente líquido permanece no reator. É representado pela relação entre o volume do tanque e a vazão do sistema (Rodrigues, 2007).

$T D H=\frac{V}{Q}, \quad$ (horas)

- Idade do lodo ou tempo de retenção celular $(\boldsymbol{\theta c})$ : consiste no quociente entre a massa de sólidos no sistema e massa de sólidos retirada do sistema por unidade de tempo (Von Sperling, 2002). Ou seja, este parâmetro indica o tempo médio de permanência do lodo no sistema. Depois de determinada a idade de lodo, a manutenção da mesma deve ser mantida através da descarga adequada do excesso de lodo (Medeiros, 2005). Para o cálculo da vazão de lodo excedente (descarte) na linha de recirculação ou diretamente do tanque de aeração (controle hidráulico), fixa-se a idade do lodo.

$\theta_{c}=\frac{X_{V} \cdot V}{Q_{e x} \cdot X_{v r}},($ dias $)$ 
O gráfico da figura 3.4 apresenta a relação entre a redução da DBO em função da idade do lodo e da relação A/M ou taxa de aplicação em sistema de lodos ativados

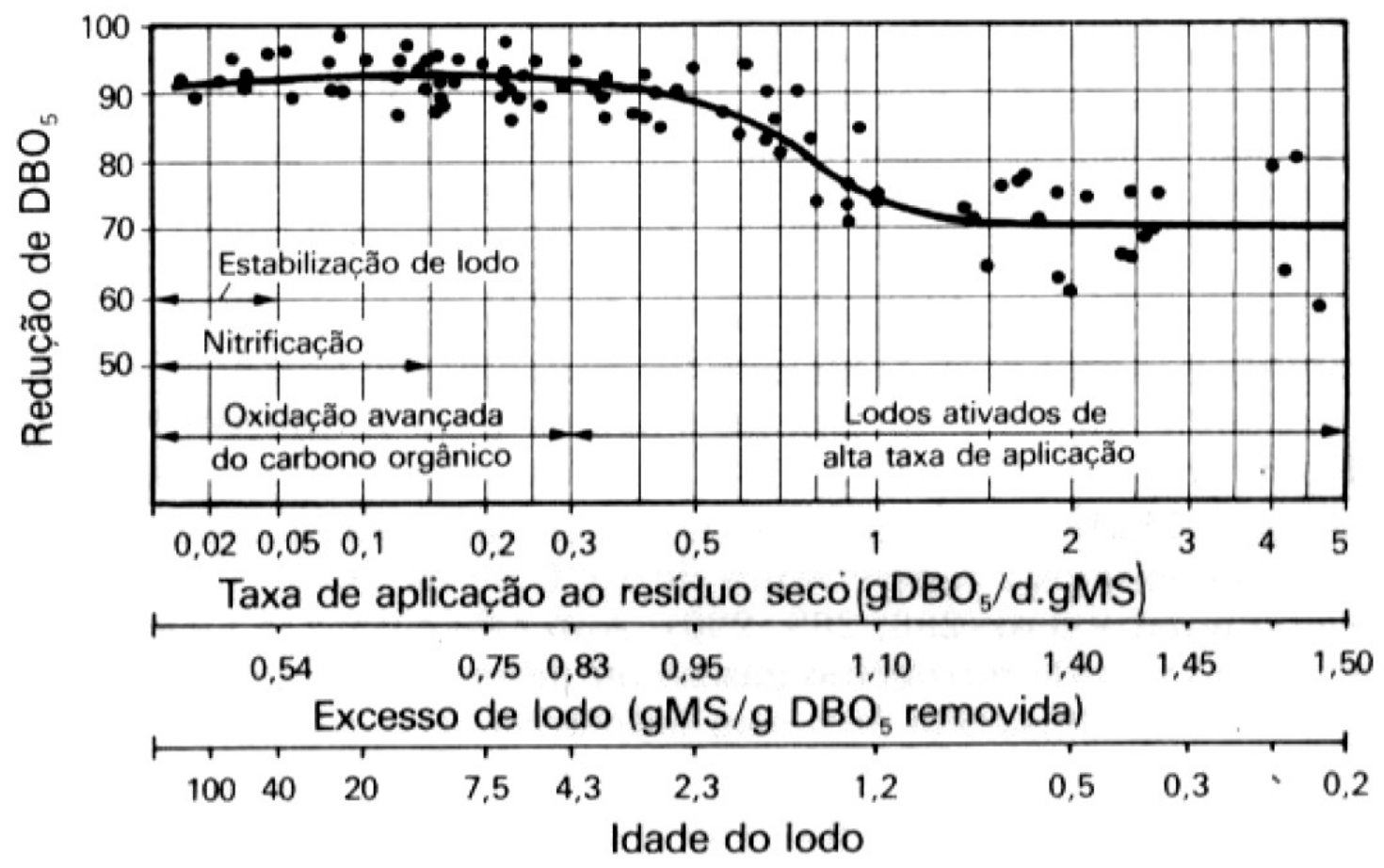

Figura 3.4 - Redução da DBO em função da idade do lodo e da relação A/M ou taxa de aplicação em sistema de lodos ativados. Acqua Engenharia (2010).

- Índice Volumétrico do Lodo (IVL): Representa o volume ocupado por $1 \mathrm{~g}$ de lodo após a sedimentação em Cone Imhoff ou proveta de $1 \mathrm{~L}$ de lodo durante 30 minutos. Valores de IVL maiores que $200 \mathrm{~mL} / \mathrm{g}$ indicam frequência de aparecimento de filamentos variando de muito comuns a abundante (Parker et al., 2001).

$$
I V L=\frac{V_{S S e d, 30 \min } \cdot 10^{3}}{S S T A},(\mathrm{~mL} / \mathrm{g})
$$

Onde,

$\mathrm{V}_{\mathrm{SSed}}$,30min - Volume de sólidos sedimentáveis em 30 minutos (mL/L); SSTA Sólidos suspensos no tanque de aeração (mg/L). 
- Taxa Específica de Utilização de Substrato (U): Envolve a carga de substrato removida, enquanto que a relação alimento/microrganismos considera a carga aplicada. Portanto, expressa a velocidade com que o substrato é consumido pela unidade de massa de organismo. Os valores de $U$ variam de 0,06 a 1,10 kgDBO/kgSSVTA.dia (Jordão \& Pessoa, 2009).

$U=\frac{Q \cdot\left(S_{0}-S\right)}{V \cdot X_{V}},(\mathrm{kgDBO} / \mathrm{kgSSV} \cdot \mathrm{dia})$

- Taxa de Consumo de Oxigênio (TCO): Em processos aeróbios, os microrganismos utilizam oxigênio para seu desenvolvimento. A taxa com que esse oxigênio é consumido é denominada de taxa de consumo de oxigênio (TCO) ou taxa de utilização do oxigênio. $O$ teste da taxa de consumo de oxigênio é utilizado para determinar a velocidade da atividade biológica nos sistemas de tratamento aeróbio com lodo em suspensão, em que alta taxa de consumo de oxigênio indica alta atividade biológica e vice-versa. A respirometria permite avaliar o efeito tóxico de algum componente afluente. Na maioria dos sistemas de lodos ativados, a TCO situa-se entre 30 e $100 \mathrm{mgO}_{2} /$ L.h: taxa baixa e taxa alta, respectivamente (Van Haandel \& Marais, 1999).

- Coeficiente de Transferência de Oxigênio $\left(K_{L} \mathbf{a}\right)$ : coeficiente que permite calcular a capacidade de oxigenação e taxa de transferência de oxigênio. São parâmetros importantes para se conhecer a real capacidade de produção e transferência de massa de oxigênio no reator nas condições reais de operação (Von Sperling, 2002).

\subsubsection{Microbiologia do processo de lodos ativados}

O processo de lodos ativados consiste primeiramente, na assimilação da matéria orgânica por uma massa ativa de microrganismos em suspensão. Posteriormente, a ocorrência de floculação dos microrganismos e outros materiais coloidais em suspensão 
tornam a biomassa (massa biológica), ou floco, sedimentável, o que determina a produção de um efluente de qualidade elevada (McKinney, 1962).

A floculação ou aglutinação biológica permite a separação dos microrganismos em suspensão, do meio líquido, dentro do decantador secundário, proporcionando assim, o seu retorno ao tanque de aeração. Por conseguinte, a eficiência global do processo de lodos ativados e, consequentemente, a qualidade do efluente final são diretamente dependentes da formação e sedimentabilidade do floco biológico (Laranjeira Filho, 1989; Maciel, 2002).

Dessa forma, o floco de lodo ativado, além de desempenhar um papel fundamental no processo de remoção da matéria orgânica, permite que os principais microrganismos envolvidos se organizem na unidade estrutural do floco, sendo capaz de se separar do líquido por sedimentação, em unidades de sedimentação, permitindo que o efluente esteja clarificado.

Baseado em estudos de suspensões de bactérias, chegou-se à conclusão que a aglutinação de bactérias (formação de flocos) é o resultado de forças físicas de atração e de repulsão e pela liberação de substâncias poliméricas extracelulares (EPS), que possuem cargas negativas em pH próximo de 7 (Branco, 1986; Li \& Ganczarczyk, 1990; Urbain, et al, 1993; Jenkis, 2003; Sheng et al., 2010).

As condições do sistema de lodos ativados estão sob constante modificações, e fatores como forças iônicas, $\mathrm{pH}$, adição de surfactantes, temperatura, presença de sulfito e condições anaeróbias podem alterar significativamente a estabilidade do floco (Mikkelsen et al., 1996; Willen, 2000; Mikkelsen et al., 2001).

As bactérias, protozoários e metazoários são os constituintes principais da microestrutura dos flocos, e o equilíbrio entre as bactérias formadoras de flocos e as filamentosas (macroestrutura) é determinante para que as mesmas apresentem uma boa estrutura. Caso não ocorra equilíbrio, e os organismos filamentosos predominem, é formada uma microestrutura prejudicando a sedimentação dos flocos (Jenkis, 2003).

Os flocos de lodo ativado são compostos por dois níveis de estrutura: a micro e a macroestrutura. A microestrutura corresponde aos processos de adesão microbiana e biofloculação. A macroestrutura é composta pelos organismos filamentosos, que formam uma espécie de rede no interior dos flocos onde as bactérias aderem (Morais, 2005; Jordão \& Pessoa, 2009). A Figura 3.5 apresenta o modelo de floco de lodo ativado proposto por Sheng (2006). 


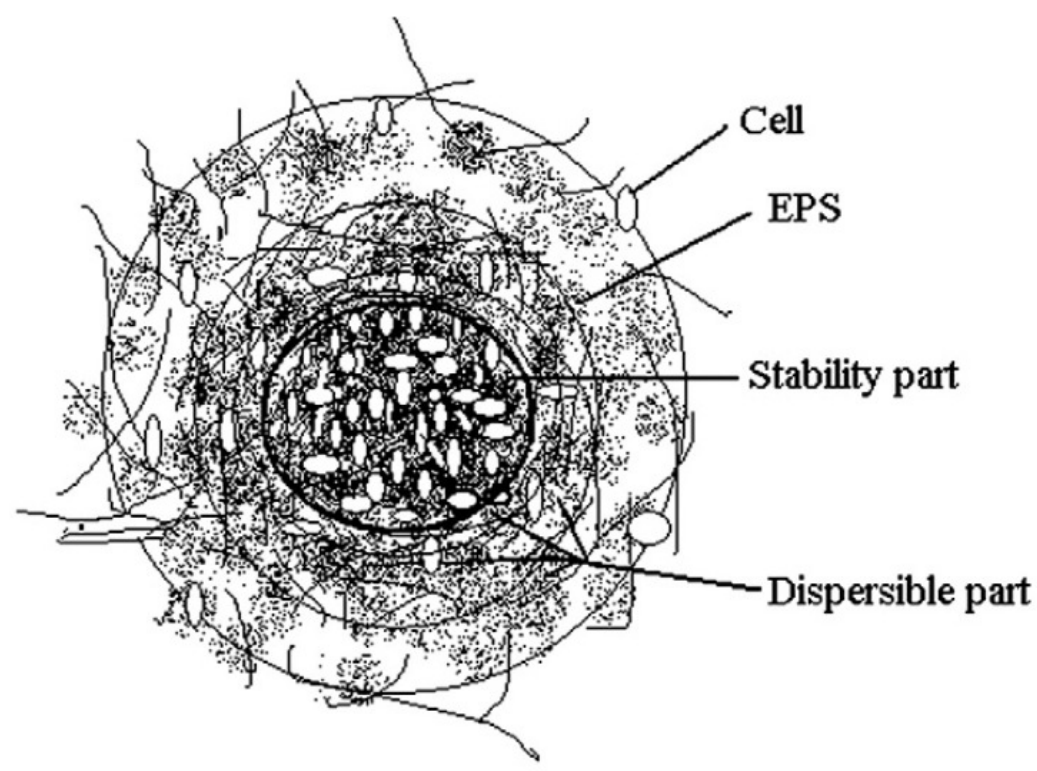

Figura 3.5 - Modelo estrutural de multi-camadas de flocos de lodo ativado.

(Sheng et al.,2006)

Em processos de lodos ativados, os principais constituintes da microbiota são representados por: decompositores (bactérias e fungos), que utilizam a matéria orgânica dissolvida; e pelos consumidores (protozoários e micrometazoários), que se alimentam dos pequenos organismos e bactérias em suspensão (Madoni,1994; Cordi, 2003).

A microbiota desempenha um importante papel no sistema de lodos ativados por clarificar o efluente, consumindo a matéria orgânica, e por ser o predador de bactérias, estimulando, desta forma, o crescimento das mesmas para decomposição de nutrientes e compostos específicos. A microbiota é um indicador do conjunto de parâmetros de lodos ativados, uma vez que sua natureza varia com o nível de depuração, concentração de oxigênio dissolvido e presença de substâncias tóxicas dentro do tanque de aeração (Maciel, 2002).

A natureza da microbiota presente é característica da idade do lodo, que é o tempo médio de permanência do lodo no reator e da relação A/M (Figura 3.6). É também característica da saprobicidade, nível de qualidade da água refletido pelas espécies que constituem a comunidade presente de acordo com a matéria orgânica biodegradável, expressa em DBO (Vazzoler, 1989). 


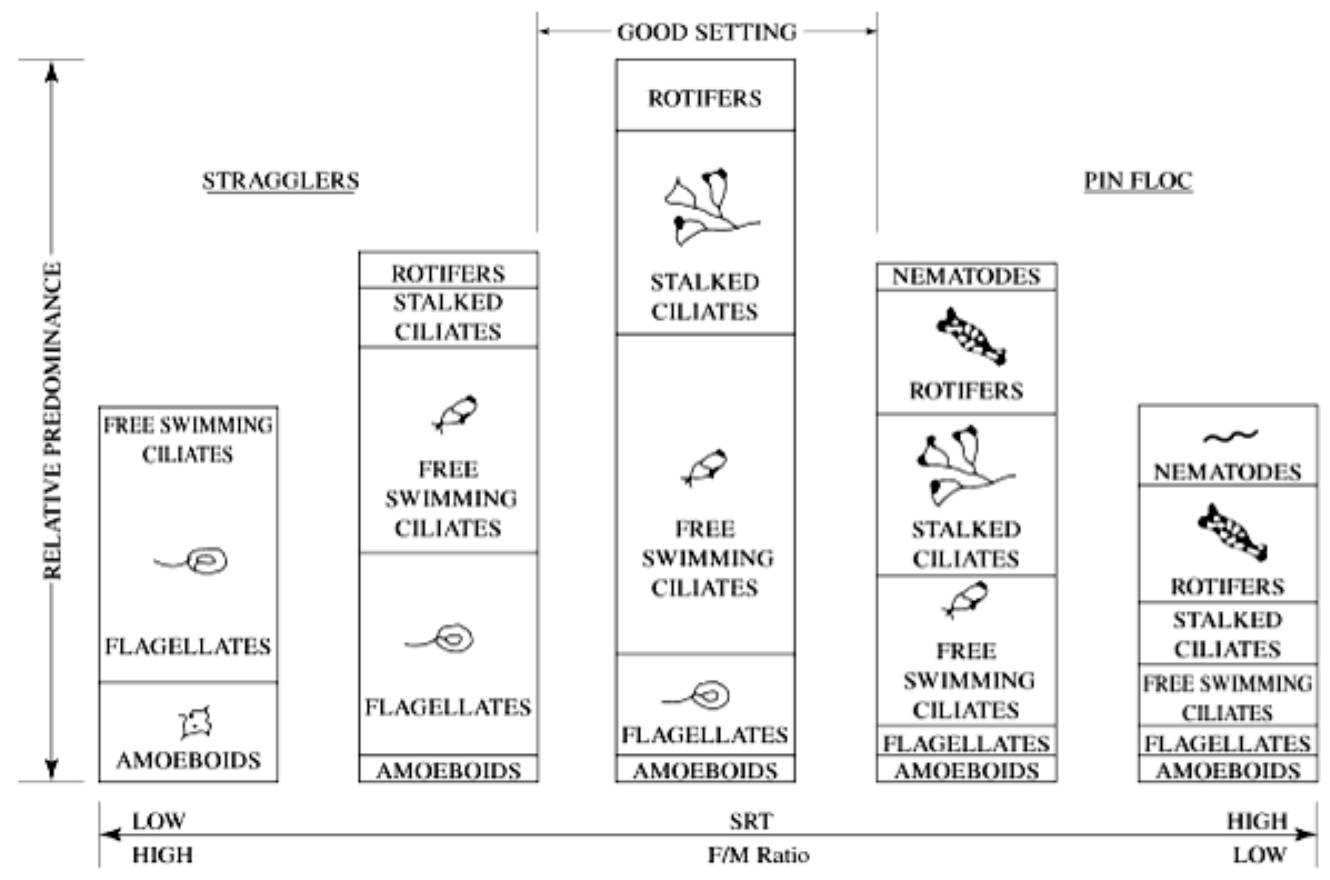

Figura 3.6 - Predomínio relativo de microrganismos versus idade do lodo e relação A/M (Jenkis et al., 2003)

A comunidade estabelecida nesse sistema é dinâmica e fundamental ao tratamento, sendo que cada espécie tem sua importância para o bom funcionamento do sistema. A estrutura dessa comunidade apresenta forte relação com as condições operacionais e com a qualidade e quantidade de efluente que alimenta o processo, de modo que a avaliação microbiológica do lodo é capaz de fornecer informações sobre o desempenho do sistema (Poole, 1984; Vazzoler, 1989; Amman et al., 1997).

Observações microscópicas rotineiras fornecem informações importantes sobre a condição da população microbiana no processo de lodos ativados. Informações específicas aliadas a mudanças no tamanho e densidade dos flocos, a posição do crescimento dos organismos filamentos no floco, a presença de determinadas espécies, e o tipo e abundância das formas de vida superiores como protozoários e rotíferos. Mudanças nessas características podem fornecer uma indicação de alterações nas características da água residuária ou de um problema operacional (Metcalf \& Eddy, 2003).

A seguir são sucintamente descritos os principais microrganismos frequentemente presentes em sistemas de lodos ativados: 


\section{- Bactérias}

São microrganismos responsáveis pela decomposição da matéria orgânica presente e pela formação do floco. No tanque de aeração, as bactérias aeróbias e facultativas oxidam a matéria orgânica a compostos de baixa energia, como nitratos, sulfatos e gás carbônico, e sintetizam o material orgânico remanescente em novas células (Braile \& Cavalcanti, 1993).

As formas mais comuns desses microrganismos são bacilos, cocos e espirilos. A bactéria heterótrofa formadora de floco, Zoogloea, é frequentemente observada em sistemas de lodos ativados. Dentre as principais bactérias heterótrofas frequentemente presentes em sistemas de lodos ativados, são citadas as dos gêneros Achromobacterium, Chromobacterium e Pseudomonas (Jenkins, 2003; Bitton, 2005).

Dentre os microrganismos filamentosos, Sphaerotilus natans é o mais comumente encontrada em lodos ativados, porém os dos gêneros Thiothrix, Beggiatoa e Nocardia são também observados (CETESB, 1989).

O aparecimento de bactérias filamentosas em sistemas aeróbios é favorecido pela escassez de nutrientes, baixa concentração de OD, baixa carga orgânica, elevada concentração de compostos de baixo peso molecular, presença de compostos reduzidos de enxofre, dentre outros (Jenkins et al., 2003)

Em alguns sistemas combinados anaeróbio/aeróbio, ocorre a presença de alguns tipos de filamentos, devido à baixa carga orgânica e escassez de nutrientes, visto que a maior parcela dos compostos orgânicos e inorgânicos é degradada no reator anaeróbio (Wanner et al.,1987; Nilsen \& Keiding, 1997; Mendonça, 2002).

A seguir são descritos resumidamente os microrganismos frequentemente presentes em sistemas de lodos ativados:

\section{- Protozoários}

Os protozoários são protistas microscópicos móveis, geralmente unicelulares e aeróbios heterótrofos, embora poucos sejam anaeróbios. Geralmente são maiores que as bactérias e atuam como polidores dos efluentes dos processos biológicos de tratamento de águas residuárias, pois consomem bactérias e matéria orgânica particulada (Metcalf \& Eddy, 2003). 
Os microrganismos envolvidos no processo de lodos ativados são identificados empregando-se observações microscópicas possibilitando verificar as condições de depuração do processo biológico. A Tabela 3.3 apresenta uma relação de alguns gêneros indicadores frequentemente apresentados na literatura.

Tabela 3.3 - Microrganismos indicadores das condições de depuração em condições aeróbias

\begin{tabular}{|c|c|}
\hline Microrganismo & Características do Processo \\
\hline Predominância de flagelados e rizópodes & $\begin{array}{r}\text { Lodo jovem, característico de início } \\
\text { de operação ou idade do lodo baixa }\end{array}$ \\
\hline Predominância de flagelados & $\begin{array}{l}\text { Deficiência de aeração, má } \\
\text { depuração e sobrecarga orgânica }\end{array}$ \\
\hline Predominância de ciliados pedunculares e livres & Boas condições de depuração \\
\hline Presença de Arcella (rizópode com teca) & Boa depuração \\
\hline Presença de Aspidisca costata (ciliado livre) & Nitrificação \\
\hline Presença de Trachelophyllum (ciliado livre) & Idade do lodo elevada \\
\hline $\begin{array}{l}\text { Presença de Vorticella microstoma (ciliado } \\
\text { peduncular) e baixa concentração de ciliados livres }\end{array}$ & Efluente de má qualidade \\
\hline Predominância de anelídeos do gênero Aelosoma & Excesso de oxigênio dissolvido \\
\hline Predominância de filamentos & $\begin{array}{r}\text { Intumescimento do lodo ou bulking } \\
\text { filamentoso* }\end{array}$ \\
\hline
\end{tabular}

* Para caracterizar o intumescimento do lodo é necessário avaliar os flocos

Fonte: Vallozer (1989)

Os protozoários são universalmente usados como organismos indicadores das condições de estabilização de sistemas de lodos ativados. As características dos protozoários, bem como a relação das condições de depuração de sistemas de lodos ativados estão descritas na Tabela 3.4. 
Tabela 3.4 - Microrganismos protozoários indicadores das condições de depuração em sistema de lodos ativados.

\begin{tabular}{|c|c|c|c|}
\hline Protozoários & Características fisiológicas & Condições do sistema & Exemplos \\
\hline $\begin{array}{l}\text { Ciliados fixos } \\
\text { (Classe ciliata) }\end{array}$ & $\begin{array}{l}\text { Protozoários em forma peduncular (contrácteis), } \\
\text { possuindo cílios utilizados na sua alimentação, } \\
\text { sendo ligados ao floco por uma haste que serve } \\
\text { como apoio. }\end{array}$ & $\begin{array}{l}\text { Sua predominância indica boas condições de } \\
\text { depuração do sistema, operação estável e formação de } \\
\text { flocos com boas características de sedimentabilidade. } \\
\text { Geralmente estão associados à baixa carga orgânica } \\
\text { (A/M) e elevada idade do lodo. }\end{array}$ & $\begin{array}{l}\text { Opercularias sp. } \\
\text { Vorticellas sp. } \\
\text { Epistylis sp. } \\
\text { Carchesium sp. }\end{array}$ \\
\hline $\begin{array}{l}\text { Ciliados livres } \\
\text { (Classe ciliata) }\end{array}$ & $\begin{array}{l}\text { O cílio responsável pela alimentação é bem mais } \\
\text { desenvolvido que os demais. Alimentam-se de } \\
\text { partículas que aderem levemente ao floco, e } \\
\text { mudam a alimentação com frequência. }\end{array}$ & $\begin{array}{l}\text { Indicam boas condições de depuração do sistema, } \\
\text { operação estável e formação de flocos com boas } \\
\text { características de sedimentabilidade. São sensíveis e } \\
\text { sua presença ou ausência pode indicar toxicidade. }\end{array}$ & $\begin{array}{l}\text { Euplotes sp. } \\
\text { Aspidisca sp. } \\
\text { Paramecium } s p \\
\text { Lionotus sp. } \\
\text { Spirostomum sp. }\end{array}$ \\
\hline $\begin{array}{c}\text { Flagelados } \\
\text { (Classe } \\
\text { Mastigophora) }\end{array}$ & $\begin{array}{l}\text { Os flagelados caracterizam-se pela locomoção por } \\
\text { meio de organelas especiais denominadas } \\
\text { flagelos, em forma de filamento alongado que } \\
\text { executam movimento ondulatório na água, } \\
\text { propelindo o animal para o próprio lado ou para o } \\
\text { lado oposto ao da inserção do flagelo. }\end{array}$ & $\begin{array}{l}\text { Consomem matéria orgânica solúvel por difusão ou } \\
\text { transporte ativo. Sua predominância indica quantidade } \\
\text { levada de matéria orgânica solúvel. } \\
\text { Sua presença pode indicar níveis significantes de } \\
\text { DBO. Alguns flagelados aparecem em condições de } \\
\text { baixas concentrações de OD e elevada carga orgânica. }\end{array}$ & $\begin{array}{l}\text { Bodo sp., } \\
\text { Pleuromonas sp. } \\
\text { Monosiga sp. } \\
\text { Hexamitus sp. } \\
\text { Poteriodendron sp. }\end{array}$ \\
\hline $\begin{array}{c}\text { Rizópodes } \\
\text { (Classe } \\
\text { Sarcodina) }\end{array}$ & $\begin{array}{l}\text { As amebas caracterizam-se, primeiramente, pela } \\
\text { locomoção por meio de pseudópodos, que são } \\
\text { organelas transitórias, constituídas por simples } \\
\text { prolongamentos protoplasmáticos que se formam } \\
\text { em qualquer ponto da célula, por uma } \\
\text { fluidificação da substância coloidal }\end{array}$ & $\begin{array}{l}\text { Indicam elevada concentração de matéria orgânica } \\
\text { particulada e toleram baixas concentrações e oxigênio } \\
\text { dissolvido; Alguns indicam ocorrência de nitrificação. }\end{array}$ & $\begin{array}{l}\text { Amoeba sp. } \\
\text { Euglypha sp. } \\
\text { Arcella sp. } \\
\text { Centropyxis sp. } \\
\text { Difflugia sp. }\end{array}$ \\
\hline
\end{tabular}

Adaptado de: Gerardi (2002); Jenkis et al., (2003); Mara \& Horan (2003); Bitton (2005) Madoni (2010). 


\section{- Micrometazoários}

Diferente das bactérias e dos protozoários, os metazoários (rotíferos, nematóides e anelídeos) são organismos pluricelulares. O tipo de sua reprodução depende das condições do ambiente em que estão presentes, podendo ser sexuada, assexuada ou alternando (WEF, 1990).

Os metazoários mais frequentes no processo de lodos ativados são os rotíferos, que são muito eficientes no consumo de bactérias dispersas ou aderidas a flocos e de pequenas partículas de matéria orgânica (Metcalf \& Eddy, 2003).

As características dos micrometazoários, bem como a relação das condições de depuração de sistemas de lodos ativados estão descritas na Tabela 3.5.

\subsubsection{Sistema de lodos ativados como pós-tratamento de efluentes}

A utilização de sistemas de tratamento de esgoto por via anaeróbia tem apresentado eficiências elevadas no que se refere à remoção de matéria carbonácea. Entretanto, devido à maior restrição imposta pelos padrões de emissão de efluentes e de qualidade das águas dos corpos receptores, torna-se necessário remover parte da carga remanescente de forma a atender à legislação.

O sistema combinado anaeróbio/aeróbio tem demonstrado ser uma opção viável, tanto técnica como economicamente, para o tratamento de esgoto sanitário, visto que promovem remoção de matéria carbonácea, nitrificação e desnitrificação, permitindo que os padrões de lançamento sejam atingidos, sendo notável o emprego destes sistemas em ETE de cidades de médio e grande porte.

Dentre os sistemas biológicos, pesquisados ou aplicados para tratamento de lixiviado, o processo aeróbio é o mais utilizado, empregando-se preferencialmente sistemas de crescimento suspenso similares ao sistema de lodos ativados, contínuos e em bateladas (Li \& Zhao, 2001; Neczad et al., 2007; Ferreira et al., 2009; Franco, 2009; Marques et al., 2010). 
Tabela 3.5 - Microrganismos micrometazoários indicadores das condições de depuração em sistema de lodos ativados.

\begin{tabular}{|c|c|c|c|}
\hline Micrometazoários & Características fisiológicas & Condições do sistema & Exemplos \\
\hline $\begin{array}{l}\text { Rotíferos } \\
\text { (Filo Rotifera) }\end{array}$ & $\begin{array}{l}\text { O corpo possui tronco e cauda afilada, que está } \\
\text { frequentemente articulada, com pés tendo as } \\
\text { glândulas adesivas para a fixação; a extremidade } \\
\text { anterior, com disco troncal contendo cílios, é } \\
\text { usada para locomoção e alimentação. Os } \\
\text { rotíferos alimentam-se de algas unicelulares, } \\
\text { plantas, protozoários, rotíferos menores e } \\
\text { bactérias. }\end{array}$ & $\begin{array}{l}\text { Eles ajudam remover bactérias em suspensão e } \\
\text { outras partículas menores, contribuindo para } \\
\text { clarificação da água residuária. Estes } \\
\text { microrganismos são bons indicadores do processo } \\
\text { de estabilização da matéria orgânica no efluente. } \\
\text { Esses organismos ocorrem em ampla faixa de idade } \\
\text { de lodo. }\end{array}$ & $\begin{array}{l}\text { Philodinavus sp. } \\
\text { Rotaria sp. } \\
\text { Epiphanes sp. } \\
\text { Lecane sp. }\end{array}$ \\
\hline $\begin{array}{l}\text { Nematoides } \\
\text { (Filo Nematoda) }\end{array}$ & $\begin{array}{l}\text { Apresentam o corpo cilíndrico, delgado, } \\
\text { frequentemente afilado nas extremidades, sem } \\
\text { segmentação ou cílios; coberto com uma } \\
\text { cutícula dura. Contam somente com músculos } \\
\text { longitudinais, produzindo movimentos de } \\
\text { flexão, mas não para alongamento ou contração. } \\
\text { Possuem um anel anterior e seis cordões } \\
\text { nervosos longitudinais na cabeça. São bem } \\
\text { maiores que os protozoários. }\end{array}$ & $\begin{array}{l}\text { Ainda não são amplamente utilizados como } \\
\text { indicadores das condições do processo e são } \\
\text { regularmente encontrados em sistema de lodos } \\
\text { ativados com baixa carga orgânica. Geralmente } \\
\text { estão relacionados à idade elevada do lodo e } \\
\text { condições avançadas de estabilização. }\end{array}$ & $\begin{array}{l}\text { Rhabditis } s p . \\
\text { Macrobiotus } s p \text {. } \\
\text { Ascaris } s p . \\
\text { Necator } s p \text {. }\end{array}$ \\
\hline $\begin{array}{l}\text { Anelídeos } \\
\text { (Filo Annelida) }\end{array}$ & $\begin{array}{l}\text { São vermes alongados, aeróbios, multicelulares } \\
\text { e de reprodução geralmente sexuada. Podem ser } \\
\text { observados segmentos ou anéis articulados em } \\
\text { toda sua extensão. }\end{array}$ & $\begin{array}{l}\text { São os metazoários menos frequentes em lodos } \\
\text { ativados. Alguns anelídeos aparecem em condições } \\
\text { de altas concentrações de OD e elevada idade do } \\
\text { lodo. }\end{array}$ & Aelosoma sp. \\
\hline
\end{tabular}

Adaptado de: Gerardi (2002); Jenkis et al., (2003); Mara \& Horan (2003); Bitton (2005) Madoni (2010). 
O sistema de lodos ativados quando utilizado como pós-tratamento de efluentes de reatores anaeróbios tipo UASB, pode ser uma alternativa bastante promissora, uma vez que no reator UASB ocorre alta taxa de remoção de material orgânico presente no esgoto sanitário (Von Sperling, 2002)

Como pós-tratamento de efluentes de processos anaeróbios em pesquisas na Escola de Engenharia de São Carlos, Universidade de São Paulo, foram empregados processos aeróbios para esgoto sanitário, em especial sistemas de lodos ativados. Segundo Colleti, et al. (1997), esta alternativa resulta em menor consumo de energia e menor produção de lodo, pois ocorre substancial remoção de matéria orgânica no processo anaeróbio com baixo consumo de energia. Ao mesmo tempo, o lodo aeróbio gerado pela remoção do remanescente de matéria orgânica, em virtude do seu menor volume, pode ser digerido em reator anaeróbio.

\subsubsection{Remoção de nitrogênio em sistema de lodos ativados}

No esgoto o nitrogênio está presente principalmente na forma de amônia ou nitrogênio orgânico; nitrato $\left(\mathrm{NO}_{3}^{-}\right)$e nitrito $\left(\mathrm{NO}_{2}^{-}\right)$não são comuns. Na forma solúvel, o nitrogênio orgânico em sua maioria é encontrado na forma de uréia e aminoácidos. (Gerardi, 2002).

A remoção biológica de nitrogênio em águas residuárias envolve dois processos principais: nitrificação e desnitrificação.

A reação de nitrificação ocorre em duas etapas: uma feita pelas bactérias autotróficas Nitrossomonas e a segunda feita pelas Nitrobacter.

A nitritação é a primeira etapa para a nitrificação, sendo tradicionalmente definida como a oxidação da amônia $\left(\mathrm{NH}_{4}^{+}\right)$a nitrito $\left(\mathrm{NO}_{2}^{-}\right)$.

$$
2 \mathrm{NH}_{4}{ }^{-}+3 \mathrm{O}_{2} \stackrel{\text { Nitrossomonas }}{\longrightarrow} 2 \mathrm{NO}_{2}{ }^{-}+4 \mathrm{H}^{+}+2 \mathrm{H}_{2} \mathrm{O} \quad \text { Eq. (1) }
$$

Na segunda etapa, chamada nitratação, o nitrito é oxidado a nitrato, conforme equação:

$$
2 \mathrm{NO}_{2}{ }^{-}+\mathrm{O}_{2} \stackrel{\text { Nitrobacter }}{\longrightarrow} 2 \mathrm{NO}_{3}{ }^{-}
$$


Durante a oxidação do íon amônio ocorre considerável consumo de alcalinidade. Segundo Metcalf e Eddy (2003), para cada $1 \mathrm{mg} / \mathrm{L}$ de amônia oxidada há o consumo de $7,14 \mathrm{mg} / \mathrm{L}$ de alcalinidade expressa por $\mathrm{CaCO}_{3}$.

A concentração de OD em sistemas biológicos pode ser um interferente para o crescimento das nitrificantes. Segundo Giradi (2002), o valor de OD deve ser igual ou superior a 2,0 $\mathrm{mgO}_{2} / \mathrm{L}$. Ferreira (2000) menciona que "taxas e velocidades ótimas podem ser obtidas com níveis de OD da ordem de 4,0 $\mathrm{mgO}_{2} / \mathrm{L}$ desde que exista uma população ótima de bactérias nitrificadoras."

Metcalf \& Eddy (2003) recomendam que o pH esteja na faixa de 7,2 a 9,0.

Há uma relação entre a idade do lodo e a concentração de nitrogênio amoniacal no efluente, sendo que a alta idade do lodo pode ser favorável ao processo de nitrificação (Ferreira, 2000).

A efetividade do processo de nitrificação depende da habilidade dos organismos nitrificantes em oxidar amônia a nitrato. Fatores como $\mathrm{pH}$, temperatura, número de microrganismos, presença de determinados compostos orgânicos e inorgânicos podem inibir o crescimento e consequentemente a ação destes organismos. Entretanto, segundo Anthonisen et al. (1976) e Abreu (1994), os dois fatores mais importantes são amônia e nitrito, sendo que as formas não ionizadas como amônia livre $\left(\mathrm{NH}_{3}\right)$ e ácido nitroso $\left(\mathrm{HNO}_{2}\right)$ possuem efeito inibitório sobre as Nitrossomonas e Nitrobacter, em concentrações acima de 10 a $150 \mathrm{mg} / \mathrm{L}$ e de 0,2 a 2,8 mg/L, respectivamente.

A desnitrificação é o segundo processo para a remoção biológica de nitrogênio presente em águas residuárias. A transformação do nitrogênio na forma de nitrato $\left(\mathrm{NO}_{3}{ }^{-}\right.$ ) para nitrogênio gasoso $\left(\mathrm{N}_{2}\right)$ é realizada sobre condições anóxicas (ausência de oxigênio molecular). Os compostos de nitrogênio ( $\mathrm{NO}^{-}$e $\mathrm{NO}^{-}$) são oxidados a nitrogênio gasoso por microrganismos heterotróficos que usam o nitrato como aceptor de elétrons e matéria orgânica como fonte de energia e carbono (Gerardi, 2002). Esse processo de redução está apresentado de forma simplificada pela equação:

$$
\mathrm{NO}_{3}^{-} \rightarrow \mathrm{NO}_{2}^{-} \rightarrow \mathrm{NO} \rightarrow \mathrm{N}_{2} \mathrm{O} \rightarrow \mathrm{N}_{2}
$$

Por envolver a atuação de organismos heterótrofos, o processo da desnitrificação requer matéria orgânica como fonte de carbono para sua síntese celular. Essa fonte pode 
ser fornecida por fontes internas (esgoto ou material celular) ou externas (por exemplo, metanol) (Metcalf \& Eddy, 2003).

Os fatores que exercem maior influência sobre o processo de desnitrificação são: tipo e concentração do substrato, concentração de oxigênio dissolvido, concentração de nitrato, temperatura e pH (Garcia, 2005). De acordo com Metcalf \& Eddy (2003), durante o processo de desnitrificação há produção de alcalinidade, resultando no aumento do valor de $\mathrm{pH}$. Os valores ótimos de $\mathrm{pH}$ para diferentes gêneros de bactérias situam-se entre 7 e 8 . A temperatura afeta a taxa de remoção de nitrato e a taxa de crescimento da biomassa, pois os organismos desnitrificantes são sensíveis às mudanças de temperatura.

Em sistemas de lodos ativados os processos de nitrificação e desnitrificação podem ocorrer simultaneamente no tanque de aeração, quando são desenvolvidas zonas anóxicas no interior dos flocos do lodo, ocasionado pela existência de zonas com pouco oxigênio dissolvido. (Metcalf \& Eddy, 2003; Ferreira, 2000).

Nesses sistemas pode ocorrer a chamada "desnitrificação acidental" no decantador secundário, acompanhada da ascensão de flocos aeróbios à superfície, devido à presença de bolhas de $\mathrm{N}_{2}$ no interior destes. Também pode ocorrer a presença em elevada frequência de microrganismos filamentosos. (Gerardi, 2002). 


\section{MATERIAL E MÉTODOS}

Para a avaliação do tratamento combinado de lixiviado de aterro com esgoto sanitário pelo processo de lodos ativados foram monitorados reatores em escala de bancada, sendo operado em regime de batelada e dois reatores em escala piloto, operados em regime contínuo.

Inicialmente foram realizados os experimentos em escala de bancada para avaliação da tratabilidade da mistura em diferentes proporções, a fim de se obter as melhores condições experimentais para o tratamento consorciado. $\mathrm{O}$ experimento em escala piloto visou à avaliação da interferência da adição de lixiviado na eficiência de remoção da matéria orgânica, na atividade e qualidade do lodo biológico, sob condições mais próximas da realidade. Neste capítulo são descritos os materiais e métodos utilizados no desenvolvimento da pesquisa.

Os experimentos foram realizados na planta experimental do Laboratório de Tratamento de Resíduos Orgânicos, segundo as etapas descritas a seguir.

\subsection{Etapas de desenvolvimento da pesquisa}

A pesquisa foi desenvolvida seguindo as etapas, conforme Figura 4.1:

- Etapa 1 - Coleta e caracterização das águas residuárias e dos inóculos;

- Etapa 2 - Inoculação e adaptação da biomassa nos reatores;

- Etapa 3 - Experimentos de tratabilidade em escala de bancada: avaliação do desempenho dos reatores de lodos ativados em regime de batelada, em função do pré-tratamento do esgoto sanitário (ES) e do lixiviado (LIX), e das proporções volumétricas de lixiviado de 0; 0,2;2 e 5\%;

- Etapa 4 - Experimento de tratabilidade em escala piloto: avaliação do desempenho do reator de lodos ativados em regime contínuo tratando esgoto sanitário com lixiviado (LIX) nas proporções volumétricas de 0 e $2 \%$ (melhores condições da Etapa 3); 


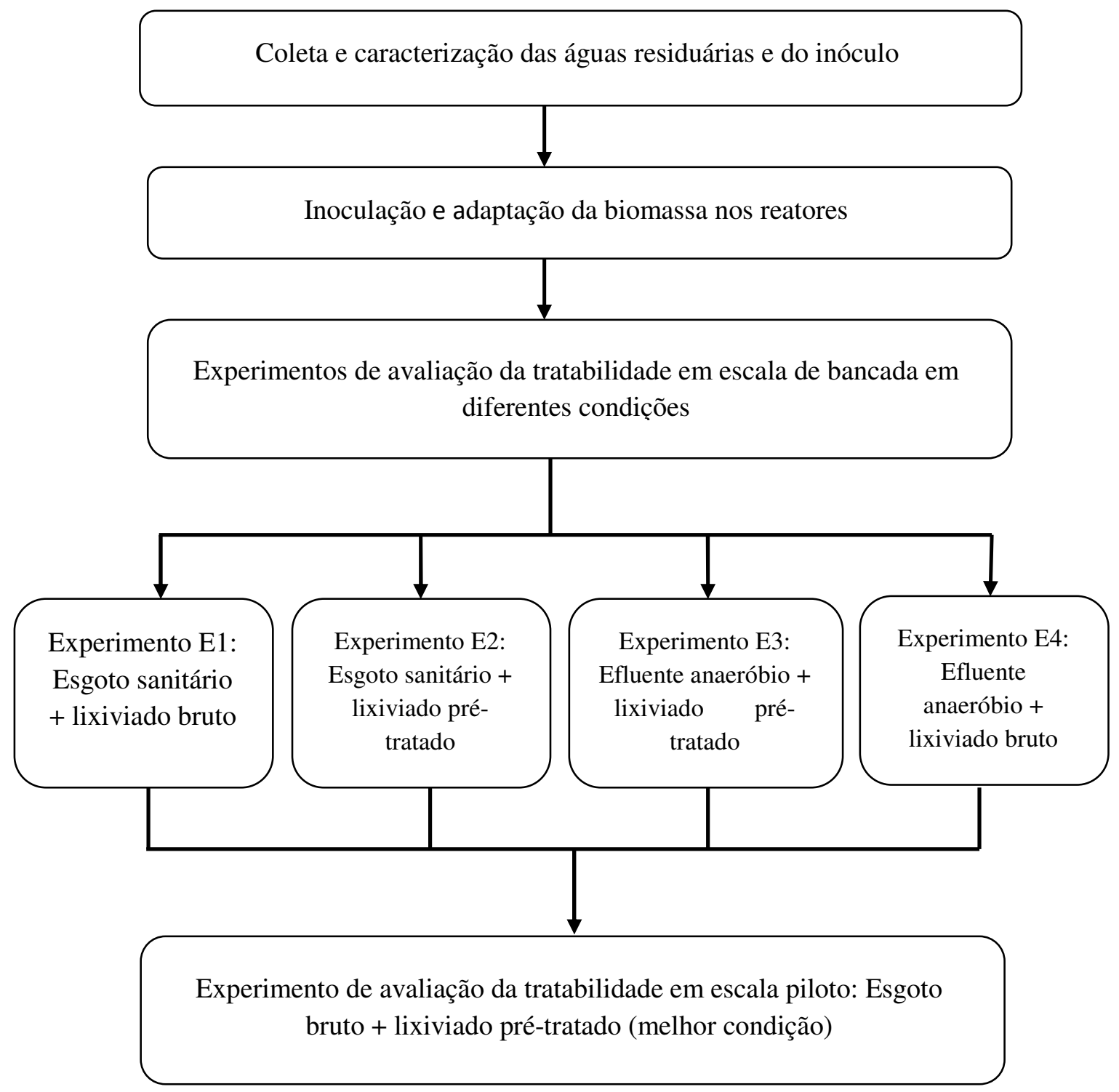

Figura 4.1 - Fluxograma ilustrativo das etapas experimentais desenvolvidas durante a pesquisa.

\subsection{ETAPA 1: Coleta e caracterização das águas residuárias e dos inóculos}

Devido à importância de se conhecer as características das águas residuárias utilizadas, esta etapa foi realizada durante todos os experimentos. Detalhes sobre a coleta e utilização do lixiviado, esgoto sanitário e mistura LIX/ES encontram-se nos itens subsequentes. 


\subsubsection{Lixiviado}

O lixiviado utilizado nos experimentos em escala de bancada (Etapa 3) foi coletado na caixa de passagem da rede de drenagem das células do aterro, enquanto o lixiviado utilizado no experimento em escala piloto (Etapa 4) foi coletado da lagoa de armazenamento do Aterro Sanitário de São Carlos, conforme indicado na Figura 4.2.

Após a coleta, o lixiviado utilizado na Etapa 3 era transportado ao Laboratório de Tratamento Avançado e Reúso de Águas (LATAR) da EESC, onde era mantido em refrigeração a $4^{\circ} \mathrm{C}$. Devido ao grande volume necessário para realização do experimento em escala piloto (Etapa 4), o lixiviado utilizado nessa etapa foi coletado e transportado por caminhão tanque equipado com bomba de auto vácuo e armazenado em reservatório de $3000 \mathrm{~L}$, instalado nas dependências da planta experimental.

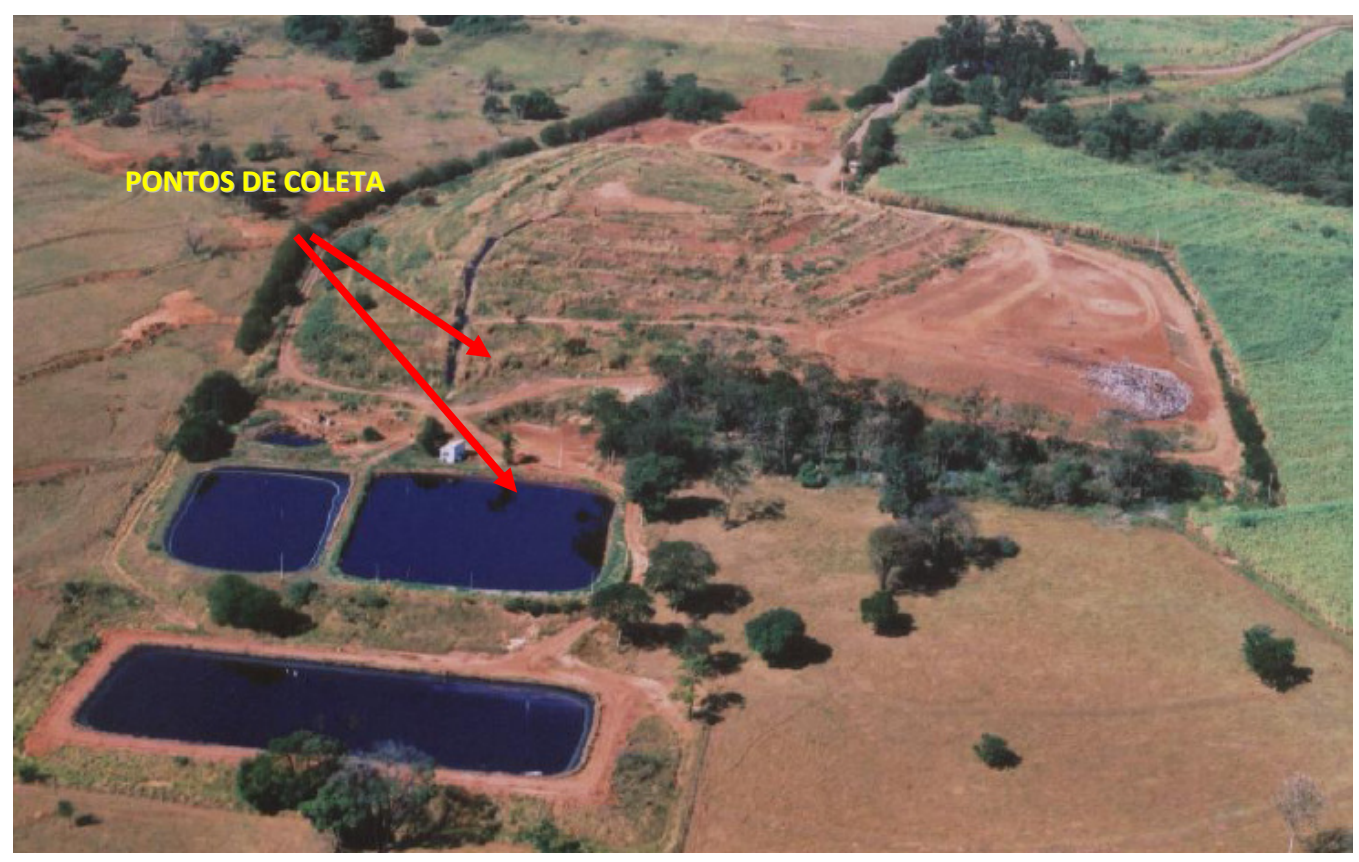

Figura 4.2- Fotografia aérea do Aterro Sanitário de São Carlos (2009) adaptada de Vega Engenharia apud FERREIRA (2010)

\subsubsection{Esgoto Sanitário}

O esgoto sanitário utilizado nos experimentos era proveniente da rede coletora pública da região residencial próxima à Escola de Engenharia de São Carlos (EESC/USP). 
O esgoto da rede local passa primeiramente por grade grossa, sendo então acumulado em um poço de sucção. A tubulação de sucção era provida de válvula de pé com crivo e em seu entorno foi instalado uma espécie de cesto cilíndrico confeccionado de chapa moeda em aço inox para retenção de material grosseiro e proteção das bombas centrífugas (Figuras 4.3 e 4.4 ).
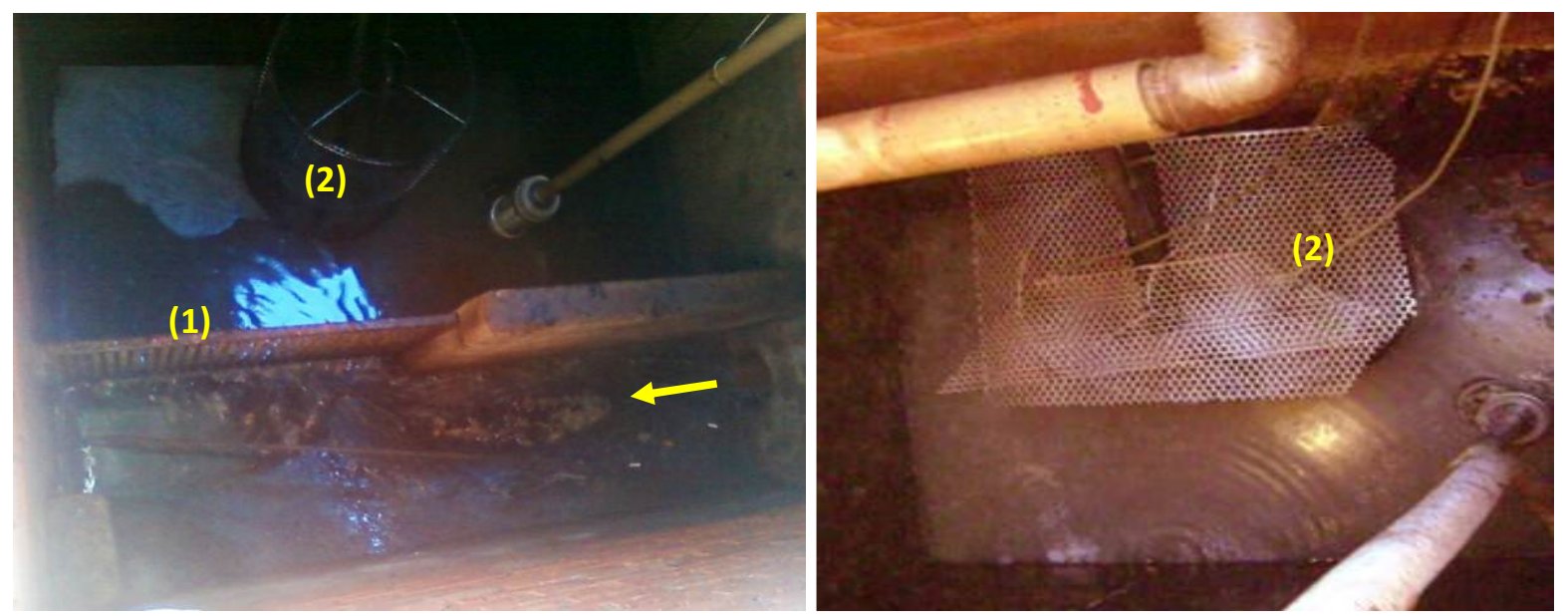

Figura 4.3 - Poço de acúmulo e sucção do esgoto sanitário da rede pública utilizado nos experimentos: (1) grade grossa; (2) cesto cilíndrico de chapa moeda.

Ressalta-se que foram necessárias limpezas diárias no poço de sucção, feitas pela abertura de uma comporta que represa o esgoto. Dessa forma, materiais como plásticos, pedra e areia que chegam ao poço de acúmulo pela rede coletora pública eram novamente transportados por essa rede para fora do poço.

\subsubsection{Efluente Anaeróbio}

O efluente anaeróbio foi obtido pelo tratamento do esgoto sanitário no Reator Anaeróbio Compartimentado (RAC).

O RAC foi construído em alvenaria revestida com argamassa de cimento e areia (25 $\mathrm{cm}$ de espessura de parede), e está instalado na planta experimental do Laboratório de Tratamento de Resíduos Orgânicos, no Departamento de Hidráulica e Saneamento da EESC-USP (Figura 4.5). 


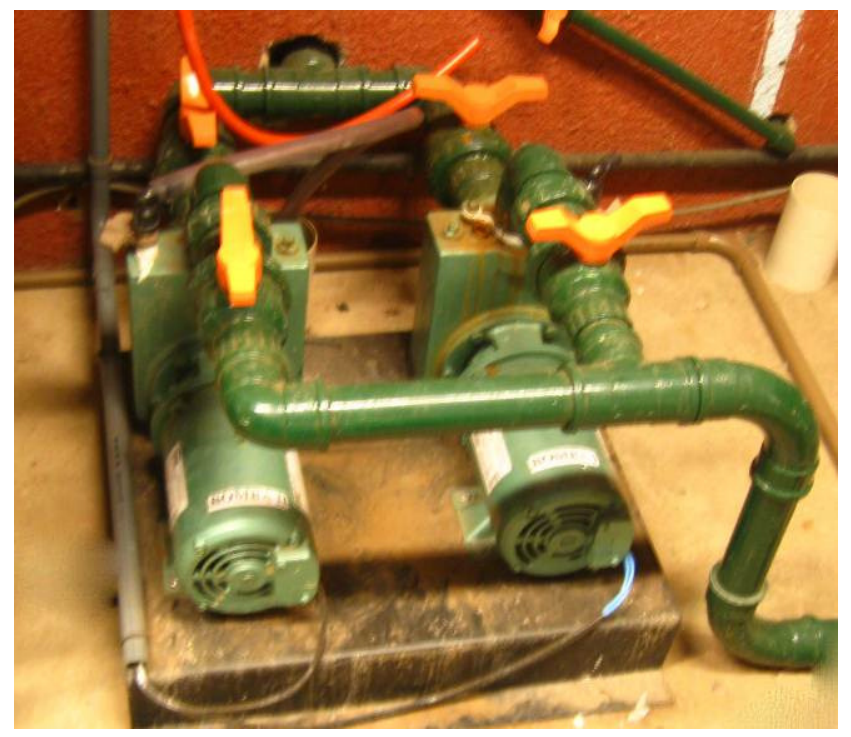

Figura 4.4 - Bombas centrífugas autoescorvantes instaladas para sucção e recalque do esgoto sanitário para alimentação dos reatores.

O reator anaeróbio apresenta volume aproximado de $11 \mathrm{~m}^{3}$ e possui 4 câmaras separadas por compensado naval tratado, 3 com volumes iguais à $3,8 \mathrm{~m}^{3}, 2,9 \mathrm{~m}^{3}, 2,7 \mathrm{~m}^{3} \mathrm{e}$ uma com volume de $1,0 \mathrm{~m}^{3}$, dentro da qual existe um filtro de pedregulho utilizado para retenção de sólidos arrastados (Figuras 4.5 e 4.6). As câmaras são interligadas por tubulações, em PVC e diâmetro de $75 \mathrm{~mm}$, que distribuem efluente de uma câmara a outra, de maneira que o líquido a ser tratado apresente movimentos descendentes e ascendentes, atravessando regiões de elevada concentração de microrganismos ativos, que se formam junto ao fundo de cada câmara (manta de lodo) (Povinelli, 1994).

$\mathrm{Na}$ entrada do reator existe um pequeno reservatório, junto à saída deste há uma grade e a seguir um vertedor triangular. O efluente tratado do reator é coletado na última câmara através de uma tubulação de $75 \mathrm{~mm}$. Na última câmara do reator existe uma saída de fundo de $100 \mathrm{~mm}$ dotada de uma válvula externa ao reator.

Cada uma das câmaras possui três pontos de coleta de amostras com tubulação de $75 \mathrm{~mm}$, junto a uma das paredes do reator. Na última câmara a coleta é feita junto ao fundo (descarga de fundo) e após a passagem pelo leito de pedregulho na parte superior (saída do efluente do reator). As três primeiras câmaras também possuem descarga de fundo de $50 \mathrm{~mm}$, que descarrega na rede coleta pública. 


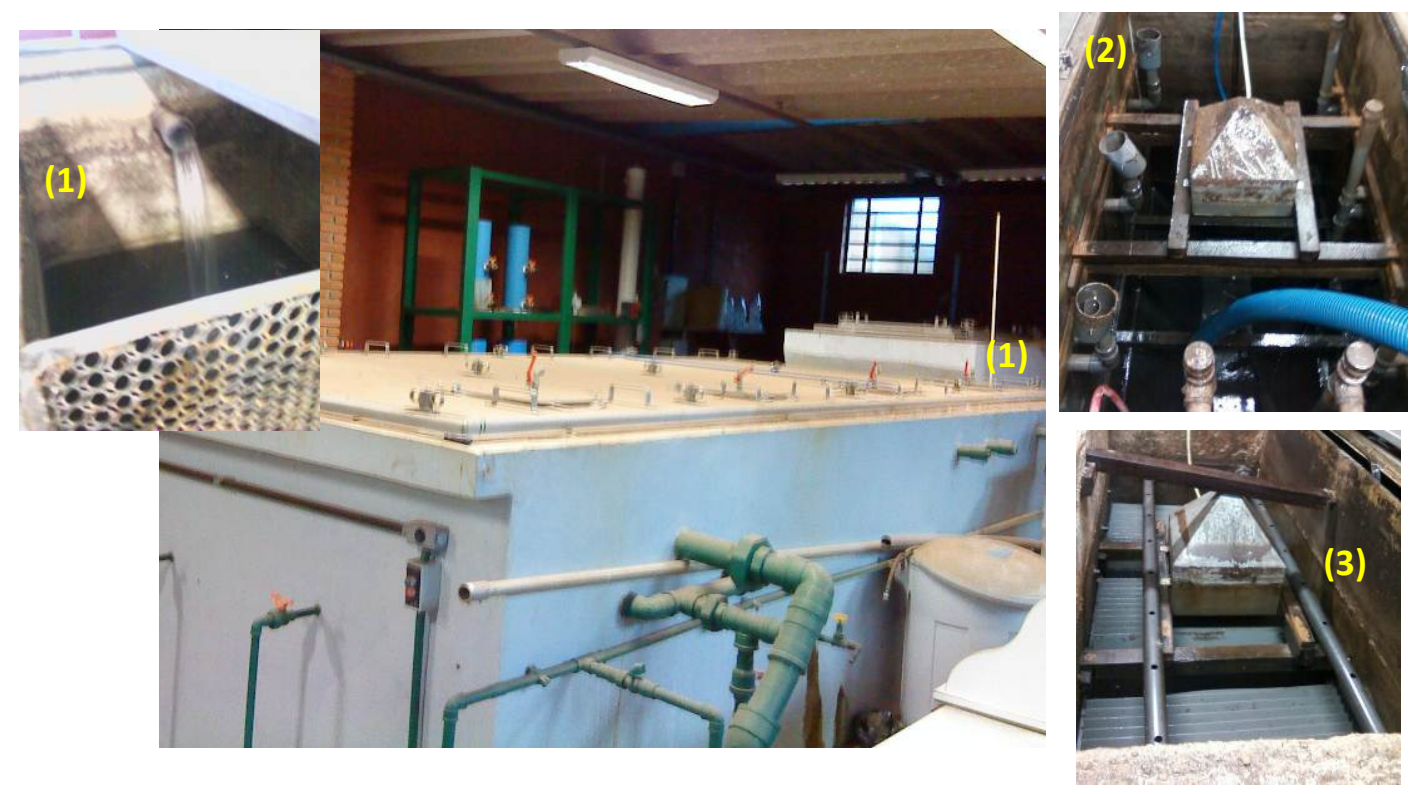

Figura 4.5 - Reator Anaeróbio Compartimentado (RAC): (1) compartimento de entrada do esgoto; (2) interior das 3 primeiras câmaras; (3) interior da câmara com decantador de placas.

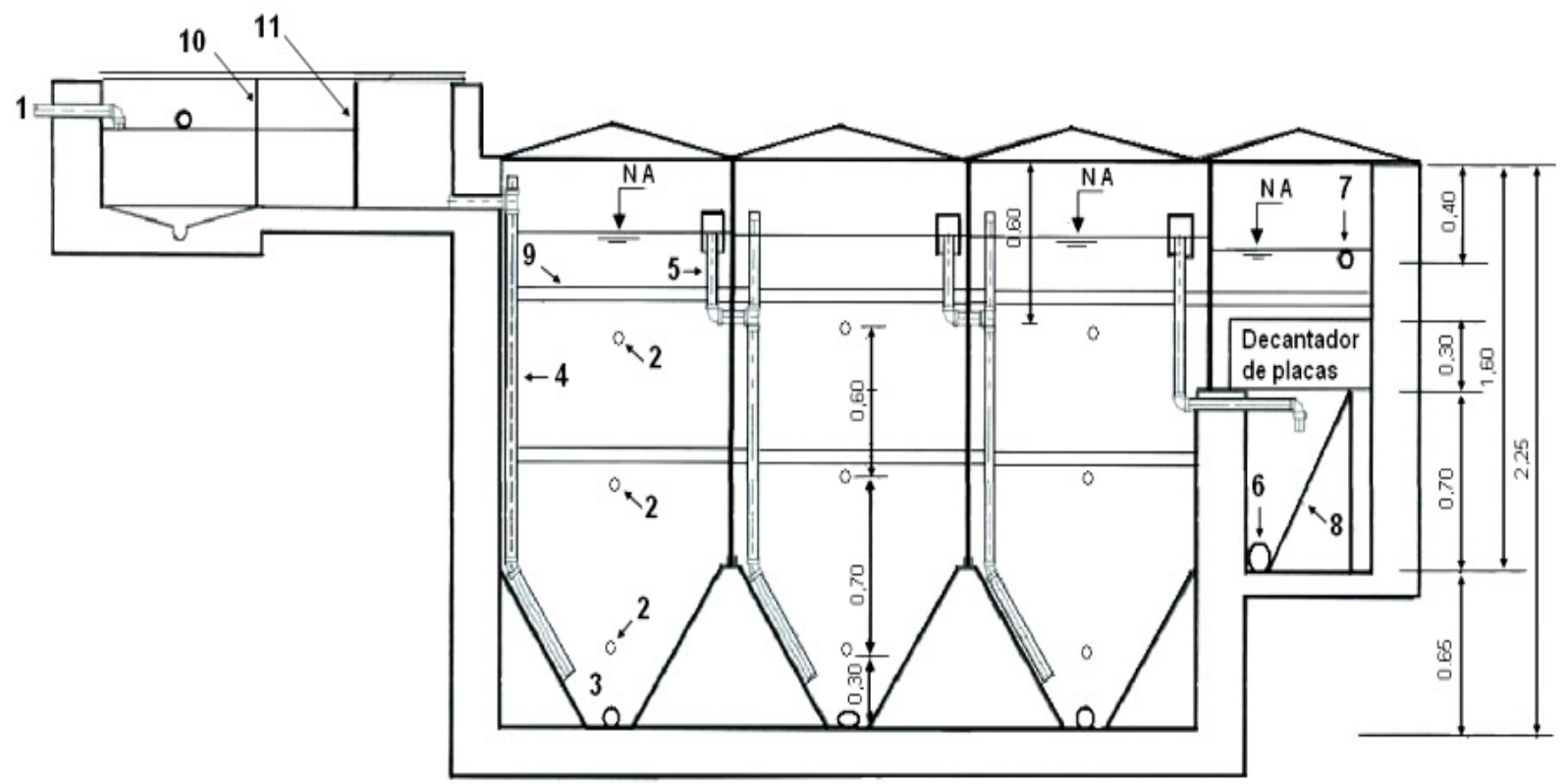

Figura 4.6 - Corte longitudinal do Reator Anaeróbio Compartimentado (RAC).

FONTE: (Povinelli, 1999).

ES efluente do tratamento preliminar; (2) pontos de amostragem; (3) descarga de fundo; (4) tubulação de PVC de distribuição do ES; (5) tubos coletores do ES tratado em cada câmara; (6) tubulação em PVC de descarga do lodo do decantador de placas; (7) tubo de coleta do efluente tratado final; (8) placa de madeira do decantador de placas; (9) travamento em caibro de 5 x $5 \mathrm{~cm}$; (10) grade de aço inox; (11) vertedor triangular. 
Esse reator anaeróbio vem sendo utilizado para tratar esgoto sanitário em diversas pesquisas do Departamento de Hidráulica e Saneamento da Escola de Engenharia de São Carlos. Como esse reator havia sido operado pela última vez em 2006, para o funcionamento adequado de todo o sistema, foi necessária manutenção e limpeza geral do RAC e da rede de esgotamento, com desobstrução de todas as caixas de inspeção e dos subcoletores da rede (Figura 4.7).

Após a limpeza do RAC, este foi inoculado com lodo anaeróbio proveniente do Reator Anaeróbio de Manta de Lodo (UASB) da ETE Flores de Rio Claro-SP. O RAC foi operado com TDH médio de 24 horas, correspondente a uma vazão de aproximadamente $458 \mathrm{~L} / \mathrm{h}$. Durante a operação do reator não foi realizado descarte de lodo, sendo apenas controlada a vazão afluente por meio de medidor de nível do vertedor triangular existente na entrada do reator.

O RAC não foi monitorado regularmente, sendo determinadas apenas as concentrações da DQO, DBO afluentes e efluentes, relação AI/AT e pH quinzenalmente a fim de verificar a estabilidade do reator.

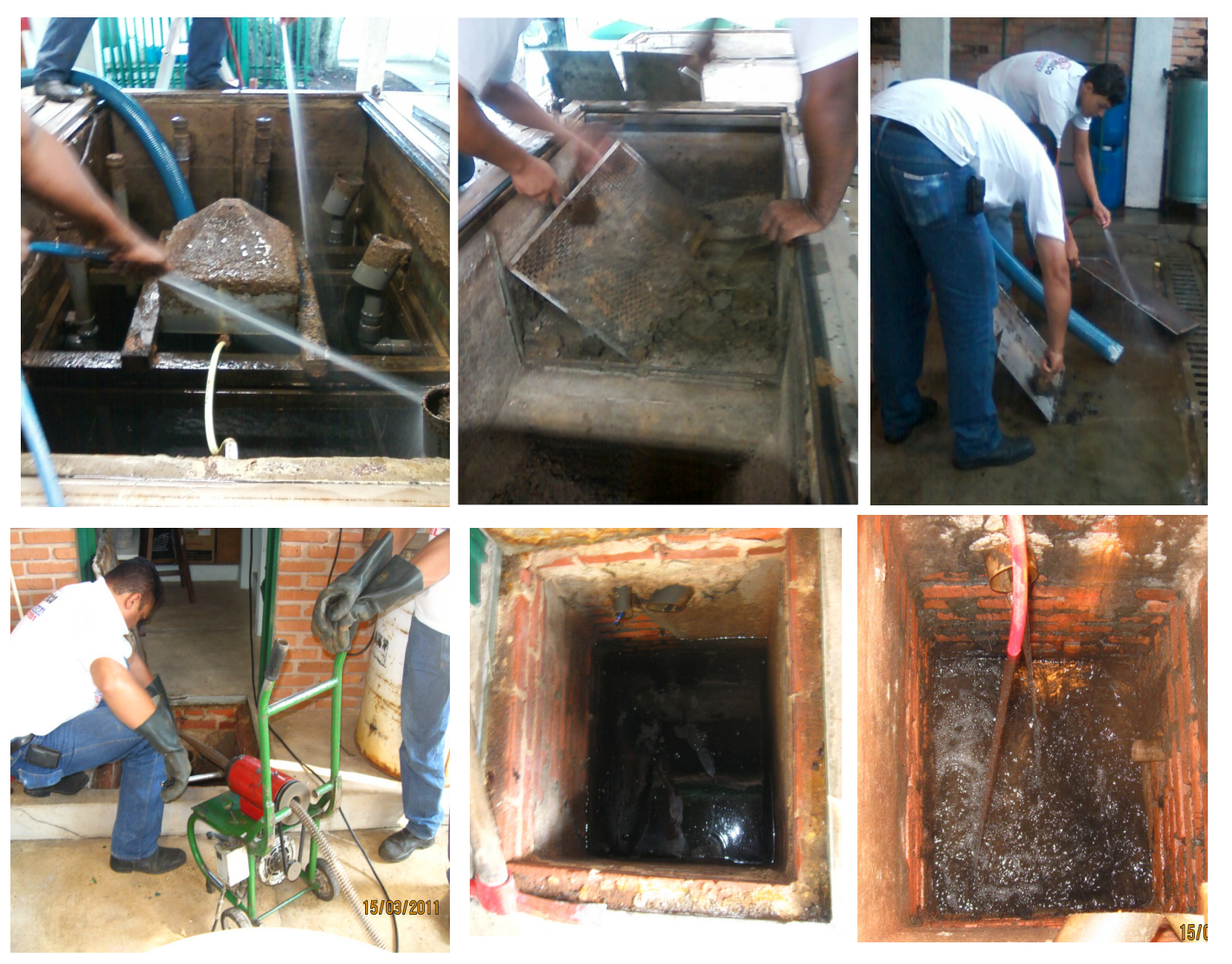

Figura 4.7 - Serviço de manutenção e limpeza do Reator Anaeróbio compartimentado (RAC) e da rede de esgotamento da planta experimental. 


\subsubsection{Lixiviado pré-tratado}

Conforme já discutido, estudos mostraram que a eficiência de sistemas de tratamento lodos ativados é bastante afetada pelas elevadas concentrações de amônia livre, devido ao efeito inibidor da atividade microbiana.

Dessa forma, nesta pesquisa realizou-se o pré-tratamento do lixiviado em torre de air stripping visando à remoção de amônia para ser utilizado nos Experimentos 2, $3 \mathrm{e}$ experimento em escala piloto. Para a minimização da poluição atmosférica, foi realizada ainda sua recuperação em forma de fertilizante por meio da absorção em solução de água e de ácido.

Visando a redução nos custos do processo, o lixiviado foi pré-alcalinizado com cal comercial. A adição de cal comercial ao lixiviado bruto foi realizada de acordo com a metodologia adotada por Souto (2009) e Ferraz (2010), até que o pH fosse ajustado para valores próximos de 11. Esse procedimento era feito no reservatório com agitador mecanizado, que está apresentado na Figura 4.8.

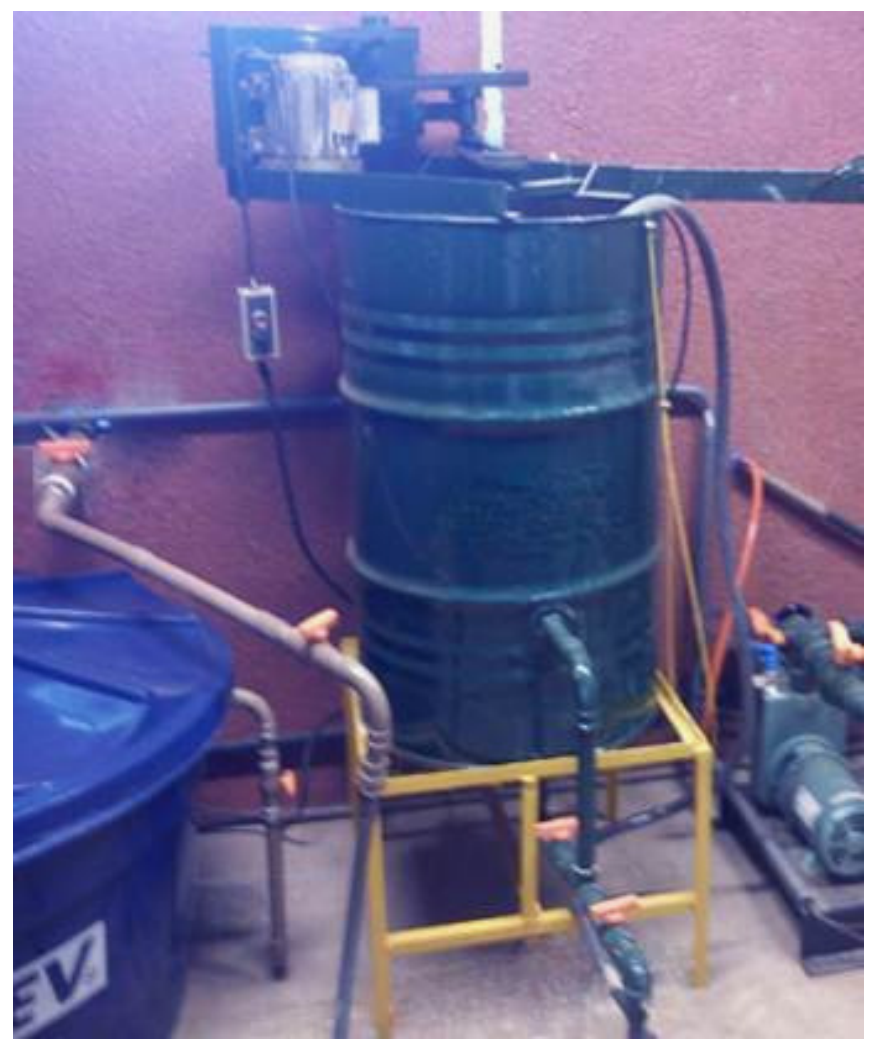

Figura 4.8 - Reservatório com agitador mecanizado para alcalinização do lixiviado. 
Os experimentos na torre de arraste foram realizados em regime de batelada, com recirculação do lixiviado, e encerrados quando a concentração de amônia no efluente líquido era de, no máximo, 20 mg/L (valor estabelecido pela Resolução 397/08 do CONAMA).

Em cada batelada, 50 L lixiviado alcalinizado foi armazenado em tanque de armazenamento e bombeado até o topo da torre por meio de uma bomba dosadora do tipo diafragma, que operou com vazão de $90 \mathrm{~L} / \mathrm{h}$. Em sentido contrário ao deslocamento do líquido, o ar era injetado na parte inferior da torre, com o emprego de um compressor operando com vazões de 3500 L/h e 6400 L/h, conforme Figuras 4.9 e 4.10.

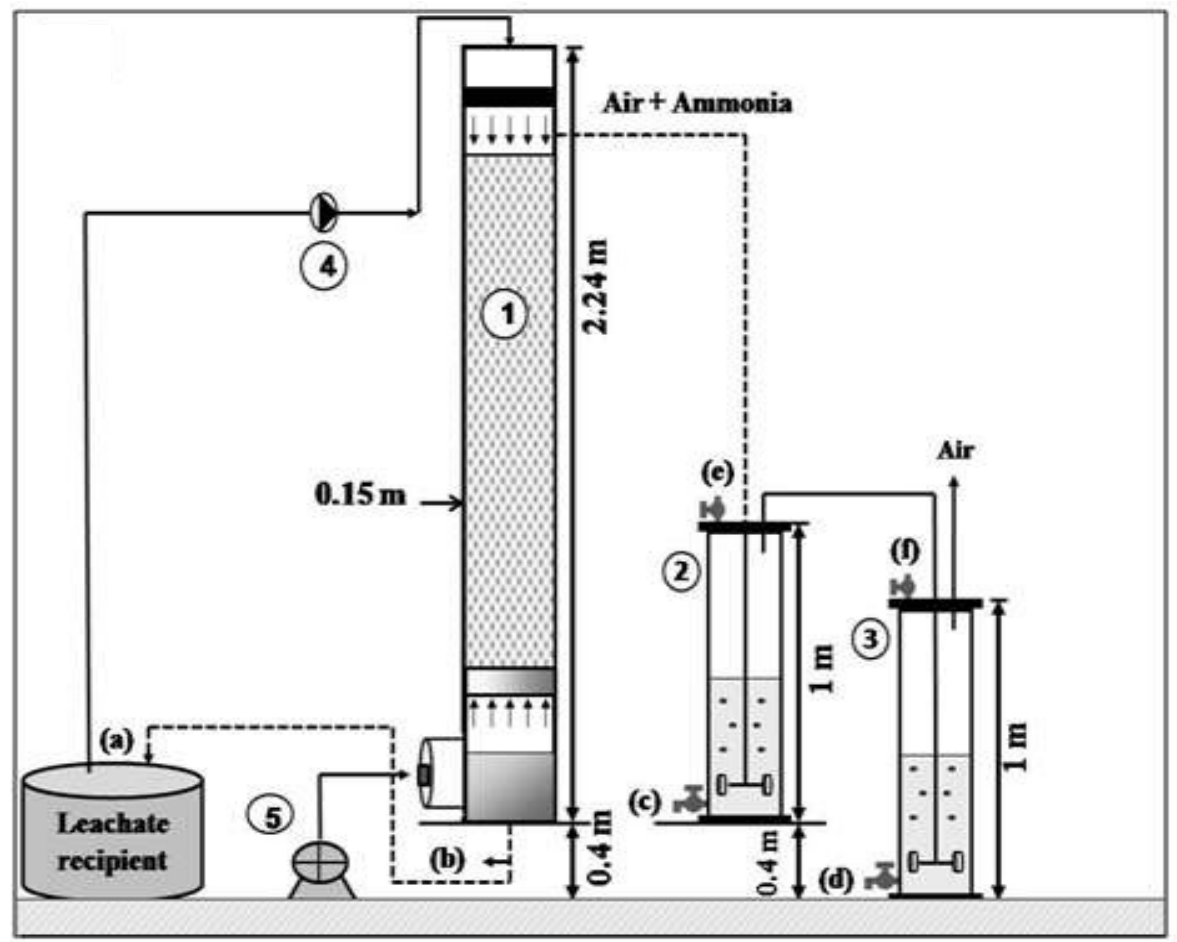

Figura 4.9 - Torre de air stripping (1) torres de recolhimento (2 e 3), sendo a, b, c e d os pontos de amostragem. Fonte: Ferraz (2011).

A torre foi construída em PVC, apresentando as dimensões de $15 \mathrm{~cm}$ de diâmetro e 2,24 m de altura. O material de recheio ocupa cerca de 1,80 m dessa altura, e foi obtido a partir de conduítes de linha popular. Assim, foram manufaturados anéis do tipo Raschig de polietileno corrugados, cujas dimensões são $1,5 \mathrm{~cm}$ de diâmetro interno e $5 \mathrm{~cm}$ de comprimento. A parte inferior da torre consiste de um fundo falso, tendo sido instalado um ralo na parte interna do Tê de PVC, como suporte ao material de recheio. 

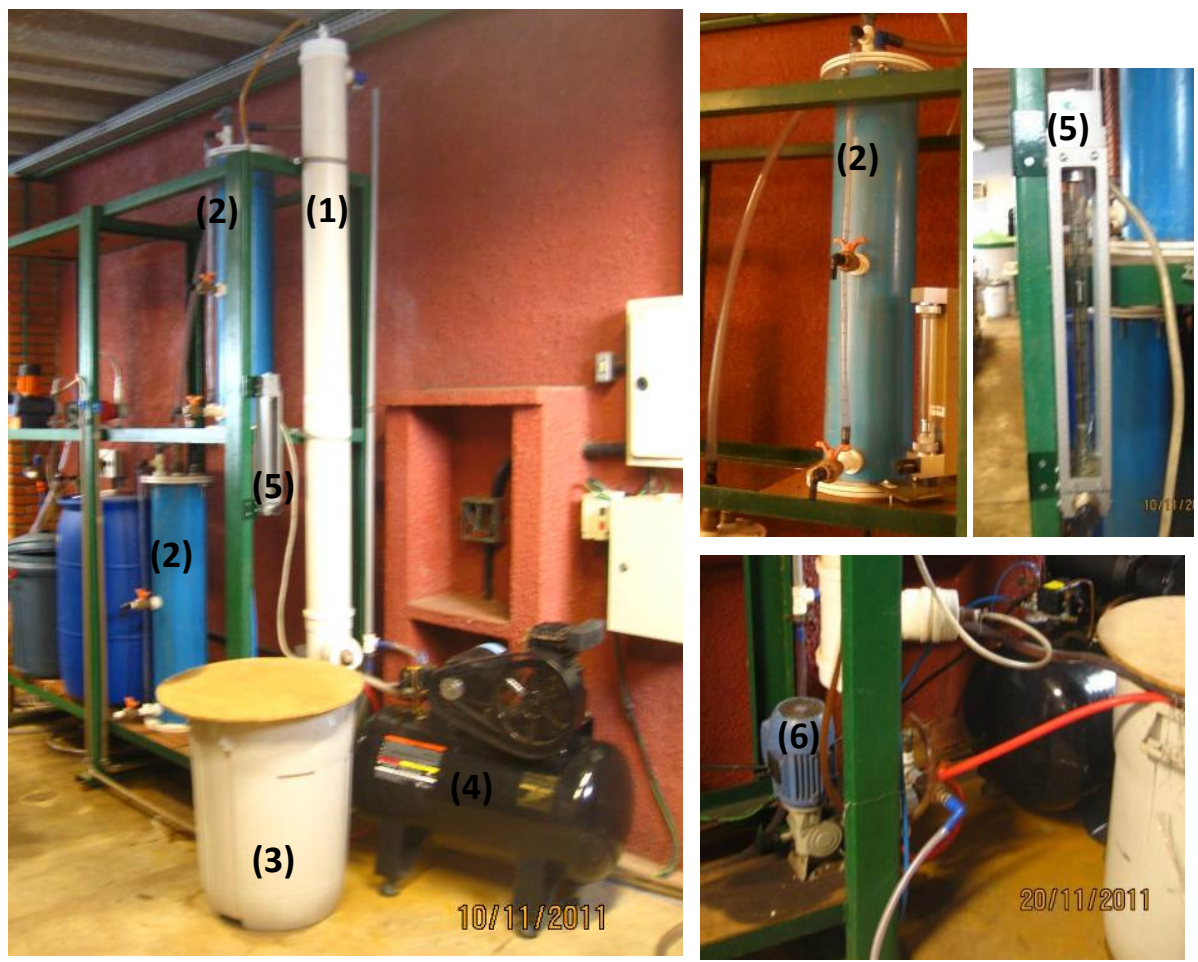

Figura 4.10 - Instalação experimental do sistema de remoção e recolhimento de amônia: (1) torre de air stripping; (2) torres de absorção; (3) reservatório para armazenamento do lixiviado; (4) compressor de ar; (5) rotâmetro; (6): bomba dosadora.

Conforme o ar entra em contato com o líquido, a amônia em sua forma livre $\left(\mathrm{NH}_{3}\right)$ é arrastada para fora da torre juntamente com o ar, a partir da saída lateral localizada no topo da estrutura.

O efluente gasoso da torre foi conduzido a duas torres de recolhimento contendo 20 L de uma solução de ácido sulfúrico 0,4 mol/L ou água (Figura 4.10 (2)). A solução resultante da neutralização da amônia pelo ácido sulfúrico é o sulfato de amônio, produto utilizado como fertilizante. Após esse procedimento de recolhimento, o efluente gasoso da segunda torre era liberado para a atmosfera. Antes do início de cada experimento, adicionava-se fenolftaleína ao conteúdo das torres, para que se pudesse identificar o ponto de saturação da solução pela neutralização da amônia. Uma vez observada a saturação, as torres eram esvaziadas e alimentadas novamente.

A concentração de nitrogênio amoniacal, $\mathrm{pH}$ e condutividade nas duas torres de recolhimento eram medidas no momento em que se observava a saturação da solução. As variáveis $\mathrm{pH}$, condutividade e nitrogênio amoniacal foram medidas de acordo com APHA-AWWA et al. (2005). 
$\mathrm{Na}$ torre de remoção de amônia, nas primeiras horas de operação, esses parâmetros eram analisados a cada intervalo de 2, 3 horas. Posteriormente, quando se observava a redução da taxa de remoção na torre de arraste, aumentou-se esse intervalo para 6 horas e depois 12 horas, de modo que fosse obtida quantidade suficiente de pontos para representar o comportamento geométrico da remoção de amônia.

\subsubsection{Inoculação e adaptação da biomassa}

Todos os reatores de lodos ativados foram inoculados com lodo aeróbio proveniente do sistema de tratamento por lodos ativados em batelada da Indústria Faber Castell LTDA, fábrica II - Cedrinho, localizada na cidade de São Carlos (SP), por apresentar boa sedimentabilidade e baixa concentração de microrganismos filamentosos. O volume de inóculo ( $25 \%$ do volume do reator) foi adotado de modo que, após a inoculação e enchimento dos reatores com esgoto, o tanque de aeração ficasse com concentração de sólidos suspensos em torno de $2000 \mathrm{mg} / \mathrm{L}$.

As amostras de lodo foram caracterizadas por meio da determinação de ST, STV, SST, SSV e exames de microscopia óptica para caracterização da diversidade de morfologias microbianas.

Antes de dar início aos experimentos, foi necessário proceder a "adaptação" da biomassa ao esgoto sanitário e ao efluente anaeróbio. A mistura foi considerada estabilizada, ou adaptada, quando nos exames de microscopia foi observada uma diversidade microbiana equilibrada.

A adaptação foi feita em reator com capacidade de 60 litros, no qual foram colocados 30 litros de esgoto e 10 litros de lodo aeróbio. Essa mistura foi submetida à aeração e após 22 horas de aeração retiravam-se 20 litros do conteúdo do reator, descartando o sobrenadante após 1 horas de sedimentação. O lodo sedimentado era retornado ao reator e completava-se o volume com esgoto. $\mathrm{O}$ procedimento foi repetido até estabilização, e esse tempo foi definido de acordo com exames microscópicos, variando de 7 a 10 dias. A Figura 4.11 apresenta o reator utilizado durante a adaptação.

Durante a adaptação o pH foi mantido em torno de 7 e OD acima de $2 \mathrm{mg} / \mathrm{L}$. 

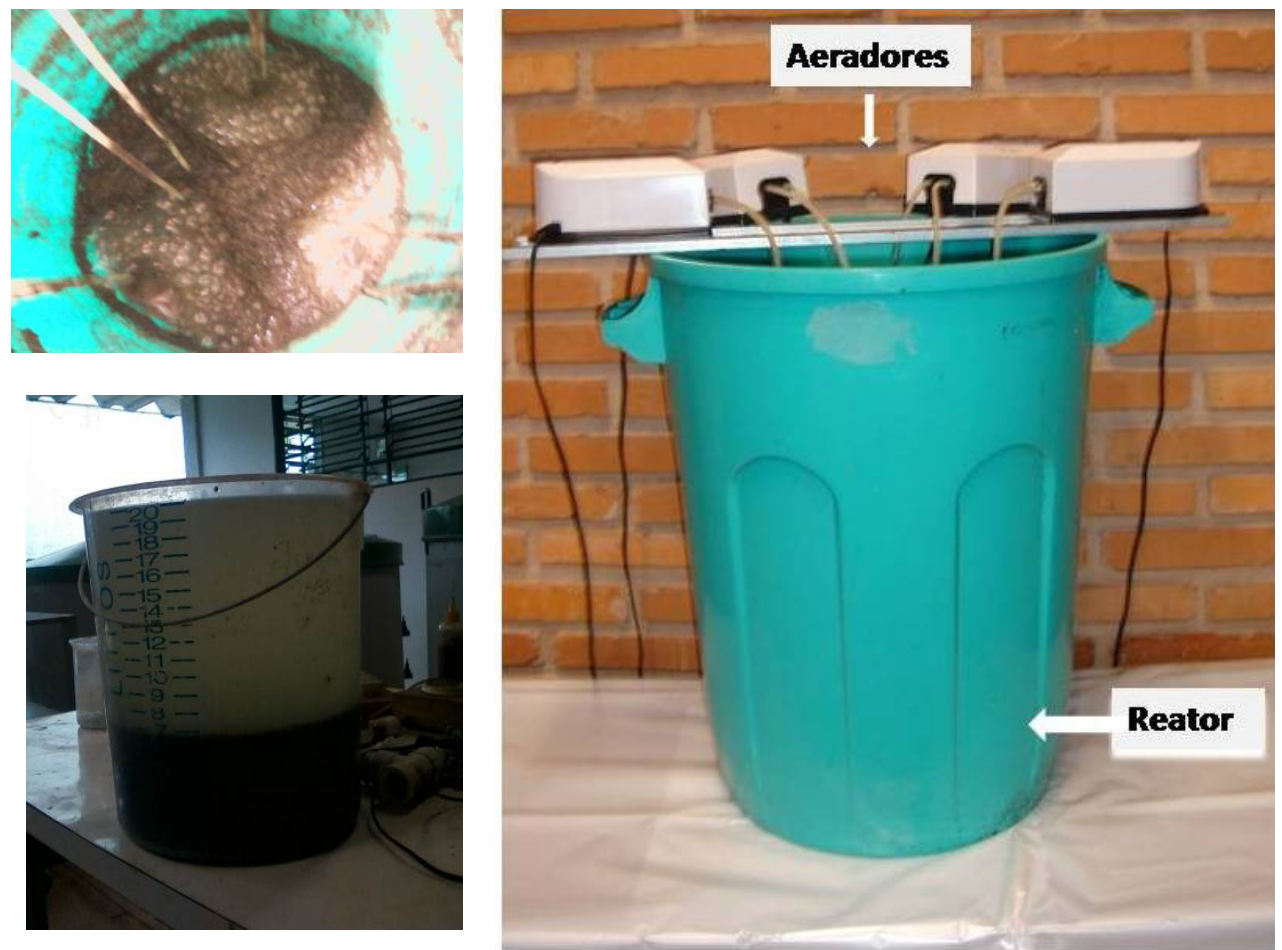

Figura 4.11 - Reator aeróbio utilizado durante a adaptação dos microrganismos aeróbios esgoto sanitário ou efluente anaeróbio sob aeração constante. Adaptado de Turetta (2011)

\subsection{Etapa 3 - Experimentos de tratabilidade em escala de bancada (operação em batelada)}

Nesta etapa, foi avaliado o potencial de biodegradabilidade da mistura de lixiviado e esgoto nas proporções de 0;0,2; 2 e 5\%, considerando-se o efeito do prétratamento do esgoto e do lixiviado. Estas proporções foram adotadas visando comparações com outros estudos já desenvolvidos com tratamento combinado de lixiviado e esgoto por processos aeróbios, a exemplo de Franco (2009) e Santos (2010).

A proporção de $0,2 \%$ foi avaliada porque, conforme estudo de Santos (2010), a relação entre a geração de lixiviado de aterro sanitário e a geração de esgoto sanitário varia entre 0,09 e $0,13 \%$.

A proporção volumétrica limite de $5 \%$ de lixiviado foi adotada devido ao insucesso obtido no tratamento consorciado em processos de lodos ativados utilizando proporções de lixiviado superiores a 5\%, conforme verificado por Turetta (2011) e por outros autores já mencionados. 
Os experimentos utilizando efluente anaeróbio (Experimentos 3 e 4) foram realizados com intuito de se verificar as interferências na tratabilidade do lixiviado, uma vez que o pré-tratamento em reator anaeróbio remove grande parcela da matéria orgânica do esgoto, portanto, conforme alguns autores, não acarretaria nenhum efeito sobre a biodegradabilidade do lixiviado. Para tanto, foi utilizado o efluente do Reator Anaeróbio Compartimentado (RAC), conforme discutido na seção 4.2.3.

Quanto ao lixiviado, foi proposto seu pré-tratamento físico-químico visando à remoção de amônia, para se verificar o efeito do pré-tratamento na tratabilidade da mistura. Para tanto, o lixiviado foi pré-tratado por alcalinização (precipitação) e em torre de air stripping, conforme discutido na seção 4.3.3.

Os experimentos desta etapa serão realizados conforme mostrado na Tabela 4.1.

Tabela 4.1 - Experimentos relativos à operação do reator de lodos ativados em escala de bancada (Etapa 3).

\begin{tabular}{lccc}
\hline Proporções volumétricas (\%) & Experimentos & ES & LIX \\
\hline & 1 & Bruto & Bruto \\
$0 ; 0,2 ; 2 ; 5$ & 2 & Bruto & Pré-tratado \\
& 3 & Pré-tratado & Pré-tratado \\
& 4 & Pré-tratado & Bruto \\
\hline
\end{tabular}

Portanto, a Etapa 3 consistiu na investigação dos efeitos da adição do lixiviado na estabilização da biomassa, permitindo a determinação das proporções volumétricas mais adequadas para tratamento aeróbio da mistura LIX/ES nas condições estudadas.

As melhores condições obtidas nos experimentos em escala de bancada (Etapa 3) foram reproduzidas em reatores de lodos ativados em escala piloto, operado em regime contínuo (Etapa 4).

\subsubsection{Descrição da unidade experimental}

A câmara de aeração utilizada nos experimentos em escala de bancada consiste em um reator dividido em quatro câmaras (R1, R2, R3 e R4, na Figura 4.12 e 4.13) com volume individual de 10,2 L. Em cada câmara há um tanque de aeração e um 
decantador, separados por uma cortina fixa. Essa unidade encontra-se instalada no Laboratório de Tratamento de Resíduos Orgânicos e vem sendo utilizada em diversas pesquisas desenvolvidas no Departamento de Hidráulica e Saneamento da Escola de Engenharia de São Carlos.

\section{ESQUEMA DO REATOR DE LODOS ATIVADOS EM ESCALA LABORATORIAL}

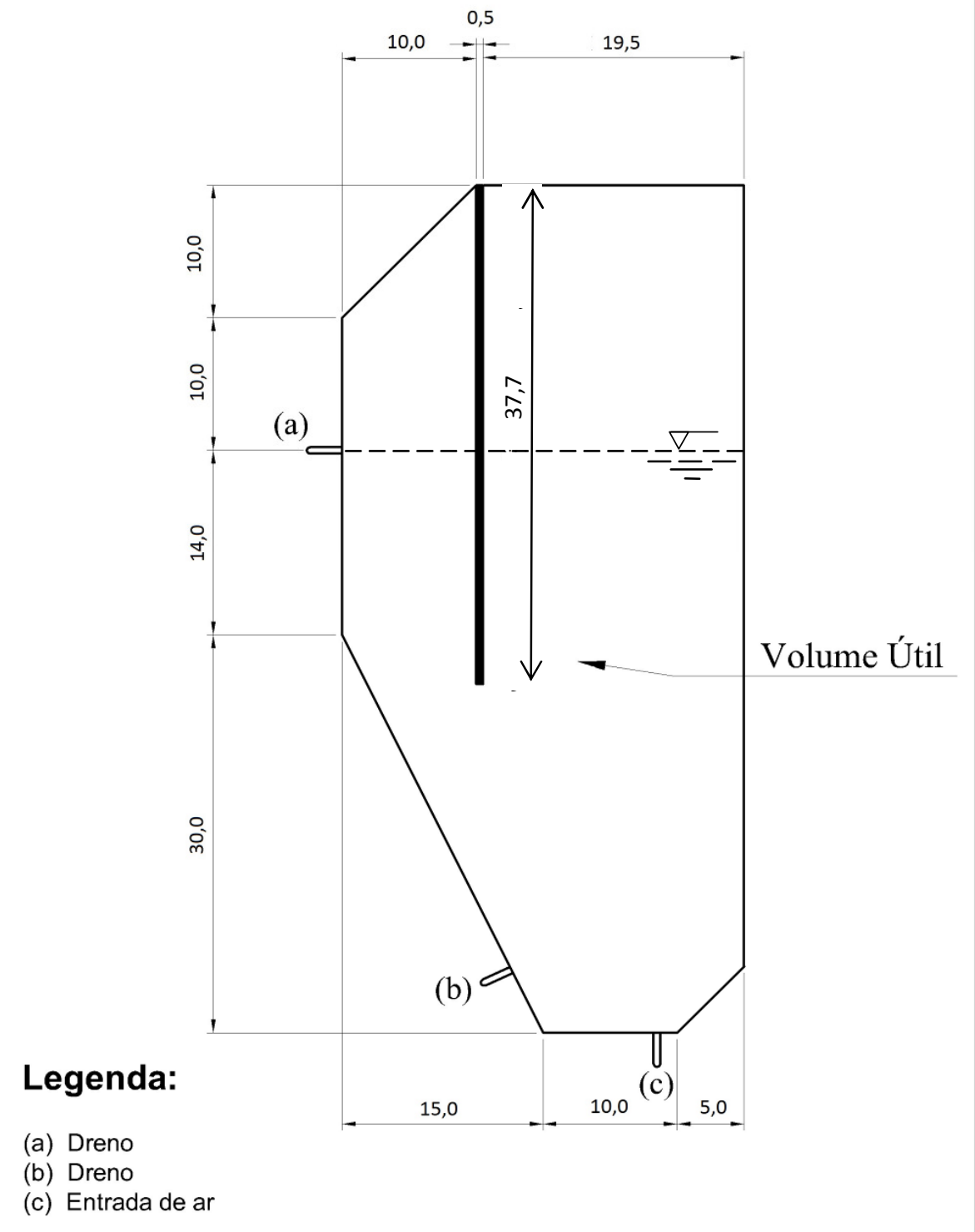

Figura 4.12- Corte esquemático do reator de lodos ativados em escala de bancada.

Fonte: Adaptado de Turetta (2011). 


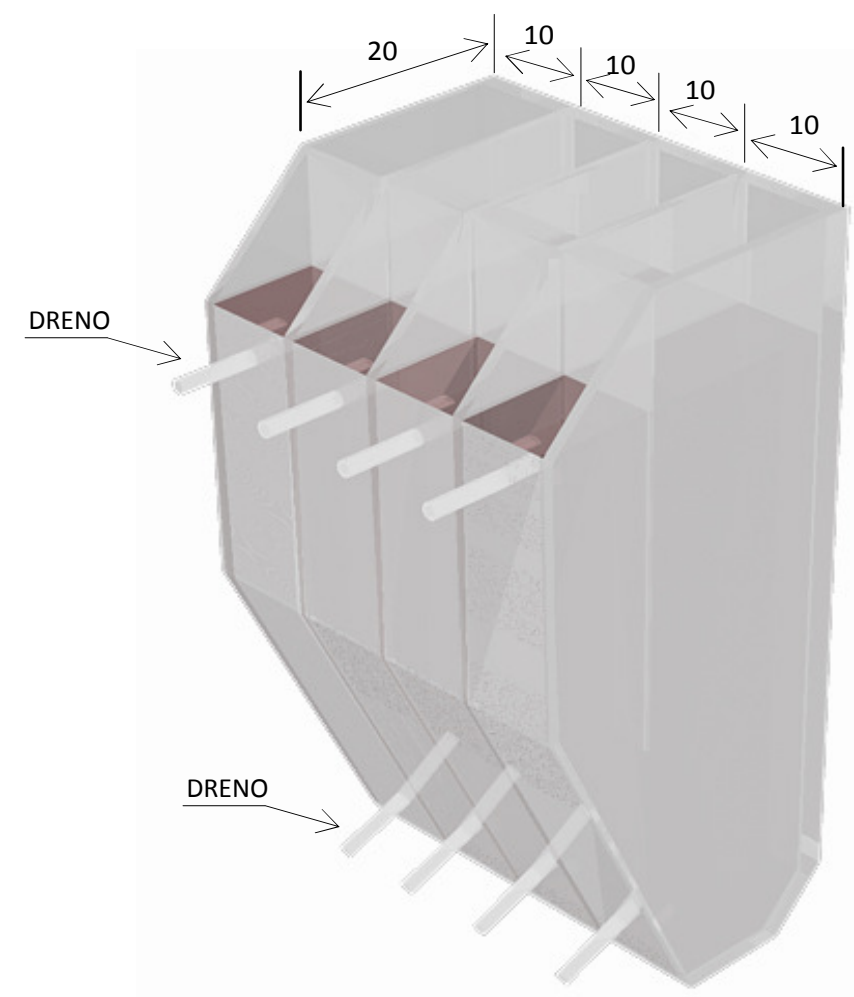

Figura 4.13- Perspectiva do reator de lodos ativados em escala de bancada.

\subsubsection{Operação e controle}

A estabilização do reator de lodos ativados desta etapa foi monitorada em todos os experimentos através de análises físico-químicas e exames microbiológicos, visando o acompanhamento das sucessões das comunidades microbianas.

Todos os experimentos descritos anteriormente foram operados da mesma maneira para permitir a comparação dos dados obtidos. A Figura 4.14 apresenta o equipamento montado para realização dos experimentos.

Para evitar o crescimento de microrganismos fotoautotróficos como as algas, envolveu-se a célula de aeração com papel alumínio em toda sua parede externa.

A aeração e agitação eram promovidas por meio de aeradores de aquário com pedras porosas, que eram instalados sobre bancada ao lado da câmara.

Durante os experimentos a totalidade da câmara funcionou como tanque de aeração, ininterruptamente. Por isso a sedimentação foi realizada em frascos de 8 litros, um para cada câmara, os quais desempenhavam a função de decantadores secundários. Os quatro reatores foram operados com ciclo de 24 horas e após 23 horas de aeração da 
mistura retiravam-se 7 litros do conteúdo de cada câmara, descartando 5 litros do sobrenadante após 1 hora de sedimentação. O lodo sedimentado era retornado ao reator e completava-se o volume com a mistura lixiviado/esgoto. A mistura era preparada diariamente para cada reator. A aeração nas câmaras não foi interrompida durante o período de sedimentação. Este procedimento foi realizado até o término do experimento.
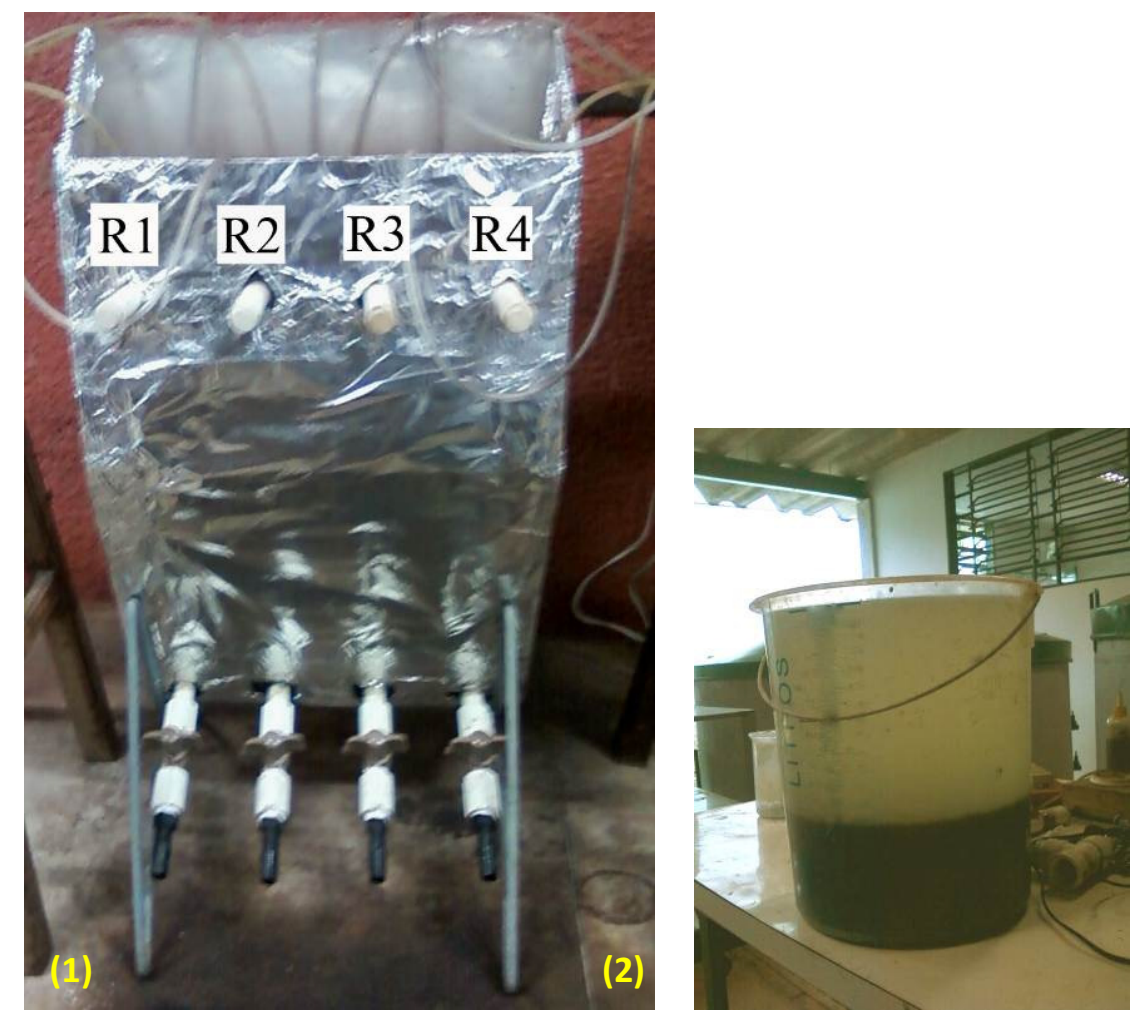

Figura 4.14 - (1) Célula de aeração com 4 reatores de 10 L cada e (2) unidades de sedimentação, utilizada nos experimentos em escala de bancada (Etapa 3).

Os valores de $\mathrm{pH}$ do tanque de aeração foi ajustado para valores próximos de 7 com adição de uma solução de hidróxido de cálcio $\mathrm{Ca}(\mathrm{OH})_{2}$.

$\mathrm{O}$ oxigênio dissolvido e a temperatura foram monitorados diariamente com a utilização de oxímetro Digimed modelo DM-4P.

Cada experimento teve duração de 20 dias de operação e foi mantido um tempo de detenção hidráulica (TDH) de 2 dias e idade de lodo $\left(\theta_{\mathrm{c}}\right)$ próxima de 30 dias, com volume de descarte em torno de $300 \mathrm{~mL}$ de amostra do tanque de aeração (controle hidráulico). 
Foi constatada formação de espuma nos tanques de aeração dos reatores com lixiviado, especialmente nos reatores com $5 \%$ de lixiviado bruto, acarretando acúmulo de lodo nas paredes dos reatores. Constantemente se fazia a raspagem das paredes de forma a retornar o lodo ao licor misto.

\subsection{Etapa 4 - Experimentos de tratabilidade em escala piloto (operação em regime contínuo)}

A fim de se obter maior consistência e confiabilidade dos dados, as melhores condições obtidas na Etapa 3 foram reproduzidas na Etapa 4, utilizando reatores de lodos ativados em escala piloto. Esta etapa teve como objetivo avaliar a tratabilidade em escala piloto em regime contínuo e verificar os efeitos advindos da adição de lixiviado em um maior tempo de operação, condições mais próximas da realidade.

Neste experimento foram reproduzidas as melhores condições obtidas nos experimentos de bancada, observada a máxima concentração de lixiviado na mistura. Dessa forma, foi escolhida a condição do Experimento 2 (esgoto bruto com lixiviado pré-tratado), com até $2 \%$ de lixiviado, montando-se duas linhas de tratamento, uma com $2 \%$ (P1) e $0 \%$ (P2-controle) de lixiviado.

Foi também um importante objetivo desta etapa verificar a qualidade do lodo aeróbio e avaliar a possibilidade de acúmulo de metais, conforme preconizado por alguns pesquisadores já mencionados.

Todas as análises estatísticas foram realizadas utilizando o software estatístico Minitab 15. A normalidade das variáveis foi verificada pelo teste estatístico de Anderdon-Darling. Todos os resultados das análises estatísticas encontram-se no Apêndice B10.

\subsubsection{Descrição da unidade experimental}

O sistema de lodos ativados em escala piloto consistiu em um tanque em aço inox, constituído por tanque de aeração, decantador e câmara de coleta do efluente, de forma conjugada. O tanque de aeração (tanque de reação) possui volume útil de 100 litros, tendo $25 \mathrm{~cm}$ de largura; $82 \mathrm{~cm}$ de comprimento e $50 \mathrm{~cm}$ de altura. $\mathrm{O}$ decantador 
possui $25 \mathrm{~cm}$ de largura; $18 \mathrm{~cm}$ de comprimento e $50 \mathrm{~cm}$ de altura e a câmara de coleta do efluente possui $25 \mathrm{~cm}$ de largura; $10 \mathrm{~cm}$ de comprimento e $20 \mathrm{~cm}$ de altura (Figuras 4.15).
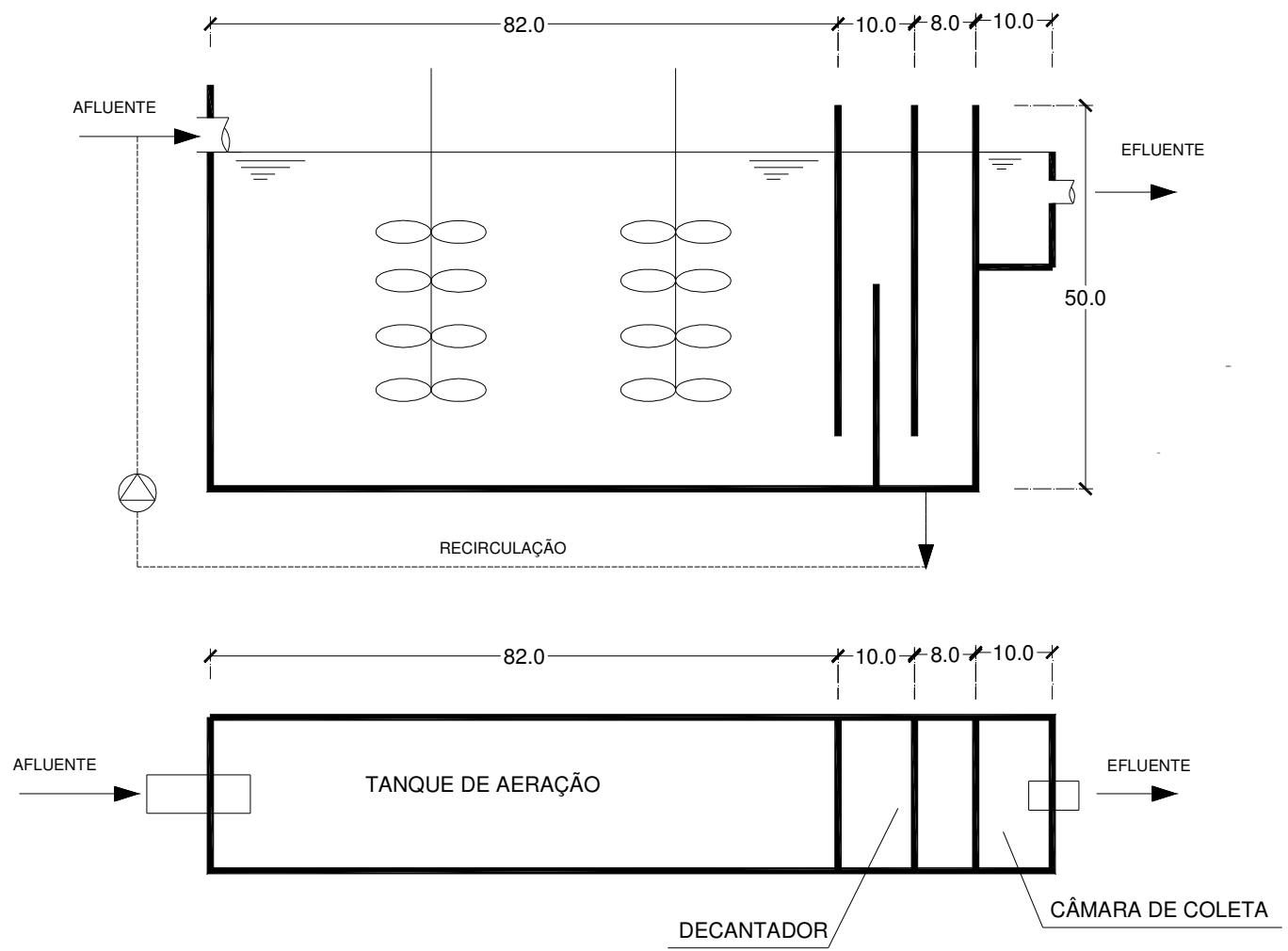

Figura 4.15 - Planta e Perfil esquemático do reator de lodos ativados em escala piloto.

As Figuras 4.15 e 4.16 apresentam os reatores montados para realização do experimento desta etapa.

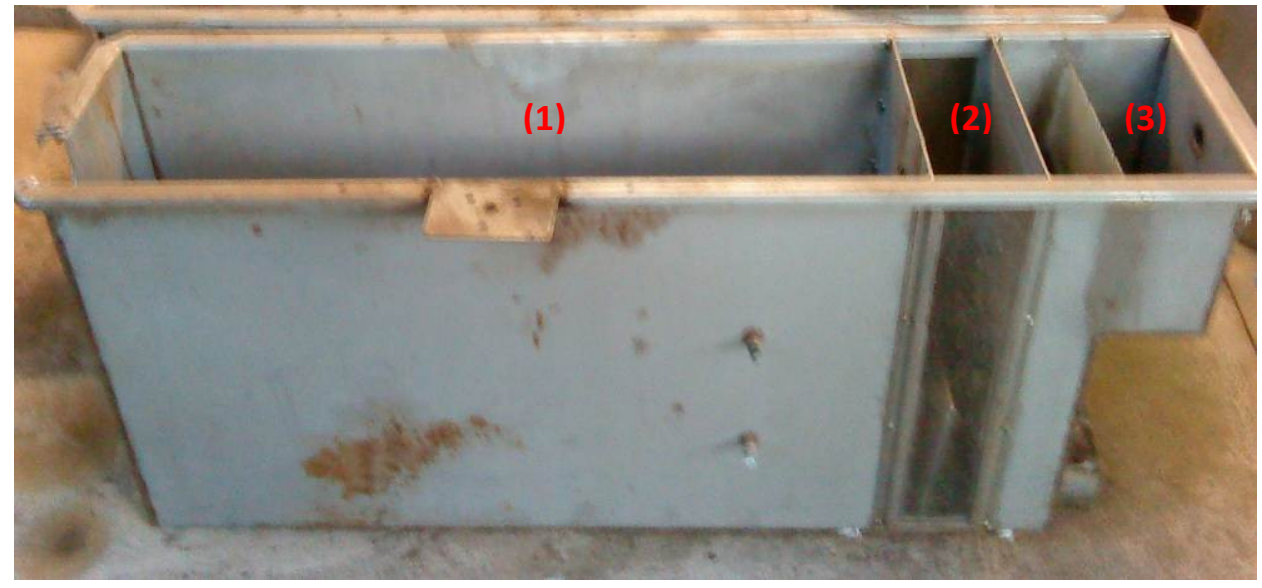

Figura 4.16 - Reator de lodos ativados em escala piloto: (1) tanque de aeração; (2) decantador justaposto; e (3) câmara para coleta do efluente. 
Devido ao surgimento de problemas de flotação do lodo observados e à dificuldade de operação pela área reduzida do decantador justaposto, foi realizada uma alteração na concepção inicial do sistema. Isto porque o decantador interno (justaposto) não ofereceu espaço suficiente para sedimentação do lodo, além da interferência direta do tanque de aeração, de maneira que a turbulência nessa região também impedia a sedimentação do lodo no decantador.

Diante do problema, foi necessário utilizar um decantador externo, com aeração de 15 minutos acionada de 2 em 2 horas por meio de temporizador, de modo a minimizar a flotação do lodo. Esse decantador consiste em uma câmara de acrílico dividida em quatro compartimentos, tal como o reator de lodos ativados em escala de bancada mostrado na Figura 4.12. Dois desses compartimentos foram utilizados como decantadores de cada reator de lodos ativados em escala piloto. O reator apresentado na Figura 4.16 foi, então, utilizado integralmente como tanque de aeração, com volume total útil de 110 litros.

Com a alteração realizada, foi possível minimizar a flotação do lodo e facilitar a operação do decantador. (Figura 4.17).
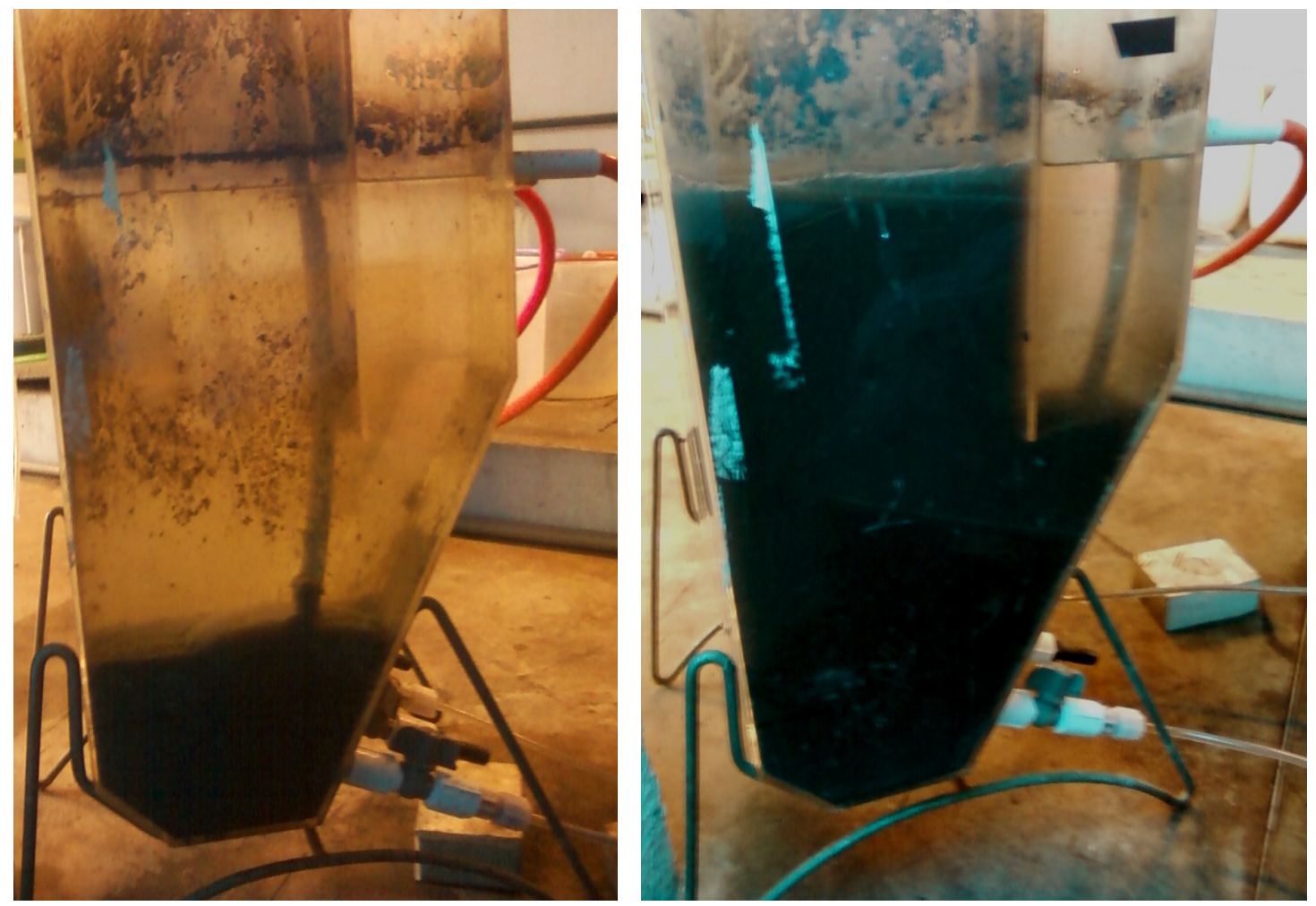

Figura 4.17 - Decantador secundário: (a) lodo sedimentado; (b) lodo suspenso pela aeração intermitente. 


\subsubsection{Operação e controle}

A estabilização dos reatores de lodos ativados desta etapa também foi monitorada através de análises físico-químicas e exames microbiológicos, visando o acompanhamento das sucessões das comunidades microbianas.

O esgoto proveniente da rede pública era recalcado pelas bombas apresentadas na Figura 4.4 até o tanque de equalização (Figura 4.18 (1)), de onde então seguia para os tanques de mistura que alimentavam os reatores em escala piloto. O efluente tratado era conduzido por mangueiras, dos drenos posicionados na parte superior do decantador, para a rede de esgotamento da planta experimental.

Os tanques de mistura possuíam agitadores, que eram acionados durante 60 minutos a cada 2 horas. Os afluentes eram então bombeados a partir desses tanques (Figura 4.18 (2)), localizados à montante dos reatores, por meio de bombas dosadoras da marca Prominent. Além dessas, foram instaladas mais duas bombas dosadoras para a recirculação do lodo sedimentado no decantador para a entrada do tanque de aeração.

O fornecimento de ar foi realizado por compressores de aquário, mantendo em pelo menos $2 \mathrm{mg} / \mathrm{L}$ a concentração de oxigênio dissolvido no reator. A distribuição de ar no reator se deu pelo uso de mangueiras porosas instaladas no fundo dos reatores (Figura 4.18 (5)); dois agitadores, também em aço inox, com quatro pás cada um, permitiram a constante suspensão dos sólidos, dispersão do oxigênio e homogeneização do meio (Figura 4.18).

A vazão de alimentação de cada reator foi de aproximadamente $110 \mathrm{~L} /$ dia (4,5 $\mathrm{L} / \mathrm{h}$ ), com a finalidade de manter o tempo de detenção hidráulica (TDH) próximo de 24 horas. A idade do lodo foi mantida em torno de 20 dias, sendo realizado descarte diário a partir da linha de retorno, com volume variando de 600 a $1100 \mathrm{~mL}$ de lodo sedimentado, de acordo com a concentração de sólidos suspensos no tanque de aeração e na linha de retorno, calculado conforme equação apresentada na seção 3.4.2.

As vazões das duas bombas de alimentação eram aferidas duas vezes por semana por meio da coleta de amostras do afluente em proveta ou béquer. As bombas dosadoras utilizadas para alimentação dos reatores, assim como as mangueiras de silicone, eram limpas semanalmente de forma a minimizar as variações no tempo de detenção hidráulica. 

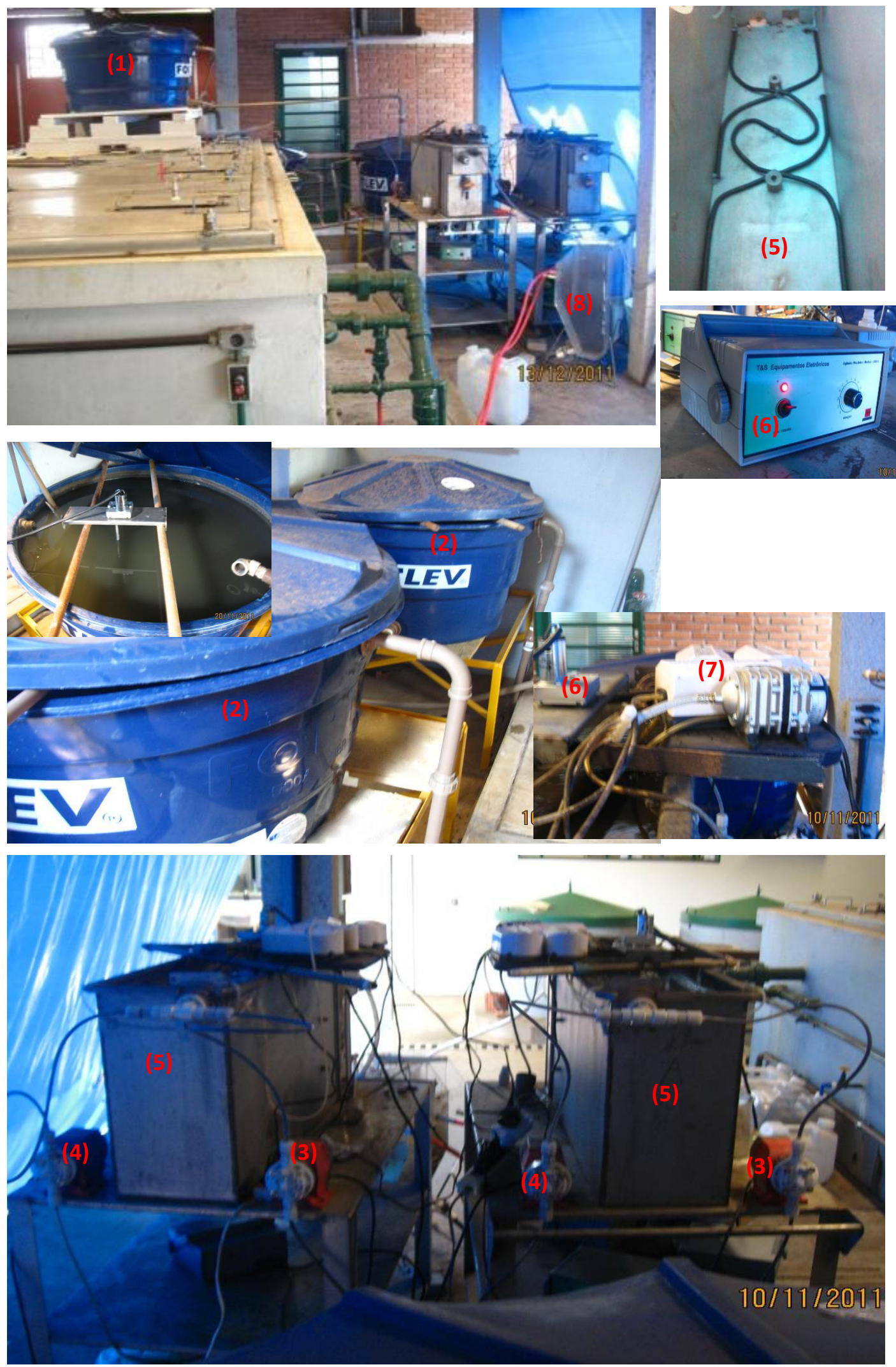

Figura 4.18 - Sistema de lodos ativados: (1) Tanque de equalização; (2)

Tanques de mistura e alimentação; (3) Bombas de alimentação dos reatores; (4) Bombas de retorno do lodo; (5) Tanques de aeração; (6) Agitadores mecanizados; (7) Aeradores; (8) Decantadores secundários. 
Devido à constante obstrução das mangueiras de silicone das bombas dosadoras, foi instalada uma peneira fina com malha de abertura de aproximadamente $2 \mathrm{~mm}$ na entrada do esgoto bruto no tanque de equalização, para remoção de sólidos grosseiros e minimizar a obstrução pelo acúmulo de material grosseiro nas mangueiras de silicone das bombas de alimentação dos reatores.

\subsection{Análises físico-químicas e exames microbiológicos}

As análises físico-químicas foram realizadas no Laboratório de Saneamento do Departamento de Hidráulica e Saneamento da EESC/USP, com exceção das determinações do COD durante a Etapa 4, que foram realizadas no Laboratório de Química Ambiental do Instituto de Química de São Carlos (IQSC). Todas as análises foram realizadas de acordo com os procedimentos descritos no Standard Methods for Examination of Water and Wastewater (APHA, 2005).

Os exames microbiológicos de microscopia óptica durante a Etapa 3 foram realizados no Laboratório de Processos Biológicos (LPB) - Campus 2 e durante a Etapa 4 no Laboratório de Tratamento Avançado de Águas e Reúso (LATAR) - Campus 1, utilizando microscópio óptico Olympus, modelo DP-72 (Figura 4.19), sendo o ImagePro Plus o programa de aquisição e processamento das imagens.

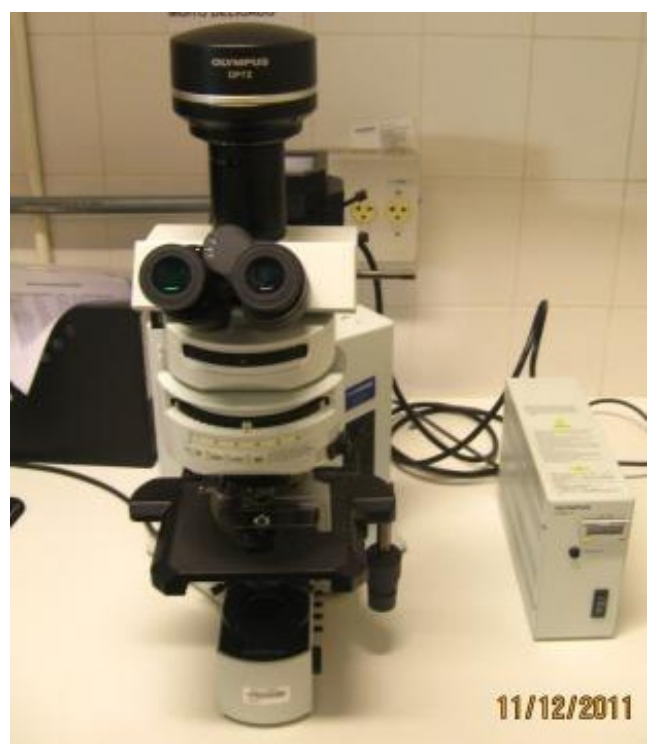

Figura 4.19 - Microscópio ótico Olympus, modelo DP-72 utilizado nos exames de microscopia durante o experimento em escala piloto. 
As determinações de $\mathrm{pH}$, OD e temperatura eram realizadas diariamente com o uso de equipamentos instalados na própria planta experimental (Laboratório de Tratamento de Resíduos Orgânicos) (Figura 4.21).
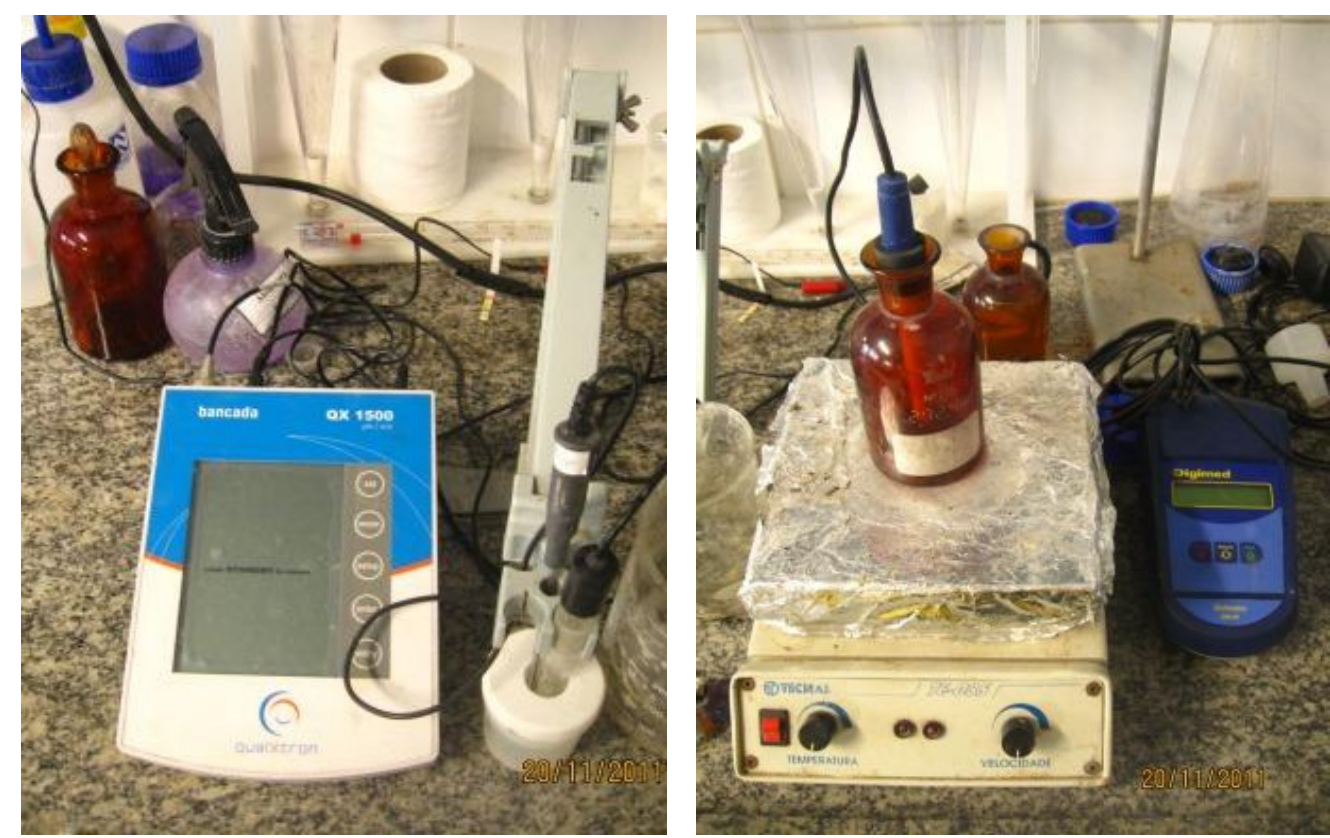

Figura 4.20 - pHmetro Qualxtron QX 1500 e Oxímetro Digimed DM-4P utilizados nas medições e $\mathrm{pH}$ e $\mathrm{OD}$, respectivamente.

As amostras do licor misto para a determinação da concentração de sólidos sedimentáveis (IVL) eram as mesmas utilizadas na determinação da concentração de sólidos suspensos.

Os resultados da caracterização das águas residuária e inóculos utilizados nesta pesquisa serão apresentados e discutidos nas seções 5.1 e 5.2.

As Tabelas 4.21 e 4.22 apresentam os parâmetros a serem monitorados, bem como a frequência das análises e os pontos de coleta nos experimentos em escala de bancada (Etapa 3) e em escala piloto (Etapa 4), respectivamente.

No experimento em escala piloto (Etapa 4) também foram determinados a Taxa de Consumo de Oxigênio específica (TCO) e o Coeficiente Global de Transferência de Oxigênio $\left(\mathrm{K}_{\mathrm{L}} \mathrm{a}\right)$. Esses parâmetros têm disso usada nos sistemas de lodos ativados para avaliar fatores que influenciam na eficiência de transferência de oxigênio e para avaliar a atividade biológica da biomassa do sistema. 
Tabela 4.2 - Parâmetros monitorados, frequência dos exames e análises realizadas nos experimentos em escala de bancada (Etapa 3)

\begin{tabular}{|c|c|c|c|c|}
\hline \multirow[b]{2}{*}{ PARÂMETRO } & \multicolumn{3}{|c|}{ LODOS ATIVADOS } & \multirow[b]{2}{*}{ MÉTODO ANALÍTICO } \\
\hline & AFLUENTE & $\begin{array}{c}T A N Q U E \\
D E \\
A E R A C \tilde{A} O\end{array}$ & EFLUENTE & \\
\hline $\mathrm{pH}$ & - & $\mathrm{D}$ & - & $4500 \mathrm{H}^{+}$(B) APHA (2005) \\
\hline Temperatura $\left({ }^{\circ} \mathrm{C}\right)$ & - & $\mathrm{D}$ & - & 4500 (O) APHA (2005) \\
\hline Condutividade $(\mu \mathrm{S} / \mathrm{cm})$ & $\mathrm{S}$ & - & $\mathrm{S}$ & 2510 (B) APHA (2005) \\
\hline Alcalinidade $\left(\mathrm{mg} \mathrm{CaCO}_{3} / \mathrm{L}\right)$ & $\mathrm{S}$ & - & $\mathrm{S}$ & 2320 (B) APHA (2005) \\
\hline Cor (mg Pt-Co/L) & $\mathrm{C}$ & - & - & 2120 (C) APHA (2005) \\
\hline Cloretos (mg/L) & $\mathrm{C}$ & - & - & 4500 (C) APHA (2005) \\
\hline Oxigênio dissolvido $\left(\mathrm{mgO}_{2} / \mathrm{L}\right)$ & - & $\mathrm{D}$ & - & 4500 (O) APHA (2005) \\
\hline $\mathrm{DQO}\left(\mathrm{mgO}_{2} / \mathrm{L}\right)$ & $S$ & - & $\mathrm{S}$ & $\begin{array}{c}5220(\mathrm{~B}) 4500(\mathrm{O}) \text { APHA } \\
(2005)\end{array}$ \\
\hline $\mathrm{DBO}_{5}\left(\mathrm{mgO}_{2} / \mathrm{L}\right)$ & $\mathrm{Q}$ & - & $\mathrm{Q}$ & 5210 (B) APHA (2005) \\
\hline Carbono orgânico dissolvido (mg C /L) & $\mathrm{S}$ & _ & $\mathrm{S}$ & 5310 (C) APHA (2005) \\
\hline Nitrogênio total Kjeldahl (mg N/L) & $\mathrm{S}$ & - & $\mathrm{S}$ & 4500 (B) APHA (2005) \\
\hline $\mathrm{N}$-amoniacal (mg N/L) & $\mathrm{S}$ & - & $\mathrm{S}$ & 4500 (C) APHA (2005) \\
\hline Nitrito $\left(\mathrm{mg} \mathrm{N}^{-\mathrm{NO}_{2}}{ }^{-} / \mathrm{L}\right)$ & $S$ & - & $\mathrm{S}$ & 4500 (I) APHA \\
\hline Nitrato $\left(\mathrm{mg} \mathrm{N}-\mathrm{NO}_{3}{ }^{-} / \mathrm{L}\right)$ & S & - & S & 4500 (B) APHA (2005) \\
\hline Fosfato total (mg P-PO $\left.{ }_{4}^{-3} / \mathrm{L}\right)$ & $\mathrm{C}$ & - & - & $\begin{array}{c}4500 \text { P (E e J) APHA } \\
(2005)\end{array}$ \\
\hline Sólidos totais (mg /L) & S & - & S & \\
\hline Sólidos fixos (mg /L) & $\mathrm{S}$ & - & S & \\
\hline Sólidos voláteis (mg /L) & S & - & S & 2540 (D,E e F) APHA \\
\hline Sólidos suspensos totais (mg /L) & S & $S$ & $S$ & (2005) \\
\hline Sólidos suspensos fixos (mg /L) & S & S & S & \\
\hline Sólidos suspensos voláteis (mg /L) & S & S & S & \\
\hline Índice volumétrico de lodo (mL/g) & - & $S$ & - & 2710 (D) APHA (2005)* \\
\hline $\begin{array}{l}\text { Metais }(\mathrm{mg} / \mathrm{L} \text { ou } \mathrm{mg} / \mathrm{kg} \text { lodo seco) - } \\
\mathrm{Zn}, \mathrm{Pb}, \mathrm{Cd}, \mathrm{Ni}, \mathrm{Fe}, \mathrm{Mn}, \mathrm{Cu}, \mathrm{Cr}\end{array}$ & - & Final** & - & $\begin{array}{c}3030(\mathrm{~F}) \text { e } 3030 \text { (D) APHA } \\
(2005)\end{array}$ \\
\hline Microscopia óptica & - & S & - & $\begin{array}{l}\text { Microscopia óptica de } \\
\text { campo claro }\end{array}$ \\
\hline
\end{tabular}

D: Diário; S: Semanal; Q: Quinzenal; C: Apenas para caracterização das águas residuárias.

*Neste estudo foi utilizado o cone Imhoff em vez da proveta. Entretanto os resultados das metodologias não são comparáveis, conforme indicado por Hoffmann et al. (2005).

**Determinado apenas no final do experimento. 
Tabela 4.3 - Parâmetros monitorados, frequência dos exames e análises realizadas nos experimentos em escala piloto (Etapa 4)

\begin{tabular}{|c|c|c|c|c|}
\hline \multirow[b]{2}{*}{ PARÂMETRO } & \multicolumn{3}{|c|}{ LODOS ATIVADOS } & \multirow[b]{2}{*}{ MÉTODO ANALÍTICO } \\
\hline & AFLUENTE & $\begin{array}{c}\text { TANQUE } \\
\text { DE } \\
\text { AERAÇÃO }\end{array}$ & EFLUENTE & \\
\hline $\mathrm{pH}$ & - & $\mathrm{D}$ & - & $4500 \mathrm{H}^{+}$(B) APHA (2005) \\
\hline Condutividade $(\mu \mathrm{S} / \mathrm{cm})$ & $\mathrm{S}$ & - & $\mathrm{S}$ & 2510 (B) APHA (2005) \\
\hline Alcalinidade $\left(\mathrm{mg} \mathrm{CaCO}_{3} / \mathrm{L}\right)$ & S & - & S & 2320 (B) APHA (2005) \\
\hline Cor (PtCo) & $\mathrm{C}$ & - & - & 2120 (C) APHA (2005) \\
\hline Cloretos (mg/L) & $\mathrm{C}$ & - & - & 4500 (C) APHA (2005) \\
\hline Oxigênio dissolvido $\left(\mathrm{mgO}_{2} / \mathrm{L}\right)$ & - & $\mathrm{D}$ & - & 4500 (O) APHA (2005) \\
\hline $\mathrm{DQO}\left(\mathrm{mgO}_{2} / \mathrm{L}\right)$ & $2 S$ & - & $2 S$ & $\begin{array}{c}5220 \text { (B) } 4500(\mathrm{O}) \text { APHA } \\
\text { (2005) }\end{array}$ \\
\hline $\mathrm{DBO}_{5}\left(\mathrm{mgO}_{2} / \mathrm{L}\right)$ & S & - & S & 5210 (B) APHA (2005) \\
\hline Carbono orgânico dissolvido (mg C /L) & $2 S$ & - & $2 S$ & 5310 (C) APHA (2005) \\
\hline Nitrogênio total Kjeldahl (mg N/L) & $S$ & - & S & 4500 (B) APHA (2005) \\
\hline $\mathrm{N}$-amoniacal (mg N/L) & S & - & S & 4500 (C) APHA (2005) \\
\hline Nitrito $\left(\mathrm{mg} \mathrm{N}-\mathrm{NO}_{2}^{-} / \mathrm{L}\right)$ & S & - & S & 4500 (I) APHA \\
\hline Nitrato $\left(\mathrm{mg} \mathrm{N}-\mathrm{NO}_{3}^{-} / \mathrm{L}\right)$ & S & - & S & 4500 (B) APHA (2005) \\
\hline Fosfato total (mg P-PO $\left.{ }_{4}^{-3} / \mathrm{L}\right)$ & $\mathrm{Q}$ & - & Q & $\begin{array}{l}4500 \text { P (E e J) APHA } \\
(2005)\end{array}$ \\
\hline Sólidos totais (mg /L) & $S$ & - & S & \\
\hline Sólidos fixos (mg /L) & $S$ & - & $S$ & \\
\hline Sólidos voláteis (mg /L) & $S$ & - & $S$ & 2540 (D,E e F) APHA \\
\hline Sólidos suspensos totais (mg /L) & $S$ & $2 \mathrm{~S}$ & $S$ & (2005) \\
\hline Sólidos suspensos fixos (mg /L) & $S$ & $2 \mathrm{~S}$ & $S$ & \\
\hline Sólidos suspensos voláteis (mg /L) & $S$ & $2 \mathrm{~S}$ & $S$ & \\
\hline Índice volumétrico de lodo (mL/g) & - & $2 \mathrm{~S}$ & - & $\begin{array}{l}2710 \text { (D) APHA (2005)* } \\
\text { com Cone Imhoff }\end{array}$ \\
\hline $\begin{array}{l}\text { Taxa de Consumo de Oxigênio } \\
\text { específica (mg } \mathrm{O}_{2} / \text { g.SSV.L.dia) }\end{array}$ & - & S & - & $\begin{array}{l}\text { Coletti (1997); Jordão e } \\
\text { Pessoa (2009) }\end{array}$ \\
\hline $\begin{array}{l}\text { Coeficiente Global de Transferência de } \\
\text { Oxigênio }\left(h^{-1}\right)\end{array}$ & - & S & - & $\begin{array}{c}\text { Coletti (1997); } \\
\text { Von Sperling (2002) }\end{array}$ \\
\hline $\begin{array}{l}\text { Metais pesados }(\mathrm{mg} / \mathrm{L} \text { ou } \mathrm{mg} / \mathrm{kg}) \\
\mathrm{Zn}, \mathrm{Pb}, \mathrm{Cd}, \mathrm{Ni}, \mathrm{Fe}, \mathrm{Mn}, \mathrm{Cu}, \mathrm{Cr}\end{array}$ & - & $S$ & - & $\begin{array}{c}3030 \text { (F) e } 3030 \text { (D) APHA } \\
(2005)\end{array}$ \\
\hline Microscopia óptica & - & S & - & $\begin{array}{l}\text { Microscopia óptica de } \\
\text { campo claro }\end{array}$ \\
\hline
\end{tabular}

D: Diário; S: Semanal; 2S: Duas vezes semanais; Q: Quinzenal; C: Apenas para caracterização das águas residuárias.

*Neste estudo foi utilizado o cone Imhoff em vez da proveta. Entretanto os resultados das metodologias não são comparáveis, conforme indicado por Hoffmann et al. (2005). 
A medição da TCO específica foi realizada conforme metodologia descrita em Coletti (1997), que consiste resumidamente na observação do decaimento de OD em intervalos de tempos regulares. As leituras foram realizadas em frasco sob agitação constante. Com os valores de OD obtidos é construída uma reta, cujo coeficiente angular da reta ajustada pelo método dos mínimos quadrados corresponde a TCO. Os experimentos foram realizados com utilização de um frasco de 1 litro, um agitador magnético e um oxímetro, de acordo com a figura 4.21 .

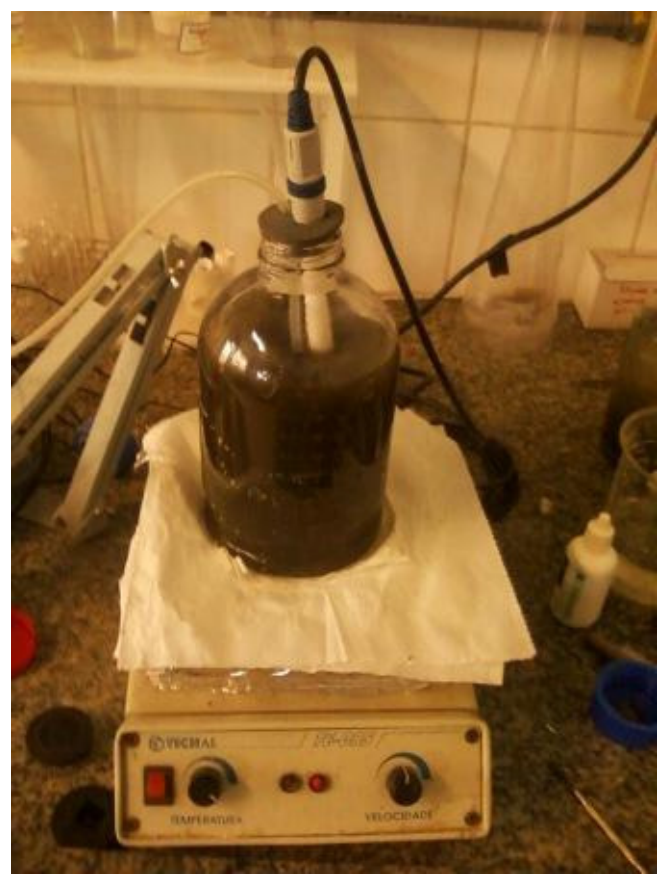

Figura 4.21 - Aparelhagem utilizada nos testes de determinação da Taxa de Consumo de Oxigênio (TCO) e Coeficiente Global de Transferência de Oxigênio $\left(\mathrm{K}_{\mathrm{L}} \mathrm{a}\right)$ no experimento em escala piloto (Etapa 4).

O Coeficiente Global de Transferência de Oxigênio $\left(\mathrm{K}_{\mathrm{L}} \mathrm{a}\right)$ foi determinado usando a mesma aparelhagem, com a inclusão de um aerador de aquário e mangueira com pedra porosa. Nesses testes, foi adicionado sulfito de sódio para acelerar a desoxigenação das amostras. Os testes foram realizados conforme os procedimentos descritos por Coletti (1997), que consiste resumidamente na observação do aumento da concentração de OD em intervalos de tempos regulares, até atingir a saturação. O coeficiente é dado pela inclinação da reta obtida após regressão linear do gráfico semilogaritmo de $\log \left(\mathrm{C}_{\mathrm{s}}-\mathrm{C}\right) \mathrm{x}$ tempo. 


\section{RESULTADOS E DISCUSSÃO}

\subsection{Caraterização das águas residuária utilizadas nos experimentos}

A caraterização do esgoto e do lixiviado foi realizada no decorrer dos diversos experimentos, antes de iniciar cada experimento, de modo que se obtivesse maior representatividade estatística dos dados.

\subsubsection{Caraterização do esgoto sanitário}

Os experimentos foram realizados no período de abril a dezembro de 2011 . Na Tabela 5.1 estão apresentados os valores mínimos e máximos das características físicoquímicas do esgoto sanitário e valores médios do efluente anaeróbio utilizados nos experimentos realizados durante a pesquisa. Optou-se por caracterizar separadamente o esgoto sanitário utilizado nos experimentos em escala de bancada (abril a agosto) e no experimento em escala piloto (setembro a dezembro), devido à maior variabilidade das características decorrente da alimentação contínua, diferentemente da alimentação em batelada, que era feita apenas uma vez por dia.

Observou-se grande variabilidade das características do esgoto sanitário no período de setembro a dezembro, principalmente da DQO bruta, DBO, COD, NAT e matéria sólida. Essa variabilidade da carga orgânica é decorrente da variação nas características do esgoto sanitário ao longo do dia, segundo os horários de pico dos despejos, o que refletiu diretamente na variação da eficiência do sistema de tratamento. Quanto à matéria sólida, a variação também esteve associada à frequência de manutenção e limpeza das grades do tratamento preliminar, bem como dos equipamentos das instalações de recalque e do poço de sucção durante o experimento em escala piloto. 
Tabela 5.1 - Características físico-químicas do esgoto sanitário e efluente anaeróbio proveniente do Reator Anaeróbio Compartimentado (RAC) utilizados nos experimentos

\begin{tabular}{|c|c|c|c|c|c|c|}
\hline \multirow{3}{*}{ Parâmetros } & \multicolumn{5}{|c|}{ Esgoto sanitário } & \multirow{3}{*}{$\begin{array}{c}\begin{array}{c}\text { Efluente } \\
\text { anaeróbio }\end{array} \\
\begin{array}{r}\text { JUN-AGO } \\
\text { (Etapa 3) }\end{array} \\
\text { Média }\end{array}$} \\
\hline & \multicolumn{2}{|c|}{$\begin{array}{c}\text { ABR-AGO } \\
\text { (Etapa 3) }\end{array}$} & \multicolumn{2}{|c|}{$\begin{array}{l}\text { SET-DEZ } \\
\text { (Etapa 4) }\end{array}$} & \multirow{2}{*}{$\begin{array}{c}\text { ABR-DEZ } \\
\text { Média }\end{array}$} & \\
\hline & Mínimo & Máximo & Mínimo & Máximo & & \\
\hline$\overline{\mathrm{pH}}$ & 6,7 & 7,6 & 7,2 & 7,8 & 7,3 & 6,9 \\
\hline Temperatura $\left({ }^{\circ} \mathrm{C}\right)$ & 23,5 & 25 & 22 & 24,7 & 23,8 & 24,5 \\
\hline Condutividade $(\mu \mathrm{S} / \mathrm{cm})$ & 363 & 505 & 320 & 658 & 461,5 & 412 \\
\hline Alcalinidade $\left(\mathrm{mg} \mathrm{CaCO}_{3} / \mathrm{L}\right)$ & 115,6 & 169,5 & 114 & 324 & 180,8 & 43,7 \\
\hline DQO bruta $\left(\mathrm{mgO}_{2} / \mathrm{L}\right)$ & 116 & 482 & 237 & 713 & 387 & 168 \\
\hline DQO solúvel $\left(\mathrm{mgO}_{2} / \mathrm{L}\right)$ & 108 & 174 & 127 & 240 & 162 & 106 \\
\hline $\mathrm{DBO}_{5}$ bruta $\left(\mathrm{mgO}_{2} / \mathrm{L}\right)$ & 94 & 214 & 131 & 302 & 185 & 90 \\
\hline $\mathrm{COD}(\mathrm{mg} \mathrm{C} / \mathrm{L})$ & 31 & 53,3 & 23 & 74 & 45 & 29 \\
\hline NTK (mg N/L) & 24 & 31,9 & 30,5 & 48 & 33,6 & 30,8 \\
\hline NAT (mg N/L) & 10 & 32,9 & 29 & 41,5 & 28,4 & 25,2 \\
\hline Nitrito $\left(m g ~ N-\mathrm{NO}_{2}{ }^{-} / \mathrm{L}\right)$ & N.D. & N.D. & N.D. & 0,4 & 0,1 & 0,01 \\
\hline Nitrato (mg N-NO${ }_{3}^{-} / \mathrm{L}$ ) & 0,1 & 1,4 & N.D. & 0,1 & 0,5 & 1,32 \\
\hline Cloretos $(\mathrm{mg} / \mathrm{L})$ & 10,4 & 42 & 10 & 16 & 19,6 & 37,4 \\
\hline Fosfato total (mg P-PO $\left.{ }_{4}^{-3} / \mathrm{L}\right)$ & 6,7 & 13,9 & 10,1 & 18,4 & 12,3 & 9,46 \\
\hline ST (mg /L) & 280 & 526 & 444 & 681 & 483 & 154 \\
\hline STF (mg /L) & 54 & 234 & 100 & 193 & 145 & 88 \\
\hline STV (mg /L) & 141 & 346 & 251 & 548 & 322 & 66 \\
\hline SDT (mg /L) & 28 & 281 & 330 & 400 & 260 & 122 \\
\hline SST (mg /L) & 77 & 416 & 114 & 281 & 222 & 33 \\
\hline SSV (mg /L) & 12 & 365 & 97 & 234 & 177 & 25 \\
\hline $\mathrm{Zn}(\mathrm{mg} / \mathrm{L})$ & - & - & - & - & 0,394 & 0,253 \\
\hline $\mathrm{Pb}(\mathrm{mg} / \mathrm{L})$ & - & - & - & - & 0,13 & 0,02 \\
\hline $\mathrm{Cd}(\mathrm{mg} / \mathrm{L})$ & - & - & - & - & N.D. & N.D. \\
\hline $\mathrm{Ni}(\mathrm{mg} / \mathrm{L})$ & - & - & - & - & 0,040 & 0,041 \\
\hline $\mathrm{Fe}(\mathrm{mg} / \mathrm{L})$ & - & - & - & - & 11,45 & 4,23 \\
\hline $\mathrm{Mn}(\mathrm{mg} / \mathrm{L})$ & - & - & - & - & 0,084 & 0,03 \\
\hline $\mathrm{Cu}(\mathrm{mg} / \mathrm{L})$ & - & - & - & - & 0,098 & 0,01 \\
\hline $\mathrm{Cr}(\mathrm{mg} / \mathrm{L})$ & - & - & - & - & 0,078 & 0,02 \\
\hline
\end{tabular}

N.D. = não detectável; - = não determinado 
Segundo os valores típicos dos parâmetros de matéria orgânica, de acordo com classificação proposta por Jordão e Pessoa (2009), o esgoto sanitário utilizado neste estudo apresenta características de esgoto médio. Conforme apresentado na Tabela 5.1, a relação DBO $_{5}$ :NTK:Fosfato de 100:11:4, obtida para o esgoto utilizado na alimentação dos reatores, revela que o esgoto bruto possui os nutrientes, nitrogênio e fósforo em concentração suficiente para promover uma boa floculação biológica, uma vez que é bem superior a relação $\mathrm{DBO}: \mathrm{N}: \mathrm{P}=100: 5: 1$ mínima recomendada para sistema de lodos ativados, segundo Além Sobrinho (1983) e Metcalf \& Eddy (2003).

Após estabilização do reator anaeróbio compartimentado (RAC), o seu efluente teve uma redução de aproximadamente $50 \%$ da DQO bruta e $62 \%$ de sólidos totais, a mesma eficiência obtida por Povinelli (1994) e Nour (1996), tratando esgoto sanitário no mesmo reator. Houve também um consumo elevado da alcalinidade total do esgoto, cerca de $60 \%$, sendo necessária adição diária de hidróxido de sódio nos reatores com $0 \%$ de lixiviado (controle) dos experimentos com o efluente anaeróbio.

\subsubsection{Caraterização dos lixiviados utilizados nos experimentos}

Conforme descrito anteriormente, o lixiviado foi pré-tratado por alcalinização e air stripping para ser utilizado nos Experimentos E2 e E3 e experimento em escala piloto. As Tabelas 5.2 e 5.3 apresentam os resultados da caracterização do lixiviado bruto, alcalinizado e pré-tratado utilizados nos experimentos em escala de bancada e piloto, respectivamente. 
Tabela 5.2 - Características físico-químicas do lixiviado bruto, alcalinizado e pré-tratado por air stripping utilizados nos experimentos de bancada.

\begin{tabular}{|c|c|c|c|c|c|}
\hline \multirow{2}{*}{ Parâmetros } & \multicolumn{3}{|c|}{ Lixiviado bruto } & \multirow{2}{*}{$\begin{array}{c}\begin{array}{c}\text { Lixiviado } \\
\text { Alcalinizado }\end{array} \\
\text { Média }\end{array}$} & \multirow{2}{*}{$\begin{array}{c}\begin{array}{c}\text { Lixiviado } \\
\text { pré-tratado }\end{array} \\
\text { Média }\end{array}$} \\
\hline & Mínimo & Máximo & Média & & \\
\hline $\mathrm{pH}$ & 8,3 & 8,5 & 8,4 & 11,6 & 9,6 \\
\hline Temperatura $\left({ }^{\circ} \mathrm{C}\right)$ & 23,0 & 25,3 & 24,1 & 22,0 & 23,4 \\
\hline Condutividade $(\mu \mathrm{S} / \mathrm{cm})$ & 2390 & 28300 & 15345 & 17285 & 13020 \\
\hline Cloretos (mg /L) & 3060 & 3900 & 3480 & 3050 & 3750 \\
\hline Cor verdadeira (mg Pl-Co/L) & 4380 & 5070 & 4725 & 3625 & 2830 \\
\hline Alcalinidade $\left(\mathrm{mg} \mathrm{CaCO}_{3} / \mathrm{L}\right)$ & 8600 & 10076 & 9338 & 3200 & 2650 \\
\hline DQO bruta $\left(\mathrm{mgO}_{2} / \mathrm{L}\right)$ & 4425 & 4860 & 4642 & 3364 & 2772 \\
\hline DQO solúvel $\left(\mathrm{mgO}_{2} / \mathrm{L}\right)$ & 2920 & 4195 & 3557 & 3042 & 2200 \\
\hline $\mathrm{DBO}_{5}$ bruta $\left(\mathrm{mgO}_{2} / \mathrm{L}\right)$ & 980 & 1090 & 1035 & - & 380 \\
\hline $\mathrm{COD}(\mathrm{mg} \mathrm{C} / \mathrm{L})$ & 853 & 1395 & 1124 & 1166 & 1098 \\
\hline NTK (mg N/L) & 2219 & 2262 & 2240 & 1570,5 & 86,7 \\
\hline NAT (mg N/L) & 1009 & 2138 & 1574 & 1384,3 & 8,85 \\
\hline Nitrito $\left(\mathrm{mg} \mathrm{N}-\mathrm{NO}_{2}^{-} / \mathrm{L}\right)$ & 0,1 & 0,1 & 0,1 & - & - \\
\hline Nitrato (mg N-NO ${ }_{3}^{-} / \mathrm{L}$ ) & - & - & - & - & - \\
\hline Fosfato total (mg P-PO $\left.{ }^{-3} / \mathrm{L}\right)$ & 23,2 & 18,6 & 20,9 & 7,6 & 6,9 \\
\hline $\mathrm{ST}(\mathrm{mg} / \mathrm{L})$ & 11868 & 12088 & 11978 & 9738 & 9140 \\
\hline $\mathrm{STF}(\mathrm{mg} / \mathrm{L})$ & 8446 & 8738 & 8592 & 7620 & 6967 \\
\hline STV (mg /L) & 3130 & 3642 & 3386 & 2118 & 2173 \\
\hline SDT (mg /L) & 11695 & 11922 & 11809 & 9581 & 9037 \\
\hline $\mathrm{SST}(\mathrm{mg} / \mathrm{L})$ & 166 & 173 & 170 & 157 & 103 \\
\hline $\mathrm{SSV}(\mathrm{mg} / \mathrm{L})$ & 31 & 82 & 57 & 63 & 48 \\
\hline Zn (mg /L) & - & - & 0,417 & 0,215 & - \\
\hline $\mathrm{Pb}(\mathrm{mg} / \mathrm{L})$ & - & - & 0,09 & 0,10 & - \\
\hline $\mathrm{Cd}(\mathrm{mg} / \mathrm{L})$ & - & - & 0,028 & 0,033 & - \\
\hline $\mathrm{Ni}(\mathrm{mg} / \mathrm{L})$ & - & - & 0,309 & 0,275 & - \\
\hline $\mathrm{Fe}(\mathrm{mg} / \mathrm{L})$ & - & - & 3,024 & 1,169 & - \\
\hline $\mathrm{Mn}(\mathrm{mg} / \mathrm{L})$ & - & - & 0,045 & 0,131 & - \\
\hline $\mathrm{Cu}(\mathrm{mg} / \mathrm{L})$ & - & - & 0,05 & N.D. & - \\
\hline $\mathrm{Cr}(\mathrm{mg} / \mathrm{L})$ & - & - & 0,362 & 0,215 & - \\
\hline
\end{tabular}

N.D.= Não detectável; - = Não determinado 
Tabela 5.3 - Características físico-químicas do lixiviado bruto, alcalinizado e pré-tratado utilizados no experimento em escala piloto.

\begin{tabular}{|c|c|c|c|}
\hline Parâmetros & $\begin{array}{l}\text { Lixiviado } \\
\text { bruto }\end{array}$ & $\begin{array}{c}\text { Lixiviado } \\
\text { alcalinizado }\end{array}$ & $\begin{array}{l}\text { Lixiviado } \\
\text { pré-tratado }\end{array}$ \\
\hline & Média & Média & Média \\
\hline $\mathrm{pH}$ & 8,5 & 11,1 & 9,3 \\
\hline Condutividade $(\mu \mathrm{S} / \mathrm{cm})$ & 15500 & 14280 & 13860 \\
\hline Cloretos (mg/L) & 3760 & 2760 & 3280 \\
\hline Cor verdadeira(mgPl-Co/L) & 8980 & 4440 & 4040 \\
\hline Alcalinidade $\left(\mathrm{mg} \mathrm{CaCO}_{3} / \mathrm{L}\right)$ & 6430 & 5421 & 2782 \\
\hline DQO bruta $\left(\mathrm{mgO}_{2} / \mathrm{L}\right)$ & 4250 & 3500 & 2960 \\
\hline DQO solúvel $\left(\mathrm{mgO}_{2} / \mathrm{L}\right)$ & 3292 & 2940 & 2536 \\
\hline $\mathrm{DBO}_{5}$ bruta $\left(\mathrm{mgO}_{2} / \mathrm{L}\right)$ & 620 & 321 & 339 \\
\hline $\mathrm{COD}(\mathrm{mg} \mathrm{C} / \mathrm{L})$ & 792 & 690 & 635 \\
\hline NTK (mg N/L) & 901 & 792 & 19 \\
\hline NAT (mg N/L) & 870 & 760 & 14 \\
\hline Nitrito $\left(m g ~ N-\mathrm{NO}_{2}^{-} / \mathrm{L}\right)$ & N.D. & N.D. & 0,8 \\
\hline Nitrato $\left(\mathrm{mg} \mathrm{N}-\mathrm{NO}_{3}^{-} / \mathrm{L}\right)$ & 0,1 & N.D. & 2,1 \\
\hline Fosfato total $\left(\mathrm{mgP}-\mathrm{PO}_{4}{ }^{-3} / \mathrm{L}\right)$ & 18,2 & 6,9 & 2,1 \\
\hline ST (mg /L) & 12623 & 12165 & 11788 \\
\hline $\operatorname{STF}(\mathrm{mg} / \mathrm{L})$ & 10145 & 10053 & 9642 \\
\hline STV (mg /L) & 2478 & 2112 & 2146 \\
\hline SDT (mg /L) & 12527 & 11914 & 11695 \\
\hline SST (mg /L) & 96 & 251 & 93 \\
\hline SSV (mg /L) & 71 & 195 & 63 \\
\hline $\mathrm{Zn}(\mathrm{mg} / \mathrm{L})$ & 0,301 & 0,165 & 0,0405 \\
\hline $\mathrm{Pb}(\mathrm{mg} / \mathrm{L})$ & 0,20 & 0,30 & 0,40 \\
\hline $\mathrm{Cd}(\mathrm{mg} / \mathrm{L})$ & 0,018 & 0,029 & 0,018 \\
\hline $\mathrm{Ni}(\mathrm{mg} / \mathrm{L})$ & 0,438 & 0,337 & 0,319 \\
\hline $\mathrm{Fe}(\mathrm{mg} / \mathrm{L})$ & 5,613 & 2,921 & 1,304 \\
\hline Mn (mg /L) & 0,234 & 0,055 & 0,030 \\
\hline $\mathrm{Cu}(\mathrm{mg} / \mathrm{L})$ & 0,08 & 0,021 & 0,028 \\
\hline $\mathrm{Cr}(\mathrm{mg} / \mathrm{L})$ & 0,448 & 0,166 & 0,147 \\
\hline
\end{tabular}

N.D.= Não detectável 
Conforme as Tabelas 5.2 e 5.3, as características do lixiviado bruto indicam seu elevado potencial poluidor, devido a elevadas concentrações de matéria orgânica em termos da DQO, DBO e COD e NAT, além de cloretos, sólidos dissolvidos e alguns metais pesados. Conforme já citado, as elevadas concentrações de NAT presentes no lixiviado bruto são apontadas como um dos poluentes que podem causar efeito tóxico e inibição da atividade biológica de degradação.

O lixiviado do aterro sanitário de São Carlos apresentou relação DBO/DQO variando de 0,15 a 0,22 , para o conjunto de amostras coletadas no sistema de drenagem e na lagoa de armazenamento, podendo ser considerado como um lixiviado de aterro com média estabilização conforme classificação proposta por Renou et al. (2008). A concentração da DQO varia de $4250 \mathrm{mg} / \mathrm{L}$ a $4860 \mathrm{mg} / \mathrm{L}$ e DBO de 620mg/L a 1090mg/L. Sua concentração de amônia também é elevada, variando de 870 a 2138 $\mathrm{mg} / \mathrm{L}$.

Conforme discutido, o lixiviado utilizado nos experimentos de bancada foi coletado na rede de drenagem do aterro, enquanto o lixiviado utilizado no experimento em escala piloto foi coletado da lagoa de armazenamento. Isso explica a menor concentração de matéria orgânica em termos da DBO e COD e de nitrogênio amoniacal total do lixiviado coletado na lagoa, devido ao favorecimento da degradação ao ser acumulado por longo período de tempo e a perdas resultantes da volatilização da amônia.

De acordo com os parâmetros analisados, pode-se observar que o pré-tratamento com cal comercial (alcalinização) promoveu a remoção de até $50 \%$ da cor verdadeira e $31 \%$ da DQO bruta do lixiviado.

Após a correção do $\mathrm{pH}$, conforme precipitava o carbonato de cálcio, a coloração escura do lixiviado bruto tornava-se amarelada, como pode ser observado na Figura 5.1. Essa redução da DQO acompanhada da clarificação do lixiviado após a alcalinização foi também observada por Aziz, et al. (2007), Souto (2009), Ferraz (2010) e Pasqualini (2010), podendo indicar que uma parcela da matéria orgânica recalcitrante (substâncias húmicas) presente no lixiviado bruto é removida por precipitação.

A adição da cal comercial ao lixiviado também promoveu uma significativa remoção de fosfato e nitrogênio amoniacal. Os resultados mostraram eficiência de remoção de NAT e fosfato de até 29 e 64\%, respectivamente, resultados próximos dos relatados por Turetta (2011). 

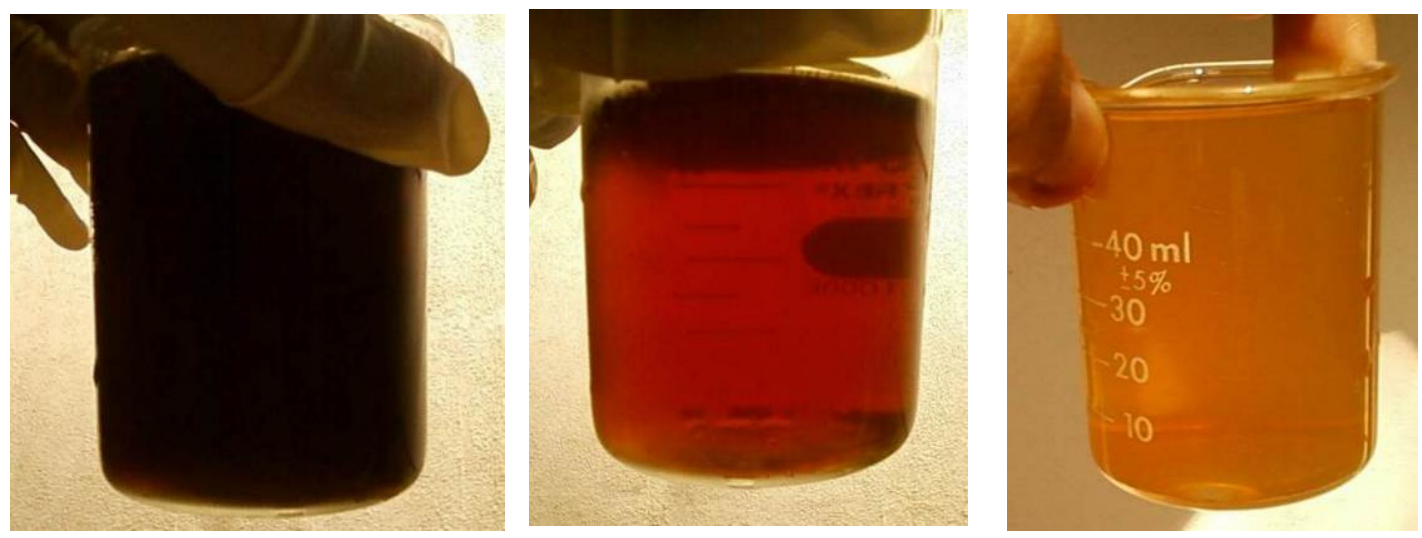

Figura 5.1 - Lixiviado bruto (a), lixiviado alcalinizado a pH 11 (b), lixiviado alcalinizado a pH 12,5 (c).

A remoção de fosfato, segundo Metcalf e Eddy (2003), se deve à reação do hidróxido de cálcio presente na cal com a alcalinidade do meio, precipitando em forma de $\mathrm{Ca}_{10}\left(\mathrm{PO}_{4}\right)_{6}(\mathrm{OH})_{2}$. Segundo os autores, até $80 \%$ do fósforo pode ser precipitado em $\mathrm{pH}$ em torno de 11.

Também houve redução significativa da concentração dos metais $\mathrm{Zn}, \mathrm{Ni}, \mathrm{Fe}$ e $\mathrm{Cr}$ na fase líquida do lixiviado após alcalinização, possivelmente pela transferência desses metais para fase sólida (lodo químico) decorrente da precipitação desses metais em pH elevado.

\subsection{Caraterísticas dos inóculos utilizados nos experimentos}

Também foi realizada a caracterização da diversidade de morfologias microbianas das amostras de lodo (inóculo) coletadas no sistema de lodos ativados da indústria Faber Castell utilizados nos experimentos. Tal caracterização refere-se à presença de microrganismos pertencentes aos Filos Protozoa (Classes Mastigophora Ciliata e Sarcodina), Metazoa Rotifera, Nematoda e Anelida observados nos exames de microscopia óptica de campo claro.

A estimativa de frequência de microrganismos observados foi avaliada subjetivamente, indicando a densidade populacional comparativa entre as amostras coletadas, conforme apresentado na Tabela 5.4. 
Tabela 5.4 - Caracterização microbiana e frequência da presença de protozoários e metazoários nos inóculos utilizados nos experimentos.

\begin{tabular}{|c|c|c|c|c|c|}
\hline & E1 & $\mathbf{E 2}$ & $\mathbf{E 3}$ & $\mathbf{E 4}$ & Piloto \\
\hline \multicolumn{6}{|c|}{ Filo Protozoa } \\
\hline Classe Mastigophora (flagelados) & - & - & - & - & - \\
\hline $\begin{array}{l}\text { Classe Ciliata (ciliados livre } \\
\text { natantes) }\end{array}$ & - & - & - & - & + \\
\hline Aspidisca sp. & - & - & - & - & + \\
\hline Paramecium sp. & - & - & - & - & - \\
\hline Trachelophyllum sp. & - & - & - & - & - \\
\hline Outros & - & - & - & - & - \\
\hline Classe Ciliata (ciliados fixos) & ++++ & +++ & ++ & ++++ & ++ \\
\hline Vorticella sp. & +++ & + & + & + & + \\
\hline Epistylis sp. & - & ++ & + & +++ & + \\
\hline Podophrya sp. & - & - & - & - & - \\
\hline Suctoria sp. & - & - & - & - & - \\
\hline Opercularia sp. & - & - & - & - & - \\
\hline Outros & ++ & - & - & - & - \\
\hline Classe Sarcodina (rizópodes) & ++ & ++ & +++ & ++ & +++ \\
\hline Amoeba sp. & - & - & - & - & - \\
\hline Euglypha sp. & ++ & + & ++ & + & +++ \\
\hline Arcella sp. & - & - & - & + & + \\
\hline Outros & - & + & + & - & - \\
\hline
\end{tabular}

\begin{tabular}{lccccc}
\hline Filo Rotifera (rotíferos) & ++ & + & + & +++ & - \\
Epiphanes $s p$. & ++ & + & - & ++ & - \\
Rotaria sp. & - & - & - & + & - \\
Philodinavus sp. & + & - & + & - & \\
Outros & - & - & - & - & - \\
\hline Filo Nematoda (vermes) & - & - & - & - & + \\
\hline Filo Anelida & - & - & - & - & - \\
\hline
\end{tabular}

Bactérias e Fungos

\begin{tabular}{lccccc}
\hline Bactérias isoladas em suspensão & +++ & +++ & +++ & ++ & - \\
\hline $\begin{array}{l}\text { Bactérias coloniais (zoogloea } \\
\text { ramigera) }\end{array}$ & - & - & - & - & - \\
\hline Bactérias filamentosas & +++ & ++ & ++ & ++ & +++ \\
\hline Fungos & - & ++ & - & - & - \\
\hline
\end{tabular}

Legenda:

Ausentes -

Frequência baixa +

Frequência média ++

Frequência elevada +++

Abundante++++
E1 - Experimento com esgoto bruto e lixiviado

E2 - Experimento com esgoto bruto e lixiviado pré-tratado

E3 - Experimento com efluente anaeróbio e lixiviado pré-tratado E4 - Experimento com efluente anaeróbio e lixiviado

Piloto - Experimentos em escala piloto 
Os resultados dos exames microscópicos revelaram predomínio de protozoários ciliados fixos, rizópodes e metazoários rotíferos. Havia também a presença de bactérias filamentosas que formam a estrutura do floco. Observou-se predomínio de rizópodes, aparecimento de ciliados livres e de alguns vermes no inóculo utilizado nos experimentos em escala piloto. A presença desses microrganismos indica boas condições de estabilidade e sedimentabilidade do lodo do reator de lodos ativados (Jekins et al., 2003).

Na Figura 5.2 são ilustrados os microrganismos presentes no lodo coletado na indústria Faber Castell LTDA. E utilizado como inóculo.
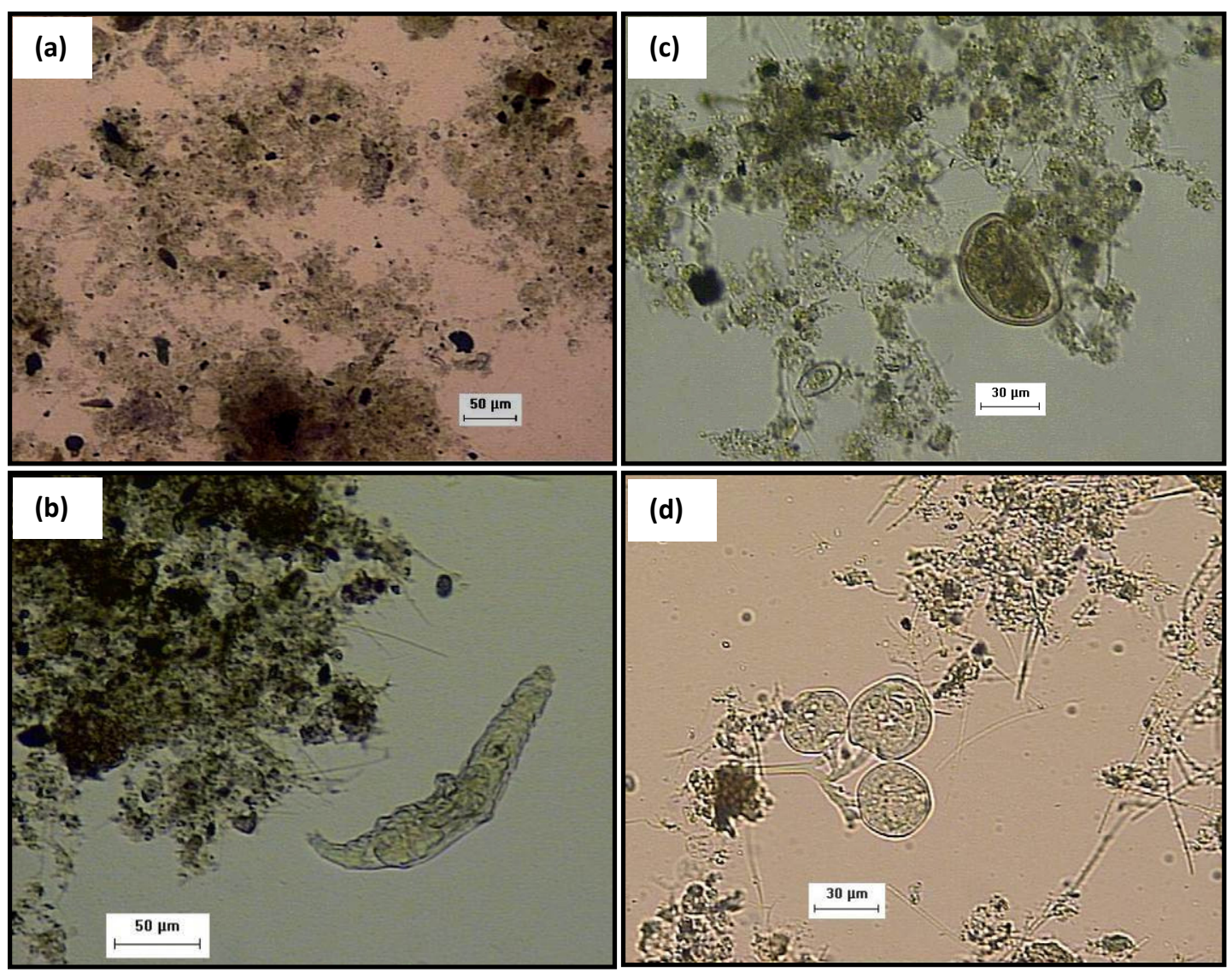

Figura 5.2 - Microscopia de campo claro da microfauna do lodo (inóculo) do sistema de lodos ativados da indústria Faber Castell: aspecto geral do floco - 50x (a); metazoário rotífero semelhante à Philodinavus sp.- 100x (b); metazoários rizópodes semelhantes a Arcella sp. e Euglypha sp.- 200x (c); protozoário ciliado fixo semelhante à Vorticella sp. - 200x (d).

Foram também determinadas as concentrações de sólidos para os diferentes inóculos, cujos resultados são apresentados na Tabela 5.5. A razão STV/ST maior que 0,6 indica elevada quantidade de matéria orgânica, em todos os inóculos, que é 
característica favorável à utilização desses em sistema de tratamento biológico (Mendonça, 2002).

Tabela 5.5 - Concentração de sólidos nos inóculos utilizados nos experimentos.

\begin{tabular}{lccccc}
\hline Parâmetro & E1 & E2 & E3 & E4 & Piloto \\
\hline ST & 10340 & 9600 & 10100 & 11030 & 8400 \\
STF & 2300 & 2190 & 2490 & 2870 & 1050 \\
STV & 8150 & 7410 & 7610 & 8160 & 7350 \\
SST & 9250 & 8800 & 8150 & 9560 & 7050 \\
SSV & 8040 & 7120 & 6890 & 7380 & 6500 \\
STV/ST & 0,79 & 0,77 & 0,75 & 0,74 & 0,87 \\
\hline
\end{tabular}

Em relação aos metais pesados nos inóculos, observou-se elevada concentração de zinco, ferro e cobre, conforme apresentado na Tabela 5.6. Tal fato pode estar associado à adsorção desses metais no lodo, comumente presentes no efluente de indústrias de papel e celulose (Deliyanni et al., 2006), tratado juntamente com esgoto sanitário no sistema de lodos ativados da ETE da Faber Castell.

Tabela 5.6 - Concentração de metais nos inóculos utilizados nos experimentos.

\begin{tabular}{|c|c|c|c|c|c|}
\hline$\frac{\text { Amostras }}{\text { Metais }}$ & E1 & $\mathbf{E} 2$ & $\mathbf{E 3}$ & E4 & PILOTO \\
\hline $\mathrm{Zn}(\mathrm{mg} / \mathrm{L})$ & 3,599 & 3,171 & 3,355 & 4,293 & 3,86 \\
\hline $\mathbf{P b}(\mathrm{mg} / \mathrm{L})$ & 0,53 & 0,31 & 0,31 & 0,37 & 0,51 \\
\hline $\mathrm{Cd}(\mathrm{mg} / \mathrm{L})$ & 0,031 & 0,03 & 0,038 & N.D. & 0,042 \\
\hline $\mathrm{Ni}(\mathrm{mg} / \mathrm{L})$ & 0,312 & 0,136 & 0,241 & 0,284 & 0,295 \\
\hline $\mathrm{Fe}(\mathrm{mg} / \mathrm{L})$ & 88,64 & 52,26 & 72,68 & 95,3 & 89,7 \\
\hline Mn (mg/L) & 0,503 & 0,524 & 0,619 & 0,735 & 0,721 \\
\hline $\mathrm{Cu}(\mathrm{mg} / \mathrm{L})$ & 1,705 & 1,404 & 1,667 & 2,066 & 2,015 \\
\hline $\mathrm{Cr}(\mathrm{mg} / \mathrm{L})$ & 0,731 & 0,296 & 0,604 & 0,645 & 0,858 \\
\hline
\end{tabular}

N.D.= Não detectável

A maior concentração de ferro nos lodos utilizados como inóculos também pode estar associado à adsorção de íons de ferro provenientes do coagulante utilizado na etapa de tratamento físico-químico que antecede o sistema de lodos ativados na referida indústria. 


\subsection{Resultados das análises físico-químicas dos experimentos de tratabilidade em escala de bancada}

\subsubsection{Considerações iniciais sobre os experimentos}

Foram realizados inicialmente quatro experimentos em escala de bancada utilizando diferentes proporções de lixiviado. Esta etapa foi dividida em quatro experimentos com diferentes condições experimentais, denominadas Experimento 1 (E1), Experimento 2 (E2), Experimento 3 (E3) e Experimento 4 (E4), já citados na seção 4.1 de Material e Métodos.

O Experimento 1 foi realizado com objetivo de verificar as possíveis interferências da adição do lixiviado bruto sobre a biomassa desenvolvida e avaliar a remoção da matéria orgânica e nitrogênio presentes na mistura de lixiviado e esgoto sanitário.

O Experimento 2 foi realizado visando à verificação das possíveis interferências da adição do lixiviado pré-tratado (alcalinizado e com remoção de NAT por air stripping) sobre a biomassa desenvolvida durante a fase de adaptação e avaliar a remoção da matéria orgânica e nitrogênio presentes na mistura de lixiviado pré-tratado e esgoto bruto.

O objetivo do Experimento 3 foi verificar as possíveis interferências da mistura com lixiviado pré-tratado (alcalinizado e com remoção de NAT por air stripping) sobre a biomassa desenvolvida durante a fase de adaptação e acompanhar a remoção da matéria orgânica e nitrogênio presentes na mistura de lixiviado pré-tratado e efluente anaeróbio tratado no Reator Anaeróbio Compartimentado (RAC).

O objetivo do Experimento 4 foi avaliar as possíveis interferências da adição do lixiviado bruto sobre a biomassa desenvolvida durante a fase de adaptação e acompanhar a remoção da matéria orgânica presente na mistura de lixiviado bruto e efluente anaeróbio proveniente do RAC.

Os experimentos utilizando efluente anaeróbio foram realizados com intuito de se verificar as interferências na tratabilidade do lixiviado, uma vez que o pré-tratamento em reator anaeróbio remove grande parcela da matéria orgânica do esgoto, portanto, conforme alguns autores, não acarretaria nenhum efeito sobre o tratamento. 
A apresentação dos resultados será procedida individualmente para cada experimento, posteriormente serão feitas as comparações entre os diversos experimentos realizados. Os resultados serão discutidos avaliando-se principalmente os parâmetros indicativos de remoção de matéria orgânica (DBO, DQO bruta e solúvel e COD) e a série de nitrogênio (NTK, NAT, nitrito e nitrato) que são utilizados como indicadores principais na avaliação do tratamento combinado de esgoto sanitário e lixiviado de aterro sanitário em diferentes condições. Além desses parâmetros, foi examinada a composição da diversidade de morfologias microbianas durante os experimentos, em termos da frequência de protozoários e micrometazoários, as características da estrutura dos flocos, sedimentabilidade e o comportamento da concentração de metais pesados no lodo aeróbio dos reatores.

Sempre que necessário, o $\mathrm{pH}$ da mistura afluente foi corrigido de modo que o tanque de aeração fosse mantido na faixa de 6,5 a 8,5 em todos os experimentos. Segundo Metcalf e Eddy (2003) essa é a faixa ótima para o crescimento bacteriano. Em todos os experimentos em que não foi adicionado lixiviado (controle) houve necessidade de correção de $\mathrm{pH}$ periodicamente.

No Apêndice A3 encontram-se os valores de pH lidos antes da correção. $\mathrm{O}$ pH foi corrigido com solução de $\mathrm{HCl}$ (ácido clorídrico) ou de $\mathrm{Ca}(\mathrm{OH})_{2}$ (hidróxido de cálcio).

Nos Apêndices A1 a A19, onde estão apresentados os resultados referentes a todos os parâmetros determinados durante a realização dos experimentos.

\subsubsection{Demanda Química de Oxigênio-DQO}

Os valores das concentrações da DQO bruta nos experimentos de bancada estão apresentados na Figura 5.3 e da DQO solúvel (filtrada em membrana de diâmetro médio de poro de 1,2 $\mu \mathrm{m}$ ) na Figura 5.4.. Todos os resultados das concentrações da DQO desta etapa encontram-se nos Apêndices A6 e A7. 
- Experimento 1: Tratamento consorciado de lixiviado em proporções de 0 a $5 \%$ e esgoto sanitário em sistema de lodos ativados em batelada

As eficiências médias de remoção da DQO bruta neste experimento em que foi adicionado lixiviado bruto nas proporções de 0; 0,2; 2 e 5\% foram: 90; 76; 70; 51\%, respectivamente, conforme apresentado na Tabela 5.6.

Tabela 5.6 - Eficiência média do sistema de lodos ativados em escala de bancada, tratando esgoto com 0 a 5\% de lixiviado (E1), na remoção da DQO bruta.

\begin{tabular}{cccc}
\hline $\begin{array}{c}\text { Proporções de } \\
\text { lixiviado (\%) }\end{array}$ & Afluente (mg/L) & Efluente (mg/L) & Eficiência (\%) \\
\hline 0 & 236 & 23 & $90 \%$ \\
0,2 & 234 & 56 & $76 \%$ \\
2 & 310 & 94 & $70 \%$ \\
5 & 430 & 210 & $51 \%$ \\
\hline
\end{tabular}

As eficiências médias de remoção da DQO solúvel nos reatores deste experimento em que foi adicionado lixiviado bruto nas proporções de 0;0,2;2 e 5\% foram de 92; 74; 69; 45\% respectivamente conforme apresentado na Tabela 5.7.

Tabela 5.7 - Eficiência média do sistema de lodos ativados em escala de bancada, tratando esgoto com 0 a 5\% de lixiviado (E1), na remoção da DQO solúvel.

\begin{tabular}{cccc}
\hline $\begin{array}{c}\text { Proporções de } \\
\text { lixiviado (\%) }\end{array}$ & Afluente (mg/L) & Efluente (mg/L) & Eficiência (\%) \\
\hline 0 & 137 & 11 & $92 \%$ \\
0,2 & 128 & 20 & $74 \%$ \\
2 & 199 & 94 & $69 \%$ \\
5 & 315 & 173 & $45 \%$ \\
\hline
\end{tabular}

Pode-se observar que houve redução na eficiência de remoção da DQO bruta e solúvel à medida que a proporção de lixiviado aumentava, o que pode estar associado ao efeito da toxicidade da amônia livre e à presença de matéria orgânica recalcitrante, de difícil degradação biológica presentes no lixiviado bruto. 
A gradativa redução da eficiência de remoção da DQO à medida que se aumenta a proporção de lixiviado bruto (0 a 5\%) no tratamento consorciado com esgoto bruto em sistema de lodos ativados também foi relatada por Henry (1985), Ehrig (1998), Borghi et al. (2001) e Franco (2009).

Henry (1985) também verificou que na proporção de 5\% de lixiviado bruto, a eficiência do sistema é fortemente comprometida, conforme verificado nessa condição.

\section{- Experimento 2: Tratamento consorciado de lixiviado pré-tratado em} proporções de 0 a $5 \%$ e esgoto sanitário em sistema de lodos ativados em batelada

As eficiências médias de remoção da DQO bruta nos reatores deste experimento em que foi adicionado lixiviado pré-tratado nas proporções de $0 ; 0,2 ; 2$ e $5 \%$ (Experimento 2) foram 92;87; 82; 69\% respectivamente conforme apresentado na Tabela 5.8.

Tabela 5.8 - Eficiência média do sistema de lodos ativados em escala de bancada, tratando esgoto com 0 a 5\% de lixiviado pré-tratado (E2), na remoção da DQO bruta.

\begin{tabular}{cccc}
\hline $\begin{array}{c}\text { Proporções de } \\
\text { lixiviado }(\%)\end{array}$ & Afluente (mg/L) & Efluente (mg/L) & Eficiência (\%) \\
\hline 0 & 288 & 25 & $92 \%$ \\
0,2 & 299 & 38 & $87 \%$ \\
2 & 342 & 59 & $82 \%$ \\
5 & 422 & 130 & $69 \%$ \\
\hline
\end{tabular}

As eficiências médias de remoção da DQO solúvel nos reatores em que foi adicionado lixiviado nas proporções de $0 ; 0,2 ; 2$ e $5 \%$ foram de $86 ; 76 ; 73 ; 54 \%$ respectivamente conforme apresentado na Tabela 5.9.

Pode-se observar nas Tabelas 5.8 e 5.9 que também houve redução na eficiência de remoção da DQO bruta e solúvel à medida que a proporção de lixiviado aumentava neste experimento. No entanto, para as condições do Experimento 2 essa redução da eficiência foi menos acentuada, especialmente ao se comparar com o reator controle 
(0\%), resultando em um efluente com menor concentração da DQO para todas as proporções, quando comparado ao Experimento 1.

Tabela 5.9 - Eficiência média do sistema de lodos ativados em escala de bancada, tratando esgoto com 0 a $5 \%$ de lixiviado pré-tratado (E2), na remoção da DQO solúvel

\begin{tabular}{cccc}
\hline $\begin{array}{c}\text { Proporções de } \\
\text { lixiviado (\%) }\end{array}$ & Afluente (mg/L) & Efluente (mg/L) & Eficiência (\%) \\
\hline 0 & 119 & 16 & $86 \%$ \\
0,2 & 124 & 31 & $76 \%$ \\
2 & 172 & 45 & $73 \%$ \\
5 & 262 & 118 & $54 \%$ \\
\hline
\end{tabular}

As maiores eficiências neste experimento podem estar associadas à redução do efeito da toxicidade da amônia livre, que foi removida na torre de air stripping (até uma concentração de NAT inferior a $20 \mathrm{mg} / \mathrm{L}$ ) e à precipitação de parte da matéria orgânica recalcitrante promovida pela pré-alcalinização do lixiviado bruto.

- Experimento 3: Tratamento consorciado de lixiviado pré-tratado em proporções de 0 a $5 \%$ e efluente anaeróbio em sistema de lodos ativados em batelada

As eficiências médias de remoção da DQO bruta nos reatores do deste experimento em que foi adicionado lixiviado bruto nas proporções de 0;0,2; 2 e $5 \%$ foram: $80 ; 73 ; 66 ; 60 \%$, respectivamente, conforme apresentado na Tabela 5.9.

Tabela 5.9 - Eficiência média do sistema de lodos ativados em escala de bancada, tratando efluente anaeróbio com 0 a 5\% de lixiviado pré-tratado (E3), na remoção da

DQO bruta

\begin{tabular}{cccc}
\hline $\begin{array}{c}\text { Proporções de } \\
\text { lixiviado (\%) }\end{array}$ & Afluente (mg/L) & Efluente (mg/L) & Eficiência (\%) \\
\hline 0 & 133 & 27 & $80 \%$ \\
0,2 & 156 & 43 & $73 \%$ \\
2 & 211 & 72 & $66 \%$ \\
5 & 327 & 129 & $60 \%$ \\
\hline
\end{tabular}


As eficiências médias de remoção da DQO solúvel nos reatores deste experimento em que foi adicionado lixiviado pré-tratado nas proporções de $0 ; 0,2 ; 2 \mathrm{e}$ 5\% foram: $74 ; 74 ; 63 ; 54 \%$, respectivamente, conforme apresentado na Tabela 5.10.

Tabela 5.10 - Eficiência média do sistema de lodos ativados em escala de bancada, tratando efluente anaeróbio com 0 a 5\% de lixiviado pré-tratado (E3), na remoção da

DQO solúvel

\begin{tabular}{cccc}
\hline $\begin{array}{c}\text { Proporções de } \\
\text { lixiviado (\%) }\end{array}$ & Afluente (mg/L) & Efluente (mg/L) & Eficiência (\%) \\
\hline 0 & 87 & 23 & $74 \%$ \\
0,2 & 88 & 23 & $74 \%$ \\
2 & 141 & 53 & $63 \%$ \\
5 & 243 & 112 & $54 \%$ \\
\hline
\end{tabular}

Pode-se observar que também houve redução na eficiência de remoção da DQO bruta e solúvel à medida que a proporção de lixiviado aumentava na mistura. No entanto, para as condições do Experimento 3 a própria eficiência verificada no reator com $0 \%$ de lixiviado (controle) foi inferior à obtida nos outros experimentos com esgoto bruto, possivelmente devido à baixa concentração da DQO afluente ao sistema aeróbio.

As menores eficiências de remoção da DQO obtidas neste experimento podem estar associadas à baixa concentração de matéria orgânica solúvel (inferior a 90 mg/L) no afluente do sistema aeróbio, a qual já havia sido parcialmente degradada no reator anaeróbio, sendo insuficiente para manter uma grande diversidade microbiana do reator de lodos ativados e elevada eficiência.

Outra possível causa das baixas eficiências neste ensaio são as condições anaeróbias do efluente do RAC e presença de sulfeto, que podem ter causado alteração na biomassa e redução da eficiência do sistema aeróbio, conforme verificado por Mikkelsen et al. (1996); Willen et al. (2000); Mikkelsen (2001) e Mikkelsen \& Nielsen (2001). 
- Experimento 4: Tratamento consorciado de lixiviado em proporções de 0 a $5 \%$ e efluente anaeróbio em sistema de lodos ativados em batelada

As eficiências médias de remoção da DQO bruta nos reatores em que foi adicionado lixiviado bruto nas proporções de 0;0,2; 2 e 5\% foram: 72;64;60;26\%, respectivamente, conforme apresentado na Tabela 5.11 .

Tabela 5.11 - Eficiência média do sistema de lodos ativados em escala de bancada, tratando efluente anaeróbio com 0 a 5\% de lixiviado (E4), na remoção da DQO bruta

\begin{tabular}{cccc}
\hline $\begin{array}{c}\text { Proporções de } \\
\text { lixiviado (\%) }\end{array}$ & Afluente (mg/L) & Efluente (mg/L) & Eficiência (\%) \\
\hline 0 & 184 & 51 & $72 \%$ \\
0,2 & 204 & 73 & $64 \%$ \\
2 & 284 & 112 & $60 \%$ \\
5 & 409 & 304 & $26 \%$ \\
\hline
\end{tabular}

As eficiências médias de remoção da DQO solúvel nos reatores em que foi adicionado lixiviado bruto nas proporções de $0 ; 0,2 ; 2$ e $5 \%$ foram $79 ; 78 ; 56 ; 18 \%$ respectivamente conforme apresentado na Tabela 5.12. Essas eficiências ficaram próximas das de remoção da DQO bruta.

Tabela 5.12 - Eficiência média do sistema de lodos ativados em escala de bancada, tratando efluente anaeróbio com 0 a 5\% de lixiviado (E4), na remoção da DQO solúvel

\begin{tabular}{cccc}
\hline $\begin{array}{c}\text { Proporções de } \\
\text { lixiviado (\%) }\end{array}$ & Afluente (mg/L) & Efluente (mg/L) & Eficiência (\%) \\
\hline 0 & 77 & 16 & $79 \%$ \\
0,2 & 78 & 18 & $78 \%$ \\
2 & 150 & 64 & $56 \%$ \\
5 & 296 & 238 & $18 \%$ \\
\hline
\end{tabular}

Pode-se observar que também houve redução na eficiência de remoção da DQO bruta e solúvel à medida que a proporção de lixiviado aumentava. Observou-se maior efeito negativo na proporção de $5 \%$ de lixiviado que nos outros experimentos. Em comparação ao experimento 3, este experimento alcançou eficiências de remoção da DQO levemente inferiores. 
As menores eficiências de remoção da DQO obtidas neste experimento, quando comparadas aos outros, podem estar associadas: à baixa concentração de matéria orgânica solúvel (inferior a $80 \mathrm{mg} / \mathrm{L}$ ) no afluente do sistema aeróbio, a qual já havia sido parcialmente degradada no reator anaeróbio, sendo insuficiente para manter uma grande diversidade microbiana do reator de lodos ativados e toxicidade do nitrogênio amoniacal presente no lixiviado bruto, em especial na proporção de 5\%; à elevada concentração de matéria orgânica recalcitrante presente no lixiviado bruto, o que também pôde ter comprometido a estabilidade da biomassa desenvolvida.

As baixas eficiências de remoção da DQO obtidas nos experimentos em sistema de lodos ativados de bancada, alimentado com efluente anaeróbio, também foram relatadas por Turetta (2011), cujas eficiências de remoção da DQO bruta obtidas nessa condição foram de 63, 57, 27 e 29\% e da DQO solúvel foram de 57, 18, 23 e 27\%, para as proporções de $0,2,5,10$ e $20 \%$ de lixiviado bruto, respectivamente.

As baixas eficiências obtidas neste ensaio também podem ter sido resultante das condições anaeróbias do efluente do RAC, presença de sulfeto e elevada força iônica presente no lixiviado, que podem ter causado alteração na biomassa e redução da eficiência do sistema aeróbio, conforme verificado por Mikkelsen et al. (1996); Willen et al. (2000); Mikkelsen (2001) e Mikkelsen \& Nielsen (2001).

Os resultados das análises da DQO bruta e solúvel obtidos durante a realização dos experimentos de bancada estão apresentados nas Figuras 5.3 e 5.4.

Para fins de comparação entre as condições dos quatro experimentos de bancada, na Figura 5.5 são apresentadas as eficiências médias de remoção da DQO bruta dos experimentos de bancada. 

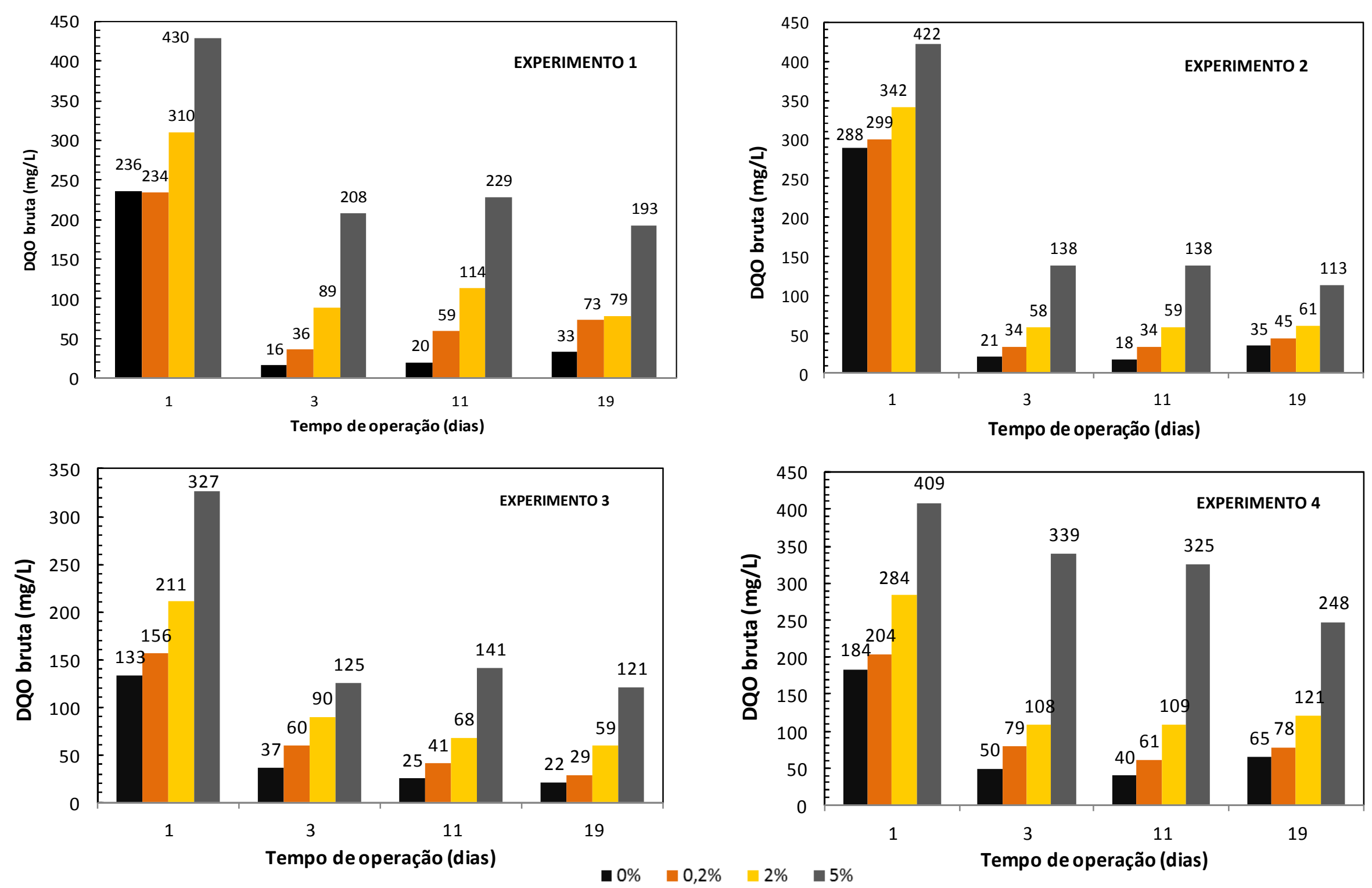

Figura 5.3 - Variação da DQO bruta nos experimentos de bancada (regime de batelada) nas proporções de 0 (controle); 0,2; 2 e 5\% de lixiviado. 

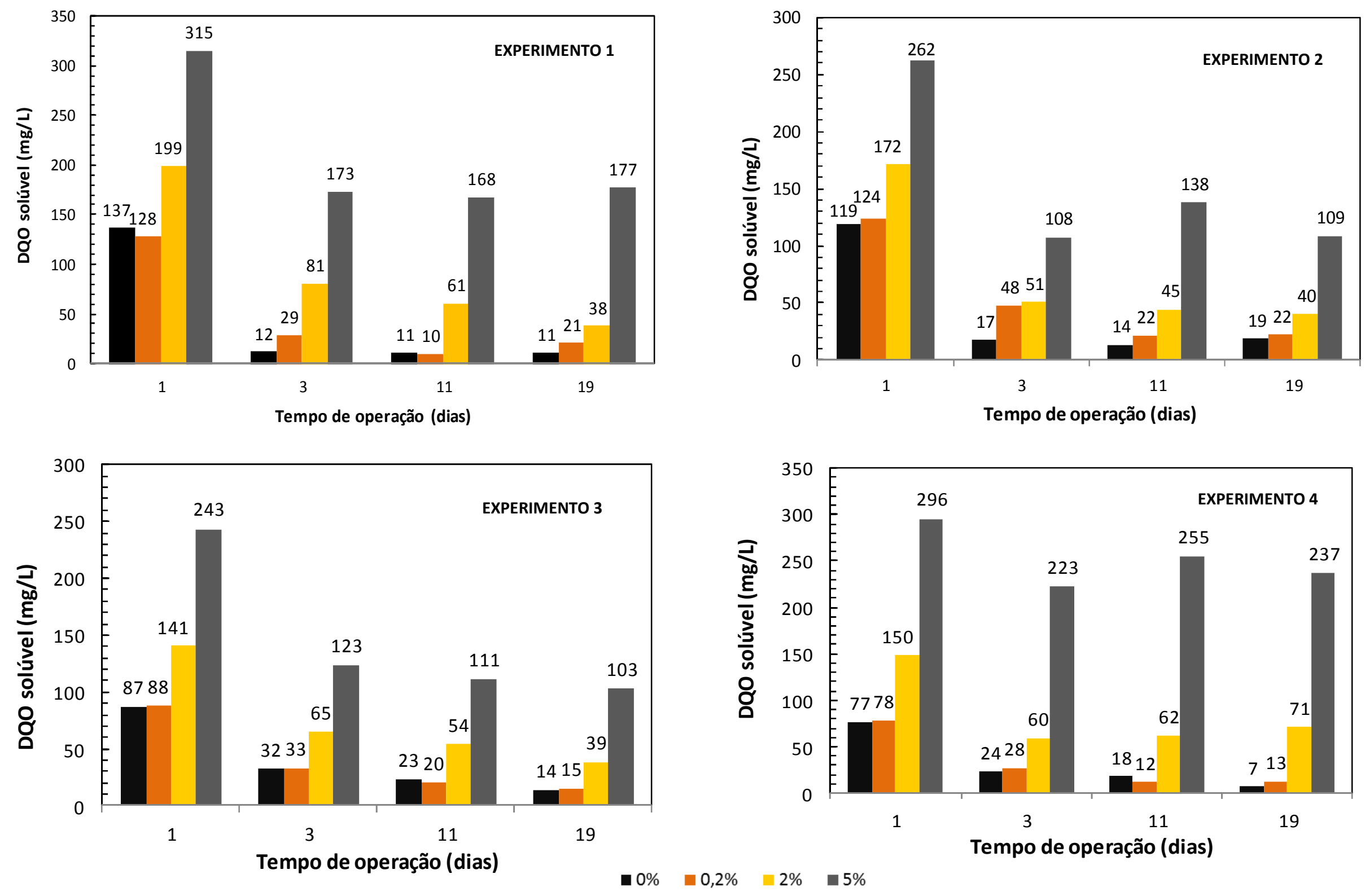

Figura 5.4 - Variação da DQO solúvel nos experimentos de bancada (regime de batelada) nas proporções de 0 (controle); 0,2; 2 e 5\% de lixiviado. 


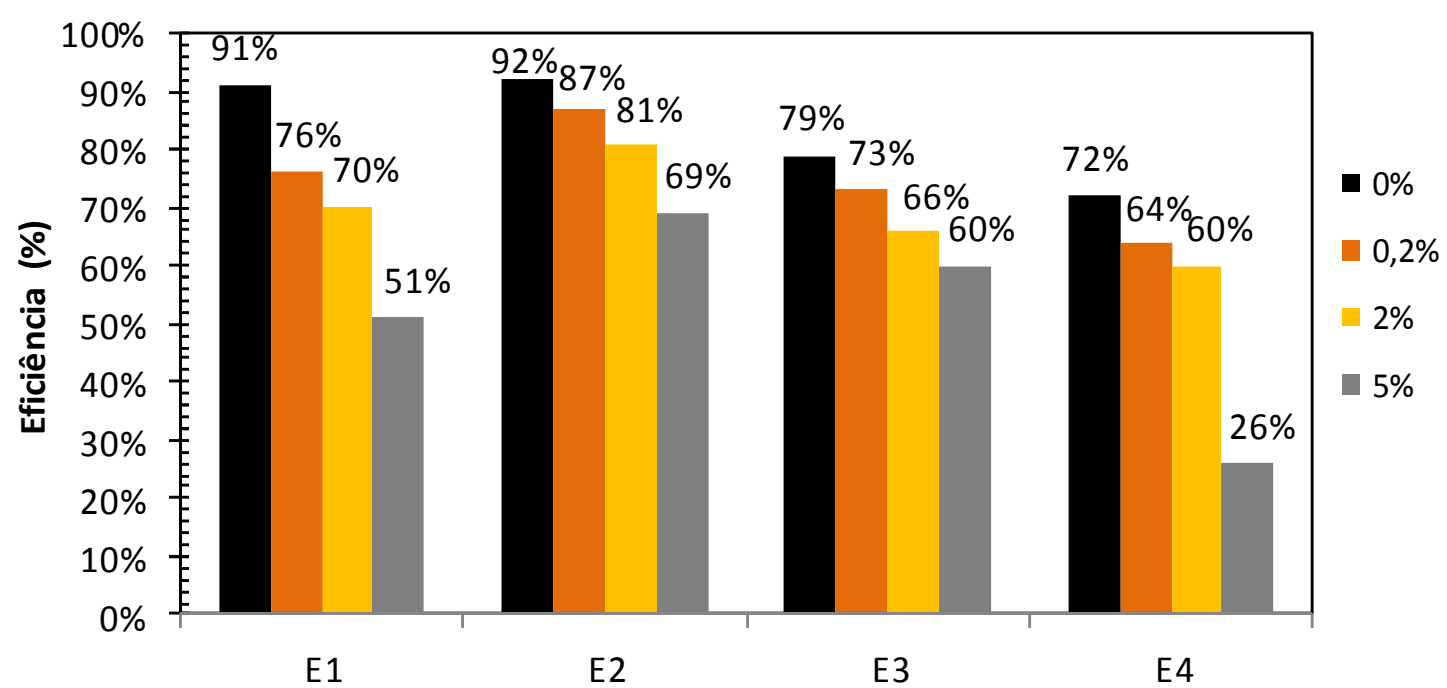

Figura 5.5 - Eficiência média de remoção da DQO bruta nos experimentos de bancada para as proporções de 0 (controle); 0,2; 2 e $5 \%$ de lixiviado em diferentes condições: E1-lixiviado mais esgoto; E2-lixiviado pré-tratado mais esgoto; E3-lixiviado pré-tratado mais efluente anaeróbio; E4-lixiviado mais efluente anaeróbio.

De maneira geral, em todos os experimentos observou-se que ocorre redução da eficiência de remoção da DQO bruta à medida que a proporção de lixiviado aumenta em relação ao esgoto, o que também foi constatado por Chang et al. (1995), Ehrig (1998) Borghi et al. (2001), Turetta (2011). Para a proporção de 5\% de lixiviado, o sistema se mostrou ineficiente em todas as condições testadas (eficiências inferiores a 70\%), resultando em concentrações da DQO efluentes superiores a $100 \mathrm{mg} / \mathrm{L}$.

Em termos gerais, os resultados indicam que o Experimento 2 sofreu menores interferências do lixiviado, promovendo maiores eficiências, resultando em concentrações da DQO efluente inferiores a $60 \mathrm{mg} / \mathrm{L}$ até a proporção de $2 \%$ de lixiviado pré-tratado. No Experimento 4, o sistema se mostrou mais susceptível, apresentando valores de concentrações da DQO efluente superiores a $100 \mathrm{mg} / \mathrm{L}$ para a proporção de $2 \%$ de lixiviado bruto.

Para fins de comparação, na Figura 5.6 são apresentadas as eficiências média de remoção da DQO solúvel dos experimentos de bancada. 


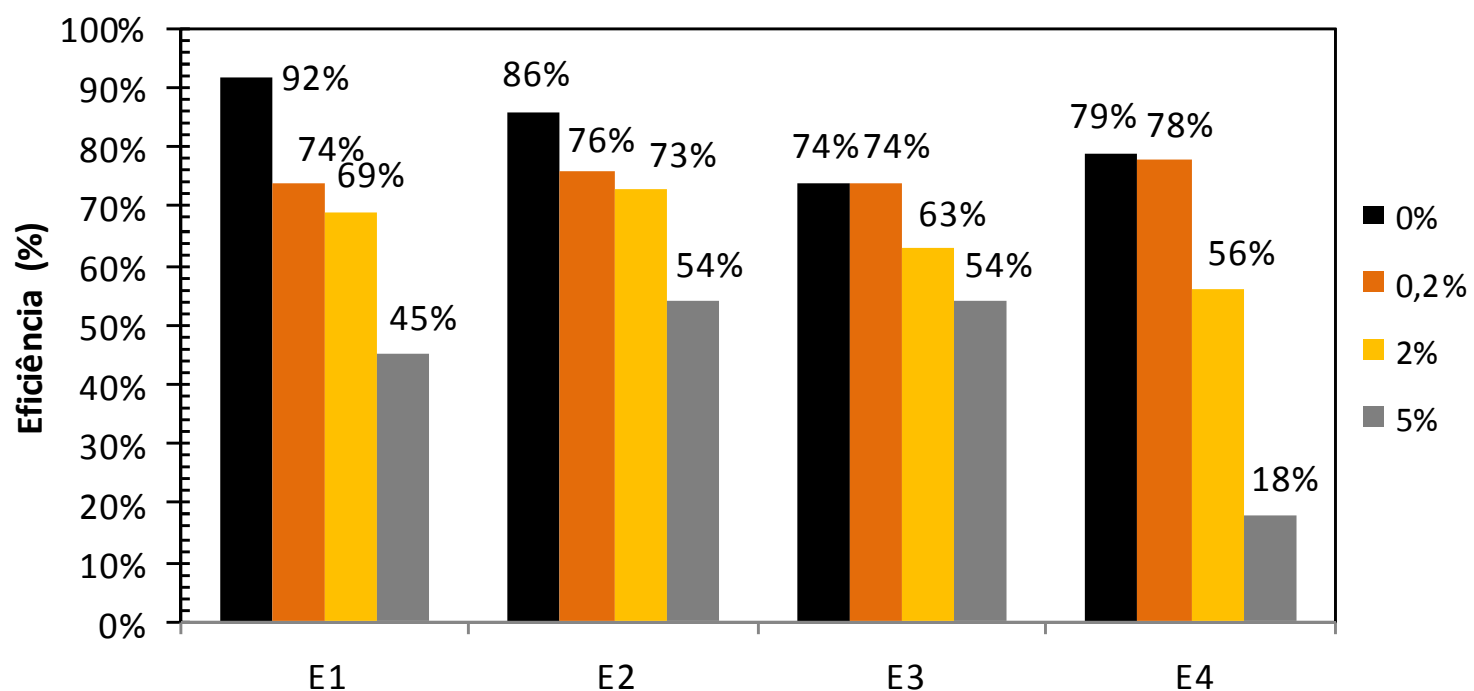

Figura 5.6 - Eficiência média de remoção da DQO solúvel nos experimentos de bancada para as proporções de 0 (controle); 0,2; 2 e 5\% de lixiviado em diferentes condições: E1-lixiviado mais esgoto; E2-lixiviado pré-tratado mais esgoto; E3-lixiviado pré-tratado mais efluente anaeróbio; E4-lixiviado mais efluente anaeróbio.

A partir dos gráficos de eficiência média de remoção da DQO solúvel, também pode-se verificar que à medida que se aumentava a proporção de lixiviado a eficiência alcançada diminuiu.

Em termos da eficiência de remoção da DQO solúvel, verificou-se que para a proporção de $0,2 \%$ de lixiviado o sistema apresentou desempenho similar em todos os experimentos, com eficiência média variando de 74 a $78 \%$. Para a proporção de $5 \%$ de lixiviado o sistema também se mostrou ineficiente em todas as condições.

De uma forma geral, o Experimento 2 apresentou eficiências de DQO superiores em relação aos outros experimentos, possivelmente devido à remoção da amônia, que é tóxica aos microrganismos, conforme relatado por Çecen \& Çakiroğlu (2001); Chen, S. et al. (2001) e Del Borghi, et al. (2003). 


\subsubsection{Demanda Bioquímica de Oxigênio - DBO}

Todas as determinações da DBO foram realizadas com a amostra bruta. Todos os resultados das determinações da DBO encontram-se no Apêndice A9.

- Experimento 1: Tratamento consorciado de lixiviado em proporções de 0 a $5 \%$ e esgoto sanitário em sistema de lodos ativados em batelada

As eficiências médias de remoção da DBO nos reatores do Experimento $1 \mathrm{em}$ que foi adicionado lixiviado pré-tratado nas proporções de $0 ; 0,2 ; 2$ e $5 \%$ foram 97; 95; $65 ; 18 \%$ respectivamente conforme apresentado na Tabela 5.13.

Tabela 5.13 - Eficiência média do sistema de lodos ativados em escala de bancada, tratando esgoto com 0 a 5\% de lixiviado (E1), na remoção da DBO.

\begin{tabular}{cccc}
\hline $\begin{array}{c}\text { Proporções de } \\
\text { lixiviado (\%) }\end{array}$ & Afluente (mg/L) & Efluente (mg/L) & Eficiência (\%) \\
\hline 0 & 172 & 4 & $97 \%$ \\
0,2 & 168 & 9 & $95 \%$ \\
2 & 181 & 63 & $65 \%$ \\
5 & 190 & 156 & $18 \%$ \\
\hline
\end{tabular}

Pode-se observar na Tabela 5.13 que a adição de 2 e $5 \%$ de lixiviado afetou significativamente a eficiência do sistema, quando comparado ao controle (0\%) alimentado apenas com esgoto bruto. As menores concentrações efluentes da DBO foram de 4 e $9 \mathrm{mg} / \mathrm{L}$ para as proporções de 0 e $0,2 \%$ de lixiviado bruto.

- Experimento 2: Tratamento consorciado de lixiviado pré-tratado em proporções de 0 a $5 \%$ e esgoto sanitário em sistema de lodos ativados em batelada

Quanto ao experimento 2, as eficiências de remoção da DBO nos reatores em que foi adicionado lixiviado pré-tratado nas proporções de 0; 0,2; 2 e 5\% foram: 97; 97; 97 e 95\%, respectivamente, conforme indicado na Tabela 5.14. 
Pode-se observar na tabela que, nas condições do Experimento 2, apenas a adição de $5 \%$ de lixiviado pré-tratado (alcalinizado e com remoção de NAT por air stripping) afetou levemente o sistema, mas ainda com elevada eficiência de remoção da DBO.

Tabela 5.14 - Eficiência média do sistema de lodos ativados em escala de bancada, tratando esgoto com 0 a 5\% de lixiviado pré-tratado (E2), na remoção da DBO.

\begin{tabular}{cccc}
\hline $\begin{array}{c}\text { Proporções de } \\
\text { lixiviado (\%) }\end{array}$ & Afluente (mg/L) & Efluente (mg/L) & Eficiência (\%) \\
\hline 0 & 155 & 4 & $97 \%$ \\
0,2 & 153 & 7 & $97 \%$ \\
2 & 211 & 9 & $97 \%$ \\
5 & 274 & 18 & $95 \%$ \\
\hline
\end{tabular}

Assim como na eficiência de remoção da DQO, este experimento proporcionou maiores eficiências na remoção da DBO e, portanto, melhor desempenho do sistema. As eficiências de remoção da DBO se mantiveram acima de $90 \%$ em todas as proporções de lixiviado. As menores concentrações efluentes da DBO foram de 4 e $7 \mathrm{mg} / \mathrm{L}$ para as proporções de 0 e $0,2 \%$ de lixiviado pré-tratado, respectivamente.

A redução brusca na eficiência de remoção da DBO no Experimento 1, comparado ao Experimento 2, indica provável efeito tóxico dos compostos presentes no lixiviado bruto, como exemplo da amônia livre, que foi previamente removida no Experimento 2.

- Experimento 3: Tratamento consorciado de lixiviado pré-tratado em proporções de 0 a $5 \%$ e efluente anaeróbio em sistema de lodos ativados em batelada

Quanto ao experimento 3, as eficiências de remoção da DBO nos reatores em que foi adicionado lixiviado bruto nas proporções de 0; 0,2; 2 e 5\% foram: 93; $94 ; 87$ e $61 \%$, respectivamente, conforme indicado na Tabela 5.15. 
Tabela 5.15 - Eficiência média do sistema de lodos ativados em escala de bancada, tratando efluente anaeróbio com 0 a $5 \%$ de lixiviado pré-tratado (E2), na remoção da DBO.

\begin{tabular}{cccc}
\hline $\begin{array}{c}\text { Proporções de } \\
\text { lixiviado (\%) }\end{array}$ & Afluente (mg/L) & Efluente (mg/L) & Eficiência (\%) \\
\hline 0 & 81 & 6 & $93 \%$ \\
0,2 & 93 & 6 & $94 \%$ \\
2 & 137 & 18 & $87 \%$ \\
5 & 197 & 72 & $61 \%$ \\
\hline
\end{tabular}

Pode-se observar na Tabela 5.15 que, nas condições do Experimento 3, a adição de $2 \%$ de lixiviado pré-tratado afetou levemente o sistema, quando comparado ao reator com $0 \%$ de lixiviado (controle). A adição de 5\% de lixiviado afetou significativamente a eficiência do sistema.

As eficiências de remoção da DBO alcançadas nas proporções de 2 e $5 \%$ de lixiviado neste experimento foram maiores que as do Experimento 1 e menores que as do experimento 2 .

As menores concentrações efluentes da DBO foram de $6 \mathrm{mg} / \mathrm{L}$ para as proporções de 0 e $0,2 \%$ de lixiviado pré-tratado.

- Experimento 4: Tratamento consorciado de lixiviado em proporções de 0 a $5 \%$ e efluente anaeróbio em sistema de lodos ativados em batelada

Quanto ao experimento 4, as eficiências de remoção da DBO nos reatores em que foi adicionado lixiviado bruto nas proporções de $0 ; 0,2 ; 2$ e $5 \%$ foram: $81 ; 63 ; 56$ e $5 \%$, respectivamente, conforme indicado na Tabela 5.16.

Tabela 5.16 - Eficiência média do sistema de lodos ativados em escala de bancada, tratando efluente anaeróbio com 0 a 5\% de lixiviado (E4), na remoção da DBO

\begin{tabular}{cccc}
\hline $\begin{array}{c}\text { Proporções de } \\
\text { lixiviado (\%) }\end{array}$ & Afluente (mg/L) & Efluente (mg/L) & Eficiência (\%) \\
\hline 0 & 96 & 18 & $81 \%$ \\
0,2 & 105 & 39 & $63 \%$ \\
2 & 123 & 54 & $56 \%$ \\
5 & 152 & 145 & $5 \%$ \\
\hline
\end{tabular}


Pode-se observar que, nas condições do Experimento 4, a adição de 0,2 e $2 \%$ de lixiviado bruto também afetou significativamente a eficiência do sistema e a adição de $5 \%$ afetou bruscamente, perdendo completamente a eficiência de tratabilidade.

As eficiências de remoção da DBO alcançadas neste experimento foram menores que todos os experimentos, resultados compatíveis com os obtidos para a remoção da DQO.

A menor concentração efluentes do DBO foi de $18 \mathrm{mg} / \mathrm{L}$ para a proporção de $0 \%$ de lixiviado bruto (controle).

Assim como verificado no Experimento 1, no Experimento 4 a adição de 5\% de lixiviado afetou bruscamente a eficiência do sistema, indicando possível efeito tóxico dos compostos presentes no lixiviado bruto, provavelmente da amônia, sobre a eficiência do sistema.

Na Figura 5.7 são apresentadas as eficiências de remoção da DBO dos experimentos de bancada.

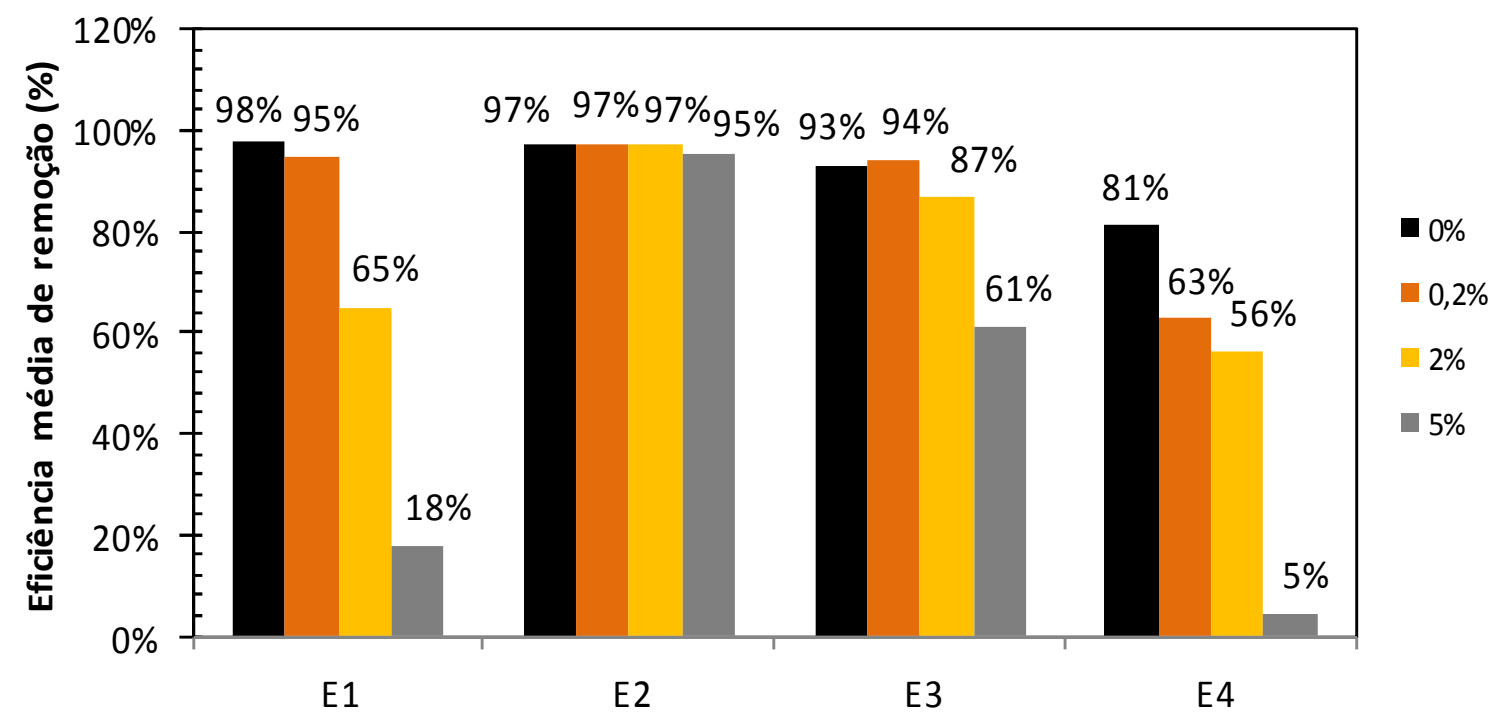

Figura 5.7 - Eficiência média de remoção da DBO nos experimentos de bancada para as proporções de 0 (controle); 0,2; 2 e 5\% de lixiviado em diferentes condições: E1lixiviado mais esgoto; E2-lixiviado pré-tratado mais esgoto; E3-lixiviado pré-tratado mais efluente anaeróbio; E4-lixiviado mais efluente anaeróbio.

A partir da Figura 5.7 observa-se uma maior redução da eficiência de remoção da DBO nos experimentos com lixiviado bruto (E1 e E4), indicando possível efeito tóxico da amônia livre, removida no pré-tratamento para os experimentos E2 e E3. 
Os resultados de remoção da DBO também indicaram melhor desempenho do sistema nas condições do Experimento 2, no qual a eficiência de remoção da DBO se manteve acima de $95 \%$ em todas as proporções.

\subsubsection{Carbono Orgânico Dissolvido - COD}

Todas as determinações do COD foram realizadas com a amostra filtrada (membrana diâmetro médio de poro de $0,45 \mu \mathrm{m}$ ) e acidificada a pH em torno de 2 .

Os valores das concentrações em termos do COD em todos os experimentos estão apresentados nos gráficos da Figura 5.8. Todos os resultados das análises COD encontram-se no Apêndice A8.

- Experimento 1: Tratamento consorciado de lixiviado em proporções de 0 a $5 \%$ e esgoto sanitário em sistema de lodos ativados em batelada

As eficiências de remoção do COD nos reatores em que foi adicionado lixiviado bruto nas proporções de $0 ; 0,2 ; 2$ e $5 \%$ foram: $69,66,52$ e $44 \%$, respectivamente.

Tabela 5.17 - Eficiência média do sistema de lodos ativados em escala de bancada, tratando esgoto com 0 a 5\% de lixiviado (E1), na remoção da COD.

\begin{tabular}{cccc}
\hline $\begin{array}{c}\text { Proporções de } \\
\text { lixiviado (\%) }\end{array}$ & Afluente (mg/L) & Efluente (mg/L) & Eficiência (\%) \\
\hline 0 & 48 & 15 & $69 \%$ \\
0,2 & 48 & 16 & $66 \%$ \\
2 & 69 & 32 & $52 \%$ \\
5 & 104 & 57 & $44 \%$ \\
\hline
\end{tabular}

Pode-se observar que a adição de 2 e $5 \%$ de lixiviado afetou significativamente o sistema, quando comparado ao reator com $0 \%$ de lixiviado (controle), alimentado apenas com esgoto bruto. As menores concentrações efluentes do COD foram de 13 e $15 \mathrm{mg} / \mathrm{L}$ para as proporções de 0 e $0,2 \%$ de lixiviado bruto. 
- Experimento 2: Tratamento consorciado de lixiviado pré-tratado em proporções de 0 a $5 \%$ e esgoto sanitário em sistema de lodos ativados em batelada

Quanto ao experimento 2, as eficiências de remoção do COD nos reatores em que foi adicionado lixiviado pré-tratado nas proporções de 0; 0,2; 2 e 5\% foram: 65; 70; 60 e 54\%, respectivamente, conforme indicado na Tabela 5.18.

Tabela 5.18 - Eficiência média do sistema de lodos ativados em escala de bancada, tratando esgoto com 0 a 5\% de lixiviado pré-tratado (E2), na remoção da COD.

\begin{tabular}{cccc}
\hline $\begin{array}{c}\text { Proporções de } \\
\text { lixiviado (\%) }\end{array}$ & Afluente (mg/L) & Efluente (mg/L) & Eficiência (\%) \\
\hline 0 & 46 & 16 & $65 \%$ \\
0,2 & 49 & 14 & $70 \%$ \\
2 & 65 & 25 & $60 \%$ \\
5 & 92 & 42 & $54 \%$ \\
\hline
\end{tabular}

Pode-se constatar que, nas condições do Experimento 2, a adição de $2 \%$ de lixiviado pré-tratado (alcalinizado e com remoção de NAT por air stripping) afetou levemente o sistema, enquanto que a adição de $5 \%$ afetou significativamente o sistema, quando comparados ao reator controle $(0 \%)$ alimentado apenas com esgoto bruto.

Vale ressaltar ainda que no experimento com $0,2 \%$ de lixiviado pré-tratado foi alcançada uma eficiência de remoção do COD maior que o controle $(0 \%)$, indicando que para essas condições o sistema teve uma resposta positiva sem afetar o desempenho do sistema de tratamento.

Assim como na eficiência de remoção da DQO e DBO, este experimento proporcionou maiores eficiências na remoção do COD e, portanto, melhor desempenho do sistema.

As menores concentrações efluentes do COD foram de $13 \mathrm{mg} / \mathrm{L}$ para as proporções de 0 e $0,2 \%$ de lixiviado pré-tratado, conforme indicado pela Figura 5.8.. 
- Experimento 3: Tratamento consorciado de lixiviado pré-tratado em proporções de 0 a $5 \%$ e efluente anaeróbio em sistema de lodos ativados em batelada

Quanto ao Experimento 3, as eficiências de remoção do COD nos reatores em que foi adicionado lixiviado bruto nas proporções de $0 ; 0,2 ; 2$ e $5 \%$ foram: $61 ; 57 ; 56$ e $54 \%$, respectivamente, conforme indicado na Tabela 5.19.

Tabela 5.19 - Eficiência média do sistema de lodos ativados em escala de bancada, efluente anaeróbio com 0 a 5\% de lixiviado pré-tratado (E3), na remoção da COD.

\begin{tabular}{cccc}
\hline $\begin{array}{c}\text { Proporções de } \\
\text { lixiviado (\%) }\end{array}$ & Afluente (mg/L) & Efluente (mg/L) & Eficiência (\%) \\
\hline 0 & 32 & 12 & $61 \%$ \\
0,2 & 34 & 15 & $57 \%$ \\
2 & 51 & 22 & $56 \%$ \\
5 & 88 & 40 & $54 \%$ \\
\hline
\end{tabular}

Pode-se verificar que, nas condições do Experimento 3, a adição de 0,2 e $2 \%$ de lixiviado pré-tratado (alcalinizado e com remoção de NAT por air stripping) afetou levemente o sistema, quando comparado ao reator com $0 \%$ de lixiviado (controle).

As eficiências de remoção do COD alcançadas nas proporções de 2 e $5 \%$ de lixiviado neste experimento foram maiores que as do Experimento 1 e menores que as do experimento 2, apesar de as concentrações efluentes deste experimento terem sido menores.

As menores concentrações efluentes do COD foram de $11 \mathrm{mg} / \mathrm{L}$ para as proporções de 0 e 0,2\% de lixiviado pré-tratado, conforme indicado pela Figura 5.8..

- Experimento 4: Tratamento consorciado de lixiviado em proporções de 0 a $5 \%$ e efluente anaeróbio em sistema de lodos ativados em batelada

Quanto ao experimento 4, as eficiências de remoção do COD nos reatores em que foi adicionado lixiviado bruto nas proporções de 0; 0,2; 2 e 5\% foram: 56; $54 ; 51$ e $33 \%$, respectivamente, conforme indicado na Tabela 5.20. 
Tabela 5.20 - Eficiência média do sistema de lodos ativados em escala de bancada, efluente anaeróbio com 0 a 5\% de lixiviado (E4), na remoção da COD.

\begin{tabular}{cccc}
\hline $\begin{array}{c}\text { Proporções de } \\
\text { lixiviado (\%) }\end{array}$ & Afluente (mg/L) & Efluente (mg/L) & Eficiência (\%) \\
\hline 0 & 34 & 15 & $56 \%$ \\
0,2 & 39 & 18 & $54 \%$ \\
2 & 60 & 29 & $51 \%$ \\
5 & 99 & 66 & $33 \%$ \\
\hline
\end{tabular}

Nas condições do Experimento 4, a adição de 0,2 e 2\% de lixiviado também afetou levemente o sistema, enquanto que a adição de $5 \%$ afetou fortemente a eficiência do sistema.

As eficiências de remoção do COD alcançadas neste experimento foram menores que todos os experimentos, resultados compatíveis com os obtidos para a remoção da DQO e DBO.

As menores concentrações efluentes do COD foram de 13 e $17 \mathrm{mg} / \mathrm{L}$ para as proporções de 0 e 0,2\% de lixiviado bruto, conforme indicado pela Figura 5.9.

Para fins de comparação, na Figura 5.8 são apresentadas as eficiências médias de remoção do COD de todos os experimentos de bancada.

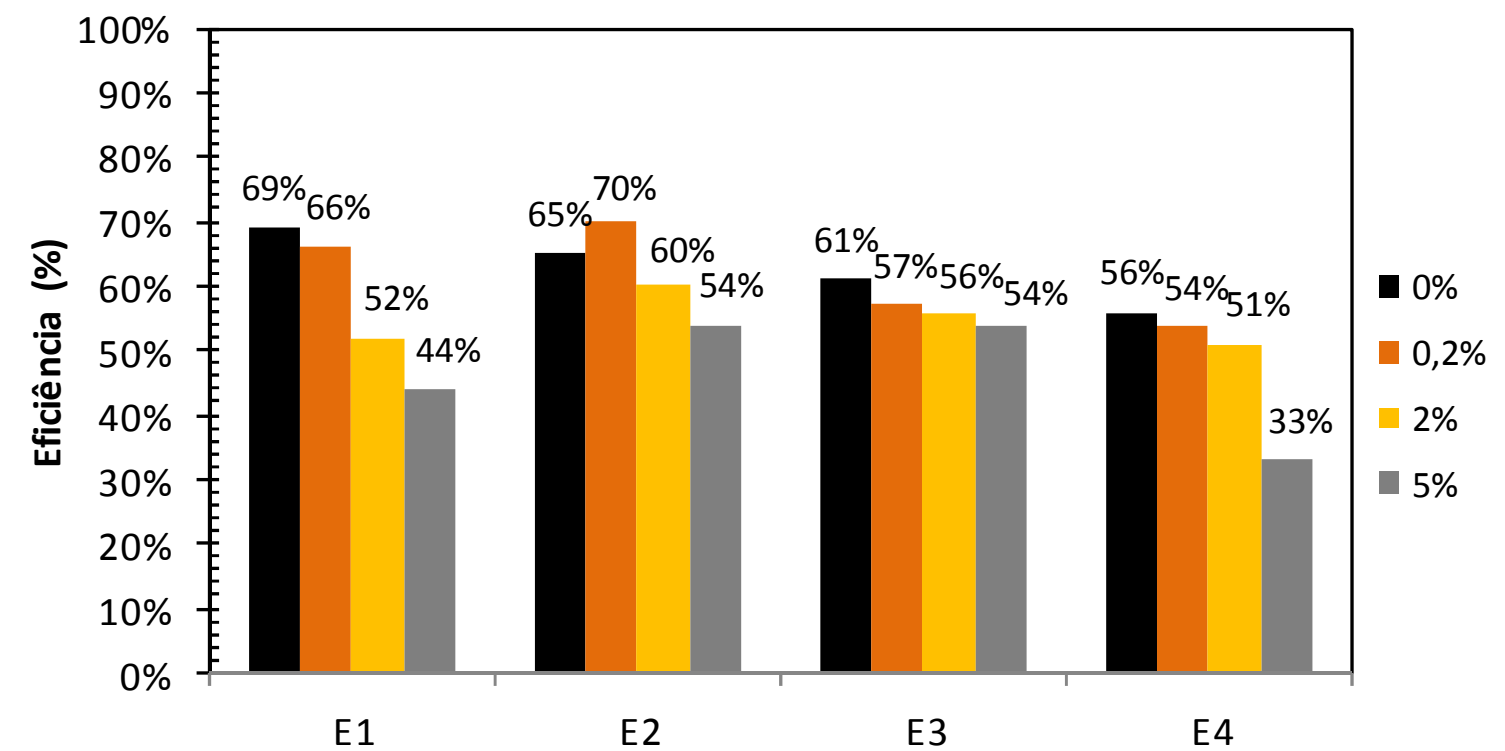

Figura 5.8 - Eficiência média de remoção do COD nos experimentos de bancada para as proporções de 0 (controle); 0,2; 2 e 5\% de lixiviado em diferentes condições: E1lixiviado mais esgoto; E2-lixiviado pré-tratado mais esgoto; E3-lixiviado pré-tratado mais efluente anaeróbio; E4-lixiviado mais efluente anaeróbio. 
As eficiências de remoção do COD apresentadas, de certa forma, são baixas, uma vez que as próprias concentrações afluentes já são reduzidas. Além disso, todas as amostras foram filtradas $(0,45 \mu \mathrm{m})$ e essas concentrações são relativas apenas à porção dissolvida do carbono orgânico.

A variação na concentração de carbono orgânico dissolvido em todos os experimentos está apresentada na Figura 5.9, que apresenta o comportamento do sistema para as diferentes proporções de lixiviado.

De maneira geral, em todos os experimentos observou-se que ocorre diminuição da eficiência de remoção do COD, assim como da DQO, à medida que a proporção de lixiviado aumenta em relação ao esgoto, conforme também foi observado por Franco (2009) e Turetta (2011).

Com base nos gráficos apresentados, pode-se observar que no Experimento 2 foram obtidas maiores eficiências de remoção do COD e menor interferência pela adição de lixiviado, quando comparado ao reator com $0 \%$ de lixiviado (controle) deste experimento. O Experimento 4 apresentou menores eficiências de remoção do COD.

Os Experimentos 1 e 4 apresentaram maior susceptibilidade ao lixiviado, uma vez que a perda da eficiência ao adicionar o lixiviado em diferentes proporções é mais nítida nesses experimentos, segundo os gráficos apresentados.

Em geral, o experimento 3 apresentou menores concentrações efluentes. No entanto isso pode ser explicado pela baixa concentração do COD afluente, em decorrência de o esgoto efluente do RAC já ter um tratamento anaeróbio prévio. 

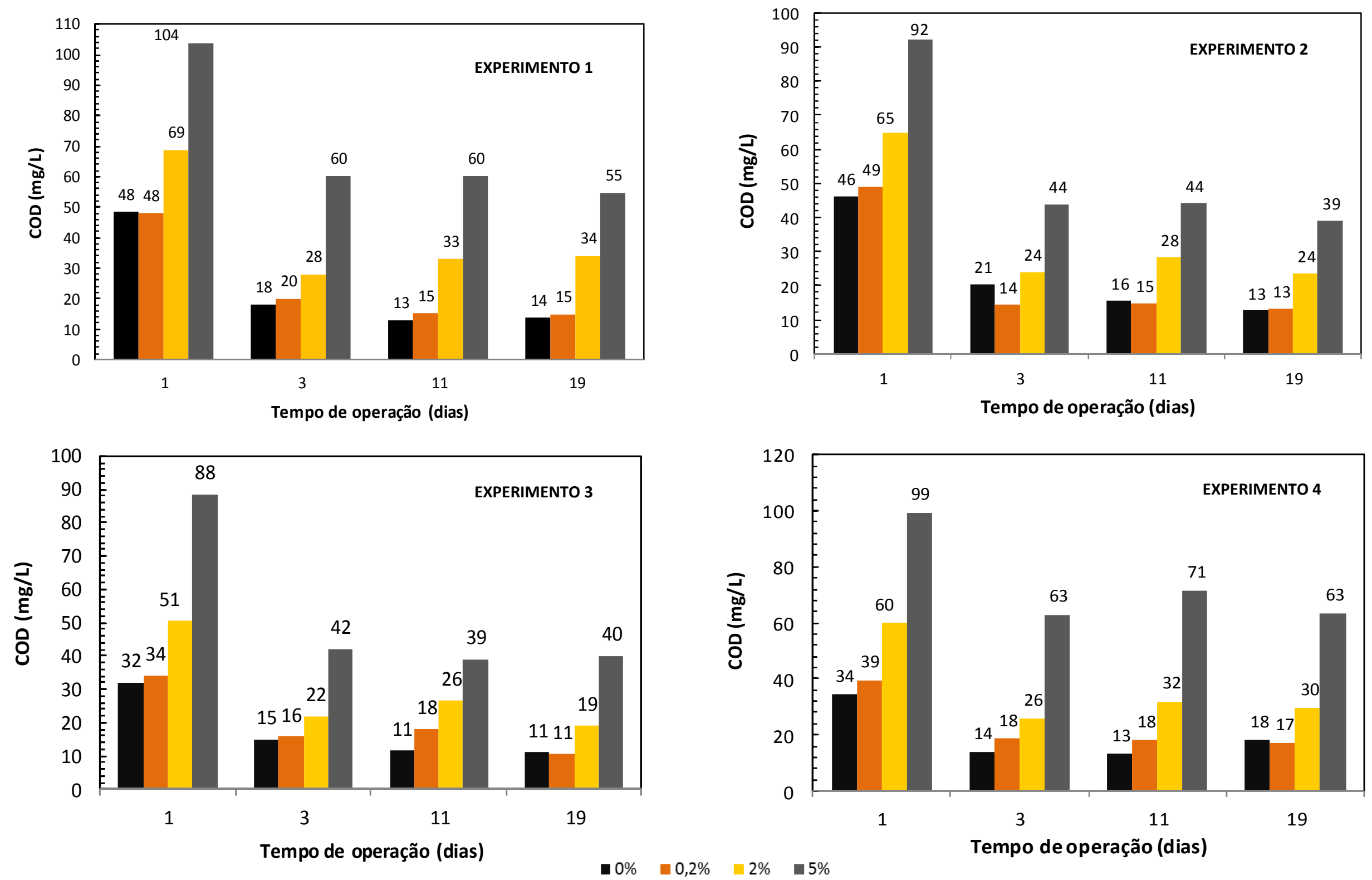

Figura 5.9 - Variação do COD nos experimentos de bancada (regime intermitente) nas proporções de 0 (controle); 0,2; 2 e 5\% de lixiviado. 


\subsubsection{Série de Nitrogênio}

Em todos os experimentos foi monitorada a série de nitrogênio de modo a avaliar a toxicidade do nitrogênio amoniacal total (NAT) presente no lixiviado ao tratamento aeróbio e a eficiência de remoção e de conversão do nitrogênio. No laboratório, as concentrações de nitrogênio nas formas de amônia livre $\left(\mathrm{N}_{-} \mathrm{NH}_{3}\right)$ e de íon amônio $\left(\mathrm{N}^{-\mathrm{NH}_{4}}{ }^{+}\right)$são determinadas em conjunto, que corresponde à soma das concentrações das duas formas, recebe o nome de nitrogênio amoniacal total (NAT) (Souto, 2009).

Foram determinadas as concentrações de nitrogênio total Kjeldal, nitrogênio amoniacal, nitrito e nitrato. $\mathrm{O}$ nitrito e nitrato foram determinados utilizando-se a metodologia de injeção de fluxo (APHA 2005). Todos os resultados das análises de nitrogênio encontram-se nos Apêndices A11 a A13.

As Figuras 5.10 a 5.13 apresentam as variações da concentração de nitrogênio total Kjeldal, nitrogênio amoniacal, nitrito e nitrato nos experimentos em escala de bancada ao longo da operação.

- Experimento 1: Tratamento consorciado de lixiviado em proporções de 0 a $5 \%$ e esgoto sanitário em sistema de lodos ativados em batelada

No Experimento 1 a remoção de NTK e NAT foi praticamente total para as proporções de 0 e $0,2 \%$ de lixiviado. Para as proporções de 2 e $5 \%$ as eficiências foram menores, mas as concentrações efluentes ainda permaneceram abaixo dos valores recomendados pelas resoluções CONAMA 357/2005 e 430/2011 (inferior a $20 \mathrm{mg} / \mathrm{L}$ ) na proporção de $2 \%$, conforme Figura 5.10.

Tabela 5.21 - Eficiência média do sistema de lodos ativados em escala de bancada, tratando esgoto com 0 a 5\% de lixiviado (E1), na remoção de nitrogênio.

\begin{tabular}{ccccc}
\hline $\begin{array}{c}\text { Proporções de } \\
\text { lixiviado (\%) }\end{array}$ & NAT $_{\mathbf{A F}}(\mathbf{m g} / \mathbf{L})$ & $\begin{array}{c}\text { Remoção de } \\
\text { NTK (\%) }\end{array}$ & $\begin{array}{c}\text { Remoção de } \\
\text { NAT (\%) }\end{array}$ & NO $_{3}{ }^{-} / \mathbf{N A T}_{\mathbf{A F}}$ \\
\hline 0 & 22,1 & $94 \%$ & $97 \%$ & 0,21 \\
0,2 & 24,2 & $100 \%$ & $100 \%$ & 0,57 \\
2 & 65 & $76 \%$ & $80 \%$ & 0,22 \\
5 & 127 & $62 \%$ & $61 \%$ & 0,11 \\
\hline
\end{tabular}

$\mathrm{NAT}_{\mathrm{AF}}=$ Concentração de Nitrogênio Amoniacal Total afluente. 
Os resultados indicam a ocorrência de nitrificação em todas as proporções de lixiviado no Experimento 1. No entanto, observou-se que à medida que se aumentava a concentração afluente de NAT, e a proporção de lixiviado, a relação máxima de conversão $\mathrm{NO}_{3}{ }^{-} / \mathrm{NAT}_{\mathrm{AF}}$ diminuía, especialmente na proporção de $5 \%$ de lixiviado, que reduziu significativamente a remoção de NTK e NAT e a relação de conversão $\mathrm{NO}_{3}{ }^{-}$ /NAT, podendo indicar possível inibição da nitrificação pela amônia livre presente no lixiviado bruto.

\section{- Experimento 2: Tratamento consorciado de lixiviado pré-tratado em} proporções de 0 a $5 \%$ e esgoto sanitário em sistema de lodos ativados em batelada

Quanto ao Experimento 2, a remoção de NTK e NAT foi praticamente total para todas as proporções de lixiviado, uma vez que as concentrações efluentes permaneceram abaixo de 4 mg/L, conforme Figura 5.11.

Tabela 5.22 - Eficiência média do sistema de lodos ativados em escala de bancada, tratando esgoto com 0 a 5\% de lixiviado pré-tratado (E2), na remoção de nitrogênio.

\begin{tabular}{ccccc}
\hline $\begin{array}{c}\text { Proporções de } \\
\text { lixiviado (\%) }\end{array}$ & NAT $_{\mathbf{A F}}(\mathbf{m g} / \mathbf{L})$ & $\begin{array}{c}\text { Remoção de } \\
\text { NTK(\%) }\end{array}$ & $\begin{array}{c}\text { Remoção de } \\
\text { NAT (\%) }\end{array}$ & NO $_{\mathbf{3}}{ }^{-} / \mathbf{N A T}_{\mathbf{A F}}$ \\
\hline 0 & 23,6 & $85 \%$ & $98 \%$ & 0,75 \\
0,2 & 24,6 & $90 \%$ & $97 \%$ & 0,91 \\
2 & 25,4 & $92 \%$ & $96 \%$ & 0,90 \\
5 & 24,5 & $84 \%$ & $95 \%$ & 0,82 \\
\hline
\end{tabular}

$\mathrm{NAT}_{\mathrm{AF}}=$ Concentração de Nitrogênio Amoniacal Total afluente.

Os resultados indicam a ocorrência de nitrificação em todas as proporções de lixiviado no Experimento 2, a relação de conversão $\mathrm{NO}_{3}{ }^{-} / \mathrm{NAT}_{\mathrm{AF}}$ se manteve acima de 0,8 nas proporções de 0,2 a $5 \%$ de lixiviado pré-tratado. 
- Experimento 3: Tratamento consorciado de lixiviado pré-tratado em proporções de 0 a $5 \%$ e efluente anaeróbio em sistema de lodos ativados em batelada

Neste experimento, a remoção de NAT foi praticamente total para todas as proporções de lixiviado. A eficiência de remoção de NTK se manteve acima de 79\%. As concentrações efluentes de NAT permaneceram abaixo de $5 \mathrm{mg} / \mathrm{L}$, conforme Figura 5.12 .

Tabela 5.23 - Eficiência média do sistema de lodos ativados em escala de bancada, tratando efluente anaeróbio com 0 a 5\% de lixiviado pré-tratado (E3), na remoção de nitrogênio.

\begin{tabular}{ccccc}
\hline $\begin{array}{c}\text { Proporções de } \\
\text { lixiviado (\%) }\end{array}$ & NAT $_{\mathbf{A F}}(\mathbf{m g} / \mathbf{L})$ & $\begin{array}{c}\text { Remoção de } \\
\text { NTK (\%) }\end{array}$ & $\begin{array}{c}\text { Remoção de } \\
\text { NAT (\%) }\end{array}$ & $\mathbf{N O}_{\mathbf{3}}{ }^{-} \mathbf{N A T}_{\mathbf{A F}}$ \\
\hline 0 & 23,5 & $80 \%$ & $92 \%$ & 0,61 \\
0,2 & 24 & $80 \%$ & $95 \%$ & 0,65 \\
2 & 24,3 & $79 \%$ & $98 \%$ & 0,75 \\
5 & 24,6 & $80 \%$ & $98 \%$ & 0,88 \\
\hline
\end{tabular}

$\mathrm{NAT}_{\mathrm{AF}}=$ Concentração de Nitrogênio Amoniacal Total afluente.

Os resultados indicam a ocorrência de nitrificação em todas as proporções de lixiviado no Experimento 1. A concentração afluente de NAT não interferiu significativamente na remoção de nitrogênio e na relação máxima de conversão $\mathrm{NO}_{3}{ }^{-}$ $/ \mathrm{NAT}_{\mathrm{AF}}$. Pode-se observar que a nitrificação foi quase total e os resultados indicam que não houve inibição provocada possivelmente pela amônia, que foi removida no prétratamento do lixiviado utilizado neste experimento.

- Experimento 4: Tratamento consorciado de lixiviado em proporções de 0 a $5 \%$ e efluente anaeróbio em sistema de lodos ativados em batelada

No Experimento 4 as eficiências de remoção de nitrogênio foram todas inferiores a 71\%, apesar de a concentração de NAT nas proporções de 0 e $0,2 \%$ ter sido inferior a $10 \mathrm{mg} / \mathrm{L}$. A eficiência de remoção de NTK variou de 55 a $70 \%$. As concentrações efluentes de NAT permaneceram abaixo de $5 \mathrm{mg} / \mathrm{L}$, conforme Figura 5.13 . 
Tabela 5.24 - Eficiência média do sistema de lodos ativados em escala de bancada, tratando efluente anaeróbio com 0 a 5\% de lixiviado (E4), na remoção de nitrogênio.

\begin{tabular}{ccccc}
\hline $\begin{array}{c}\text { Proporções de } \\
\text { lixiviado (\%) }\end{array}$ & NAT $_{\mathbf{A F}}(\mathbf{m g} / \mathbf{L})$ & $\begin{array}{c}\text { Eficiência } \\
\text { NTK (\%) }\end{array}$ & $\begin{array}{c}\text { Eficiência } \\
\text { NAT (\%) }\end{array}$ & $\mathbf{N O}_{\mathbf{3}}{ }^{-} \mathbf{N A T}_{\mathbf{A F}}$ \\
\hline 0 & 24,1 & $70 \%$ & $71 \%$ & 0,49 \\
0,2 & 28,6 & $60 \%$ & $65 \%$ & 0,74 \\
2 & 67,8 & $63 \%$ & $63 \%$ & 0,63 \\
5 & 140,6 & $55 \%$ & $56 \%$ & 0,20 \\
\hline
\end{tabular}

$\mathrm{NAT}_{\mathrm{AF}}=$ Concentração de Nitrogênio Amoniacal Total afluente.

Os resultados indicam a ocorrência de nitrificação em todas as proporções de lixiviado no Experimento 4. No entanto, é nítida a interferência da concentração de NAT afluente, que afetou significativamente a eficiência de remoção de nitrogênio e na relação máxima de conversão $\mathrm{NO}_{3}{ }^{-} / \mathrm{NAT}_{\mathrm{AF}}$, indicando provável inibição da nitrificação pela amônia presente no lixiviado bruto utilizado neste experimento.

A proporção de 5\% de lixiviado, conforme Figura 5.13, apresentou elevada produção de nitrito e reduzida produção de nitrato, indicando possível inibição da nitrificação completa pela redução da atividade das bactérias Nitrobacter, que são as mais sensíveis à presença de amônia livre e níveis elevados de pH que as Nitrosomonas, conforme constatado por Munch et al. (1996).

As Figuras 5.10 a 5.13 apresentam as variações da concentração de nitrogênio total Kjeldal, nitrogênio amoniacal, nitrito e nitrato nos experimentos em escala de bancada.

Antes de se realizar uma análise geral dos experimentos quanto à remoção de nitrogênio, é importante salientar que: o $\mathrm{pH}$ foi mantido na faixa de 6,5 a $8 \mathrm{em}$ todos os experimentos; a concentração média de oxigênio dissolvido (OD) nos experimentos variou de 2 a $6 \mathrm{mg} / \mathrm{L}$; e a temperatura variou de 18 a $23^{\circ} \mathrm{C}$. Todos os dados de OD, pH e temperatura encontram-se no anexo A.

De forma geral, foi observado em todos os experimentos que a adição de lixiviado bruto também comprometeu a eficiência de remoção de nitrogênio, assim como da matéria orgânica. No entanto, no experimento 2 a interferência da adição de lixiviado foi praticamente desprezível, mantendo elevadas eficiências em todas as proporções.

Os resultados indicam a ocorrência de nitrificação em todas as proporções de lixiviado e em todos os experimentos em batelada. Uma pequena parcela do NAT pode 
ter sido removida por arraste (stripping) pela aeração do próprio reator, ou seja, nem todo NAT foi oxidado a nitrito e a nitrato. No entanto, como o $\mathrm{pH}$ foi mantido sempre inferior a 8 , apenas $5 \%$ do NAT permanece na forma de $\mathrm{NH}_{3}$, podendo ser removida por arraste.

Nota-se que nos Experimentos 2 e 3 foram alcançadas maiores eficiências de remoção de NTK e NAT. Nessas condições foi observado ainda que a adição do lixiviado pré-tratado promoveu uma redução tênue nas eficiências de remoção/conversão, de modo que houve maior produção de nitrato ao longo dos dias de operação.

Quanto aos experimentos 1 e 4, foram alcançadas menores eficiências e foi observada severa interferência na eficiência de remoção de nitrogênio e produção de nitrato devido a adição do lixiviado bruto nesses experimentos, podendo indicar possível inibição da nitrificação pela amônia presente no lixiviado bruto, conforme observado por Çecen \& Çakiroğlu (2001); Chen, S. et al. (2001); Del Borghi, et al. (2003).

\subsubsection{Concentração de sólidos nos reatores}

Em todos os experimentos foram determinadas as concentrações de sólidos suspensos totais (SST), sólidos suspensos fixos (SSF) e voláteis (SSV) no tanque de aeração. Além disso, foram monitorados sólidos suspensos totais suspensos fixos e suspensos voláteis e sólidos totais, fixos nas amostras de afluente e efluente do sistema, cujos resultados encontram-se nos gráficos das Figuras 5.14 e 5.15 e nos Apêndices A14 a A17.

Em todos os experimentos (E1, E2, E3 e E4) foram realizados com a inoculação de lodo aeróbio proveniente do sistema de lodos ativados da Faber Castell.

No Experimento 1, as concentrações de SST e SSV se mantiveram praticamente constante do início ao fim do experimento, variando em torno de $1800 \mathrm{mg} / \mathrm{L}$ e de 1500 $\mathrm{mg} / \mathrm{L}$, respectivamente. 

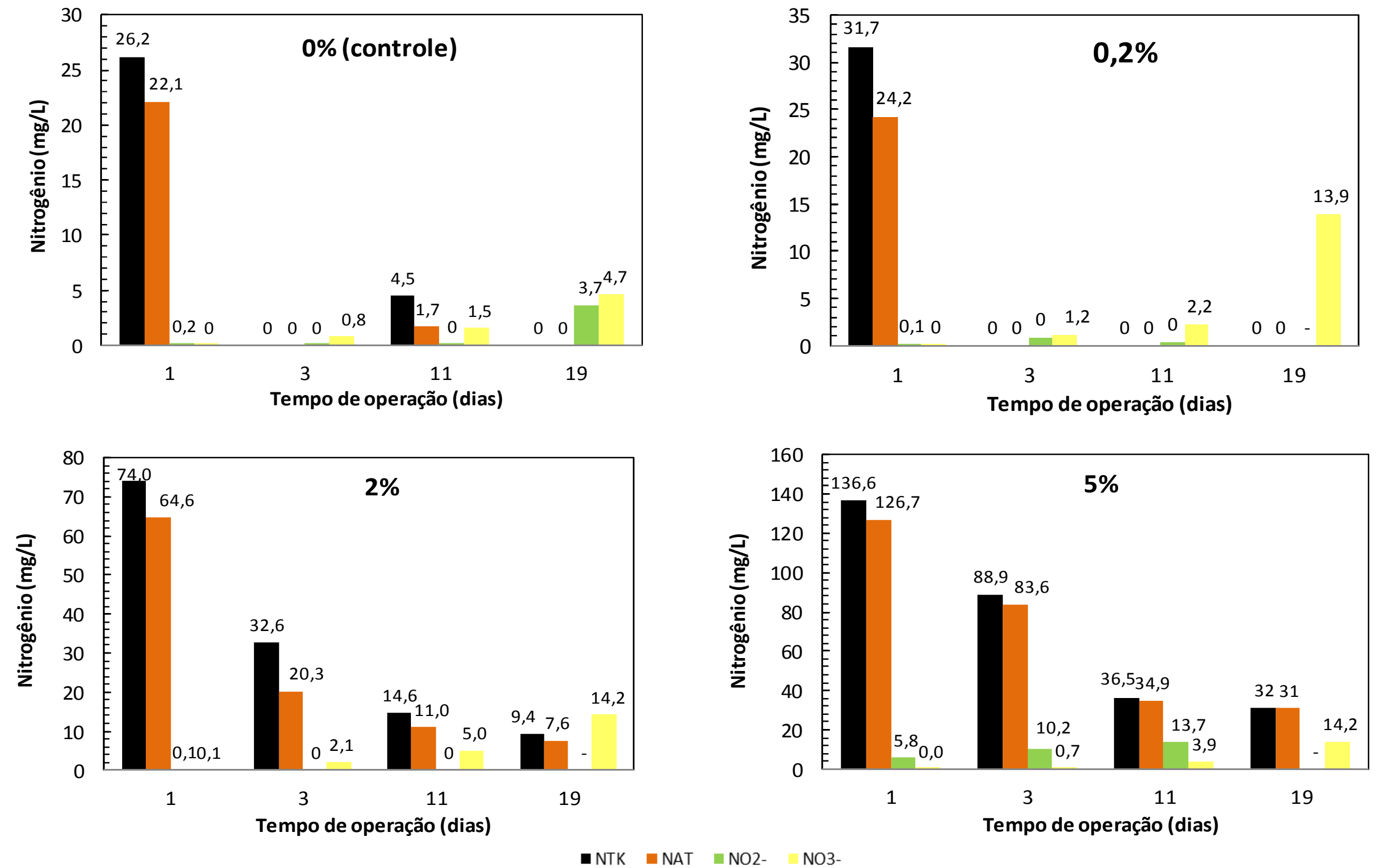

Figura 5.10 - Variação nas formas de Nitrogênio no Experimento 1 de bancada nas proporções de 0 (controle); 0,2; 2 e 5\% de lixiviado. 

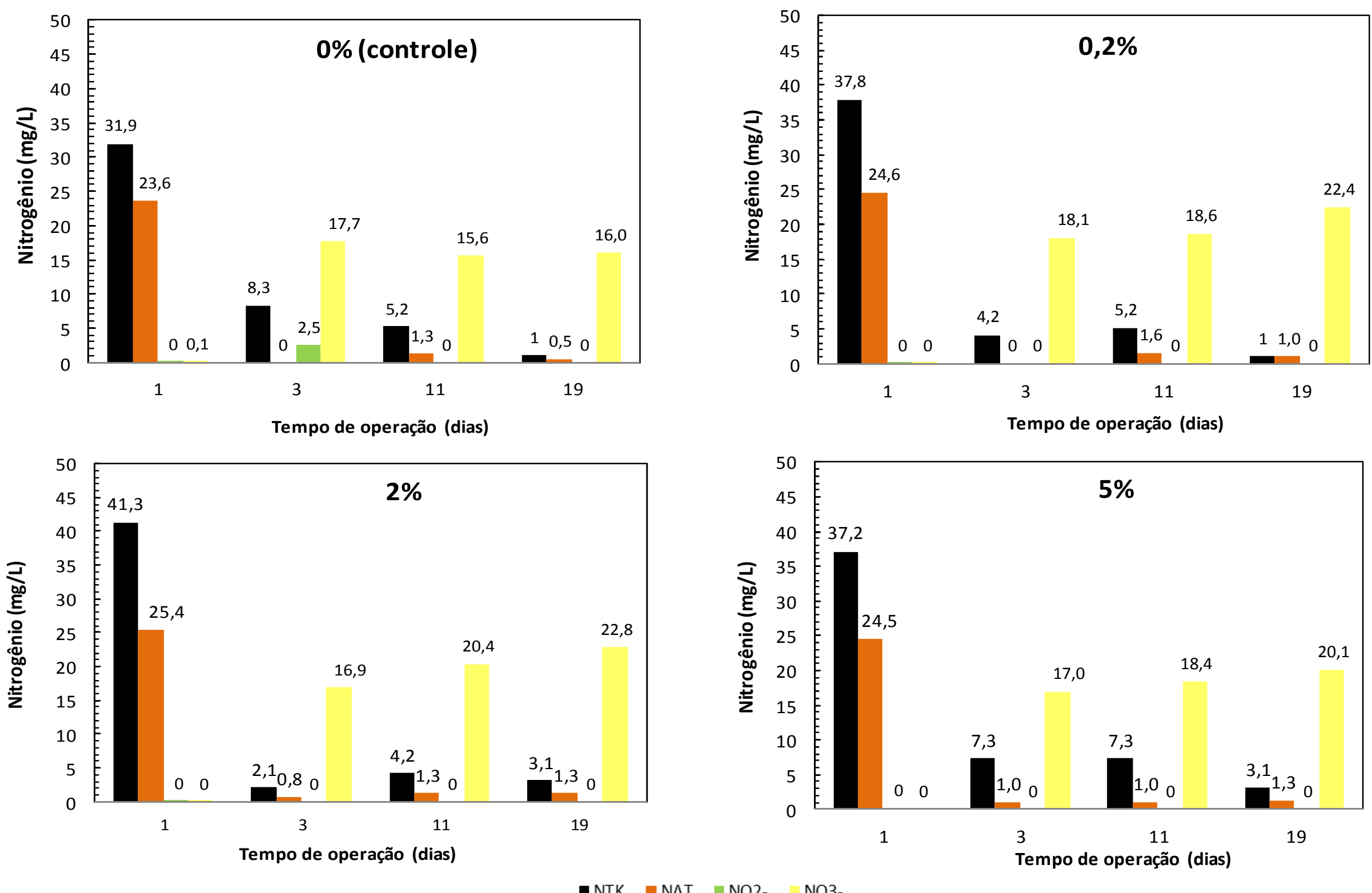

Figura 5.11 - Variação nas formas de Nitrogênio no Experimento 2 de bancada nas proporções de 0 (controle); 0,2; 2 e 5\% de lixiviado. 

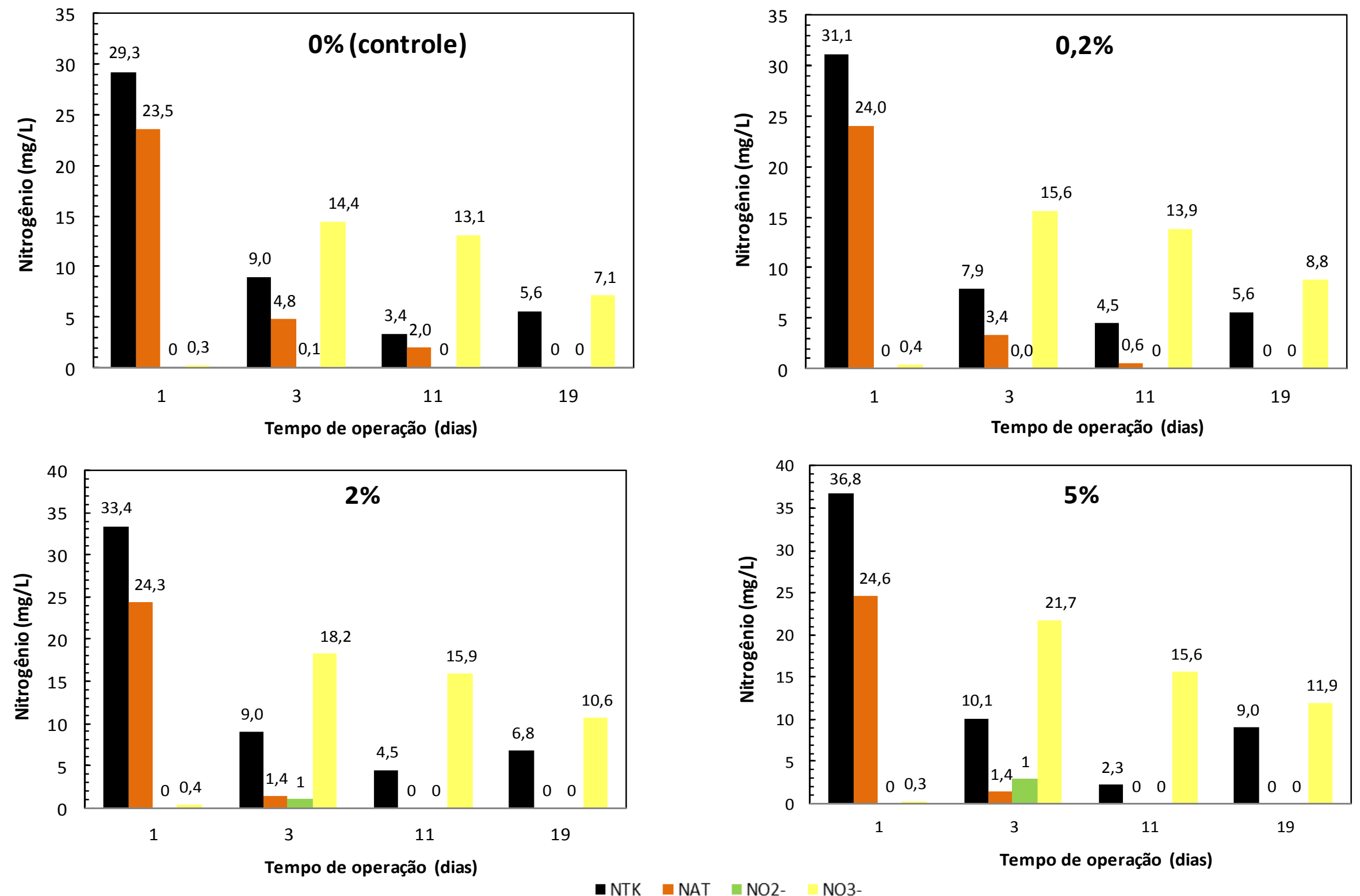

Figura 5.12 - Variação nas formas de Nitrogênio no Experimento 3 de bancada nas proporções de 0 (controle); 0,2; 2 e 5\% de lixiviado. 

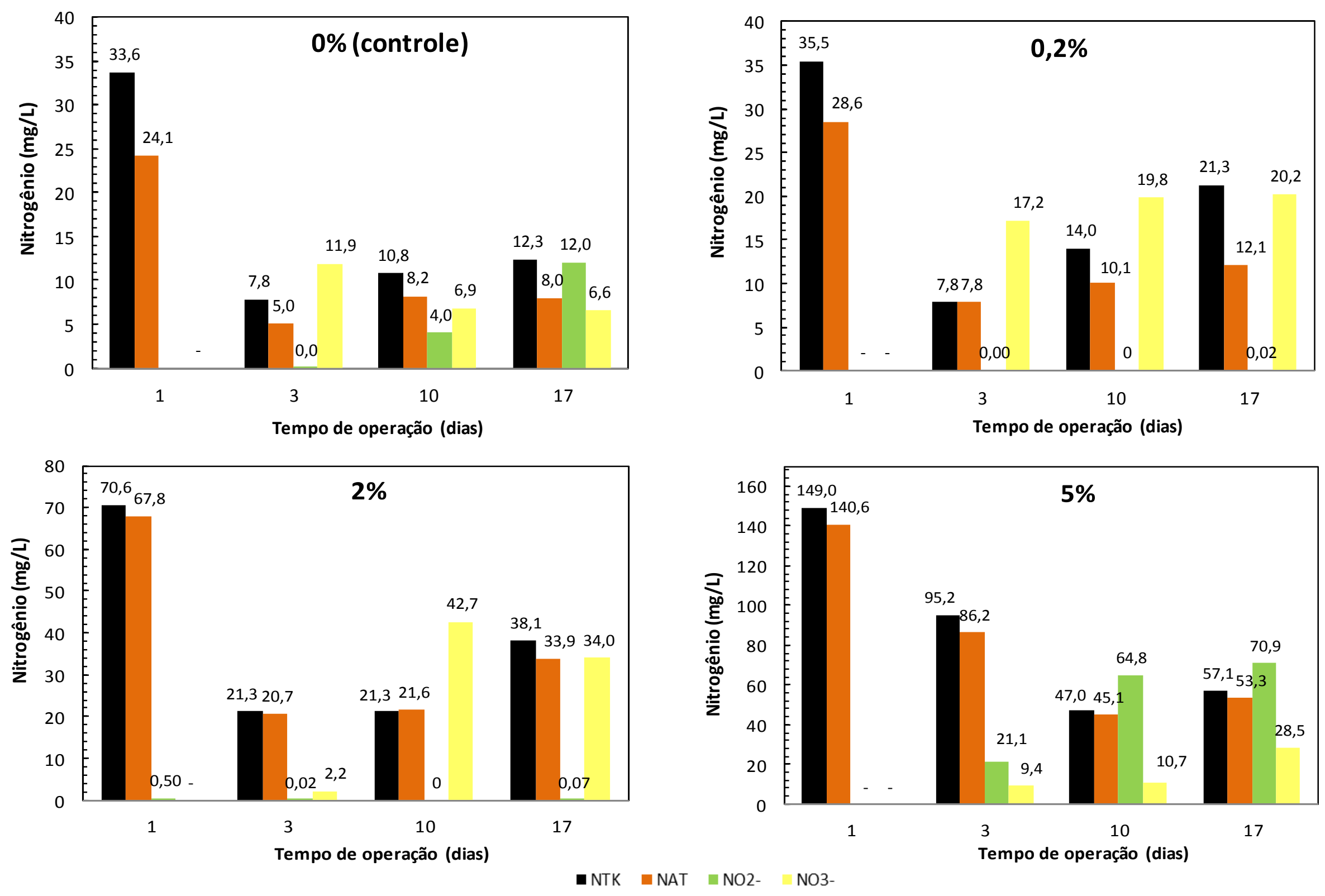

Figura 5.13 - Variação nas formas de Nitrogênio no Experimento 4 de bancada nas proporções de 0 (controle); 0,2; 2 e 5\% de lixiviado. 
Observou-se um aumento significativo na concentração de sólidos suspensos ao longo do Experimento $2 \mathrm{em}$ todas as proporções, especialmente no reator com $0 \%$ de lixiviado (controle), alcançando uma concentrações de SST e SSV próximas de 3500 e $2800 \mathrm{mg} / \mathrm{L}$, respectivamente. Na proporção de 5\% a concentração não teve aumento significativo.

Quanto ao Experimento 3, observou-se uma pequena redução na concentração de sólidos suspensos em relação ao início do experimento, especialmente para a proporção de 5\% de lixiviado, cujas concentrações de SST e SSV final foram inferiores a $1500 \mathrm{mg} / \mathrm{L}$.

No Experimento 4 houve redução da concentração de sólidos suspensos em todas as proporções, principalmente na proporção de 5\% de lixiviado, cuja redução de SST e SSV foi em torno de $55 \%$ em relação à concentração no $3^{\circ}$ dia de experimento. A concentração final de SST e SSV no final do experimento foi em torno de $1000 \mathrm{mg} / \mathrm{L} \mathrm{e}$ $750 \mathrm{mg} / \mathrm{L}$, respectivamente.

De forma geral, foram observadas pequenas variações na concentração de sólidos suspensos sob diferentes proporções de lixiviado. Houve elevação significativa da concentração de sólidos no Experimento 2, especialmente no reator com $0 \%$ (controle) de lixiviado. O experimento 4 apresentou constante redução da concentração de sólidos, principalmente nas maiores proporções de lixiviado. Nesse experimento, a diminuição acentuada da concentração de biomassa pode estar associada à toxicidade provocada pela adição de lixiviado bruto ao sistema de tratamento aeróbio proposto.

Os resultados indicaram que a relação SSV/SST variou entre 0,67 a 0,86 ao longo da operação dos experimentos de bancada.

Os menores valores da relação foram obtidos no Experimento 4, cuja relação média foi de 0,73 , indicando pequena perda da biomassa possivelmente pela toxicidade do lixiviado bruto e por condições desfavoráveis à manutenção da biomassa aeróbia em decorrência do substrato anaeróbio. 

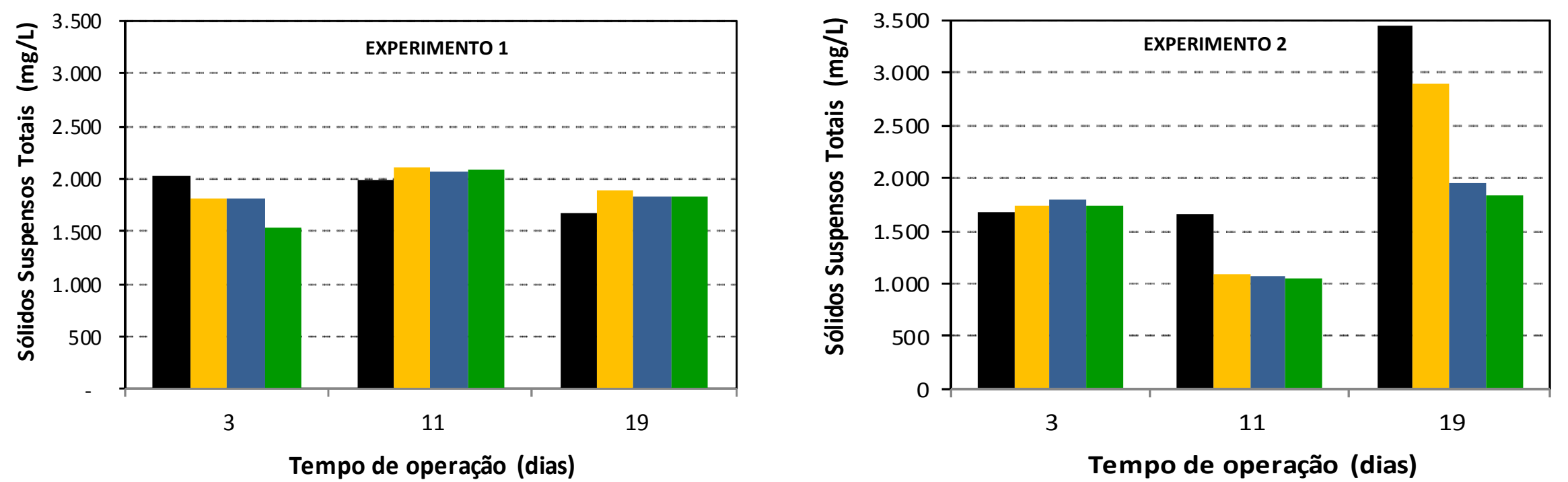

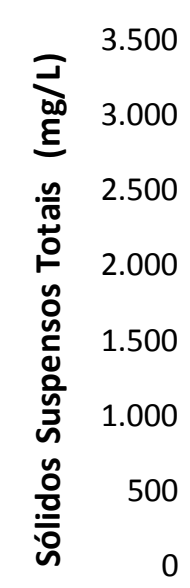

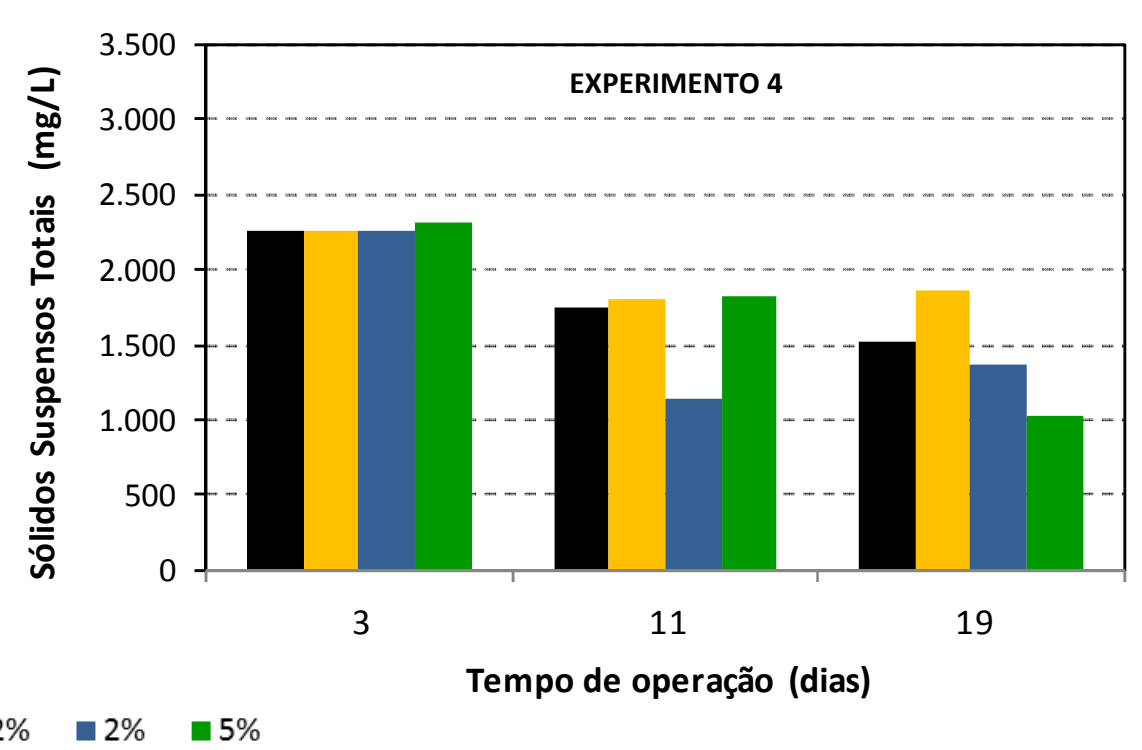

Figura 5.14 - Variação da concentração de SST no tanque de aeração nos experimentos de bancada nas proporções de 0 (controle); 0,2; 2 e 5\% de lixiviado. 

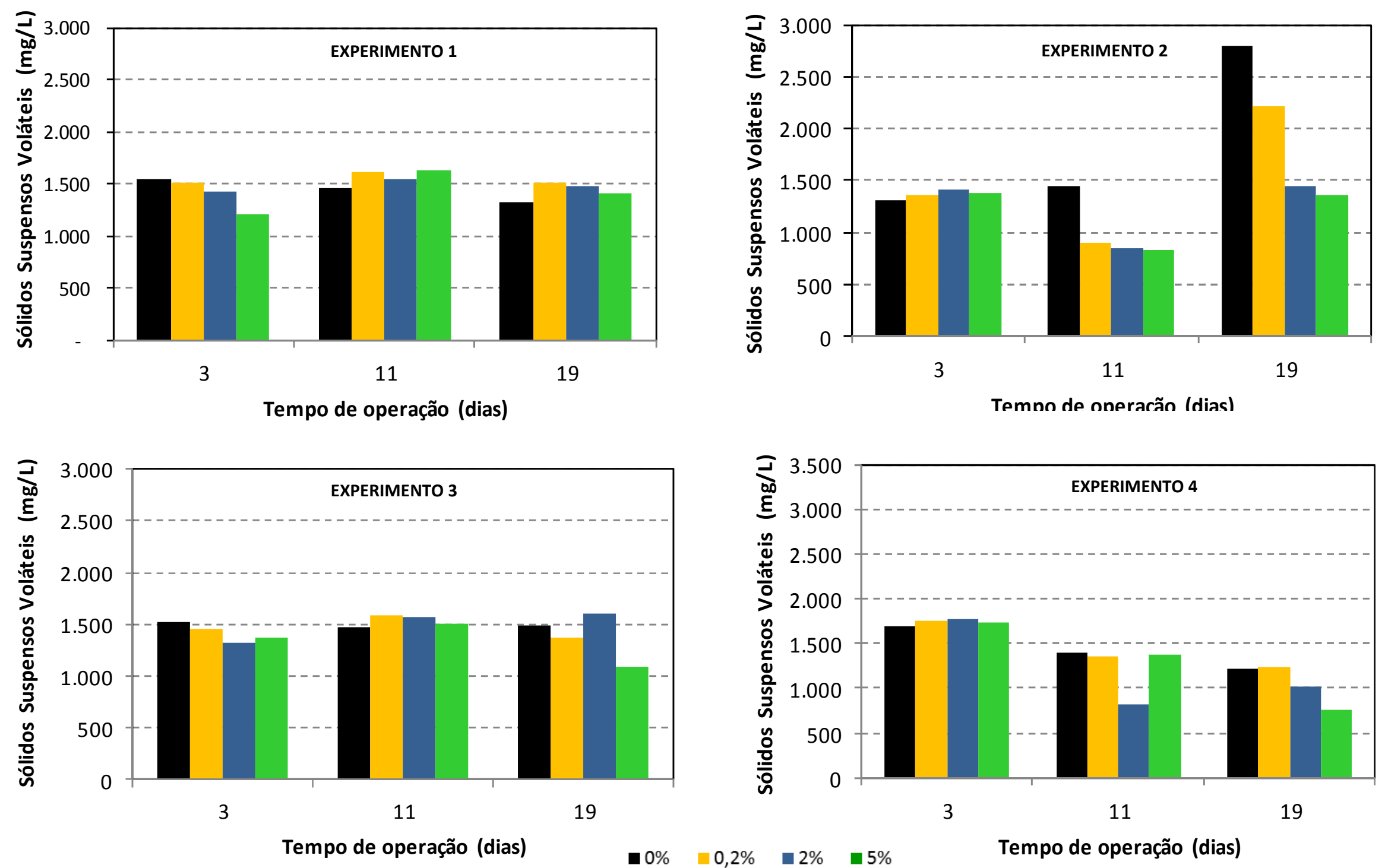

Figura 5.15 - Variação da concentração de SSV no tanque de aeração nos experimentos de bancada nas proporções de 0 (controle); 0,2; 2 e 5\% de lixiviado. 
A sedimentabilidade do lodo foi avaliada por meio do teste de IVL, sem agitação durante o período de sedimentação. Essa modalidade do teste, que é a mais utilizada no Brasil, consiste em deixar $1 \mathrm{~L}$ de amostra do tanque de aeração sedimentar durante 30 minutos em cone Imhoff. Após o período de sedimentação foi medido o volume de sólidos sedimentáveis. Esse volume foi relacionado com a concentração de sólidos suspensos naquela amostra, determinado por meio de filtração de $1,2 \mu \mathrm{m}$ e secagem em estufa, resultando IVL em $\mathrm{mL} / \mathrm{g}$.

Os valores médios de IVL do lodo variaram entre 48 e $172 \mathrm{~mL} / \mathrm{g}$ ao longo da operação dos reatores de bancada (Figura 5.16). Foram constatados maiores valores de IVL no Experimento 2, apesar de no final da operação estes valores serem inferiores a $150 \mathrm{~mL} / \mathrm{g}$. De forma geral, foi observada influência da adição de lixiviado no aumento dos valores de IVL, especialmente nos Experimentos 3 e 4.

Segundo Parker (2001), valores de IVL inferiores a $150 \mathrm{~mL} / \mathrm{g}$ indicam geralmente uma boa qualidade do lodo biológico formado. Desta forma, valores fora desta faixa podem comprometer a sedimentabilidade do lodo e com isso o bom funcionamento do sistema de lodos ativados. Wanner et al. (1998) afirmaram que baixos valores de IVL estão mais relacionados com as boas propriedades de sedimentação do flocos e que valores de IVL maiores que $200 \mathrm{~mL} / \mathrm{g}$ indicam frequência de aparecimento de filamentos variando de muito comuns a abundante.

Apesar de maiores valores de IVL no Experimento 2 em relação aos outros experimentos, não foi observada alterações críticas da biomassa, conforme se pode observar nos resultados do monitoramento microbiológico. 

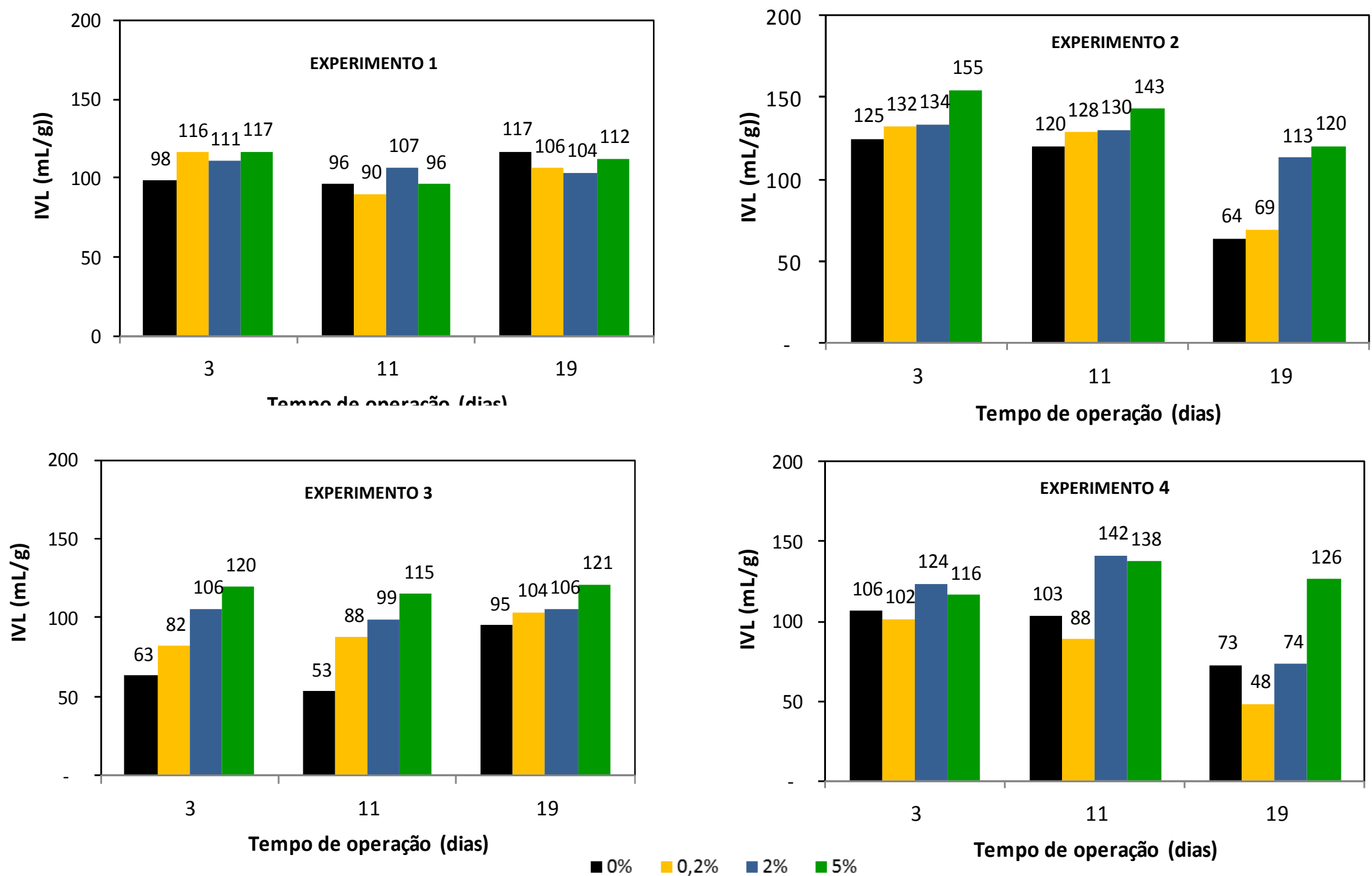

Figura 5.16 - Variação dos valores de IVL no tanque de aeração nos experimentos de bancada nas proporções de 0 (controle); 0,$2 ; 2$ e 5\% de lixiviado. 


\subsubsection{Metais Pesados}

Nos experimentos também foram determinadas as concentrações de alguns metais pesados ( $\mathrm{Zn}, \mathrm{Pb}, \mathrm{Cd}, \mathrm{Ni}, \mathrm{Fe}, \mathrm{Mn}, \mathrm{Cu}, \mathrm{Cr}$ ) nas fases sólidas (lodo) e líquidas (afluente e efluente). Todos os resultados dessas análises encontram-se no anexo A.

Essas determinações foram realizadas com intuito de monitorar a qualidade do lodo do sistema, verificando-se a sua conformidade com os critérios estabelecidos para uso agrícola (Resolução 375/2006 do CONAMA) e tentar verificar a possibilidade de acúmulo de metais pesados na biomassa de sistemas biológicos decorrente da adição de lixiviado, conforme elucidado por Cheng, et al.(1975); Avezzù, et al. (1995); Chipasa (2003); Deng \& Englehardt (2006); Andersson et al. (2007); Renou et al. (2008); Bocchiglieri (2010); Diniz (2010).

As Figuras 5.17 a 5.20 apresentam os gráficos das concentrações de metais pesados no lodo dos experimentos de bancada para as proporções de 0, 0,2, 2 e $5 \%$ de lixiviado. As concentrações apresentadas no gráfico são relativas ao inóculo e às amostras coletas no último dia de operação de cada experimento, para cada proporção.

De acordo com os gráficos, foi possível observar que houve maiores concentrações de chumbo nos reatores do Experimento 2, quando comparado aos outros experimentos.

Os resultados indicam que praticamente não houve variação da concentração de chumbo $(\mathrm{Pb})$ no lodo dos experimentos 2 e 3 com adição das proporções de lixiviado, mantendo-se próxima da concentração do experimento controle (0\%). Nos Experimentos 1 e 2 essa variação foi mais nítida. No entanto, não foi possível observar alguma indicação de tendência de acúmulo de chumbo no lodo dos experimentos.

Quanto ao níquel (Ni), Pode-se observar um leve decréscimo da concentração desta à medida que se aumentava a proporção de lixiviado no Experimento 1. Por outro lado, os resultados indicaram aumento da concentração de níquel à medida que se aumentava a proporção de lixiviado no experimento 2 .

Os resultados apresentaram grande variação na concentração de cromo $(\mathrm{Cr})$ e ferro $(\mathrm{Fe})$ no lodo dos experimentos de bancada, não sendo possível identificar alguma indicação de tendência de acúmulo de chumbo no lodo dos experimentos.

Quanto ao zinco $(\mathrm{Zn})$ e ao manganês ( $\mathrm{Mn})$, verificou-se decréscimo gradativo da concentração do metal no lodo à medida que se adicionava lixiviado no Experimento 1. 
Nos demais experimentos os resultados foram muito variáveis, não indicando nenhuma tendência.

Quanto ao cobre $(\mathrm{Cu})$, observou-se aumento da concentração no lodo nas proporções de 2 e $5 \%$ de lixiviado no Experimento 3. Todos os reatores do experimento 4 obtiveram uma concentração em torno de $50 \mathrm{mg} / \mathrm{kg}$, concentração esta baixa em relação à obtida nos outros experimentos (superiores a 150mg/kg).

Com relação ao cádmio $(\mathrm{Cd})$, os resultados indicaram maiores concentrações no lodo dos reatores do Experimento 2, apesar de essas concentrações ainda serem relativamente baixas. No Experimento 4 o metal foi detectado apenas no lodo do reator com 5\% de lixiviado, podendo indicar possível acúmulo desse metal nessa condição.

Em geral, foram obtidas concentrações dos metais na fase sólida de ordem crescente: $\mathrm{Cd}<\mathrm{Ni}<\mathrm{Pb}<\mathrm{Mn}<\mathrm{Cr}<\mathrm{Zn}<\mathrm{Cu}<\mathrm{Fe}$.

No que tange aos requisitos mínimos de qualidade do lodo de esgoto destinado à agricultura, definidos pela resolução CONAMA n 375/2006 através do art. 11, todas as amostras de lodo dos experimentos de bancada respeitam os limites máximos de concentração de metais pesados analisados.

Vale ressaltar, no entanto, que a referia resolução impõe ainda limites máximos de concentração dos metais como arsênio, bário, mercúrio, molibdênio, selênio, que não foram determinados neste estudo.

Observou-se redução da concentração de $\mathrm{Fe}, \mathrm{Mn}, \mathrm{Cu}$ dolo nos Experimentos $1 \mathrm{e}$ 2 e aumento da concentração de Fe e Mn nos experimentos 3 e 4, conforme resultados apresentados nas Figuras 5.18 e 5.19. 

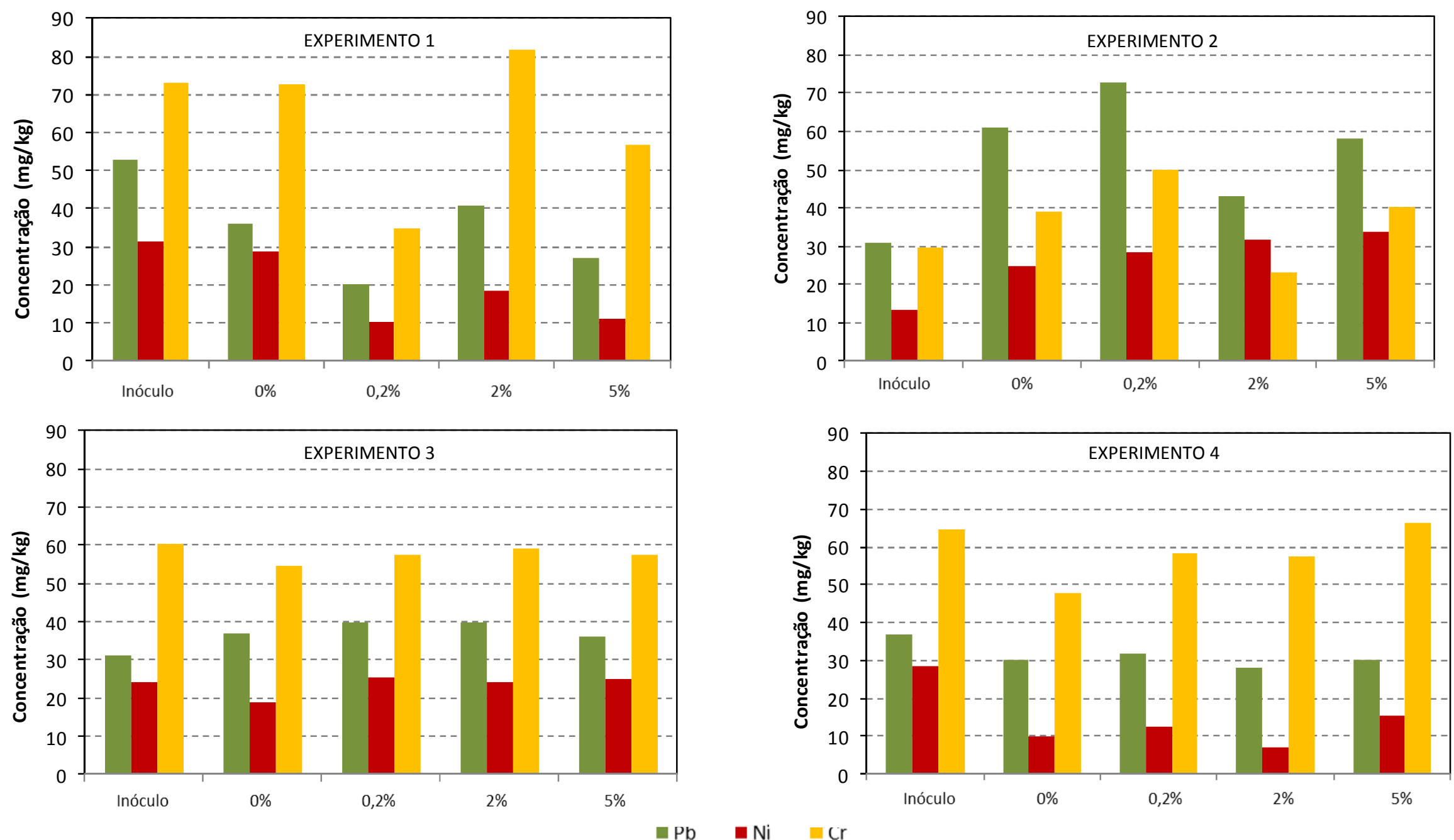

Figura 5.17 - Concentração de metais ( $\mathrm{Pb}, \mathrm{Ni}, \mathrm{Cr})$ no lodo dos experimentos de bancada nas proporções de 0 (controle); 0,2; 2 e 5\% de lixiviado. 

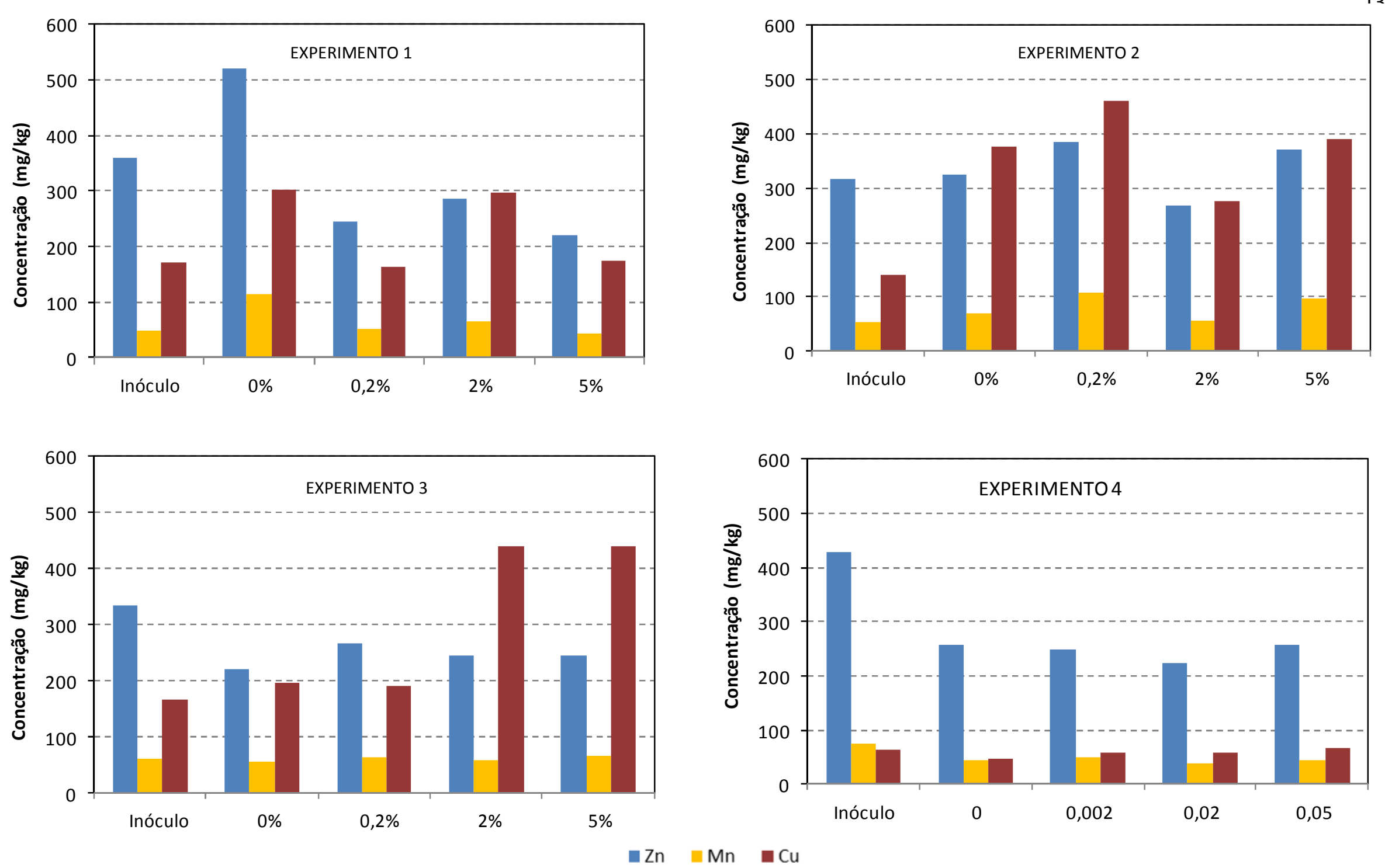

Figura 5.18 - Concentração de metais ( $\mathrm{Zn}, \mathrm{Mn}, \mathrm{Cu})$ no lodo dos experimentos de bancada nas proporções de 0 (controle); 0,$2 ; 2$ e 5\% de lixiviado. 

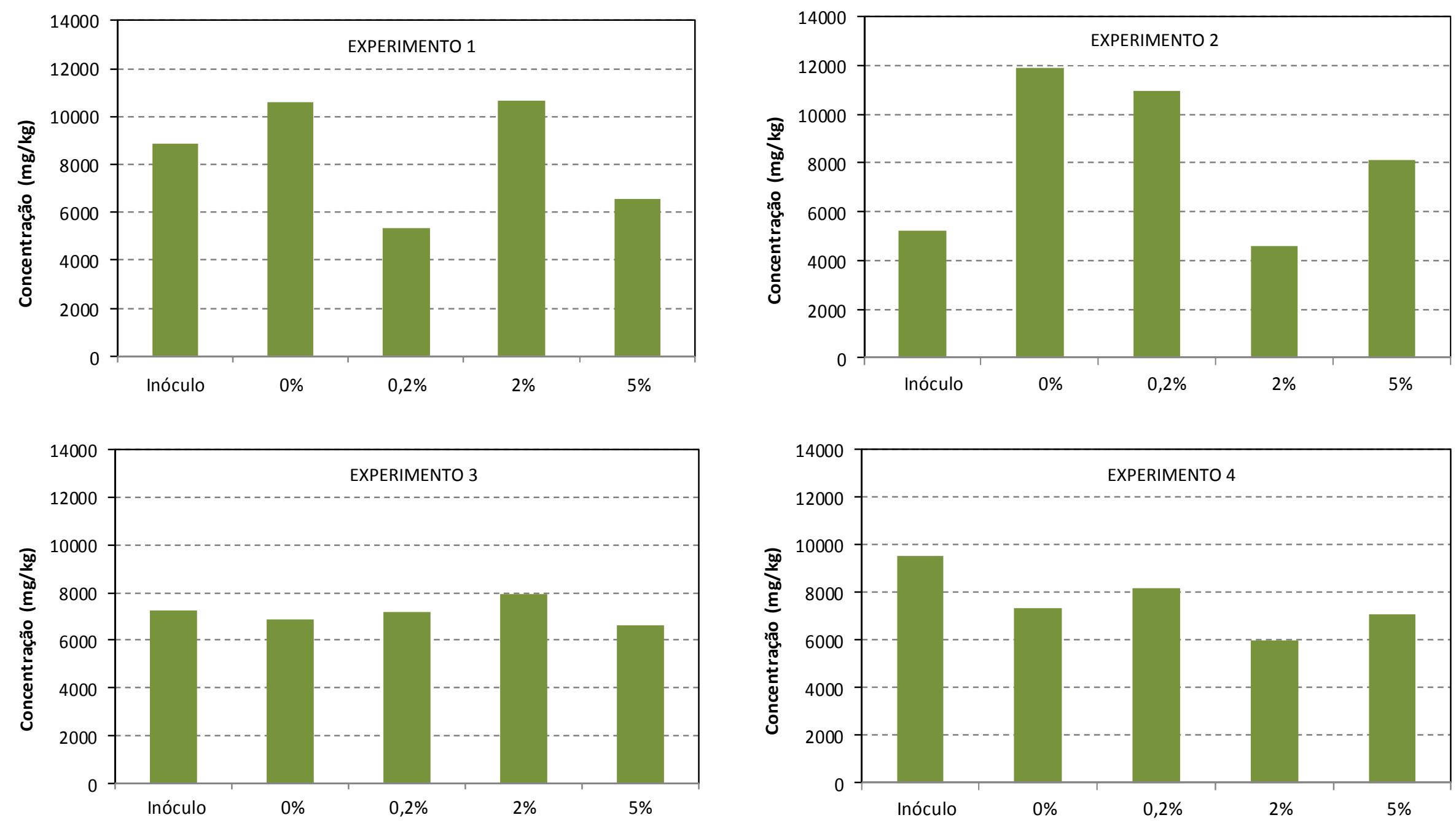

- Fe

Figura 5.19 - Concentração de metais (Fe) no lodo dos experimentos de bancada nas proporções de 0 (controle); 0,2; 2 e 5\% de lixiviado. 

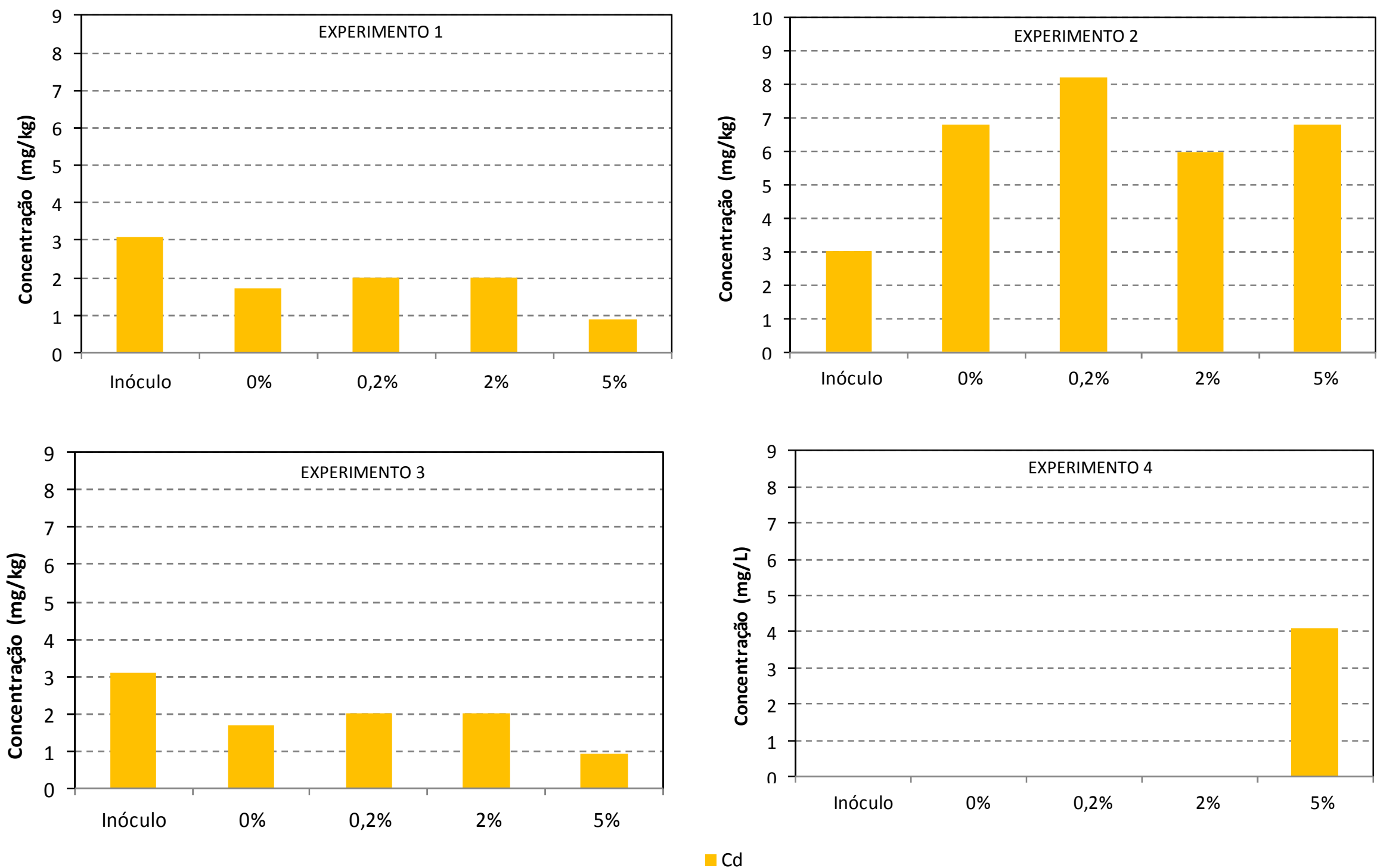

Figura 5.20 - Concentração de metais (Cd) no lodo dos experimentos de bancada nas proporções de 0 (controle); 0,2; 2 e 5\% de lixiviado. 


\subsection{Resultados do monitoramento microbiológico dos experimentos em escala de bancada}

Além do monitoramento físico-químico, foram realizados exames microscópicos das amostras de lodo retiradas semanalmente para cada condição em estudo. A microbiota presente nas amostras coletadas foi correlacionada com os parâmetros físicoquímicos do sistema de lodos ativados.

O estudo microbiológico do sistema de lodos ativados, tratando mistura de esgoto sanitário e lixiviado de aterro, compreendeu no monitoramento microbiológico e característica dos flocos por microscopia óptica de campo claro para estudo comparativo da diversidade microbiana desenvolvida nos reatores nas diferentes condições em estudo.

\subsubsection{Resultados do monitoramento microbiológico por microscopia óptica}

As Tabelas 5.25 a 5.28 apresentam resumidamente as morfologias observadas nas amostras de cada experimento, por meio de microscopia óptica de campo claro. Essa caracterização refere-se à presença de microrganismos pertencentes aos Filos Protozoa (Classes Mastigophora, Ciliata e Sarcodina), Metazoa, Rotifera, Nematoda e Annelida. A estimativa de frequência dos organismos observados foi avaliada subjetivamente, indicando a densidade populacional comparativa entre as amostras coletadas.

A taxonomia utilizada na classificação dos microrganismos observados foi baseada em Barnes \& Ruppert (2005).

A Tabela 5.25 apresenta a frequência de observação dos protozoários e micrometazoários nos reatores do Experimento 1, para o $1^{\circ}$ (inóculo após 7 dias de adaptação), $6^{\circ}, 13^{\circ}$ e $20^{\circ}$ dias. 
Tabela 5.25 - Frequência dos microrganismos observados no sistema de lodos ativados em escala de bancada ao longo do Experimento 1.

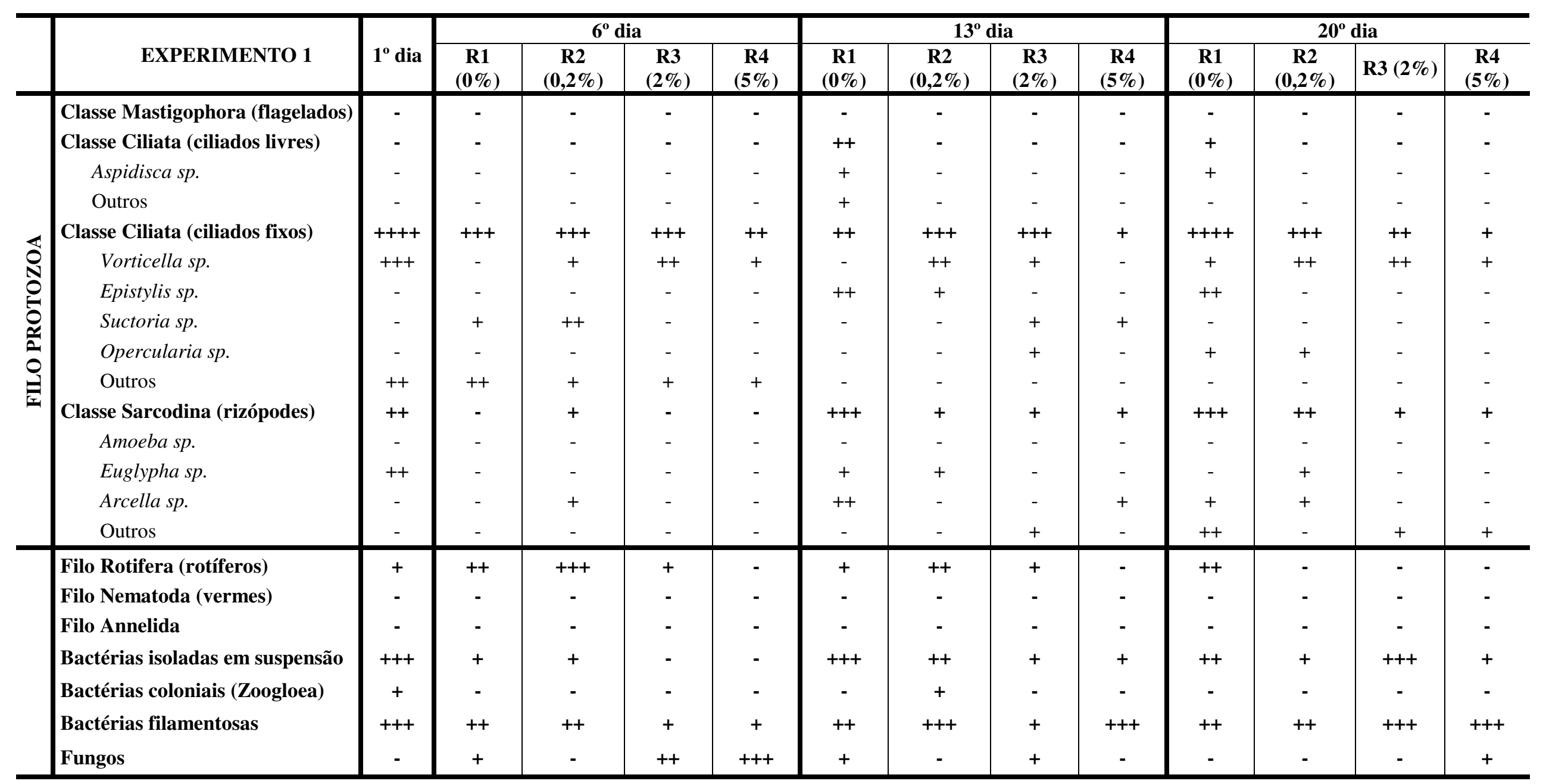

Legenda: Ausentes - ; Frequência Baixa + ; Frequência Média ++ ; Frequência Elevada +++; Abundante ++++.

R1, R2, R3 e R4: Reatores com 0; 0,2; 2 e 5\% de lixiviado, respectivamente. 
Conforme indicado na Tabela 5.25, foi observada elevada diversidade de morfologias microbianas na caracterização do lodo adaptado (inóculo).

Os flocos desenvolvidos em R1 (controle) (Figura 5.21 $1^{\mathrm{a}}$ ) apresentaram-se em grande número e tamanho, estrutura densa e com frequência média de bactérias filamentosas (Figura 5.21 ${ }^{\mathrm{a}}$.).

Observou-se a manutenção dos microrganismos provenientes do inóculo até o final da operação, em especial dos ciliados fixos semelhantes a Epistylis sp. e alguns semelhantes à Opercularia sp. (Figura 5.21c e d)). Foi possível verificar o surgimento de alguns ciliados livres natantes, semelhante à Aspidisca sp. Quanto aos metazoários observou-se aumento significativo na frequência de rotíferos (Figura 5.21b.) e redução de bactérias filamentosas.
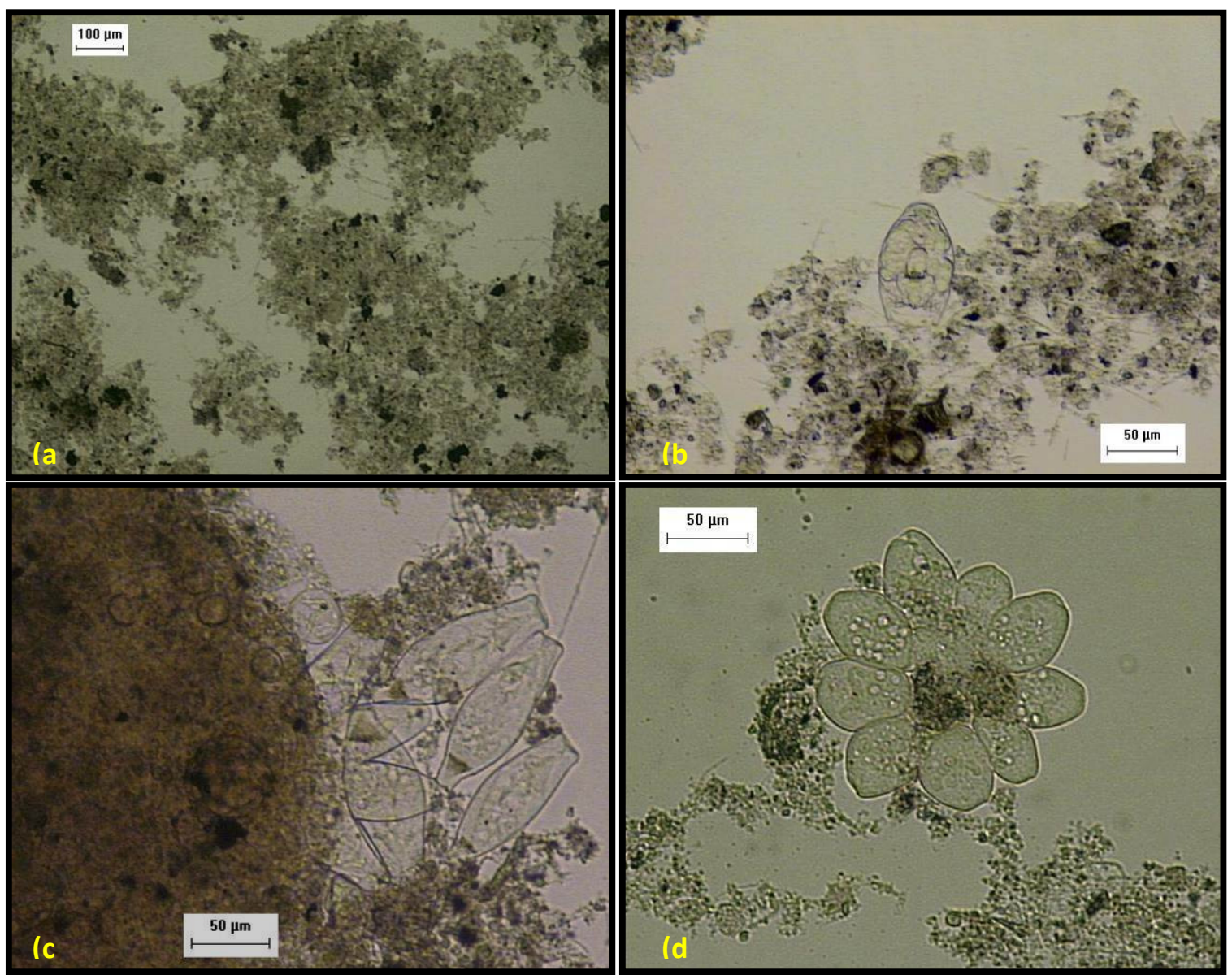

Figura 5.21 - Caracterização da composição da microfauna em R1E1 (0\% Experimento 1) do sistema de lodos ativados em escala de bancada. (a) Estrutura física do floco. (b)Metazoário rotífero semelhante à Epiphanes sp.. Ciliados fixos semelhantes à: (c)Epistylis sp. e (d)Opercularia sp.. Aumentos originais 50x, (a); 100x, (b); 300x, (c) e $100 x,(d)$. 
Os flocos desenvolvidos em R2 (0,2\%) (Figura 5.22d) apresentaram-se em grande número, tamanho médio, estrutura medianamente compacta e com frequência média de bactérias filamentosas (Figura 5.22d.), o que condiz com o resultado do IVL reduzido, indicando boas condições de sedimentabilidade e estabilidade do lodo.

Observou-se manutenção dos microrganismos provenientes do inóculo até o final da operação, em especial dos ciliados fixos semelhantes a Vorticella sp. e Opercularia sp. (Figura 5.22 b). Foi possível verificar discreta redução da frequência de alguns ciliados fixos e surgimento de rizópodes semelhantes à Euglypha sp. (Figura 5.22c.). Quanto aos metazoários observou-se redução gradativa na frequência de rotíferos e redução de bactérias filamentosas.
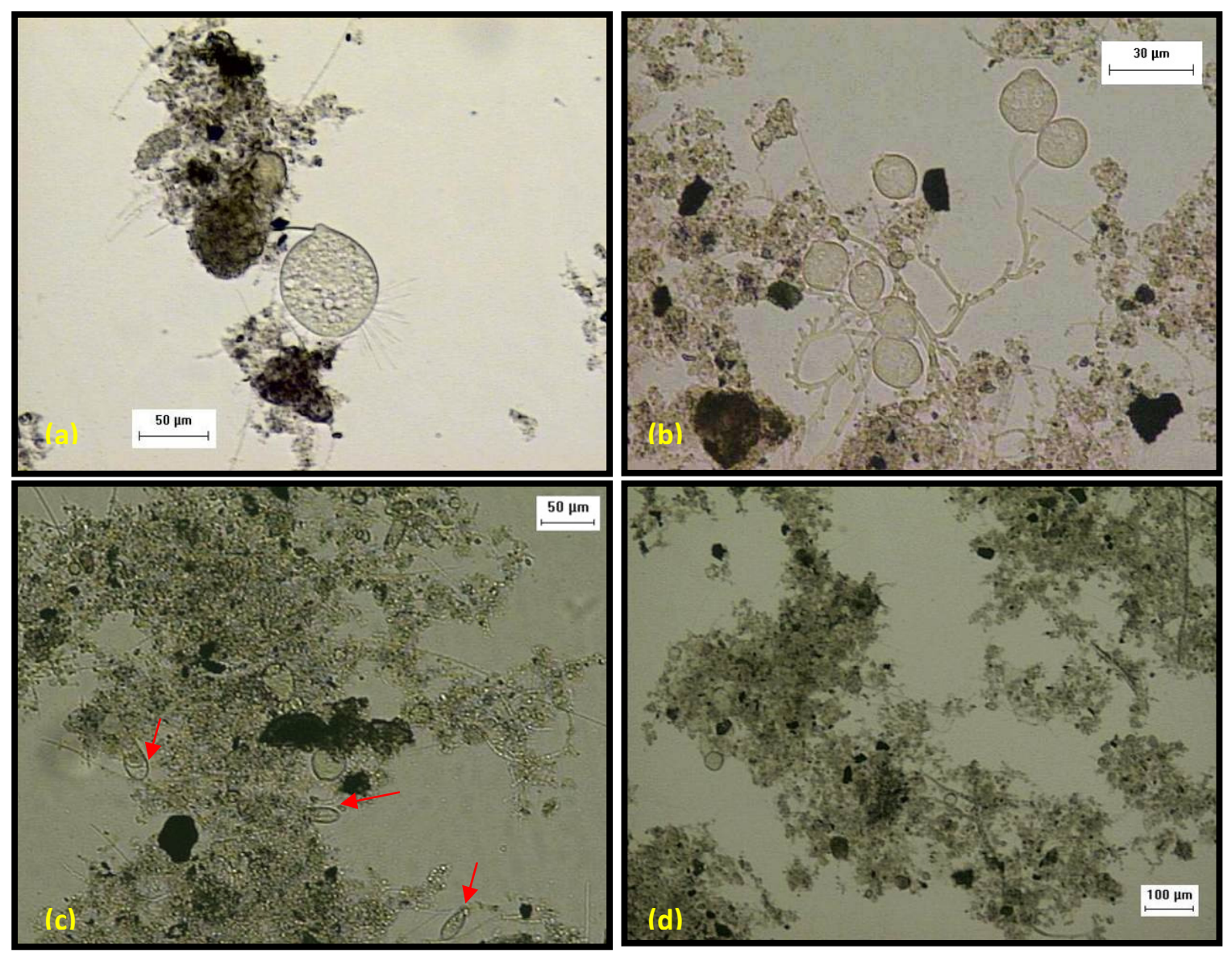

Figura 5.22 - Caracterização da composição da microfauna em R2E1 (0,2\% Experimento 1) do sistema de lodos ativados em escala de bancada. Ciliados fixos semelhantes à: (a)Podophrya sp. e (b)Vorticella sp.; (c) Rizópodes semelhantes a Euglypha sp.. (d)Estrutura física do floco. Aumentos originais 100x, (a); 200x, (b); 75x, (c) e $50 x,(d)$. 
Os flocos desenvolvidos em R3 (2\%) (Figura 5.23c) apresentaram-se em quantidade razoável e tamanho médio, estrutura pouco compacta a dispersa e com frequência elevada de bactérias filamentosas (Figura 5.23d.).

Apesar da diminuição gradativa da diversidade, observou-se manutenção de alguns microrganismos provenientes do inóculo até o final da operação, em especial dos ciliados fixos como Vorticella sp.. (Figura 5.23 ${ }^{\mathrm{a}} \mathrm{e}$ b).. Quanto aos metazoários observou-se redução gradativa na frequência de rotíferos (Figura 5.23 ${ }^{\mathrm{a}}$.) e aumento gradativo de bactérias filamentosas (Figura 5.23d.).

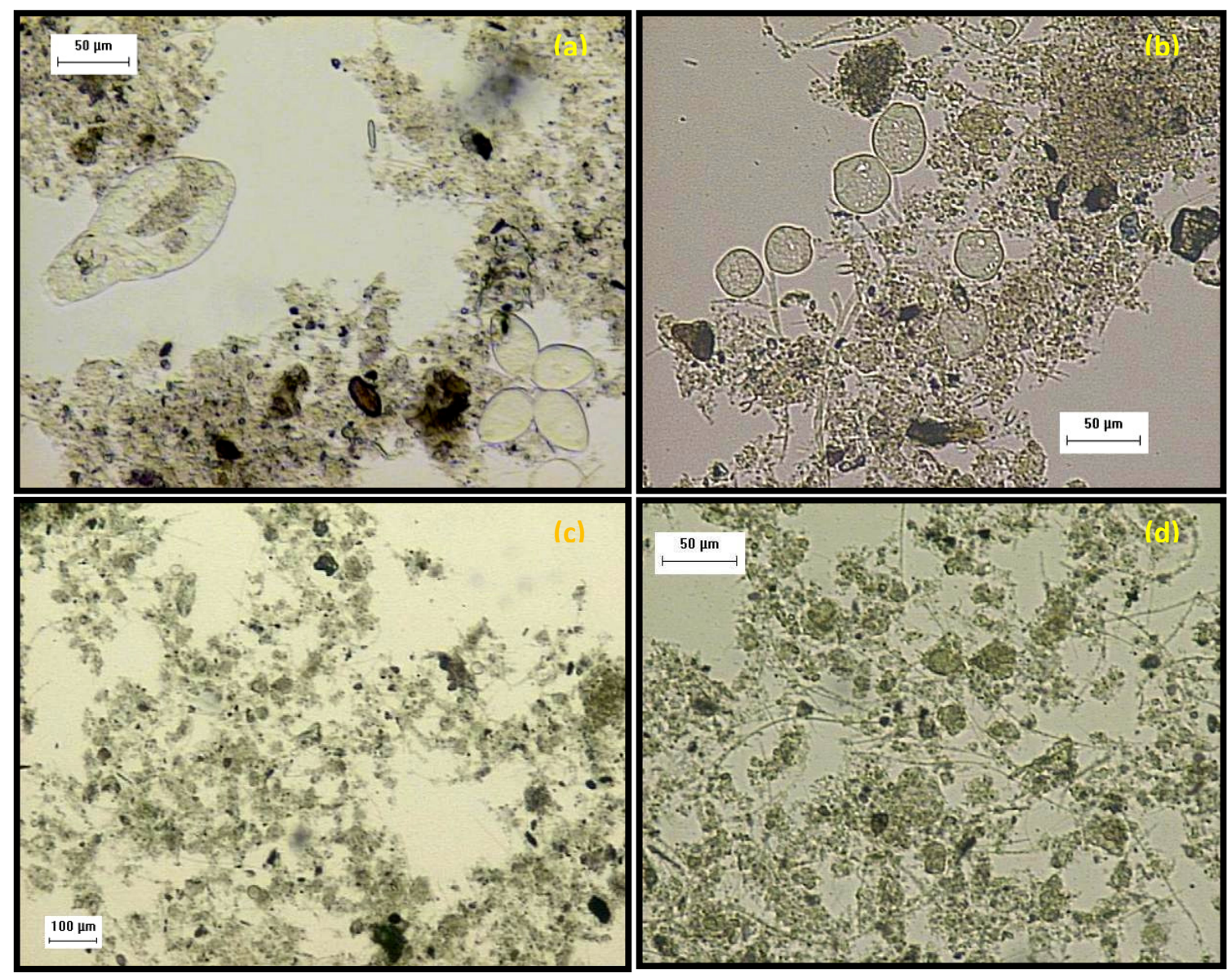

Figura 5.23 - Caracterização da composição da microfauna em R3E1 (2\% Experimento 1) do sistema de lodos ativados em escala de bancada. Colônia de ciliados fixos semelhantes à: (a) e (b)Vorticella sp.; (a) Metazoário rotífero semelhante a Epiphanes sp.; (c) Estrutura física do floco; (d) Bactérias filamentosas. Aumentos originais 100x, (a) e (b); 50x, (c) e 75x, (d).

Os flocos desenvolvidos em R4 (5\%) (Figura 5.24c) apresentaram-se em quantidade razoável e tamanho médio, estrutura dispersa e com frequência elevada de bactérias filamentosas (Figura 5.24d.). 
Observou-se diminuição aparente da diversidade de morfologias microbianas, indicado pela redução de todos os microrganismos provenientes do inóculo até o final da operação, em especial dos ciliados fixos e rizópodes. Foram observados ainda alguns rizópodes semelhantes à Euglypha sp. e Arcella sp. (Figura 5.24a e b). Quanto aos metazoários observou-se redução na frequência de rotíferos desde a $1^{\mathrm{a}}$ semana e aumento gradativo de bactérias filamentosas (Figura 5.24d.).

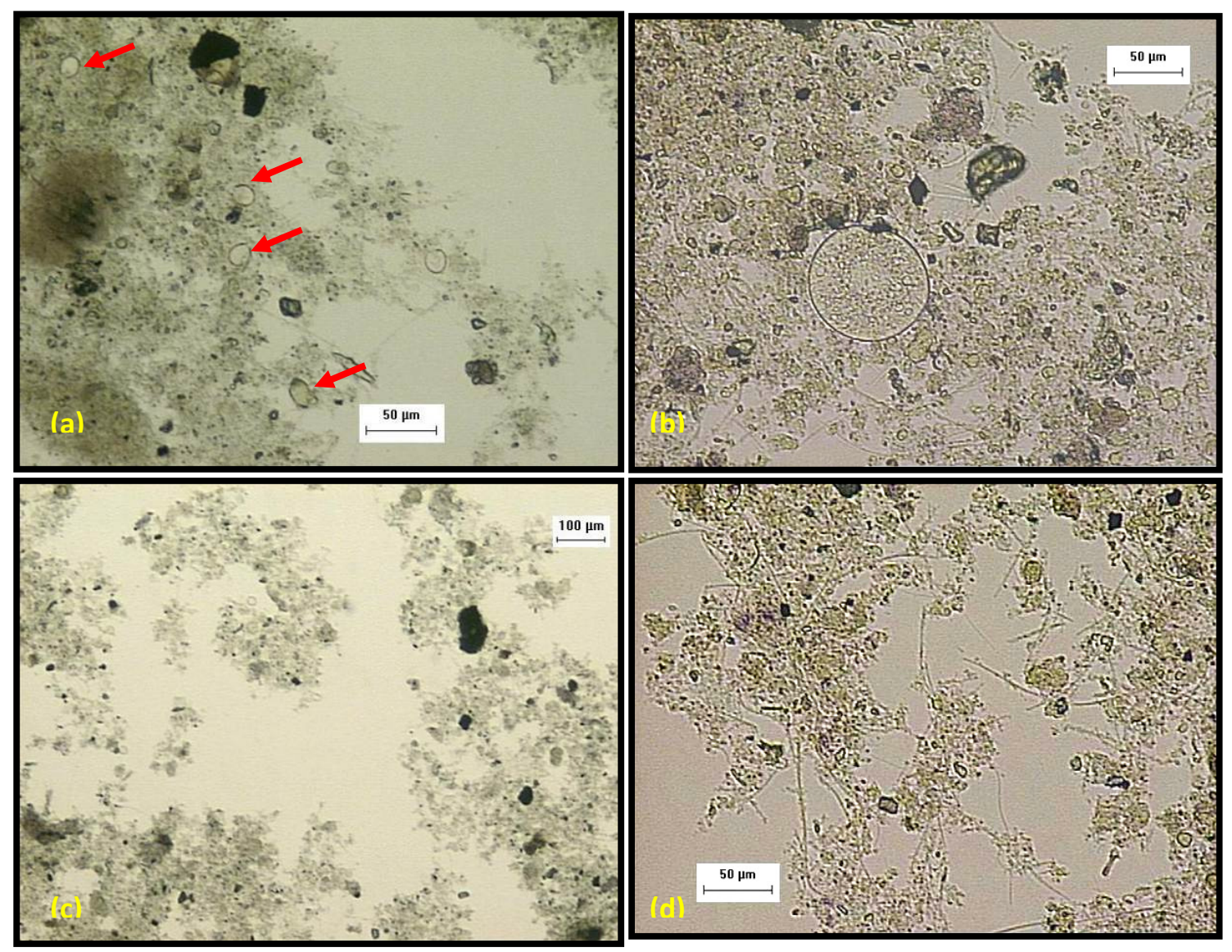

Figura 5.24 - Caracterização da composição da microfauna em R4E1 (5\% Experimento 1) do sistema de lodos ativados em escala de bancada. Rizópodes semelhantes à: (a) Euglypha sp. e (b) Arcella sp.; (c) Estrutura física do floco; (d) Bactérias filamentosas. Aumentos originais 100x, (a) e (b); 50x, (c) e 75x, (d).

Baseado nos resultados do monitoramento microbiológico dos reatores do Experimento 1, foi possível observar um decréscimo aparente na frequência de protozoários ciliados fixos e rizópodes e um acréscimo de bactérias filamentosas à medida que foi aumentada a proporção de lixiviado bruto.

A ocorrência de protozoários ciliados fixos em quase todas as condições deste experimento, especialmente dos gêneros Vorticella sp. e Epystilis sp., se deve, 
principalmente, às condições operacionais do sistema em estudo: elevada idade do lodo; baixa-média carga orgânica e baixa relação A/M), conforme Jenkis (2003).

Conforme estudos de Branco (1986), Pinto (1998), Zhou et al. (2006) e Oliveira, et al. (2008), esses microrganismos observados nesta condição estão associados à estabilidade do lodo e à baixa concentração de DBO e DQO efluentes.

De acordo com os resultados do monitoramento microbiológico, a frequência destes protozoários foi decrescente à medida que se aumentava a proporção de lixiviado. Assim, a baixa frequência desses protozoários ciliados fixos no reator R4 (5\%) durante toda a operação é compatível com as baixas eficiências de remoção de DBO e DQO nessa condição.

Chen S. et al. (2004) e Zhou K. et al. (2006) encontraram elevada correlação do gênero Arcella sp. com a baixa concentração efluente de DQO, DBO, SS e IVL. Neste experimento também foi possível verificar a presença de protozoários rizópodes (amebas) em todas as proporções de lixiviado, em maior frequência nos reatores R1(0\%) e R2(0,2\%), especialmente dos gêneros Arcella sp e Euglypha sp., em que também foram obtidas menores concentrações da DQO e DBO efluente.

Segundo Vazzoler (1989) e Mandoni et al. (1993), Bento et al. (2005) a presença de protozoários do gênero Aspidisca sp, Arcella sp. e Euglypha sp. indica a ocorrência de nitrificação. . Os resultados físico-químicos também indicaram a ocorrência de nitrificação em todas as proporções deste experimento. A baixa frequência de amebas nos reatores R3 (2\%) e R4 (5\%) indica menor eficiência de nitrificação e maior concentração de amônia remanescente.

A frequência de bactérias filamentosas se manteve média nos reatores, com exceção do reator R4(5\%), a qual se manteve elevada por duas semanas.

A Tabela 5.26 apresenta a frequência de observação dos protozoários e micrometazoários nos reatores do Experimento 2, para o $1^{\circ}$ (inóculo após 7 dias de adaptação), $6^{\circ}, 13^{\circ}$ e $20^{\circ}$ dias. 
Tabela 5.26 - Frequência dos microrganismos observados no sistema de lodos ativados em escala de bancada ao longo do Experimento 2.

\begin{tabular}{|c|c|c|c|c|c|c|c|c|c|c|c|c|c|c|}
\hline & \multirow{2}{*}{ EXPERIMENTO 2} & \multirow{2}{*}{ Inóculo } & \multicolumn{4}{|c|}{$6^{\circ}$ dia } & \multicolumn{4}{|c|}{$13^{\circ}$ dia } & \multicolumn{4}{|c|}{$20^{\circ}$ dia } \\
\hline & & & $\mathbf{R} 1$ & $\mathbf{R 2}$ & $\mathbf{R 3}$ & $\mathbf{R 4}$ & $\mathbf{R} 1$ & $\mathbf{R 2}$ & $\mathbf{R 3}$ & $\mathbf{R 4}$ & $\mathbf{R} 1$ & $\mathbf{R 2}$ & $\mathbf{R 3}$ & $\mathbf{R 4}$ \\
\hline \multirow{22}{*}{ 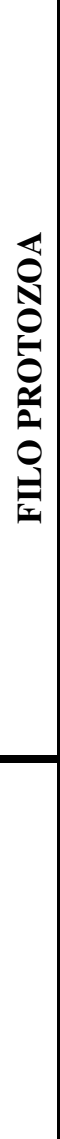 } & Classe Mastigophora (flagelados) & - & - & - & - & - & + & - & + & - & ++ & - & - & - \\
\hline & Classe Ciliata (ciliados livres) & - & - & - & - & - & + & - & - & - & ++ & + & + & + \\
\hline & Aspidisca sp. & - & - & - & - & - & + & - & - & - & + & + & + & + \\
\hline & Outros & - & - & - & - & - & + & - & - & - & + & - & - & - \\
\hline & Classe Ciliata (ciliados fixos) & ++ & ++++ & +++ & ++ & ++ & +++ & ++++ & +++ & + & ++++ & +++ & +++ & +++ \\
\hline & Vorticella sp. & + & + & + & ++ & + & ++ & + & ++ & - & ++ & + & ++ & ++ \\
\hline & Epistylis sp. & + & ++ & + & - & - & - & ++ & - & - & + & ++ & + & - \\
\hline & Suctoria sp. & - & + & - & - & - & - & + & + & + & - & - & - & - \\
\hline & Opercularia sp. & - & - & - & - & - & - & - & - & - & - & - & + & - \\
\hline & Outros & - & - & + & - & + & + & - & - & - & + & - & - & + \\
\hline & Classe Sarcodina (rizópodes) & ++ & ++ & ++ & + & ++ & +++ & ++ & ++ & ++ & ++++ & +++ & ++ & +++ \\
\hline & Amoeba sp. & - & - & + & - & - & - & - & - & - & + & - & - & - \\
\hline & Euglypha sp. & + & + & + & + & + & ++ & + & - & + & - & + & + & - \\
\hline & Arcella sp. & - & + & - & - & + & + & + & ++ & + & ++ & ++ & + & ++ \\
\hline & Outros & + & - & - & - & - & - & - & - & - & + & - & - & + \\
\hline & Filo Rotifera (rotíferos) & - & - & + & ++ & +++ & + & ++ & ++ & +++ & ++ & ++ & + & ++ \\
\hline & Filo Nematoda (vermes) & - & - & - & - & - & - & - & - & - & - & - & - & + \\
\hline & Filo Annelida & - & - & - & - & - & - & - & - & - & - & - & - & - \\
\hline & Bactérias isoladas em suspensão & ++ & ++++ & + & + & ++ & + & + & +++ & +++ & ++ & + & ++ & ++ \\
\hline & Bactérias coloniais (zoogloea) & + & ++ & - & - & - & +++ & ++ & + & + & +++ & + & + & + \\
\hline & Bactérias filamentosas & ++ & ++ & ++ & ++ & ++ & ++ & +++ & ++ & ++ & ++ & ++ & ++ & +++ \\
\hline & Fungos & ++ & - & - & + & +++ & - & - & - & - & - & + & - & + \\
\hline
\end{tabular}

Legenda: Ausentes - ; Frequência Baixa + ; Frequência Média ++ ; Frequência Elevada +++; Predominante ++++.

R1, R2, R3 e R4: Reatores com 0; 0,2; 2 e 5\% de lixiviado, respectivamente. 
Os flocos desenvolvidos em R1 (controle) no Experimento 2 apresentaram-se em grande quantidade e tamanho médios, estrutura compacta e com frequência média de bactérias filamentosas (Figura 5.25d.).

Observou-se aumento da diversidade de morfologias microbianas na biomassa desenvolvida no reator R1 até o final da operação, em relação ao inóculo caracterizado.

Observou-se aumento da frequência de microrganismos provenientes do inóculo até o final da operação, em especial dos ciliados fixos semelhantes à Epistylis sp. e Vorticella sp. (Figura 5.25 a b). Foi possível verificar o surgimento de alguns ciliados livres natantes, como Aspidisca sp. e Paramecium sp. e de protozoários flagelados. Quanto aos metazoários observou-se aumento significativo na frequência de rotíferos (Figura 5.25b.) e de bactérias coloniais Zoogloea ramigera.
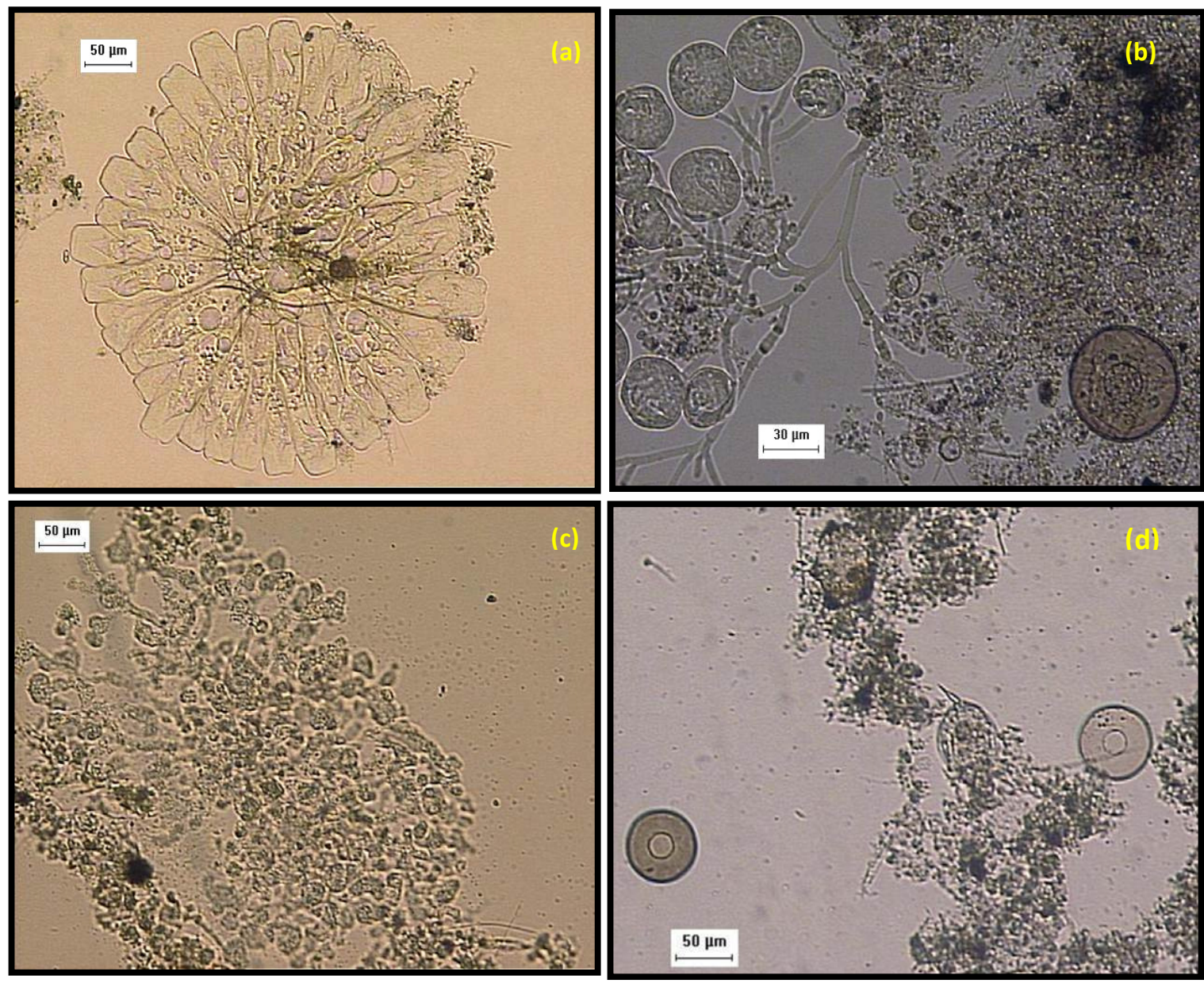

Figura 5.25 - Caracterização da composição da microfauna em R1E2 (0\% Experimento 2) do sistema de lodos ativados em escala de bancada. Colônias de ciliados fixos semelhantes à: (a) Epistylis sp. e (b) Vorticella sp.; (c) Bactérias coloniais Zoogloea ramigera; (d) Rizópodes semelhantes a Arcella sp. e rotífero. Aumentos originais 100x, (a); 200x, (b); 100x, (c) e (d). 
Os flocos desenvolvidos em R2 (0,2\%) no Experimento 2 apresentaram-se em grande quantidade e tamanho, estrutura compacta e com frequência média de bactérias filamentosas (Figura 5.26d.).

Observou-se aparente aumento da diversidade de morfologias microbiana na biomassa desenvolvida no reator R2 até o final da operação, em relação ao inóculo caracterizado, em especial dos ciliados fixos como Epistylis sp. (Figura 5.26b). Foi possível verificar o desenvolvimento de alguns ciliados livres natantes, como Aspidisca sp. e de alguns rizópodes como Arcella sp. (Figura 5.26c.). Quanto aos metazoários observou-se aumento significativo na frequência de rotíferos (Figura 5.26c.).

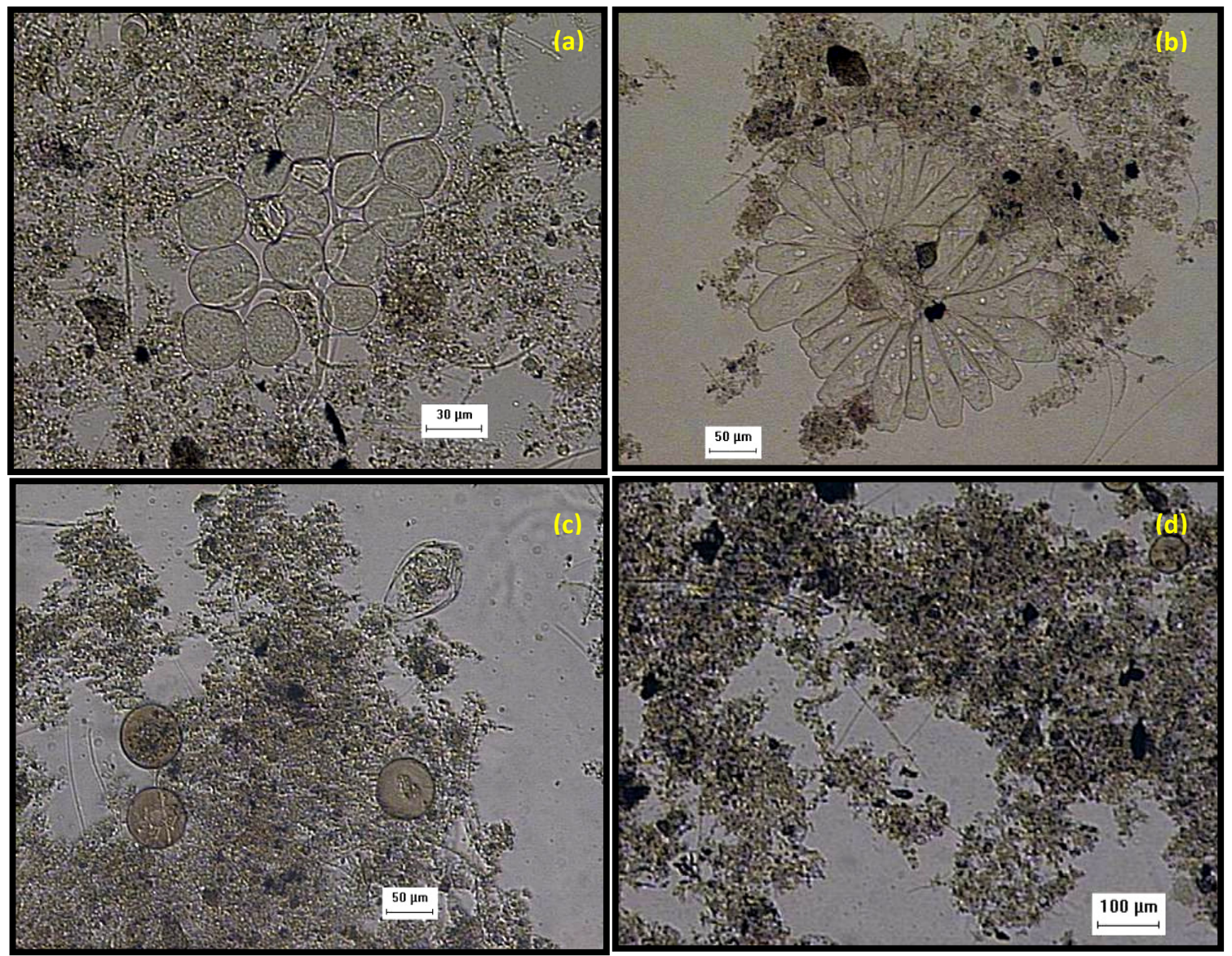

Figura 5.26 - Caracterização da composição da microfauna em R2E2 (0,2\% Experimento 2) do sistema de lodos ativados em escala de bancada. Colônias de ciliados fixos semelhantes à: (a) Vorticella sp. e (b) Epistylis sp.; (c) Rizópodes semelhantes a Arcella sp. e rotífero; (d) Estrutura geral do floco. Aumentos originais 200x, (a); 100x, (b) e (c); 50x, (d). 
Os flocos desenvolvidos em R3 (2\%) no Experimento 2 apresentaram-se em grande quantidade e tamanho médio, estrutura medianamente compacta e com frequência média de bactérias filamentosas (Figura 5.27d.).

Observou-se manutenção da diversidade microbiana na biomassa desenvolvida e pequeno aumento desta no reator R3 até o final da operação, em relação ao inóculo caracterizado.

Observou-se aumento da frequência de microrganismos provenientes do inóculo até o final da operação, em especial dos ciliados fixos semelhantes à Epistylis sp. e surgimento de Vorticella sp. Opercularia sp. (Figura $5.27^{\mathrm{a}}$ e b). Foi possível verificar o surgimento de alguns ciliados livres natantes, semelhantes à Aspidisca sp. e de alguns rizópodes semelhante à Arcella sp. (Figura 5.27c.). Quanto aos metazoários observou-se aumento na frequência de rotíferos (Figura 5.27c.).
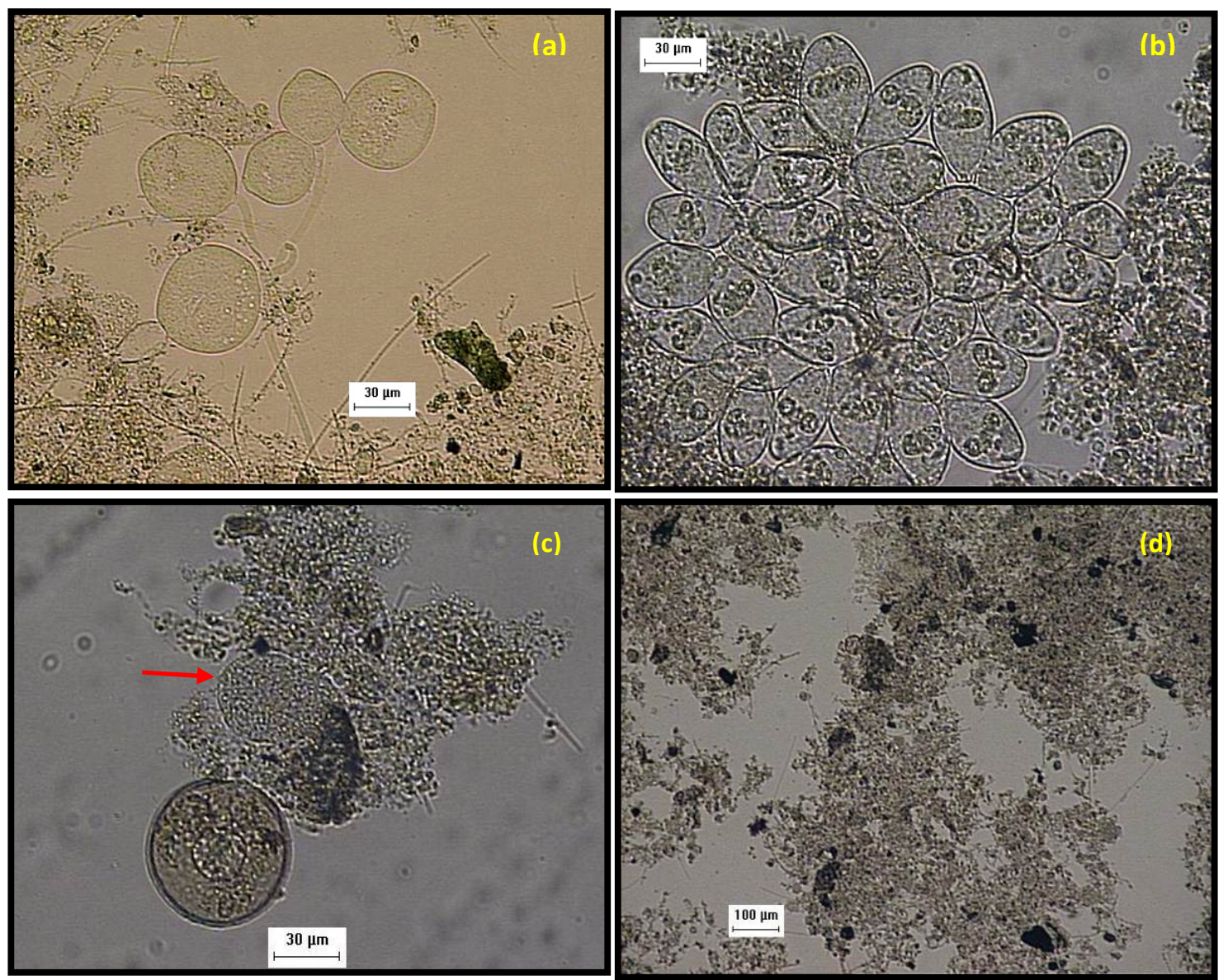

Figura 5.27 - Caracterização da composição da microfauna em R2E2 (0,2\% Experimento 2) do sistema de lodos ativados em escala de bancada. Colônias de ciliados fixos semelhantes à: (a) Vorticella sp. e (b) Opercularia sp.; (c) Rizópodes semelhantes a Arcella sp. e bactérias coloniais semelhantes à Zoogloea ramigera.; (d)

Estrutura geral do floco. Aumentos originais 200x, (a); 100x, (b) e (c); 50x, (d). 
Os flocos desenvolvidos em R4 (5\%) no Experimento 2 apresentaram-se em grande quantidade e tamanho, estrutura medianamente compacta e com frequência elevada de bactérias filamentosas (Figura 28d.).

Observou-se manutenção da diversidade microbiana na biomassa desenvolvida e pequeno aumento desta no reator R4 até o final da operação, em relação ao inóculo caracterizado.

Observou-se aumento da frequência de microrganismos provenientes do inóculo, em especial dos ciliados fixos semelhantes à Vorticella sp.. (Figura 28 $8^{\mathrm{a}}$ ). Foi possível verificar o surgimento de alguns ciliados livres natantes, semelhantes à Aspidisca sp. e alguns flagelados e de rizópodes semelhante à Arcella sp. (Figura 28b.). Quanto aos metazoários observou-se desenvolvimento de rotíferos, vermes e aumento da frequência de bactérias isoladas em suspensão e bactérias filamentosas (Figura 28c.).
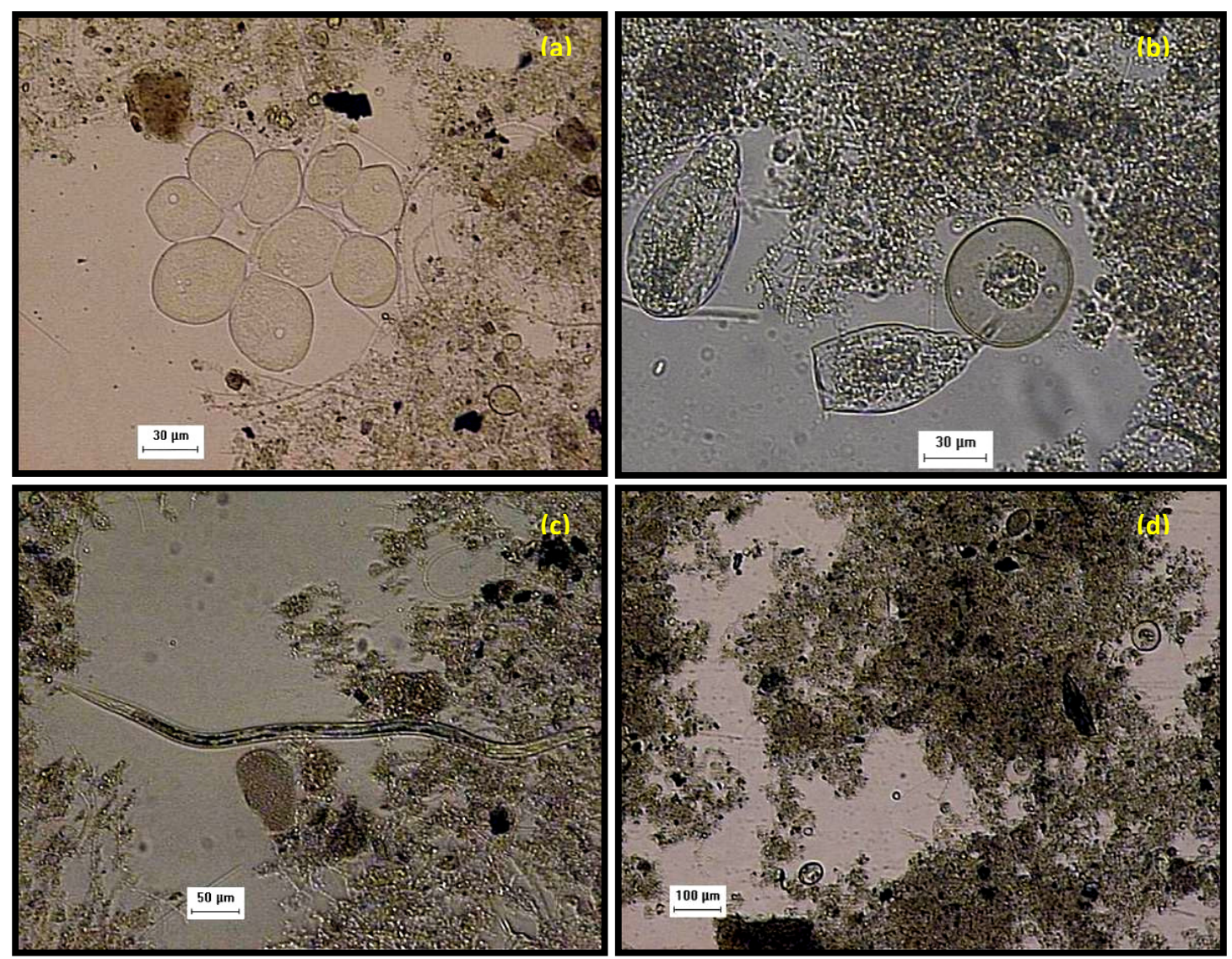

Figura 5.28 - Caracterização da composição da microfauna em R4E2 (5\% Experimento 2) do sistema de lodos ativados em escala de bancada. Colônias de ciliados fixos semelhantes à: (a) Vorticella sp.; (b) Metazoários rotíferos semelhantes à Epiphanes sp. e protozoário rizópode semelhante à Arcella sp.; (c) Nematóide; (d)

Estrutura geral do floco. Aumentos originais 200x, (a) e (b); 100x, (c); 50x, (d). 
Baseado nos resultados do monitoramento microbiológico dos reatores do Experimento 2, foi observado que não houve grandes diferenças entre os reatores. Observou-se grande diversidade morfológica de eucariotos em todos os reatores.

A frequência de protozoários ciliados fixos do gênero Vorticella sp., Epistylis sp. e rizópodes do gênero Arcella sp. se manteve elevada durante toda a operação nos reatores R1 (0\%), R2(0,2\%) e R3(2\%). No reator R4(5\%) a frequência foi se elevando gradativamente até o final dos 20 dias de operação.

Estudos de Chen et al. (2004), Zhou et al. (2008) e Signorile et al. (2010), mostraram elevada correlação desses gêneros com a estabilidade do lodo e alta eficiência de remoção de DBO e DQO. As maiores eficiências de remoção de DBO e de DQO obtidas neste experimento são compatíveis com a estabilidade biológica adquirida pelo sistema.

A associação da presença de protozoários ciliados fixos à ocorrência de nitrificação e à presença de íons nitrito e nitrato no meio, relatada por Curds (1982) e Gerardi (2002), foi verificada neste experimento. Houve ocorrência de nitrificação quase completa em todas as proporções de lixiviado, conforme discutido na seção 5.3.4.

Os protozoário ciliado livre do gênero Aspidisca sp. e de rotíferos, embora baixa e média frequência, desenvolveram-se em todos os reatores em estudo. Segundo Pinto (1998), o consórcio de Aspidisca sp e rotíferos também encontra-se associado a uma nitrificação completa, sendo sensíveis a amônia livre, confirmando a ocorrência de nitrificação praticamente completa em todas as proporções de lixiviado.

A frequência de bactérias filamentosas se manteve média na maior parte do experimento, elevando-se apenas na última semana no reator R4(5\%), mas permanecendo em níveis toleráveis.

A Tabela 5.27 apresenta a frequência de observação dos protozoários e micrometazoários nos reatores do Experimento 3, para o $1^{\circ}$ (inóculo após 7 dias de adaptação), $6^{\circ}, 13^{\circ}$ e $20^{\circ}$ dias. 
Tabela 5.27 - Frequência dos microrganismos observados no sistema de lodos ativados em escala de bancada ao longo do Experimento 3 .

\begin{tabular}{|c|c|c|c|c|c|c|c|c|c|c|c|c|c|c|}
\hline & \multirow{2}{*}{ EXPERIMENTO 3} & \multirow{2}{*}{ Inóculo } & \multicolumn{4}{|c|}{$6^{\circ}$ dia } & \multicolumn{4}{|c|}{$13^{\circ}$ dia } & \multicolumn{4}{|c|}{$20^{\circ}$ dia } \\
\hline & & & $\mathbf{R} 1$ & $\mathbf{R 2}$ & $\mathbf{R 3}$ & $\mathbf{R 4}$ & $\mathbf{R} 1$ & $\mathbf{R 2}$ & $\mathbf{R 3}$ & $\mathbf{R 4}$ & $\mathbf{R} 1$ & $\mathbf{R 2}$ & $\mathbf{R 3}$ & R4 \\
\hline \multirow{22}{*}{ 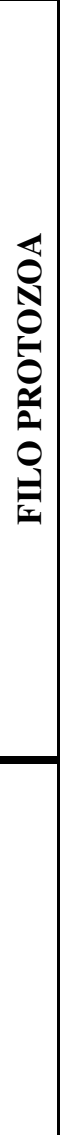 } & Classe Mastigophora (flagelados) & - & - & - & - & - & ++ & + & ++ & - & + & + & ++ & ++ \\
\hline & Classe Ciliata (ciliados livres) & + & - & - & - & - & - & - & - & - & - & - & - & - \\
\hline & Aspidisca sp. & - & - & - & - & - & - & - & - & - & - & - & - & - \\
\hline & Outros & + & - & - & - & - & - & - & - & - & - & - & - & - \\
\hline & Classe Ciliata (ciliados fixos) & ++ & + & + & ++ & + & +++ & ++ & + & ++ & +++ & ++ & ++ & + \\
\hline & Vorticella sp. & + & + & + & + & + & + & - & + & - & + & - & - & - \\
\hline & Epistylis sp. & + & - & - & + & - & + & ++ & - & ++ & ++ & ++ & + & + \\
\hline & Suctoria sp. & - & - & - & - & - & + & & + & - & - & - & - & - \\
\hline & Opercularia sp. & - & - & - & - & - & - & - & - & - & - & - & + & - \\
\hline & Outros & - & - & - & - & - & - & - & - & - & - & - & - & - \\
\hline & Classe Sarcodina (rizópodes) & ++ & +++ & +++ & ++ & ++ & ++ & ++ & ++ & ++ & ++ & ++ & ++ & +++ \\
\hline & Amoeba sp. & + & + & + & - & + & - & - & - & - & - & - & - & - \\
\hline & Euglyphasp. & + & +++ & ++ & + & + & ++ & + & + & ++ & ++ & ++ & ++ & +++ \\
\hline & Arcella sp. & - & - & - & + & - & - & + & + & - & + & + & - & - \\
\hline & Outros & + & - & - & - & - & - & - & - & - & & - & - & - \\
\hline & Filo Rotifera (rotíferos) & - & - & - & + & ++ & - & - & ++ & - & - & - & ++ & +++ \\
\hline & Filo Nematoda (vermes) & - & - & - & - & - & - & - & - & - & - & - & - & - \\
\hline & Filo Annelida & - & - & - & - & - & - & - & - & - & - & - & - & - \\
\hline & Bactérias isoladas em suspensão & + & - & - & - & ++ & ++ & + & +++ & + & + & - & ++ & + \\
\hline & Bactérias coloniais (Zoogloea) & + & - & - & - & - & - & - & - & + & - & - & + & - \\
\hline & Bactérias filamentosas & ++ & ++ & ++ & ++ & ++ & +++ & +++ & ++ & ++++ & +++ & +++ & +++ & ++++ \\
\hline & Fungos & - & - & - & - & - & - & - & - & - & - & + & + & - \\
\hline
\end{tabular}

Legenda: Ausentes - ; Frequência Baixa + ; Frequência Média ++ ; Frequência Elevada +++; Predominante ++++.

R1, R2, R3 e R4: Reatores com 0; 0,2; 2 e 5\% de lixiviado, respectivamente. 
Os flocos desenvolvidos em R1 (controle) no Experimento 3 apresentaram-se em quantidade e tamanho médios, estrutura pouco compacta e com frequência elevada de bactérias filamentosas (Figura 5.29c e d).

Observou-se manutenção da diversidade de microrganismos provenientes do inóculo até o final da operação, em especial dos ciliados fixos como Epistylis sp. e Vorticella sp. (Figura 5.29a). Foi possível verificar o surgimento de protozoários flagelados. Observou-se aumento de bactérias filamentosas (Figura 5.29c.).

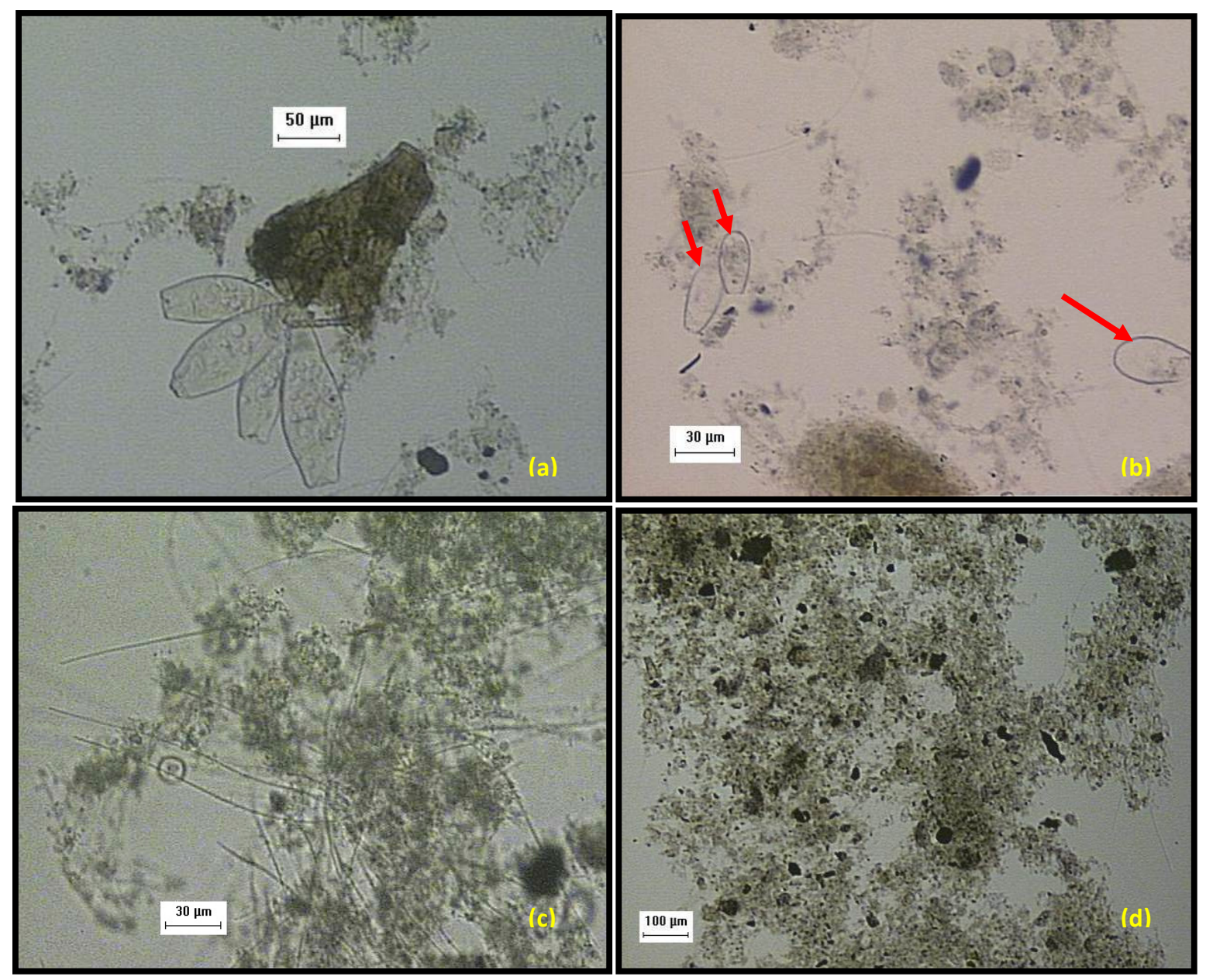

Figura 5.29 - Caracterização da composição da microfauna em R1E3 (controle Experimento 3) do sistema de lodos ativados em escala de bancada. Colônias de ciliados fixos semelhantes à: (a) Epistylis sp.; (b) Rizópodes semelhantes à Euglypha sp.; (c) Bactérias filamentosas (d) Estrutura geral do floco. Aumentos originais 100x, (a); 200x, (b) e (c); 50x, (d). 
Os flocos desenvolvidos em R2 (0,2\%) no Experimento 3 apresentaram-se em quantidade e tamanho médios, estrutura pouco compacta a dispersa e com frequência elevada de bactérias filamentosas (Figura 5.30d).

Observou-se manutenção da diversidade de microrganismos provenientes do inóculo até o final da operação, em especial dos ciliados fixos como Epistylis sp. (Figura 5.30b). Foi possível verificar o surgimento de alguns protozoários flagelados. Constatou-se o aumento de bactérias filamentosas, algumas semelhantes à Beggiatoa sp. (Figura $\left.5 \cdot 30^{\mathrm{a}}\right)$.

Como o sistema de lodos ativados era alimentado pelo efluente do RAC, compostos reduzidos de enxofre, resultantes da oxidação biológica desse elemento químico, certamente estavam presentes no afluente do reator aeróbio, favorecendo o desenvolvimento de bactérias filamentosas como Beggiatoa sp., fato que também foi identificado por Mendonça (2002).
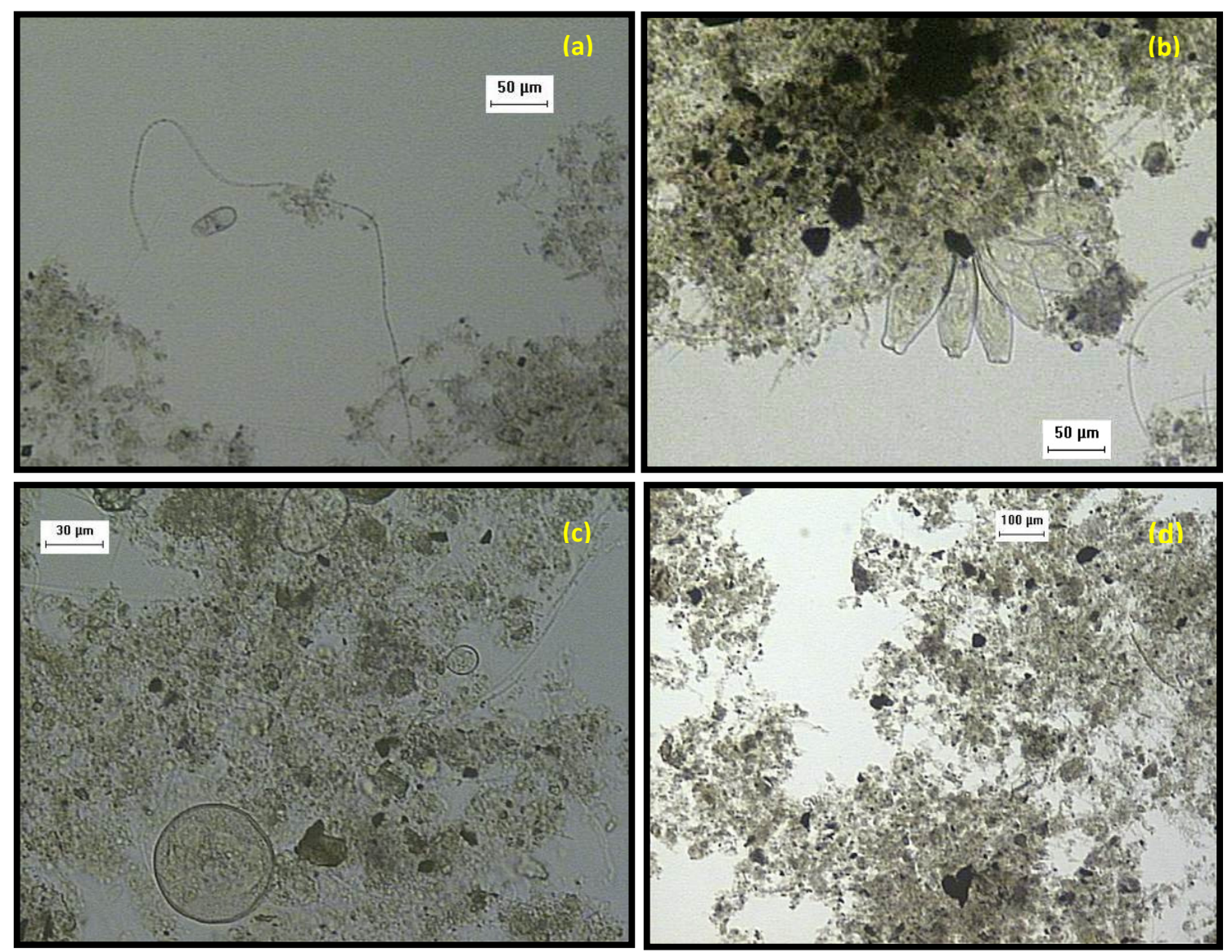

Figura 5.30 - Caracterização da composição da microfauna em R2E3 (controle Experimento 3) do sistema de lodos ativados em escala de bancada. (a) Bactérias filamentosas semelhantes à Beggiatoa sp.; (b) Colônias de ciliados fixos semelhantes à Epistylis sp.; (c) Rizópodes semelhantes à Arcella sp.; (d) Estrutura geral do floco. Aumentos originais 100x, (a) e (b); 200x, (c); 50x, (d). 
Os flocos desenvolvidos em R3 (2\%) no Experimento 3 apresentaram-se em quantidade e tamanho médios, estrutura pouco compacta a dispersa e com frequência elevada de bactérias filamentosas (Figura 5.31d).

Observou-se manutenção da diversidade de microrganismos provenientes do inóculo até o final da operação, em especial dos ciliados fixos como Epistylis sp. (Figura 5.31b). Foi possível verificar o surgimento de alguns protozoários flagelados. Quanto aos metazoários observou-se surgimento de alguns rotíferos e aumento de bactérias filamentosas. (Figura $5.31^{\mathrm{a}}$ ).
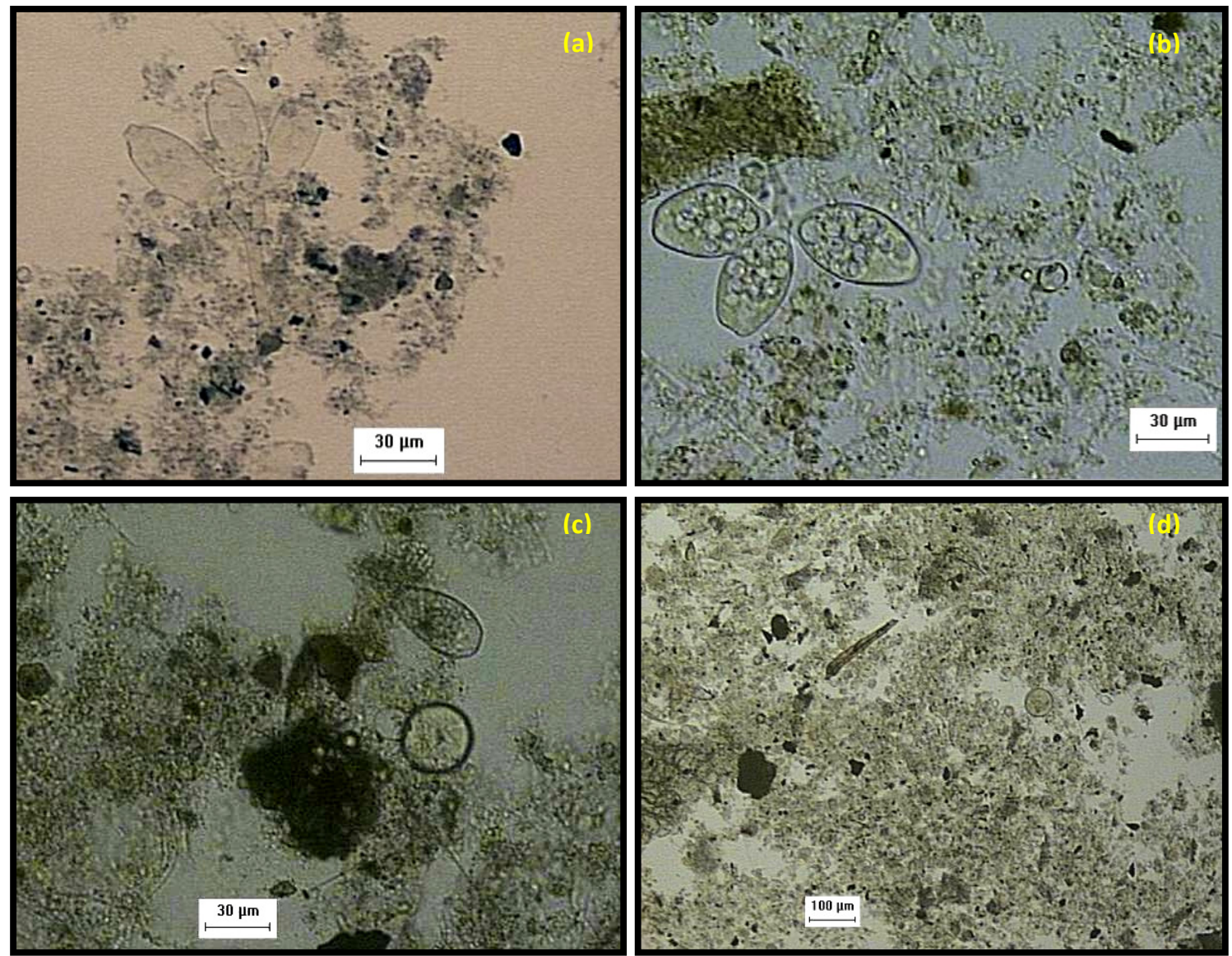

Figura 5.31 - Caracterização da composição da microfauna em R3E3 (controle Experimento 3) do sistema de lodos ativados em escala de bancada. (a) Colônias de ciliados fixos semelhantes à Epistylis sp. e (b) à Opercularia sp.; (c) Rizópodes semelhantes à Arcella sp. e Euglypha sp.; (d) Estrutura geral do floco. Aumentos originais 200x, (a), (b) e (c); 50x, (d). 
Os flocos desenvolvidos em R4 (5\%) no Experimento 3 apresentaram-se em quantidade e tamanho reduzidos, muito dispersa e com alta frequência de bactérias filamentosas (Figura 5.32 e d).

Apesar da ausência de flagelados, observou-se manutenção de alguns ciliados fixos semelhantes à Epistylis sp. (Figura 5.32b). Foi possível verificar o aumento da frequência de protozoários rizópodes semelhantes à Euglypha sp., de metazoários rotíferos e de bactérias filamentosas. (Figura $5.32^{\mathrm{a}}$ e c).

É importante salientar que, na última semana de monitoramento, houve predominância de rizópodes semelhantes à Euglypha sp. e de bactérias filamentosas.
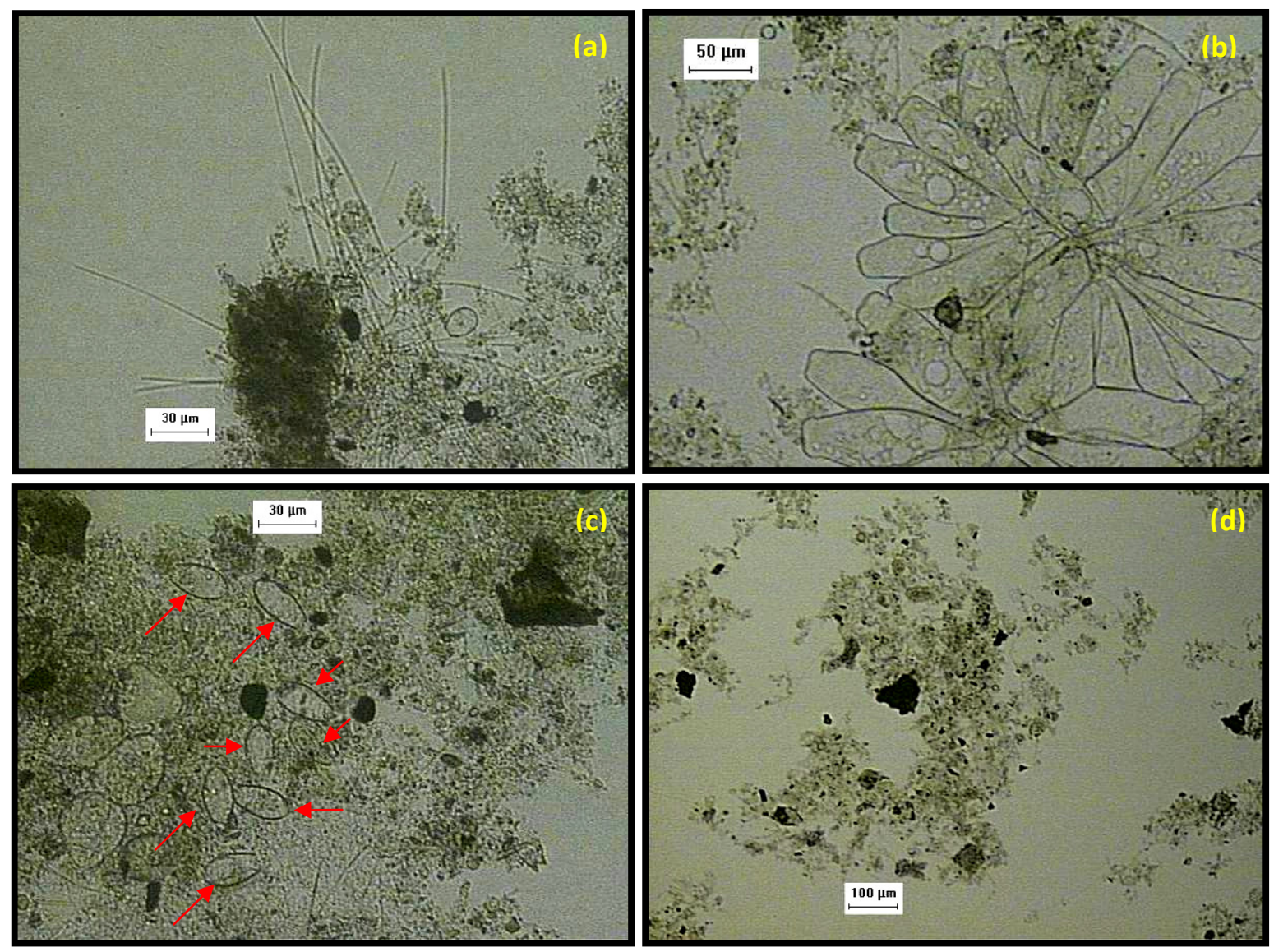

Figura 5.32 - Caracterização da composição da microfauna em R3E3 (controle Experimento 3) do sistema de lodos ativados em escala de bancada. (a) Bactérias filamentosas; (b) Colônias de ciliados fixos semelhantes à Epistylis sp.; (c) Rizópodes semelhantes à Euglypha sp.; (d) Estrutura geral do floco. Aumentos originais 200x, (a); 100x, (b); 200x, (c); 50x, (d). 
Baseado nos resultados do monitoramento microbiológico do Experimento 3, foi observado presença de protozoários ciliados fixos do gênero Epistylis sp. e rizópodes do gênero Euglypha sp. em todos os reatores.

Chen et al. (2004) e Gerardi (2002) observaram correlação positiva desses dois gêneros de protozoários com a eficiência de nitrificação. Essa correlação condiz com a eficiência de nitrificação obtida pelos reatores, conforme discutido na seção 5.3.4.

A frequência de protozoários ciliados fixos do gênero Epistylis sp. se manteve média durante toda a operação nos reatores R1 (0\%) e R2(0,2\%). Nos reatores R3(2\%) e $\mathrm{R} 4(5 \%)$ a frequência daquele gênero de ciliado fixo se manteve baixa, enquanto que a de rotíferos se manteve média a alta.

Estudos de Chen et al. (2004) mostraram associação negativa entre a presença elevada de rotíferos e ciliados flagelados e positiva de ciliados fixos do gênero Epistylis sp. com a eficiência de remoção de DBO e DQO. Assim, a presença de ciliados flagelados, a menor frequência desse ciliado fixo e maior frequência de rotíferos nos reatores $\mathrm{R} 3(2 \%)$ e $\mathrm{R} 4(5 \%)$ podem estar associados com as baixas eficiências de remoção de DBO e de DQO nessas proporções.

Neste experimento foi observado elevada frequência de bactérias filamentosas em todos os reatores, em especial no reator R4(5\%), o que explica os maiores valores de IVL obtidos nesse reator, variando de 95 a $121 \mathrm{~mL} / \mathrm{g}$, apesar de ainda permanecerem abaixo do limite $(150 \mathrm{~mL} / \mathrm{g})$ considerado ideal segundo alguns autores.

Segundo Jenkis (2003), a abundância de bactérias filamentosas está associada à deficiência nutricional, baixos níveis de oxigênio dissolvido e à presença de matéria orgânica recalcitrante ou tóxica. Assim, a baixa concentração de matéria orgânica do esgoto anaeróbio (DBO inferior a $100 \mathrm{mg} / \mathrm{L}$ ) pode ter contribuído para condições favoráveis ao desenvolvimento de bactérias filamentosas neste experimento, principalmente nas maiores proporções de lixiviado.

A Tabela 5.28 apresenta a frequência de observação dos protozoários e micrometazoários nos reatores do Experimento 4, para o $1^{\circ}$ (inóculo após 7 dias de adaptação), $6^{\circ}, 13^{\circ}$ e $20^{\circ}$ dias. 
Tabela 5.28 - Frequência dos microrganismos observados no sistema de lodos ativados em escala de bancada ao longo do Experimento 4.

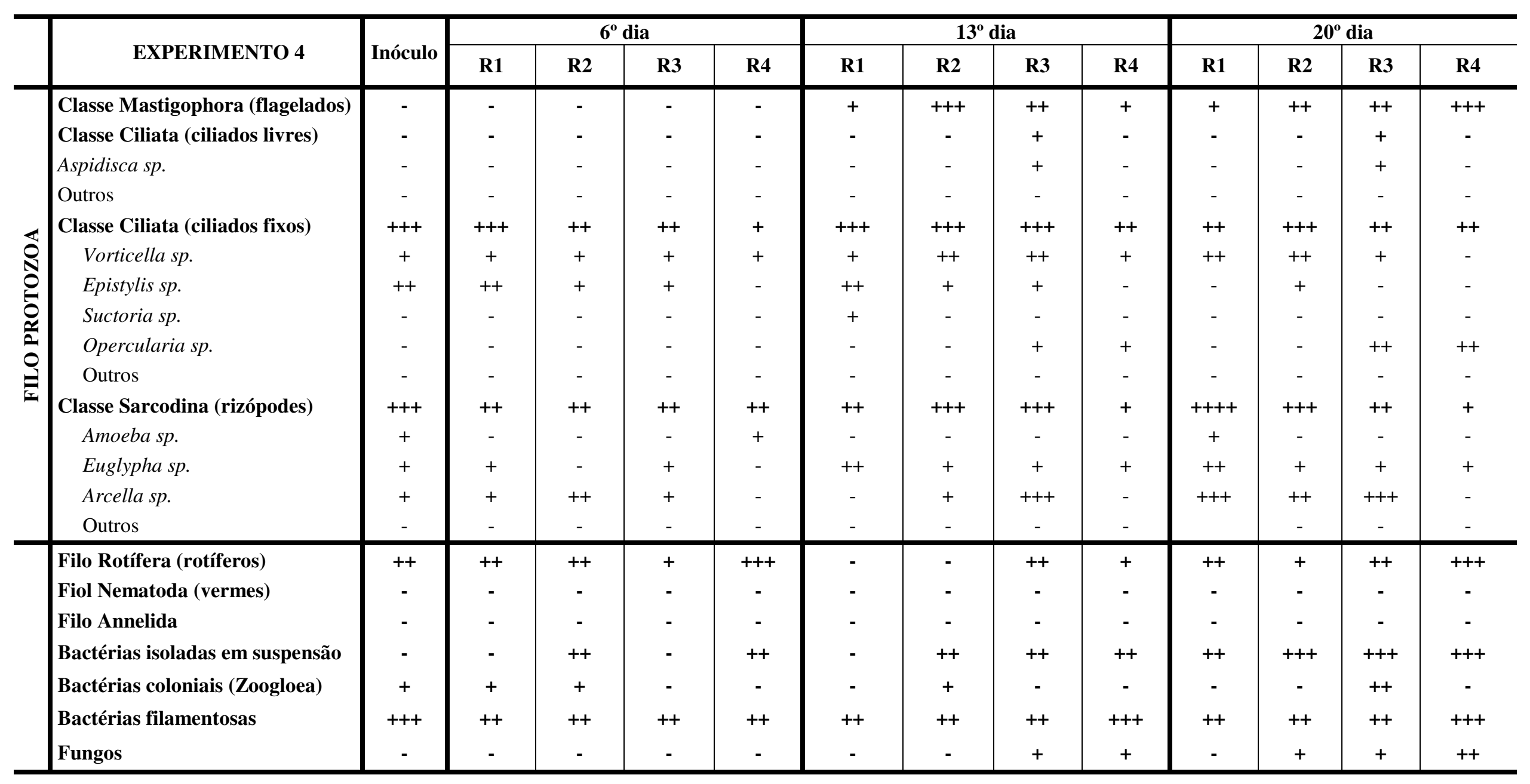

Legenda: Ausentes - ; Frequência Baixa + ; Frequência Média ++ ; Frequência Elevada +++; Predominante ++++.

R1, R2, R3 e R4: Reatores com 0; 0,2; 2 e 5\% de lixiviado, respectivamente. 
Os flocos desenvolvidos em R1 (controle) no Experimento 4 apresentaram-se em quantidade e tamanho médios, pouco compacta a dispersa e com frequência média de bactérias filamentosas (Figura 5.33d).

Observou-se manutenção da diversidade de microrganismos até o final da operação, especialmente protozoários ciliados fixos semelhantes à Epistylis sp. e Vorticella sp. (Figura $5.33^{\mathrm{a}}$ e b) e metazoários rotíferos (Figura $5.33^{\mathrm{a}}$ e c.). Foi possível verificar o aumento da frequência de protozoários rizópodes semelhantes à Euglypha sp e Arcella sp.. (Figura 5.33c).
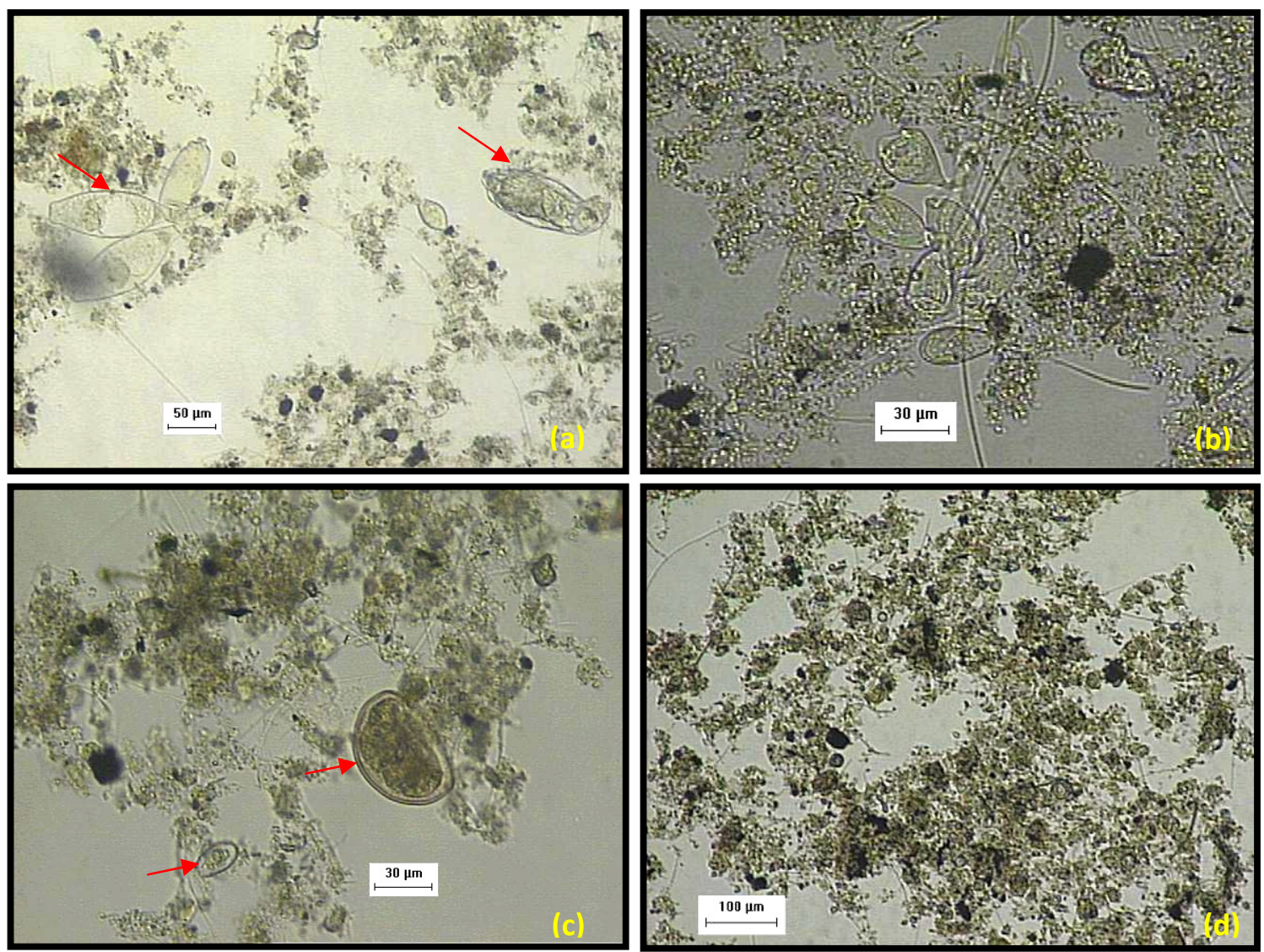

Figura 5.33 - Caracterização da composição da microfauna em R1E4 (controle Experimento 4) do sistema de lodos ativados em escala de bancada. (a) e (b) Colônias de ciliados fixos semelhantes à Epistylis sp. e Vorticella sp.; (c) Rizópodes semelhantes à Euglypha sp. e à Arcella sp.; (d) Estrutura geral do floco. Aumentos originais 100x, (a); 200x, (b) e (c); 50x, (d). 
Os flocos desenvolvidos em R2 (0,2\%) no Experimento 4 apresentaram-se em grande quantidade e tamanho médios, estrutura pouco compacta a dispersa e com frequência média de bactérias filamentosas (Figura 5.34d.).

Observou-se aumento da frequência de microrganismos provenientes do inóculo até o final da operação, em especial dos ciliados fixos semelhantes à Vorticella sp. (Figura $5.34^{\mathrm{a}} \mathrm{e}$ b). Foi possível verificar o surgimento de alguns protozoários flagelados. Foi possível verificar também o aumento significativo da frequência do aparecimento de grande quantidade de protozoários flagelados (Figura 5.34c.).
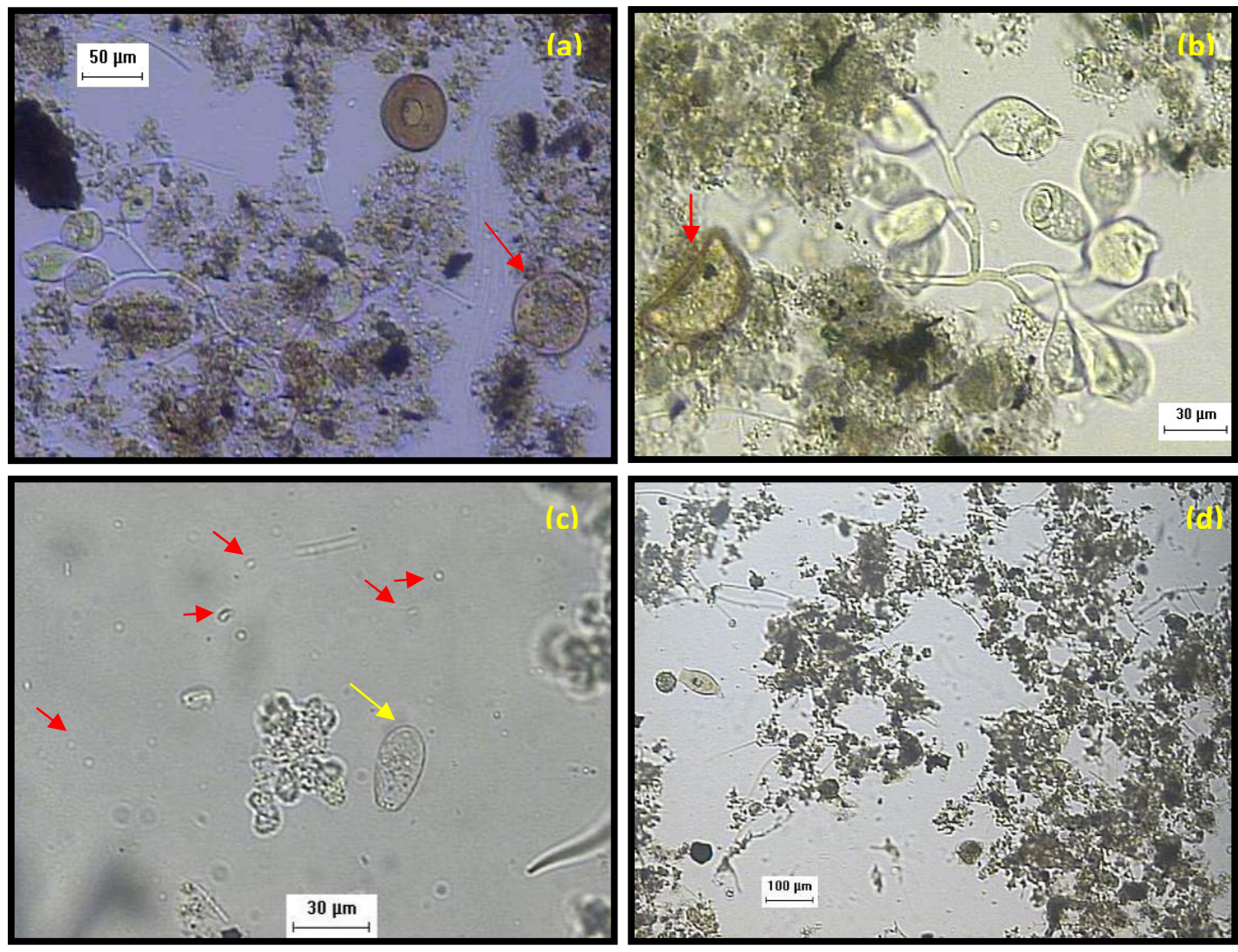

Figura 5.34 - Caracterização da composição da microfauna em R2E4 (controle Experimento 4) do sistema de lodos ativados em escala de bancada. (a) e (b) Colônias de ciliados fixos semelhantes à Vorticella sp.; (a), (b) e (c) Rizópodes semelhantes à Arcella sp. e à Euglypha sp.; (d) Estrutura geral do floco. Aumentos originais 100x, (a); 200x, (b) e (c); 50x, (d). 
Os flocos desenvolvidos em R3 (2\%) no Experimento 4 apresentaram-se em quantidade e tamanho médios, estrutura pouco compacta a dispersa e com frequência média de bactérias filamentosas (Figura 5.35d.).

Observou-se leve redução da diversidade de microrganismos provenientes do inóculo até o final da operação, em especial dos ciliados fixos semelhantes à Vorticella sp. Foi possível verificar o surgimento de alguns protozoários flagelados e ciliados fixos semelhantes à Opercularia sp. (Figura 5.35 ). Foi possível verificar também o aumento significativo da frequência do aparecimento de rizópodes semelhantes à Arcella sp. (Figura $5.35^{\mathrm{a}}$ e b) e de bactérias em suspensão.
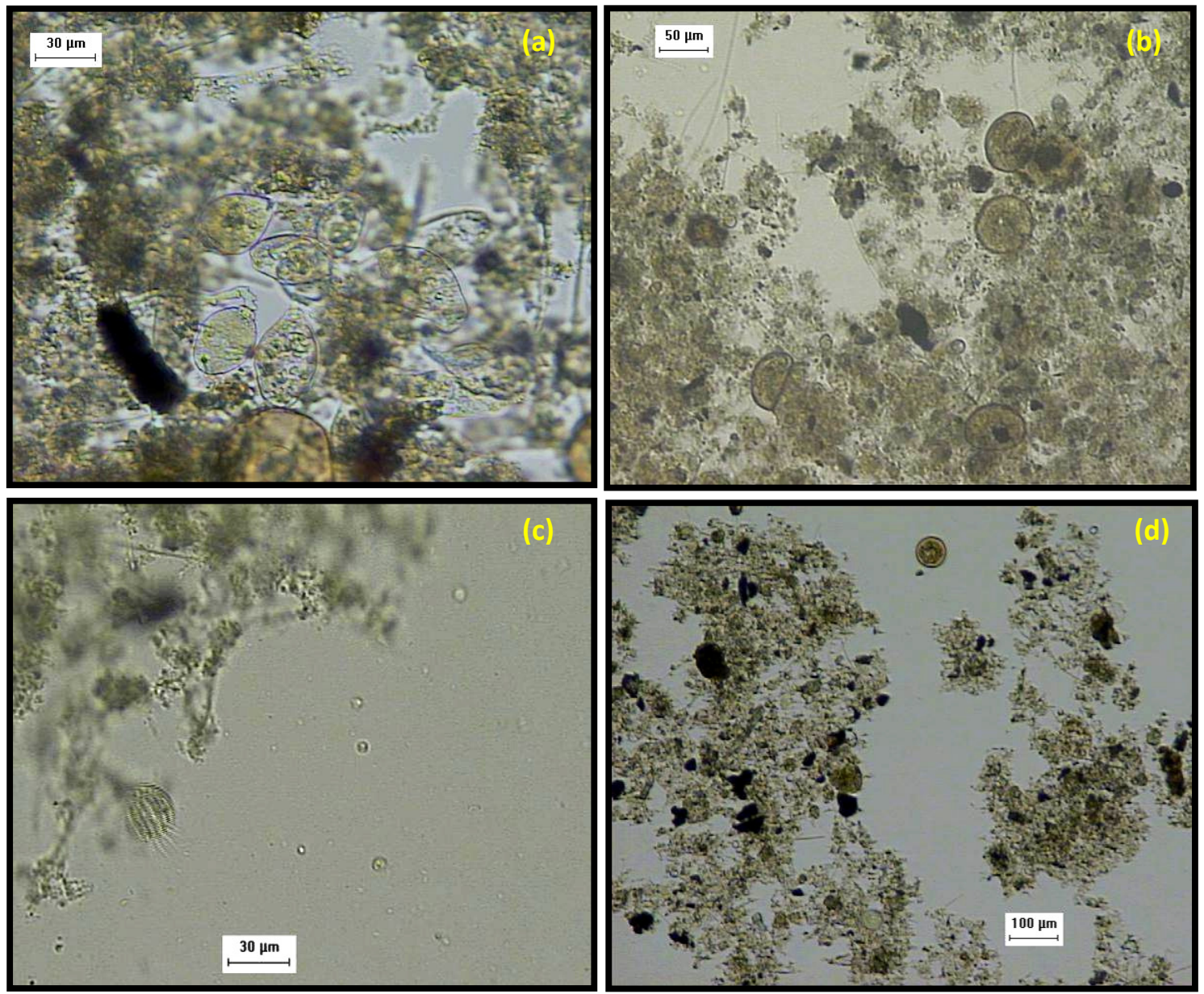

Figura 5.35 - Caracterização da composição da microfauna em R3E4 (controle Experimento 4) do sistema de lodos ativados em escala de bancada. (a) Colônias de ciliados fixos semelhantes à Vorticella sp.; Rizópodes semelhantes à: (a), (b) Arcella sp. e (c) Euglypha sp.; (d) Estrutura geral do floco. Aumentos originais 100x, (a), (b) e (c); 50x, (d). 
Os flocos desenvolvidos em R4 (5\%) no Experimento 4 apresentaram-se em quantidade e tamanho reduzidos, estrutura dispersa e com frequência elevada de bactérias filamentosas (Figura 5.36d.).

Observou-se diminuição da diversidade de microrganismos provenientes do inóculo até o final da operação, extinção dos rizópodes semelhantes à Arcella sp. Foi possível verificar o surgimento de quantidade considerável de ciliados fixos semelhantes à Opercularia sp. e de flagelados (Figura $5.36^{\mathrm{a}}$ e b), extinção dos ciliados fixos semelhantes a Vorticella sp. e Epystilis sp. Verificou-se aumento da frequência de bactérias em suspensão e de bactérias filamentosas e o aparecimento de metazoários rotíferos (Figuras 5.36c e d).
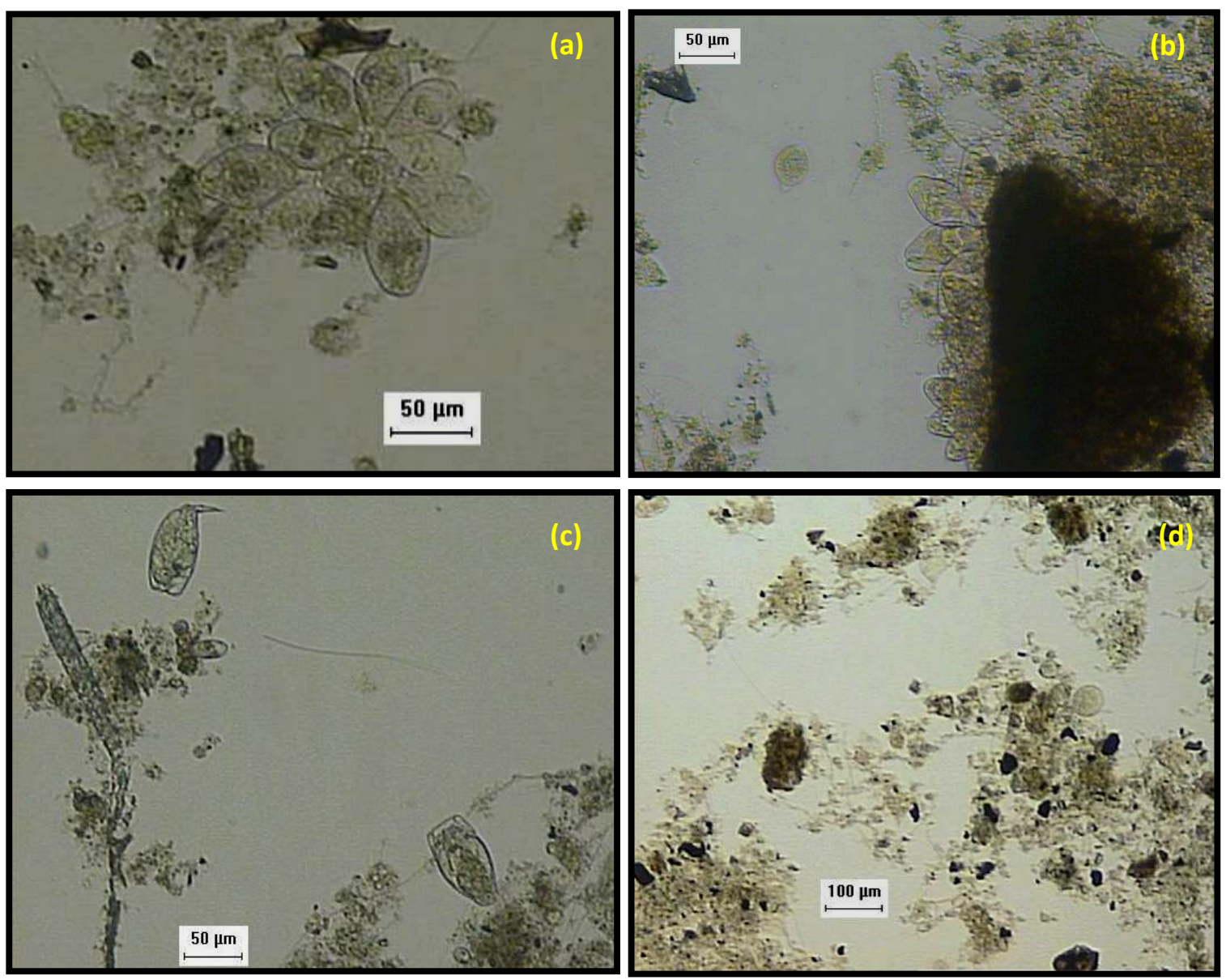

Figura 5.36 - Caracterização da composição da microfauna em R4E4 (controle Experimento 4) do sistema de lodos ativados em escala de bancada. (a) e (b) Colônias de ciliados fixos semelhantes à Opercularia sp.; (c) Rizópodes rotíferos semelhantes à Epiphanes sp. ; (d) Estrutura geral do floco. Aumentos originais 100x, (a), (b) e (c); $50 x,(d)$. 
Conforme apresentado nos resultados do monitoramento microbiológico do Experimento 4, de forma geral, nos reatores foi observado presença de protozoários ciliados fixos do gênero Vorticella sp. e Opercularia sp. e rizópodes do gênero Arcella sp. e Euglypha sp., presença de flagelados, rotíferos e elevada frequência de bactérias em suspensão.

Observou-se substituição gradativa dos protozoários ciliados fixos dos gêneros Vorticella sp. e Epistylis sp. pelos microrganismos semelhantes à Opercularia sp. nos reatores $\mathrm{R} 3(2 \%)$ e R4(5\%), de modo que ao final da operação, aqueles gêneros eram quase ausentes e o gênero Opercularia sp se mostrou em elevada frequência.

Salvadó et al.(1995); Chen et al. (2004) e Zhou et al. (2008) observaram relação da abundância de protozoários ciliados fixos do gêneros Opercularia sp. com baixa eficiência de remoção de DBO e SS e associação negativa entre a presença de rotíferos e ciliados flagelados com a eficiência de remoção de DBO e DQO. Os resultados físicoquímicos também indicaram baixa eficiência do sistema nos reatores R3(2\%) e R4(5\%), especialmente no último, onde a eficiência de remoção de DBO foi inferior a 5\%, no qual teve abundância de Opercularia sp., frequência elevada de flagelados e rotíferos.

Verificou-se também a diminuição da frequência de rizópodes (amebas) do gênero Arcella sp. e Euglypha sp. à medida que se aumentava a proporção de lixiviado. No reator R4(5\%) esses microrganismos eram quase ausentes.

As amebas são conhecidas pela sensibilidade à amônia, indicando ocorrência de nitrificação no tanque (Madoni et al.,1993; Madoni, 2011). Os resultados de conversão de nitrogênio também indicaram menor eficiência de nitrificação e acúmulo de nitrito nas proporções de 2 e $5 \%$, o que pode indicar toxicidade da amônia remanescente proveniente do lixiviado bruto.

Segundo Pinto (1998) e Cutolo e Rocha (2000) e Bento et al. (2005), o aumento gradativo do número de flagelados está associado à um período de transição, recuperação do sistema após choque de carga orgânica (tóxica ou não) e pode estar vinculado à produção de grande número de bactérias em suspensão. Tal configuração pode ser indício de choque de carga orgânica (tóxica ou não) e possível início de desfloculamento do lodo.

Verificou-se que no reator R4 (5\%) elevada frequência de ciliados flagelados com bactérias em suspensão, conforme observado por esses autores. Os flocos em número e tamanho reduzidos e estrutura dispersa, além das baixas eficiências de remoção de DQO, DBO e nitrogênio podem indicam provável toxicidade do lixiviado 
bruto à microbiota do sistema, devido principalmente à elevada concentração de amônia, salinidade e outros compostos presentes no lixiviado, os quais podem inibir parcialmente a atividade microbiana e causar alterações na estrutura dos flocos do lodo ativado, conforme mostrado por Wilén et. al. (2003) e Wei et al. (2009).

No experimento 1, a microbiota se manteve diversificada e equilibrada até $2 \%$ de lixiviado. A proporção de 5\% de lixiviado provocou uma diminuição significativa da diversidade, especialmente de protozoários ciliados fixos e elevando bruscamente a presença de bactérias filamentosas, ocasionando redução da eficiência de tratamento do sistema. Verificou-se, no entanto, que a proporção de $2 \%$ já reduziu significativamente a frequência de amebas.

No experimento 2, a diversidade microbiana sofreu menor efeito pela adição de lixiviado em relação ao Experimento 1, permanecendo elevada em todas as proporção de lixiviado. É importante salientar que a proporção de 5\% promoveu uma estabilização defasada em relação às demais, corroborando com a menor eficiência de remoção de DQO e DBO neste experimento. Os microrganismos indicadores de nitrificação se mantiveram em elevada frequência durante todo o experimento, condizendo com os resultados físico-químicos, indicando nitrificação em todas as proporções.

No experimento 3, a microbiota se manteve equilibrada até a proporção de $0,2 \%$. A partir de $2 \%$ já houve redução significativa na frequência de alguns microrganismos indicadores de eficiência de remoção de DBO e DQO. Os microrganismos indicadores de nitrificação se mantiveram em média frequência em todas as proporções de lixiviado, já que houve nitrificação em todos os reatores deste experimento. É importante salientar que em todas as proporções deste experimento foi observada a elevada frequência de bactérias filamentosas, possivelmente pela menor concentração de matéria orgânica e nutrientes presentes no esgoto anaeróbio, em comparação ao esgoto bruto utilizado nos Experimentos 1 e 2.

No Experimento 4, observou-se distinção da diversidade microbiana à partir da adição de $2 \%$ de lixiviado. Houve alteração de alguns microrganismos na proporção de $5 \%$, indicando baixa eficiência de remoção de matéria orgânica. Houve também diminuição na frequência de indicadores de nitrificação à medida que se aumentava a proporção de lixiviado, sendo quase ausentes na proporção de 5\%, já que nessa proporção houve menor nitrificação e maior amônia remanescente. 


\subsection{Resultados das análises físico-químicas do experimento de tratabilidade em escala piloto}

\subsubsection{Considerações iniciais sobre o experimento}

A tratabilidade do lixiviado de aterro sanitário e esgoto sanitário foi estudada conforme descrito em Material e métodos. Após estudo da tratabilidade em escala de bancada (regime de batelada), foi realizado um experimento em escala piloto (regime contínuo), reproduzindo as melhores condições obtidas nos experimentos de bancada, observada a máxima concentração de lixiviado na mistura.

A melhor condição foi escolhida em função dos menores efeitos advindos da adição de lixiviado ao sistema de tratamento combinado, baseado no monitoramento físico-químico e microbiológico dos experimentos de tratabilidade em escala de bancada. Dessa forma, foi reproduzida a condição do Experimento 2 (esgoto sanitário e lixiviado pré-tratado), com $2 \%$ de lixiviado. O experimento possuía duas linhas de tratamento, chamadas P1 (2\%) e P2 (0\% - controle).

O objetivo deste experimento foi avaliar as possíveis interferências da adição do lixiviado pré-tratado sobre a biomassa desenvolvida e acompanhar a remoção da matéria orgânica e nitrogênio presente na mistura de lixiviado e no esgoto bruto.

Os resultados de todos os experimentos serão discutidos avaliando-se principalmente os parâmetros indicativos de remoção de matéria orgânica (DQO bruta e solúvel e COD) e a série de nitrogênio (NTK, NTK solúvel, NAT, nitrito e nitrato) que foram utilizados como indicadores principais na avaliação do tratamento combinado de esgoto sanitário e lixiviado de aterro sanitário. Além desses parâmetros, foi examinada a composição da diversidade microbiana, em termos da frequência de protozoários e micrometazoários, as características da estrutura dos flocos, atividade biológica e concentração de metais no lodo aeróbio. Os demais dados encontram-se em tabelados no Apêndice B.

Antes do início definitivo da operação, o inóculo foi adaptado por um período de aproximadamente 30 dias. Nesse período de adaptação houve monitoramento apenas da DQO, SS no tanque de aeração, IVL e microscopia. Após esse período de adaptação os reatores foram operados paralelamente por 65 dias, período este em que houve o monitoramento de todos os parâmetros. 
O pH no tanque de aeração foi mantido na faixa de 6,5 a 8,5 nos dois reatores. Não houve necessidade de adição de base para correção do pH no reator P1(2\%), uma vez que o lixiviado pré-tratado já era alcalinizado e ao final dos experimentos de remoção por air stripping possuía $\mathrm{pH}$ em torno de 9. No reator P2(controle) houve necessidade de correção frequente com adição de hidróxido de cálcio.

No Apêndice B2 encontram-se os valores de pH lidos antes da correção. $\mathrm{O}$ pH foi corrigido com solução de $\mathrm{HCl}$ (ácido clorídrico), $\mathrm{Ca}(\mathrm{OH})_{2}$ (hidróxido de cálcio) ou $\mathrm{Ca}\left(\mathrm{HCO}_{3}\right)_{2}$ (bicarbonato de cálcio).

As condições operacionais e alguns resultados obtidos nos reatores do Experimento em escala piloto estão apresentados na Tabela 5.29.

Tabela 5.29 - Condições operacionais e resultados do experimento com reatores de lodos ativados em escala piloto tratando esgoto com $2 \%(\mathrm{P} 1)$ e $0 \%$ (P2-controle) de lixiviado pré-tratado.

\begin{tabular}{cccc}
\hline Parâmetros* & Unidades & $\begin{array}{c}\text { P1 } \\
(\mathbf{2 \%})\end{array}$ & $\begin{array}{c}\text { P2 } \\
(\mathbf{0 \%} \text {-controle })\end{array}$ \\
\hline TDH & (h) & 24 \\
Idade do lodo & $($ dias $)$ & \multicolumn{2}{c}{20} \\
Vazão & (L/dia) & \multicolumn{2}{c}{101} \\
& kg DBO/kgSSV.d & 0,22 & 0,22 \\
A/M & kg DQO/kgSSV.d** & 0,20 & 0,18 \\
IVL & mL/g & 105 & 152 \\
Remoção de DQO & $(\%)$ & 86 & 92 \\
Remoção de DBO & $(\%)$ & 93 & 94 \\
Remoção de COD & $(\%)$ & 58 & 70 \\
\hline
\end{tabular}

TDH: Tempo de detenção hidráulica; * Valores médios; **Valores obtidos em termos da DQO solúvel

Nos Apêndices B1 a B7, nas quais estão apresentados todos os resultados obtidos durante a realização dos experimentos. 


\subsubsection{Demanda Química de Oxigênio-DQO}

Os valores das concentrações da DQO bruta nos reatores do experimento piloto estão apresentados nas Figuras 5.37 e 5.38 que contém os gráficos do comportamento da DQO bruta ao longo da operação. Todos os resultados das análises da DQO encontram-se no Apêndice B3.

Os valores da concentração afluente, efluente e as eficiências médias de remoção da DQO bruta no reator com esgoto sanitário e $2 \%$ de lixiviado pré-tratado (P1)estão apresentados no gráfico da Figura 5.37.

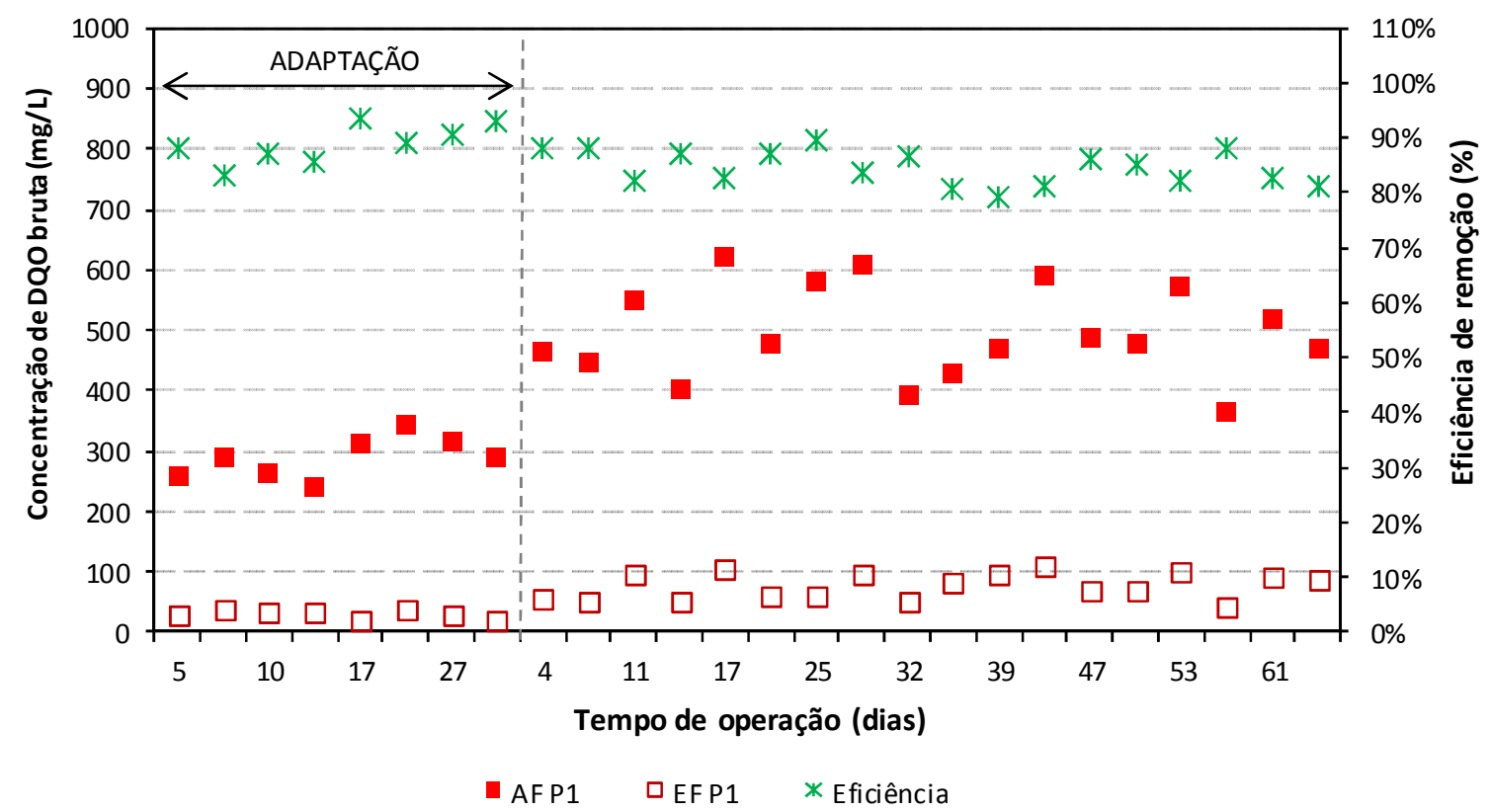

Figura 5.37 - Comportamento dos valores da DQO bruta no afluente e efluente e eficiência média de remoção no reator tratando esgoto sanitário com $2 \%$ de lixiviado pré-tratado (P1) do experimento em escala piloto.

O primeiro trecho do gráfico assinalado consiste no período de adaptação do reator, durante o qual foi alimentado apenas com esgoto bruto. Após esse período o reator foi alimentado com mistura de esgoto e lixiviado pré-tratado na proporção volumétrica de $2 \%$.

Pode-se observar a redução da eficiência de remoção da DQO bruta após adição de lixiviado. Conforme apresentado no gráfico, houve certa variabilidade no 
comportamento das concentrações da DQO afluente, sendo estatisticamente uma série de média dispersão (C.V.=16\%).

A concentração da DQO bruta afluente (esgoto mais lixiviado) no reator com esgoto sanitário e 2\% de lixiviado pré-tratado (P1) variou entre 365 e $609 \mathrm{mg} / \mathrm{L}$. A concentração da DQO bruta efluente variou entre 43 a $110 \mathrm{mg} / \mathrm{L}$, com média de 77 $\mathrm{mg} / \mathrm{L}$, valor superior à DQO efluente média obtida na mesma condição em escala de bancada, que foi em torno de $59 \mathrm{mg} / \mathrm{L}$.

Os valores da concentração afluente, efluente e as eficiências médias de remoção da DQO bruta no reator com $0 \%$ de lixiviado (P2-controle) estão apresentados no gráfico da Figura 5.38.

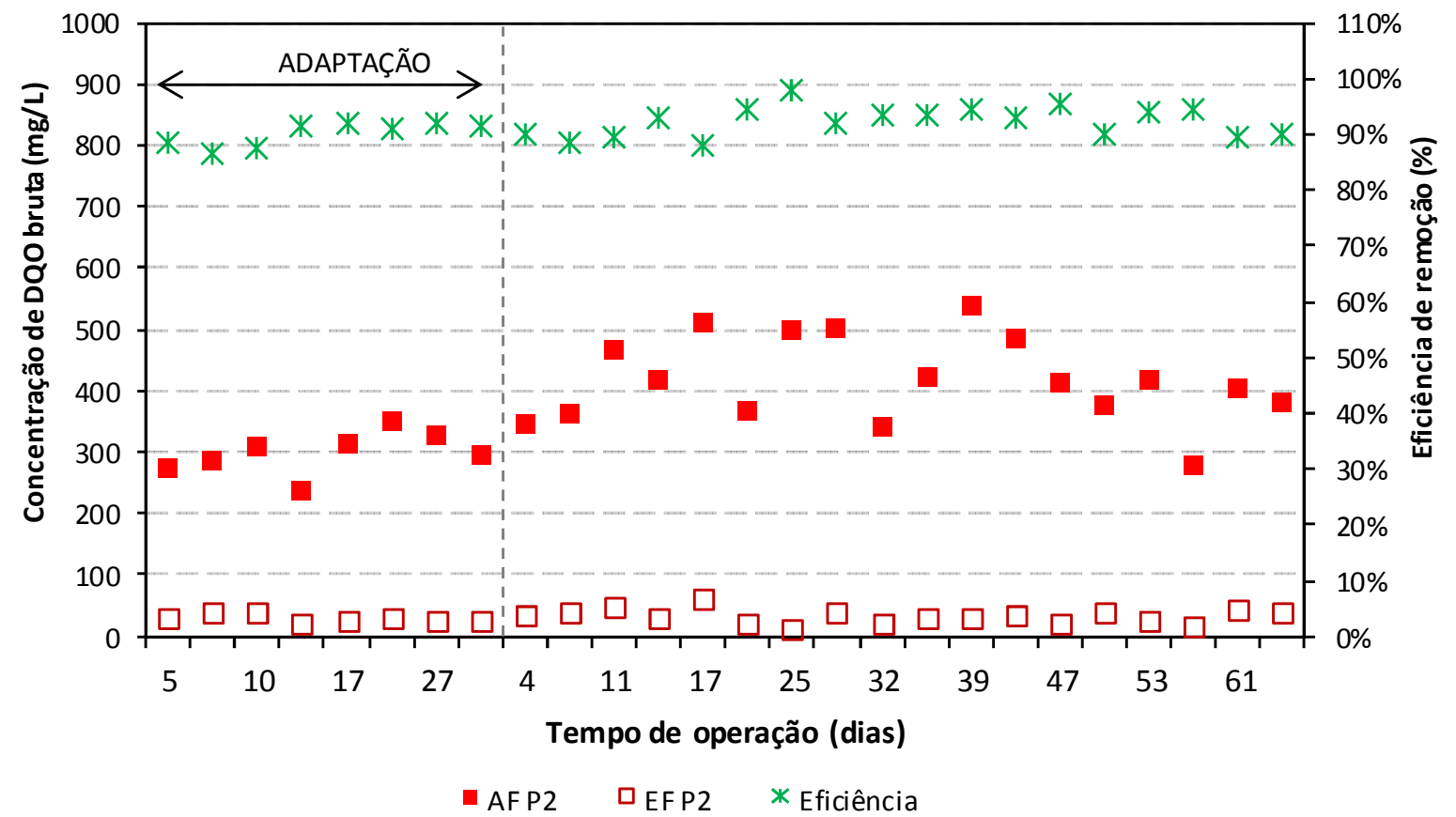

Figura 5.38 - Comportamento dos valores da DQO bruta no afluente e efluente e eficiência média de remoção no reator tratando esgoto sanitário com $0 \%$ de lixiviado pré-tratado (P2-controle) do experimento em escala piloto.

Conforme observado no gráfico da Figura 5.38, a concentração da DQO bruta afluente (esgoto sanitário) no reator com $0 \%$ de lixiviado (P2-controle) variou entre 280 e $540 \mathrm{mg} / \mathrm{L}$, enquanto a concentração da DQO bruta efluente variou entre 13 a $61 \mathrm{mg} / \mathrm{L}$, com média de $32 \mathrm{mg} / \mathrm{L}$. 
A série dos dados da DQO bruta afluente do reator P2(0\%) também apresentou certa dispersão em relação à media, sendo estatisticamente uma série de média dispersão (C.V.=17\%).

A concentração da DQO efluente média obtida no reator com $0 \%$ de lixiviado (P2-controle) também foi superior à média obtida nos reatores controle em escala de bancada, em torno de $24 \mathrm{mg} / \mathrm{L}$.

As diferenças das concentrações da DQO bruta efluente obtidas no experimento piloto em relação aos de bancada se deve, além das características geométricas do reator, hidrodinâmica e das condições operacionais, à diferença da composição tanto do lixiviado quanto do esgoto, conforme apresentado e discutido na seção 5.1..

A variação nos valores da DQO afluente dos reatores pilotos é coerente com um sistema que operou com efluente real, transferido diretamente do poço de sucção, sendo a variabilidade temporal das características do esgoto inerente ao sistema.

A Figura 5.39 apresenta o gráfico boxplot das eficiências de remoção da DQO bruta obtidas pelos reatores P1 e P2 no experimento em escala piloto.

Conforme observado no gráfico, a eficiência de remoção da DQO bruta no reator com esgoto sanitário e $2 \%$ de lixiviado pré-tratado (P1) variou de 79 a 89\%, média em torno de $85 \%$. A série apresentou C.V. em torno de $11 \%$, sendo estatisticamente estável e de baixa dispersão.

A eficiência de remoção da DQO bruta no reator P2(controle) variou de 88 a 97\%, média em torno de 92\%. A série apresentou menor C.V., em torno de 7\%, sendo estável e homogênea.

Os resultados do comportamento das eficiências de remoção da DQO bruta indicam que a adição de $2 \%$ lixiviado acarretou uma redução de $8 \%$ da eficiência do sistema.

Os valores da concentração da DQO solúvel (filtrada em membrana de diâmetro médio de poro de $1,2 \mu \mathrm{m})$ nos reatores do experimento piloto são apresentados na Figura 5.40 e 5.41. Todos os resultados das análises DQO encontram-se no Apêndice B3. 


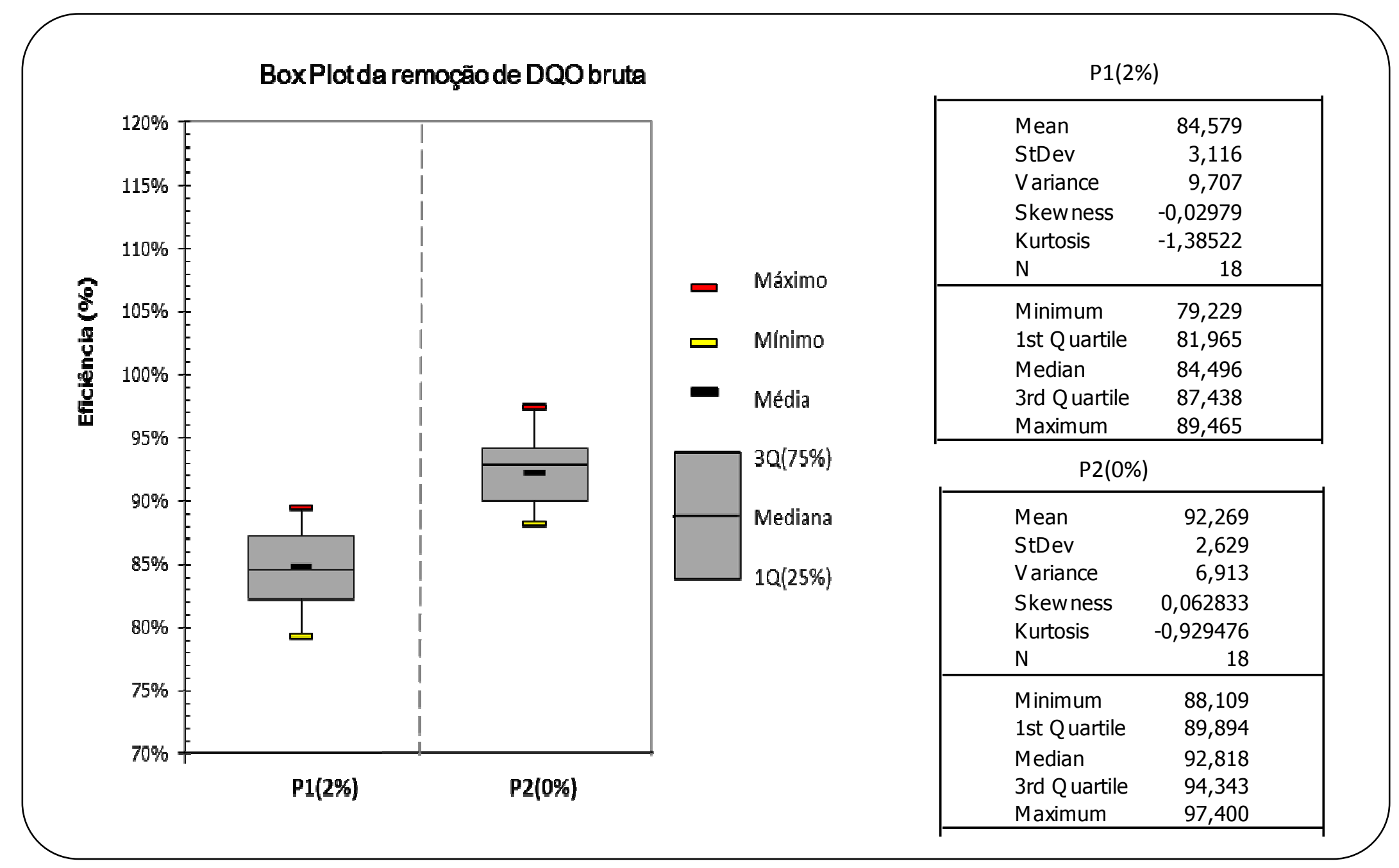

Figura 5.39 - Gráfico Boxplot das eficiências de remoção da DQO bruta e medidas estatísticas dos reatores de lodos ativados tratando esgoto sanitário com 2\% (P1) e 0\% (P2-controle) de lixiviado pré-tratado do experimento em escala piloto. 
Os valores da concentração afluente, efluente e as eficiências médias de remoção da DQO solúvel no reator com esgoto sanitário e $2 \%$ de lixiviado pré-tratado (P1) estão apresentados no gráfico da Figura 5.40.

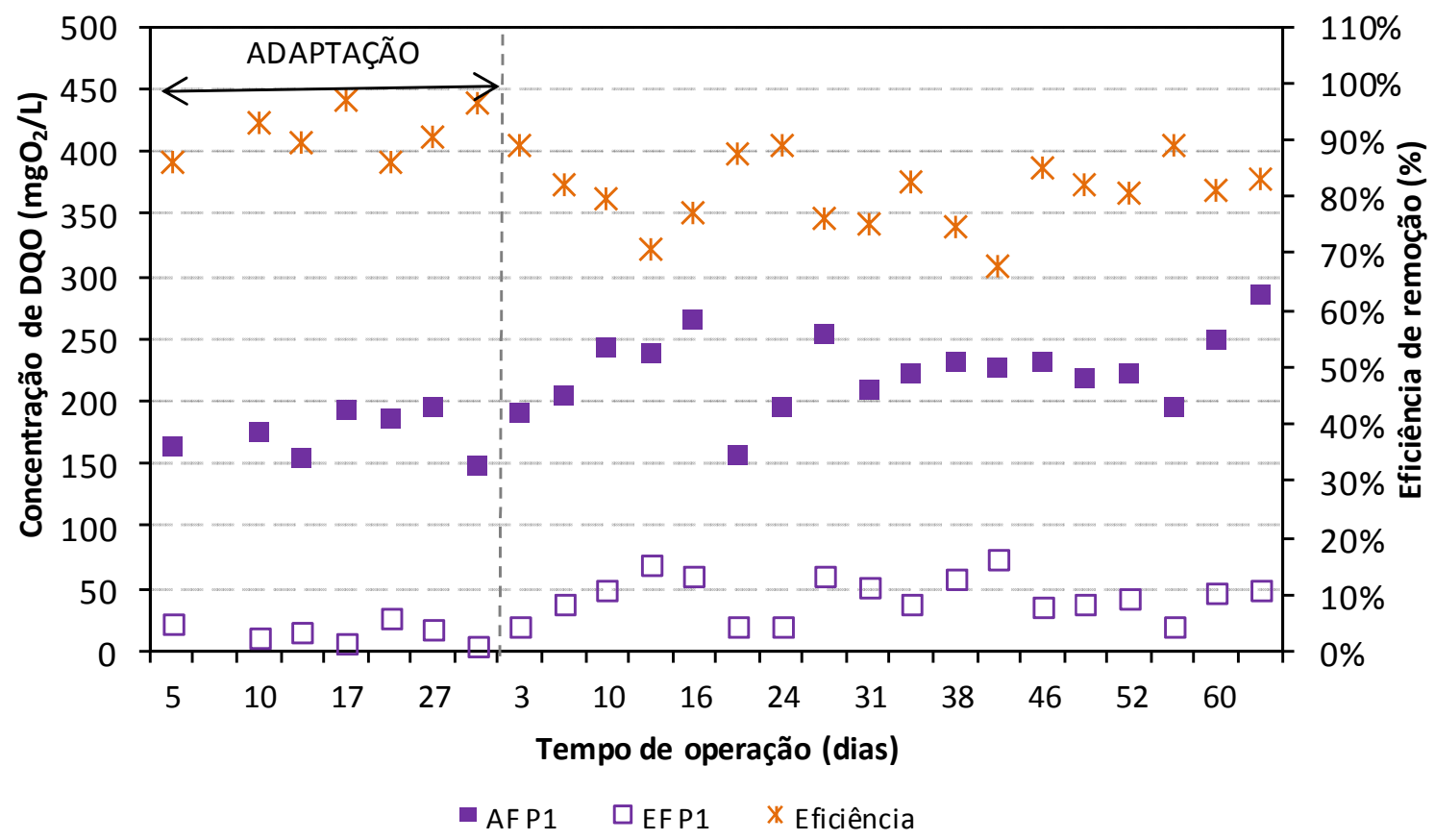

Figura 5.40 - Comportamento dos valores da DQO solúvel no afluente e efluente e eficiências de remoção no reator tratando esgoto sanitário com $2 \%$ de lixiviado prétratado (P1) do experimento em escala piloto.

Semelhante ao comportamento da DQO bruta, pode-se observar claramente a redução da eficiência de remoção da DQO solúvel após adição de lixiviado. Conforme apresentado na Figura 5.40, houve menor variabilidade no comportamento das concentrações da DQO solúvel afluente e efluente, em relação à da DQO bruta.

A série dos dados da DQO solúvel afluente do reator com esgoto sanitário e $2 \%$ de lixiviado pré-tratado (P1) apresentou baixa dispersão, sendo estatisticamente homogênea e estável (C.V.=13\%).

A concentração da DQO solúvel afluente (esgoto bruto mais lixiviado) no reator com esgoto sanitário e 2\% de lixiviado pré-tratado (P1) variou entre 190 e 286 mg/L, média de $224 \mathrm{mg} / \mathrm{L}$. A concentração da DQO bruta efluente variou entre 20 a $73 \mathrm{mg} / \mathrm{L}$, com média de $44 \mathrm{mg} / \mathrm{L}$, valor muito próximo à DQO solúvel efluente média obtida na mesma condição em escala de bancada, que foi de $45 \mathrm{mg} / \mathrm{L}$.

A série dos dados da DQO solúvel afluente do reator P2(0\%) apresentou baixa dispersão, sendo estatisticamente homogênea e estável (C.V. inferior a 15\%). 
Os valores das concentrações afluente, efluente, e as eficiências médias de remoção da DQO solúvel no reator P2(controle) estão apresentados no gráfico da Figura 5.45 .

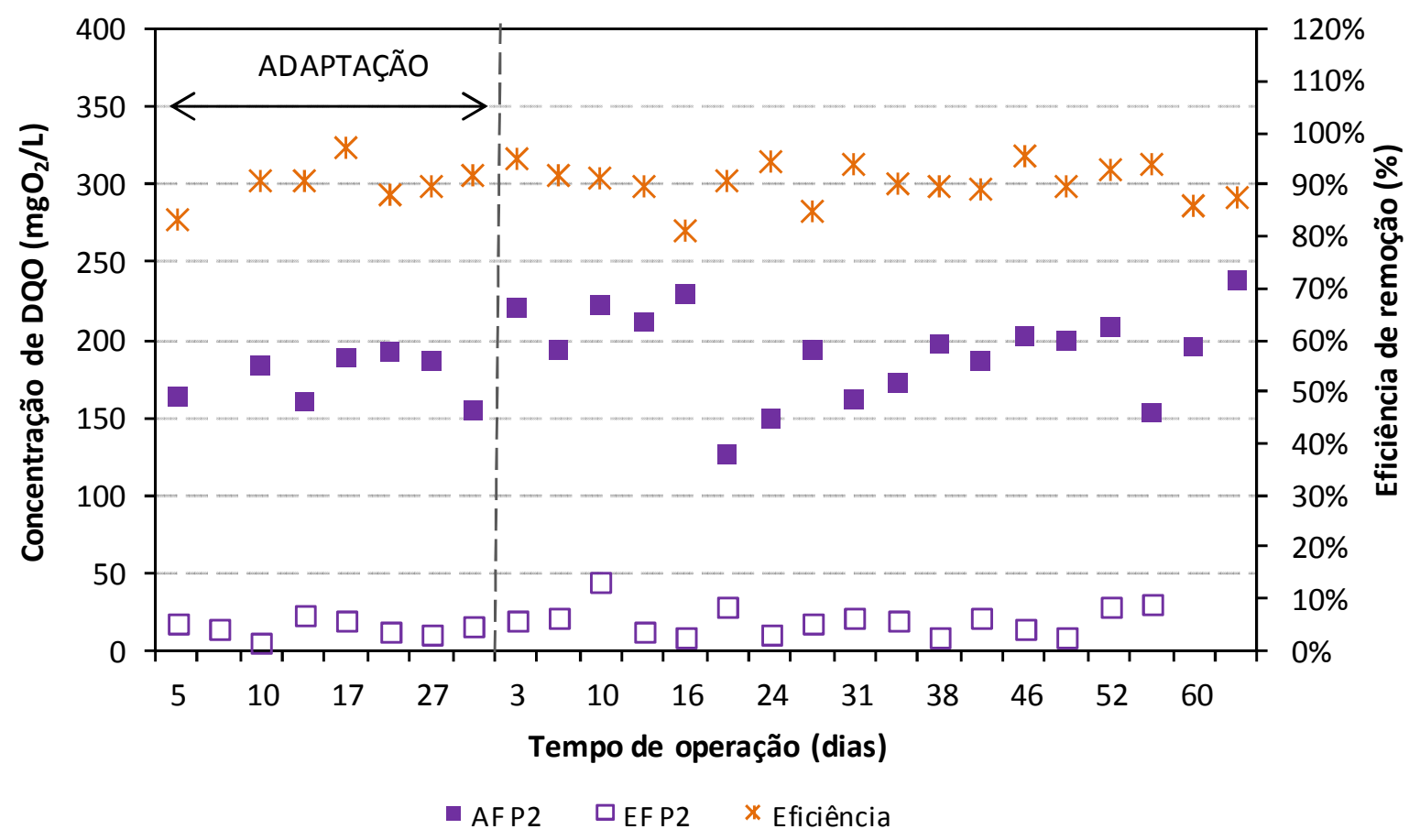

Figura 5.41 - Comportamento dos valores da DQO solúvel no afluente e efluente e eficiências de remoção no reator tratando esgoto sanitário com $0 \%$ de lixiviado (P2controle) do experimento em escala piloto.

Conforme se pode observar no gráfico da Figura 5.41, a concentração da DQO solúvel afluente (esgoto bruto) no reator com $0 \%$ de lixiviado (P2-controle)variou entre 127 e $238 \mathrm{mg} / \mathrm{L}$, enquanto a concentração da DQO bruta efluente variou entre 8 a 44 mg/L, com média de 19 mg/L.

A concentração da DQO solúvel efluente média obtida no reator com $0 \%$ de lixiviado (P2-controle) também foi próxima da média obtida nos experimentos controle em escala de bancada, em torno de $16 \mathrm{mg} / \mathrm{L}$.

Apesar da variação dos valores da DQO, segundo análise estatística, a série apresentou média dispersão (C.V. $=15 \%)$.

A Figura 5.42 apresenta o gráfico boxplot das eficiências de remoção da DQO solúvel obtidas pelos reatores P1 e P2 no experimento em escala piloto. 


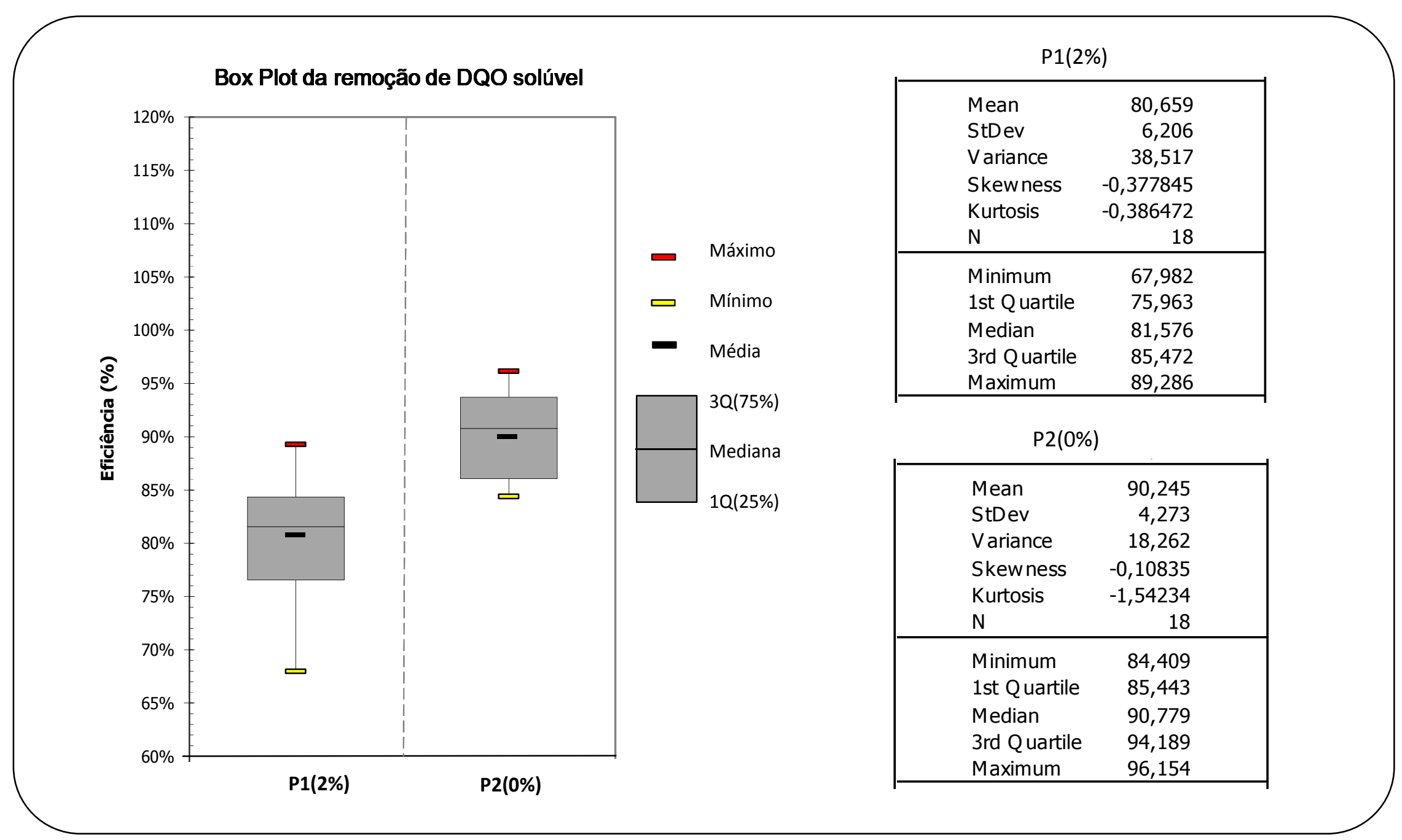

Figura 5.42 - Gráfico Boxplot das eficiências de remoção da DQO solúvel e medidas estatísticas dos reatores de lodos ativados tratando esgoto sanitário e $2 \%(\mathrm{P} 1)$ e $0 \%$ (P2-controle) de lixiviado pré-tratado do experimento em escala piloto. 
Conforme observado no gráfico, a eficiência de remoção da DQO solúvel no reator com esgoto sanitário e $2 \%$ de lixiviado pré-tratado (P1) variou de 68 a $89 \%$, média em torno de $80 \%$. A distribuição apresentou C.V. próxima de $8 \%$, sendo homogênea e estável.

A eficiência de remoção da DQO solúvel no reator P2(controle) variou de 84 a 96\%, média em torno de 90\%. A distribuição apresentou C.V.=4\%, sendo uma série homogênea e com baixíssima dispersão.

Os resultados do comportamento das eficiências de remoção da DQO solúvel indicam que a adição de $2 \%$ lixiviado acarretou uma redução de $10 \%$ da eficiência do sistema.

\subsubsection{Demanda Bioquímica de Oxigênio-DBO}

O comportamento dos valores da concentração afluente, efluente e as eficiências médias de remoção da DBO nos reatores com esgoto sanitário e lixiviado pré-tratado estão apresentados nos gráficos das Figuras 5.43. e 5.44. Todos os resultados das análises da DBO encontram-se no Apêndice B4.

Conforme observado nas Figuras 5.43 e 5.44, a concentração da DBO afluente nos dois reatores variou entre 172 e $320 \mathrm{mg} / \mathrm{L}$. A concentração da DBO bruta efluente variou entre 10 a $24 \mathrm{mg} / \mathrm{L}$, com média de $15 \mathrm{mg} / \mathrm{L}$. em com esgoto sanitário e $2 \%$ de lixiviado pré-tratado (P1) e de 7 a $18 \mathrm{mg} / \mathrm{L}$, com média de $11 \mathrm{mg} / \mathrm{L}$ em P2(0\%).

A Figura 5.45 apresenta o gráfico "boxplot" das eficiências de remoção da DBO obtidas pelos reatores $\mathrm{P} 1$ e $\mathrm{P} 2$ no experimento em escala piloto. 


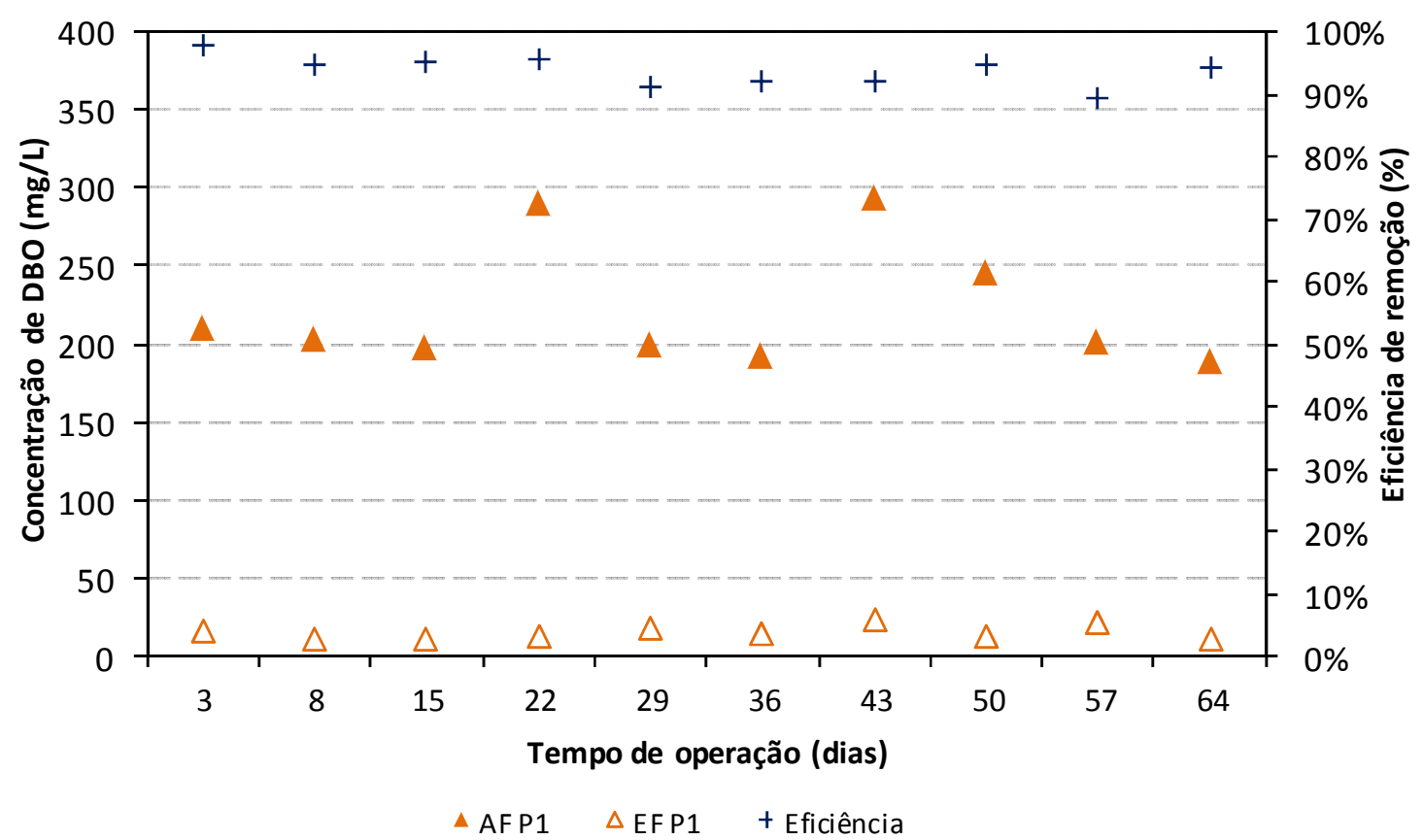

Figura 5.43 - Comportamento dos valores da DBO no afluente e efluente e eficiências de remoção no reator tratando esgoto sanitário com $2 \%$ de lixiviado pré-tratado (P1) do experimento em escala piloto.

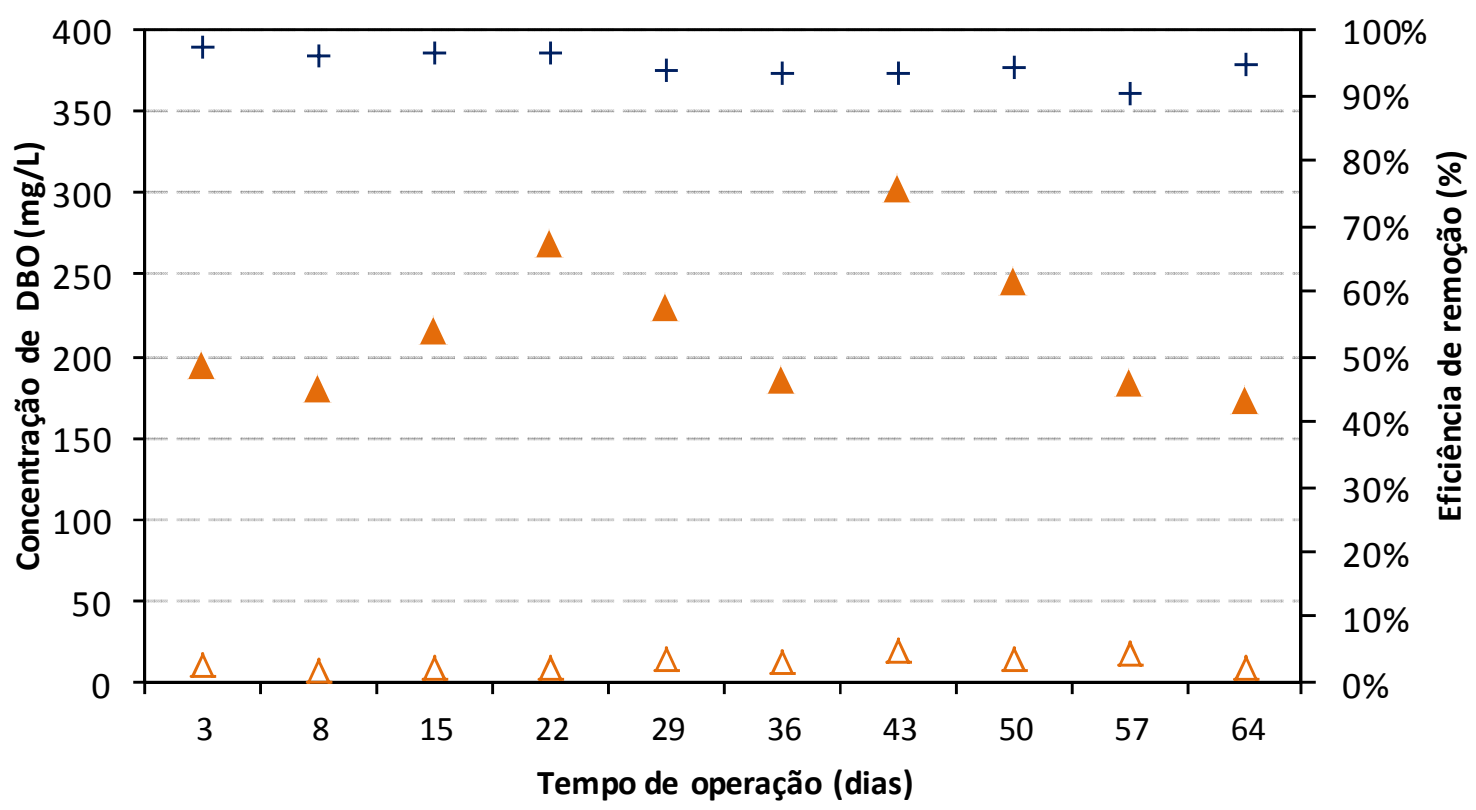

$\triangle$ AF P2 $\triangle$ EFP2 + Eficiência

Figura 5.44 - Comportamento dos valores da DBO no afluente e efluente e eficiências de remoção no reator tratando esgoto sanitário com $0 \%$ de lixiviado (P2-controle) do experimento em escala piloto. 
Box Plot da remoção de DBO

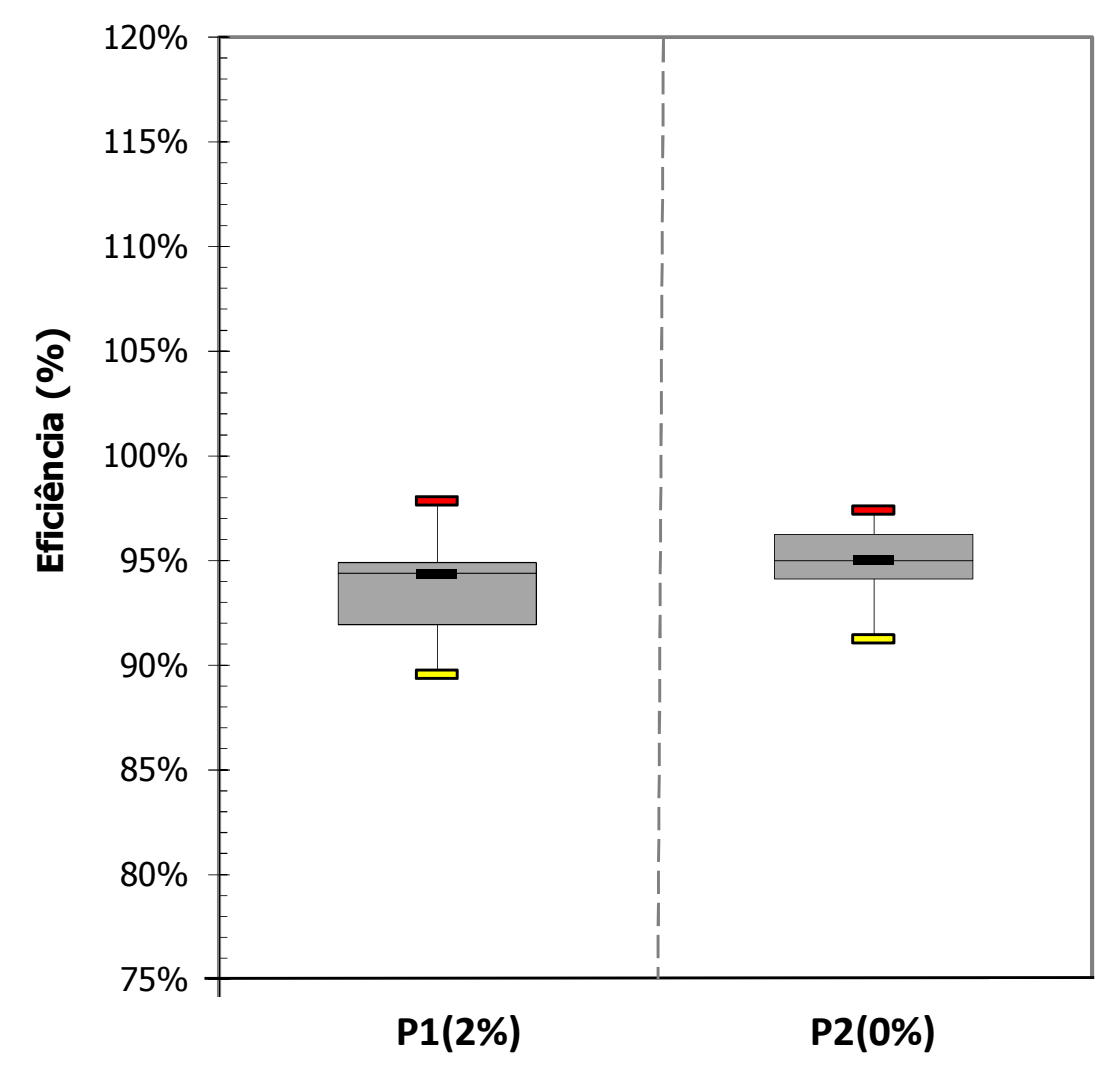

$\mathrm{P} 1(2 \%)$

\begin{tabular}{|l|lr|}
\cline { 2 - 3 } & Mean & \multicolumn{1}{c|}{93,642} \\
StDev & 2,457 \\
Variance & 6,035 \\
Skewness & $-0,088362$ \\
Kurtosis & $-0,279775$ \\
$\mathrm{~N}$ & 10 \\
\hline \multirow{3}{*}{ Máximo } & Minimum & 89,552 \\
& 1st Quartile & 91,628 \\
& Median & 94,381 \\
& 3rd Quartile & 95,091 \\
& Maximum & 97,861 \\
\hline
\end{tabular}

Média

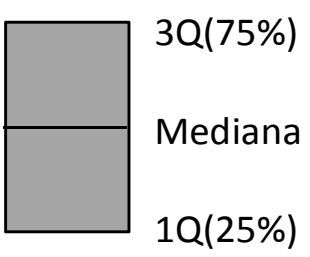

\section{P2(0\%)}

\begin{tabular}{|lr|}
\hline Mean & \multicolumn{1}{|c|}{94,954} \\
StDev & 1,800 \\
Variance & 3,241 \\
Skewness & $-0,733339$ \\
Kurtosis & 0,691810 \\
$\mathrm{~N}$ & 10 \\
\hline Minimum & 91,257 \\
1st Quartile & 93,908 \\
Median & 94,992 \\
3rd Quartile & 96,370 \\
Maximum & 97,423 \\
\hline
\end{tabular}

Figura 5.45 - Gráfico Boxplot das eficiências de remoção da DBO e medidas estatísticas dos reatores de lodos ativados tratando esgoto sanitário com 2\% (P1) e 0\% (P2-controle) de lixiviado pré-tratado do experimento em escala piloto. 
Conforme observado no gráfico, a eficiência de remoção da DBO no reator com esgoto sanitário e 2\% de lixiviado pré-tratado (P1) variou de 90 a $98 \%$ média em torno de $93 \%$.

A eficiência de remoção da DBO no reator P2(controle) variou de 91 a 97\%, média em torno de 95\%. Ambas as distribuições apresentaram C.V. inferior a 3\%, sendo homogêneas e sem dispersão.

As eficiências médias de remoção da DBO em ambos os reatores foram próximas às obtidas na mesma condição em escala de bancada.

Os resultados do comportamento das eficiências de remoção da DBO não indicaram redução significativa da eficiência do sistema com a adição de $2 \%$ de lixiviado.

\subsubsection{Carbono Orgânico Dissolvido-COD}

Os valores das concentrações da COD (filtrada em membrana de diâmetro médio de poro de $0,45 \mu \mathrm{m}$ ) nos reatores do experimento piloto são apresentados na Figura 5.46 e 5.47 que contém os gráficos da variação do COD. Todos os resultados das análises do COD encontram-se no Apêndice B.

Os valores da concentração afluente, efluente e as eficiências médias de remoção do COD no reator com esgoto sanitário e $2 \%$ de lixiviado pré-tratado (P1) estão apresentados no gráfico da Figura 5.46.

Conforme observado no gráfico da Figura 5.46, a concentração do COD afluente (esgoto) no reator com esgoto sanitário e $2 \%$ de lixiviado pré-tratado (P1) variou entre 48 e $91 \mathrm{mg} / \mathrm{L}$, enquanto a concentração do COD efluente variou entre 19 a $38 \mathrm{mg} / \mathrm{L}$, com média de $28 \mathrm{mg} / \mathrm{L}$, valor este próximo da média obtida nos experimentos em escala de bancada, de $25 \mathrm{mg} / \mathrm{L}$.

A série dos dados do COD afluente do reator com esgoto sanitário e $2 \%$ de lixiviado pré-tratado (P1) apresentou média dispersão (C.V. entre 15\% e 30\%).

Os valores da concentração afluente, efluente e as eficiências médias de remoção do COD no reator com $0 \%$ de lixiviado (P2-controle) estão apresentados no gráfico da Figura 5.47. 


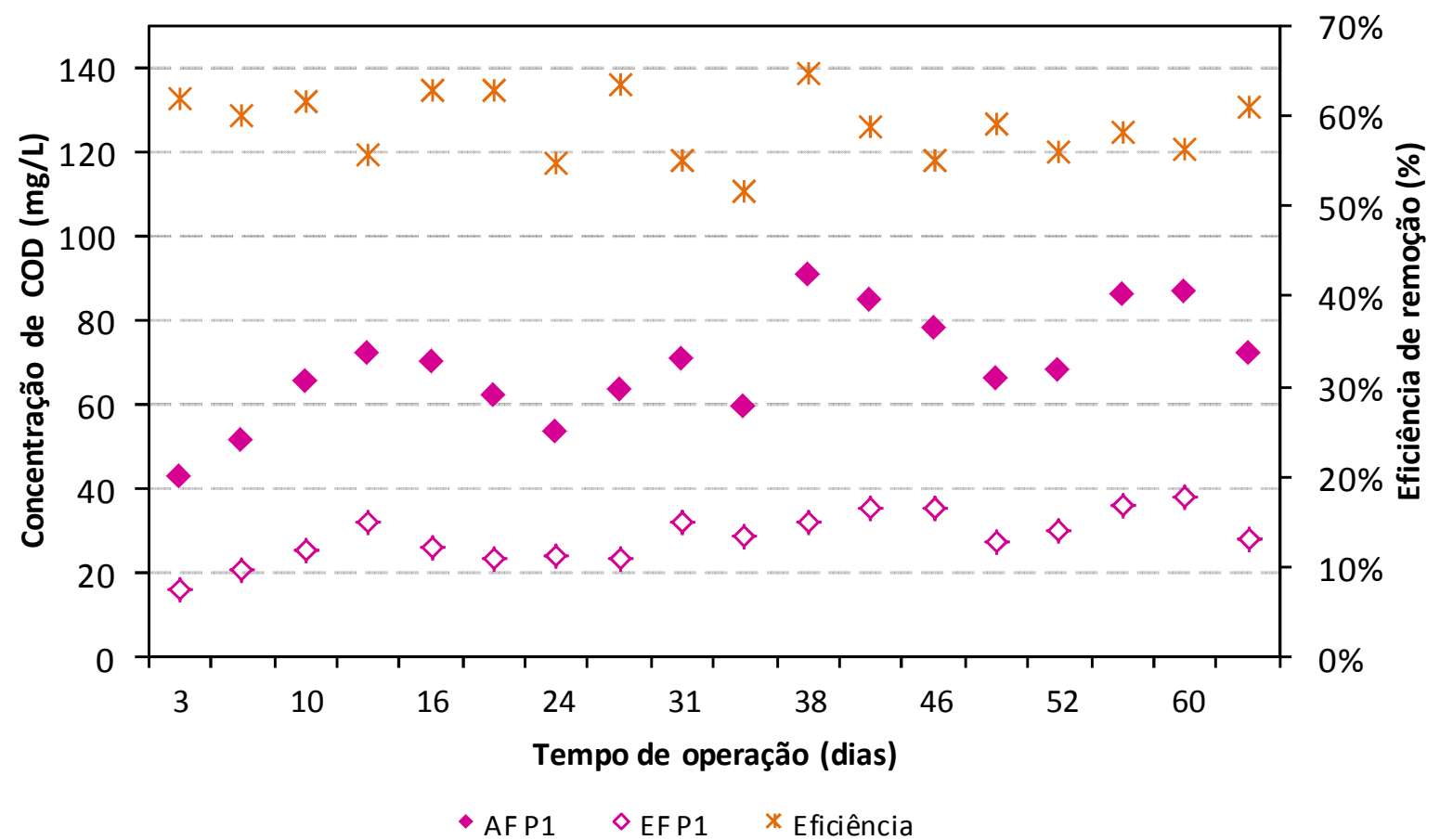

Figura 5.46 - Comportamento dos valores do COD no afluente e efluente e eficiências de remoção no reator tratando esgoto sanitário com $2 \%$ de lixiviado pré-tratado $(\mathrm{P} 1)$ do experimento em escala piloto.

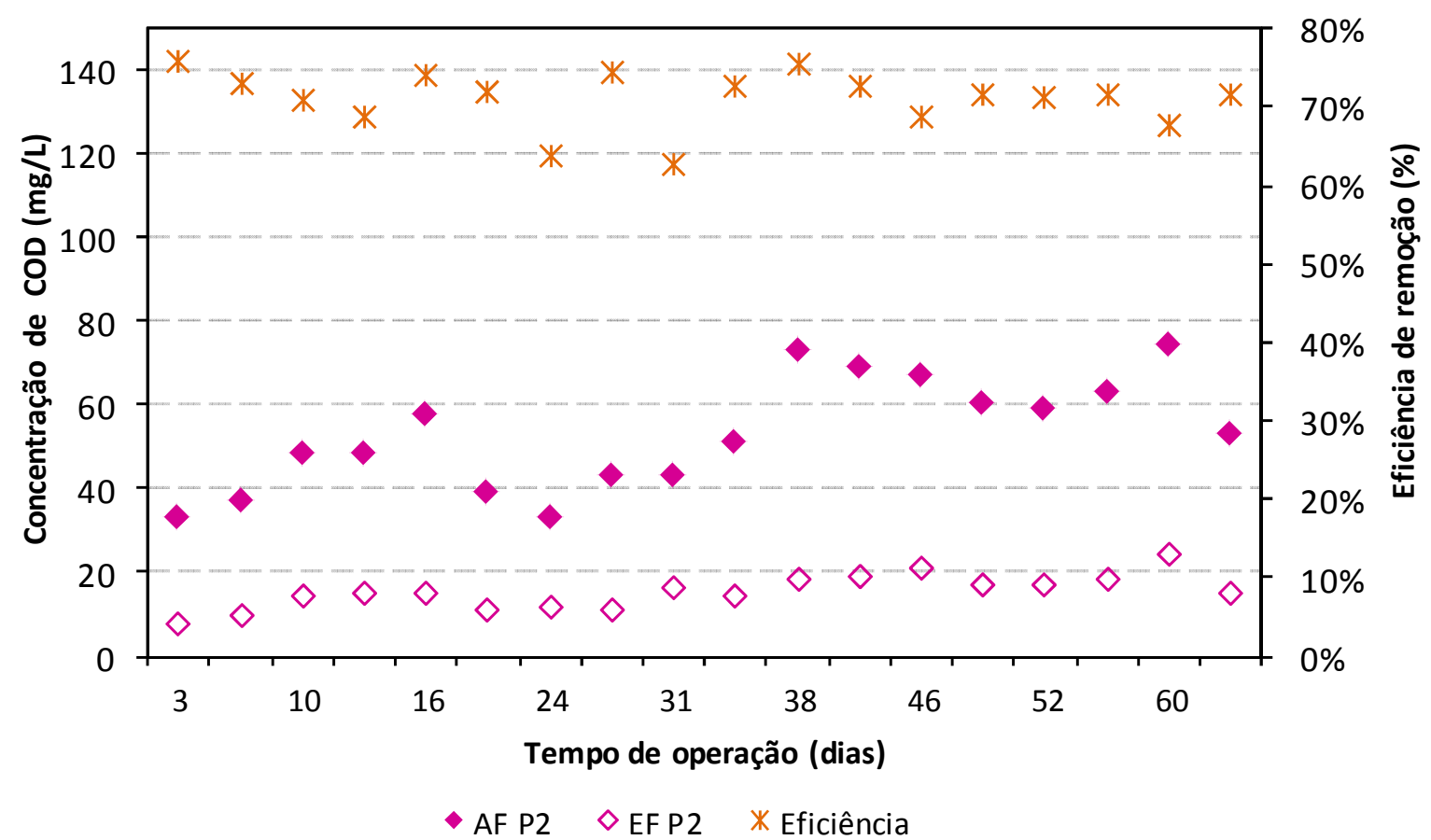

Figura 5.47 - Comportamento dos valores do COD no afluente e efluente e eficiências de remoção no reator tratando esgoto sanitário com $0 \%$ de lixiviado (P2-controle) do experimento em escala piloto. 
Conforme se pode observar no gráfico da Figura 5.47, a concentração do COD afluente (esgoto) no reator com 0\% de lixiviado (P2-controle)variou entre 33 e $74 \mathrm{mg} / \mathrm{L}$, média de $53 \mathrm{mg} / \mathrm{L}$. A série dos dados do COD do afluente do reator P2(0\%) apresentou média dispersão (C.V. entre 15\% e 30\%).

A concentração do COD efluente variou entre 8 a $24 \mathrm{mg} / \mathrm{L}$, com média de 15 $\mathrm{mg} / \mathrm{L}$, valor este próximo da média obtida nos experimentos em escala de bancada, de $16 \mathrm{mg} / \mathrm{L}$.

A Figura 5.48 apresenta o gráfico "boxplot" das eficiências de remoção do COD obtidas pelos reatores $\mathrm{P} 1$ e $\mathrm{P} 2$ no experimento em escala piloto.

\subsubsection{Série de Nitrogênio}

Durante o experimento foi monitorada a série completa de nitrogênio de modo a se avaliar a eficiência de remoção de nitrogênio. No laboratório, as concentrações de nitrogênio nas formas de amônia livre $\left(\mathrm{N}^{\left.-\mathrm{NH}_{3}\right)}\right.$ e de íon amônio $\left(\mathrm{N}^{-} \mathrm{NH}_{4}^{+}\right)$são determinadas em conjunto, que corresponde à soma das concentrações das duas formas, recebe o nome de nitrogênio amoniacal total (NAT) (Souto, 2009).

Foram determinadas as concentrações de nitrogênio total Kjeldal da amostra bruta e solúvel, nitrogênio amoniacal, nitrito e nitrato. $\mathrm{O}$ nitrito e nitrato foram determinados utilizando-se a metodologia de injeção de fluxo (APHA 2005). As amostras para análise de NTK solúvel, nitrito e nitrato foram filtradas em membrana de diâmetro médio de poro de $0,45 \mu \mathrm{m}$, para efetuar do balanço de nitrogênio.

Todos os resultados das análises de nitrogênio encontram-se no Apêndice B8. 
Box Plot da remoção de COD

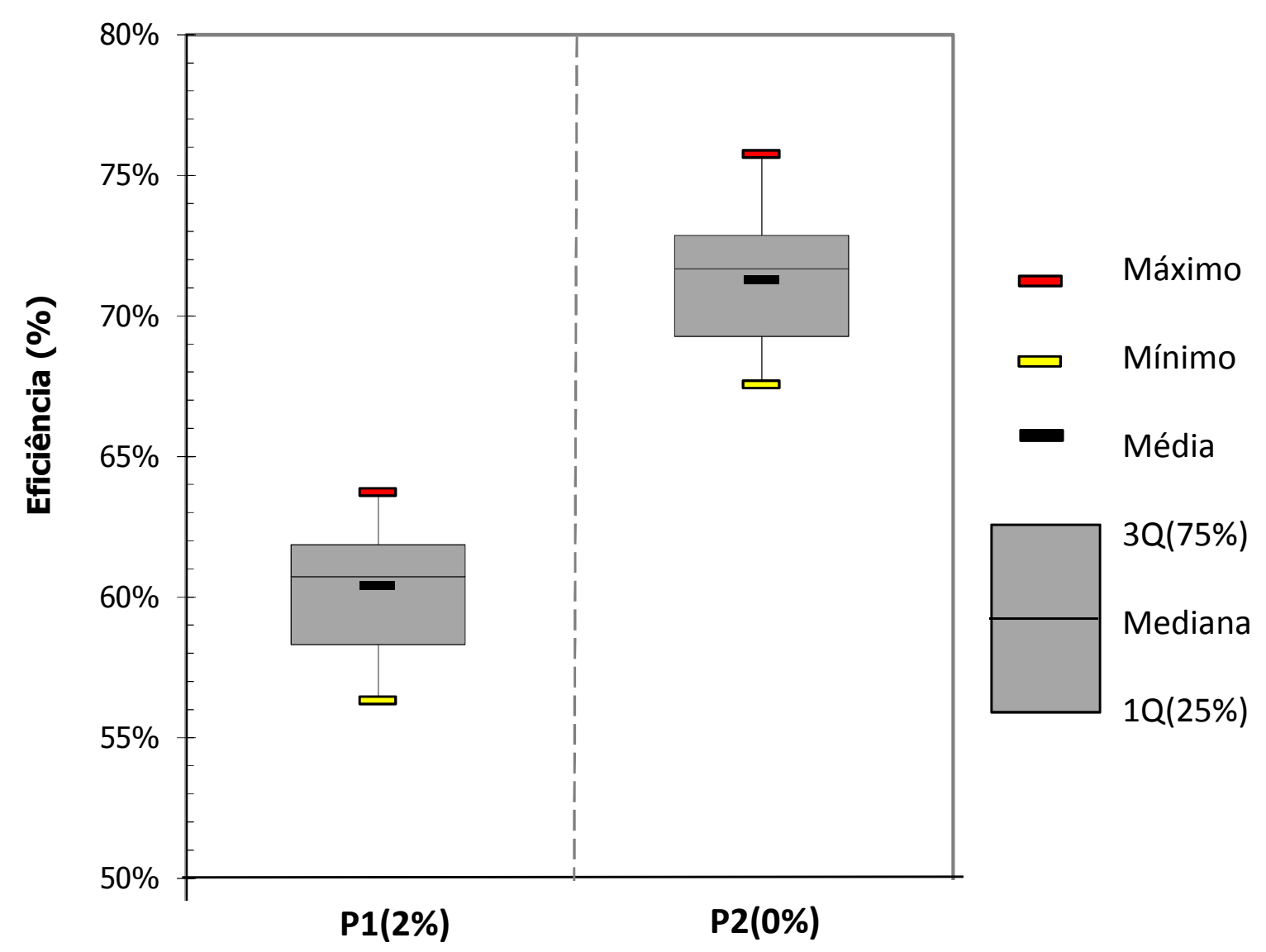

$\mathrm{P} 1(2 \%)$

\begin{tabular}{|lr|}
\hline Mean & 60,224 \\
StDev & 2,228 \\
Variance & 4,966 \\
Skew ness & $-0,24227$ \\
Kurtosis & $-1,12531$ \\
N & 18 \\
\hline Minimum & 56,322 \\
1st Q uartile & 58,041 \\
Median & 60,717 \\
3rd Quartile & 61,946 \\
Maximum & 63,736 \\
\hline
\end{tabular}

$\mathrm{P} 2(0 \%)$

\begin{tabular}{|lr|}
\hline Mean & 70,971 \\
StDev & 3,565 \\
Variance & 12,712 \\
Skewness & $-1,06151$ \\
Kurtosis & 0,89889 \\
N & 18 \\
\hline Minimum & 62,791 \\
1st Quartile & 68,727 \\
Median & 71,682 \\
3rd Quartile & 73,219 \\
Maximum & 75,758 \\
\hline
\end{tabular}

Figura 5.48 - Gráfico Boxplot das eficiências de remoção do COD e medidas estatísticas dos reatores de lodos ativados tratando esgoto sanitário e $2 \%$ (P1) e $0 \%$ (P2-controle) de lixiviado pré-tratado do experimento em escala piloto. 
As Figuras 5.49 e 5.50 apresentam as variações na eficiência de remoção do nitrogênio total Kjeldal (NTK) e do nitrogênio amoniacal total (NAT) nos reatores em escala piloto.

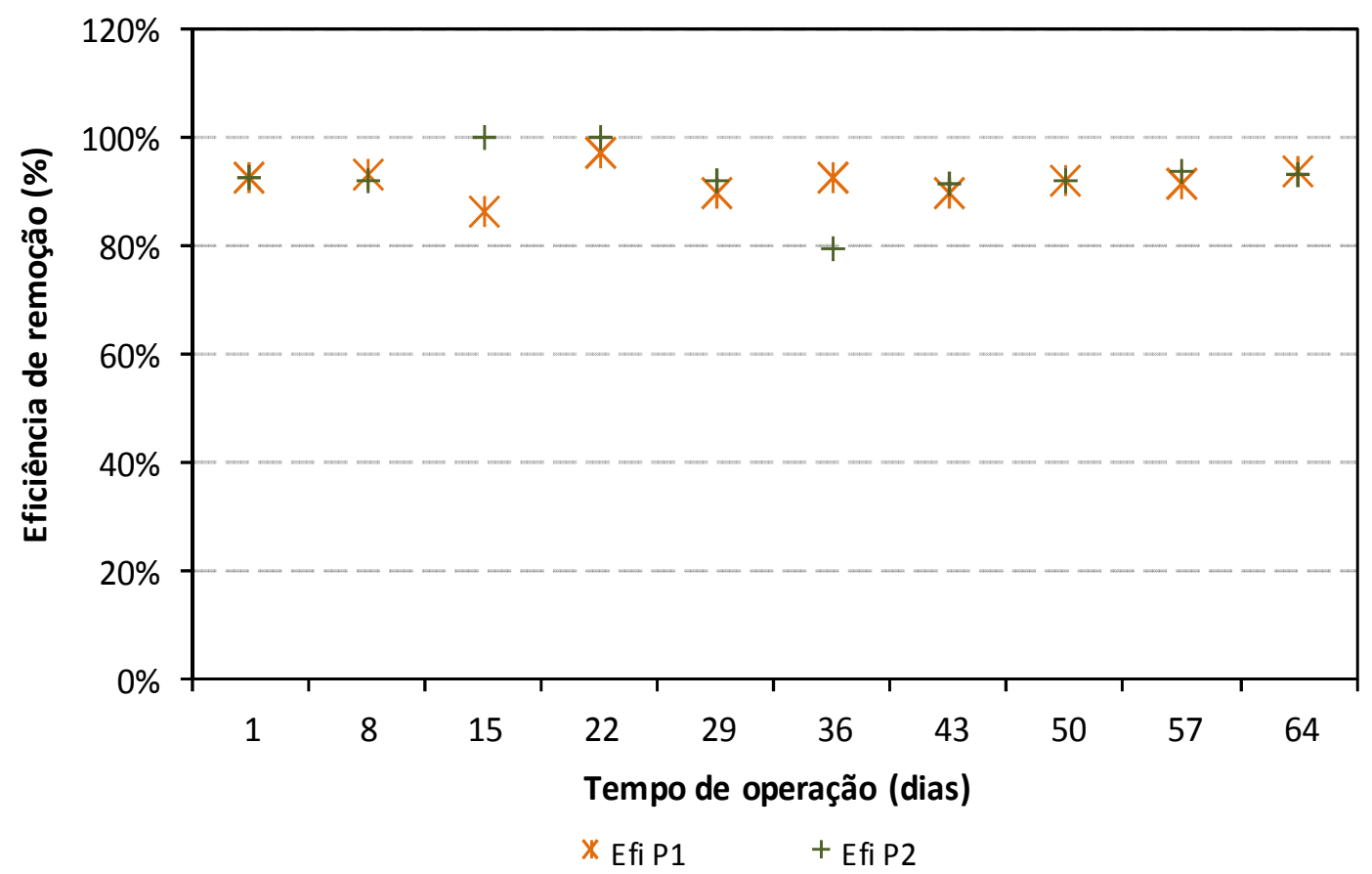

Figura 5.49 - Comportamento da eficiência de remoção de NTK nos reatores tratando esgoto com $2 \%$ (P1) e $0 \%$ (P2-controle) de lixiviado pré-tratado do experimento em escala piloto.

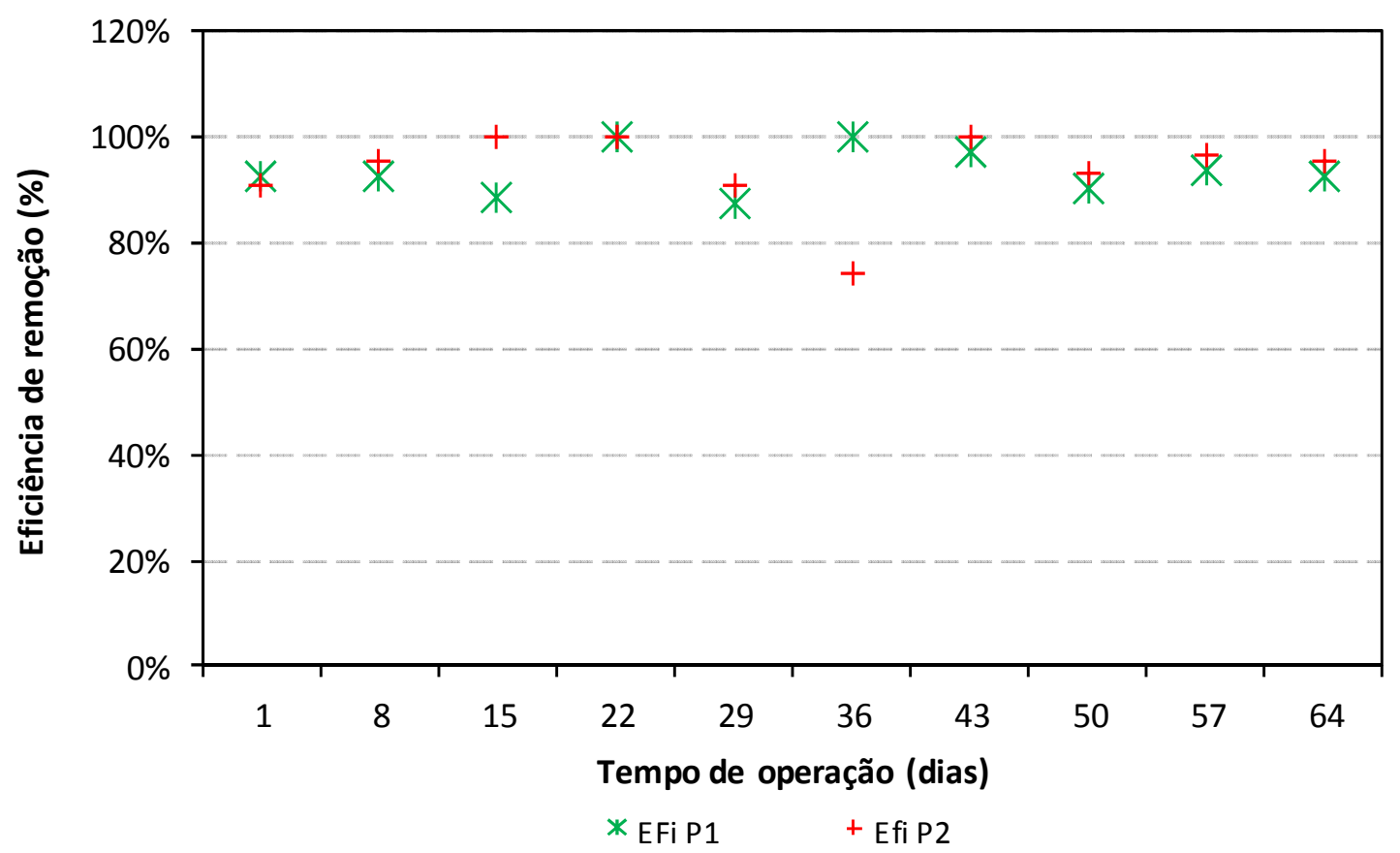

Figura 5.50 - Comportamento da eficiência de remoção de NAT nos reatores tratando esgoto sanitário com $2 \%(\mathrm{P} 1)$ e $0 \%$ (P2-controle) de lixiviado pré-tratado do experimento em escala piloto. 
Neste experimento, as remoções de NTK e NAT se mantiveram elevadas durante todo o experimento nos dois reatores. A remoção média de NTK foi de $92 \%$ no reator $\mathrm{P} 1(2 \%)$, e de $93 \%$ no reator $\mathrm{P} 2(0 \%)$.

A remoção média de NAT foi de $93 \%$, no reator P1(2\%), e de $94 \%$ no reator P2(\%0). É preciso destacar, porém, que parte da amônia pode ter sido removida por arraste (stripping) pela aeração do próprio tanque de aeração, ou seja, nem toda a amônia foi oxidada a nitrito e a nitrato.

Os resultados indicaram comportamento muito similar na remoção de NTK e de NAT dos dois reatores em escala piloto, sem interferência significativa da adição do lixiviado na eficiência de remoção, assim como encontrado no experimento de bancada nas mesmas condições.

A Figura 5.51 apresenta o comportamento da concentração de NAT afluente e efluente e Nitrato efluente no reator P1(2\%).

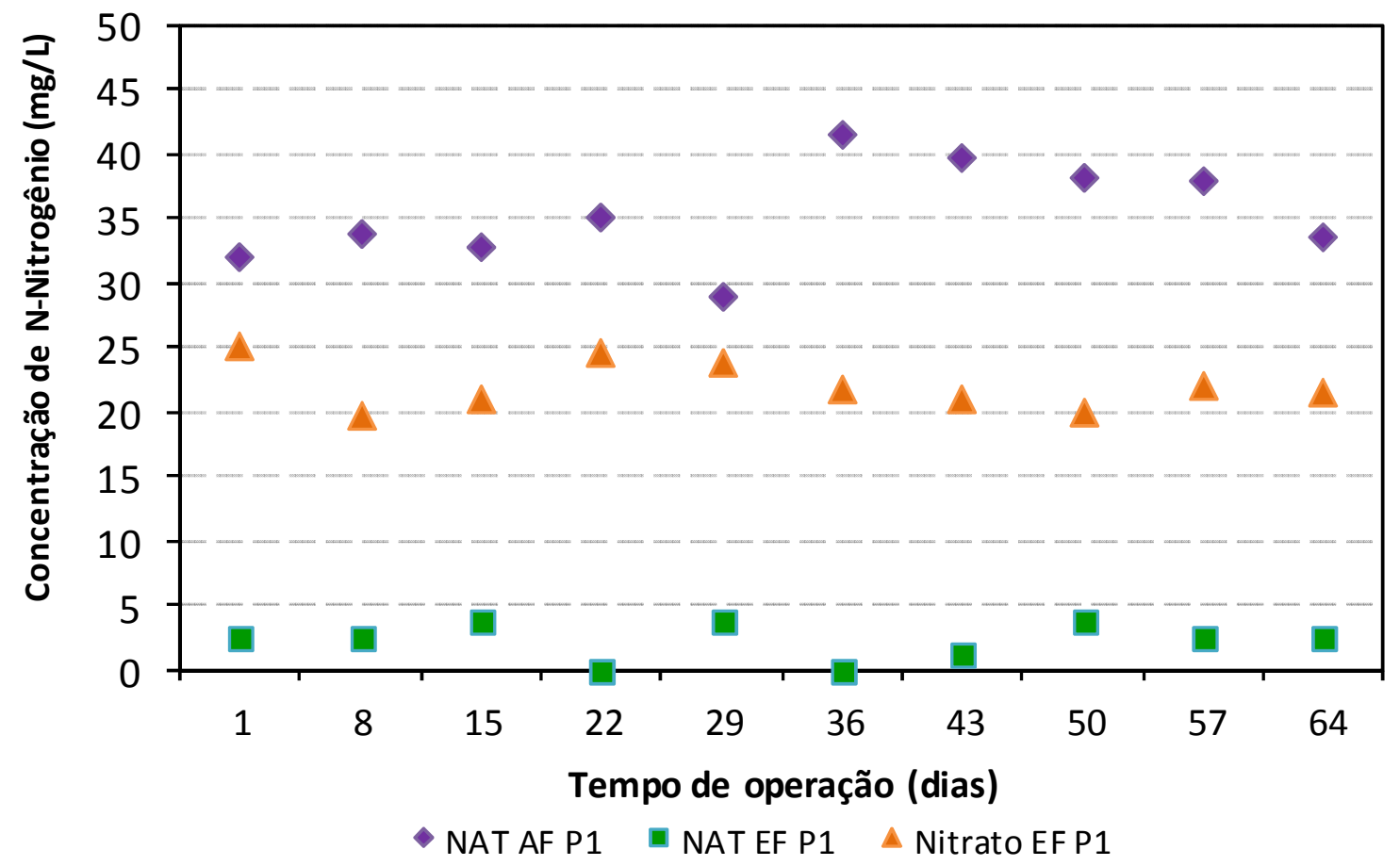

Figura 5.51 - Valores das concentrações afluente e efluente de NAT e efluente de $\mathrm{NO}_{3}{ }^{-}$ no reator tratando esgoto sanitário com $2 \%$ (P1) de lixiviado pré-tratado do experimento em escala piloto. 
Pode-se observar que a concentração afluente de NAT variou entre 29 e 42 $\mathrm{mg} / \mathrm{L}$, com média de $36 \mathrm{mg} / \mathrm{L}$. O sistema promoveu remoção quase total de NAT, com concentração efluente variando de 0 a $4 \mathrm{mg} / \mathrm{L}$.

Ao mesmo tempo, verificou-se a ocorrência de nitrificação pela formação de íons $\mathrm{NO}_{3}{ }^{-}$no efluente do reator. A concentração efluente de $\mathrm{NO}_{3}{ }^{-}$variou de 20 a 25 $\mathrm{mg} / \mathrm{L}$, com média de em torno de $23 \mathrm{mg} / \mathrm{L}$. Verificou-se a ocorrência de nitrificação também pelo surgimento de microrganismos indicadores de nitrificação, conforme será discutido na seção 5.52 .

A Figura 5.52 apresenta os valores das concentrações de NAT afluente e efluente e de Nitrato efluente no reator $\mathrm{P} 2(0 \%)$.

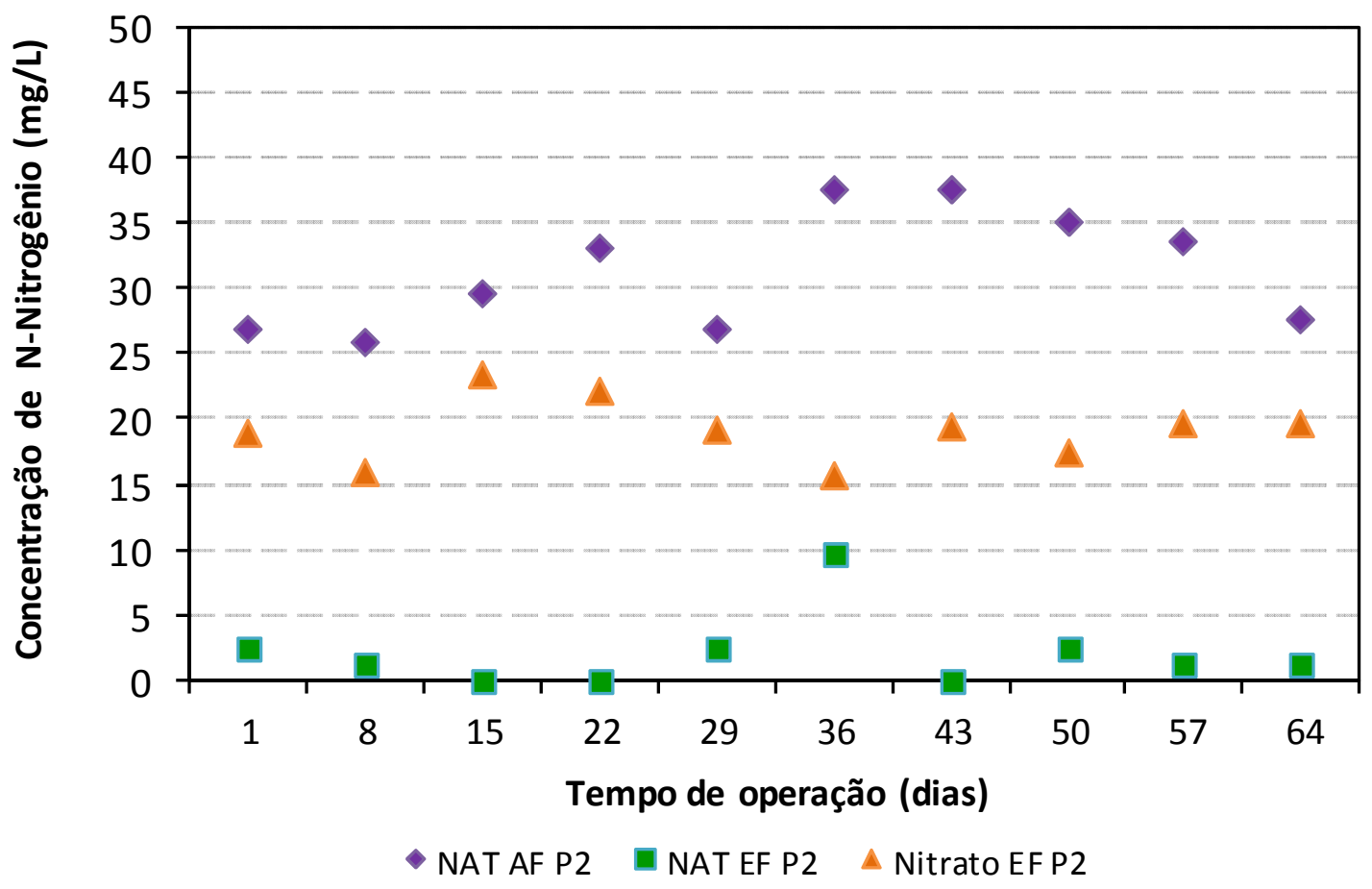

Figura 5.52 - Valores das concentrações afluente e efluente de NAT e efluente de $\mathrm{NO}_{3}{ }^{-}$ no reator tratando esgoto sanitário com $0 \%$ (P2-controle) de lixiviado pré-tratado do experimento em escala piloto.

Pode-se observar que a concentração afluente de NAT variou entre 27 e 45 $\mathrm{mg} / \mathrm{L}$, com média de $36 \mathrm{mg} / \mathrm{L}$. A concentração efluente de NAT variou de 0 a $10 \mathrm{mg} / \mathrm{L}$, com média em torno de $2 \mathrm{mg} / \mathrm{L}$. 
Também se verificou a ocorrência de nitrificação pela formação de íons $\mathrm{NO}_{3}{ }^{-}$no efluente do reator $\mathrm{P} 2(0 \%)$. A concentração efluente de $\mathrm{NO}_{3}{ }^{-}$neste reator também foi menor que P1(2\%), variando de 16 a $24 \mathrm{mg} / \mathrm{L}$, com média de em torno de $20 \mathrm{mg} / \mathrm{L}$.

Houve a ocorrência de nitrificação nos dois reatores, com comportamento similar, não havendo diferenças significativas. A elevada idade do lodo e a baixa relação $\mathrm{A} / \mathrm{M}$ favoreceram a nitrificação em ambos os reatores.

A nitrificação também foi acompanhada pelo elevado consumo de alcalinidade. O consumo médio de alcalinidade foi de 71 e $79 \%$ nos reatores P1 e P2, respectivamente. Os dados de alcalinidade estão tabelados no anexo B.

Relacionando-se a formação de $\mathrm{NO}_{3}{ }^{-}$com a concentração de SSV e a vazão de alimentação, Pode-se verificar que a taxa de desnitrificação específica foi de 0,019 e 0,017 $\mathrm{mgNO}_{3}{ }^{-} / \mathrm{mgSSV}$ dia, no reator com 2\%(P1) e 0\% (P2-controle) de lixiviado, respectivamente. Essas taxas estão dentro da faixa esperada para idade do lodo elevada e predominância de zonas anóxicas à jusante do tanque de aeração, conforme Metcalf \& Eddy (2003).

As características geométricas e hidrodinâmicas dos reatores de bancada possibilitaram mistura completa, de forma que as zonas mortas eram praticamente inexistentes, obtendo uma elevada dispersão do oxigênio no meio, de forma que se observava pouca variação da concentração de OD vários pontos do reator.

Por outro lado, os reatores que foram utilizados nos experimento em escala piloto, conforme Mendonça (2002) tiveram alguns parâmetros hidrodinâmicos indicando escoamento intermediário, entre pistonado e mistura completa. Dessa maneira, as características geométricas (dimensões predominantemente lineares, maior volume) e hidrodinâmicas, apesar da agitação mecanizada, contribuem para surgimento de zonas mortas, fluxos preferenciais, curtos circuitos e gradientes longitudinais de OD em diferentes pontos do reator.

Nessas condições há possibilidade do aparecimento de zonas anóxicas (OD inferior a $1 \mathrm{mg} / \mathrm{L}$ ) dentro do próprio tanque de aeração, promovendo condições favoráveis à ocorrência de desnitrificação e consequente redução da concentração de $\mathrm{NO}_{3}{ }^{-}$no efluente.

Foi constatada também, e de forma mais nítida, a ocorrência de desnitrificação no decantador secundário, caracterizado pela ascensão do lodo e desprendimento de microbolhas de gás dos flocos quando submetidos à agitação. 
Isso porque o oxigênio é rapidamente consumido, permitindo desenvolvimento de condições predominantemente anóxicas, portanto favorecendo a redução de íons nitrato e nitrito a nitrogênio gasoso pelas bactérias desnitrificantes (Gerardi, 2002).

A flotação de aglomerados de lodo foi observada já nos primeiros dias da adaptação no decantador justaposto dos reatores em escala piloto. Pela Figura 5.53 pode-se observar parte do lodo na superfície do decantador.

Foi observada que a ascensão do lodo ocorria a cada 2 horas, justamente o período de consumo de todo o oxigênio presente no meio. A partir daí, o meio fica em condições anaeróbias e os flocos tendem a ascender para a superfície e as microbolhas de $\mathrm{N}_{2}$ se desprendem por efeito da desnitrificação, conforme Gerardi (2002).

Como os flocos ascendiam para a superfície do decantador, havia elevada perda de biomassa no efluente, reduzindo a eficiência do sistema. Diante do quadro desfavorável foi feita uma alteração no sistema, com a instalação de um decantador externo ao reator, que ficou sendo utilizado integralmente como tanque de aeração.

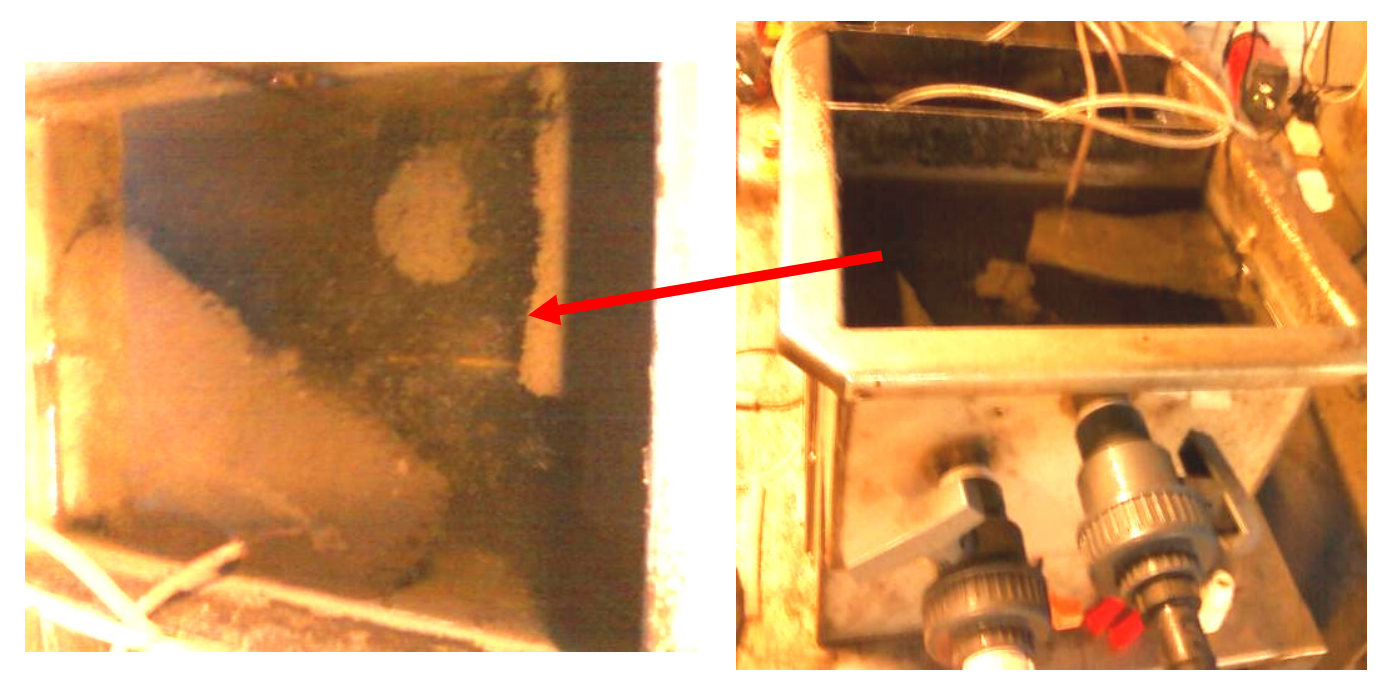

Figura 5.53 - Reator de lodos ativados, destacando a flotação de aglomerados de lodo na superfície do decantador na fase de adaptação durante o experimento em escala piloto.

No decantador externo foi inserida uma agitação intermitente, acionada em intervalos de 2 horas por meio de temporizador. Dessa forma, com a agitação as microbolhas se desprendiam do aglomerado de lodo flutuante e seu peso próprio promovia a sedimentação natural. 
Outra indicação da ocorrência de desnitrificação foi a presença elevada de microrganismos filamentosos nos flocos, eles aparecem porque capturam facilmente grande quantidade de gases, conforme Gerardi (2002).

Diante disso, no experimento em escala piloto também foi monitorada a remoção de $\mathrm{N}$-total nos reatores.

Para determinação do N-total foi realizada análise de NTK solúvel (membrana de diâmetro médio de poro de $0,45 \mu \mathrm{m}$ ). Pela soma da concentração de $\mathrm{NTK}$ sol, $\mathrm{NO}_{2}{ }^{-}$, $\mathrm{NO}_{3}{ }^{-}$foi determinado $\mathrm{N}$-total nas amostras afluente e efluente no sistema. $\mathrm{O}$ gráfico da Figura 5.54 apresenta a eficiência de remoção de N-total nos reatores.

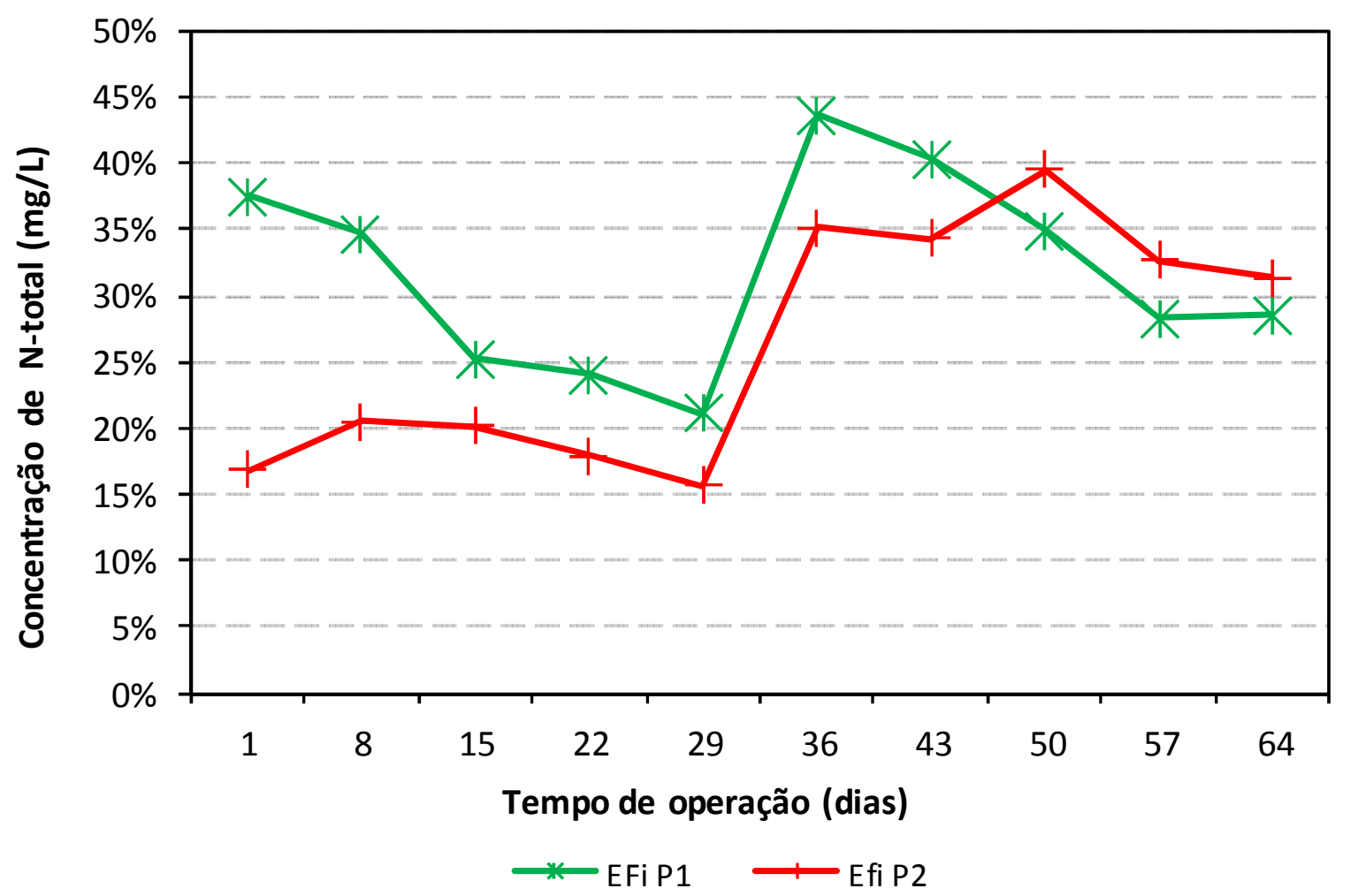

Figura 5.54 - Variação da eficiência de remoção de N-total nos reatores tratando esgoto sanitário com $2 \%(\mathrm{P} 1)$ e $0 \%$ (P2-controle) de lixiviado pré-tratado no experimento em escala piloto.

A eficiência de remoção de N-total no reator com esgoto sanitário e $2 \%$ de lixiviado pré-tratado $(\mathrm{P} 1)$ se manteve maior parte da operação superior à do reator P2(2\%), variando de 21 a 44\%, com média de $32 \%$.

Quanto ao reator P2(0\%), a eficiência de remoção de N-total variou de 16 a $40 \%$, com média de $26 \%$, remoção esta que está dentro da faixa de eficiência de sistemas de lodo ativados, segundo apresentado por Von Sperling (2002). 
Pode-se observar uma elevação na eficiência a partir após o $30^{\circ}$ dia de operação em ambos os reatores. Isto pode estar associado à concentração de OD, a qual se manteve em uma faixa inferior nesse período, em relação aos dias anteriores em que a concentração de OD se manteve acima de $4 \mathrm{mg} / \mathrm{L}$, conforme pode ser observado nos dados apresentados no Apêndice B2.

Mantida concentração de OD mais baixa, a perda de NAT por arraste é menor, e teria maior possibilidade de formação de zona anóxica no próprio tanque de aeração, aumentando a taxa específica de desnitrificação (Metcalf \& Eddy, 2003).

Pode-se verificar que a eficiência de remoção de $\mathrm{N}$-total no reator em que foi adicionado lixiviado foi superior ao reator alimentado apenas com esgoto sanitário.

\subsubsection{Série de Sólidos}

No experimento em escala piloto foram determinadas as concentrações de sólidos suspensos totais (SST), sólidos suspensos fixos (SSF) e voláteis (SSV) no tanque de aeração. Além disso, foram monitorados sólidos suspensos totais suspensos fixos e suspensos voláteis e sólidos totais, fixos nas amostras de afluente e efluente do sistema cujos resultados encontram-se nos gráficos das Figuras 5.61 a 5.64 e no Apêndice B5 a B7.

Em ambos os reatores a inoculação foi feita com lodo aeróbio proveniente do sistema de lodos ativados da Faber Castell.

As concentrações de SST e SSV variaram de 900 a 1900 mg/L e de 800 a 1500 $\mathrm{mg} / \mathrm{L}$ em ambos os reatores, respectivamente. Em geral, a concentração de SST no reator com esgoto sanitário e $2 \%(\mathrm{P} 1)$ de lixiviado se manteve levemente superior a do reator com $0 \%$ (P2-controle) de lixiviado, conforme mostrado no gráfico da Figura 5.55.

A concentração média de SST no tanque de aeração foi de 1402 e 1375 mg/L nos reatores $\mathrm{P} 1$ e $\mathrm{P} 2$, respectivamente.

A avaliação dos valores de SSV/SST ao longo da operação dos reatores em escala piloto indica que os valores desta relação variaram de 0,75 a 0,88 , com valor médio de 0,81e 0,82 no reator com esgoto sanitário e 2\% (P1) e 0\% (P2-controle) de lixiviado, respectivamente, conforme apresentado na Figura 5.60. 


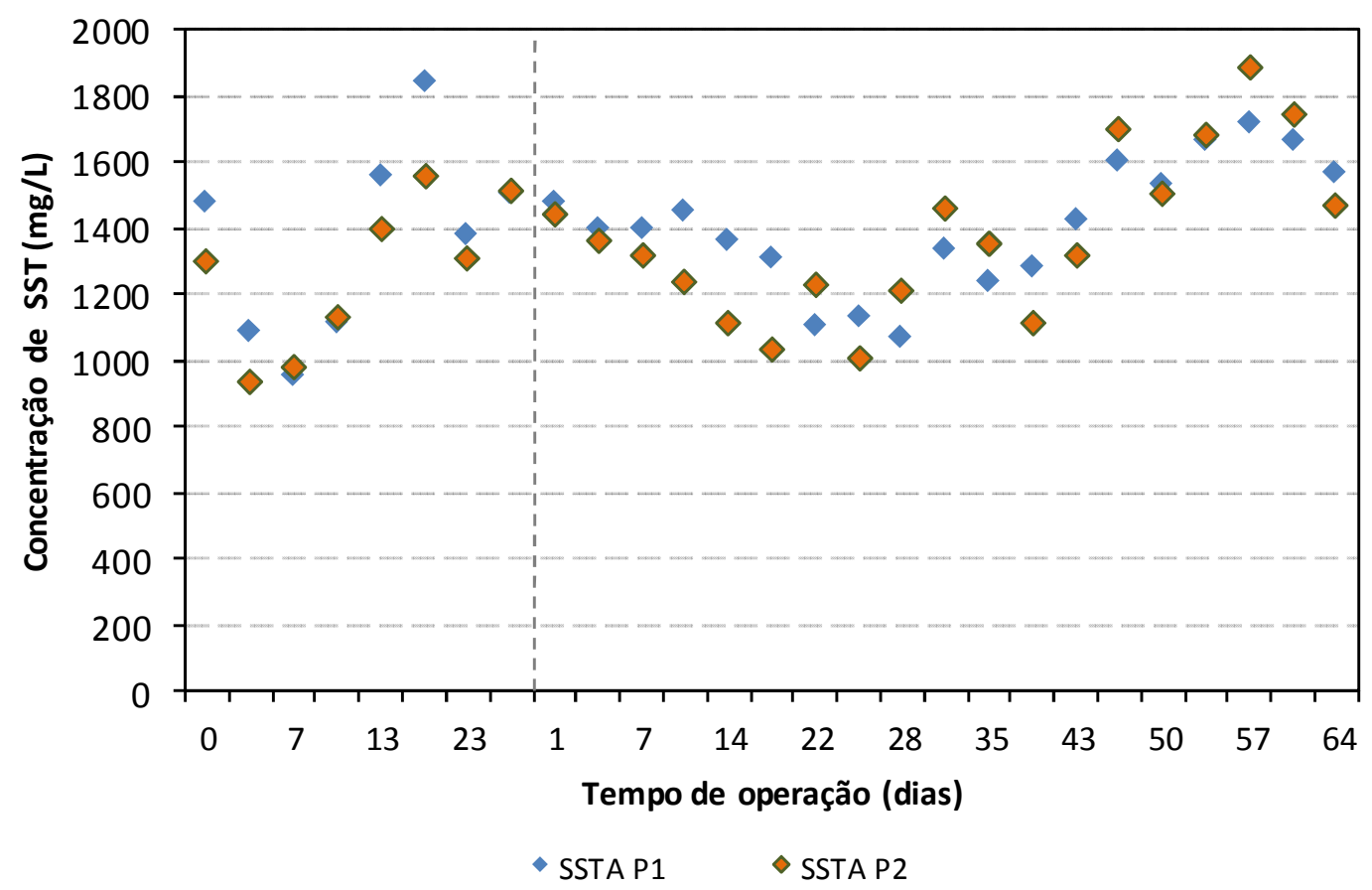

Figura 5.55 - Variação da concentração de SST no tanque de aeração dos reatores tratando esgoto sanitário com $2 \%(\mathrm{P} 1)$ e $0 \%$ (P2-controle) de lixiviado pré-tratado no experimento em escala piloto.

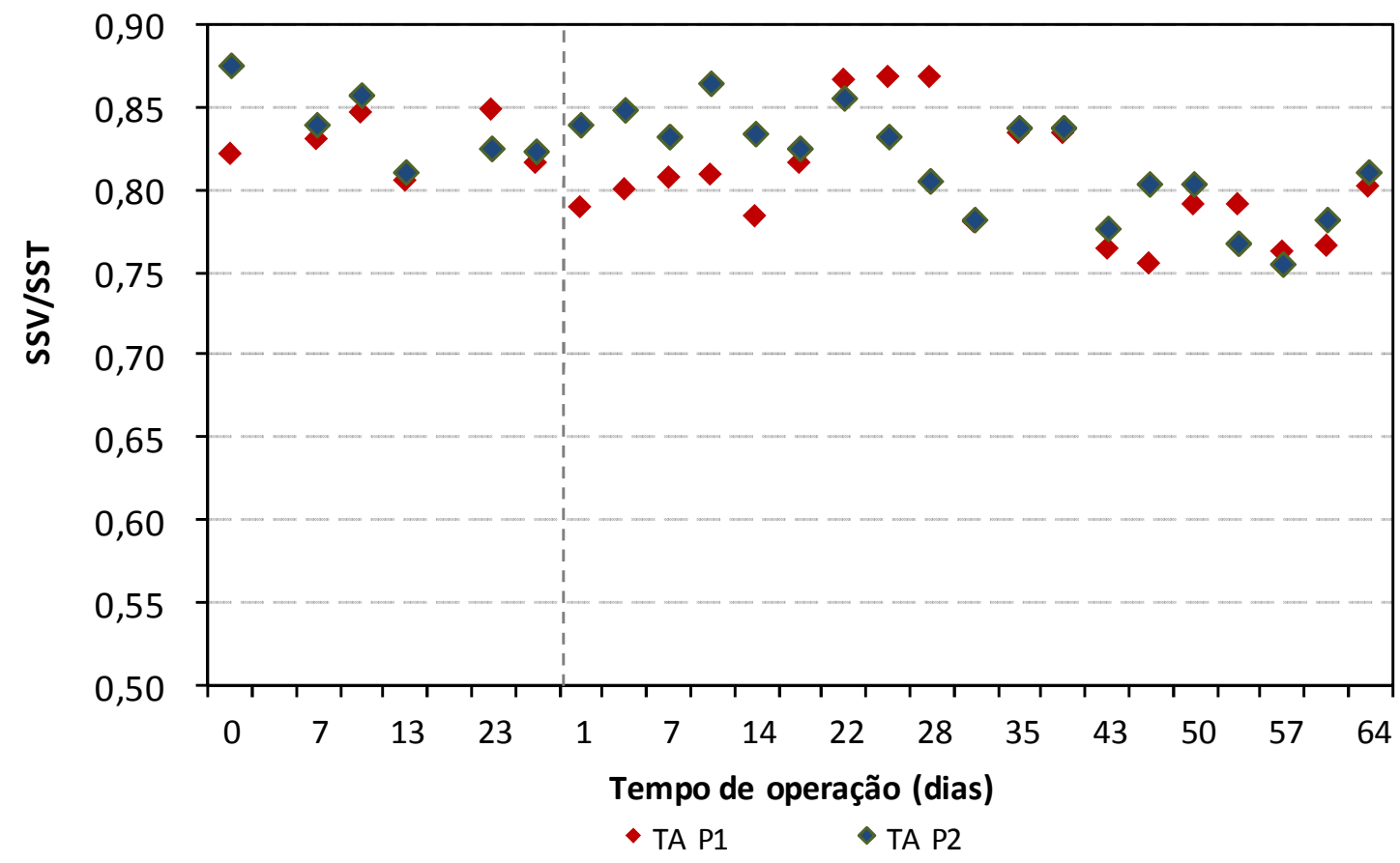

Figura 5.56 - Variação da relação SSV/SST no tanque de aeração dos reatores tratando esgoto sanitário com 2\% (P1) e 0\% (P2-controle) de lixiviado pré-tratado no experimento em escala piloto. 
Uma relação SSV/SST de 0,81 indica elevada fração orgânica na composição do lodo, ou seja, o lodo é pouco mineralizado e com elevada proporção de sólidos microbianos (biomassa), conforme critério adotado por (Mendonça, 2002).

Os gráficos da Figura 5.57 indicam a variação dos valores de IVL para os reatores $\mathrm{P} 1$ e $\mathrm{P} 2$.

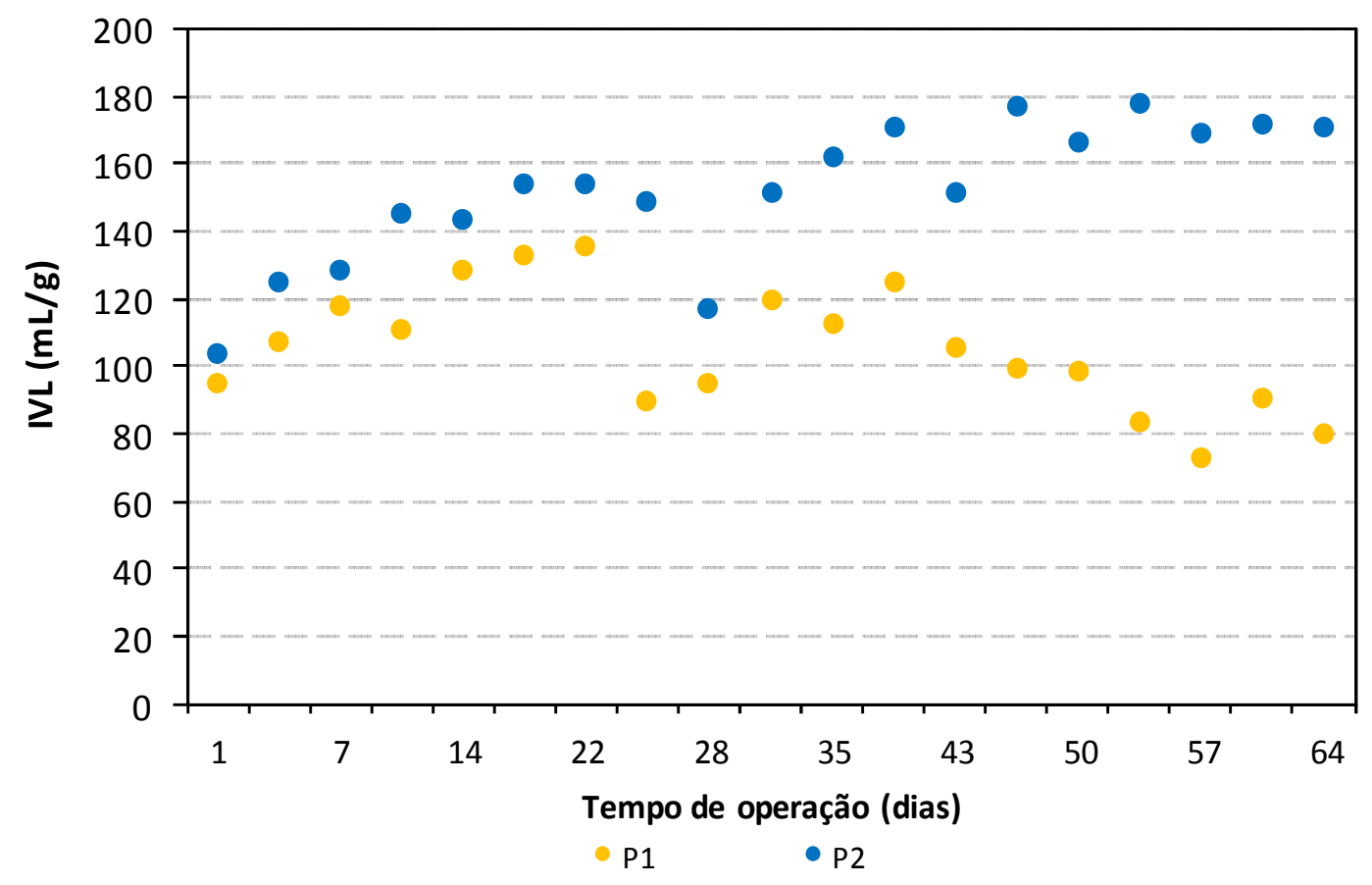

Figura 5.57 - Variação dos valores de IVL dos reatores tratando esgoto sanitário com $2 \%$ (P1) e $0 \%$ (P2-controle) de lixiviado pré-tratado no experimento em escala piloto.

Os valores médios de IVL do lodo no reator com esgoto sanitário e $2 \%$ (P1) e 0\% (P2-controle) de lixiviado variaram entre 70 e $140 \mathrm{~mL} / \mathrm{g}$, com média em torno de $105 \mathrm{~mL} / \mathrm{g}$.

Os valores médios de IVL do lodo no reator P2(controle) variaram entre $100 \mathrm{e}$ $180 \mathrm{~mL} / \mathrm{g}$, com média em torno de $152 \mathrm{~mL} / \mathrm{g}$. Pode-se observar no gráfico que os valores de IVL de P2 se mantiveram sempre superiores aos de P1.

Segundo Parker (2001) e Jordão e Pessôa (2005), valores de IVL na faixa de 40 a $150 \mathrm{~mL} / \mathrm{g}$ indicam geralmente uma boa qualidade do lodo biológico formado. Desta forma, valores fora desta faixa podem comprometer a sedimentabilidade do lodo e com isso o bom funcionamento do sistema de lodos ativados. Wanner et al. (1998) afirmaram que valores de IVL maiores que $200 \mathrm{~mL} / \mathrm{g}$ indicam frequência de aparecimento de filamentos variando de muito comuns a abundante. 
A partir de determinado momento, observou-se constante elevação dos valores de IVL no reator P2(controle). Vale ressaltar que esse aumento também foi acompanhado pela elevada frequência de microrganismos filamentosos, chegando a ser abundantes em alguns períodos da semana, conforme será discutido posteriormente.

Essa elevação dos valores de IVL no reator P2, associada ao aumento da frequência de microrganismos filamentosos, pode estar associada a maiores taxas de desnitrificação, conforme observado no aumento da eficiência de remoção de N-total no mesmo período. Conforme relação abordada por Jordão e Pessoa (2009), menores valores da relação $\mathrm{A} / \mathrm{M}$ estão relacionados à má sedimentabilidade e altos valores de IVL. A menor carga orgânica neste reator também pode ter favorecido a ocorrência de nitrificação e, com isso, de desnitrificação, criando condições favoráveis para abundância de microrganismos filamentosos.

A Figura 5.58 apresenta um dos testes de sedimentabilidade, evidenciando a diferença do volume de sólidos sedimentáveis entre os reatores.
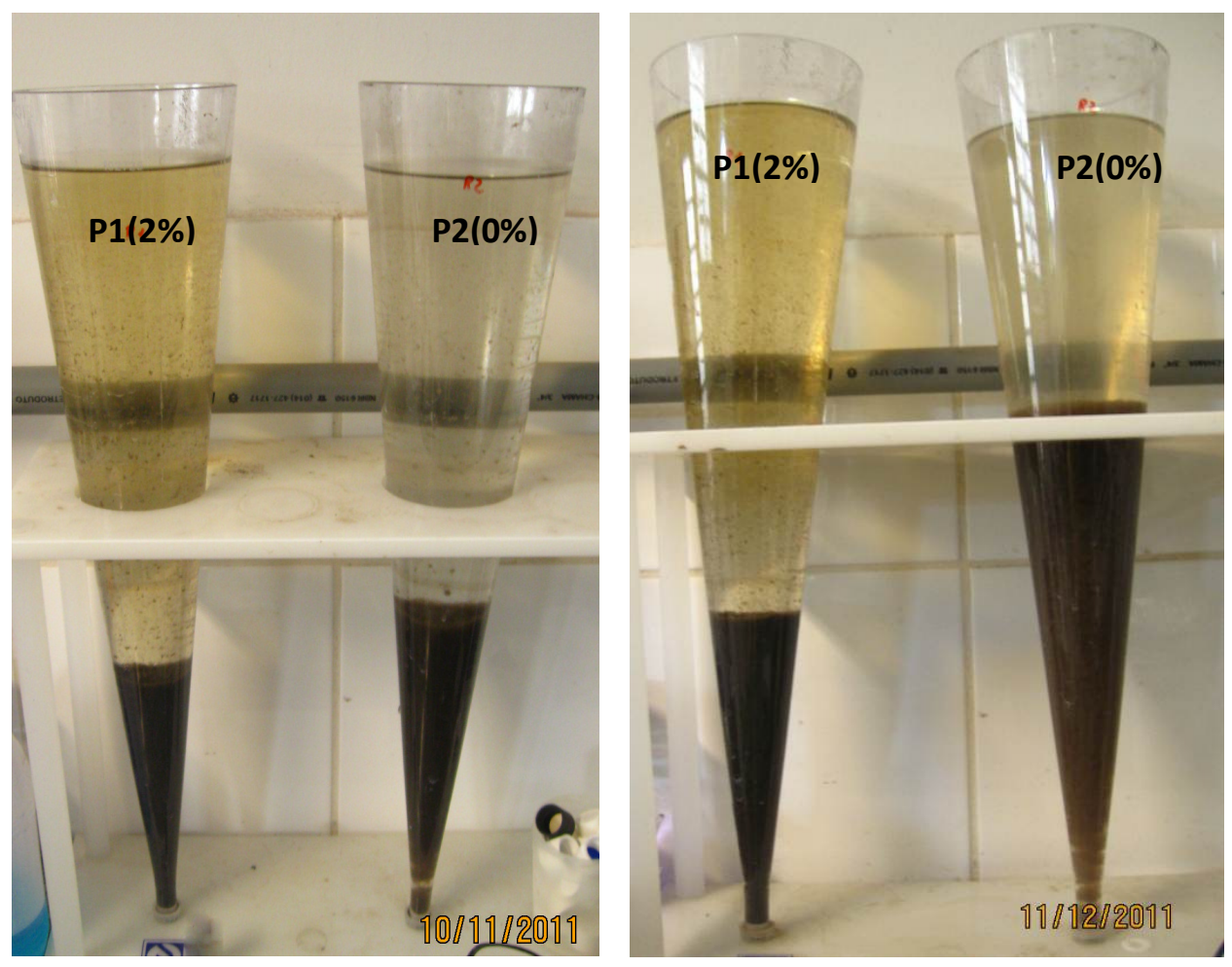

Figura 5.58 - Testes de sedimentabilidade com amostras do tanque de aeração dos reatores tratando esgoto sanitário com 2\% (P1) e 0\% (P2-controle) de lixiviado prétratado no experimento em escala piloto.

Os gráficos "boxplot" da Figura 5.59 apresentam a variação e resumo das análises estatísticas dos valores de IVL nos reatores P1 e P2. 


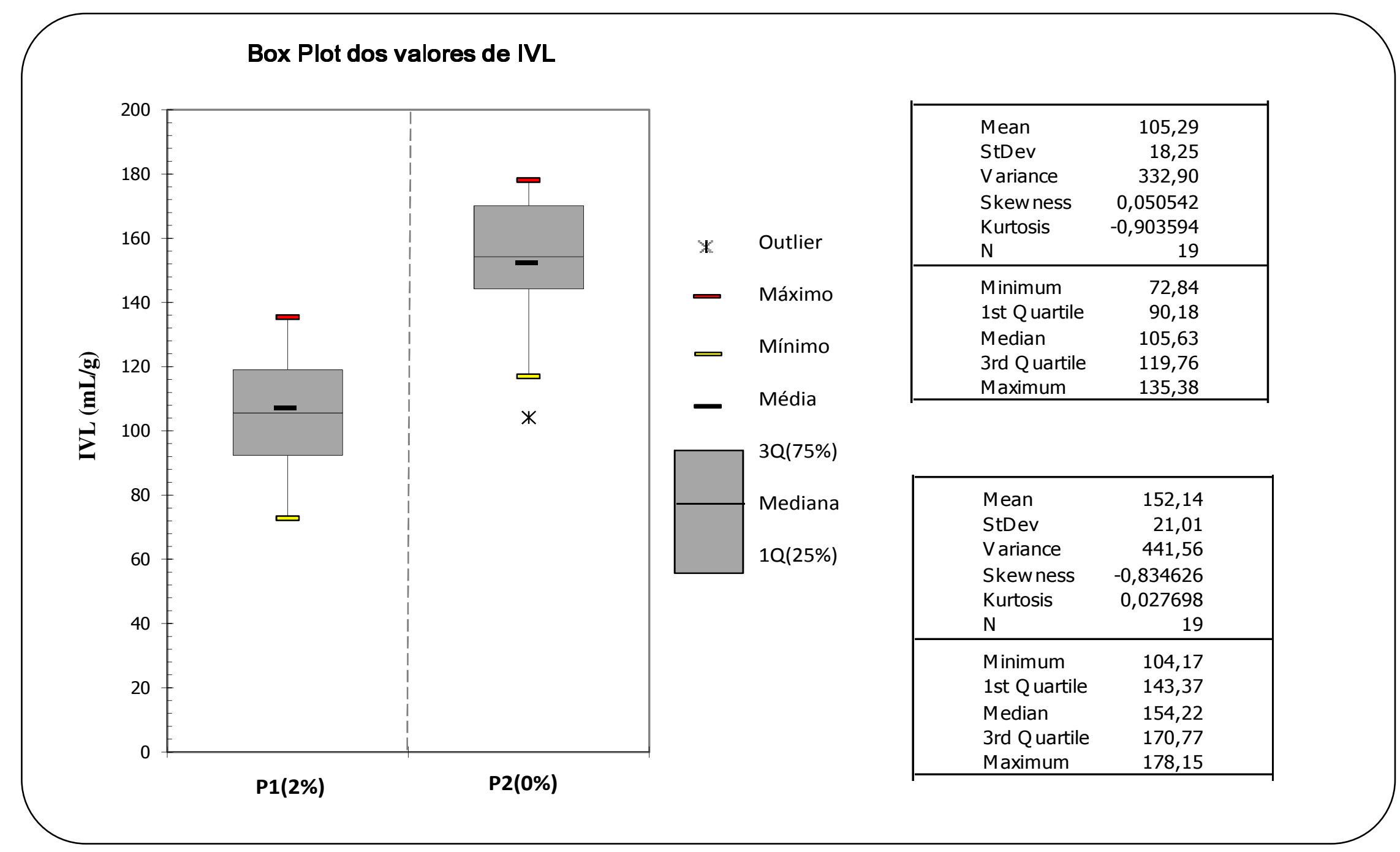

Figura 5.59 - Gráfico Boxplot dos valores de IVL e medidas estatísticas dos reatores de lodos ativados tratando esgoto sanitário e $2 \%$ (P1) e 0\% (P2-controle) de lixiviado pré-tratado do experimento em escala piloto. 
Os gráficos da Figura 5.60 apresentam a variação da relação A/M, em função da DQO solúvel e da DBO, respectivamente, nos reatores P1 e P2.
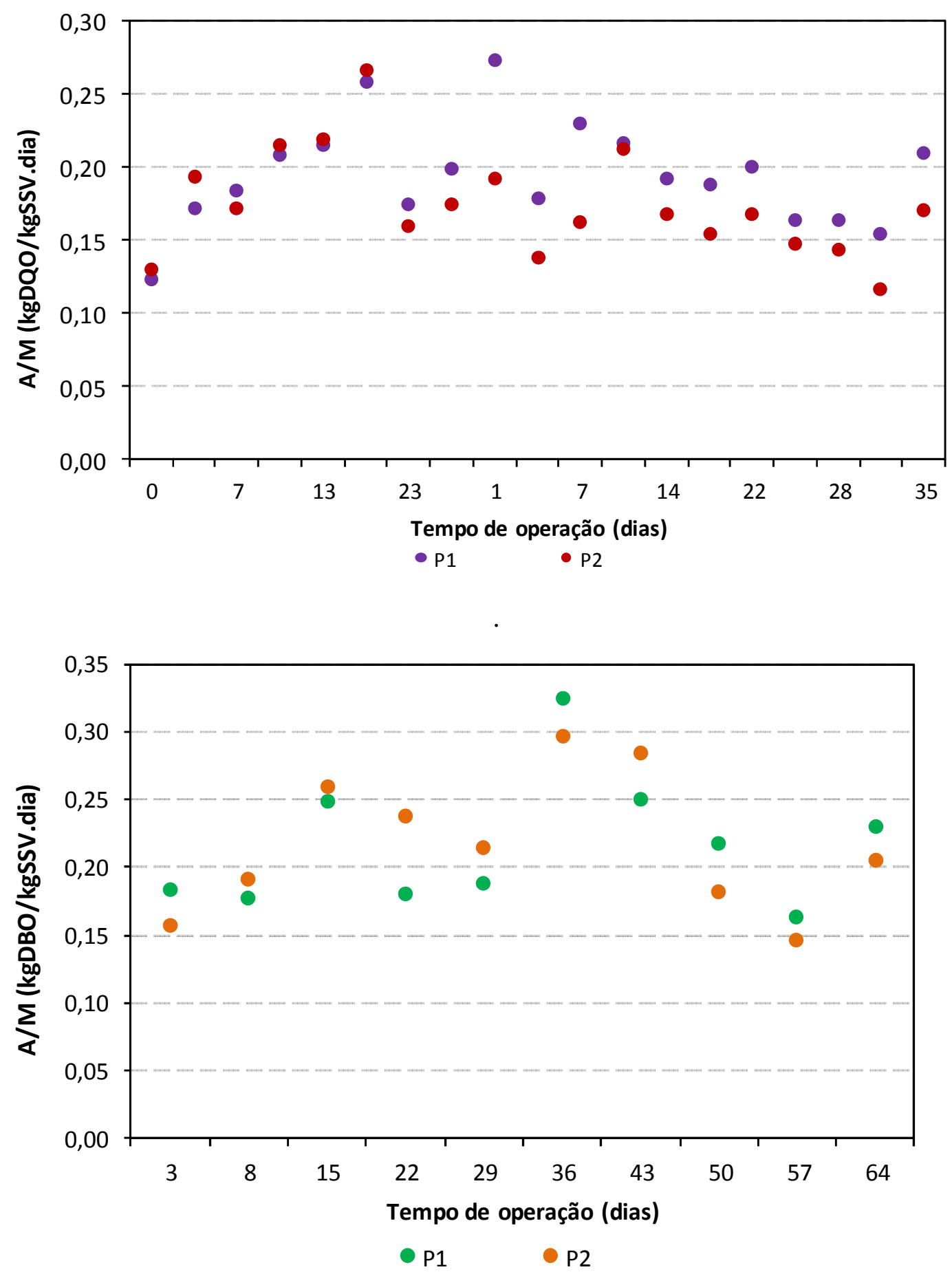

Figura 5.60 - Variação da relação A/M em função da DQO solúvel e da DBO nos reatores tratando esgoto sanitário com $2 \%$ (P1) e 0\%(P2-controle) de lixiviado prétratado do experimento em escala piloto 
A relação A/M nos dois reatores em escala piloto variou de 0,15 e 0,35 , quando calculado em função da DBO, com uma relação A/M média de $0,22 \mathrm{kgDBO} / \mathrm{kgSSV}$.dia em ambos os reatores.

Em função da DQO solúvel, os valores variaram de 0,12 a 0,27, com média de 0,20 e 0,18 kgDQO/kgSSV.dia, no reator com 2\% (P1) e 0\% (P2-controle) de lixiviado do experimento em escala piloto.

Os valores de $\mathrm{A} / \mathrm{M}$ em $\mathrm{P} 1$ se mantiveram superiores na maior parte da operação em relação aos de $\mathrm{P} 2$, o que é coerente pela maior concentração de matéria orgânica na mistura esgoto mais lixiviado.

Pela análise estatística, é possível observar que a maior parte dos valores da relação $\mathrm{A} / \mathrm{M}$ dos reatores estão em faixa intermediária entre a faixa de operação da modalidade aeração prolongada e lodos ativados convencional. No entanto, a idade do lodo em torno de 20 dias e o TDH de 24 horas são características de sistemas de lodos ativados de aeração prolongada.

As Figuras 5.61 e 5.62 apresentam o comportamento da concentração de SST no afluente e efluente dos reatores em escala piloto.

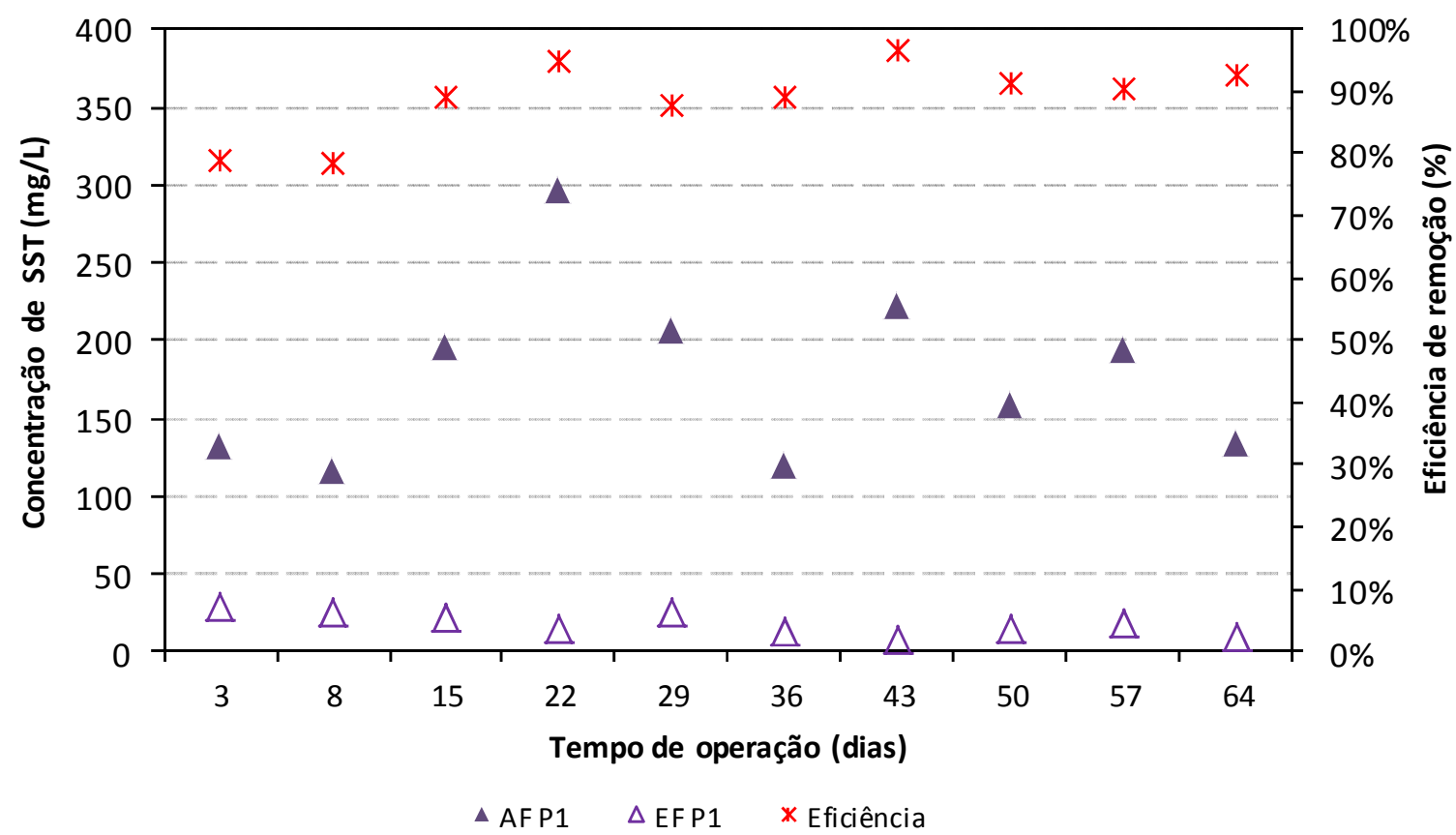

Figura 5.61 - Comportamento das concentrações de SST no afluente e efluente e eficiências de remoção no reator tratando esgoto sanitário com $2 \%$ (P1) de lixiviado pré-tratado do experimento em escala piloto. 
Com relação à remoção de SST, a concentração no afluente do reator com $2 \%$ (P1) de lixiviado variou de 100 a $300 \mathrm{mg} / \mathrm{L}$, com média de $177 \mathrm{mg} / \mathrm{L}$. A eficiência média de remoção de SST foi de $89 \%$, com concentração efluente abaixo de $28 \mathrm{mg} / \mathrm{L}$ e média de $18 \mathrm{mg} / \mathrm{L}$.

A concentração afluente do reator com $0 \%$ (P2-controle) de lixiviado também variou de 100 a $300 \mathrm{mg} / \mathrm{L}$, com média de $179 \mathrm{mg} / \mathrm{L}$. A eficiência média de remoção de SST no reator P2 foi superior à de P1,94\%, com concentração efluente média de 12 $\mathrm{mg} / \mathrm{L}$.

As eficiências médias de remoção de SST alcançadas pelos dois reatores estão dentro da faixa usual de sistemas de lodos ativados, que segundo Von Sperling (2002), varia de 85 a $95 \%$ de remoção.

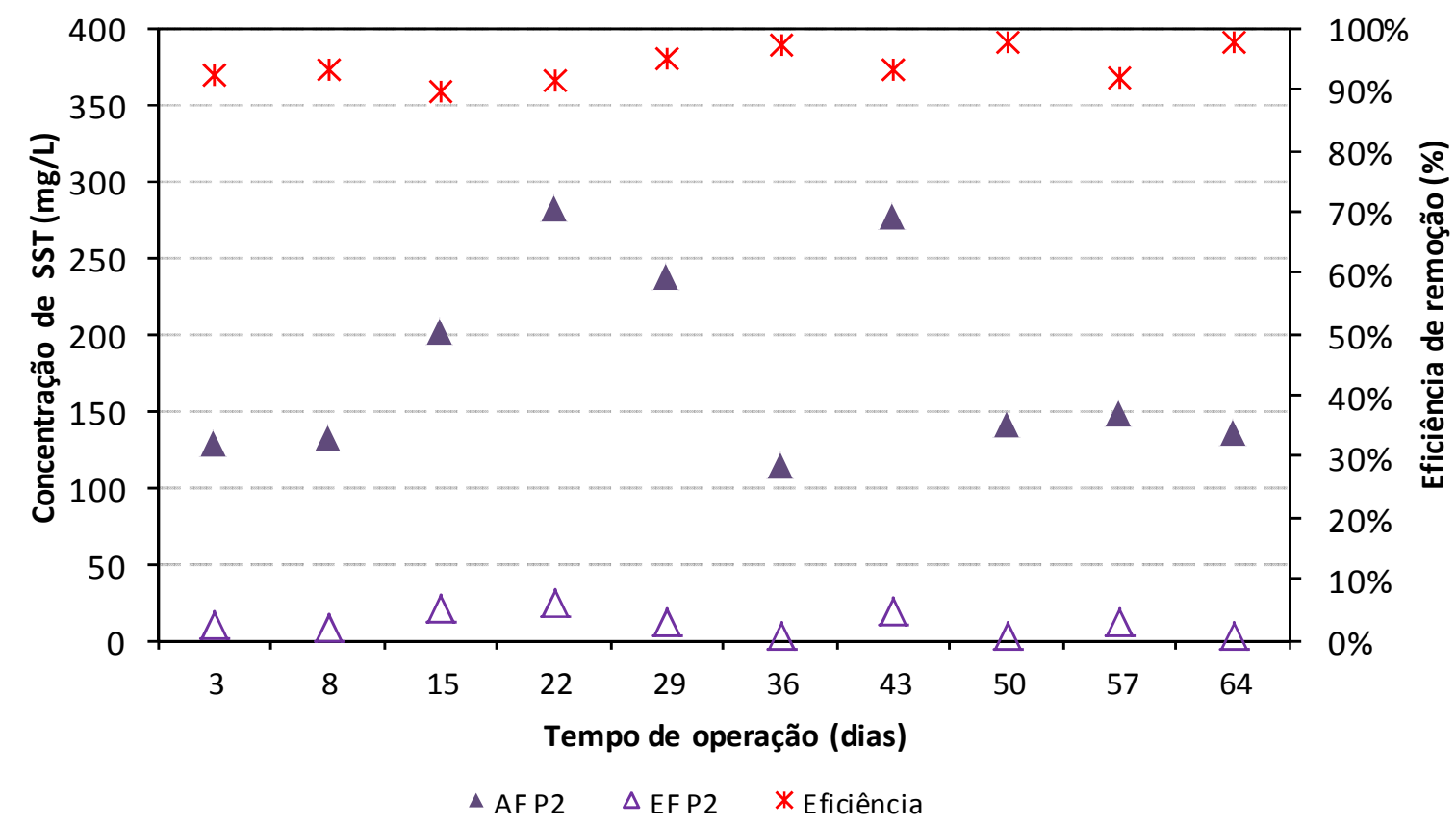

Figura 5.62 - Comportamento das concentrações de SST no afluente e efluente e eficiências de remoção no reator tratando esgoto sanitário com $0 \%$ (P2-controle) de lixiviado pré-tratado do experimento em escala piloto.

As Figuras 5.63 e 5.64 apresentam o comportamento da concentração de ST no afluente e efluente dos reatores em escala piloto. 


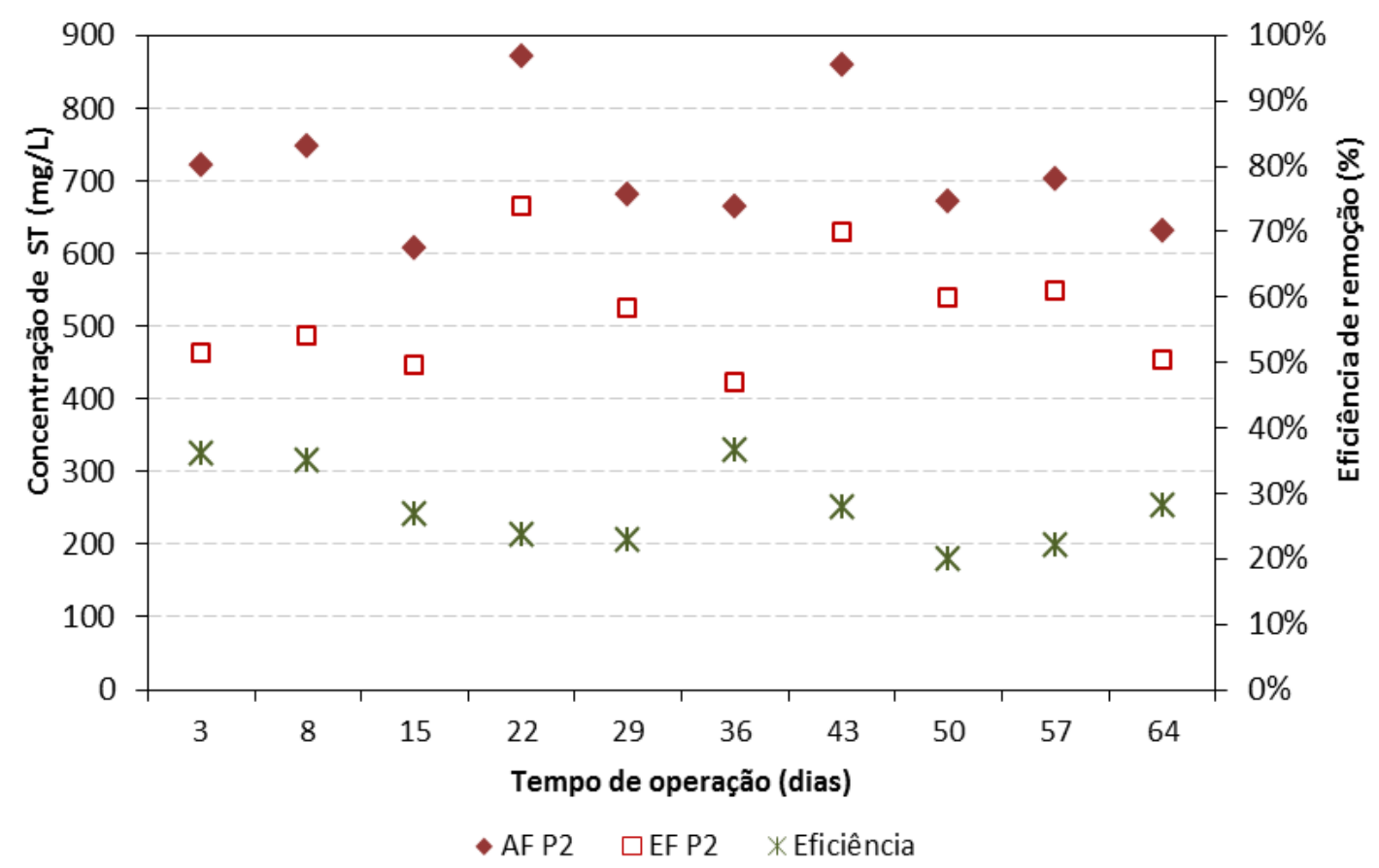

Figura 5.63 - Comportamento das concentrações de ST no afluente e efluente e eficiências de remoção no reator tratando esgoto sanitário com $2 \%(\mathrm{P} 1)$ de lixiviado pré-tratado do experimento em escala piloto.

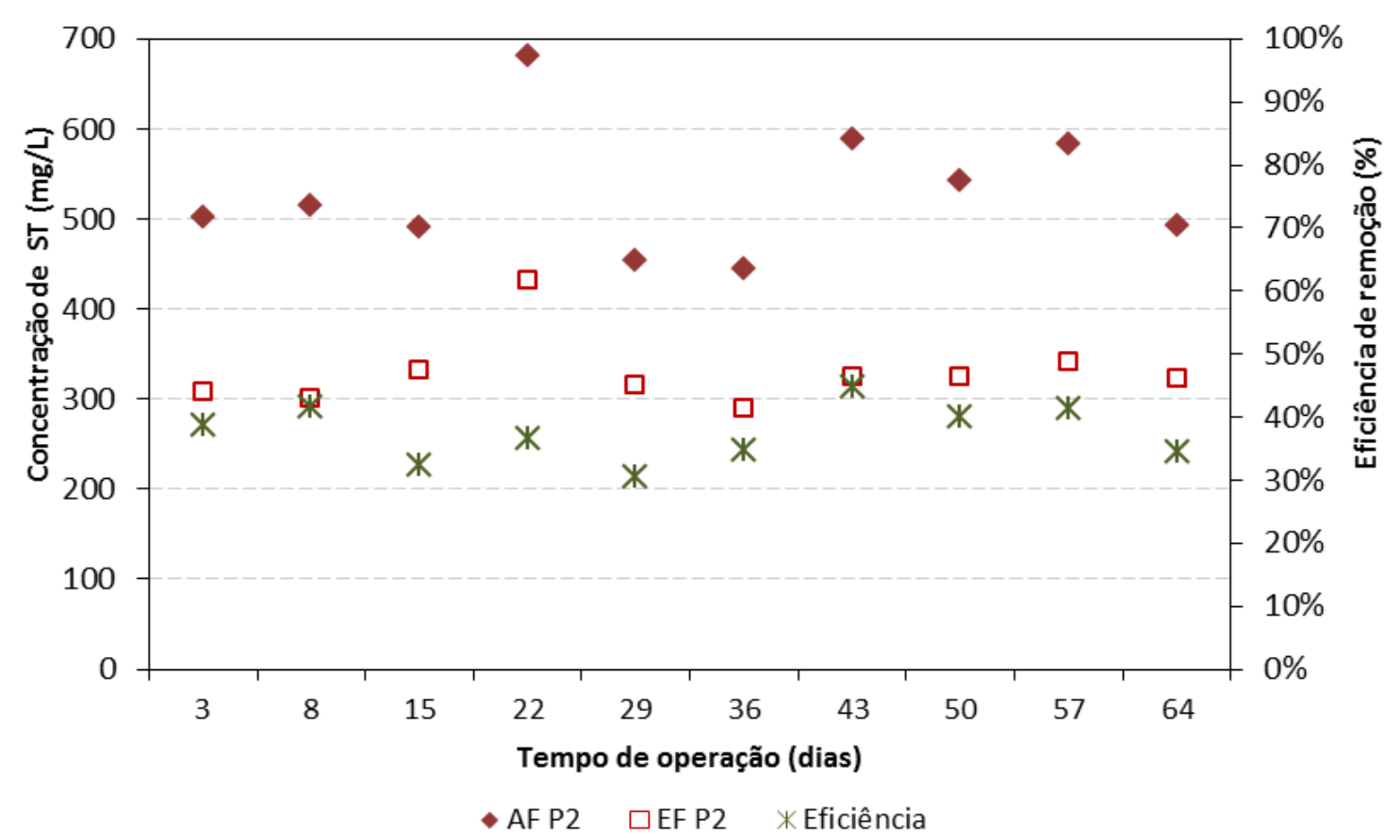

Figura 5.64 - Comportamento das concentrações de ST no afluente e efluente e eficiências de remoção no reator no reator tratando esgoto sanitário com 0\% (P2controle) de lixiviado pré-tratado do experimento em escala piloto. 
A concentração afluente do reator com $2 \%$ de lixiviado pré-tratado (P1) variou de 600 a 900 mg/L, com média de 716 mg/L. A eficiência média de remoção de SST no reator P1 de 28\%, com concentração efluente média de $517 \mathrm{mg} / \mathrm{L}$.

Com relação ao reator $0 \%$ de lixiviado (P2-controle), a concentração afluente do reator variou de 400 a $700 \mathrm{mg} / \mathrm{L}$, com média de $529 \mathrm{mg} / \mathrm{L}$. A eficiência média de remoção de ST no reator P1 de 38\%, com concentração efluente média de 329 mg/L.

Assim como a eficiência de remoção de SST, o reator P2(0\%) alcançou maiores eficiências de remoção de ST.

\subsubsection{Metais pesados}

No experimento em escala piloto também foram determinadas as concentrações de alguns metais pesados ( $\mathrm{Zn}, \mathrm{Pb}, \mathrm{Cd}, \mathrm{Ni}, \mathrm{Fe}, \mathrm{Mn}, \mathrm{Cu}, \mathrm{Cr}$ ) nas fases sólidas (lodo) e

líquidas (afluente e efluente). Pela dificuldade de observar alguma tendência com apenas análises pontuais como foi feito nos experimentos de bancada, neste experimento optou-se em monitorar a variação da concentração de metais a cada 10 dias. Todos os resultados dessas análises encontram-se no anexo B.

Essas análises foram realizadas com intuito de monitorar a qualidade do lodo aeróbio do sistema, verificando a sua conformidade com os critérios estabelecidos para uso agrícola (Resolução 380/06 do CONAMA) e tentar verificar a possibilidade de acúmulo de metais pesados na biomassa de sistemas biológicos decorrente da adição de lixiviado.

As Figuras 5.65 a 5.67 apresentam os gráficos das concentrações de metais pesados no lodo dos reatores com $2 \%(\mathrm{P} 1)$ e $0 \%(\mathrm{P} 2)$ de lixiviado, termos da massa seca. As concentrações apresentadas no gráfico são relativas ao inóculo e às amostras coletadas a cada 10 dias de operação de cada experimento para cada proporção.

Os resultados indicam concentrações de manganês (Mn) em torno de $100 \mathrm{mg} / \mathrm{kg}$ de lodo seco em ambos os reatores, com variação muito similiar nas duas condições.

Comparando-se as concentrações de cobre $(\mathrm{Cu})$ nos reatores, Pode-se observar nitidamente as maiores concentrações desse metal no reator P1(2\%), cuja concentração foi de $495 \mathrm{mg} / \mathrm{kg}$ no $65^{\circ}$ dia de operação, enquanto no reator com $0 \%$ de lixiviado (P2controle) essa concentração foi de $340 \mathrm{mg} / \mathrm{kg}$. 
As concentrações de zinco $(\mathrm{Zn})$ também foram maiores no reator P1(2\%), apresentando tendência cumulativa desse metal no lodo deste reator. A concentração de zinco variou em torno de $400 \mathrm{mg} / \mathrm{kg}$ no reator com $0 \%$ de lixiviado (P2-controle) enquanto que no reator com $2 \%(\mathrm{P} 1)$ de lixiviado, a concentração final foi próxima de $600 \mathrm{mg} / \mathrm{kg}$ de lodo seco.

A mesma tendência de acúmulo de zinco e cobre na fase sólida também foi verificada por Avezzù, et al. (1995) no lodo de sistema de lodos ativados tratando lixiviados de diferentes aterros sanitários, apesar de não ter constatado efeitos significativos sobre a eficiência de remoção da DBO e DQO no sistema.

As maiores concentrações de cobre e zinco encontradas são devidas à solubilidade desses metais pesados em esgoto sanitário em, conforme verificado por Brown \& Lester (1979) Jenkins et al. (1981) e podem estar relacionadas ao acúmulo por adsorção na biomassa, conformou verificado por Chipasa (2003).

Rudolfs \& Zuber (1953) constatou uma correlação entre decréscimo do IVL com aumento da concentração de metais pesados no lodo de sistema de lodos ativados. A tendência de decréscimo dos valores de IVL no final da operação do reator com $2 \%$ (P1) de lixiviado pode estar relacionada à absorção de zinco e cobre na biomassa.

Foi constatado comportamento muito similar quanto à variação da concentração de cromo $(\mathrm{Cr})$ e cádmio $(\mathrm{Cd})$ nos reatores. Observou-se uma tendência de decréscimo da concentração dos dois metais no lodo, com concentração final de cromo em torno de $40 \mathrm{mg} / \mathrm{kg}$ e não foi detectado cádmio no lodo nas últimas 3 semanas nos dois reatores.

Quanto ao níquel (Ni), no reator com $2 \%$ de lixiviado pré-tratado (P1) a concentração desse metal permaneceu em torno de $30 \mathrm{mg} / \mathrm{kg}$. Observou-se maior oscilação na concentração de níquel no reator controle, com picos de até $70 \mathrm{mg} / \mathrm{kg}$. No entanto não foi possível constatar nenhuma tendência quanto ao comportamento da concentração desse metal na fase sólida dos reatores.

Comparando-se as concentrações de chumbo $(\mathrm{Pb})$ nos reatores, pode-se observar uma leve tendência de maiores concentrações desse metal ao longo da operação do reator P1(2\%), cuja concentração no último dia de operação foi de $76 \mathrm{mg} / \mathrm{kg}$, enquanto no reator com $0 \%$ de lixiviado (P2-controle) essa concentração foi de $64 \mathrm{mg} / \mathrm{kg}$. 

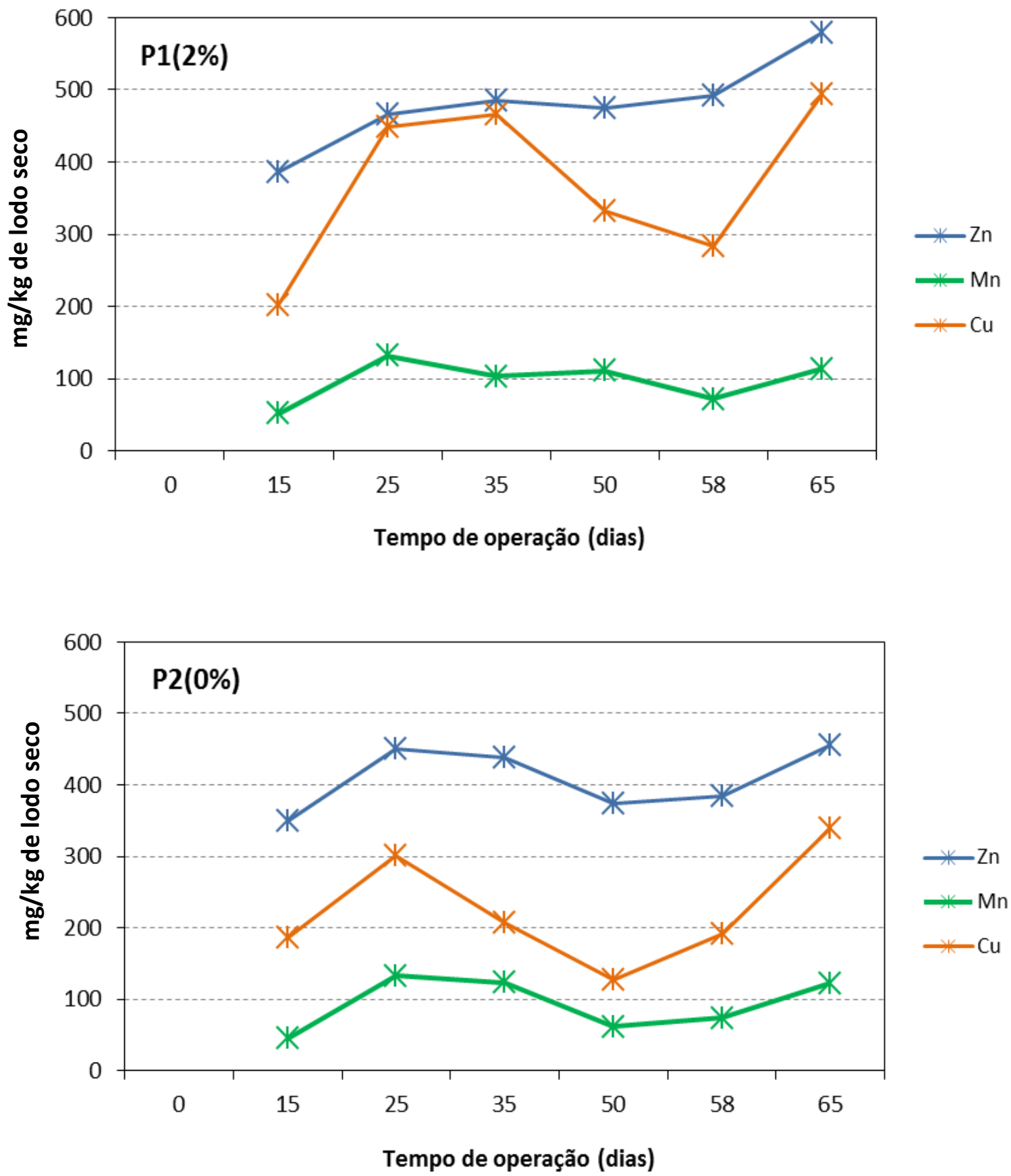

Figura 5.65 - Concentração de metais ( $\mathrm{Zn}, \mathrm{Mn}, \mathrm{Cu})$, em termos da massa seca de lodo (ST) dos reatores tratando esgoto sanitário com $2 \%(\mathrm{P} 1)$ e $0 \%(\mathrm{P} 2)$ de lixiviado prétratado do experimento em escala piloto.

Em geral, as concentrações de zinco e cobre no lodo do reator com $2 \%$ (P1) de lixiviado foi superior às concentração desses metais nos reatores de bancada e no reator com $0 \%$ (P2-controle). 

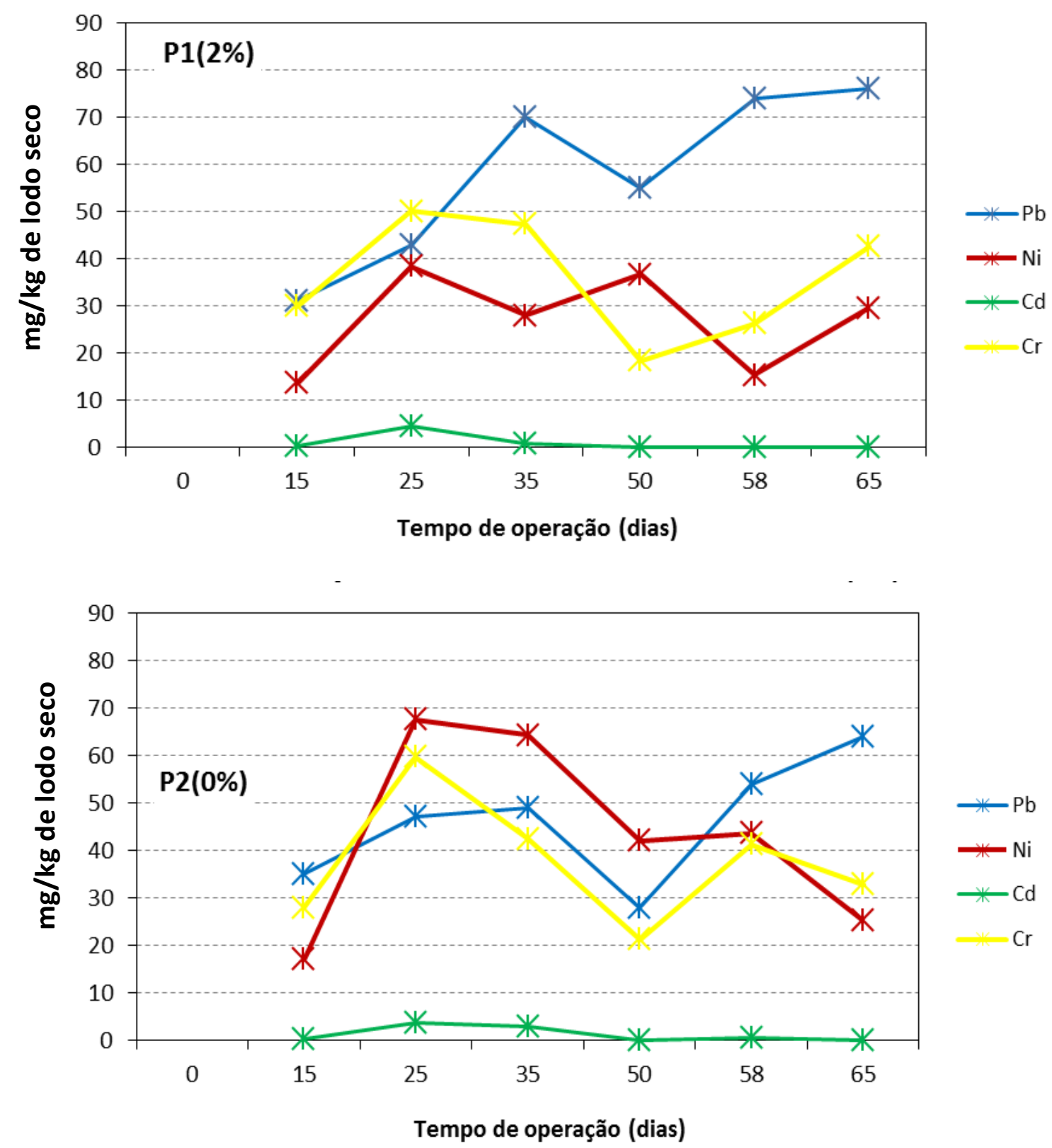

Figura 5.66 - Concentração de metais ( $\mathrm{Pb}, \mathrm{Ni}, \mathrm{Cd}, \mathrm{Cr})$ em termos da massa seca de lodo (ST) dos reatores tratando esgoto sanitário com 2\% (P1) e 0\% (P2-controle) de lixiviado pré-tratado do experimento em escala piloto.

A mesma tendência do aumento de concentração de chumbo $(\mathrm{Pb})$ na biomassa de lodos ativados em escala plena foi verificada por Chipasa (2003), após 2 anos de monitoramento. O mesmo autor também constatou variação positiva mais nítida na concentração de zinco $(\mathrm{Zn})$ e cobre $(\mathrm{Cu})$, enquanto para o chumbo $(\mathrm{Pb})$ essa variação foi menos visível, o que condiz com os resultados obtidos neste estudo. 


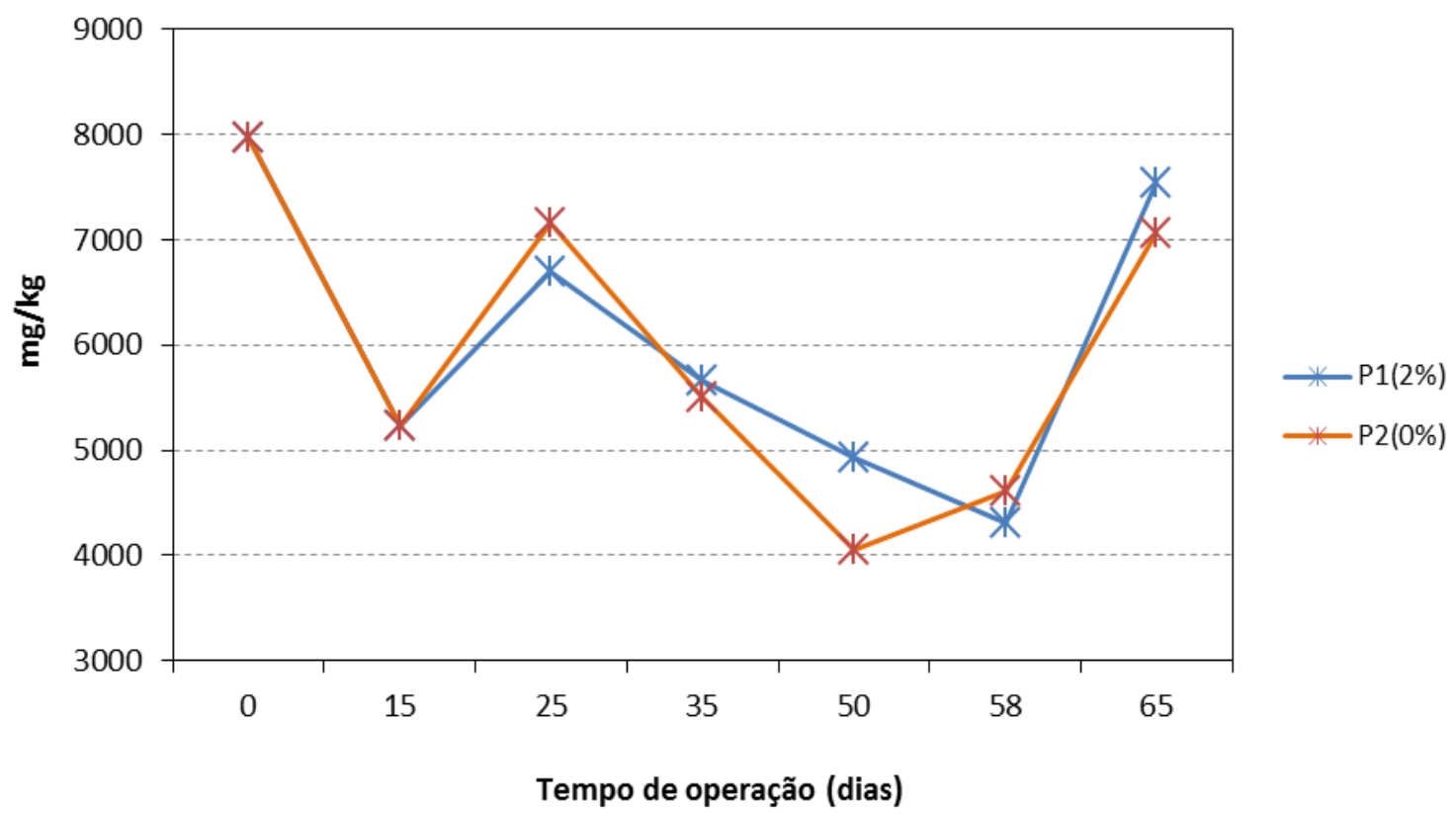

Figura 5.67 - Concentração de ferro (Fe) em termos da massa seca de lodo (ST) dos reatores tratando esgoto sanitário com $2 \%(\mathrm{P} 1)$ e $0 \%$ (P2-controle) de lixiviado prétratado do experimento em escala piloto.

A variação da concentração de ferro $(\mathrm{Fe})$ foi muito similar nos dois reatores. A partir dos resultados não foi possível verificar nenhuma tendência quanto ao comportamento da concentração desse metal no lodo dos reatores. A concentração inicial e final de ferro no lodo dos reatores foi em torno de $8000 \mathrm{mg} / \mathrm{kg}$ de lodo seco.

O conteúdo de metais pesados encontrados no lodo seguiu a seguinte ordem crescente: $\mathrm{Cd}<\mathrm{Ni}<\mathrm{Cr}<\mathrm{Pb}<\mathrm{Mn}<\mathrm{Cu}<\mathrm{Zn}<\mathrm{Fe}$. Diferentemente do resultado obtido nos experimentos em escala de bancada, nos quais a concentração de cobre $(\mathrm{Cu})$ superou à de zinco $(\mathrm{Zn})$ e a concentração de cromo $(\mathrm{Cr})$ superou à de manganês $(\mathrm{Mn})$ e de chumbo $(\mathrm{Pb})$.

No que tange aos requisitos mínimos de qualidade do lodo de esgoto destinado à agricultura, definidos pela resolução CONAMA n 375/2006 através do art. 11, todas as amostras de lodo dos experimentos de bancada respeitaram os limites máximos de concentração dos metais pesados analisados e contemplados pela resolução. É importante salientar que a resolução não impõe limites máximos de concentração para os metais ferro (Fe), manganês (Mn).

Vale ressaltar, no entanto, que a mesma resolução impõe ainda limites máximos de concentração dos metais arsênio, bário, mercúrio, molibdênio, selênio, os quais não foram analisados neste estudo. 


\subsubsection{Parâmetros cinéticos}

\subsubsection{Taxa de Consumo de Oxigênio específica (TCO)}

A verificação de efeitos tóxicos ao lodo aeróbio utilizando a respirometria tem se mostrado ser bastante confiável, uma vez que avaliada a taxa de consumo de oxigênio pelos microrganismos durante a oxidação da matéria orgânica, podendo informar sobre a atividade biológica destes (Santos, 2007).

Neste estudo foram realizados testes semanais para determinação da Taxa de Consumo de Oxigênio, a fim de se avaliar possível efeito tóxico proveniente do lixiviado sobre a atividade microbiana aeróbia no sistema de lodos ativados em escala piloto. Vale ressaltar, no entanto, que esses testes foram realizados somente a partir da $4^{\mathrm{a}}$ semana de operação dos reatores.

A Figura 5.68 apresenta a variação dos valores da TCO ao longo da operação dos reatores em escala piloto.

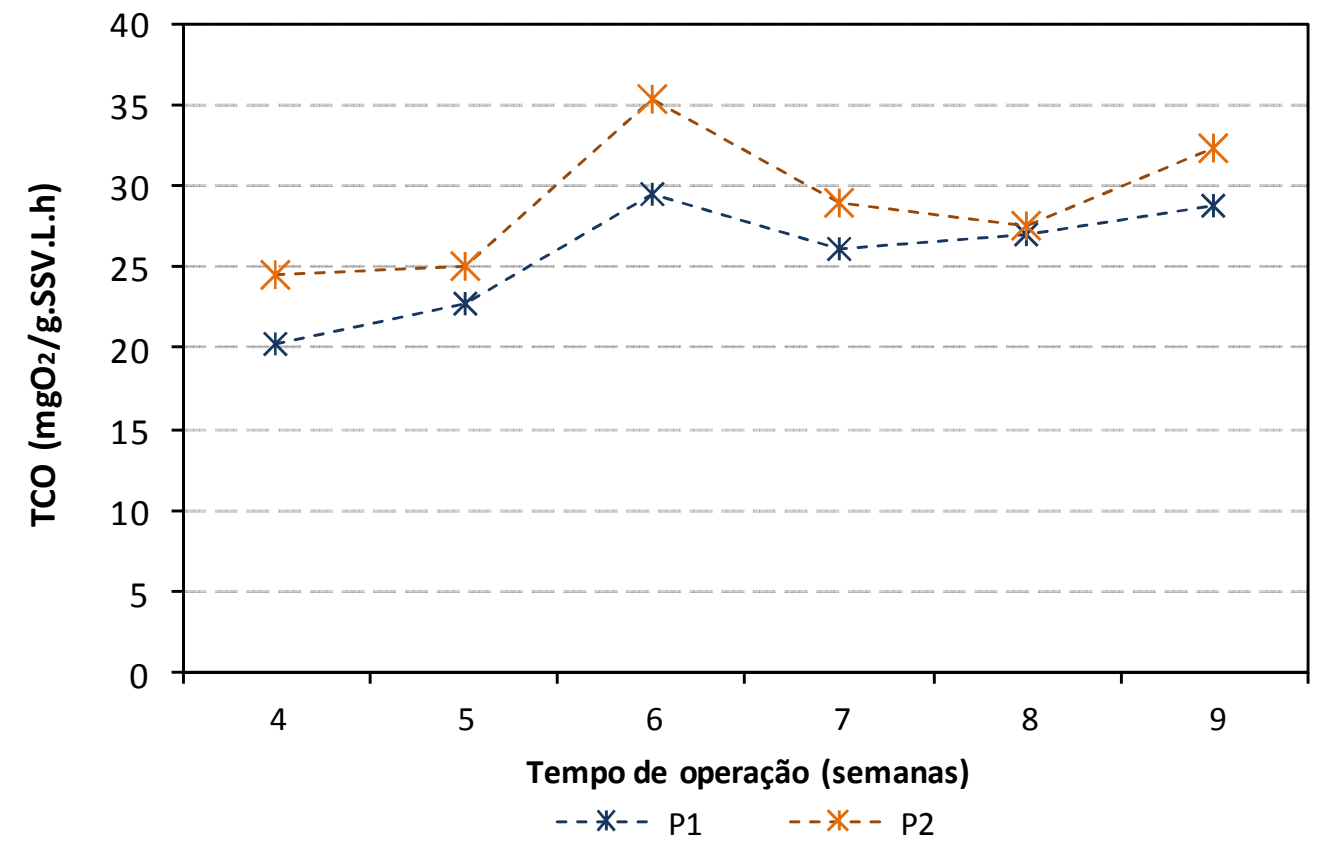

Figura 5.68 - Variação dos valores da Taxa Específica de Consumo de Oxigênio (TCO) da biomassa dos reatores tratando esgoto sanitário com 2\% (P1) e 0\% (P2controle) de lixiviado pré-tratado do experimento em escala piloto. 
Conforme gráficos da Figura 5.68, os valores da TCO variaram entre 20 e 36 $\mathrm{mgO}_{2} / \mathrm{gSSV}$.L.h, com média de 25,7 e $29 \mathrm{mgO}_{2} / \mathrm{gSSV}$.L.h, nos reatores tratando $2 \%$ (P1) e $0 \%$ (P2-controle) de lixiviado, respectivamente. É possível observar que os valores de TCO específica no reator tratando $2 \%(\mathrm{P} 1)$ de lixiviado pré-tratado se mantiveram levemente menores que os do reator com $0 \%$ ( $\mathrm{P} 2$-controle), podendo indicar que a atividade biológica da biomassa foi ligeiramente superior no reator com 0\% de lixiviado ( $\mathrm{P} 2$-controle), apesar de essa diferença ser pequena.

Os valores obtidos neste estudo foram superiores aos obtidos por Franco (2009), cujas médias foram de 12,9 e 4,8 $\mathrm{mgO}_{2} / \mathrm{gSSV}$.L.h para as proporções volumétricas de 0,5 a $1 \%$ e 2 a $2,5 \%$ de lixiviado bruto, respectivamente, sendo mais nítido o decaimento desses valores com o aumento da proporção de lixiviado na mistura.

\subsubsection{Coeficiente Global de Transferência de Oxigênio (KLa)}

Em sistemas de lodos ativados é fundamental o conhecimento da real capacidade de transferência de oxigênio, nas condições de operação. O Coeficiente Global de Transferência de Oxigênio $\left(\mathrm{K}_{\mathrm{L}} \mathrm{a}\right)$ está diretamente relacionado com a taxa de transferência de oxigênio por aeradores e difusão deste na massa líquida, sofrendo interferência da temperatura, concentração de oxigênio dissolvido, características da água residuária, do aerador e configuração do reator (Von Sperling, 2003).

Neste estudo foram realizados testes semanais para determinação do Coeficiente Global de Transferência de Oxigênio $\left(\mathrm{K}_{\mathrm{L}} \mathrm{a}\right)$, a fim de se avaliar a capacidade de transferência e dispersão de oxigênio nos reatores. Vale ressaltar, no entanto, que esses testes foram realizados somente a partir da $4^{\mathrm{a}}$ semana de operação dos reatores. Todos os valores obtidos nos testes foram corrigidos para a temperatura padrão de $20^{\circ} \mathrm{C}$.

Diferentes valores de $\mathrm{K}_{\mathrm{L}} \mathrm{a}$ foram observados em outros estudos. Rodgers determinou $\mathrm{K}_{\mathrm{L}}$ a de 46,2 $\mathrm{h}^{-1}$ em processo aeróbio com suporte fixo. Viero determinou valores de $\mathrm{K}_{\mathrm{L}}$ a de 30 a $150 \mathrm{~h}^{-1}$ em bio-reator com membrana submersa. Em reator aeróbio de leito fixo em PVC Fica-Piras obteve valores de 6 a $12 \mathrm{~h}^{-1}$. Motta obteve valores de $\mathrm{K}_{\mathrm{L}}$ a na faixa de $8,4 \mathrm{~h}^{-1}$ para reator aeróbio com suporte fixo. Em reatores aeróbios de leito fluidizado em escala piloto, Gebara obteve valores entre 6 e $42 \mathrm{~h}^{-1}$. (Vendramel, 2004). 
A Figura 5.69 apresenta a variação dos valores corrigidos de $\mathrm{K}_{\mathrm{L}}$ a ao longo da operação dos reatores em escala piloto.

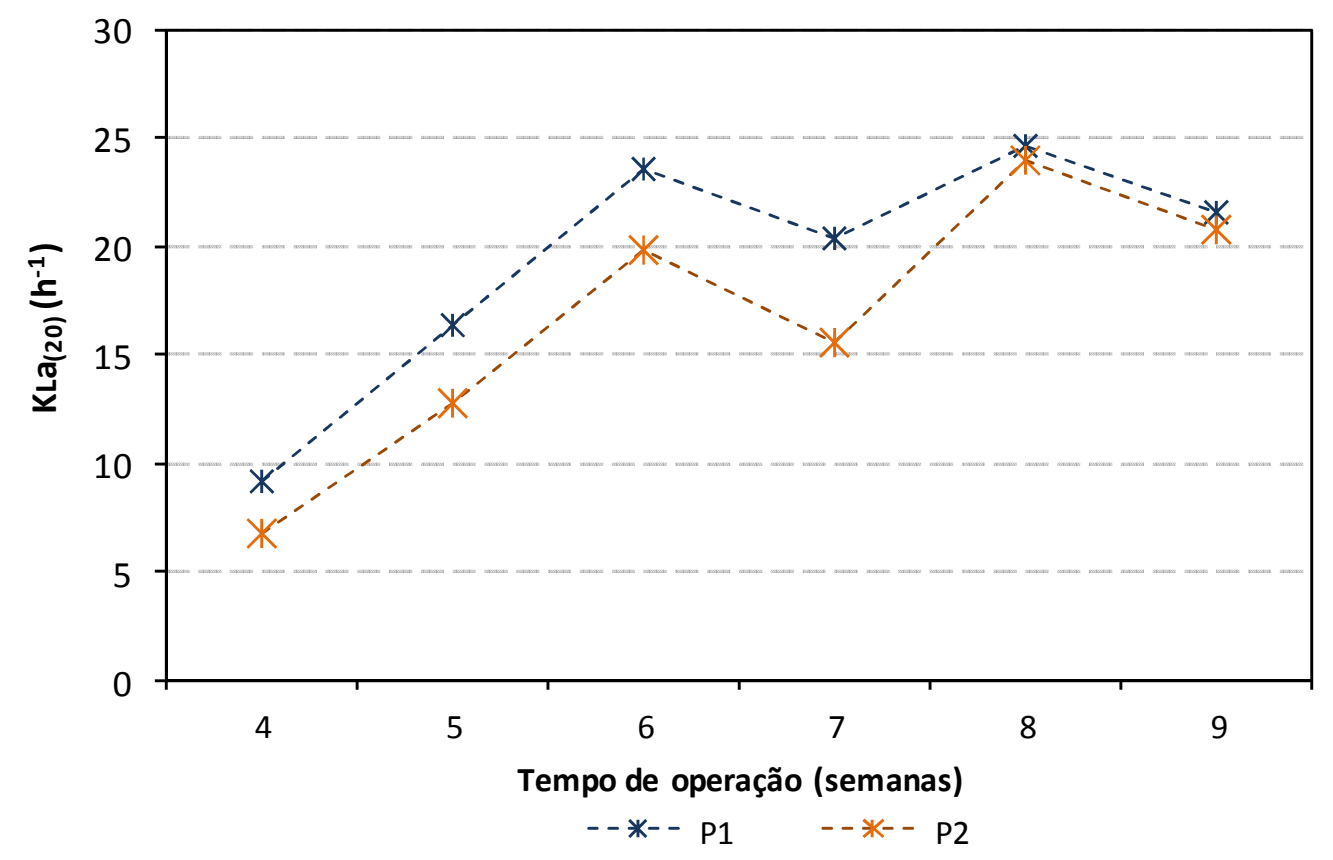

Figura 5.69 - Variação dos valores Coeficiente Global de Transferência de Oxigênio $\left(\mathrm{K}_{\mathrm{L}} \mathrm{a}\right)$ a $20^{\circ} \mathrm{C}$, na massa líquida dos reatores tratando esgoto sanitário com $2 \%$ (P1) e $0 \%$ (P2-controle) de lixiviado pré-tratado do experimento em escala piloto.

A elevação dos valores nas primeiras semanas em que foram medido o coeficiente $\mathrm{K}_{\mathrm{L}} \mathrm{a}$, podem estar associados ao aumento da vazão de ar e agitação pela adição de mais aeradores nesse período.

Conforme gráficos da Figura 5.69, os valores de $\mathrm{K}_{\mathrm{L}} \mathrm{a}$ variaram entre 6 e $25 \mathrm{~h}^{-1}$, com média de 19,3 e 16,6 $\mathrm{h}^{-1}$, nos reatores tratando $2 \%$ (P1) e $0 \%$ (P2-controle) de lixiviado, respectivamente. É possível observar que os valores de $\mathrm{K}_{\mathrm{L}}$ a no reator tratando $2 \%$ (P1) de lixiviado pré-tratado se mantiveram sempre maiores que os do reator com 0\% (P2-controle), indicando melhor transferência e dispersão de oxigênio naquele reator.

Os valores obtidos neste estudo também foram superiores ao obtido por Franco (2009), de 9,46 $\mathrm{h}^{-1}$, possivelmente essa diferença está relacionada ao sistema de dispersão do ar dentro do reator e às características do reator em escala piloto utilizado pela autora, com geometria circular e volume de 1150 litros, ou seja, 10 vezes maior ao utilizado neste estudo. 


\subsection{Resultados do monitoramento microbiológico do experimento em escala piloto}

Além do monitoramento físico-químico, foram realizados exames microscópicos de amostras de lodo retiradas semanalmente para cada condição em estudo.

O estudo microbiológico do sistema de lodos ativados, tratando mistura de esgoto sanitário e lixiviado de aterro, consistiu no monitoramento microbiológico e característica dos flocos por microscopia óptica de campo claro para estudo comparativo da diversidade microbiana desenvolvida nos dois reatores.

\subsubsection{Resultados do monitoramento microbiológico por microscopia óptica}

Foram examinadas as morfologias observadas nas amostras de cada reator, por meio de microscopia óptica de campo claro. Essa caracterização refere-se à presença de microrganismos pertencentes aos Filos Protozoa (Classe Mastigophora, Ciliata e Sarcodina), Metazoa, Rotífera, Nematoda e Annelida. A quantidade de organismos observados foi avaliada subjetivamente, indicando a densidade populacional comparativa entre as amostras coletadas.

A taxonomia utilizada na classificação dos microrganismos observados foi baseada em Barnes \& Ruppert (2005).

Aa Tabelas 5.30 e 5.31 apresentam a frequência de observação dos protozoários e micrometazoários no reator $\mathrm{P} 1(2 \%)$ e $\mathrm{P} 2$ (controle), respectivamente, para o inóculo (após 30 dias de adaptação), $1^{\text {a a }} 9^{\text {a }}$ semana de operação. 
Tabela 5.30 - Frequência de microrganismos observados no reator com 2\% de lixiviado pré-tratado (P1) do experimento em escala piloto.

\begin{tabular}{|c|c|c|c|c|c|c|c|c|c|c|c|}
\hline & REATOR P1(2\%) & Inóculo & $\mathbf{1}^{\mathrm{a}}$ & $2^{\mathrm{a}}$ & $\mathbf{3}^{\mathbf{a}}$ & $4^{a}$ & $5^{\mathrm{a}}$ & $6^{a}$ & $7^{\mathrm{a}}$ & $8^{\mathrm{a}}$ & $9^{a}$ \\
\hline 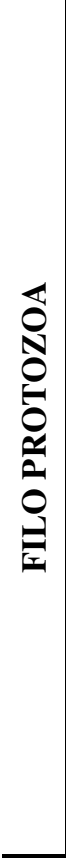 & $\begin{array}{l}\text { Classe Mastigophora (flagelados) } \\
\text { Classe Ciliata (ciliados livres e rastejantes) } \\
\text { Aspidisca } s p . \\
\text { Euplotes } s p . \\
\text { Paramecium } s p . \\
\text { Litonotus } s p \text {. } \\
\text { Classe Ciliata (ciliados fixos) } \\
\text { Vorticella sp. } \\
\text { Epistylis sp. } \\
\text { Suctoria sp. } \\
\text { Opercularia } s p . \\
\text { Outros } \\
\text { Classe Sarcodina (rizópodes) } \\
\text { Amoeba } s p . \\
\text { Euglypha } s p . \\
\text { Arcella sp. } \\
\text { Outros }\end{array}$ & $\begin{array}{c}+ \\
++ \\
+ \\
- \\
+ \\
- \\
+++ \\
++ \\
++ \\
- \\
- \\
- \\
++ \\
- \\
+ \\
+ \\
-\end{array}$ & $\begin{array}{c}+ \\
- \\
- \\
- \\
- \\
- \\
+++ \\
+++ \\
++ \\
- \\
- \\
- \\
+ \\
- \\
- \\
- \\
-\end{array}$ & $\begin{array}{c}- \\
++ \\
- \\
+ \\
++ \\
- \\
++ \\
++ \\
+ \\
- \\
- \\
- \\
+++ \\
- \\
++ \\
++ \\
-\end{array}$ & $\begin{array}{c}- \\
+++ \\
- \\
+ \\
++ \\
+ \\
+ \\
- \\
+ \\
- \\
- \\
- \\
+++ \\
- \\
+++ \\
+ \\
-\end{array}$ & $\begin{array}{c}+ \\
++++ \\
++ \\
++ \\
- \\
++ \\
+ \\
+ \\
- \\
- \\
- \\
- \\
+++ \\
- \\
++ \\
++ \\
-\end{array}$ & $\begin{array}{c}+ \\
++++ \\
+++ \\
++ \\
+ \\
+ \\
- \\
- \\
- \\
- \\
- \\
- \\
++++ \\
+ \\
+++ \\
++ \\
-\end{array}$ & $\begin{array}{c}- \\
+++ \\
++ \\
+ \\
- \\
+ \\
+ \\
+ \\
- \\
- \\
- \\
- \\
+ \\
- \\
+ \\
- \\
-\end{array}$ & $\begin{array}{c}- \\
+++ \\
++ \\
+ \\
- \\
++ \\
+ \\
- \\
+ \\
- \\
- \\
- \\
+++ \\
- \\
+++ \\
+ \\
+\end{array}$ & $\begin{array}{c}+ \\
++ \\
++ \\
+ \\
- \\
++ \\
++ \\
++ \\
+ \\
- \\
- \\
- \\
+++ \\
- \\
++ \\
+++ \\
-\end{array}$ & $\begin{array}{c}+ \\
++ \\
++ \\
- \\
- \\
++ \\
+++ \\
++ \\
++ \\
+ \\
+ \\
- \\
- \\
+++ \\
- \\
++ \\
++ \\
-\end{array}$ \\
\hline & $\begin{array}{l}\text { Filo Rotifera (rotíferos) } \\
\text { Filo Nematoda (vermes) } \\
\text { Filo Annelida } \\
\text { Bactérias isoladas em suspensão } \\
\text { Bactérias coloniais (Zoogloea) } \\
\text { Bactérias filamentosas } \\
\text { Fungos }\end{array}$ & $\begin{array}{c}++ \\
+ \\
- \\
- \\
- \\
+++ \\
-\end{array}$ & $\begin{array}{c}++ \\
- \\
- \\
+ \\
- \\
++ \\
+\end{array}$ & $\begin{array}{c}++++ \\
+ \\
- \\
- \\
+ \\
++ \\
-\end{array}$ & $\begin{array}{c}++ \\
++ \\
- \\
- \\
- \\
++ \\
+\end{array}$ & $\begin{array}{c}+ \\
+++ \\
- \\
+ \\
- \\
++ \\
-\end{array}$ & $\begin{array}{c}+ \\
++ \\
- \\
+ \\
+ \\
++ \\
+\end{array}$ & $\begin{array}{l}++ \\
+ \\
- \\
+ \\
+ \\
++ \\
+\end{array}$ & $\begin{array}{c}+ \\
++ \\
+ \\
+ \\
- \\
++ \\
++\end{array}$ & $\begin{array}{c}+ \\
++ \\
+ \\
- \\
- \\
++ \\
++\end{array}$ & $\begin{array}{c}++ \\
+ \\
+ \\
- \\
-\end{array}$ \\
\hline
\end{tabular}

Legenda: Ausentes - ; Frequência Baixa + ; Frequência Média ++ ; Frequência Elevada +++; Predominante ++++. 
Conforme a Tabela apresentada, observou-se diversidade de morfologias microbianas no reator P1(2\%). Ficou caracterizada uma sucessão microbiana ao longo do tempo nas condições operacionais do reator.

É possível observar que houve redução brusca na frequência de protozoários ciliados fixos, provenientes do inóculo, da $3^{\mathrm{a}}$ a $7^{\mathrm{a}}$ semana, voltando a aparecer em frequência significativa somente nas últimas semanas de operação. Ao mesmo tempo, a partir da $3^{\text {a }}$ semana também houve elevação gradativa da frequência de rizópodes e de protozoários ciliados livres e rastejantes. Essa alternância entre a população de protozoários ciliados fixos e ciliados livres também foi observado por Maciel (2002) em sistema de lodos ativados tratando efluentes domésticos e industriais de processo de produção de peças automotivas.

Os protozoários livres são abundantes quando os flocos são escassos e, portanto, estão competindo com os flagelados por bactérias dispersas. Segundo Pinto (1998) os ciliados livres sobrevivem melhor que os outros microrganismos quando existem substâncias tóxicas ou falta de oxigênio.

As imagens da Figura 5.70 apresentam as características estruturais do floco ao longo da operação. É possível notar que realmente houve notável alteração estrutural dos flocos, com diminuição gradativa do tamanho e quantidade deste.

Wilén et. Al. (2003) e Wei et al. (2009) associaram salinidade e compostos orgânicos presentes no lixiviado à inibição parcial da atividade microbiana, causando alterações na estrutura dos flocos do lodo ativado, podendo levar à desfloculação.

A partir da $7^{\text {a }}$ semana, o monitoramento indicou melhora significativa na floculação, com aparecimento de flocos maiores, mais robustos e em maior número (Figura 5.71). Também observou-se tendência de equilíbrio entre ciliados fixos, rastejantes, livres e rizópodes, conforme apresentado na Tabela 5.31.

Segundo Jardim et al. (1998), observa-se uma correlação positiva entre a remoção de sólidos sedimentáveis e a densidade de ciliados livres no tanque de aeração. Esta relação poderá ser explicada pelo fato de os ciliados livres liberarem polissacarídeos e mucoproteínas, contribuindo para a formação do floco no tanque de aeração, favorecendo consequentemente a sedimentação do lodo. 

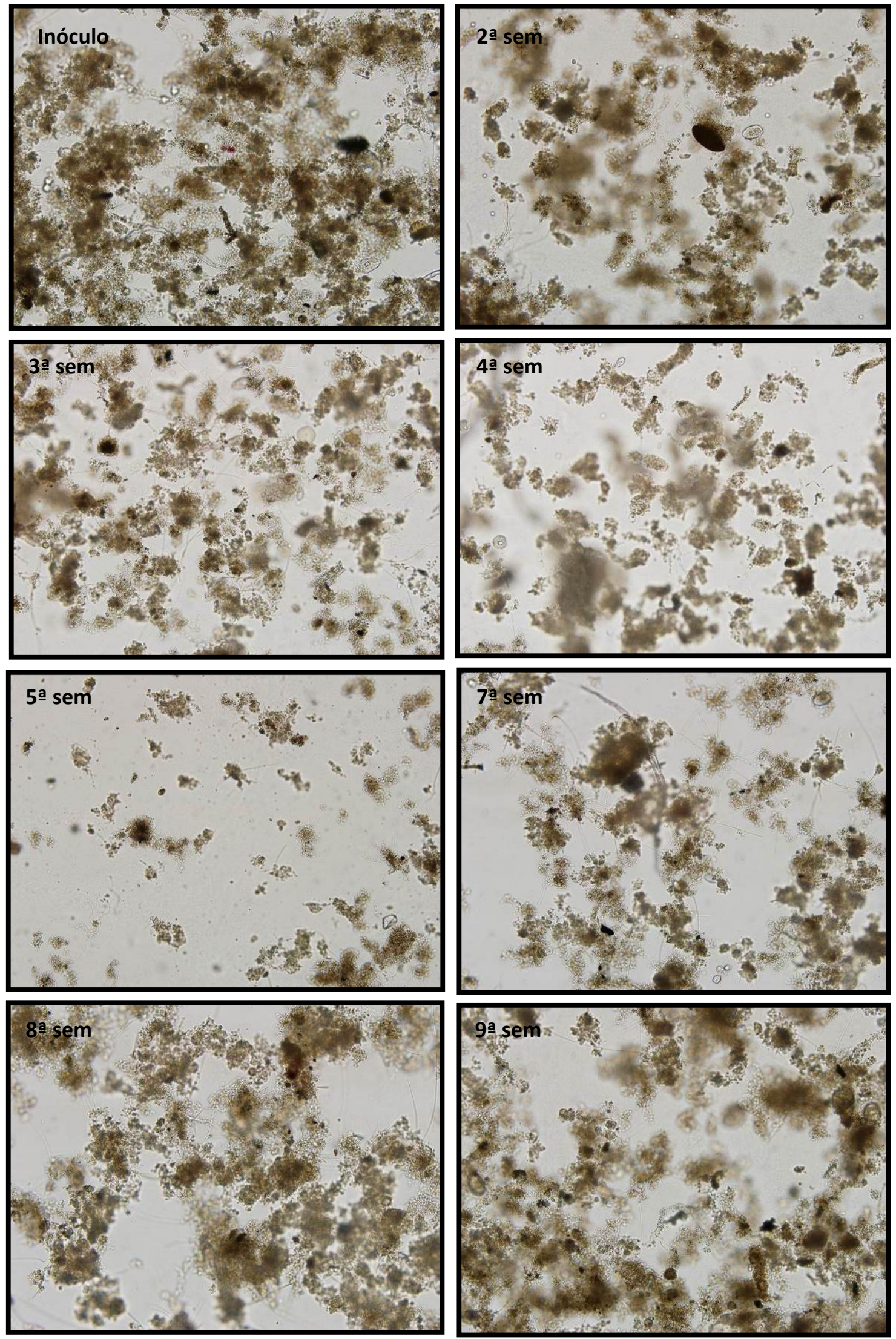

Figura 5.70 - Imagens panorâmicas da estrutura geral do floco de lodos ativados do reator com $2 \%$ de lixiviado pré-tratado (P1) ao longo da operação. Aumento original $100 \mathrm{x}$. 
Chen et al. (2004) e Zhou et al. (2006) encontraram elevada correlação do gênero Arcella sp. com a baixa concentração efluente de DQO, DBO, SS e IVL. Neste reator foi possível verificar a presença de protozoários rizópodes (amebas) durante todo o experimento, especialmente dos gêneros Arcella sp e Euglypha sp.. Também foram obtidas elevadas eficiências de remoção de DQO e DBO.

Vale ressaltar que, segundo Vazzoler (1989) e Mandoni et al. (1993), Bento et al. (2005) a presença desses protozoários também indica a ocorrência de nitrificação, condizendo com os resultados obtidos na nitrificação nesta condição experimental.

A Figura 5.71 apresenta alguns microrganismos encontrados no reator P1.
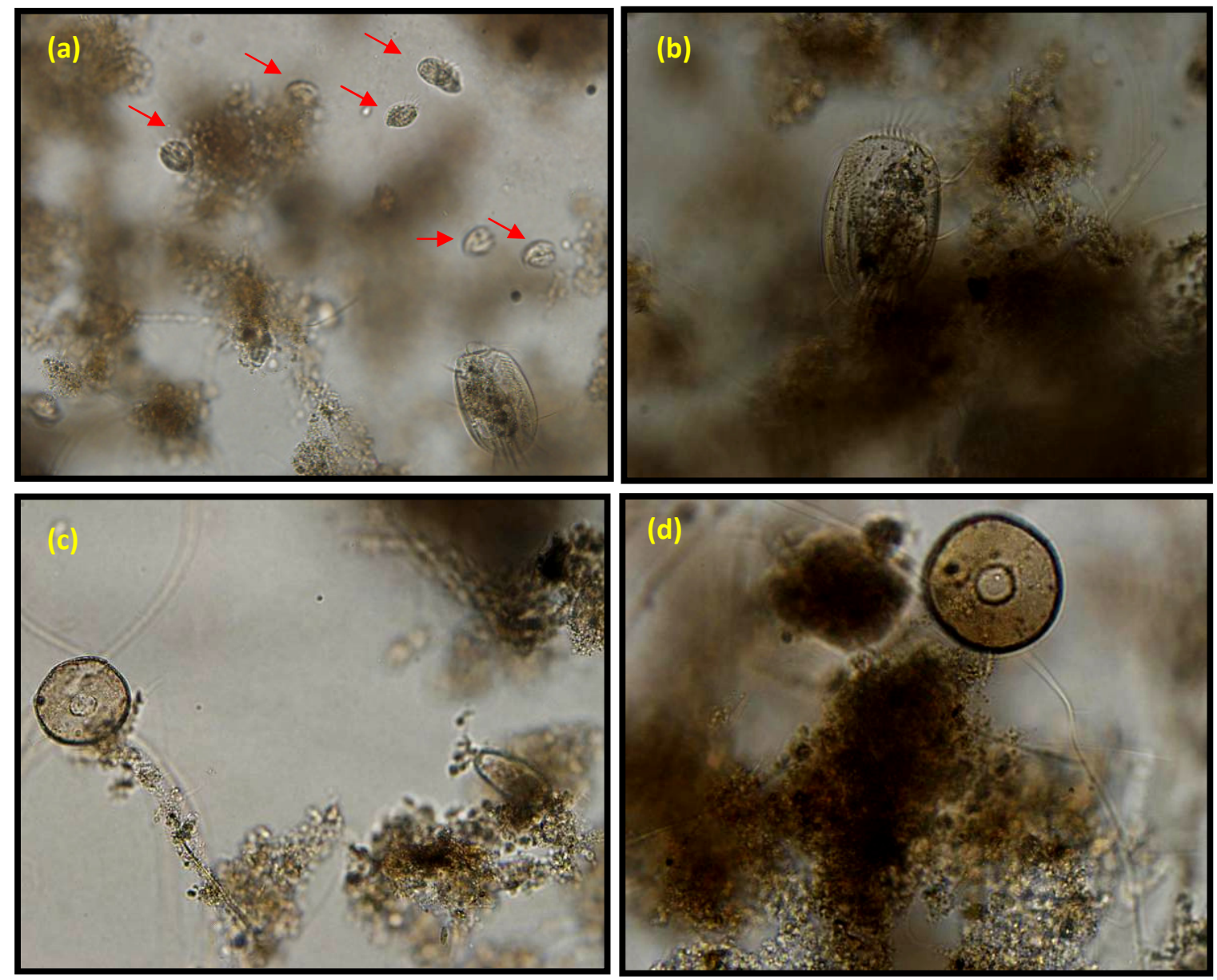

Figura 5.71 - Caracterização da composição da microfauna no reator com $2 \%$ de lixiviado pré-tratado ( $\mathrm{P} 1)$ do sistema de lodos ativados em escala piloto. (a) Protozoários livre rastejantes semelhantes a Aspidisca sp. e Euplotes sp.; (b) Protozoário livre rastejante semelhante a Euplotes sp.; (c) Protozoários rizópodes semelhantes a Arcella sp e Euglypha sp. Aumentos originais 400x, (b); 200x (a), (c) e (d). 
Observou-se também frequência contínua de protozoários ciliados livres semelhantes à Litonotus sp. durante toda a operação. Os ciliados semelhantes à Paramecium sp. foram observados em menor frequência durante 3 semanas consecutivas.

Diversos autores como Chen (2004) e Lee (2004), encontraram elevada associação da frequência do protozoário ciliado carnívoro do gênero Litonotus sp com elevado IVL, o que não foi o caso deste reator. Martin-Cereceda (1996) e Chen (2004) e Tyagi et al.(2008) encontraram elevada correlação entre os gêneros Litonotus sp. e Paramecium sp. e baixas concentrações de SS e DBO efluentes.

O nematoide do gênero Tardigrades sp. está geralmente associado à ocorrência de nitrificação, assim como os protozoários ciliados livres do gênero Aspidisca sp. (Jenkis, 2003). A Figura 5.72 apresenta alguns desses microrganismos encontrados no reator $\mathrm{P} 1$.
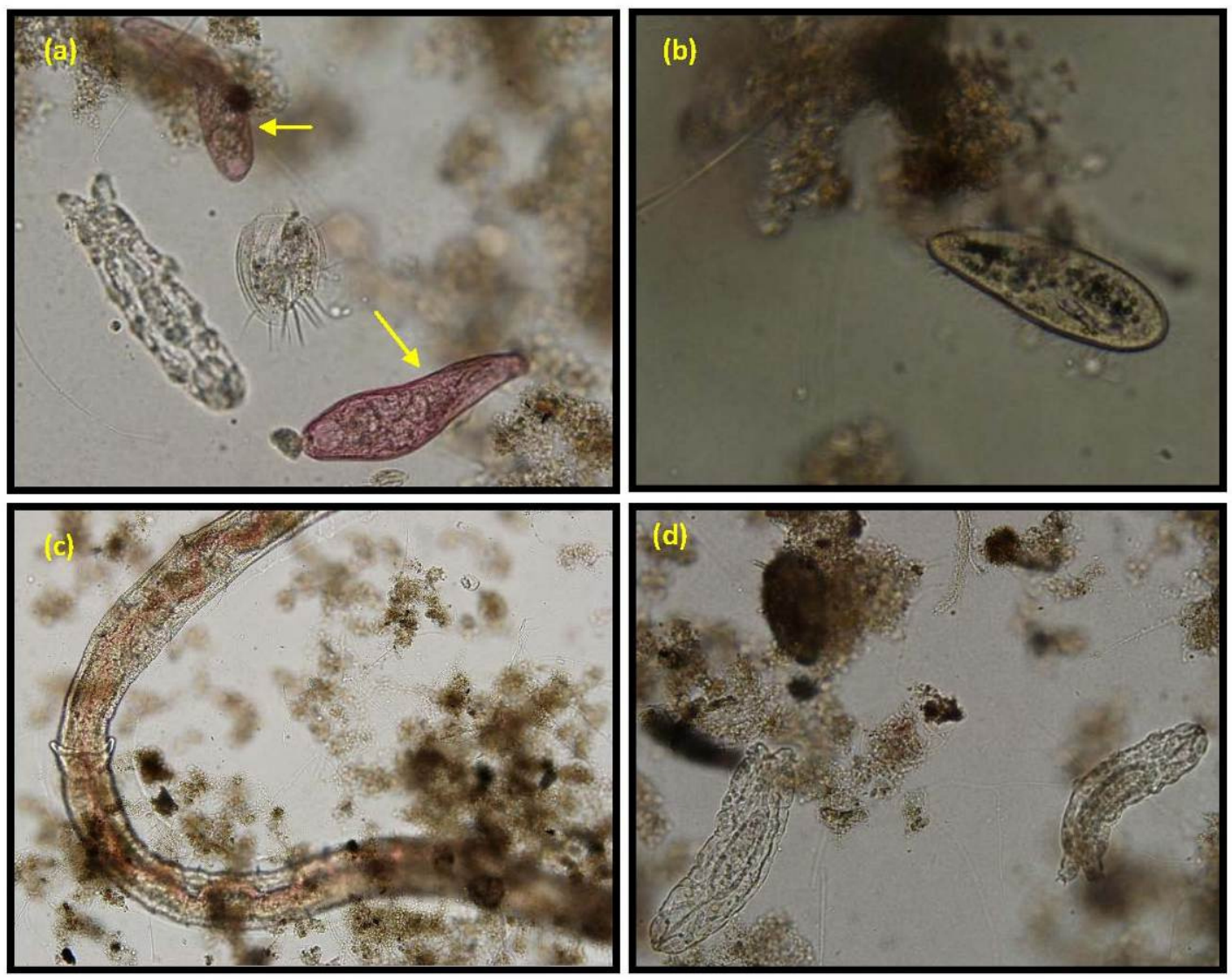

Figura 5.72 - Caracterização da composição da microfauna em com $2 \%$ de lixiviado pré-tratado (P1) do sistema de lodos ativados em escala piloto. (a) Protozoários livres semelhantes a Aspidisca sp. e Litonotus sp.; (b) Protozoário livre semelhante a Paramecium sp.; Metazoário anelídeo semelhantes a (c) Aelossoma sp e (d) Tardigrades. Aumentos originais 200x, (a) e (d); 400x (b); 100x, (c). 
Tabela 5.31 - Frequência de microrganismos observados no reator com 0\% de lixiviado (P2-controle) do experimento em escala piloto.

\begin{tabular}{|c|c|c|c|c|c|c|c|c|c|c|c|}
\hline & REATOR P2(CONTROLE) & Inóculo & $\mathbf{1}^{\mathrm{a}}$ & $2^{\mathrm{a}}$ & $3^{\mathbf{a}}$ & $4^{\mathrm{a}}$ & $5^{\mathrm{a}}$ & $6^{\mathbf{a}}$ & $7^{\mathrm{a}}$ & $8^{\mathbf{a}}$ & $9^{\mathbf{a}}$ \\
\hline 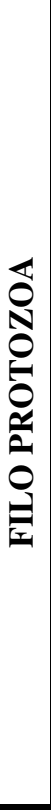 & $\begin{array}{l}\text { Classe Mastigophora (flagelados) } \\
\text { Classe Ciliata (ciliados livres) } \\
\text { Aspidisca } s p . \\
\text { Paramecium } s p . \\
\text { Litonotus } s p . \\
\text { Classe Ciliata (ciliados fixos) } \\
\text { Vorticella } s p . \\
\text { Epistylis } s p . \\
\text { Suctoria } s p . \\
\text { Opercularia } s p . \\
\text { Outros } \\
\text { Classe Sarcodina (rizópodes) } \\
\text { Amoeba } s p . \\
\text { Euglypha } s p . \\
\text { Arcella } s p . \\
\text { Outros }\end{array}$ & $\begin{array}{l}++ \\
+ \\
+ \\
- \\
+++ \\
++ \\
++ \\
- \\
- \\
- \\
++ \\
+ \\
- \\
+ \\
-\end{array}$ & $\begin{array}{c}+ \\
+++ \\
++ \\
+ \\
- \\
++++ \\
+++ \\
++ \\
- \\
- \\
- \\
+ \\
- \\
- \\
- \\
-\end{array}$ & $\begin{array}{c}- \\
++ \\
- \\
++ \\
- \\
++ \\
++ \\
+ \\
- \\
- \\
- \\
+++ \\
- \\
++ \\
++ \\
-\end{array}$ & $\begin{array}{c}+ \\
++ \\
+ \\
+ \\
- \\
++ \\
+ \\
+ \\
- \\
- \\
- \\
+++ \\
+ \\
++ \\
+ \\
-\end{array}$ & $\begin{array}{c}- \\
++ \\
++ \\
+ \\
- \\
+ \\
+ \\
- \\
- \\
- \\
- \\
+ \\
+ \\
+ \\
+\end{array}$ & $\begin{array}{c}- \\
++ \\
++ \\
- \\
- \\
++ \\
++ \\
- \\
- \\
- \\
- \\
+ \\
+ \\
+ \\
+\end{array}$ & $\begin{array}{c}+ \\
++ \\
++ \\
+ \\
- \\
++ \\
+ \\
+ \\
+ \\
- \\
- \\
+ \\
+ \\
+ \\
-\end{array}$ & $\begin{array}{c}+ \\
++ \\
++ \\
- \\
- \\
+++ \\
+++ \\
+ \\
- \\
- \\
- \\
+++ \\
+ \\
+++ \\
- \\
-\end{array}$ & $\begin{array}{c}++ \\
++ \\
++ \\
+ \\
+ \\
++ \\
++ \\
+ \\
- \\
- \\
- \\
++ \\
- \\
++ \\
++ \\
+\end{array}$ & $\begin{array}{c}+ \\
+++ \\
+ \\
+ \\
+ \\
++ \\
++ \\
+ \\
- \\
- \\
- \\
++ \\
+ \\
+ \\
+ \\
-\end{array}$ \\
\hline & $\begin{array}{l}\text { Filo Rotifera (rotíferos) } \\
\text { Filo Nematoda (vermes) } \\
\text { Filo Annelida } \\
\text { Bactérias isoladas em suspensão } \\
\text { Bactérias coloniais (Zoogloea) } \\
\text { Bactérias filamentosas } \\
\text { Fungos }\end{array}$ & $\begin{array}{c}+++ \\
+ \\
+ \\
- \\
+ \\
+++ \\
-\end{array}$ & $\begin{array}{c}+++ \\
- \\
- \\
+ \\
- \\
+++ \\
+\end{array}$ & $\begin{array}{c}+++ \\
+ \\
- \\
- \\
+ \\
+++ \\
-\end{array}$ & $\begin{array}{c}++++ \\
+ \\
- \\
- \\
- \\
+++ \\
+\end{array}$ & $\begin{array}{c}++ \\
++ \\
- \\
- \\
- \\
+++ \\
-\end{array}$ & $\begin{array}{c}++ \\
+ \\
- \\
++ \\
+ \\
+++ \\
+\end{array}$ & $\begin{array}{c}++ \\
+ \\
- \\
- \\
+ \\
+++ \\
-\end{array}$ & $\begin{array}{c}++ \\
+ \\
- \\
- \\
- \\
++++ \\
++\end{array}$ & $\begin{array}{c}+ \\
+ \\
+ \\
+ \\
- \\
+++ \\
++\end{array}$ & $\begin{array}{c}++ \\
+ \\
- \\
+ \\
- \\
+++ \\
-\end{array}$ \\
\hline
\end{tabular}

Legenda: Ausentes - ; Frequência Baixa + ; Frequência Média ++ ; Frequência Elevada +++; Predominante ++++. 
As imagens da Figura 5.73 apresentam as características estruturais do floco ao longo da operação.
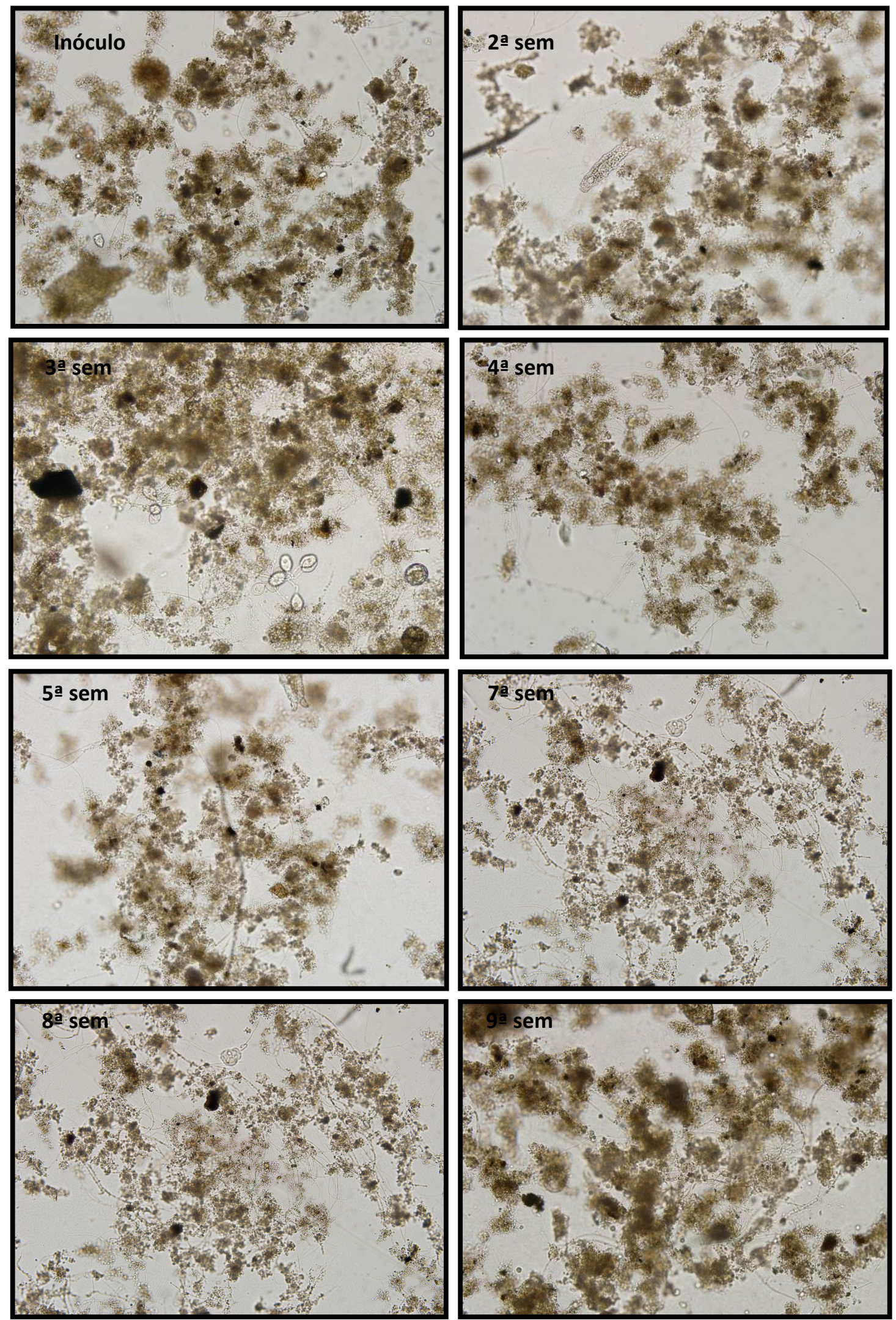

Figura 5.73 - Imagens panorâmicas da estrutura geral do floco de lodos ativados do reator com 0\% (P2-controle) de lixiviado ao longo da operação. Aumento original 100x. 
Conforme a tabela apresentada, observou-se uma boa diversidade de microrganismos no reator $\mathrm{P} 2(0 \%)$. Em termos gerais, foi mantida a diversidade microbiana ao longo da operação do sistema.

É possível observar que houve equilíbrio na presença de protozoários ciliados livres, fixos, rizópodes e rotíferos.

Dentre os protozoários ciliados fixos, houve frequência contínua de microrganismos do gênero Vorticella sp. e, em menor frequência, Epistylis sp. ( Estudos de Chen et al. (2004), Zhou et al. (2008) e Signorile et al. (2010), mostraram elevada correlação desse gênero com a estabilidade do lodo e alta eficiência de remoção de DBO e DQO. As maiores eficiências de remoção de DBO e de DQO obtidas neste reator são compatíveis com a estabilidade biológica adquirida pelo sistema.

Quanto aos protozoários livres rastejantes e natantes, houve predomínio dos gêneros Aspidisca sp. e Paramecium sp.

A Figura 5.74 apresenta alguns desses microrganismos encontrados no reator P2.
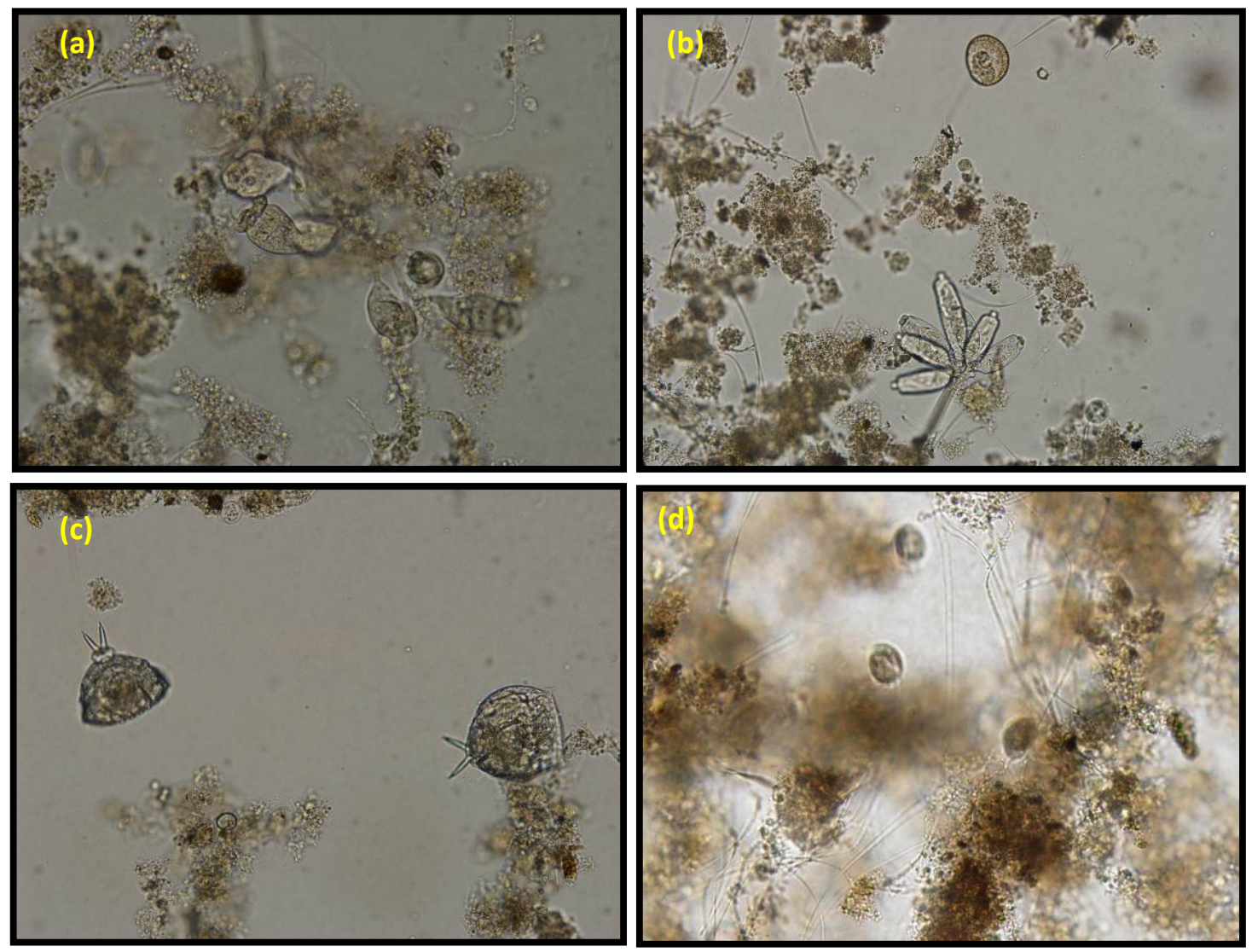

Figura 5.74 - Caracterização da composição da microfauna do reator com 0\% (P2controle) de lixiviado do sistema de lodos ativados em escala piloto. Protozoários ciliados fixos semelhantes à (a) Vorticella sp. e (b) Epistylis sp.; (c) Metazoários rotíferos; (d) Protozoário livre rastejante semelhante a Aspidisca sp.. Aumentos originais 200x, (a) e (b); 400x (c); 100x (d). 
Martin-Cereceda (1996) e Chen (2004) e Tyagi et al.(2008) encontraram correlação entre os gêneros Litonotus sp. e Paramecium sp. e baixas concentrações de SS e DBO efluentes.

O aparecimento de protozoários ciliados livres do gênero Aspidisca sp., das amebas do gênero Arcella sp. e Euglypha sp. e de rotíferos, foi contínuo, durante todo o experimento. Segundo Pinto (1998), o consórcio de Aspidisca sp e rotíferos e amebas também encontram-se associados a uma nitrificação completa, sendo sensíveis a amônia livre, confirmando a ocorrência de nitrificação nesta condição.

A Figura 5.75 apresenta alguns desses microrganismos encontrados no reator P2.
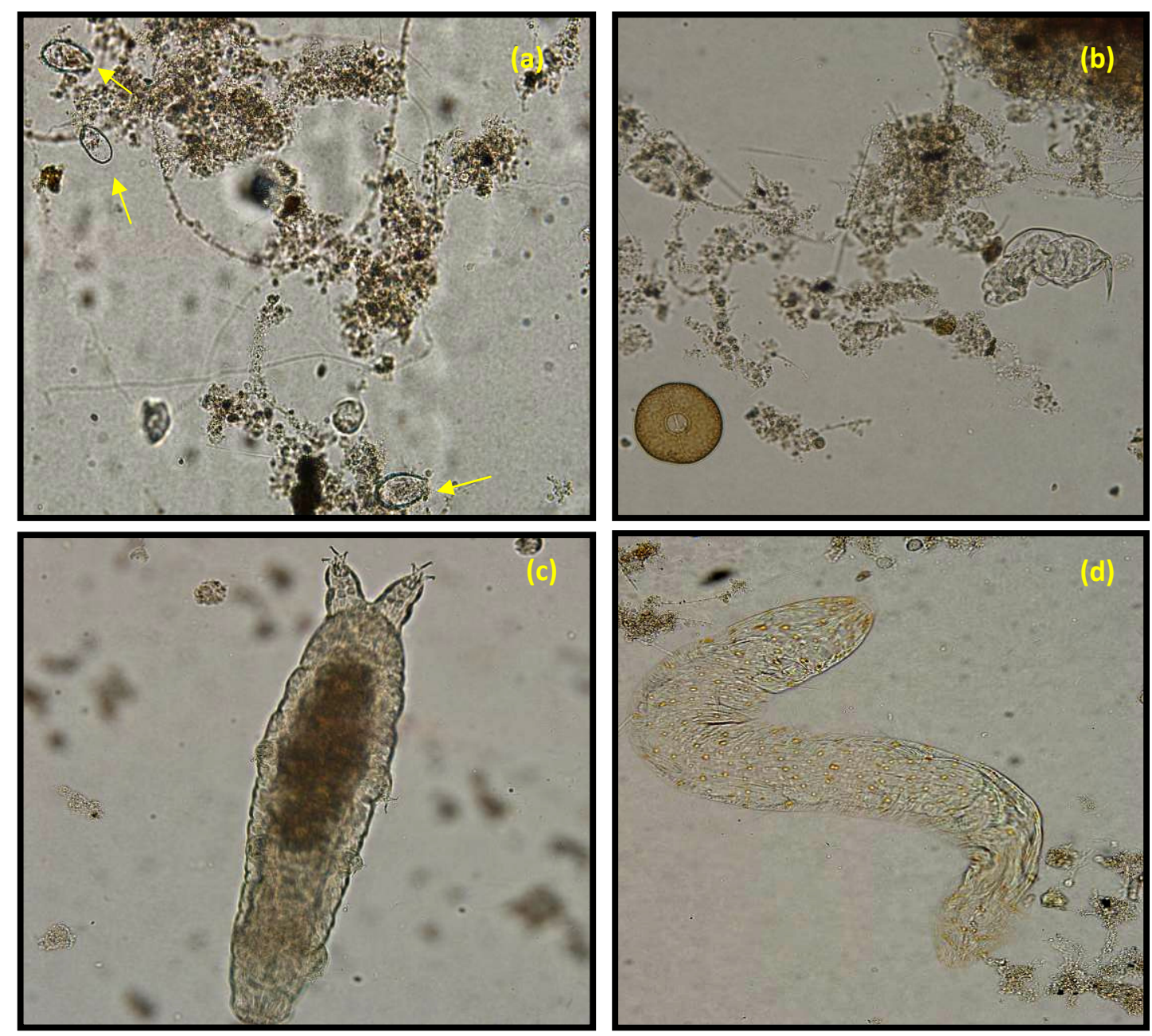

Figura 5.75 - Caracterização da composição da microfauna do reator com 0\% (P2controle) de lixiviado do sistema de lodos ativados em escala piloto. Protozoários rizópodes semelhantes à (a) Euglypha sp. e (b) Arcella sp.; (c) Metazoários nematoides semelhantes à (c) Tadigrades sp. e Aelossoma sp.. Aumentos originais 200x, (a), (b), (c) e (d). 
Foi observado também presença significativa de anelídeos, especialmente semelhantes Aelossoma sp. e do gênero Tardigrade. O primeiro gênero está associado à ocorrência de nitrificação, enquanto o segundo aparece em sistema com elevada idade do lodo e relação A/M baixa (Jenkis, 2003), que é o caso desta condição.

Vale ressaltar que nesta condição foi observada elevada frequência de microrganismos filamentosos durante toda a operação, com alteração apenas da frequência, variando de elevada a predominante (Figura 5.76). Isso explica os elevados valores de IVL, principalmente após o $30^{\circ}$ dia de operação.

Tyagi et al.(2008) também constataram grande frequência de nematoides e microrganismos filamentoso em sistema de lodos ativados com aeração prolongada tratando esgoto sanitário.
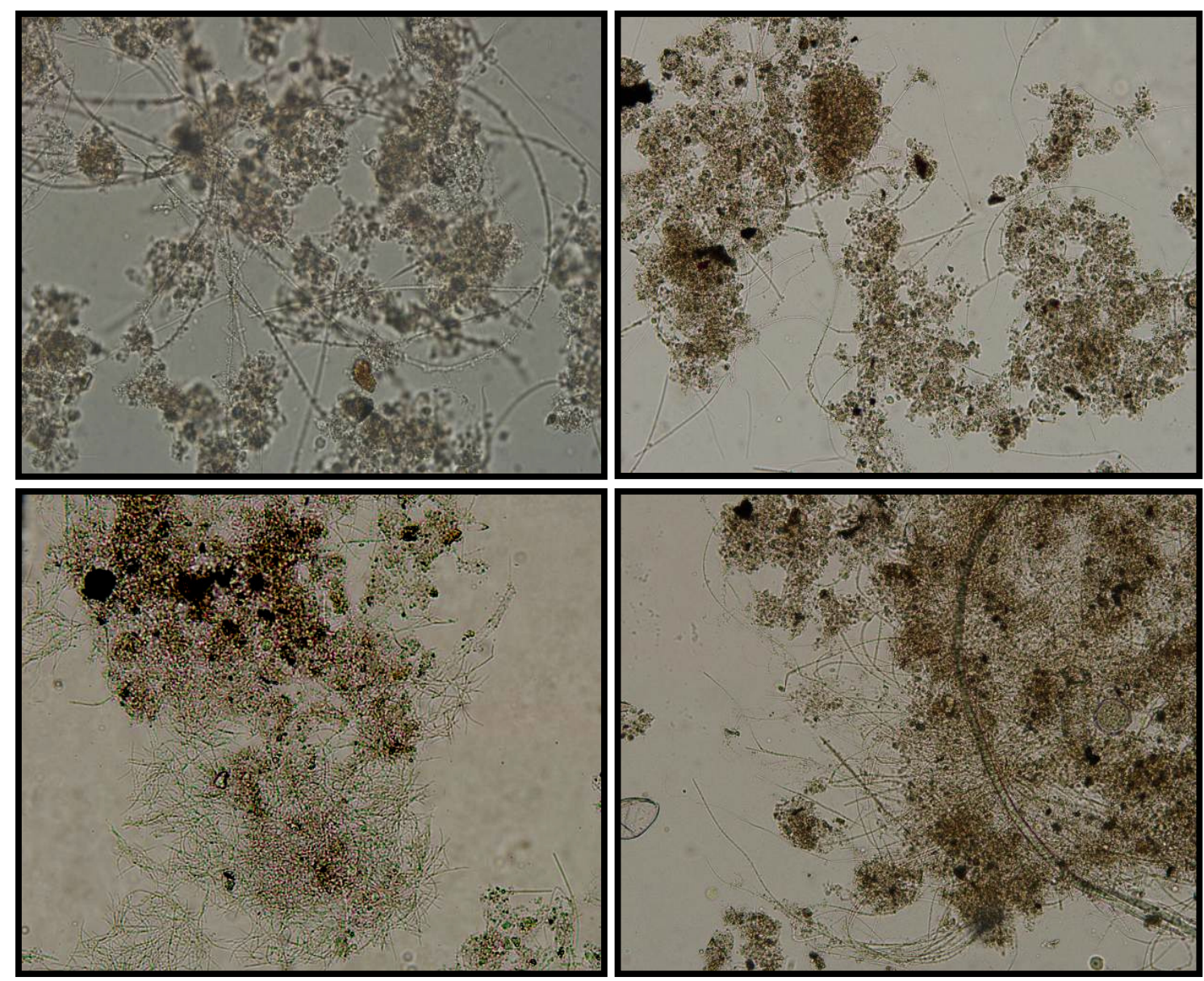

Figura 5.77 - Caracterização da composição da microfauna do reator com 0\% (P2controle) de lixiviado do sistema de lodos ativados em escala piloto. Estrutura do floco com destaque nos microrganismos filamentosos. Aumentos originais 400x, (a); 100x,

$$
\text { (b), (c) e (d). }
$$




\subsection{Resultados complementares}

Além do monitoramento físico-químico e microbiológico dos reatores de lodos ativados, foram ainda realizados outras análises e exames que serviram de base para alcançar os objetivos desta pesquisa e complementar os resultados de forma a tentar esclarecer as incertezas que norteiam o tratamento consorciado de lixiviado de aterro com esgoto sanitário.

\subsubsection{Avaliação do acúmulo de carbono orgânico no lodo}

Considerando que, segundo os resultados das concentrações da DQO e do COD, houve remoção de carbono orgânico da mistura lixiviado mais esgoto (fase líquida). No entanto, pelo fato de o lixiviado conter inúmeros compostos de difícil degradação, é importante investigar se o carbono orgânico removido da fase líquida foi efetivamente degradado ou apenas adsorvido pela biomassa (fase sólida).

Nesse sentido, também foi realizada uma avaliação do acúmulo de carbono orgânico no lodo dos reatores do experimento em escala piloto, a fim de se verificar e comparar a tendência de acúmulo de compostos orgânicos no lodo proveniente dos reatores.

Para tal verificação foi realizado um estudo tentativo que consistiu em quantificar a concentração de carbono orgânico dissolvido (COD) nas amostras de lodo durante o experimento com reatores em escala piloto. A metodologia utilizada foi a mesma para determinação da concentração da DQO em amostras de sólidos utilizada por Gomes (1989), seguido de filtração em membrana de $0,45 \mu \mathrm{m}$ e acidificação (pH 2) para posterior análise em equipamento de COT.

Vale ressaltar que foram realizadas análises esporádicas, apenas com intuito de estudo tentativo do acúmulo de carbono na fase sólida dos sistemas de tratamento. Para avaliação minuciosa e mais precisa recomenda-se que seja feita essa quantificação com mais frequência e por um período de operação maior, de modo que se obtenha uma série de dados mais representativa e que seja possível fazer um tratamento estatístico específico para comprovação da hipótese em questão. 
O gráfico da Figura 5.78 apresenta o comportamento da concentração de carbono orgânico dissolvido (COD) nas amostras de lodo dos reatores com 2\% (P1) e 0\% (P2) de lixiviado, bem como as tendências lineares das séries.

Vale ressaltar que os coeficientes de correlação estiveram em torno de 0,85 , indicando que há uma correlação elevada entre as variáveis em questão (COD x t), em ambas as séries amostrais. Portanto, Pode-se fazer alguma inferência a respeito das tendências resultantes do comportamento dos dados.

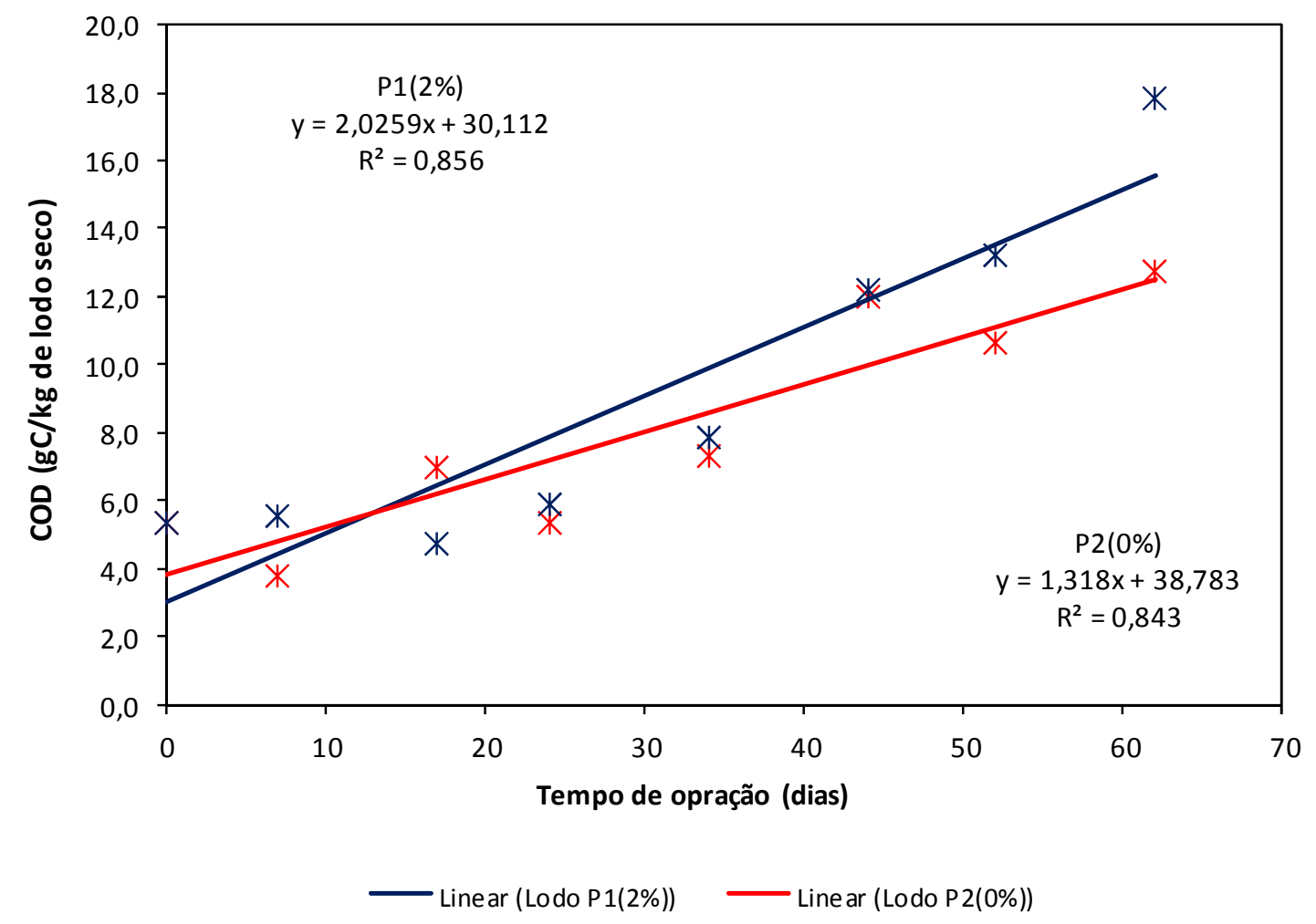

Figura 5.78 - Concentrações de COD em termos da massa seca de lodo dos reatores tratando esgoto sanitário com $2 \%(\mathrm{P} 1)$ e $0 \%$ (P2-controle) de lixiviado pré-tratado do experimento em escala piloto.

Conforme apresentado no gráfico, os resultados indicam que houve tendência de aumento da concentração de carbono orgânico no lodo de ambos os reatores. No entanto, o lodo do reator com $2 \%$ de lixiviado pré-tratado (P1) teve uma tendência de crescimento maior, constatada pelo coeficiente angular (inclinação) da reta de tendência linear $(2,0)$ superior ao da reta do lodo de $\mathrm{P} 2(0 \%)(1,3)$.

Os resultados da tendência podem prever uma maior taxa (COD/t-tempo) de elevação da concentração de carbono orgânico no lodo do reator com esgoto sanitário e 
$2 \%$ de lixiviado pré-tratado (P1) do que no reator com $0 \%$ (P2-controle), podendo indicar possível acúmulo de compostos orgânicos complexados e de difícil degradação no lodo do reator alimentado com $2 \%$ (P1) de lixiviado.

No entanto, conforme já mencionado, este estudo teve caráter tentativo, já que se dispôs de poucos dados para fazer uma investigação mais precisa. Para que seja efetivamente comprovada essa tendência deve-se dispor de uma série mais representativa, bem como realizar tratamento estatístico específico.

\subsubsection{Resultados dos experimentos de remoção de amônia por air stripping}

O lixiviado utilizado nos Experimentos 2 e 3 de bancada e no reator com $2 \%$ de lixiviado pré-tratado (P1) do experimento em escala piloto foi previamente alcalinizado e tratado em torre de arraste, com o intuito de remover a elevada concentração de amônia presente no lixiviado.

Os experimentos foram realizados em regime de batelada, com recirculação do lixiviado, e encerrados quando a concentração de amônia no efluente líquido era de, no máximo, 20 mg/L (valor estabelecido pela Resolução CONAMA 430/2011). Visando a redução nos custos do processo, o lixiviado foi pré-alcalinizado com cal comercial, de modo que seu pH fosse ajustado para 11, conforme Ferraz (2010).

Os experimentos foram realizados em diferentes condições operacionais (Tabela 1), de maneira que se pudesse avaliar o desempenho da torre e das torres de recolhimento.

Tabela 5.33 - Condições operacionais e resultados das torres de remoção e de recolhimento de amônia avaliadas nos experimentos.

\begin{tabular}{lcccccc}
\hline Experimentos & $\begin{array}{c}\mathbf{V}_{\text {lix }} \\
(\mathbf{L})\end{array}$ & $\mathbf{p H}$ & $\begin{array}{c}\mathbf{Q}_{\mathrm{ar}} \\
(\mathbf{L} / \mathbf{h})\end{array}$ & $\begin{array}{c}\text { Tempo de } \\
\text { operação } \\
\text { (horas) }\end{array}$ & $\begin{array}{c}\text { Eficiência de } \\
\text { recolhimento } \\
(\%)\end{array}$ & $\begin{array}{c}\text { Solução de } \\
\text { neutralização } \\
\text { da amônia }\end{array}$ \\
\hline $\mathrm{EX}-1$ & 55 & 11,6 & 3500 & 87 & $64 \%$ & $\mathrm{H}_{2} \mathrm{O}$ \\
$\mathrm{EX}-2$ & 55 & 11,3 & 6400 & 62 & $52 \%$ & $\mathrm{H}_{2} \mathrm{O}$ \\
$\mathrm{EX}-3$ & 50 & 11,0 & 3500 & 85 & $80 \%$ & $\begin{array}{c}\mathrm{H}_{2} \mathrm{SO}_{4}(0.4 \\
\mathrm{mol} / \mathrm{L}) \mathrm{e} \mathrm{H}_{2} \mathrm{O}\end{array}$ \\
\hline
\end{tabular}

Qlix: vazão de lixiviado; $\mathrm{Q}_{\mathrm{ar}}$ : vazão de ar; (*) pH ajustado com uso de cal comercial. 
De acordo com a Figura 5.79, a remoção de NAT foi praticamente completa nos experimentos EX-1, EX-2 e EX-3, e a qualidade dos efluentes em conformidade com a Resolução CONAMA 430/2011.

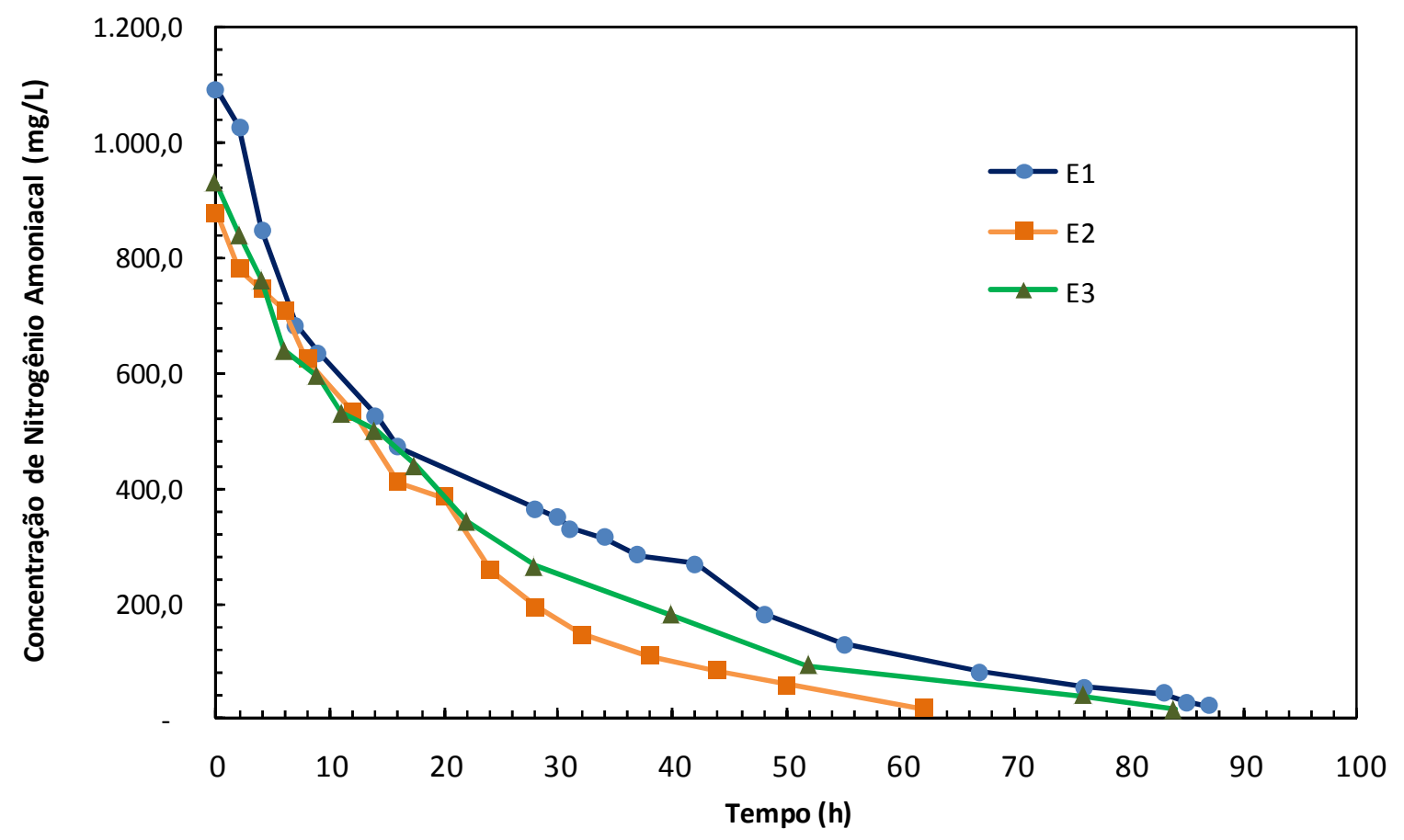

Figura 5.79 - Remoção do nitrogênio amoniacal total pela torre de air stripping nos experimentos EX-1, EX-2 e EX-3, no pré-tratamento do lixiviado.

Em todos os experimentos o $\mathrm{pH}$ do lixiviado foi ajustado com cal comercial para aproximadamente 11 , de modo a se obter maior eficiência no sistema.

Houve variação nos tempos de operação da torre em função das vazões de ar utilizadas. No experimento EX-1 o tempo de operação da torre foi de 87 horas (Figura $5.80)$.

Para se verificar a eficiência de recolhimento, no experimento EX-2 foi testada uma vazão de $6400 \mathrm{~L} / \mathrm{h}$. Como esperado, foi o que teve menor tempo de operação da torre de arraste, 62 horas. Todavia, essa condição operacional resultou em eficiência muito baixa no recolhimento da amônia, conforme discutido em item posterior.

Devido à queda da eficiência de recolhimento da amônia no experimento EX-2, no terceiro experimento EX-3, ajustou-se novamente a vazão de ar para $3500 \mathrm{~L} / \mathrm{h}$ e adicionou-se solução de $\mathrm{H}_{2} \mathrm{SO}_{4}(0.4 \mathrm{~mol} / \mathrm{L})$ na primeira torre de recolhimento, a fim de 
elevar a eficiência de recolhimento de amônia. Com esse procedimento, o tempo de operação da torre foi elevado para 88 horas.

Nota-se na Figura 5.79 que o desempenho da torre foi praticamente igual aquele obtido no experimento EX-1 e EX-3.

Os compostos recalcitrantes presentes em líquidos lixiviados de aterros são, na sua grande maioria, substância húmicas originadas da decomposição de vegetais, responsáveis pela conferência de cor pronunciada ao despejo (Harmsen, 1983; Renou et al., 2008; Amaral, 2009).

Em todos os experimentos, houve uma tendência de redução da concentração DQO acompanhada da redução de 35-45\% da Cor Aparente do lixiviado bruto. Após a correção do pH para valores entre 11 e 12, conforme o carbonato de cálcio precipitava, a coloração escura do lixiviado bruto tornava-se amarelada. Essa clarificação do lixiviado após a alcalinização foi também observada por Aziz, et al. (2007), Souto (2009) e Ferraz (2010).

A redução da DQO e de cor resultante da pré-alcalinização com $\mathrm{Ca}(\mathrm{OH})_{2}$ indicam que uma parcela da matéria orgânica recalcitrante (substâncias húmicas) presentes no lixiviado bruto seria removida por precipitação.

Nas Figuras 5.80 a 5.82 são mostradas as eficiências do recolhimento da amônia liberada pela torre de arraste nos experimentos EX-1, EX-2 e EX-3. No experimento EX-1, a neutralização da amônia foi satisfatória, porém a eficiência total foi reduzida para 64\% (Figuras 5.80), já que a capacidade de absorção da água é muito inferior ao do ácido.

No experimento EX-2 (Figura 5.81), a eficiência total de recolhimento foi menor ainda, de aproximadamente 51,5\%. A baixa eficiência de recolhimento obtida no experimento EX-2 pode estar relaciona ao menor tempo de contato (62 horas) entre a amônia e a solução de neutralização (no caso, a água) devido à maior vazão de ar empregada, em comparação às 87 horas do experimento EX-1.

Os melhores resultados da neutralização da amônia foram obtidos com a solução de ácido sulfúrico 0,4 M, no experimento EX-3 (Figura 5.82), com eficiência total de aproximadamente $80 \%$. 


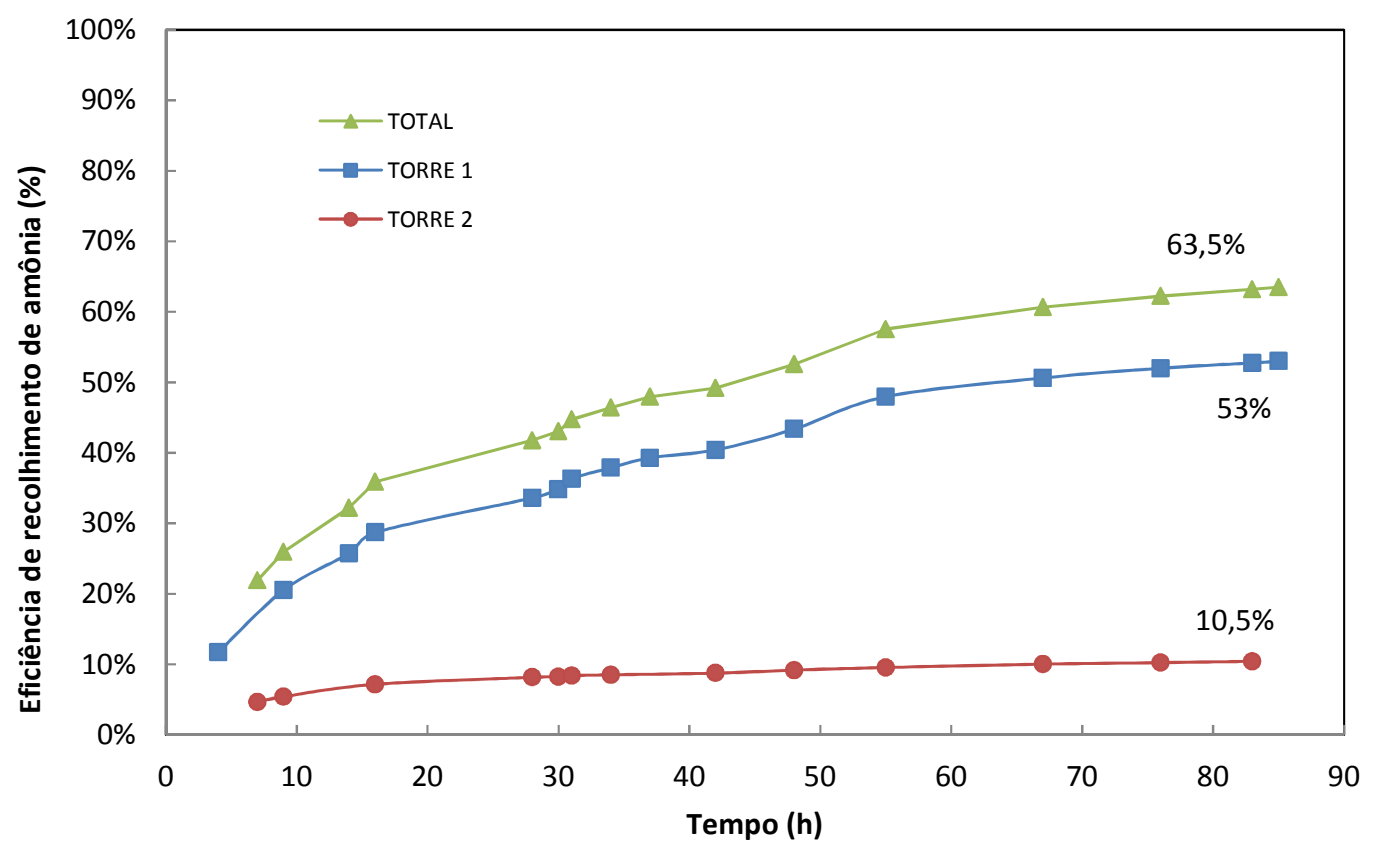

Figura 5.80 - Eficiência de recolhimento da amônia no experimento EX-1, com vazão de $90 \mathrm{~L} / \mathrm{h}$ de lixiviado alcalinizado $(\mathrm{pH}$ de 11,6) e $3500 \mathrm{~L} / \mathrm{h}$ de ar, em solução de água à temperatura ambiente.

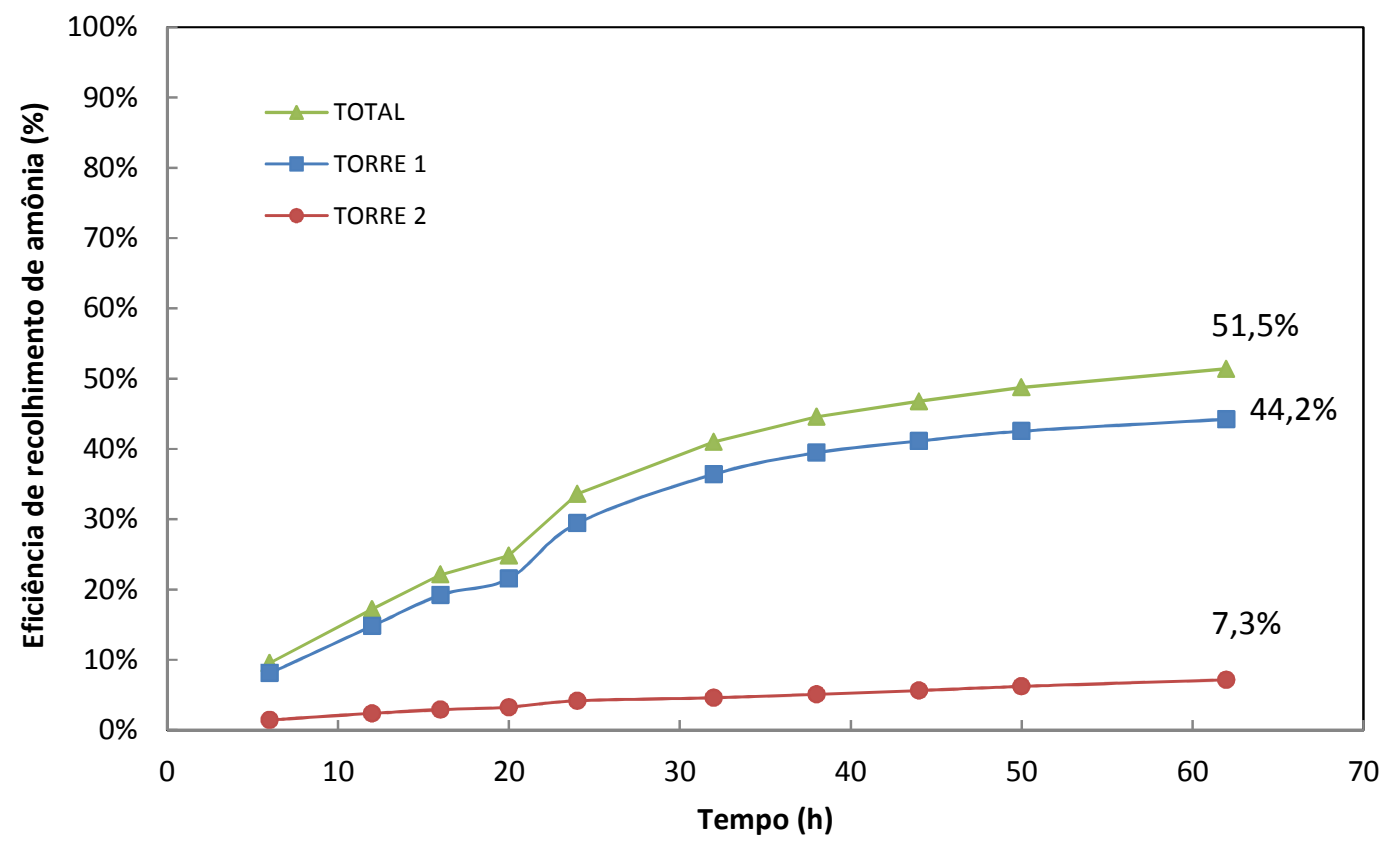

Figura 5.81- Eficiência de recolhimento da amônia no experimento EX-2, com vazão de $90 \mathrm{~L} / \mathrm{h}$ de lixiviado alcalinizado $(\mathrm{pH}$ de 11,3) e $6400 \mathrm{~L} / \mathrm{h}$ de ar, em solução de água à temperatura ambiente. 


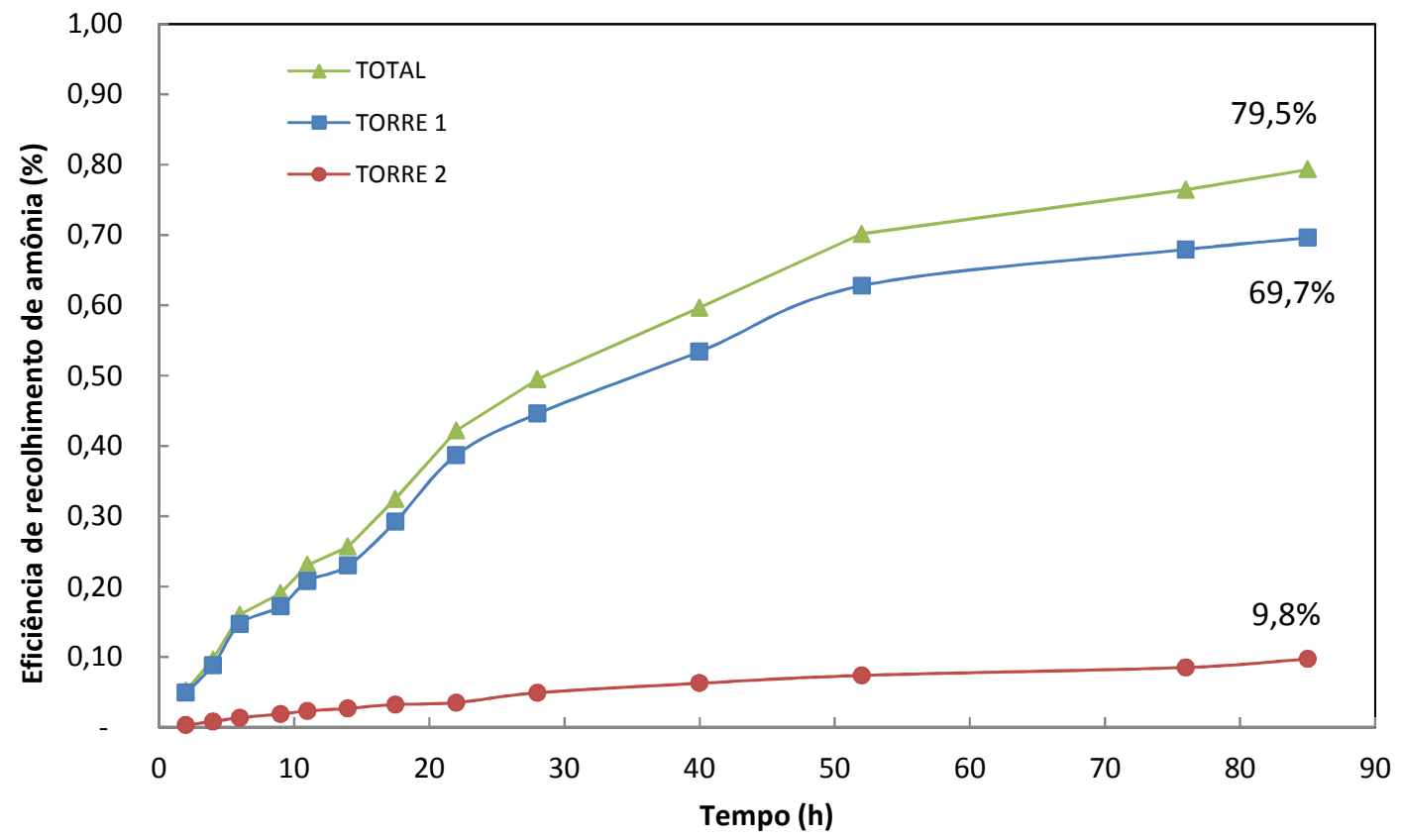

Figura 5.82 - Eficiência de recolhimento da amônia no experimento EX-3, com vazão de $90 \mathrm{~L} / \mathrm{h}$ de lixiviado alcalinizado (pH de 11) e $3500 \mathrm{~L} / \mathrm{h}$ de ar, em solução de água e ácido sulfúrico $0,4 \mathrm{~mol} / \mathrm{L}$ à temperatura ambiente.

Conforme discutido, os resultados obtidos indicaram que o pré-tratamento de lixiviado em torre de air stripping foi tecnicamente viável, uma vez que a qualidade do lixiviado em todos os experimentos satisfez às exigências da resolução CONAMA $397 / 2008$ quanto ao nitrogênio amoniacal, removendo mais de $98 \%$ em todos os experimentos, e além de ser uma alternativa interessante para remoção prévia de nitrogênio amoniacal visando posterior tratamento biológico. 


\section{CONCLUSÕES}

Diante dos resultados apresentados, observando-se as condições investigadas, Pode-se concluir que:

- No Experimento 1 (esgoto mais lixiviado bruto), o reator alimentado com 0,2\% de lixiviado bruto apresentou melhores resultados, alcançando eficiência de remoção da DBO, da DQO e do COD de 95, 76 e 66\%, respectivamente. Apesar de a proporção de $2 \%$ ter alcançado elevada eficiência de remoção da DQO, teve sua eficiência de remoção da DBO e COT fortemente afetada.

- No Experimento 2 (esgoto mais lixiviado pré-tratado), as eficiências de remoção da DBO, da DQO e do COD foram mantidas acima de 97, 82, 60\%, respectivamente, até a proporção de $2 \%$ de lixiviado pré-tratado, com concentrações efluentes da DBO e da DQO inferiores a 9 e $61 \mathrm{mg} / \mathrm{L}$, respectivamente.

- No Experimento 3 (efluente de reator anaeróbio mais lixiviado pré-tratado), o reator alimentado com $0,2 \%$ de lixiviado pré-tratado apresentou melhores resultados, alcançando eficiências de remoção da DBO, da DQO e do COD de 94, 70, 57\%, apesar de que na proporção de $2 \%$ de lixiviado pré-tratado, as concentrações efluentes da DBO e DQO foram mantidas abaixo de a 18 e $72 \mathrm{mg} / \mathrm{L}$, respectivamente.

- No Experimento 4 (efluente de reator anaeróbio mais lixiviado bruto), foram alcançadas menores eficiências. O reator alimentado com $0,2 \%$ de lixiviado pré-tratado apresentou melhores resultados, alcançando eficiências de remoção da DBO, da DQO e do COD de 63, 64, 54\%, com concentrações efluentes da DQO abaixo de a $73 \mathrm{mg} / \mathrm{L}$, respectivamente.

- Dentre as condições estudadas em escala de bancada, o Experimento 2 (mistura de esgoto sanitário com lixiviado pré-tratado) se mostrou mais viável tecnicamente. Nesse experimento foram alcançadas maiores eficiências e constatados menores efeitos pela adição do lixiviado sobre a eficiência de remoção de matéria orgânica e de nitrogênio e equilíbrio da diversidade microbiana. 
- A proporção de 5\% de lixiviado se mostrou inviável tecnicamente nas condições de todos os experimentos realizados neste estudo, com eficiências de remoção da DQO abaixo de $69 \%$ e concentração efluente acima de $112 \mathrm{mg} / \mathrm{L}$.

- O lixiviado pré-tratado promoveu aumento significativo na eficiência de remoção de matéria orgânica (10 a 20\%). Foi nítida a menor interferência sobre o desempenho do sistema, de forma que a redução das eficiências, em relação aos reatores controles, foi menos acentuada nos experimentos com lixiviado pré-tratado.

- Os resultados de eficiência de remoção da DBO, de NTK e de NAT indicaram que houve efeitos de toxicidade do lixiviado bruto sobre o desempenho do sistema, provavelmente pela amônia livre, principalmente na proporção de 5\%, na qual o sistema foi fortemente afetado tanto na eficiência de remoção de matéria orgânica quanto de nitrogênio.

- Os resultados não indicaram melhoras significativas quando utilizado efluente anaeróbio na mistura com lixiviado. Nessas condições, foram obtidas baixas eficiências de remoção de matéria orgânica e de nitrogênio.

- Quanto à diversidade microbiana, em geral, esta sofreu desequilíbrio significativo na proporção de 5\% de lixiviado em todos os experimentos, com exceção do Experimento 2. Nos Experimentos com efluente anaeróbio foi observada uma redução na diversidade microbiana, com aumento da frequência de microrganismos filamentosos, possivelmente pela baixa concentração de matéria orgânica solúvel afluente e pelas condições anaeróbias do efluente do RAC.

- No experimento em escala piloto, os resultados indicaram viabilidade do tratamento nas condições estudadas com $2 \%$ de lixiviado pré-tratado, com eficiências médias de remoção da DBO, da DQO, do COD de 93, 84 e 60\%. Em geral, houve uma redução próxima de $10 \%$ da eficiência de remoção de matéria orgânica em relação ao reator controle. Quanto à qualidade do lodo, no reator alimentado com $2 \%$ de lixiviado prétratado foram obtidos menores valores de IVL, com melhores condições de sedimentabilidade e média frequência de microrganismos filamentosos e não houve diferença significativa da TCO entre as duas condições estudadas.

- Quanto aos metais, foram encontradas maiores concentrações de ferro (Fe), zinco ( $\mathrm{Zn}$ ) e cobre $(\mathrm{Cu})$ na fase sólida. No que tange aos requisitos mínimos de qualidade do lodo de esgoto destinado à agricultura, definidos pela resolução CONAMA n ${ }^{\circ}$ 375/2006 
através do art. 11, todas as amostras de lodo respeitaram os limites máximos de concentração de metais pesados analisados.

\section{RECOMENDAÇÕES}

Tendo em vista futuras pesquisas de tratamento combinado de lixiviado com esgoto sanitário empregando o processo de lodos ativados, recomenda-se:

- Repetir as quatro condições estudadas nos experimentos em escala de bancada em reatores em escala piloto aumentando gradativamente a proporção volumétrica (carga orgânica) de lixiviado de 0 a 5\% para verificar 0 comportamento do sistema em regime contínuo;

- Para melhor investigação, é necessário prolongar o experimento em escala piloto desenvolvido neste estudo por um maior tempo de operação a fim de se verificar as possíveis alterações e interferências na tratabilidade indicadas à longo prazo;

- Repetir os experimentos de tratabilidade com o esgoto sanitário e lixiviado prétratado apenas por air stripping, sem pré-alcalinização, e comparar com os resultados obtidos neste estudo, para se verificar o maior fator responsável pelo aumento da eficiência adquirida nessa condição, se pela remoção da amônia ou pela simples precipitação de compostos recalcitrantes.

- Em termos de operação, é necessário realizar aferição constante das condições operacionais por meio de calibração frequente das bombas utilizadas, limpeza e manutenção das mangueiras de silicone, a fim de evitar grandes variações no tempo de detenção hidráulica adotado. Recomenda-se determinação mais frequente da concentração de sólidos suspensos no tanque de aeração através de instrumentos específicos, a fim de se obter maior exatidão nos descartes diários para manutenção da idade do lodo adotado.

- Realizar determinação da concentração de sulfeto $\left(\mathrm{H}_{2} \mathrm{~S}\right)$ no efluente anaeróbio, a fim de se verificar possíveis efeitos tóxicos aos microrganismos aeróbios do sistema de lodos ativados e a determinação de óleos e graxas no licor misto dos 
reatores em escala piloto, com o intuito de se verificar possível influência na flotação do lodo no decantador secundário;

- Acompanhar por maior período de tempo as concentrações de COD e metais pesados presentes no lodo aeróbio, a fim de se confirmar a possível tendência cumulativa na fase sólida, bem como verificar todos os requisitos mínimos de qualidade do lodo aeróbio para fins de uso agrícola, definidos pela resolução CONAMA n 375/2006;

- Desenvolver estudo específico para avaliar a possível toxicidade de compostos orgânicos do lixiviado no tratamento combinado com esgoto sanitário, utilizando-se medidas de DBO, organismos indicadores de toxicidade e experimentos de respirometria em sistema de lodos ativados, empregando-se substratos como lactose alimentando os reatores com lixiviado;

- Desenvolver estudo específico para avaliação da biodegradabilidade do lixiviado por meio de análise espectroscópicas de seus constituintes antes e depois do tratamento combinado em sistema de lodos ativados, a fim de se comprovar se ocorre a efetiva degradação dos compostos presentes no lixiviado ou simples diluição destes no esgoto sanitário;

- Desenvolver estudos por meio de análises qualitativas e quantitativas do lodo, utilizando microscopia óptica com contagem em placa e técnicas de biologia molecular para uma avaliação mais criteriosa da influência da adição de lixiviado sobre a diversidade microbiana e das características dos flocos que constituem a biomassa do sistema; 


\section{REFERÊNCIAS BIBLIOGRÁFICAS}

ABRELPE - Associação Brasileira de Empresas de Limpeza Pública e Resíduos Especiais. Panorama de Resíduos Sólidos no Brasil- 2009. São Paulo: Abrelpe, 2009.

ABREU, L. M. (1994). Aspectos Microbiológicos de los Procesos de NitrificaciónDesnitrificación, in: "III Taller Y Seminario Latino Americano: Tratamiento Anaerobio de Aguas Residuales", p.55-64, Montevidéu, Uruguai.

ACQUA ENGENHARIA (2010). Manual de operação lodos ativados. Acqua Engenharia e Consultoria S/C Ltda. Pirassununga SP. 27 p. Disponível em: $<$ http://www.acquaeng.com.br/wp-content/uploads/2010/01/ControleLodos-

Ativados.pdf>

ALBUQUERQUE, E. M.; POVINELLI, J.. (2011) Caracterização da eficiência dos processos de tratamento de lixiviado de aterro sanitário no Brasil. In: $26^{\circ}$ Congresso Brasileiro de Engenharia Sanitária e Ambiental, Porto Alegre-RS. Trabalhos técnicos $26^{\circ}$ CBESA, 2011.

ANTHONISEN, A. C.; LOEHR, R.C.; PRAKASAM, T.B.S. E SRINATH, E.G. (1976). Inhibition of nitrification by ammonia and nitrous acid. Journal of the Water Pollut Control Federation, 48(5), 835-852.

ALÉM SOBRINHO, P. (1983). Estudo dos fatores que influem no desempenho do processo de lodos ativados - determinação de parâmetros de projeto para esgotos predominantemente domésticos. Revista DAE, 132, 49-85.

AMARAL, MAILER SENE. (2009) Tratamento físico-químico de lixiviado de aterro sanitário pré-tratado por processo biológico aeróbio. Dissertação (Mestrado) - Escola Politécnica da Universidade de São Paulo. Departamento de Engenharia Hidráulica e Sanitária, 104p..

ANDERSSON, A., LA COUR JANSEN, J. e PERSSON, K.M. (2007) Matching Laechate Treatment to New Regulation, Requirement s and Conditions - SYSAV Spillepeng Experiences 1997-2007. In: XI International Waste Management and Landfill Symposium. Sardinia, Italy.

APHA, AWWA. (2005) Standard Methods for Examination of Water and Wastewater. 21 ed., New York, WPCF.

ARCHER, D. B.(1985) Microbiology and anaerobic digestion. In: Seminar the biomass industries: The impact of biotechnology, Wales. Biotechnology Centre Wales B.A.B.A. University College, Swansea.

ASSOCIAÇÃO BRASILEIRA DE NORMAS TÉCNICAS. (1984) NBR 8419: Apresentação de projetos de aterros sanitários de resíduos sólidos urbanos. Rio de Janeiro: ABNT, 1984. 
AZIZ, H.A.; ADLAN, M.N.; ZAHAR, M.S.M.; ALIAS, S. (2004). Removal of ammoniacal nitrogen $\left(\mathrm{N}-\mathrm{NH}_{3}\right)$ from municipal solid waste leachate by using activated carbon and limestone. Waste Management Research, v.22, p. 371-37.

AZIZ H. A, ALIAS S., ADLAN M. N., FARIDAH, ASAARI A. H. AND ZAHARI, M. N. (2007) Colour removal from landfill leachate by coagulation and flocculation processes. Bioresource Technology, v. 98 p 218-220, 2007.

AVEZZÙ, F. et al. (1995) Behaviour of heavy metals in activated sludge biological treatment of landfill leachate. Waste Management \& Research (1995) 13, 103-121.

BARKER, J.D.; MANNUCCHI, G. A. SALVI, S. M. L. \& STUCKEY, D. C. (1999). Characterisation of Soluble Residual Chemical Oxygen Demand (COD) in Anaerobic Wastewater Treatment Effluents, Water Research, 34 (14), p.3487- 3494.

BARLAZ, M.A. (1996). Microbiology of Solid Waste Landfills. In: Palmisano, A.C. \& Barlaz, M.A. (Eds). Microbiology of Solid Waste. Cap. 2. New York: CRC Press.

BARNES, R. D.; RUPPERT, E. E. (2005) Zoologia dos Invertebrados, $7^{a}$ ed., São Paulo: Roca, 1996.

BENTO, A.P. et al. (2005) Caracterização da microfauna em estação de tratamento de esgotos do tipo lodos ativados: um instrumento de avaliação e controle do processo. Revista Engenharia Sanitária e Ambiental, v. 10, n. 4, p. 329-338.

BENTO, E.R.; LEITE, V.D.; LOPES, W.S.; OLIVEIRA, M.J.; MONTE, F.P. (2009) Estudo do processo de stripping e da recuperação de nitrogênio amoniacal de lixiviado de aterro sanitário. In: CONGRESSO BRASILEIRO DE ENGENHARIA SANITÁRIA E AMBIENTAL, 25., 2009, Recife. Anais...Recife: ABES, 2009. CD ROM.

BIDONE, F.R.A. \& POVINELLI, J. (2010) Conceitos Básicos de Resíduos Sólidos. São Carlos: EESC-USP. Projeto REENGE.

BITTON, G. (2005). Wastewater Microbiology. $3^{\text {rd }}$ edition, John Wiley \& Sons, Inc., Hoboken, NJ, USA, ISBN 0-471-65071-4.

BOCCHICLIERI, M. M. (2005) A influência do recebimento de chorume dos aterros sanitários da Região Metropolitana de São Paulo nas estações de tratamento de esgotos do sistema integrado. 177 f. Dissertação de Mestrado Programa de Pós-Graduação em Saúde Pública, Universidade de São Paulo, São Paulo.

BOCCHIGLIERI, M. M. (2010). O Lixiviado dos Aterros Sanitários em Estações de Tratamento dos Sistemas Públicos de Esgotos. Tese doutorado, Universidade de São Paulo/ Faculdade de Saúde Pública.

BOYLE, W. C.; HAM, R. K. (1974) Biological Treatability of Landfill Leachate. Journal of Water Pollution Control Federation, v. 46, n. 5, p. 860-873.

BOOTH, S. D. J.; URFER, D.; PEREIRA, G.; COBER, K. J. (1996) Assessing the Impact of a Landfill Leachate on a Canadian Waste Water Treatment Plant. Water Environment Research, v. 68, n. 7, p. 1179-1186. 
BORGHI et al. (2001) Combined Treatment of a Mixture of Old and Young Leachates with Wastewater by Activated Sludge System. In: Proceedings of Sardinia - Eighth International Waste Management and Landfill Symposium, 2001, S. Margherita di Pula. Cagliari (Italy): CISA - Environmental Sanitary Engineering Centre.

BOUALLAGUI, H.; TORRIJOS, M.; GODON, J.J.; MOLLETA, R.; BEN CHEIKH, R.; TOUHAMI, Y. (2004) "Two-phase anaerobic digestion fruit and vegetable wastes: bioreactors performance". Biochemical Engineering Journal. (21): 193-7.

BRAILE, P. M. \& CAVALCANTI, J. E. W. A. (1993). Manual de Tratamento de Águas Residuárias, CETESB, 764p., São Paulo, SP

BRANCO, S.M. (1986) Hidrobiologia aplicada à engenharia sanitária, $3^{\text {a }}$ ed., São Paulo: CETESB/ASCETESB.

BRASIL (2010) - Lei 12.305 de 2 de agosto de 2010. Institui a Política Nacional de Resíduos Sólidos; altera a Lei no 9.605, de 12 de fevereiro de 1998; e dá outras providências. Disponível em: <http://www.planalto.gov.br/ccivil_03/_ato20072010/2010/lei/112305.htm>. Acessado em 02 de novembro de 2010.

BROWN, M.J., LESTER, J.N.(1979) Metal removal in activated sludge: the role of bacterial equenciais polymers. Water Research 13, 817-837.

BUSCA, G.; PISSARINO, C. (2003). Abatement of ammonia and amines from waste gases: a summary. Journal of Loss Prevention in the Process Industries, v.16, p.157-163.

CALli, B.; MERTOGLU, B.; INANC, B; YENIGUM, O. (2005) Effects of high ammonia concentrations on the performances of anaerobic bioreactors. Process Biochemistry 40p. 1285-1292.

CARDILLO, L. (2002) Pré-tratamento de líquidos percolados do aterro sanitário para remoção do nitrogênio amoniacal e geração de fosfato de amônia: estudo de viabilidade técnicoeconômica.. Revista Limpeza Pública, v.59, p.18-26.

ÇEÇEN, F.; ÇAKIROĞLU, D. (2001) Impact of landfill leachate on the cotreatment of domestic wastewater. Biotechnology Letters, v. 23, p. 821-826.

CHANG, D. et al. (1995) Feasibility of Combined Treatment of Leachate from a Mature Codisposal Landfill and Its Pretreatment Option. In: Proceedings of Sardinia - Fifth International Landfill Symposium, 1995, S. Margherita di Pula. Cagliari (Italy): CISA - Environmental Sanitary Engineering Centre.

CHANG, D. et al. (1998). Biological co-treatment of equenci with sewage and onsite physicochemical treatment. Envirom. Eng. Res. Vol3, No1, pp. 1-10.

CHEN, S.; SUN, D.; CHUNG, J. (2001). Simultaneous organic and nitrogen removal from municipal landfill leachate using an anaerobic-aerobic system. Water Research 35, 2403-2410. 
CHENG, M.H., PATTERSON, E.R., MINEAR, R.A. (1975) Heavy metals uptake by activated sludge, J.. Water Pollut. Control Fed. 47, 362-376.

CHEN, S.G. et al. (2004) The relationship between dynamics of activated sludge fauna and effluent quality. European Journal Protistology (40), p.147-152.

CHIPASA, K. B. (2003). Accumulation and fate of selected heavy metals in a biological wastewater treatment system. Waste Management 23 (2003) 135-143.

COLETTI, F.J.(1997). Pós-tratamento por lodos ativados de efluente de um Reator Anaeróbio no tratamento de esgoto sanitário. Dissertação (Mestrado). Programa de pós-graduação em Engenharia Hidráulica e Saneamento da Escola de Engenharia de São Carlos - Universidade de São Paulo. 2v.

CONTRERA, R.C. (2008) Estudo da tratabilidade de lixiviados de aterros sanitários em sistemas de reatores anaeróbios e aeróbio operados em bateladas sequenciais e em filtro biológico anaeróbio contínuo de fluxo ascentente $.789 \mathrm{p}$. Tese de Doutorado, Programa de Pós-Graduação da Escola de Engenharia de São Carlos - Universidade de São Paulo, São Carlos.

CORDI, L. et al.(2003) Impacto na microbiota do lodos ativados durante a aclimatação com diferentes efluentes industriais. In: Simpósio Nacional de Fermentações, 14., 2003, Florianópolis. Anais... Florianópolis. P.353.

CURDS, C.R.(1982) The ecology and role of protozoa in aerobic sewage treatment processes. Annual Review of Microbiology, v. 36, p. 27-28.

CUTOLO, S.A.; ROCHA, A.A. (2000) Correlação entre a microfauna e as condições operacionais de um processo de lodos ativados. In: XXVII Congresso Interamericano De Engenharia Sanitária E Ambiental. Porto Alegre, RS, Anais... Rio de Janeiro; ABES.

DEL BORGHI, A.; BINAGHI, L.; DEL BORGHI M. (2003). Combined treatment of leachate from landfill and municipal wastewater by activated sludge. Chem. Biochem. Eng. Q. 17 (4) 277 - 283.

DELIYANNI, E. A., PELEKA, E. N., MATIS, K. A. (2006) Removal of Zinc Ion from Water by Sorption onto Iron-based Nanoadsorbent, Journal of Hazardous Materials, pp. 1-9.

DENG, Y; ENGLEHARDT, J. D.(2006) Treatment of landfill leachate by the Fenton process.Water Research, v. 40, n.20, p. 3683-3694.

DIAMADOPOULOS, E.; SAMARAS P.; DABOU, X.; SAKELLAROPOULOS, G.P.(1997) Combined treatment of leachate and domestic sewage in a sequencing batchreactor, Water Sci. Technol. V. 36, n. 2-3, p.61-68.

DIAS, J.; LOPES, W. S; QUEIROZ, M.B.; CAMPOS, D. C.; OLIVEIRA, M. J.D.; BENTO, E. R.; ARAÚJO, P. T. (2007). Tratamento conjugado de lixiviado. In:Congresso Brasileiro de Química, 47, Natal, RN. Anais eletrônicos. Disponível em: http://www.abq.org.br/cbq/2007/trabalhos/5/5-717-853.htm. Acesso em: 24 dez.2010 
DILALLO, R.; ALBERTSON, O.E. (1961) Volatile acids by direct titration. Journal Water Pollution Control Federation, v.33, n.4, p.350-364, 1961.

DINIZ, DÉBORA TOLENTINO LUZZI (2010). Remoção de Nitrogênio amoniacal de lixiviado de aterro por precipitação química com formação de estruvita. 111p. Dissertação de mestrado. Departamento de Engenharia civil e Ambiental-UNB, Brasília-DF.

EHRIG, H. J. (1998) Co-treatment in Domestic Sewage Facilities. In: Proceedings of International Training Seminar: Management and Treatment of MSW Landfill Leachate, 1998, Venice, p. XI-1 a XI-10. Cagliari (Italy): CISA - Sanitary Environmental Engineering Centre.

FACCHIN, J.M.J; COLOMBO, M.C.R.; COTRIM, S.L.S.; REICHERT, G.A.(2000) Avaliação do tratamento combinado do esgoto e lixiviado de aterro sanitário na ETE Lami (Porto Alegre) após o primeiro ano de operação. In: Congresso Interamericano de Engenharia Sanitária e Ambiental, 27, Porto Alegre, RS. Anais...CDROM.

FERNANDES, J. G. S. (1999) Utilização da Respirometria no Controle Operacional de Sistemas Aeróbios de Tratamento de Águas Residuárias. Dissertação (Mestrado) Universidade Federal da Paraíba, Campina Grande.

FERRAZ, F.M. (2010). Recuperação da amônia liberada no processo de "air stripping" aplicado ao tratamento do lixiviado de aterros sanitários. $129 \mathrm{p}$. Dissertação (Mestrado), Escola de Engenharia de São Carlos, Universidade de São Paulo, São Carlos.

FERREIRA, EDUARDO S. (2000) Cinética Química e fundamentos dos processos de nitrificação e desnitrificação biológica. In: XXVII Congresso Interamericano de Engenharia Sanitária e Ambiental, 2000, Porto Alegre-RS. AIDIS - Asociación Interamericana de Ingeniería Sanitaria y Ambiental, 2000. P. 1-25.

FERREIRA, J.A.; MANNARINO,F.C.; MOREIRA, C.J.; ARIASM,L.R.A.;BILA,M.D. (2007) Avaliação da eficiência do tratamento combinado de lixiviados de aterros de resíduos sólidos urbanos em estações de tratamento de esgoto usando experimentos ecotoxicologicos - estudo de casos. In: Congresso Brasileiro de Engenharia Sanitária e Ambiental, 24, Belo Horizonte, MG. Anais...CD-ROM

FERREIRA, J.A.; CANTANHEDE, A.L.G.; LEITE, V.L.; BILA, D.M.; CAMPOS, J.C.; YOKOYAMA, L.; FIGUEIREDO, I.C.; MANNARINO, C.F., SANTOS, A.S., FRANCO, R.S.O.; LOPES, W.S.; SOUSA, J.T. (2009) Tratamento combinado de lixiviados de aterros de resíduos sólidos urbanos com esgoto sanitário. In: GOMES, L.P. Estudos de caracterização e tratabilidade de lixiviados de aterros sanitários para condições brasileiras. Livro 3 do Projeto PROSAB. Rio de Janeiro: ABES, 2009a 360 p.

FILHO, I. N.; VON MUHLEN; CAMARAO, E. B (2001). Estudo de compostos orgânicos em lixiviado de aterros sanitários por EFS e CG/EM. Quim. Nova, Vol. 24, No. 4, 554-556, 2001. 
FRANCO, R. S. O. (2009) Avaliação da eficiência do tratamento combinado de lixiviado com esgoto sanitário em estação de tratamento de esgoto. $109 \mathrm{f}$. Dissertação (Mestrado em Engenharia Ambiental) - Faculdade de Engenharia, Universidade Estado do Rio de Janeiro, Rio de Janeiro.

GARCIA, D.A. (2005). Aplicación de Métodos Estadísticos Multivariantes para la Modelación la Monitorización de un Reactor Discontinuo Sequencial para el Tratamiento de Águas Residuales. Tesis doctoral, Universidad Politécnica de Valencia, Departament de Ingeniería Hidráulica y Medio Ambiente, Valencia, España, 297p.

GERARDI, MICHAEL H. (2002) Wastewater microbiology: nitrification/ denitrification in the activated sludge process. Eiley-Interscience. John Wiley and Sons, Inc., New York USA, 2002.

GIUSTI, L. (2009) A Review of Waste Management Practices and Their Impacts of Human Health. Waste Management, 29: 2227-2239.

GOMES, L. P. (1989) Estudo da Caracterização Física e da Biodegradabilidade dos Resíduos Sólidos Urbanos em Aterros Sanitários. Dissertação (Mestrado em Engenharia Hidráulica e Saneamento). Escola de Engenharia de São Carlos, Universidade de São Paulo. São Carlos-SP.

GOMES, L.P. (2009) Estudos de Caracterização e Tratabilidade de Lixiviados de Aterros Sanitários para as Condições Brasileiras. PROSAB - tema III edital V. Rio de Janeiro, 2009 - 360p.

GUIMARÃES, E. S.; LACAVA, P. M.; MAGAlHÃES, N. P. (1995) Avaliação da toxicidade aguda com daphnia similis na água captada no rio paraíba do sul e processada na estação de tratamento de água do município de Jacareí - SP Brasil. Engenharia Sanitária e Amiental, v 9 nº 2, p. 124 - 130.

HARADA, T., TANIZAWA, F., TAUE, S., NISHIMURA, Y., OSHIKATA, T., FURUICHI, T. e HANASHIMA, M. (2007) Changes in Subsurface Linear Systems and Leachate Treatment Technologies for Final Disposal Sites in Japan. In: XI International Waste Management and Landfill Symposium. Sardinia, Italy.

HARMESEN, J. (1983). Identification of organic compounds in leachate from a waste tip. Water Research, v. 17, nº 6, p. 699-705.

HEYER, KAI-UWE; STEGMANN, RAINER; EHRIG, HANS-JÜRGEN. (1998) Leachate treatment: Principles and options. In: Proceedings of International Training Seminar: Management and Treatment of MSW Landfill Leachate, 1998, Venice. Cagliari (Italy): CISA - Sanitary Environmental Engineering Centre, 1998. P. $\mathrm{X}-1-\mathrm{X}-18$.

HENRY, J. G. (1987) New Developments in Landfill Leachate Treatment. Water Pollution ... Water Research 21: 1395-1399.

KELLY, H.G. (1987) Pilot Testing for Combined Treatment of Leachate from a Domestic Waste Landfill Site. Journal of Water Pollution Control Federation, v. 59, n. 5, p. 254-261. 
HOFFMANN, HEIKE et al. (2005). Decantabilidade do lodo e formação de grânulos em reator sequencial por batelada. In: Associação Brasileira de Engenharia Sanitária e Ambiental. Saneamento ambiental Brasileiro. Rio de Janeiro, ABES, p.1-8.

HORAN, N. J.(1996) Biological wastewater treatment systems. Theory and operation. John Wiley \& Sons, Chichester, 1990, 310p. apud VON SPERLING, Marcos. Princípios do tratamento biológico de águas residuárias. V. 2. Belo Horizonte: Departamento de Engenharia Sanitária e Ambiental; Universidade Federal de Minas Gerais.

HOSSAKA, A. L.(2008). Tratamento biológico de lixiviados de aterro sanitário, utilizando como pré-tratamento a remoção parcial de $\mathrm{N}$-amoniacal por stripping. Dissertação (Mestrado em Engenharia de Edificações e Saneamento) - Universidade Estadual de Londrina.

HWANG, B-H. et al. (2000) Enhanced nitrite build-up in proportion to increasing equenciai/ $\mathrm{NH}_{4}{ }^{+}$ratio of influent in biofilm reactor. Biotechnology Letters 22: 1287-1290, 2000.

IBGE - INSTITUTO BRASILEIRO DE GEOGRAFIA E ESTATÍSTICA. Pesquisa nacional de saneamento básico. Apresentada em 2000. Disponível em:<www.ibge.gov.br>.Acesso em: 12 fev.2010.

JENKINS, R.L. et al. (1981) Metals removal, recovery from municipal sludge, 1981. J. Water Pollut. Control Fed. 53, 25-32.

JENKINS, D.; RICHARD, M.G.; DAIGGER, G.T. (2003) Manual on the causes and control of activated sludge bulking, foaming, and other solids separation problems. 3. Ed. Boca Raton: Lewis Publishers.

JORDÃO, E. P., PESSÔA, C. A.(2009) Tratamento de Esgotos Domésticos. Rio de Janeiro: Associação Brasileira de Engenharia Sanitária - ABES.

KELLY, H. G. (1997) Pilot Testing for Combined Treatment of Leachate from a DomesticWaste Landfill Site. Journal of Water Pollution Control Federation.. v. 59, n. 5 p. $254-261$.

KOSTOVA, I. (2006). Leachate from Sanitary Landfills-Origin, Characteristics, Treatment. University of Architecture, Civil Engineering and Geodesy, "Iskar's Summer School"-Borovetz, 26-29 July.

KURNIAWAN, T.A. et al. (2006). Physico-chemical treatments for removal of recalcitrant contaminants from landifill leachate. Journal of Hazardous Materials. V. B129, p. 80-100.

LANGE, C.L.; AMARAL, M.C.S. (2009) Geração e características do lixiviado. In: GOMES, L.P. Estudos de caracterização e tratabilidade de lixiviados de aterros sanitários para condições brasileiras. Rio de Janeiro: PROSAB/ABES, 360 p.

LEE S, BASU S, TYLER C W, WEI I W, (2004). Ciliate populations as bioindicators at Deer Island Treatment Plant. Advances in Environmental Research, 8: 371-378. 
LEMA, J. M.; MENDEZ, R.; BLAZQUEZ, R. (1988) Characteristics of Landfill Leachates and Alternatives for Their Treatment: A Review. Water, Air, and Soil Pollution, v. 40, p.223-250.

LI, DA-HONG \& GANCZARCZYK, JERZY, J. (1990) Structure of activatedsludge flocs. Biotechnology and Bioengineering, 35 (1990), pp. 57-65.

LI, X. Z. \& ZHAO, Q. L. (1999) Inhibition of microbial activity of activated sludge by ammonia in leachate. Environment International, Vol. 25, No. 8, pp. 961-968

LI, X. Z.; ZHAO, Q. L.; HAO, X. D. (1999). Ammonium removal from landfill leachate by chemical precipitation. Waste Management. V, 19, p. 409-415.

LIU, YAN; FRANG, H. P. (2003) Influences of Extracellular Polymeric Substances (EPS) on Flocculation, Settling, and Dewatering of Activated Sludge. Critical Reviews in Environmental Science and Technology, Volume 33, Issue 3, 2003.

MACIEL, CRISTIANE BOFF (2002). Microbiologia de lodos ativados da empresa FRAS-LE. Trabalho de conclusão de Curso. Engenharia Química. Caxias do Sul-RS.

MADONI, P.; DAVOLI, D.; CHIERICI, E.(1993) Comparative analysis of the activated sludge microfauna in several sewage treatment works. Water Research, v. 27, n. 9, p. 1485-1491.

MARA, DUNCAN \& HORAN, NIGEL. (2003) Handbook of water and wastewater microbiology. Elsevier ISBN 0-12-470100-0.

MARQUES, E. V. et al. (2010). Tratamento conjunto do liquido lixiviado de aterro sanitário e esgoto domestico no processo de lodos ativados convencional. In: Anais do X Simpósio Ítalo-Brasileiro de Engenharia Sanitária e Ambiental, Maceió-AL.

MENDONÇA, C. L.(2002). Microbiologia e cinética de sistema de lodos ativados como pós-tratamento de efluente de reator anaeróbio de leito expandido. 240p. Tese de doutorado, Programa de Pós-Graduação da Escola de Engenharia de São Carlos- Universidade de São Paulo, São Carlos.

MCBEAN, E. A. et al. (1955) Solid Waste Landfill Engineering and Design. New Jersey: Prentice Hall.

MCCARTY, P.L. (1964) "Anaerobic waste treatment fundamentals, part one chemistry and microbiology", Public Works November, 95, (11), pp107-112.

METCALF \& EDDY (2003). Wastewater engineering: treatment, disposal and reuse. 4. Ed. NewYork, McGraw - Hill Book, 1815p.

MCKINNEY, R. E. (1962) Microbiology for sanitary engineers: McGraw-Hill 293 p.

MIKKELSEN, L.H. (2001). The shear sensitivity of activated sludge. Relations to filterability, rheology and surface chemistry. Colloids Surf A: Physicochem Eng Aspects 2001;182:1-14. 
MIKKELSEN LH, GOTFREDSEN AK, AGERBÆK ML, NIELSEN PH, KEIDING K. (2006) Effects of colloidal stability on clarification and dewatering of activated sludge. Water Sci Technol 1996;34:449-57.

MIKKELSEN LH, NIELSEN PH. (2001) Quantification of the bond energy of bacteria attached to activated sludge floc surfaces. Water Sci Technol 2001;43:6775 .

MINISTÉRIO DO MEIO AMBIENTE. (2005). Conselho Nacional do Meio Ambiente (CONAMA). Resolução no 357, de 17 de março de 2005: Dispõe sobre a classificação dos corpos de água e diretrizes ambientais para seu enquadramento, bem como estabelece as condições e padrões de lançamento de efluentes, e dá outras providências. Diário Oficial da União, Brasília, 7 de abril de 2008. Seção 1, p. 68.

MINISTÉRIO DO MEIO AMBIENTE (2008). Conselho Nacional do Meio Ambiente (CONAMA). Resolução no 397, 03 de abril de 2008, altera o inciso II do $\S 4^{\circ}$ e a Tabela X do $\S 5^{\circ}$, ambos do art. 34 da Resolução do Conselho Nacional do Meio Ambiente- CONAMA n ${ }^{\circ} 357$, de 2005, que dispõe sobre a classificação dos corpos de água e diretrizes ambientais para o seu enquadramento, bem como estabelece as condições e padrões de lançamento de efluentes. Diário Oficial da União, Brasília, 7 de abril de 2008. Seção 1, p. 68.

MINISTÉRIO DO MEIO AMBIENTE (2011). Conselho Nacional do Meio Ambiente (CONAMA). Resolução no 430, 13 de maio de 2011, altera a Resolução no 357, de 17 de março de 2005, do Conselho Nacional do Meio Ambiente-CONAMA. Diário Oficial da União, Brasília, 16 de maio de 2011. Seção 1, p. 69.

MORAIS, J.L. (2005) Estudo da Potencialidade de Processos Oxidativos Avançados, isolados e integrados com processos biológicos tradicionais, para tratamento de lixiviado de Aterro Sanitário. Tese de Doutarado em Química, UFPR, Curitiba.

MUNCH, E. V.; BAND, P. AND KELLER, J. (1996) Simultaneos nitrification and denitrification in banchscale sequencing batch reactors Water Research, Vol. 30, n.2, pp 277-284.

NILSEN, P. H; KEIDING, K. (1998). Disintegration of activated sludge flocs in presence of sulfide. Wat. Res. Vol. 32, No. 2, pp. 313-320.

NECZAJ, E.; KACPRZAK, M.;LACH, J.; OKONIEWSKA, E.; (2007) Effect of sonication on combined treatment of landfill leachate and domestic sewage in SBR reactor. Desalination v.204, n.1-3, p. 227-233.

NOUR, E. A. A. Tratamento de esgoto sanitário empregando-se reator anaeróbio compartimentado. São Carlos: EESC, USP, 1996. Tese (Doutorado) - Escola de Engenharia de São Carlos, Universidade de São Paulo, 1996, 148p.

PAGANINI, W. S.; BOCCHIGLIERI, M. M.; LOPES, G. F. (2003) Avaliação da Capacidade das Estações de Tratamento de Esgotos do Sistema Integrado da Região Metropolitana de São Paulo - RMSP - para o Recebimento do Chorume Produzido nos Aterros Sanitários da Região. In: Anais do $22^{\circ}$ Congresso Brasileiro 
de Engenharia Sanitária e Ambiental, 2003, Joinville. Rio de Janeiro: Associação Brasileira de Engenharia Sanitária e Ambiental, 2003.

PARKER, D. S., D. J. KINNEAR, E. J. WAHLBERG (2001). Review of folklore in design and operation of secondary clarifiers. Journal of Environmental Engineering, vol. 127, pp. 467-484.

PASQUALINI, L.N. (2010) Oxidação da material orgânica dos lixiviados de aterros sanitários por ozônio, peróxido de hidrogênio e radiação ultravioleta. $144 \mathrm{p}$. Dissertação de Mestrado, Programa de Pós-Graduação da Escola de Engenharia de São Carlos - Universidade de São Paulo, São Carlos.

PERSSON, K.M., VAN PRAAGH, M. e OLSBERG, E. (2007) Removal of Heavy Metals from Landfill Leachate by an Artificial Wetland During a Nordic Autum. In: XI International Waste Management and Landfill Symposium. Sardinia, Italy.

PINTO, C. R. R. (1998) Nitrificação em reatores equenciais em batelada (RSB) e sua relação com a microfauna. Porto Alegre, 1998. 127f. Dissertação (Mestrado em Engenharia Ambiental) - Instituto de Pesquisas Hidráulicas - UFRGS.

PINTO, D. M. C. L. (2000) Avaliação da partida da digestão anaeróbia da fração orgânica de resíduos sólidos domésticos inoculados com percolado. $0 \mathrm{f}$. Tese (Doutorado em Engenharia Hidráulica e Saneamento) - Universidade de São Paulo, . Orientador: Jurandyr Povinelli.

POVINELLI, S.C.S. (1999). Cinética, hidrodinâmica e biomassa em reator anaeróbio compartimentado alimentado com esgoto sanitário. 137p. Tese de Doutorado, Programa de Pós-Graduação da Escola de Engenharia de São Carlos Universidade de São Paulo, São Carlos, 1999.

POVINELLI, S. C. C. (1994) Estudo da hidrodinâmica e partida de reator anaeróbio com chicanas tratando esgoto sanitário. São Carlos: EESC, USP, 1994. Tese (Mestrado) - Escola de Engenharia de São Carlos, Universidade de São Paulo, 1994. $181 \mathrm{p}$.

QASIM, S.R.; CHIANG, W. (1994) Sanitary landfill leachate: generation, control and treatment. Lancaster, Pennsylvania, EUA: Technomic Publishing Company, Inc, 1994. $339 \mathrm{p}$.

REYNOLDS, T. D.; RICHARDS, P. A. (1995) Unit Operations and Processes in Environmental Engineering. $2^{\mathrm{a}}$ ed. Boston: PWS Publishing Company.

RENOU, S; GIVAUDAN, J; G.POULAIN, S; DIRASSOUYAN, F, MOULIN, P. (2008) Landfill leachate treatment: Review and opportunity. Journal of Hazardous Materials,v. 150,n.3,p 468-493.

RODRIGUES, F.S.F.(2005) Aplicação da Ozonização e do Reativo de Fenton com prétratamento de chorume com os objetivos de redução da toxicidade e do impacto no processo biológico. Dissertação de Mestrado em Engenharia Civil. COPPE/UFRJ, Rio de Janeiro. 
ROJAS, J. A. R. (2000). Tratamiento de Aguas Residuales - Teoría y Principios de Diseño, Editorial Escuela Colombiana de Ingeniería, 1.232p, Bogotá, Colômbia.

SALVADÓ, H., GRACIA, M.P., AMIGO, J.M. (1995) Capability of ciliated protozoa as indicators of effluent quality in activated sludge plants. Water Research. 29, 1041-1050.

SANTANNA, F. S. P. (1982) Tratamento de águas residuárias da industrialização de frutas cítricas pelo processo de lodos ativados. São Carlos-SP, 165 p. Dissertação (mestrado) - Escola de Engenharia de são Carlos, Universidade de São Paulo.

SANTOS, A. S. P. (2010). Aspectos técnicos e econômicos do tratamento combinado de lixiviado de aterro sanitário com esgoto doméstico em lagoas de estabilização. Tese (doutorado) - COPPE/ UFRJ Programa de Engenharia Civil, Rio de Janeiro.

SANTOS, T. G. (2007) Utilização da respirometria para avaliar o grau de toxicidade de poluentes prioritários em sistemas biológicos de tratamento de águas residuárias. Dissertação de Mestrado em Engenharia civil-Recursos Hídricos/ Universidade Federal de Campina Grande (UFCG). Campina Grande-PB

SCHARFF, H., KOK, B. e KROM, A.H.(2007) The Role of Sustainable Landfill in Future Waste Management Systems. In: XI International Waste Management and Landfill Symposium. Sardinia, Italy.

SHISKOWSKI, D.M.; MAVINIC, D.S. (1998). Biological treatment of a high ammonia leachate: influence of external carbon during initial startup. Water Research, v. 32, no 8, p. 2533-2541.

SHENG, GUO-PING; YU, HAN-QING; LI, XIAO-YAN (2010) Extracellular polymeric substances (EPS) of microbial aggregates in biological wastewater treatment systems: A review. Biotechnology Advances. Volume 28, Issue 6, November-December 2010, Pages 882-894

SHENG, GUO-PING; YU, HAN-QING. (2006) Characterization of extracellular polymeric substances of aerobic and anerobic sludge using 3-dimensional excitation and emission matrix fluorescence spectroscopy. Water Res 2006a;40:1233-9

SIGNORILE, S. et al. (2010) Study of the correlation between microfauna and the macrostructure of activated sludge and the efficiency of biological wastewater treatment plants. Journal Prev Med Hyg. 2010 Mar;51(1):15-9.

SILVA, F.V.B. (2005) Avaliação da Influência da Correção do Teor de Umidade na Degradação Anaeróbia de Resíduos Sólidos Urbanos. Dissertação de Mestrado, Departamento de Engenharia Sanitária e Ambiental da Universidade Federal de Minas Gerais - DESA/UFMG.

SISTEMA NACIONAL DE INFORMAÇÕES SOBRE SANEAMENTO. MINISTÉRIO DAS CIDADES (2007). Diagnóstico do manejo de resíduos sólidos urbanos. Brasília, 2007. Disponível em < http://www.snis.gov.br>. Acessado em 12 de outubro de 2010. 
SOUTO, G.D.B. (2009) Lixiviado de aterros sanitários brasileiros - estudo de remoção do nitrogênio amoniacal por processo de arraste com ar ("stripping"). 371 p. Tese de Doutorado, Programa de Pós-Graduação da Escola de Engenharia de São Carlos - Universidade de São Paulo, São Carlos.

TCHOBANOGLOUS, G.; THEISEN, H.; VIGIL, S.A. (1993). Integrated solid waste management: engineering principles and management issues. New York: McGrawHill, 1993.978 p.

THORNELOE, S.A. U.S. (2007) EPA's Research to Update Guidance for Quantifying Landfill Gas Emissions. In: XI International Waste Management and Landfill Symposium. Sardinia, Italy.

TURETTA, L. (2011) Estudo da tratabilidade de efluente de reator anaeróbio e lixiviado de aterro sanitário utilizando o processo de lodos ativados. 2011. 103 p. Dissertação (Mestrado) - Escola de Engenharia de São Carlos, Universidade de São Paulo, São Carlos.

TYAGI, V. K et al.(2008) Microbial community in conventional and extended aeration activated sludge plants in India. Ecological indicators 8(2008) 550 - 554.

URASE, T., SALEQUZZAMAN, M., KOBAYASHI, S., MATSUO, K.Y.T e SUZUKI, N. (1997) Effect of High Concentration of Organic and Inorganic Matters in Landfill Leachate on the Treatment of Heavy Metals in Very Low Concentration Level. Water Science Technology. Vol. 36: 349-356.

US Environmental Protection Agency (USEPA).(2000) 40 CFR Parts 136 and 445. Effluent Limitations Guidelines, Pretreatment Standards, and New Source Performance Standards for the Landfills Point Source Category; Final Rule. United States, Washington: 2000.

URBAIN, V; BLOCK, J. C.; MANEM, J. (1993) Bioflocculation In Activated Sludge: An Analytic Approach. Water Research. Vol. 27, No. 5, pp. 829-838, 0043-1354.

VIANA, A. S. P. S.; FIGUEIREDO, I. C.; CANTANHEDE, A.(2007). Avaliação do Cotratamento biológico de lixiviados de aterros sanitários com esgoto doméstico no município do Rio de Janeiro - Universidade Federal do Rio de Janeiro, Rio de Janeiro, $24^{\circ}$ Congresso Brasileiro de Engenharia Sanitária e Ambiental.

VON SPERLING, M. (2002). Princípios do tratamento biológico de águas residuárias. Vol. 4. Lodos ativados. Departamento de Engenharia Sanitária e Ambiental - UFMG. Belo Horizonte: Editora SEGRAC 415 p.

WANNER, J. et al.(1987) Effect of anaerobic conditions on activated sludge filamentous bulking in laboratory systems. Water Research Vol. 21, No. 12, pp. 1541-1546, 1987

WANNER, J.; RUZICKOVÁ, I.; JETMAROVÁ, P.; KRHUTKOVÁ, O. \& PARANIAKOVÁ, J. (1998). A National Survey of Activated Sludge Separation Problems in the Czech Republic: Filaments, Floc Characteristics and Activated Sludge Metabolic Properties, Water Science and Technology, 37 (4-5), p.271-279. 
WEI, Y.; JI, M.; CHEN, Y.; QIN, F. (2009) Inhibitory factors for aerobic granulation with landfill leachate. Proceedings of $3^{\text {rd }}$ International Conference on Bioinformatics and Biomedical Engineering, ICBBE 2009.

WILLEN B-M, NIELSEN JL, KEIDING K, NIELSEN PH.(2000) Influence of microbial activity on the stability of activated sludge flocs. Colloids Surf $B$ : Biointerfaces 2000;18:145-56.

WILÉN, B-M.; JIN, B.; LANT, P. (2003) Impacts of structural characteristics on activated sludge floc stability. Water Research Journal.37 (2003) p. 3632-3645.

WISZNIOWSKI, J.; SURMACZ-GÓRSKA, J.; ROBERT, D.; WEBER, J.-V. (2007). The effect of landfill leachate composition on organics and nitrogen removal in an activated sludge system with bentonite additive. Journal of Environmental Management, v.85, p. 59- 68.

WORLD HEALTH ORGANIZATION (WHO). (1986) Environmental health criteria, $\mathrm{n}^{\circ}$ 54: Ammonia. Geneva. Disponível em: $<$ http://www.inchem.org/documents/ehc/ehc/ehc54.htm>.

ZGAJNAR-GOTVAJN, A., ZAGORC-KONCAN, J. e COTMAN, M. (2009) Comparison of different methods for removal of metals from landfill leachate. In: XII International Waste Management and Landfill Symposium. Sardinia, Italy.

ZHANG et al.. (2009). Pretreatment of ammonium removal from landfill leachate by chemical precipitation, Journal of Hazardous Materials 166 (2/3) (2009), pp. 911915

VENDRAMEL, S. M. R. (2004) Tratamento de Efluente de Refinaria de Petróleo em Bio-Reator Aeróbio de Leito Fixo Submerso. Dissertação de Mestrado. Universidade Federal do Rio de Janeiro. Rio de Janeiro-RJ.

VAN HAANDEL, A. C. \& MARAIS, G. (1999). O Comportamento do Sistema de Lodo Ativado - Teoria e Aplicações para Projetos e Operação, Efgraf, 472p., Campina Grande, PB.

VAZOLLÉR, R.F. et al. (1989) Microbiologia de lodos ativados. São Paulo: CETESB.

VON SPERLING, M. (2002). Princípios do tratamento biológico de águas residuárias. Vol. 4. Lodos ativados. Departamento de Engenharia Sanitária e Ambiental - UFMG. Belo Horizonte: Editora UFMG 428 p.

ZHOU, K.; XU, M.; DAI, J.; CAO, H. (2006). The microfauna communities and operational monitoring of na activated sludge plant in China. European Journal of Protistology, 42, p. 291-295. 


\section{APÊNDICE A - Monitoramento físico-químico dos experimentos em escala de bancada \\ (Etapa 3)}


A1 - Concentração da alcalinidade total nas amostras dos experimentos em escala de bancada, para as proporções de 0; 0,2; 2 e 5\% de lixiviado, para tempo de operação de 3, 11 e 19 dias.

\begin{tabular}{|c|c|c|c|c|c|c|c|c|c|c|c|c|}
\hline \multirow{3}{*}{$\begin{array}{c}\text { Etapa } 3 \\
\text { Dias de } \\
\text { operação }\end{array}$} & \multicolumn{12}{|c|}{ Alcalinidade Total $\left(\mathrm{mgCaCO}_{3} / \mathrm{L}\right)$} \\
\hline & \multicolumn{3}{|c|}{$0 \%$} & \multicolumn{3}{|c|}{$0,20 \%$} & \multicolumn{3}{|c|}{$2 \%$} & \multicolumn{3}{|c|}{$5 \%$} \\
\hline & AFLUENTE & EFLUENTE & $\begin{array}{c}\text { Remoção } \\
(\%)\end{array}$ & AFLUENTE & EFLUENTE & $\begin{array}{c}\text { Remoção } \\
(\%)\end{array}$ & AFLUENTE & EFLUENTE & $\begin{array}{c}\text { Remoção } \\
(\%)\end{array}$ & AFLUENTE & EFLUENTE & $\begin{array}{c}\text { Remoção } \\
(\%)\end{array}$ \\
\hline \multicolumn{13}{|c|}{ Experimento 1} \\
\hline $3^{o}$ & 174 & 5 & 97 & 279 & 9 & 97 & 357 & 58 & 84 & 541 & 389 & 28 \\
\hline $11^{\circ}$ & 149 & 27 & 82 & 198 & 6 & 97 & 336 & 11 & 97 & 484 & 19 & 96 \\
\hline $19^{\circ}$ & 151 & 14 & 91 & 164 & 6 & 96 & 334 & 8 & 98 & 595 & 46 & 92 \\
\hline \multicolumn{13}{|c|}{ Experimento 2} \\
\hline $3^{o}$ & 132 & 7 & 94 & 160 & 7 & 96 & 190 & 15 & 92 & 228 & 46 & 80 \\
\hline $11^{\circ}$ & 173 & 8 & 95 & 180 & 5 & 97 & 201 & 20 & 90 & 252 & 69 & 73 \\
\hline $19^{\circ}$ & 151 & 9 & 94 & 152 & 4 & 97 & 178 & 18 & 90 & 214 & 59 & 72 \\
\hline \multicolumn{13}{|c|}{ Experimento 3} \\
\hline $11^{\circ}$ & 190 & 3 & 98 & 165 & 2 & 99 & 189 & 5 & 97 & 220 & 32 & 86 \\
\hline $19^{\circ}$ & 82 & 7 & 91 & 98 & 6 & 94 & 126 & 29 & 77 & 180 & 73 & 59 \\
\hline \multicolumn{13}{|c|}{ Experimento 4} \\
\hline $3^{o}$ & 107 & 4 & 96 & 132 & 5 & 97 & 278 & 8 & 97 & 579 & 227 & 61 \\
\hline $11^{\circ}$ & 120 & 21 & 83 & 134 & 13 & 90 & 283 & 5 & 98 & 553 & 36 & 94 \\
\hline $19^{\circ}$ & 93 & 2 & 98 & 114 & 2 & 98 & 283 & 4 & 99 & 579 & 17 & 97 \\
\hline
\end{tabular}


A2 - Concentração da condutividade nas amostras dos experimentos em escala de bancada, para as proporções de 0; 0,2; 2 e 5\% de lixiviado, para tempo de operação de 3, 11 e 19 dias.

\begin{tabular}{|c|c|c|c|c|c|c|c|c|}
\hline \multirow{3}{*}{$\begin{array}{c}\text { Etapa } 3 \\
\text { Dias de } \\
\text { operação }\end{array}$} & \multicolumn{8}{|c|}{ Condutividade $(\mu \mathrm{S} / \mathrm{cm})$} \\
\hline & \multicolumn{2}{|c|}{$0 \%$} & \multicolumn{2}{|c|}{$0,20 \%$} & \multicolumn{2}{|c|}{$2 \%$} & \multicolumn{2}{|c|}{$5 \%$} \\
\hline & AFLUENTE & EFLUENTE & AFLUENTE & EFLUENTE & AFLUENTE & EFLUENTE & AFLUENTE & EFLUENTE \\
\hline \multicolumn{9}{|c|}{ Experimento 1} \\
\hline $3^{\circ}$ & 528 & 410 & 562 & 430 & 1040 & 830 & 2010 & 1220 \\
\hline $11^{\circ}$ & 854 & 853 & 872 & 860 & 875 & 847 & 875 & 865 \\
\hline $19^{\circ}$ & 521 & 410 & 573 & 442 & 1180 & 890 & 2100 & 1710 \\
\hline \multicolumn{9}{|c|}{ Experimento 2} \\
\hline $3^{\circ}$ & 495 & 363 & 567 & 435 & 899 & 650 & 1440 & 1150 \\
\hline $11^{\circ}$ & 466 & 320 & 480 & 382 & 756 & 629 & 1354 & 1122 \\
\hline $19^{\circ}$ & 493 & 362 & 556 & 326 & 805 & 546 & 1260 & 951 \\
\hline \multicolumn{9}{|c|}{ Experimento 3} \\
\hline $3^{\circ}$ & 498 & 368 & 560 & 431 & 843 & 652 & 1424 & 951 \\
\hline $11^{\circ}$ & 467 & 215 & 506 & 246 & 718 & 484 & 1178 & 893 \\
\hline $19^{\circ}$ & 339 & 80 & 384 & 155 & 666 & 458 & 1210 & 980 \\
\hline \multicolumn{9}{|c|}{ Experimento 4} \\
\hline $3^{\circ}$ & 387 & 296 & 426 & 338 & 1014 & 760 & 2090 & 1538 \\
\hline $11^{\circ}$ & 396 & 381 & 483 & 410 & 1100 & 910 & 2180 & 1715 \\
\hline $19^{\circ}$ & 427 & 344 & 486 & 407 & 1125 & 914 & 2100 & 1605 \\
\hline
\end{tabular}


A3 - pH no tanque de aeração nas amostras dos reatores em escala de bancada, para as proporções de 0; 0,2; 2 e 5\% de lixiviado, para tempo de operação de 3, 11 e 19 dias.

\begin{tabular}{|c|c|c|c|c|c|c|c|c|c|c|c|c|c|c|c|c|}
\hline \multicolumn{17}{|c|}{ pH no tanque de aeração } \\
\hline \multirow{2}{*}{$\begin{array}{c}\text { Dias de } \\
\text { operação }\end{array}$} & \multicolumn{4}{|c|}{ Experimento 1} & \multicolumn{4}{|c|}{ Experimento 2} & \multicolumn{4}{|c|}{ Experimento 3} & \multicolumn{4}{|c|}{ Experimento 4} \\
\hline & $0 \%$ & $0,2 \%$ & $2 \%$ & $5 \%$ & $0 \%$ & $0,2 \%$ & $2 \%$ & $5 \%$ & $0 \%$ & $0,2 \%$ & $2 \%$ & $5 \%$ & $0 \%$ & $0,2 \%$ & $2 \%$ & $5 \%$ \\
\hline 1 & 7,42 & 7,70 & 7,80 & 8,14 & 7,61 & 7,53 & 7,40 & 7,40 & 7,33 & 7,47 & 7,53 & 7,77 & 7,26 & 7,32 & 7,87 & 8,31 \\
\hline 2 & 7,34 & 7,34 & 7,87 & 8,28 & 7,47 & 7,52 & 7,59 & 7,60 & 7,25 & 7,27 & 7,31 & 7,40 & 6,97 & 7,08 & 7,50 & 8,34 \\
\hline 3 & 7,08 & 7,57 & 7,81 & 8,20 & 7,44 & 7,60 & 7,60 & 7,85 & 7,08 & 7,17 & 7,15 & 7,38 & 6,82 & 7,01 & 7,30 & 7,80 \\
\hline 4 & 6,81 & 7,16 & 7,35 & 8,27 & 7,60 & 7,40 & 7,80 & 7,75 & 7,06 & 7,00 & 7,00 & 7,30 & 6,90 & 6,80 & 7,20 & 7,91 \\
\hline 5 & 7,30 & 7,13 & 7,22 & 8,02 & 7,30 & 7,41 & 7,56 & 7,76 & 7,15 & 7,04 & 7,02 & 7,80 & 6,76 & 6,90 & 7,24 & 7,95 \\
\hline 6 & 7,30 & 7,18 & 7,32 & 7,66 & 7,43 & 7,52 & 7,70 & 7,36 & 7,00 & 6,95 & 7,01 & 7,14 & 7,04 & 7,10 & 7,39 & 8,28 \\
\hline 7 & 7,30 & 7,14 & 7,36 & 7,63 & 7,42 & 7,17 & 7,34 & 7,43 & 7,24 & 7,12 & 7,20 & 7,51 & 7,06 & 7,23 & 7,40 & 8,10 \\
\hline 8 & 7,25 & 7,30 & 7,35 & 7,65 & 7,39 & 7,40 & 7,45 & 7,64 & 7,30 & 7,32 & 7,34 & 7,39 & 7,70 & 7,08 & 7,30 & 8,01 \\
\hline 9 & 7,40 & 7,26 & 7,37 & 7,66 & 7,35 & 7,20 & 7,55 & 7,76 & 7,50 & 7,50 & 7,68 & 7,60 & - & - & - & - \\
\hline 10 & 7,23 & 6,98 & 7,16 & 7,39 & 7,40 & 7,27 & 7,48 & 7,60 & 7,23 & 7,80 & 7,20 & 7,80 & - & - & - & - \\
\hline 11 & 7,33 & 7,20 & 7,55 & 7,72 & 7,41 & 7,15 & 7,47 & 7,60 & - & - & - & - & 7,40 & 7,30 & 7,70 & 7,80 \\
\hline 12 & 7,02 & 6,95 & 7,27 & 7,47 & 7,19 & 7,24 & 7,40 & 7,66 & 7,10 & 7,30 & 7,45 & 7,43 & 7,89 & 7,10 & 7,50 & 8,00 \\
\hline 13 & 7,26 & 7,19 & 7,42 & 7,69 & 7,06 & 7,12 & 7,25 & 7,02 & 7,30 & 7,23 & 7,32 & 7,30 & 7,32 & 7,80 & 7,70 & 7,75 \\
\hline 14 & 7,41 & 7,09 & 7,26 & 7,56 & 6,91 & 6,80 & 7,06 & 7,03 & 7,23 & 7,34 & 7,45 & 7,55 & 7,60 & 7,90 & 7,45 & 7,98 \\
\hline 15 & - & - & - & - & 6,80 & 6,80 & 7,11 & 7,32 & 7,10 & 7,15 & 7,24 & 7,43 & 7,50 & 7,40 & 7,68 & 7,80 \\
\hline 16 & 7,65 & 7,36 & 7,64 & 7,89 & 7,30 & 7,00 & 7,30 & - & - & - & - & - & 7,21 & 7,20 & 7,70 & 8,00 \\
\hline 17 & 7,49 & 7,42 & 7,65 & 7,95 & 7,10 & 7,20 & 7,10 & 7,50 & 7,36 & 7,19 & 7,38 & 7,63 & 7,02 & 7,27 & 7,44 & 8,12 \\
\hline 18 & 7,60 & 7,47 & 7,60 & 7,79 & 7,20 & 7,08 & 7,38 & 7,58 & 7,20 & 7,19 & 7,15 & 7,32 & 6,90 & 7,40 & 7,30 & 7,89 \\
\hline 19 & 7,40 & 7,34 & 7,50 & 7,84 & 6,97 & 7,2 & 7,32 & 7,4 & 6,94 & 6,91 & 7,00 & 7,17 & 7,10 & 7,34 & 7,54 & 8,00 \\
\hline 20 & 7,40 & 7,21 & 7,32 & 7,55 & 7,02 & 7,10 & 7,19 & 7,40 & 7,00 & 6,95 & 7,01 & 7,14 & 7,40 & 7,12 & 7,40 & 7,80 \\
\hline
\end{tabular}


A4 - Concentração de Oxigênio Dissolvido (OD) no tanque de aeração nas amostras dos reatores em escala de bancada, para as proporções de 0; 0,2; 2 e 5\% de lixiviado, para tempo de operação de 3, 11 e 19 dias.

\begin{tabular}{|c|c|c|c|c|c|c|c|c|c|c|c|c|c|c|c|c|}
\hline \multicolumn{17}{|c|}{ Oxigênio Dissolvido no tanque de aeração (mg/L) } \\
\hline \multirow{2}{*}{$\begin{array}{c}\text { Dias de } \\
\text { operaçãao }\end{array}$} & \multicolumn{4}{|c|}{ Experimento 1} & \multicolumn{4}{|c|}{ Experimento 2} & \multicolumn{4}{|c|}{ Experimento 3} & \multicolumn{4}{|c|}{ Experimento 4} \\
\hline & $0 \%$ & $0,2 \%$ & $2 \%$ & $5 \%$ & $0 \%$ & $0,2 \%$ & $2 \%$ & $5 \%$ & $0 \%$ & $0,2 \%$ & $2 \%$ & $5 \%$ & $0 \%$ & $0,2 \%$ & $2 \%$ & $5 \%$ \\
\hline 1 & 9,30 & 7,65 & 8,32 & 7,76 & 2,58 & 2,39 & 2,17 & 1,91 & 6,30 & 4,10 & 6,36 & 6,00 & 7,91 & 7,48 & 7,52 & 4,50 \\
\hline 2 & 8,44 & 6,81 & 7,62 & 7,37 & 7,20 & 6,80 & 5,72 & 3,60 & 5,96 & 5,64 & 5,65 & 5,14 & 4,88 & 5,79 & 4,87 & 4,38 \\
\hline 3 & 6,65 & 5,81 & 7,88 & 7,31 & 6,90 & 3,75 & 5,80 & 3,95 & 5,75 & 5,70 & 5,64 & 3,15 & 5,60 & 6,94 & 6,83 & 5,60 \\
\hline 4 & 5,32 & 5,26 & 6,44 & 5,78 & 5,19 & 4,90 & 6,19 & 3,30 & 8,00 & 7,63 & 5,00 & 5,20 & 4,50 & 6,60 & 6,35 & 5,40 \\
\hline 5 & 4,50 & 3,60 & 2,80 & 2,62 & 7,60 & 6,50 & 4,70 & 2,90 & 8,24 & 8,30 & 6,40 & 4,50 & 4,00 & 5,86 & 5,98 & 4,30 \\
\hline 6 & 5,60 & 3,65 & 4,91 & 1,90 & 6,90 & 5,90 & 4,35 & 4,06 & - & - & - & - & 7,20 & 7,00 & 7,13 & 6,30 \\
\hline 7 & 1,86 & 1,30 & 1,00 & 1,01 & 5,40 & 4,32 & 3,39 & 2,55 & 7,56 & 6,80 & 6,20 & 6,29 & 6,81 & 6,66 & 4,91 & 5,10 \\
\hline 8 & 4,00 & 3,46 & 3,00 & 1,50 & 4,10 & 4,25 & 2,93 & 2,20 & 6,45 & 4,70 & 5,70 & 6,23 & 7,10 & 6,10 & 3,94 & 2,52 \\
\hline 9 & 9,70 & 9,49 & 8,89 & 7,01 & 2,65 & 3,86 & 2,62 & 2,05 & 6,23 & 4,67 & 4,21 & 4,23 & 5,75 & 6,29 & 5,46 & 4,52 \\
\hline 10 & 4,46 & 4,36 & 2,38 & 3,16 & 2,90 & 3,58 & 2,90 & 2,79 & 4,56 & 3,24 & 3,78 & 4,60 & 4,67 & 6,60 & 5,40 & 5,40 \\
\hline 11 & 5,80 & 4,90 & 5,59 & 3,02 & 3,57 & 3,21 & 3,42 & 3,09 & 5,63 & 4,67 & 5,30 & 5,32 & 6,40 & 6,90 & 5,78 & 6,22 \\
\hline 12 & 5,90 & 6,11 & 5,11 & 2,44 & 5,85 & 2,98 & 2,19 & 2,32 & - & - & - & - & 5,62 & 5,23 & 6,40 & 5,67 \\
\hline 13 & 5,47 & 6,21 & 4,61 & 7,00 & - & - & - & - & 6,51 & 5,96 & 5,61 & 4,89 & - & - & - & - \\
\hline 14 & - & - & - & - & 3,31 & 3,98 & 2,51 & 3,83 & 5,40 & 4,32 & 5,20 & 3,94 & 4,78 & 5,90 & 5,20 & 4,50 \\
\hline 15 & 5,48 & 4,88 & 4,13 & 3,55 & 4,62 & 2,82 & 2,95 & 2,22 & 6,77 & 5,46 & 5,33 & 4,32 & 4,70 & 3,56 & 3,70 & 4,30 \\
\hline 16 & 7,21 & 6,34 & 4,35 & 3,71 & 4,81 & 5,50 & 4,90 & 5,35 & 5,67 & 5,89 & 4,89 & 4,75 & 4,10 & 4,20 & 2,50 & 2,20 \\
\hline 17 & 4,95 & 4,82 & 5,47 & 5,83 & 9,53 & 9,70 & 9,16 & 9,97 & 4,18 & 5,12 & 3,51 & 3,30 & 3,06 & 4,02 & 2,10 & 2,20 \\
\hline 18 & 5,63 & 5,21 & 5,86 & 5,90 & 2,82 & 2,56 & 2,00 & 2,35 & 7,80 & 7,40 & 7,13 & 6,10 & - & - & - & - \\
\hline 19 & 8,57 & 6,63 & 5,58 & 4,09 & 3,32 & 2,57 & 4,67 & 3,95 & 6,24 & 5,03 & 5,88 & 6,40 & 6,40 & 6,45 & 4,95 & 5,19 \\
\hline 20 & - & - & - & - & 4,66 & 2,64 & 3,88 & 2,50 & 6,80 & 6,08 & 5,79 & 4,50 & - & - & - & - \\
\hline
\end{tabular}


A5 - Temperatura no tanque de aeração nas amostras dos reatores em escala de bancada, para as proporções de 0; 0,2; 2 e 5\% de lixiviado, para tempo de operação de 3, 11 e 19 dias.

\begin{tabular}{|c|c|c|c|c|c|c|c|c|c|c|c|c|c|c|c|c|}
\hline \multicolumn{17}{|c|}{ Temperatura no tanque de aeração $\left({ }^{\circ} \mathrm{C}\right)$} \\
\hline \multirow{2}{*}{$\begin{array}{c}\text { Dias de } \\
\text { operação }\end{array}$} & \multicolumn{4}{|c|}{ Experimento 1} & \multicolumn{4}{|c|}{ Experimento 2} & \multicolumn{4}{|c|}{ Experimento 3} & \multicolumn{4}{|c|}{ Experimento 4} \\
\hline & $0 \%$ & $0,2 \%$ & $2 \%$ & $5 \%$ & $0 \%$ & $0,2 \%$ & $2 \%$ & $5 \%$ & $0 \%$ & $0,2 \%$ & $2 \%$ & $5 \%$ & $0 \%$ & $0,2 \%$ & $2 \%$ & $5 \%$ \\
\hline 1 & 20,20 & 20,80 & 20,50 & 20,70 & 21,70 & 21,50 & 21,70 & 21,70 & 20,00 & 19,70 & 19,70 & 19,50 & 21,00 & 21,40 & 20,80 & 21,10 \\
\hline 2 & 18,60 & 18,90 & 18,80 & 18,90 & 19,90 & 20,00 & 20,00 & 20,20 & 22,10 & 22,00 & 22,30 & 22,30 & 21,90 & 21,80 & 22,00 & 22,00 \\
\hline 3 & 20,20 & 20,70 & 20,10 & 21,00 & 18,80 & 18,80 & 19,50 & 19,00 & 20,00 & 20,00 & 20,00 & 20,00 & 22,60 & 22,70 & 22,60 & 22,70 \\
\hline 4 & 20,50 & 21,00 & 19,70 & 19,70 & 18,00 & 17,80 & 18,90 & 19,00 & 19,00 & 18,80 & 18,80 & 18,90 & 21,90 & 22,00 & 22,10 & 22,20 \\
\hline 5 & 21,40 & 22,00 & 22,20 & 21,50 & 19,80 & 20,00 & 20,30 & 20,50 & 18,30 & 18,00 & 18,00 & 17,30 & 18,90 & 18,30 & 19,00 & 18,70 \\
\hline 6 & 21,00 & 21,30 & 20,90 & 20,70 & 19,90 & 20,30 & 20,50 & 20,60 & - & - & - & - & 15,90 & 16,00 & 15,80 & 15,80 \\
\hline 7 & 22,50 & 22,10 & 22,10 & 22,30 & 19,90 & 20,60 & 21,10 & 21,70 & 18,50 & 19,20 & 18,40 & 18,40 & 19,00 & 18,90 & 19,10 & 19,40 \\
\hline 8 & 23,20 & 23,00 & 22,90 & 22,80 & 20,10 & 20,20 & 20,20 & 20,50 & 18,90 & 18,80 & 18,70 & 18,80 & 23,30 & 22,90 & 23,10 & 23,40 \\
\hline 9 & 21,60 & 22,10 & 21,70 & 21,90 & 20,40 & 20,30 & 20,70 & 20,90 & 18,80 & 18,60 & 18,50 & 18,60 & 18,90 & 18,40 & 19,00 & 18,70 \\
\hline 10 & 21,50 & 19,60 & 18,20 & 19,60 & 19,70 & 19,90 & 19,80 & 19,90 & 19,30 & 19,40 & 19,30 & 19,20 & 19,40 & 19,20 & 19,00 & 19,20 \\
\hline 11 & 22,70 & 21,90 & 22,70 & 22,50 & 19,80 & 19,80 & 19,80 & 20,10 & 18,40 & 19,30 & 18,50 & 18,80 & 18,90 & 18,40 & 19,00 & 18,70 \\
\hline 12 & 21,20 & 20,10 & 21,80 & 21,60 & 20,50 & 20,60 & 21,00 & 21,10 & - & - & - & - & 19,40 & 19,20 & 19,00 & 19,20 \\
\hline 13 & 21,50 & 21,30 & 21,10 & 21,00 & 19,80 & 20,00 & 19,80 & 19,80 & 20,20 & 20,50 & 20,70 & 20,90 & - & - & - & - \\
\hline 14 & 21,00 & 20,80 & 20,80 & 20,80 & 16,50 & 15,80 & 15,60 & 16,30 & - & - & - & - & 19,70 & 19,90 & 19,80 & 19,90 \\
\hline 15 & 19,00 & 19,40 & 19,40 & 19,40 & - & - & - & - & 22,50 & 22,00 & 21,50 & 21,50 & 20,40 & 20,50 & 20,40 & 20,50 \\
\hline 16 & 20,40 & 20,40 & 20,20 & 20,10 & 19,00 & 19,00 & 19,00 & 19,00 & 21,20 & 22,30 & 22,00 & 22,00 & 21,00 & 21,40 & 21,20 & 21,20 \\
\hline 17 & 19,00 & 19,30 & 19,30 & 19,10 & 18,00 & 18,00 & 18,00 & 18,00 & 19,80 & 20,00 & 20,50 & 20,00 & 22,00 & 23,00 & 22,50 & 22,40 \\
\hline 18 & 19,70 & 19,70 & 19,70 & 19,70 & 20,20 & 20,50 & 20,70 & 20,90 & 22,40 & 22,40 & 21,40 & 21,90 & - & - & - & - \\
\hline 19 & 20,10 & 20,50 & 20,90 & 21,80 & 19,5 & 19,3 & 19,2 & 19,4 & 22,20 & 21,90 & 21,90 & 21,90 & 23,60 & 23,60 & 23,40 & 23,80 \\
\hline 20 & 21,00 & 20,80 & 20,80 & 20,80 & 19,50 & 19,70 & 19,70 & 19,70 & 23,50 & 23,70 & 22,10 & 23,50 & - & - & - & - \\
\hline
\end{tabular}


A6 - Concentrações da DQO bruta nas amostras dos reatores em escala de bancada, para as proporções de 0; 0,2; 2 e 5\% de lixiviado, para tempo de operação de 3, 11 e 19 dias.

\begin{tabular}{|c|c|c|c|c|c|c|c|c|c|c|c|c|}
\hline \multirow{3}{*}{$\begin{array}{c}\text { Etapa } 3 \\
\text { Dias de } \\
\text { operação }\end{array}$} & \multicolumn{12}{|c|}{ DQO bruta $\left(\mathrm{mgO}_{2} / \mathrm{L}\right)$} \\
\hline & \multicolumn{3}{|c|}{$0 \%$} & \multicolumn{3}{|c|}{$0,20 \%$} & \multicolumn{3}{|c|}{$2 \%$} & \multicolumn{3}{|c|}{$5 \%$} \\
\hline & AFLUENTE & EFLUENTE & $\begin{array}{c}\text { Remoção } \\
(\%)\end{array}$ & AFLUENTE & EFLUENTE & $\begin{array}{c}\text { Remoção } \\
(\%)\end{array}$ & AFLUENTE & EFLUENTE & $\begin{array}{c}\text { Remoção } \\
(\%)\end{array}$ & AFLUENTE & EFLUENTE & $\begin{array}{c}\text { Remoção } \\
(\%)\end{array}$ \\
\hline \multicolumn{13}{|c|}{ Experimento 1} \\
\hline $3^{\circ}$ & 205 & 16 & 92 & 210 & 36 & 83 & 300 & 89 & 70 & 416 & 208 & 50 \\
\hline $11^{\circ}$ & 252 & 20 & 92 & 249 & 59 & 76 & 361 & 114 & 69 & 423 & 229 & 46 \\
\hline $19^{\circ}$ & 251 & 33 & 87 & 244 & 73 & 70 & 269 & 79 & 71 & 451 & 193 & 57 \\
\hline \multicolumn{13}{|c|}{ Experimento 2} \\
\hline $3^{\circ}$ & 312 & 21 & 93 & 327 & 34 & 90 & 374 & 58 & 84 & 483 & 138 & 71 \\
\hline $11^{\circ}$ & 240 & 18 & 92 & 248 & 34 & 86 & 296 & 59 & 80 & 393 & 138 & 65 \\
\hline $19^{\circ}$ & 313 & 35 & 89 & 322 & 45 & 86 & 355 & 61 & 83 & 389 & 113 & 71 \\
\hline \multicolumn{13}{|c|}{ Experimento 3} \\
\hline $3^{\circ}$ & 180 & 37 & 80 & 185 & 60 & 68 & 250 & 90 & 64 & 375 & 125 & 67 \\
\hline $11^{\circ}$ & 95 & 25 & 74 & 140 & 41 & 71 & 209 & 68 & 67 & 307 & 141 & 54 \\
\hline $19^{\circ}$ & 125 & 22 & 83 & 143 & 29 & 80 & 174 & 59 & 66 & 298 & 121 & 59 \\
\hline \multicolumn{13}{|c|}{ Experimento 4} \\
\hline $3^{\circ}$ & 188 & 50 & 74 & 213 & 79 & 63 & 310 & 108 & 65 & 447 & 339 & 24 \\
\hline $11^{\circ}$ & 182 & 40 & 78 & 187 & 61 & 67 & 275 & 109 & 60 & 422 & 325 & 23 \\
\hline $19^{\circ}$ & 182 & 65 & 64 & 212 & 78 & 63 & 266 & 121 & 55 & 358 & 248 & 31 \\
\hline
\end{tabular}


A7 - Concentrações da DQO solúvel nas amostras dos reatores em escala de bancada, para as proporções de 0; 0,2; 2 e 5\% de lixiviado, para tempo de operação de 3, 11 e 19 dias.

\begin{tabular}{|c|c|c|c|c|c|c|c|c|c|c|c|c|}
\hline \multirow{3}{*}{$\begin{array}{c}\text { Etapa } 3 \\
\text { Dias de } \\
\text { operação }\end{array}$} & \multicolumn{12}{|c|}{$\mathrm{DQO}$ solúvel $\left(\mathrm{mgO}_{2} / \mathrm{L}\right)$} \\
\hline & \multicolumn{3}{|c|}{$0 \%$} & \multicolumn{3}{|c|}{$0,20 \%$} & \multicolumn{3}{|c|}{$2 \%$} & \multicolumn{3}{|c|}{$5 \%$} \\
\hline & AFLUENTE & EFLUENTE & $\begin{array}{c}\text { Remoção } \\
(\%)\end{array}$ & AFLUENTE & EFLUENTE & $\begin{array}{c}\text { Remoção } \\
(\%)\end{array}$ & AFLUENTE & EFLUENTE & $\begin{array}{c}\text { Remoção } \\
(\%)\end{array}$ & AFLUENTE & EFLUENTE & $\begin{array}{c}\text { Remoção } \\
(\%)\end{array}$ \\
\hline \multicolumn{13}{|c|}{ Experimento 1} \\
\hline $3^{\circ}$ & 146 & 12 & 92 & 123 & 29 & 76 & 183 & 81 & 56 & 305 & 173 & 43 \\
\hline $11^{\circ}$ & 135 & 11 & 92 & 125 & 10 & 92 & 186 & 61 & 67 & 297 & 168 & 44 \\
\hline $19^{\circ}$ & 129 & 11 & 91 & 136 & 21 & 85 & 227 & 38 & 83 & 344 & 177 & 48 \\
\hline \multicolumn{13}{|c|}{ Experimento 2} \\
\hline $3^{\circ}$ & 131 & 17 & 87 & 137 & 48 & 65 & 208 & 51 & 76 & 292 & 108 & 63 \\
\hline $11^{\circ}$ & 119 & 14 & 89 & 124 & 22 & 83 & 173 & 45 & 74 & 245 & 138 & 44 \\
\hline $19^{\circ}$ & 108 & 19 & 83 & 110 & 22 & 80 & 135 & 40 & 70 & 251 & 109 & 57 \\
\hline \multicolumn{13}{|c|}{ Experimento 3} \\
\hline $3^{\circ}$ & 120 & 32 & 73 & 121 & 33 & 73 & 168 & 65 & 61 & 272 & 123 & 55 \\
\hline $11^{\mathrm{o}}$ & 82 & 23 & 72 & 83 & 20 & 76 & 139 & 54 & 61 & 239 & 111 & 53 \\
\hline $19^{\circ}$ & 58 & 14 & 76 & 60 & 15 & 75 & 116 & 39 & 67 & 219 & 103 & 53 \\
\hline \multicolumn{13}{|c|}{ Experimento 4} \\
\hline $3^{\circ}$ & 108 & 24 & 78 & 112 & 28 & 76 & 182 & 60 & 67 & 336 & 223 & 34 \\
\hline $11^{\circ}$ & 59 & 18 & 70 & 60 & 12 & 80 & 136 & 62 & 54 & 280 & 255 & 9 \\
\hline $19^{\circ}$ & 63 & 7 & 89 & 63 & 13 & 79 & 131 & 71 & 46 & 271 & 237 & 13 \\
\hline
\end{tabular}


A8 - Concentrações do COD nas amostras dos reatores em escala de bancada, para as proporções de 0; 0,2; 2 e 5\% de lixiviado, para tempo de operação de 3, 11 e 19 dias.

\begin{tabular}{|c|c|c|c|c|c|c|c|c|c|c|c|c|}
\hline \multirow{3}{*}{$\begin{array}{c}\text { Etapa } 3 \\
\text { Dias de } \\
\text { operação }\end{array}$} & \multicolumn{12}{|c|}{$C O D(m g C / L)$} \\
\hline & \multicolumn{3}{|c|}{$0 \%$} & \multicolumn{3}{|c|}{$0,20 \%$} & \multicolumn{3}{|c|}{$2 \%$} & \multicolumn{3}{|c|}{$5 \%$} \\
\hline & AFLUENTE & EFLUENTE & $\begin{array}{c}\text { Remoção } \\
(\%)\end{array}$ & AFLUENTE & EFLUENTE & $\begin{array}{c}\text { Remoção } \\
(\%)\end{array}$ & AFLUENTE & EFLUENTE & $\begin{array}{c}\text { Remoção } \\
(\%)\end{array}$ & AFLUENTE & EFLUENTE & $\begin{array}{c}\text { Remoção } \\
(\%)\end{array}$ \\
\hline \multicolumn{13}{|c|}{ Experimento 1} \\
\hline $3^{\circ}$ & 38 & 18 & 53 & 40 & 20 & 50 & 51 & 28 & 45 & 86 & 60 & 30 \\
\hline $11^{\circ}$ & 55 & 13 & 76 & 54 & 15 & 72 & 71 & 33 & 54 & 104 & 60 & 42 \\
\hline $19^{\circ}$ & 50 & 14 & 73 & 49 & 15 & 69 & 76 & 34 & 55 & 113 & 55 & 52 \\
\hline \multicolumn{13}{|c|}{ Experimento 2} \\
\hline $3^{\circ}$ & 58 & 21 & 65 & 61 & 14 & 77 & 80 & 24 & 70 & 106 & 44 & 59 \\
\hline $11^{\circ}$ & 41 & 16 & 62 & 46 & 15 & 67 & 63 & 28 & 55 & 90 & 44 & 51 \\
\hline $19^{\circ}$ & 39 & 13 & 68 & 40 & 13 & 67 & 51 & 24 & 53 & 81 & 39 & 52 \\
\hline \multicolumn{13}{|c|}{ Experimento 3} \\
\hline $3^{\circ}$ & 38 & 15 & 61 & 39 & 16 & 60 & 54 & 22 & 60 & 97 & 42 & 57 \\
\hline $11^{\circ}$ & 30 & 11 & 62 & 34 & 18 & 47 & 53 & 26 & 51 & 82 & 39 & 53 \\
\hline $19^{\circ}$ & 28 & 11 & 60 & 29 & 11 & 64 & 45 & 19 & 57 & 86 & 40 & 54 \\
\hline \multicolumn{13}{|c|}{ Experimento 4} \\
\hline $3^{\circ}$ & 39 & 14 & 64 & 41 & 18 & 54 & 64 & 26 & 60 & 109 & 63 & 42 \\
\hline $11^{\circ}$ & 27 & 13 & 51 & 34 & 18 & 46 & 52 & 32 & 38 & 89 & 71 & 20 \\
\hline $19^{\circ}$ & 37 & 18 & 51 & 44 & 17 & 61 & 65 & 30 & 55 & 99 & 63 & 36 \\
\hline
\end{tabular}


A9 - Concentrações da DBO nas amostras dos reatores em escala de bancada, para as proporções de 0; 0,2; 2 e 5\% de lixiviado

\begin{tabular}{|c|c|c|c|c|c|c|c|c|c|c|c|c|}
\hline \multirow{3}{*}{$\begin{array}{c}\text { Etapa } 3 \\
\text { Dias de } \\
\text { operação }\end{array}$} & \multicolumn{12}{|c|}{$\mathrm{DBO}\left(\mathrm{mgO}_{2} / \mathrm{L}\right)$} \\
\hline & \multicolumn{3}{|c|}{$0 \%$} & \multicolumn{3}{|c|}{$0,20 \%$} & \multicolumn{3}{|c|}{$2 \%$} & \multicolumn{3}{|c|}{$5 \%$} \\
\hline & AFLUENTE & EFLUENTE & $\begin{array}{c}\text { Remoçã } \\
(\%)\end{array}$ & AFLUENTE & EFLUENTE & $\begin{array}{c}\text { Remoção } \\
(\%)\end{array}$ & AFLUENTE & EFLUENTE & $\begin{array}{c}\text { Remoção } \\
(\%)\end{array}$ & AFLUENTE & EFLUENTE & $\begin{array}{c}\text { Remoção } \\
(\%)\end{array}$ \\
\hline \multicolumn{13}{|c|}{ Experimento 1} \\
\hline $11^{\circ}$ & 172 & 4 & 98 & 168 & 9 & 95 & 181 & 63 & 65 & 190 & 156 & 18 \\
\hline \multicolumn{13}{|c|}{ Experimento 2} \\
\hline $11^{\circ}$ & 155 & 4 & 97 & 153 & 7 & 95 & 211 & 9 & 96 & 274 & 18 & 93 \\
\hline \multicolumn{13}{|c|}{ Experimento 3} \\
\hline $11^{\circ}$ & 81 & 6 & 93 & 93 & 6 & 94 & 137 & 18 & 87 & 187 & 72 & 61 \\
\hline \multicolumn{13}{|c|}{ Experimento 4} \\
\hline $11^{\circ}$ & 96 & 18 & 81 & 105 & 39 & 63 & 123 & 54 & 56 & 152 & 145 & 5 \\
\hline
\end{tabular}


A10 - Concentrações de NTK nas amostras dos reatores em escala de bancada, para as proporções de 0; 0,2; 2 e 5\% de lixiviado, para tempo de operação de 3, 11 e 19 dias.

\begin{tabular}{|c|c|c|c|c|c|c|c|c|c|c|c|c|}
\hline \multirow{3}{*}{$\begin{array}{c}\text { Etapa } 3 \\
\text { Dias de } \\
\text { operação }\end{array}$} & \multicolumn{12}{|c|}{$N T K(m g N / L)$} \\
\hline & \multicolumn{3}{|c|}{$0 \%$} & \multicolumn{3}{|c|}{$0,20 \%$} & \multicolumn{3}{|c|}{$2 \%$} & \multicolumn{3}{|c|}{$5 \%$} \\
\hline & AFLUENTE & EFLUENTE & $\begin{array}{c}\text { Remoção } \\
(\%)\end{array}$ & AFLUENTE & EFLUENTE & $\begin{array}{c}\text { Remoção } \\
(\%)\end{array}$ & AFLUENTE & EFLUENTE & $\begin{array}{c}\text { Remoção } \\
(\%)\end{array}$ & AFLUENTE & EFLUENTE & $\begin{array}{c}\text { Remoção } \\
(\%)\end{array}$ \\
\hline \multicolumn{13}{|c|}{ Experimento 1} \\
\hline $3^{\circ}$ & 34 & 0 & 100 & 32 & 0 & 100 & 86 & 33 & 62 & 144 & 89 & 38 \\
\hline $11^{\circ}$ & 25 & 5 & 82 & 29 & 0 & 100 & 71 & 15 & 79 & 128 & 36 & 72 \\
\hline $19^{\circ}$ & 20 & 0 & 100 & 34 & 0 & 100 & 66 & 9 & 86 & 137 & 31 & 77 \\
\hline \multicolumn{13}{|c|}{ Experimento 2} \\
\hline $3^{\circ}$ & 32 & 8 & 74 & 33 & 4 & 88 & 37 & 2 & 94 & 34 & 7 & 79 \\
\hline $11^{\circ}$ & 30 & 5 & 83 & 39 & 5 & 86 & 42 & 4 & 90 & 37 & 7 & 81 \\
\hline $19^{\circ}$ & 33 & 1 & 97 & 42 & 1 & 98 & 45 & 3 & 93 & 40 & 3 & 92 \\
\hline \multicolumn{13}{|c|}{ Experimento 3} \\
\hline $3^{\circ}$ & 30 & 9 & 70 & 32 & 8 & 75 & 34 & 9 & 73 & 43 & 10 & 76 \\
\hline $11^{\circ}$ & 29 & 3 & 88 & 35 & 5 & 87 & 41 & 5 & 89 & 39 & 2 & 94 \\
\hline $19^{\circ}$ & 28 & 6 & 80 & 27 & 6 & 79 & 26 & 7 & 74 & 28 & 9 & 68 \\
\hline \multicolumn{13}{|c|}{ Experimento 4} \\
\hline $3^{\circ}$ & 29 & 8 & 73 & 30 & 8 & 74 & 66 & 21 & 68 & 147 & 95 & 35 \\
\hline $11^{\circ}$ & 35 & 11 & 69 & 38 & 14 & 63 & 65 & 21 & 67 & 144 & 47 & 67 \\
\hline $19^{\circ}$ & 37 & 12 & 67 & 38 & 21 & 44 & 81 & 38 & 53 & 156 & 57 & 63 \\
\hline
\end{tabular}


A11 - Concentrações de NAT nas amostras dos reatores em escala de bancada, para as proporções de 0; 0,2; 2 e 5\% de lixiviado, para tempo de operação de 3, 11 e 19 dias.

\begin{tabular}{|c|c|c|c|c|c|c|c|c|c|c|c|c|}
\hline \multirow{3}{*}{$\begin{array}{c}\text { Etapa } 3 \\
\text { Dias de } \\
\text { operação }\end{array}$} & \multicolumn{12}{|c|}{$N A T(m g N / L)$} \\
\hline & \multicolumn{3}{|c|}{$0 \%$} & \multicolumn{3}{|c|}{$0,20 \%$} & \multicolumn{3}{|c|}{$2 \%$} & \multicolumn{3}{|c|}{$5 \%$} \\
\hline & AFLUENTE & EFLUENTE & $\begin{array}{c}\text { Remoção } \\
(\%)\end{array}$ & AFLUENTE & EFLUENTE & $\begin{array}{c}\text { Remoção } \\
(\%)\end{array}$ & AFLUENTE & EFLUENTE & $\begin{array}{c}\text { Remoção } \\
(\%)\end{array}$ & AFLUENTE & EFLUENTE & $\begin{array}{c}\text { Remoção } \\
(\%)\end{array}$ \\
\hline \multicolumn{13}{|c|}{ Experimento 1} \\
\hline $3^{\circ}$ & 30 & 0 & 100 & 30 & 0 & 100 & 67 & 20 & 70 & 136 & 84 & 38 \\
\hline $19^{\circ}$ & 18 & 0 & 100 & 22 & 0 & 100 & 60 & 8 & 88 & 120 & 31 & 74 \\
\hline \multicolumn{13}{|c|}{ Experimento 2} \\
\hline $3^{\circ}$ & 22 & - & 100 & 23 & - & 100 & 24 & 1 & 97 & 23 & 1 & 95 \\
\hline $11^{\circ}$ & 24 & 1 & 95 & 25 & 2 & 94 & 25 & 1 & 95 & 24 & 1 & 96 \\
\hline $19^{\circ}$ & 25 & 1 & 98 & 26 & 1 & 96 & 27 & 1 & 95 & 27 & 1 & 95 \\
\hline \multicolumn{13}{|c|}{ Experimento 3} \\
\hline $3^{\circ}$ & 26 & 5 & 82 & 26 & 3 & 87 & 27 & 1 & 95 & 29 & 1 & 95 \\
\hline $11^{\circ}$ & 27 & 2 & 93 & 29 & 1 & 98 & 30 & 0 & 100 & 29 & 0 & 100 \\
\hline $19^{\circ}$ & 17 & 0 & 100 & 17 & 0 & 100 & 17 & 0 & 100 & 16 & 0 & 100 \\
\hline \multicolumn{13}{|c|}{ Experimento 4} \\
\hline $3^{\circ}$ & 21 & 5 & 76 & 25 & 8 & 69 & 65 & 21 & 68 & 138 & 86 & 38 \\
\hline $11^{\circ}$ & 25 & 8 & 68 & 32 & 10 & 69 & 62 & 22 & 65 & 136 & 45 & 67 \\
\hline $19^{\circ}$ & 26 & 8 & 69 & 28 & 12 & 57 & 76 & 34 & 56 & 148 & 53 & 64 \\
\hline
\end{tabular}


A12 - Concentrações de Nitrato nas amostras dos reatores em escala de bancada, para as proporções de 0; 0,2; 2 e 5\% de lixiviado, para tempo de operação de 3, 11 e 19 dias.

\begin{tabular}{|c|c|c|c|c|c|c|c|c|}
\hline \multirow{3}{*}{$\begin{array}{c}\text { Etapa } 3 \\
\text { Dias de } \\
\text { operação }\end{array}$} & \multicolumn{8}{|c|}{ Nitrato $\left(\mathrm{mg} \mathrm{N}^{-\mathrm{NO}_{3}}{ }^{-} / \mathrm{L}\right)$} \\
\hline & \multicolumn{2}{|c|}{$0 \%$} & \multicolumn{2}{|c|}{$0,20 \%$} & \multicolumn{2}{|c|}{$2 \%$} & \multicolumn{2}{|c|}{$5 \%$} \\
\hline & AFLUENTE & EFLUENTE & AFLUENTE & EFLUENTE & AFLUENTE & EFLUENTE & AFLUENTE & EFLUENTE \\
\hline \multicolumn{9}{|c|}{ Experimento 1} \\
\hline $3^{\circ}$ & 0,0 & 0,8 & 0,0 & 1,2 & 0,0 & 2,1 & 0,0 & 0,7 \\
\hline $11^{\circ}$ & 0,0 & 1,5 & 0,1 & 2,2 & 0,3 & 5,0 & - & 3,9 \\
\hline $19^{\circ}$ & 0,0 & 4,7 & - & 13,9 & 0,0 & 14,2 & - & 14,2 \\
\hline \multicolumn{9}{|c|}{ Experimento 2} \\
\hline $3^{\circ}$ & 0,0 & 17,7 & 0,0 & 18,1 & 0,0 & 16,9 & 0,0 & 17,0 \\
\hline $11^{\circ}$ & 0,1 & 15,6 & 0,0 & 18,6 & 0,0 & 20,4 & 0,0 & 18,4 \\
\hline $19^{\circ}$ & 0,2 & 12,0 & 0,0 & 22,4 & 0,0 & 22,8 & 0,0 & 20,1 \\
\hline \multicolumn{9}{|c|}{ Experimento 3} \\
\hline $3^{\circ}$ & 0,0 & 14,4 & 0,0 & 15,6 & 0,0 & 18,2 & 0,0 & 21,7 \\
\hline $11^{\circ}$ & 0,0 & 13,1 & 0,6 & 13,9 & 0,4 & 15,9 & 0,5 & 15,6 \\
\hline $19^{\circ}$ & 0,8 & 7,1 & 0,7 & 8,8 & 0,7 & 10,6 & 0,4 & 11,9 \\
\hline \multicolumn{9}{|c|}{ Experimento 4} \\
\hline $3^{\circ}$ & 0,1 & 11,9 & 0,0 & 17,2 & 0,0 & 2,2 & 0,0 & 9,4 \\
\hline $11^{\circ}$ & 0,0 & 6,9 & 0,0 & 19,8 & 0,0 & 42,7 & 0,0 & 10,7 \\
\hline $19^{\circ}$ & 0,0 & 6,6 & 0,0 & 20,2 & 0,0 & 34,0 & 0,0 & 28,5 \\
\hline
\end{tabular}


A13 - Concentrações de Nitrito nas amostras dos reatores em escala de bancada, para as proporções de 0; 0,2; 2 e 5\% de lixiviado, para tempo de operação de 3, 11 e 19 dias.

\begin{tabular}{|c|c|c|c|c|c|c|c|c|}
\hline \multirow{3}{*}{$\begin{array}{c}\text { Etapa } 3 \\
\text { Dias de } \\
\text { operação }\end{array}$} & \multicolumn{8}{|c|}{ Nitrito $\left(m g \mathrm{~N}-\mathrm{NO}_{2}^{-} / \mathrm{L}\right)$} \\
\hline & \multicolumn{2}{|c|}{$0 \%$} & \multicolumn{2}{|c|}{$0,20 \%$} & \multicolumn{2}{|c|}{$2 \%$} & \multicolumn{2}{|c|}{$5 \%$} \\
\hline & AFLUENTE & EFLUENTE & AFLUENTE & EFLUENTE & AFLUENTE & EFLUENTE & AFLUENTE & EFLUENTE \\
\hline \multicolumn{9}{|c|}{ Experimento 1} \\
\hline $3^{\circ}$ & N.D. & N.D. & N.D. & 0,9 & N.D. & 0,1 & N.D. & 10,2 \\
\hline $11^{\circ}$ & 0,4 & 0,1 & 0,3 & 0,3 & 0,4 & 0,1 & 17,4 & 13,7 \\
\hline $19^{\circ}$ & 0,1 & 3,7 & - & - & - & - & - & - \\
\hline \multicolumn{9}{|c|}{ Experimento 2} \\
\hline $3^{\circ}$ & N.D. & 2,5 & N.D. & N.D. & N.D. & N.D. & N.D. & N.D. \\
\hline $11^{\circ}$ & 0,1 & N.D. & 0,1 & N.D. & 0,1 & N.D. & 0,3 & N.D. \\
\hline $19^{\circ}$ & N.D. & N.D. & N.D. & N.D. & 0,0 & N.D. & N.D. & N.D. \\
\hline \multicolumn{9}{|c|}{ Experimento 3} \\
\hline $3^{\circ}$ & N.D. & 0,1 & N.D. & N.D. & N.D. & 1,0 & N.D. & 2,9 \\
\hline $11^{\circ}$ & N.D. & N.D. & N.D. & N.D. & N.D. & N.D. & N.D. & N.D. \\
\hline $19^{\circ}$ & N.D. & N.D. & N.D. & N.D. & N.D. & N.D. & N.D. & N.D. \\
\hline \multicolumn{9}{|c|}{ Experimento 4} \\
\hline $3^{\circ}$ & N.D. & N.D. & N.D. & N.D. & N.D. & 0,02 & N.D. & 21,1 \\
\hline $11^{\circ}$ & ND & 4,0 & ND & N.D. & ND & N.D. & 0,043 & 64,8 \\
\hline $19^{\circ}$ & 0,01 & 12,0 & N.D. & 0,02 & 1,50 & 0,07 & N.D. & 70,9 \\
\hline
\end{tabular}


A14 - Concentrações de Sólidos Suspensos Totais no tanque de aeração (SSTA) nas amostras dos reatores em escala de bancada, para as proporções de 0; 0,2; 2 e $5 \%$ de lixiviado, para tempo de operação de 3, 11 e 19 dias.

\begin{tabular}{|c|c|c|c|c|c|c|c|c|c|c|c|c|}
\hline \multirow{2}{*}{$\begin{array}{c}\text { Dias de } \\
\text { operação }\end{array}$} & \multicolumn{4}{|c|}{$S S T(m g / L)$} & \multicolumn{4}{|c|}{$S S F(m g / L)$} & \multicolumn{4}{|c|}{$S S V(m g / L)$} \\
\hline & $0 \%$ & $0,20 \%$ & $2 \%$ & $5 \%$ & $0 \%$ & $0,20 \%$ & $2 \%$ & $5 \%$ & $0 \%$ & $0,20 \%$ & $2 \%$ & $5 \%$ \\
\hline \multicolumn{13}{|c|}{ Experimento 1} \\
\hline 3 & 2032 & 1808 & 1804 & 1540 & 492 & 292 & 372 & 336 & 1540 & 1516 & 1432 & 1204 \\
\hline 11 & 1980 & 2110 & 2060 & 2080 & 510 & 490 & 505 & 455 & 1470 & 1620 & 1555 & 1625 \\
\hline 19 & 1665 & 1880 & 1833 & 1827 & 340 & 360 & 360 & 413 & 1325 & 1520 & 1473 & 1414 \\
\hline \multicolumn{13}{|c|}{ Experimento 2} \\
\hline 3 & 1680 & 1740 & 1795 & 1745 & 375 & 380 & 385 & 375 & 1305 & 1360 & 1410 & 1370 \\
\hline 11 & 1665 & 1090 & 1075 & 1050 & 215 & 185 & 230 & 225 & 1450 & 905 & 845 & 825 \\
\hline 19 & 3440 & 2900 & 1950 & 1830 & 640 & 680 & 500 & 470 & 2800 & 2220 & 1450 & 1360 \\
\hline \multicolumn{13}{|c|}{ Experimento 3} \\
\hline 3 & 1900 & 1830 & 1705 & 1755 & 375 & 380 & 385 & 375 & 1525 & 1450 & 1320 & 1380 \\
\hline 11 & 1875 & 2045 & 2020 & 1950 & 395 & 450 & 455 & 440 & 1480 & 1595 & 1565 & 1510 \\
\hline 19 & 1735 & 1640 & 1890 & 1360 & 250 & 260 & 285 & 265 & 1485 & 1380 & 1605 & 1095 \\
\hline \multicolumn{13}{|c|}{ Experimento 4} \\
\hline 3 & 2255 & 2265 & 2265 & 2320 & 560 & 510 & 495 & 580 & 1695 & 1755 & 1770 & 1740 \\
\hline 11 & 1740 & 1810 & 1130 & 1815 & 345 & 450 & 305 & 435 & 1395 & 1360 & 825 & 1380 \\
\hline 19 & 1510 & 1860 & 1360 & 1030 & 290 & 615 & 345 & 265 & 1220 & 1245 & 1015 & 765 \\
\hline
\end{tabular}


A15 - Concentrações de Sólidos Suspensos Totais (SST) nas amostras dos reatores em escala de bancada, para as proporções de 0; 0,2; 2 e 5\% de lixiviado, para tempo de operação de 3,11 e 19 dias.

\begin{tabular}{|c|c|c|c|c|c|c|c|c|c|c|c|c|}
\hline \multirow{3}{*}{$\begin{array}{c}\text { Etapa } 3 \\
\text { Dias de } \\
\text { operaçãoo }\end{array}$} & \multicolumn{12}{|c|}{$S S T(m g / L)$} \\
\hline & \multicolumn{3}{|c|}{$0 \%$} & \multicolumn{3}{|c|}{$0,20 \%$} & \multicolumn{3}{|c|}{$2 \%$} & \multicolumn{3}{|c|}{$5 \%$} \\
\hline & AFLUENTE & EFLUENTE & $\begin{array}{c}\text { Remoção } \\
(\%)\end{array}$ & AFLUENTE & EFLUENTE & $\begin{array}{c}\text { Remoção } \\
(\%)\end{array}$ & AFLUENTE & EFLUENTE & $\begin{array}{c}\text { Remoção } \\
(\%)\end{array}$ & AFLUENTE & EFLUENTE & $\begin{array}{c}\text { Remoção } \\
(\%)\end{array}$ \\
\hline \multicolumn{13}{|c|}{ Experimento 1} \\
\hline 3 & 100 & 28 & 72 & 122 & 6 & 95 & 94 & 30 & 68 & 170 & 38 & 78 \\
\hline 11 & 68 & 6 & 91 & 54 & 2 & 96 & 66 & 28 & 58 & 50 & 26 & 48 \\
\hline 19 & 74 & 10 & 86 & 64 & 32 & 50 & 78 & 28 & 64 & 56 & 40 & 29 \\
\hline \multicolumn{13}{|c|}{ Experimento 2} \\
\hline 3 & 74 & 2 & 97 & 84 & 6 & 93 & 86 & 10 & 88 & 37 & 10 & 73 \\
\hline 11 & 67 & 9 & 87 & 64 & 17 & 73 & 50 & 16 & 68 & 59 & 22 & 63 \\
\hline 19 & 140 & 18 & 87 & 126 & 30 & 76 & 138 & 15 & 89 & 124 & 24 & 81 \\
\hline \multicolumn{13}{|c|}{ Experimento 3} \\
\hline 3 & 65 & 7 & 89 & 64 & 9 & 86 & 73 & 16 & 78 & 80 & 18 & 78 \\
\hline 11 & 76 & 13 & 83 & 79 & 23 & 71 & 89 & 30 & 66 & 90 & 27 & 70 \\
\hline 19 & 55 & 6 & 89 & 56 & 6 & 89 & 55 & 7 & 87 & 67 & 12 & 82 \\
\hline \multicolumn{13}{|c|}{ Experimento 4} \\
\hline 3 & 65 & 27 & 58 & 54 & 38 & 30 & 51 & 23 & 55 & 71 & 51 & 28 \\
\hline 11 & 60 & 23 & 62 & 55 & 37 & 33 & 58 & 22 & 62 & 51 & 48 & 6 \\
\hline 19 & 89 & 30 & 66 & 62 & 25 & 60 & 50 & 45 & 10 & 60 & 40 & 33 \\
\hline
\end{tabular}


A16 - Concentrações de Sólidos Suspensos Voláteis (SSV) nas amostras dos reatores em escala de bancada, para as proporções de 0; 0,2; 2 e $5 \%$ de lixiviado, para tempo de operação de 3, 11 e 19 dias.

\begin{tabular}{|c|c|c|c|c|c|c|c|c|c|c|c|c|}
\hline \multirow{3}{*}{$\begin{array}{c}\text { Etapa } 3 \\
\text { Dias de } \\
\text { operação }\end{array}$} & \multicolumn{12}{|c|}{$S S V(m g / L)$} \\
\hline & \multicolumn{3}{|c|}{$0 \%$} & \multicolumn{3}{|c|}{$0,20 \%$} & \multicolumn{3}{|c|}{$2 \%$} & \multicolumn{3}{|c|}{$5 \%$} \\
\hline & AFLUENTE & EFLUENTE & $\begin{array}{c}\text { Remoção } \\
(\%)\end{array}$ & AFLUENTE & EFLUENTE & $\begin{array}{c}\text { Remoção } \\
(\%)\end{array}$ & AFLUENTE & EFLUENTE & $\begin{array}{c}\text { Remoção } \\
(\%)\end{array}$ & AFLUENTE & EFLUENTE & $\begin{array}{c}\text { Remoção } \\
(\%)\end{array}$ \\
\hline \multicolumn{13}{|c|}{ Experimento 1} \\
\hline 3 & 76 & 16 & 79 & 86 & 6 & 93 & 58 & 22 & 62 & 92 & 28 & 70 \\
\hline 11 & 52 & 2 & 96 & 42 & 2 & 95 & 45 & 20 & 56 & 22 & 18 & 18 \\
\hline 19 & 59 & 7 & 88 & 48 & 26 & 46 & 60 & 16 & 73 & 33 & 26 & 21 \\
\hline \multicolumn{13}{|c|}{ Experimento 2} \\
\hline 3 & 63 & 1 & 98 & 74 & 4 & 95 & 70 & 8 & 89 & 27 & 7 & 74 \\
\hline 11 & 58 & 6 & 90 & 58 & 15 & 74 & 38 & 15 & 61 & 43 & 16 & 63 \\
\hline 19 & 102 & 3 & 97 & 102 & 19 & 81 & 112 & 3 & 97 & 90 & 17 & 81 \\
\hline \multicolumn{13}{|c|}{ Experimento 3} \\
\hline 3 & 61 & 7 & 89 & 63 & 9 & 86 & 68 & 15 & 78 & 79 & 18 & 77 \\
\hline 11 & 56 & 6 & 89 & 66 & 23 & 65 & 62 & 30 & 52 & 90 & 27 & 70 \\
\hline 19 & 50 & 4 & 92 & 54 & 6 & 89 & 54 & 7 & 87 & 58 & 9 & 84 \\
\hline \multicolumn{13}{|c|}{ Experimento 4} \\
\hline 3 & 49 & 26 & 47 & 50 & 34 & 32 & 48 & 20 & 58 & 58 & 47 & 19 \\
\hline 11 & 50 & 19 & 62 & 51 & 34 & 33 & 55 & 20 & 64 & 41 & 41 & - \\
\hline 19 & 77 & 27 & 65 & 57 & 21 & 63 & 46 & 43 & 7 & 53 & 34 & 36 \\
\hline
\end{tabular}


A17 - Concentrações de Sólidos Totais (ST) nas amostras dos reatores em escala de bancada, para as proporções de 0; 0,2; 2 e 5\% de lixiviado, para tempo de operação de 3, 11 e 19 dias.

\begin{tabular}{|c|c|c|c|c|c|c|c|c|c|c|c|c|}
\hline \multirow{3}{*}{$\begin{array}{c}\text { Etapa } 3 \\
\text { Dias de } \\
\text { operação }\end{array}$} & \multicolumn{12}{|c|}{$S T(m g / L)$} \\
\hline & \multicolumn{3}{|c|}{$0 \%$} & \multicolumn{3}{|c|}{$0,20 \%$} & \multicolumn{3}{|c|}{$2 \%$} & \multicolumn{3}{|c|}{$5 \%$} \\
\hline & AFLUENTE & EFLUENTE & $\begin{array}{c}\text { Remoção } \\
(\%)\end{array}$ & AFLUENTE & EFLUENTE & \begin{tabular}{|c|} 
Remoção \\
$(\%)$
\end{tabular} & AFLUENTE & EFLUENTE & $\begin{array}{c}\text { Remoção } \\
(\%)\end{array}$ & AFLUENTE & EFLUENTE & $\begin{array}{c}\text { Remoção } \\
(\%)\end{array}$ \\
\hline \multicolumn{13}{|c|}{ Experimento 1} \\
\hline 3 & 438 & 316 & 28 & 472 & 254 & 46 & 758 & 414 & 45 & 1230 & 722 & 41 \\
\hline 11 & 320 & 100 & 69 & 306 & 200 & 35 & 472 & 282 & 40 & 896 & 756 & 16 \\
\hline 19 & 232 & 118 & 49 & 248 & 162 & 35 & 518 & 350 & 32 & 748 & 636 & 15 \\
\hline \multicolumn{13}{|c|}{ Experimento 2} \\
\hline 3 & 416 & 270 & 35 & 494 & 302 & \begin{tabular}{|l|}
39 \\
\end{tabular} & 574 & 442 & 23 & 870 & 618 & 29 \\
\hline 11 & 346 & 160 & 54 & 364 & 241 & 34 & 630 & 385 & 39 & 931 & 736 & 21 \\
\hline 19 & 394 & 258 & 35 & 405 & 311 & 23 & 484 & 383 & 21 & 680 & 332 & 51 \\
\hline \multicolumn{13}{|c|}{ Experimento 3} \\
\hline 3 & 386 & 256 & 34 & 458 & 300 & \begin{tabular}{|l|}
34 \\
\end{tabular} & 520 & 445 & 14 & 825 & 602 & 27 \\
\hline 11 & 349 & 247 & 29 & 356 & 259 & 27 & 483 & 431 & 11 & 803 & 699 & 13 \\
\hline 19 & 274 & 141 & 48 & 299 & 195 & 35 & 394 & 232 & 41 & 694 & 614 & 11 \\
\hline \multicolumn{13}{|c|}{ Experimento 4} \\
\hline 3 & 228 & 191 & 16 & 230 & 181 & 21 & 457 & 416 & 9 & 770 & 699 & 9 \\
\hline 11 & 495 & 315 & 36 & 525 & 459 & 13 & 733 & 655 & 11 & 1101 & 1000 & 9 \\
\hline 19 & 260 & 220 & 15 & 275 & 250 & 9 & 556 & 470 & 15 & 664 & 614 & 8 \\
\hline
\end{tabular}


A18 - Concentrações de Sólidos Totais Voláteis (STV) nas amostras dos reatores em escala de bancada, para as proporções de 0; 0,2; 2 e 5\% de lixiviado, para tempo de operação de 3,11 e 19 dias.

\begin{tabular}{|c|c|c|c|c|c|c|c|c|c|c|c|c|}
\hline \multirow{3}{*}{$\begin{array}{c}\text { Etapa } 3 \\
\text { Dias de } \\
\text { operação }\end{array}$} & \multicolumn{12}{|c|}{$S T V(m g / L)$} \\
\hline & \multicolumn{3}{|c|}{$0 \%$} & \multicolumn{3}{|c|}{$0,20 \%$} & \multicolumn{3}{|c|}{$2 \%$} & \multicolumn{3}{|c|}{$5 \%$} \\
\hline & AFLUENTE & EFLUENTE & $\begin{array}{c}\text { Remoção } \\
(\%)\end{array}$ & AFLUENTE & EFLUENTE & $\begin{array}{c}\text { Remoção } \\
(\%)\end{array}$ & AFLUENTE & EFLUENTE & $\begin{array}{c}\text { Remoção } \\
(\%)\end{array}$ & AFLUENTE & EFLUENTE & $\begin{array}{c}\text { Remoção } \\
(\%)\end{array}$ \\
\hline \multicolumn{13}{|c|}{ Experimento 1} \\
\hline 3 & 162 & 162 & 0 & 200 & 100 & 50 & 484 & 188 & 61 & 418 & 348 & 17 \\
\hline 11 & 140 & 26 & 81 & 114 & 72 & 37 & 238 & 84 & 65 & 452 & 391 & 13 \\
\hline 19 & 140 & 80 & 43 & 130 & 109 & 16 & 358 & 218 & 39 & 382 & 380 & 1 \\
\hline \multicolumn{13}{|c|}{ Experimento 2} \\
\hline 3 & 386 & 270 & 30 & 469 & 300 & 36 & 382 & 304 & 20 & 476 & 298 & 37 \\
\hline 11 & 288 & 154 & 47 & 300 & 233 & 22 & 425 & 258 & 39 & 650 & 520 & 20 \\
\hline 19 & 320 & 250 & 22 & 309 & 279 & 10 & 261 & 232 & 11 & 257 & 138 & 46 \\
\hline \multicolumn{13}{|c|}{ Experimento 3} \\
\hline 3 & 356 & 256 & 28 & 432 & 298 & 31 & 328 & 307 & 6 & 431 & 282 & 35 \\
\hline 11 & 179 & 147 & 18 & 134 & 87 & 35 & 189 & 156 & 17 & 276 & 224 & 19 \\
\hline 19 & 197 & 111 & 44 & 169 & 125 & 26 & 194 & 100 & 48 & 213 & 201 & 5 \\
\hline \multicolumn{13}{|c|}{ Experimento 4} \\
\hline 3 & 84 & 61 & 28 & 70 & 60 & 14 & 157 & 149 & 5 & 247 & 189 & 23 \\
\hline 11 & 152 & 77 & 49 & 235 & 192 & 18 & 283 & 265 & 6 & 511 & 456 & 11 \\
\hline 19 & 144 & 124 & 14 & 120 & 110 & 8 & 300 & 260 & 13 & 144 & 124 & 14 \\
\hline
\end{tabular}


A19 - Concentrações de Metais pesados nas amostras dos reatores em escala de bancada, para as proporções de $0 ; 0,2 ; 2$ e $5 \%$ de lixiviado, para tempo de operação de 3, 11 e 19 dias.

\begin{tabular}{|c|c|c|c|c|c|c|c|c|c|c|c|c|}
\hline \multirow{3}{*}{ Netall } & \multicolumn{12}{|c|}{ Metais $(m g / L)$} \\
\hline & \multicolumn{3}{|c|}{$0 \%$} & \multicolumn{3}{|c|}{$0,2 \%$} & \multicolumn{3}{|c|}{$2 \%$} & \multicolumn{3}{|c|}{$5 \%$} \\
\hline & $A F$ & LODO & $E F$ & $A F$ & LODO & $E F$ & $A F$ & LODO & $E F$ & $A F$ & LODO & $E F$ \\
\hline \multicolumn{13}{|c|}{ Experimento 1} \\
\hline $\mathrm{Zn}$ & 0,08 & 520 & 0,046 & 0,165 & 245 & 0,071 & 0,213 & 286 & 0,054 & 0,094 & 221 & 0,108 \\
\hline $\mathrm{Pb}$ & 0,05 & 36 & 0,03 & 0,08 & 20 & 0,004 & 0,1 & 41 & ND & ND & 27 & ND \\
\hline $\mathrm{Cd}$ & 0,023 & 1,7 & 0,019 & 0,004 & 2 & 0,018 & 0,025 & 2 & 0,016 & 0,024 & 0,9 & 0,015 \\
\hline $\mathrm{Ni}$ & 0,027 & 28,6 & 0,021 & ND & 10,4 & 0,068 & 0,052 & 18,4 & 0,03 & 0,059 & 11,2 & 0,038 \\
\hline $\mathrm{Fe}$ & 1,125 & 10580 & 0,259 & 0,893 & 5330 & 0,675 & 1,18 & 10650 & 0,689 & 1,343 & 6550 & 1,001 \\
\hline $\mathrm{Mn}$ & 0,038 & 113,7 & 0,011 & 0,031 & 51,2 & 0,022 & 0,041 & 65,2 & 0,025 & 0,033 & 44,8 & 0,023 \\
\hline $\mathrm{Cu}$ & 0,014 & 303,7 & ND & 0,016 & 163,9 & ND & 0,012 & 296,6 & 0,006 & 0,027 & 174,1 & 0,022 \\
\hline $\mathrm{Cr}$ & $\mathrm{ND}$ & 72,6 & $\mathrm{ND}$ & $\mathrm{ND}$ & 34,9 & ND & $\mathrm{ND}$ & 81,9 & $\mathrm{ND}$ & ND & 56,7 & ND \\
\hline \multicolumn{13}{|c|}{ Experimento 2} \\
\hline $\mathrm{Zn}$ & 0,124 & 324,3 & 0,077 & 0,143 & 385,9 & 0,135 & 0,098 & 267,5 & 0,059 & 0,135 & 371,5 & 0,086 \\
\hline $\mathrm{Pb}$ & 0,06 & 61 & $<0,001$ & 0,09 & 73 & 0,03 & 0,05 & 43 & $<0,01$ & 0,09 & 58 & $<0,01$ \\
\hline $\mathrm{Cd}$ & 0,026 & 6,8 & 0,007 & 0,019 & 8,2 & 0,011 & 0,015 & 6 & 0,01 & 0,017 & 6,8 & 0,005 \\
\hline $\mathrm{Ni}$ & 0,043 & 24,6 & 0,021 & 0,027 & 28,5 & $<0,008$ & 0,035 & 31,6 & 0,035 & 0,084 & 33,7 & 0,055 \\
\hline $\mathrm{Fe}$ & 3,27 & 11930 & 0,765 & 1,995 & 10990 & 0,405 & 1,085 & 4627 & 0,307 & 1,563 & 8150 & 0,241 \\
\hline $\mathrm{Mn}$ & 0,04 & 71 & 0,019 & 0,026 & 108,6 & 0,023 & 0,018 & 55,2 & 0,008 & 0,023 & 95,9 & 0,007 \\
\hline $\mathrm{Cu}$ & 0,09 & 378 & 0,01 & 0,109 & 460,3 & 0,012 & 0,076 & 275,5 & $<0,003$ & 0,14 & 390,6 & 0,01 \\
\hline $\mathrm{Cr}$ & 0,049 & 39,1 & 0,071 & 0,01 & 50,1 & 0,037 & 0,007 & 23,1 & 0,023 & 0,018 & 40,3 & $<0,005$ \\
\hline \multicolumn{13}{|c|}{ Experimento 3} \\
\hline $\mathrm{Zn}$ & 0,103 & 222 & 0,077 & 0,088 & 266,5 & 0,158 & 0,069 & 244,3 & 0,091 & 0,103 & 246 & 0,12 \\
\hline $\mathrm{Pb}$ & 0,02 & 37 & 0,02 & 0,02 & 40 & 0,02 & 0,03 & 40 & 0,02 & 0,03 & 36 & 0,03 \\
\hline $\mathrm{Cd}$ & 0,022 & 3,2 & 0,032 & 0,019 & 3,6 & 0,024 & 0,025 & 3,9 & 0,018 & 0,024 & 3,4 & 0,032 \\
\hline $\mathrm{Ni}$ & 0,043 & 18,9 & 0,039 & 0,031 & 25,6 & 0,043 & 0,039 & 24 & 0,047 & 0,061 & 25,2 & 0,085 \\
\hline $\mathrm{Fe}$ & 0,461 & 6903 & 0,363 & 0,548 & 7200 & 0,6 & 0,535 & 7955 & 0,383 & 0,529 & 6643 & 0,508 \\
\hline $\mathrm{Mn}$ & 0,028 & 55,3 & 0,024 & 0,026 & 63,8 & 0,043 & 0,036 & 59,5 & 0,028 & 0,028 & 65,4 & 0,031 \\
\hline $\mathrm{Cu}$ & 0,013 & 196,6 & 0,003 & 0,014 & 192,2 & 0,036 & 0,047 & 439,5 & 0,025 & 0,155 & 438,6 & 0,062 \\
\hline $\mathrm{Cr}$ & 0,012 & 54,7 & 0,01 & 0,016 & 57,5 & 0,016 & 0,023 & 59,3 & 0,023 & 0,025 & 57,5 & 0,052 \\
\hline \multicolumn{13}{|c|}{ Experimento 4} \\
\hline $\mathrm{Zn}$ & 0,103 & 256,1 & 0,077 & 0,088 & 249,4 & 0,158 & 0,069 & 223,6 & 0,091 & 0,103 & 258,1 & 0,12 \\
\hline $\mathrm{Pb}$ & 0,02 & 30 & 0,02 & 0,02 & 32 & 0,02 & 0,03 & 28 & 0,02 & 0,03 & 30 & 0,03 \\
\hline $\mathrm{Cd}$ & 0,022 & 0 & 0,032 & 0,019 & 0 & 0,024 & 0,025 & 0 & 0,018 & 0,024 & 4,1 & 0,032 \\
\hline $\mathrm{Ni}$ & 0,043 & 9,9 & 0,039 & 0,031 & 12,5 & 0,043 & 0,039 & 7,1 & 0,047 & 0,061 & 15,5 & 0,085 \\
\hline $\mathrm{Fe}$ & 0,461 & 7320 & 0,363 & 0,548 & 8170 & 0,6 & 0,535 & 5990 & 0,383 & 0,529 & 7080 & 0,508 \\
\hline $\mathrm{Mn}$ & 0,028 & 45 & 0,024 & 0,026 & 50,7 & 0,043 & 0,036 & 39,8 & 0,028 & 0,028 & 45,1 & 0,031 \\
\hline $\mathrm{Cu}$ & 0,013 & 198,6 & 0,003 & 0,014 & 204,8 & 0,036 & 0,047 & 163,7 & 0,025 & 0,155 & 147,8 & 0,062 \\
\hline $\mathrm{Cr}$ & 0,012 & 48 & 0,01 & 0,016 & 58,5 & 0,016 & 0,023 & 57,5 & 0,023 & 0,025 & 66,2 & 0,052 \\
\hline
\end{tabular}




\section{APÊNDICE B - Monitoramento físico-químico dos experimentos em escala piloto}

(Etapa 4) 
B1 - Concentração da alcalinidade total, condutividade e fosfato nas amostras dos reatores em escala piloto, para as proporções de 0 e $2 \%$ de lixiviado, para tempo de operação de 1 a 64 dias.

\begin{tabular}{|c|c|c|c|c|c|c|c|c|c|c|c|c|c|c|}
\hline \multirow{3}{*}{$\begin{array}{c}\text { Tempo de } \\
\text { operação } \\
\text { (dias) }\end{array}$} & \multicolumn{4}{|c|}{ Alcalinidade $(\mathrm{mg} / \mathrm{L})$} & \multicolumn{4}{|c|}{ Condutividade $(\mu \mathrm{S} / \mathrm{cm})$} & \multicolumn{6}{|c|}{ Fosfato $(\mathrm{mg} / \mathrm{L})$} \\
\hline & \multicolumn{2}{|c|}{$(P 1) 2 \%$} & \multicolumn{2}{|c|}{$(P 2) 0 \%$} & \multicolumn{2}{|c|}{$(P 1) 2 \%$} & \multicolumn{2}{|c|}{$(P 2) 0 \%$} & \multicolumn{3}{|c|}{$(P 1) 2 \%$} & \multicolumn{3}{|c|}{$(P 2) 0 \%$} \\
\hline & $A F$ & $E F$ & $A F$ & $E F$ & $A F$ & $E F$ & $\boldsymbol{A} \boldsymbol{F}$ & $E F$ & $A F$ & $E F$ & $\%$ & $\boldsymbol{A} \boldsymbol{F}$ & $E F$ & $\%$ \\
\hline 1 & 196 & 62 & 162 & 33 & 990 & 759 & 580 & 560 & 12,9 & 10,2 & $21 \%$ & 12,7 & 9,7 & $23 \%$ \\
\hline 8 & 181 & 51 & 158 & 41 & 980 & 712 & 510 & 630 & 11,0 & 8,9 & $19 \%$ & 13,3 & 10 & $25 \%$ \\
\hline 15 & 187 & 65 & 143 & 11 & 972 & 880 & 586 & 500 & 13,5 & - & - & 12,0 & - & - \\
\hline 22 & 238 & 83 & 198 & 45 & 972 & 880 & 586 & 500 & 9,9 & - & - & 10,1 & - & - \\
\hline 29 & 207 & 36 & 152 & 45 & 879 & 933 & 506 & 447 & 18,9 & 14,2 & $25 \%$ & 18,4 & 14,0 & $24 \%$ \\
\hline 36 & 249 & 68 & 114 & 36 & 903 & 820 & 340 & 544 & 10,9 & - & - & 10,8 & - & - \\
\hline 43 & 380 & 103 & 196 & 40 & 1108 & 940 & 496 & 396 & 13,1 & - & - & 15,0 & - & - \\
\hline 50 & 251 & 90 & 186 & 30 & 1038 & 1010 & 638 & 456 & 14,1 & 12,0 & $15 \%$ & 14,8 & 9,5 & $36 \%$ \\
\hline 57 & 276 & 87 & 214 & 36 & 1030 & 844 & 634 & 513 & 15,9 & - & - & 15,4 & - & - \\
\hline 64 & 321 & 72 & 295 & 57 & 1004 & 850 & 658 & 580 & 13,5 & 10,2 & $24 \%$ & 13,3 & 10 & $25 \%$ \\
\hline Média & 248 & 72 & 182 & 37 & 988 & 863 & 553 & 513 & 13,4 & 11,1 & $21 \%$ & 13,6 & 10,6 & $27 \%$ \\
\hline
\end{tabular}


B2 - Concentração Oxigênio Dissolvido (OD) e pH nas amostras dos reatores do experimento em escala piloto, para as proporções de 0 e $2 \%$ de lixiviado, para tempo de operação de 1 a 64 dias.

\begin{tabular}{|c|c|c|c|c|c|c|c|c|c|c|c|c|c|c|}
\hline \multirow{3}{*}{$\begin{array}{c}\text { Tempo de } \\
\text { operação }\end{array}$} & \multicolumn{4}{|c|}{-} & \multirow{3}{*}{$\begin{array}{c}\text { Tempo de } \\
\text { operação }\end{array}$} & \multicolumn{4}{|c|}{-} & \multirow{3}{*}{$\begin{array}{c}\begin{array}{c}\text { Tempo de } \\
\text { operação }\end{array} \\
\text { dias }\end{array}$} & \multicolumn{4}{|c|}{ - } \\
\hline & \multicolumn{2}{|c|}{$(P 1) 2 \%$} & \multicolumn{2}{|c|}{$(P 2) 0 \%$} & & \multicolumn{2}{|c|}{$(P 1) 2 \%$} & \multicolumn{2}{|c|}{$(P 2) 0 \%$} & & \multicolumn{2}{|c|}{$(P 1) 2 \%$} & \multicolumn{2}{|c|}{$(P 2) 0 \%$} \\
\hline & $p H$ & $\begin{array}{c}O D \\
(m g / L)\end{array}$ & $p H$ & $\begin{array}{c}O D \\
(m g / L)\end{array}$ & & $p H$ & $\begin{array}{c}O D \\
(m g / L)\end{array}$ & $p H$ & $\begin{array}{c}O D \\
(m g / L)\end{array}$ & & $p H$ & $\begin{array}{c}O D \\
(m g / L)\end{array}$ & $p H$ & $\begin{array}{c}O D \\
(m g / L)\end{array}$ \\
\hline 1 & 7,7 & 6 & 7,2 & 6,1 & 22 & 6,6 & 7,2 & 7,3 & 6,8 & 43 & 7,4 & 3,5 & 7,2 & 2 \\
\hline 2 & 7,1 & 7 & 7 & 7 & 23 & 7,6 & 7,2 & 7,4 & 7 & 44 & 7,5 & 3 & 7,5 & 1,8 \\
\hline 3 & 7,8 & 7 & 7,5 & 6 & 24 & 7,1 & 6,5 & 7,3 & 6,7 & 45 & 7 & 4 & 7,4 & 2,5 \\
\hline 4 & 8 & 5,6 & 7,2 & 6,5 & 25 & & & & & 46 & 7,6 & 4,4 & 7 & 2,5 \\
\hline 5 & 7,2 & 7 & 7,5 & 6,2 & 26 & 7,5 & 6,5 & 7,4 & 7 & 47 & 7,7 & 5,6 & 6,7 & 2,3 \\
\hline 6 & 7,3 & 6,2 & 7 & 6,5 & 27 & 7,3 & 6,8 & 7,4 & 6,5 & 48 & 7,4 & 4 & 7,2 & 2,5 \\
\hline 7 & 7 & 6,5 & 7,4 & 6 & 28 & 7,8 & 7 & 7,5 & 6,7 & 49 & 7,3 & 3,5 & 7,4 & 3 \\
\hline 8 & 7,8 & 5,8 & 7,2 & 6,1 & 29 & 7,5 & 5,5 & 7 & 6 & 50 & 7,6 & 3,9 & 7,5 & 4,8 \\
\hline 9 & 7,5 & 6 & 7 & 6 & 30 & 7,6 & 6,2 & 7,6 & 5,8 & 51 & 7,5 & 4,2 & 7,2 & 3,5 \\
\hline 10 & 7,8 & 5,5 & 7,4 & 6,8 & 31 & 7,5 & 5,8 & 7,5 & 6 & 52 & 7,3 & 4 & 7,2 & 2 \\
\hline 11 & 7,5 & 6,5 & 7,4 & 7 & 32 & 7 & 6,4 & 6,8 & 4,5 & 53 & 7,5 & 3 & 7 & 3,2 \\
\hline 12 & & & & & 33 & 7,1 & 3,7 & 7 & 3,5 & 54 & 7,6 & 2,5 & 7,1 & 4 \\
\hline 13 & 7,5 & 6 & 7,1 & 6,1 & 34 & 6,8 & 3,7 & 6,6 & 2,4 & 55 & 7,3 & 2,6 & 7,5 & 3,4 \\
\hline 14 & & & & & 35 & 7,5 & 5,5 & 7,3 & 5,5 & 56 & 7,1 & 3 & 7,1 & 4,4 \\
\hline 15 & 7,7 & 5,8 & 7,3 & 5,6 & 36 & 7,4 & 4 & 7,5 & 5 & 57 & 7,4 & 5,2 & 7,2 & 4,6 \\
\hline 16 & 7,6 & 7,2 & 7,4 & 7 & 37 & 7,1 & 5,8 & 7,5 & 5,2 & 58 & 7,5 & 4 & 7,4 & 4,3 \\
\hline 17 & 7,3 & 6 & 6,8 & 6,2 & 38 & 7,1 & 2,2 & 7,3 & 3 & 59 & 7,3 & 5 & 7 & 4 \\
\hline 18 & 7,5 & 7,3 & 7,4 & 7,1 & 39 & 7,5 & 3,4 & 7,2 & 2,1 & 60 & 7 & 3,5 & 7,6 & 3 \\
\hline 19 & 7,6 & 7,2 & 7,4 & 7 & 40 & 7,4 & 3,1 & 7 & 2,5 & 61 & 7,6 & 2 & 7 & 2,4 \\
\hline 20 & & & & & 41 & 7,3 & 2,8 & 6,8 & 5 & 62 & 7,4 & 3,3 & 7,2 & 2,8 \\
\hline 21 & 7,3 & 5 & 7 & 6,2 & 42 & 7,4 & 3,1 & 7,2 & 4,1 & 63 & 7,1 & 2,8 & 7 & 3,6 \\
\hline
\end{tabular}


B3 - Concentração de DQO bruta e solúvel nas amostras dos reatores do experimento em escala piloto, para as proporções de 0 e $2 \%$ de lixiviado, para tempo de operação de 1 a 64 dias.

\begin{tabular}{|c|c|c|c|c|c|c|c|c|c|c|c|c|}
\hline \multirow{3}{*}{$\begin{array}{c}\text { Tempo de } \\
\text { operaçãa } \\
\text { (dias) }\end{array}$} & \multicolumn{6}{|c|}{ DQO bruta $(m g / L)$} & \multicolumn{6}{|c|}{ DQO solúvel $(m g / L)$} \\
\hline & \multicolumn{3}{|c|}{ (R1)2\% } & \multicolumn{3}{|c|}{$(\mathrm{R} 2) 0 \%$} & \multicolumn{3}{|c|}{$(R 1) 2 \%$} & \multicolumn{3}{|c|}{$(\mathrm{R} 2) 0 \%$} \\
\hline & $A F$ & $E F$ & $\%$ & $A F$ & $E F$ & $\%$ & $A F$ & $E F$ & $\%$ & $A F$ & $\overline{E F}$ & $\%$ \\
\hline \multicolumn{13}{|l|}{0} \\
\hline 5 & 257 & 30 & $88 \%$ & 273 & 32 & $88 \%$ & 163 & 23 & $86 \%$ & 163 & 27 & $83 \%$ \\
\hline 7 & 289 & 40 & $83 \%$ & 285 & 38 & $87 \%$ & & & & & & \\
\hline 10 & 263 & 34 & $87 \%$ & 310 & 39 & $87 \%$ & 176 & 12 & $93 \%$ & 184 & 17 & $91 \%$ \\
\hline 13 & 238 & 34 & $86 \%$ & 237 & 20 & $92 \%$ & 154 & 16 & $90 \%$ & 160 & 15 & $91 \%$ \\
\hline 17 & 311 & 20 & $94 \%$ & 316 & 25 & $92 \%$ & 193 & 6 & $97 \%$ & 189 & 5 & $97 \%$ \\
\hline 23 & 345 & 38 & $89 \%$ & 352 & 31 & $91 \%$ & 187 & 26 & $86 \%$ & 192 & 23 & $88 \%$ \\
\hline 27 & 318 & 30 & $91 \%$ & 328 & 27 & $92 \%$ & 195 & 18 & $91 \%$ & 187 & 19 & $90 \%$ \\
\hline 31 & 287 & 20 & $93 \%$ & 295 & 25 & $92 \%$ & 149 & 5 & $97 \%$ & 154 & 13 & $92 \%$ \\
\hline 3 & 463 & 56 & $88 \%$ & 347 & 34 & $90 \%$ & 190 & 21 & $89 \%$ & 221 & 11 & $95 \%$ \\
\hline 6 & 445 & 52 & $88 \%$ & 364 & 41 & $89 \%$ & 205 & 37 & $82 \%$ & 193 & 16 & $92 \%$ \\
\hline 10 & 550 & 98 & $82 \%$ & 469 & 50 & $89 \%$ & 243 & 50 & 79\% & 222 & 19 & $91 \%$ \\
\hline 13 & 401 & 51 & $87 \%$ & 418 & 30 & $93 \%$ & 238 & 70 & $71 \%$ & 211 & 22 & $90 \%$ \\
\hline 16 & 620 & 107 & $83 \%$ & 513 & 61 & $88 \%$ & 265 & 60 & $77 \%$ & 230 & 44 & $81 \%$ \\
\hline 21 & 478 & 62 & $87 \%$ & 370 & 20 & $95 \%$ & 158 & 20 & $87 \%$ & 127 & 12 & $91 \%$ \\
\hline 24 & 579 & 61 & $89 \%$ & 500 & 13 & $97 \%$ & 195 & 21 & $89 \%$ & 150 & 8 & $95 \%$ \\
\hline 27 & 609 & 98 & $84 \%$ & 501 & 40 & $92 \%$ & 253 & 60 & $76 \%$ & 194 & 29 & $85 \%$ \\
\hline 31 & 392 & 52 & $87 \%$ & 340 & 22 & $94 \%$ & 208 & 52 & $75 \%$ & 162 & 10 & $94 \%$ \\
\hline 34 & 430 & 82 & $81 \%$ & 420 & 28 & $93 \%$ & 222 & 39 & $82 \%$ & 172 & 17 & $90 \%$ \\
\hline 38 & 467 & 97 & 79\% & 540 & 31 & $94 \%$ & 231 & 59 & $74 \%$ & 198 & 21 & $89 \%$ \\
\hline 42 & 590 & 110 & $81 \%$ & 487 & 35 & $93 \%$ & 228 & 73 & $68 \%$ & 186 & 20 & $89 \%$ \\
\hline 46 & 485 & 68 & $86 \%$ & 415 & 19 & $95 \%$ & 231 & 35 & $85 \%$ & 203 & 9 & $96 \%$ \\
\hline 49 & 476 & 71 & $85 \%$ & 379 & 38 & $90 \%$ & 217 & 39 & $82 \%$ & 200 & 21 & $90 \%$ \\
\hline 52 & 572 & 102 & $82 \%$ & 416 & 25 & $94 \%$ & 222 & 43 & $81 \%$ & 208 & 15 & $93 \%$ \\
\hline 56 & 365 & 43 & $88 \%$ & 280 & 15 & $95 \%$ & 196 & 21 & $89 \%$ & 153 & 9 & $94 \%$ \\
\hline 60 & 520 & 90 & $83 \%$ & 406 & 42 & $90 \%$ & 250 & 47 & $81 \%$ & 195 & 28 & $86 \%$ \\
\hline 63 & 468 & 88 & $81 \%$ & 380 & 38 & $90 \%$ & 286 & 49 & $83 \%$ & 238 & 30 & $87 \%$ \\
\hline Média & 495 & 77 & $85 \%$ & 419 & 32 & $92 \%$ & 224 & 44 & $80 \%$ & 192 & 19 & $90 \%$ \\
\hline
\end{tabular}


B4 - Concentração do COD e da DBO nas amostras dos reatores do experimento em escala piloto, para as proporções de 0 e $2 \%$ de lixiviado, para tempo de operação de 1 a 64 dias.

\begin{tabular}{|c|c|c|c|c|c|c|c|c|c|c|c|c|c|}
\hline \multirow{3}{*}{$\begin{array}{c}\text { Tempo de } \\
\text { operaçãa } \\
\text { (dias) }\end{array}$} & \multicolumn{6}{|c|}{$C O D(m g / L)$} & \multirow{3}{*}{$\begin{array}{c}\text { Tempo de } \\
\text { operaçãa } \\
\text { (dias) }\end{array}$} & \multicolumn{6}{|c|}{ DBO bruta $(\mathrm{mg} / \mathrm{L})$} \\
\hline & \multicolumn{3}{|c|}{$(P 1) 2 \%$} & \multicolumn{3}{|c|}{$(P 2) 0 \%$} & & \multicolumn{3}{|c|}{$(P 1) 2 \%$} & \multicolumn{3}{|c|}{$(P 2) 0 \%$} \\
\hline & $A F$ & $E F$ & $\%$ & $A F$ & $E F$ & $\%$ & & $A F$ & $E F$ & $\%$ & $A F$ & $E F$ & $\%$ \\
\hline 3 & 48 & 19 & $60 \%$ & 33 & 8 & $76 \%$ & 3 & 210 & 17 & $98 \%$ & 194 & 10 & $97 \%$ \\
\hline 6 & 51 & 21 & $60 \%$ & 37 & 10 & $73 \%$ & 8 & 203 & 11 & $95 \%$ & 180 & 7 & $96 \%$ \\
\hline 10 & 65 & 25 & $62 \%$ & 48 & 14 & $71 \%$ & 15 & 198 & 10 & $95 \%$ & 215 & 8 & $96 \%$ \\
\hline 13 & 72 & 31 & $57 \%$ & 48 & 15 & $69 \%$ & 22 & 290 & 13 & $96 \%$ & 268 & 9 & $97 \%$ \\
\hline 16 & 70 & 26 & $63 \%$ & 58 & 15 & $74 \%$ & 29 & 200 & 18 & $91 \%$ & 230 & 11 & $95 \%$ \\
\hline 21 & 62 & 23 & $63 \%$ & 39 & 11 & $72 \%$ & 36 & 193 & 15 & $92 \%$ & 185 & 12 & $94 \%$ \\
\hline 24 & 58 & 22 & $62 \%$ & 33 & 12 & $64 \%$ & 43 & 294 & 24 & $92 \%$ & 302 & 18 & $94 \%$ \\
\hline 27 & 63 & 24 & $62 \%$ & 43 & 11 & $74 \%$ & 50 & 246 & 13 & $95 \%$ & 245 & 14 & $94 \%$ \\
\hline 31 & 71 & 30 & $58 \%$ & 43 & 16 & $63 \%$ & 57 & 201 & 21 & $90 \%$ & 183 & 16 & $91 \%$ \\
\hline 34 & 59 & 23 & $61 \%$ & 51 & 14 & $73 \%$ & 64 & 189 & 11 & $94 \%$ & 172 & 9 & $95 \%$ \\
\hline 38 & 91 & 33 & $64 \%$ & 73 & 18 & $75 \%$ & Média & 222 & 15 & $93 \%$ & 217 & 11 & $95 \%$ \\
\hline 42 & 85 & 35 & $59 \%$ & 69 & 19 & $72 \%$ & & & & & & & \\
\hline 46 & 78 & 33 & $58 \%$ & 67 & 21 & $69 \%$ & & & & & & & \\
\hline 49 & 66 & 27 & $59 \%$ & 60 & 17 & $72 \%$ & & & & & & & \\
\hline 52 & 68 & 26 & $62 \%$ & 59 & 17 & $71 \%$ & & & & & & & \\
\hline 56 & 86 & 36 & $58 \%$ & 63 & 18 & $71 \%$ & & & & & & & \\
\hline 60 & 87 & 38 & $56 \%$ & 74 & 24 & $68 \%$ & & & & & & & \\
\hline 63 & 72 & 28 & $61 \%$ & 53 & 15 & $72 \%$ & & & & & & & \\
\hline Média & 70 & 28 & $60 \%$ & 53 & 15 & $71 \%$ & & & & & & & \\
\hline
\end{tabular}


B5 - Concentração sólidos no tanque de aeração dos reatores do experimento em escala piloto, para as proporções de 0 e $2 \%$ de lixiviado, para tempo de operação de 1 a 64 dias.

\begin{tabular}{|c|c|c|c|c|c|c|}
\hline \multirow{3}{*}{$\begin{array}{c}\text { Tempo de } \\
\text { operação } \\
\text { (dias) }\end{array}$} & \multicolumn{2}{|c|}{$S S T(m g / L) T A$} & \multicolumn{2}{|c|}{$S S F(m g / L) T A$} & \multicolumn{2}{|c|}{$S S V(m g / L) T A$} \\
\hline & $(P 1) 2 \%$ & $(P 2) 0 \%$ & $(P 1) 2 \%$ & $(P 2) 0 \%$ & $(P 1) 2 \%$ & $(P 2) 0 \%$ \\
\hline & $T A$ & $T A$ & $T A$ & $T A$ & $T A$ & $T A$ \\
\hline 0 & 1480 & 1303 & 280 & 277 & 1200 & 1027 \\
\hline 5 & 1083 & 933 & 193 & 217 & 890 & 717 \\
\hline 7 & 950 & 980 & - & - & - & - \\
\hline 10 & 1117 & 1133 & 190 & 183 & 927 & 950 \\
\hline 13 & 1560 & 1400 & 240 & 200 & 1320 & 1200 \\
\hline 18 & 1840 & 1560 & 360 & 296 & 1480 & 1264 \\
\hline 23 & 1376 & 1308 & - & - & - & - \\
\hline 27 & 1504 & 1512 & 228 & 264 & 1276 & 1248 \\
\hline 1 & 1480 & 1440 & 272 & 256 & 1208 & 1184 \\
\hline 4 & 1400 & 1360 & 296 & 220 & 1104 & 1140 \\
\hline 7 & 1396 & 1320 & 280 & 200 & 1116 & 1120 \\
\hline 11 & 1448 & 1240 & 280 & 208 & 1168 & 1032 \\
\hline 14 & 1364 & 1116 & 260 & 152 & 1104 & 964 \\
\hline 17 & 1312 & 1036 & 284 & 172 & 1028 & 864 \\
\hline 22 & 1108 & 1232 & 204 & 216 & 904 & 1016 \\
\hline 25 & 1132 & 1005 & 152 & 145 & 980 & 860 \\
\hline 28 & 1065 & 1212 & 140 & 204 & 925 & 1008 \\
\hline 32 & 1336 & 1456 & 176 & 284 & 1160 & 1172 \\
\hline 35 & 1240 & 1356 & 272 & 296 & 968 & 1060 \\
\hline 39 & 1280 & 1112 & 212 & 180 & 1068 & 932 \\
\hline 43 & 1420 & 1320 & 236 & 216 & 1184 & 1104 \\
\hline 47 & 1605 & 1695 & 380 & 380 & 1225 & 1315 \\
\hline 50 & 1528 & 1505 & 376 & 296 & 1152 & 1209 \\
\hline 53 & 1668 & 1684 & 348 & 332 & 1320 & 1352 \\
\hline 57 & 1716 & 1888 & 360 & 438 & 1356 & 1450 \\
\hline 61 & 1663 & 1744 & 396 & 428 & 1267 & 1316 \\
\hline 64 & 1563 & 1464 & 368 & 320 & 1195 & 1144 \\
\hline Média & 1402 & 1375 & 279 & 260 & 1124 & 1114 \\
\hline
\end{tabular}


B6 - Concentração de sólidos nas amostras dos reatores do experimento em escala piloto, para as proporções de 0 e $2 \%$ de lixiviado, para tempo de operação de 1 a 64 dias.

\begin{tabular}{|c|c|c|c|c|c|c|c|c|c|c|c|c|c|c|c|c|c|c|}
\hline \multirow{3}{*}{$\begin{array}{c}\text { Tempo de } \\
\text { operação } \\
\text { (dias) }\end{array}$} & \multicolumn{6}{|c|}{$S S T(m g / L)$} & \multicolumn{6}{|c|}{$S S F(m g / L)$} & \multicolumn{6}{|c|}{$S S V(m g / L)$} \\
\hline & \multicolumn{3}{|c|}{$(P 1) 2 \%$} & \multicolumn{3}{|c|}{$(P 2) 0 \%$} & \multicolumn{3}{|c|}{ (P1)2\% } & \multicolumn{3}{|c|}{$(P 2) 0 \%$} & \multicolumn{3}{|c|}{$(P 1) 2 \%$} & \multicolumn{3}{|c|}{$(P 2) 0 \%$} \\
\hline & $A F$ & $E F$ & $\%$ & $A F$ & $E F$ & $\%$ & $A F$ & $E F$ & $\%$ & $A F$ & $E F$ & $\%$ & $A F$ & $E F$ & $\%$ & $A F$ & $E F$ & $\%$ \\
\hline 1 & 132 & 28 & $79 \%$ & 128 & 10 & $92 \%$ & 27 & 16 & $41 \%$ & 31 & 9 & $71 \%$ & 105 & 12 & $89 \%$ & 97 & 1 & $99 \%$ \\
\hline 8 & 116 & 25 & $78 \%$ & 131 & 9 & $93 \%$ & 24 & 16 & $33 \%$ & 29 & 8 & $72 \%$ & 92 & 9 & $90 \%$ & 102 & 1 & $99 \%$ \\
\hline 15 & 195 & 21 & $89 \%$ & 201 & 21 & $90 \%$ & 34 & 5 & $85 \%$ & 45 & 12 & $73 \%$ & 161 & 16 & $90 \%$ & 156 & 9 & $94 \%$ \\
\hline 22 & 296 & 15 & $95 \%$ & 281 & 24 & $91 \%$ & 40 & 3 & $93 \%$ & 59 & 3 & $95 \%$ & 256 & 12 & $95 \%$ & 223 & 21 & $90 \%$ \\
\hline 29 & 205 & 25 & $88 \%$ & 237 & 11 & $95 \%$ & 23 & 2 & $89 \%$ & 40 & 2 & $94 \%$ & 182 & 23 & $88 \%$ & 197 & 9 & $96 \%$ \\
\hline 36 & 119 & 13 & $89 \%$ & 114 & 3 & $97 \%$ & 8 & 2 & $75 \%$ & 8 & 1 & $87 \%$ & 111 & 11 & $90 \%$ & 106 & 2 & $98 \%$ \\
\hline 43 & 221 & 8 & $96 \%$ & 276 & 19 & $93 \%$ & 12 & 0 & $100 \%$ & 42 & 7 & $83 \%$ & 209 & 8 & $96 \%$ & 234 & 12 & $95 \%$ \\
\hline 50 & 158 & 14 & $91 \%$ & 140 & 3 & $98 \%$ & 22 & 0 & $100 \%$ & 28 & 2 & $93 \%$ & 136 & 14 & $90 \%$ & 112 & 1 & $99 \%$ \\
\hline 57 & 194 & 19 & $90 \%$ & 147 & 12 & $92 \%$ & 25 & 2 & $92 \%$ & 29 & 2 & $93 \%$ & 169 & 17 & $90 \%$ & 118 & 10 & $92 \%$ \\
\hline 64 & 134 & 10 & $93 \%$ & 135 & 3 & $98 \%$ & 19 & 0 & $100 \%$ & 25 & 2 & $92 \%$ & 115 & 10 & $91 \%$ & 110 & 1 & $99 \%$ \\
\hline Média & 177 & 18 & $89 \%$ & 179 & 12 & $94 \%$ & 23 & 5 & $81 \%$ & 34 & 5 & $85 \%$ & 154 & 13 & $91 \%$ & 145 & 7 & $96 \%$ \\
\hline
\end{tabular}


B7 - Concentração de sólidos no tanque de aeração dos reatores do experimento em escala piloto, para as proporções de 0 e $2 \%$ de lixiviado, para tempo de operação de 1 a 64 dias.

\begin{tabular}{|c|c|c|c|c|c|c|c|c|c|c|c|c|c|c|c|c|c|c|}
\hline \multirow{3}{*}{$\begin{array}{c}\text { Tempo de } \\
\text { operação } \\
\text { (dias) }\end{array}$} & \multicolumn{6}{|c|}{$S T(m g / L)$} & \multicolumn{6}{|c|}{$S F(m g / L)$} & \multicolumn{6}{|c|}{$S V(m g / L)$} \\
\hline & \multicolumn{3}{|c|}{$(P 1) 2 \%$} & \multicolumn{3}{|c|}{$(P 2) 0 \%$} & \multicolumn{3}{|c|}{$(P 1) 2 \%$} & \multicolumn{3}{|c|}{$(P 2) 0 \%$} & \multicolumn{3}{|c|}{ (P1)2\% } & \multicolumn{3}{|c|}{$(P 2) 0 \%$} \\
\hline & $A F$ & $E F$ & $\%$ & $A F$ & $E F$ & $\%$ & $A F$ & $E F$ & $\%$ & $A F$ & $E F$ & $\%$ & $A F$ & $E F$ & $\%$ & $A F$ & $E F$ & $\%$ \\
\hline 1 & 722 & 462 & $36 \%$ & 502 & 308 & $39 \%$ & 196 & 73 & $63 \%$ & 168 & 78 & $54 \%$ & 526 & 389 & $26 \%$ & 334 & 230 & $31 \%$ \\
\hline 8 & 748 & 487 & $35 \%$ & 514 & 300 & $42 \%$ & 181 & 54 & $70 \%$ & 171 & 80 & $53 \%$ & 567 & 433 & $24 \%$ & 343 & 220 & $36 \%$ \\
\hline 15 & 607 & 445 & $27 \%$ & 490 & 332 & $32 \%$ & 117 & 65 & $44 \%$ & 100 & 62 & $38 \%$ & 490 & 380 & $22 \%$ & 390 & 270 & $31 \%$ \\
\hline 22 & 871 & 664 & $24 \%$ & 681 & 432 & $37 \%$ & 214 & 99 & $54 \%$ & 133 & 64 & $52 \%$ & 657 & 565 & $14 \%$ & 548 & 368 & $33 \%$ \\
\hline 29 & 681 & 525 & $23 \%$ & 454 & 316 & $30 \%$ & 267 & 179 & $33 \%$ & 184 & 100 & $46 \%$ & 414 & 346 & $16 \%$ & 270 & 216 & $20 \%$ \\
\hline 36 & 664 & 421 & $37 \%$ & 444 & 290 & $35 \%$ & 306 & 208 & $32 \%$ & 193 & 119 & $38 \%$ & 358 & 213 & $41 \%$ & 251 & 171 & $32 \%$ \\
\hline 43 & 860 & 629 & $28 \%$ & 588 & 324 & $45 \%$ & 483 & 390 & $19 \%$ & 105 & 54 & $49 \%$ & 388 & 239 & $38 \%$ & 483 & 270 & $44 \%$ \\
\hline 50 & 672 & 538 & $20 \%$ & 543 & 325 & $40 \%$ & 251 & 224 & $11 \%$ & 140 & 95 & $32 \%$ & 421 & 314 & $25 \%$ & 403 & 230 & $43 \%$ \\
\hline 57 & 702 & 548 & $22 \%$ & 583 & 342 & $41 \%$ & 271 & 204 & $25 \%$ & 170 & 103 & $39 \%$ & 431 & 344 & $20 \%$ & 413 & 239 & $42 \%$ \\
\hline 64 & 632 & 454 & $28 \%$ & 493 & 323 & $34 \%$ & 280 & 184 & $34 \%$ & 120 & 63 & $48 \%$ & 352 & 270 & $23 \%$ & 373 & 260 & $30 \%$ \\
\hline Média & 716 & 517 & $28 \%$ & 529 & 329 & $38 \%$ & 257 & 168 & $39 \%$ & 148 & 82 & $45 \%$ & 460 & 349 & $25 \%$ & 381 & 247 & $34 \%$ \\
\hline
\end{tabular}


B8 - Concentração de Nitrogênio nas amostras dos reatores do experimento em escala piloto, para as proporções de 0 e $2 \%$ de lixiviado, para tempo de operação de 1 a 64 dias.

\begin{tabular}{|c|c|c|c|c|c|c|c|c|c|c|c|c|c|c|c|c|c|c|}
\hline \multirow{3}{*}{$\begin{array}{c}\text { Tempo de } \\
\text { operação } \\
\text { (dias) }\end{array}$} & \multicolumn{6}{|c|}{$N T K(m g / L)$} & \multicolumn{6}{|c|}{ NTK solúvel $(\mathrm{mg} / \mathrm{L})$} & \multicolumn{6}{|c|}{$N A T(m g / L)$} \\
\hline & \multicolumn{3}{|c|}{$(P 1) 2 \%$} & \multicolumn{3}{|c|}{$(P 2) 0 \%$} & \multicolumn{3}{|c|}{$(P 1) 2 \%$} & \multicolumn{3}{|c|}{$(P 2) 0 \%$} & \multicolumn{3}{|c|}{ (P1)2\% } & \multicolumn{3}{|c|}{$($ (P2)0\% } \\
\hline & $A F$ & $E F$ & $\%$ & $A F$ & $E F$ & $\%$ & $A F$ & $E F$ & $\%$ & $A F$ & $E F$ & $\%$ & $A F$ & $E F$ & $\%$ & $A F$ & $E F$ & $\%$ \\
\hline 1 & 51,3 & 3,7 & $93 \%$ & 34,2 & 2,4 & $93 \%$ & 43,9 & 2,4 & $94 \%$ & 25,6 & 2,4 & $90 \%$ & 32,0 & 2,4 & $92 \%$ & 26,9 & 2,4 & $91 \%$ \\
\hline 8 & 37,8 & 2,4 & $94 \%$ & 31,7 & 2,4 & $92 \%$ & 34,2 & 2,4 & $93 \%$ & 23,2 & 2,4 & $89 \%$ & 33,9 & 2,4 & $93 \%$ & 25,9 & 1,2 & $95 \%$ \\
\hline 15 & 36,6 & 4,9 & $87 \%$ & 33,0 & 0,0 & $100 \%$ & 33,0 & 3,7 & $89 \%$ & 29,3 & 0,0 & $100 \%$ & 32,7 & 3,7 & $89 \%$ & 29,6 & 0,0 & $100 \%$ \\
\hline 22 & 47,6 & 1,2 & $97 \%$ & 42,7 & 0,0 & $100 \%$ & 33,0 & 1,2 & $96 \%$ & 26,9 & 0,0 & $100 \%$ & 35,1 & 0,0 & $100 \%$ & 33,0 & 0,0 & $100 \%$ \\
\hline 29 & 36,6 & 3,7 & $90 \%$ & 30,5 & 2,4 & $92 \%$ & 31,7 & 1,2 & $96 \%$ & 25,6 & 2,4 & $90 \%$ & 29,0 & 3,7 & $87 \%$ & 26,9 & 2,4 & $91 \%$ \\
\hline 36 & 50,1 & 3,7 & $93 \%$ & 47,6 & 9,8 & $79 \%$ & 37,8 & 0,0 & $100 \%$ & 36,6 & 4,9 & $87 \%$ & 41,5 & 0,0 & $100 \%$ & 37,5 & 9,8 & $74 \%$ \\
\hline 43 & 48,8 & 4,9 & $90 \%$ & 45,2 & 3,7 & $92 \%$ & 41,5 & 3,7 & $91 \%$ & 36,6 & 2,4 & $93 \%$ & 39,7 & 1,2 & $97 \%$ & 37,5 & 0,0 & $100 \%$ \\
\hline 50 & 48,8 & 3,7 & $93 \%$ & 46,4 & 3,7 & $92 \%$ & 36,6 & 3,7 & $90 \%$ & 34,2 & 2,4 & $93 \%$ & 38,2 & 3,7 & $90 \%$ & 35,1 & 2,4 & $93 \%$ \\
\hline 57 & 42,7 & 3,7 & $91 \%$ & 40,3 & 2,4 & $94 \%$ & 34,2 & 2,4 & $93 \%$ & 33,0 & 2,4 & $93 \%$ & 37,8 & 2,4 & $94 \%$ & 33,6 & 1,2 & $96 \%$ \\
\hline 64 & 39,1 & 2,4 & $94 \%$ & 36,6 & 2,4 & $93 \%$ & 31,7 & 1,2 & $96 \%$ & 30,5 & 1,2 & $96 \%$ & 33,6 & 2,4 & $93 \%$ & 27,5 & 1,2 & $96 \%$ \\
\hline MÉDIA & 43,9 & 3,4 & $92 \%$ & 38,8 & 2,9 & $93 \%$ & 35,8 & 2,2 & $94 \%$ & 30,2 & 2,1 & $93 \%$ & 35,3 & 2,2 & $93 \%$ & 31,3 & 2,1 & $94 \%$ \\
\hline
\end{tabular}


B9 - Concentração de Nitrogênio nas amostras dos reatores do experimento em escala piloto, para as proporções de 0 e $2 \%$ de lixiviado, para tempo de operação de 1 a 64 dias.

\begin{tabular}{|c|c|c|c|c|c|c|c|c|c|c|c|c|c|c|c|c|c|c|c|}
\hline \multicolumn{6}{|c|}{ N-Orgânico $(m g / L)$} & \multicolumn{4}{|c|}{$\mathrm{N}-\mathrm{NO}_{2}^{-}(\mathrm{mg} / \mathrm{L})$} & \multicolumn{4}{|c|}{$\mathrm{N}-\mathrm{NO}_{3}^{-}(\mathrm{mg} / \mathrm{L})$} & \multicolumn{6}{|c|}{$N$-total $(m g / L)$} \\
\hline \multicolumn{3}{|c|}{$(P 1) 2 \%$} & \multicolumn{3}{|c|}{$(P 2) 0 \%$} & \multicolumn{2}{|c|}{$(P 1) 2 \%$} & \multicolumn{2}{|c|}{$(P 2) 0 \%$} & \multicolumn{2}{|c|}{$(P 1) 2 \%$} & \multicolumn{2}{|c|}{$(P 2) 0 \%$} & \multicolumn{3}{|c|}{$(P 1) 2 \%$} & \multicolumn{3}{|c|}{$(P 2) 0 \%$} \\
\hline$A F$ & $E F$ & $\%$ & $A F$ & $E F$ & $\%$ & $A F$ & $E F$ & $A F$ & $E F$ & $A F$ & $E F$ & $A F$ & $E F$ & $A F$ & $E F$ & $\%$ & $\overrightarrow{A F}$ & $E F$ & $\%$ \\
\hline 19,2 & 1,2 & $94 \%$ & 7,3 & 0,0 & $100 \%$ & 0,0 & 0,0 & 0,3 & 0,3 & 0,0 & 18,3 & 0,0 & 20,3 & 43,9 & 20,7 & $53 \%$ & 25,9 & 23,0 & $11 \%$ \\
\hline 4,0 & 0,0 & $100 \%$ & 5,8 & 1,2 & $79 \%$ & 0,0 & 0,2 & 0,0 & 0,0 & 0,0 & 16,6 & 0,0 & 17,0 & 34,2 & 19,2 & $44 \%$ & 23,2 & 19,4 & $16 \%$ \\
\hline 4,0 & 1,2 & $69 \%$ & 3,4 & 0,0 & $100 \%$ & 0,0 & 0,0 & 0,0 & 0,0 & 0,0 & 25,2 & 0,0 & 22,9 & 33,0 & 28,9 & $12 \%$ & 29,3 & 22,9 & $22 \%$ \\
\hline 12,5 & 1,2 & $90 \%$ & 9,8 & 0,0 & $100 \%$ & 0,0 & 0,0 & 0,0 & 0,0 & 1,1 & 24,6 & 0,0 & 22,0 & 34,1 & 25,8 & $24 \%$ & 26,9 & 22,0 & $18 \%$ \\
\hline 7,6 & 0,0 & $100 \%$ & 3,7 & 0,0 & $100 \%$ & 0,0 & 0,0 & 0,0 & 0,1 & 0,0 & 23,8 & 0,0 & 19,1 & 31,7 & 25,1 & $21 \%$ & 25,6 & 21,6 & $16 \%$ \\
\hline 8,5 & 3,7 & $57 \%$ & 10,1 & 0,0 & $100 \%$ & 0,0 & 0,1 & 0,0 & 3,2 & 1,0 & 21,8 & 0,0 & 15,7 & 38,8 & 21,9 & $44 \%$ & 36,6 & 23,8 & $35 \%$ \\
\hline 9,2 & 3,7 & $60 \%$ & 7,6 & 3,7 & $52 \%$ & 0,0 & 0,2 & 0,0 & 2,2 & 0,0 & 20,9 & 0,0 & 19,4 & 41,5 & 24,8 & $40 \%$ & 36,6 & 24,1 & $34 \%$ \\
\hline 10,7 & 0,0 & $100 \%$ & 11,3 & 1,2 & $89 \%$ & 0,0 & 0,3 & 0,2 & 0,9 & 0,0 & 19,9 & 0,1 & 17,5 & 36,7 & 23,9 & $35 \%$ & 34,5 & 20,8 & $40 \%$ \\
\hline 4,9 & 1,2 & $75 \%$ & 6,7 & 1,2 & $82 \%$ & 0,1 & 0,2 & 0,1 & 0,3 & 0,1 & 22,6 & 0,0 & 19,5 & 34,4 & 25,2 & $27 \%$ & 33,1 & 22,2 & $33 \%$ \\
\hline 5,5 & 0,0 & $100 \%$ & 9,2 & 1,2 & $87 \%$ & 0,1 & 0,2 & 0,1 & 0,3 & 0,1 & 22,6 & 0,0 & 19,5 & 31,9 & 24,0 & $25 \%$ & 30,6 & 21,0 & $31 \%$ \\
\hline 8,6 & 1,2 & $85 \%$ & 7,5 & 0,9 & $89 \%$ & 0,0 & 0,1 & 0,1 & 0,7 & 0,2 & 21,6 & 0,0 & 19,3 & 36,0 & 24,0 & $32 \%$ & 30,2 & 22,1 & $26 \%$ \\
\hline
\end{tabular}


B10 - Resultados das análises estatísticas dos parâmetros físico-químicos do experimento em escala piloto (Etapa 4), realizadas no software Minitab 5.
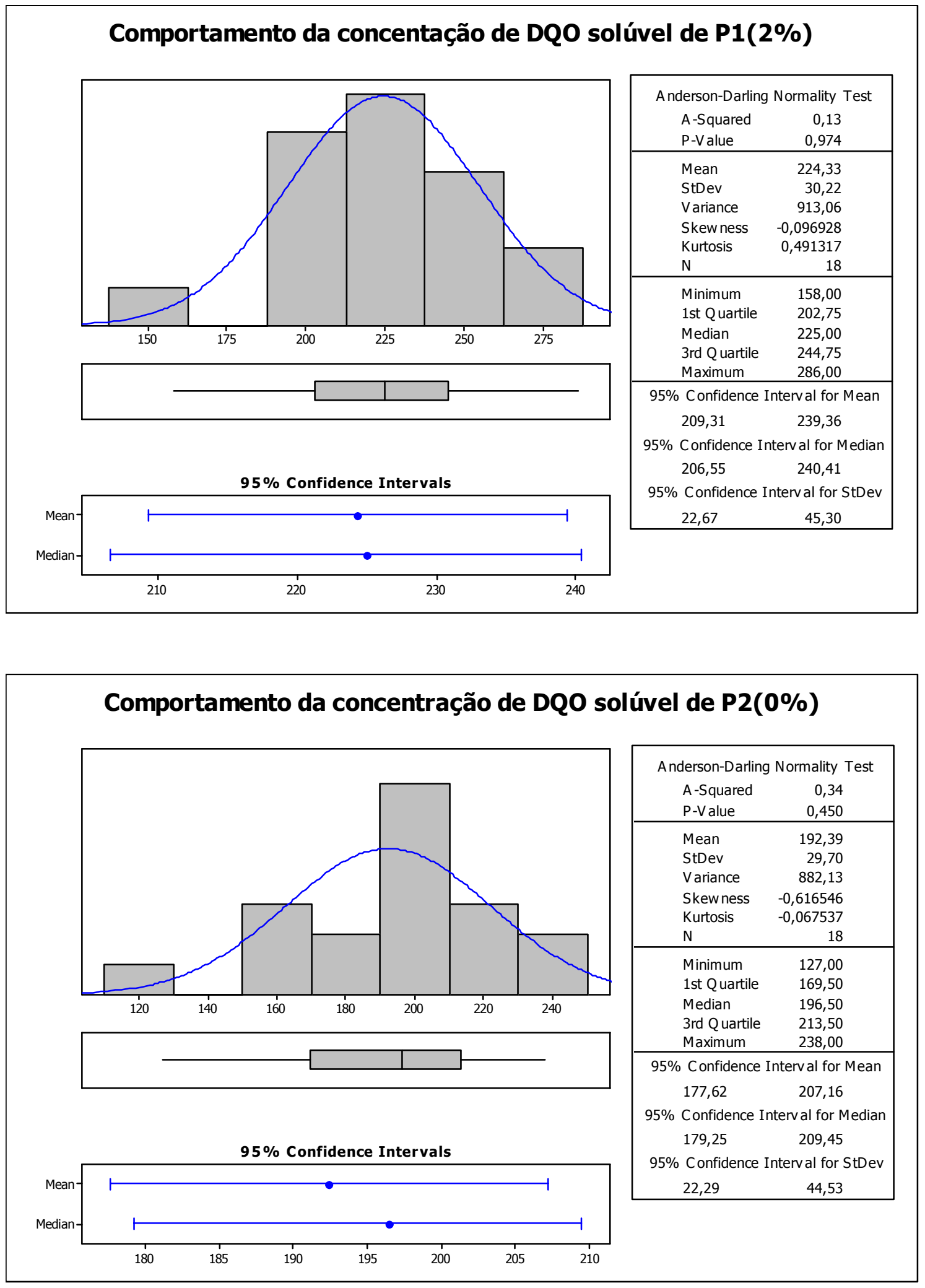

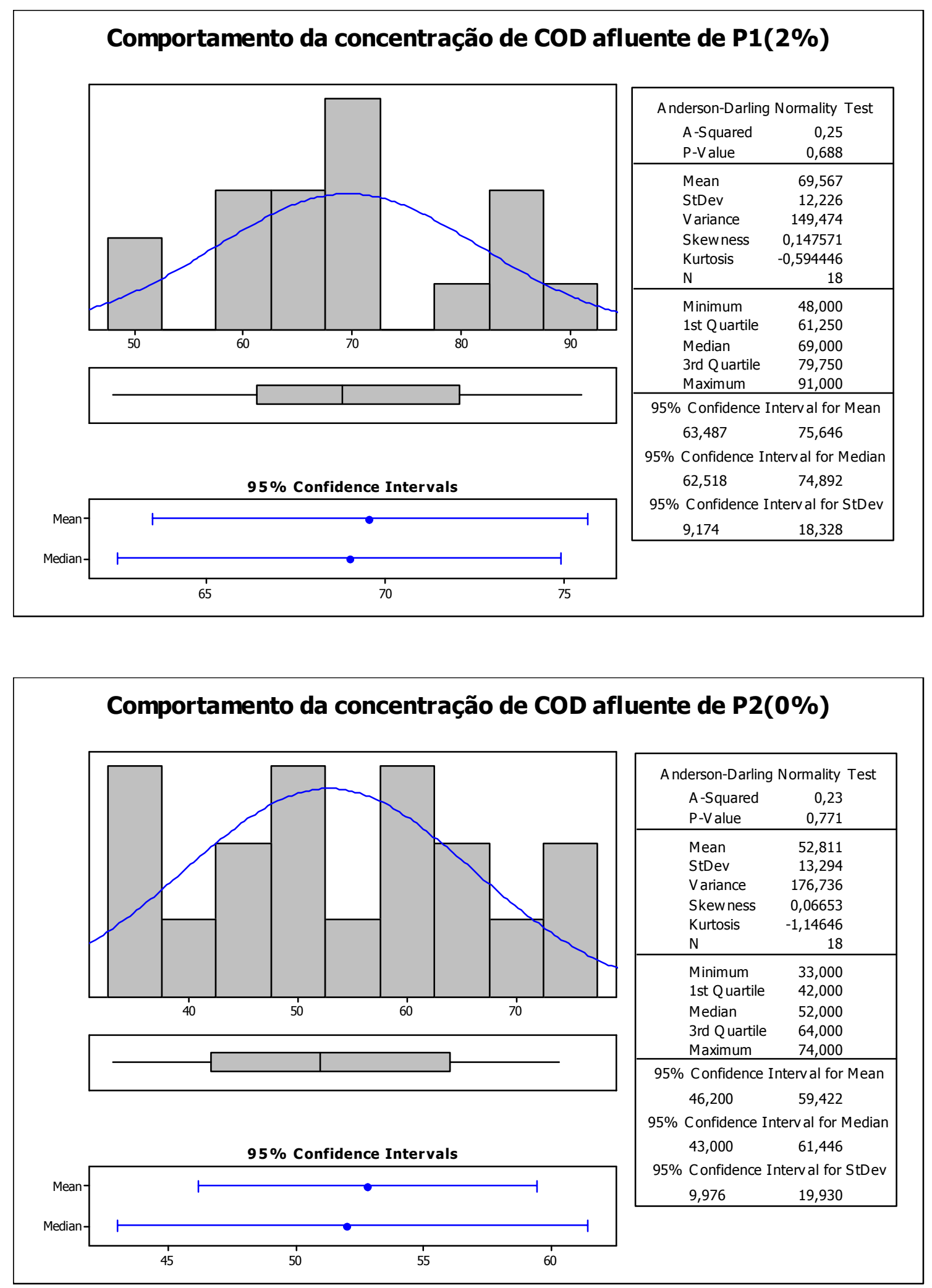

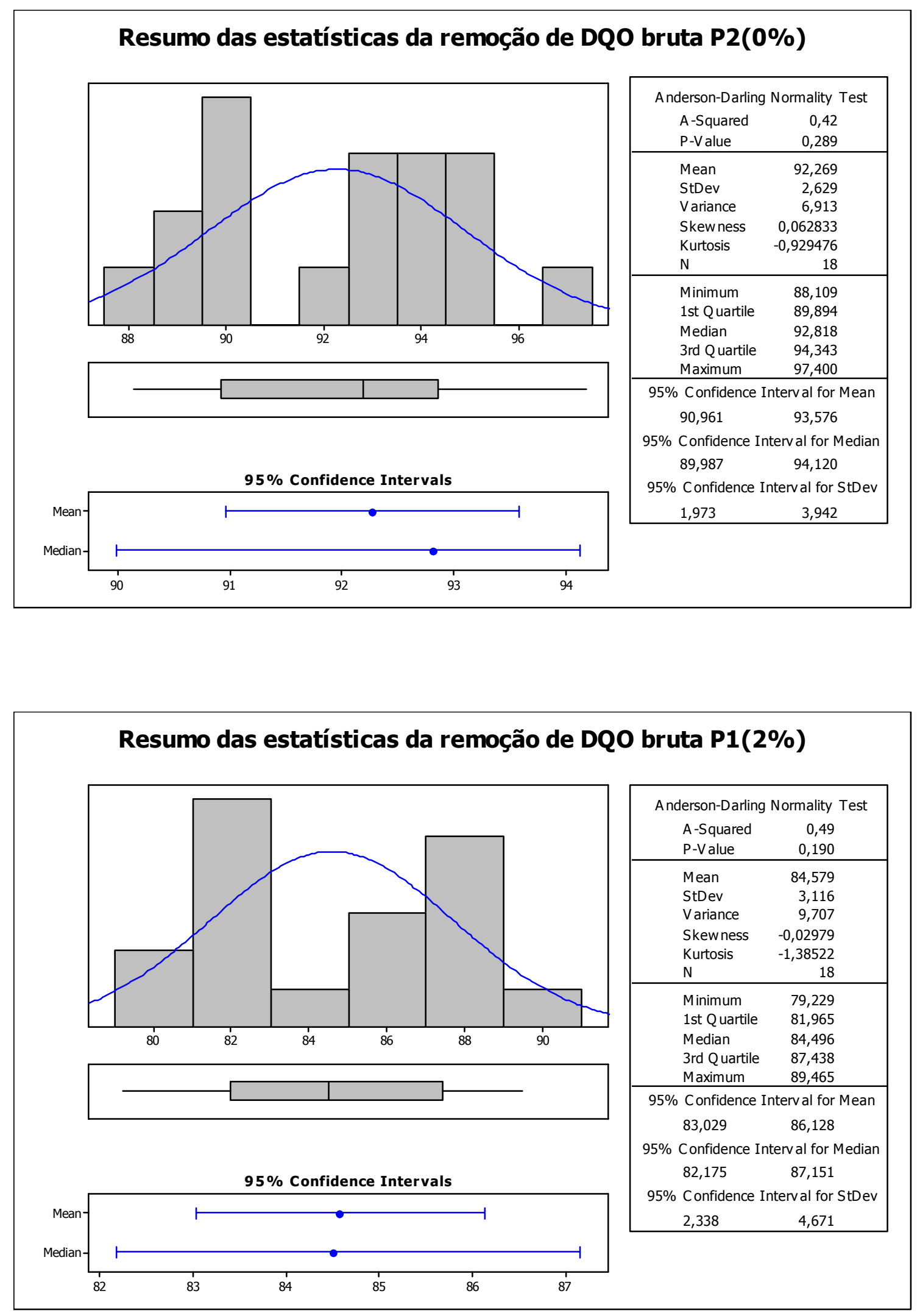

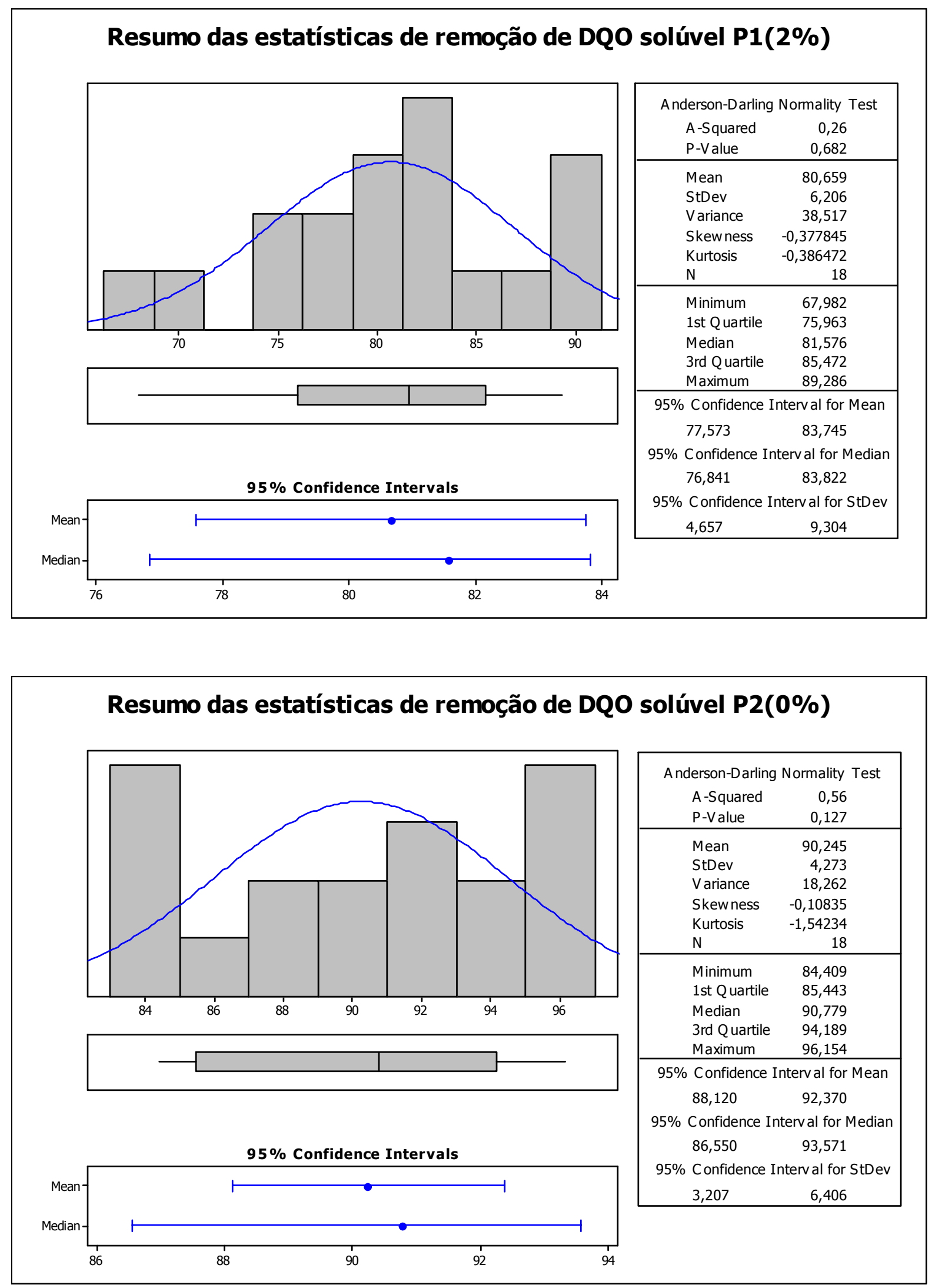

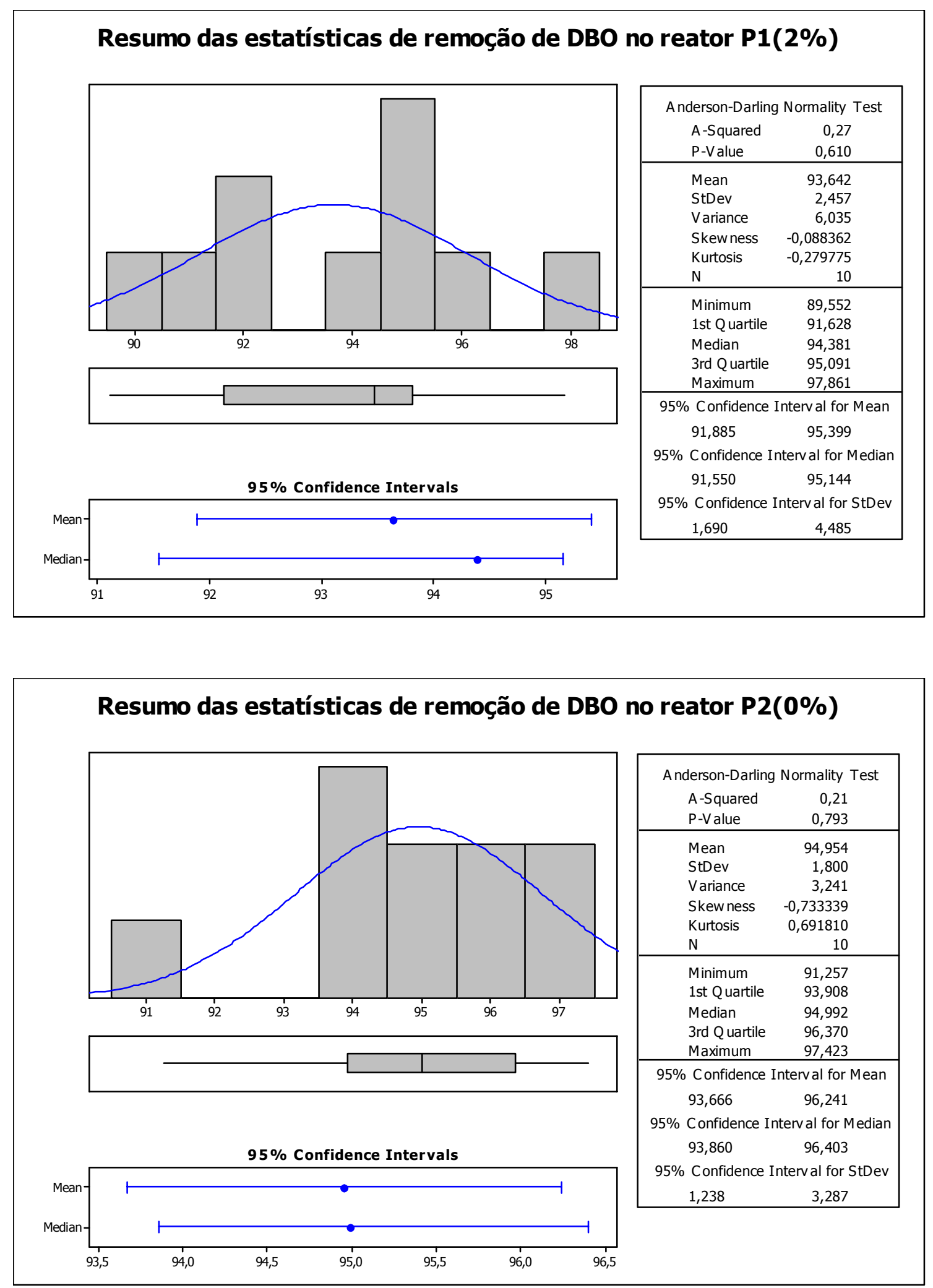

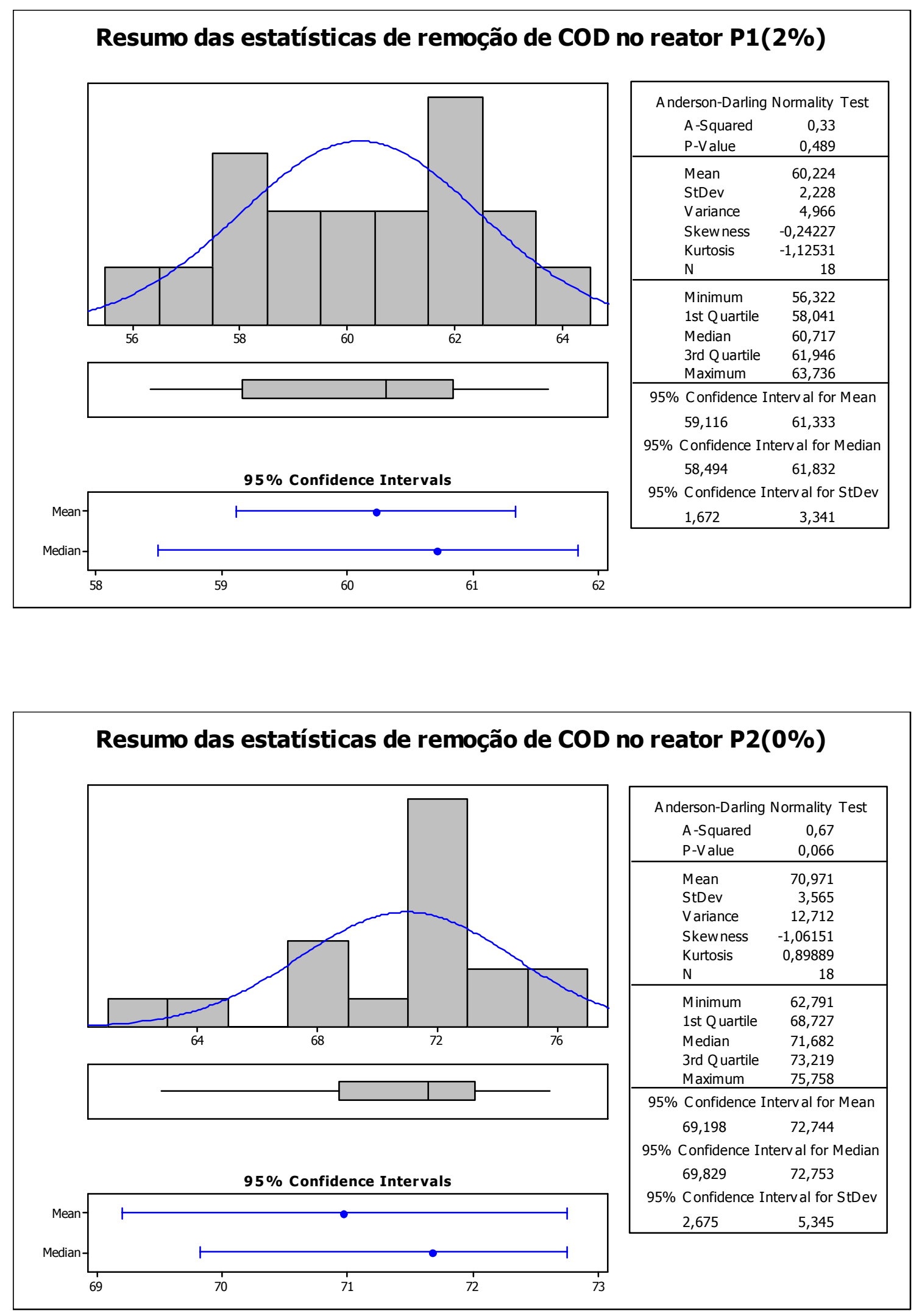


\section{Resumo das estatísticas da variação dos valores de IVL no reator P1(2\%)}

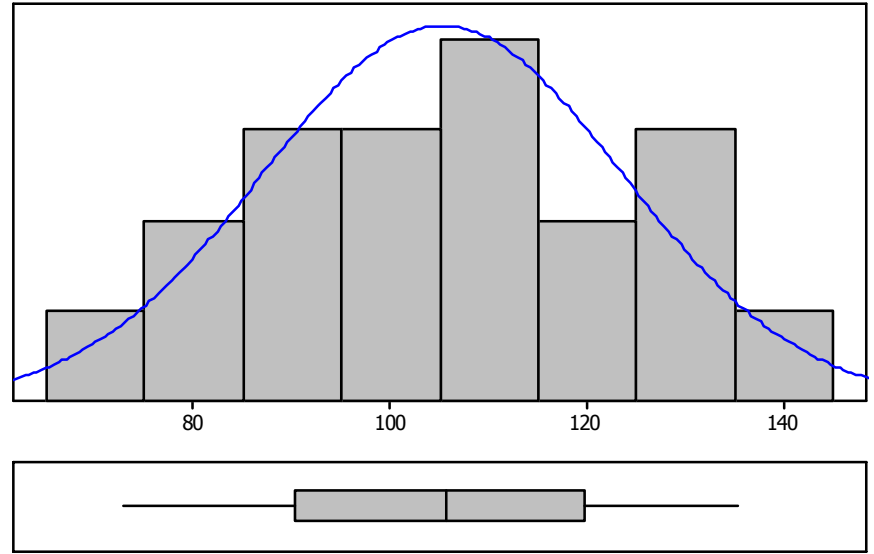

\begin{tabular}{|c|c|}
\hline \multicolumn{2}{|c|}{ A nderson-Darling Normality Test } \\
\hline A-Squared & 0,16 \\
\hline P-Value & 0,935 \\
\hline Mean & 105,29 \\
\hline StDev & 18,25 \\
\hline Variance & 332,90 \\
\hline Skew ness & 0,050542 \\
\hline Kurtosis & $-0,903594$ \\
\hline $\mathrm{N}$ & 19 \\
\hline Minimum & 72,84 \\
\hline 1st Q uartile & 90,18 \\
\hline Median & 105,63 \\
\hline 3rd Q uartile & 119,76 \\
\hline Maximum & 135,38 \\
\hline
\end{tabular}

95\% Confidence Interval for Mean
96,50
114,09

95\% Confidence Interval for Median

93,99 118,41

95\% Confidence Interval for StDev

13,79

26,98
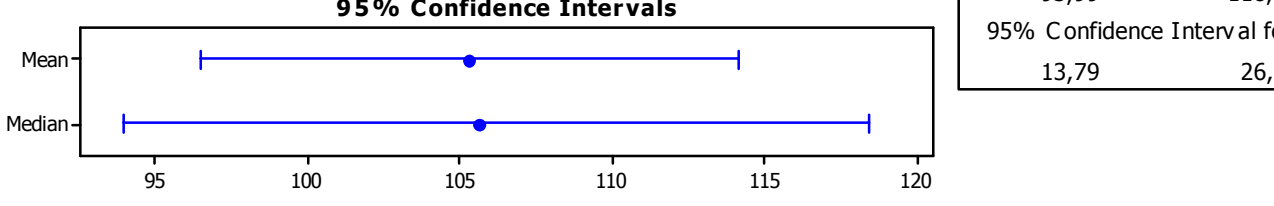

\section{Resumo das estatísticas da variação dos valores de IVL no reator P2(0\%)}

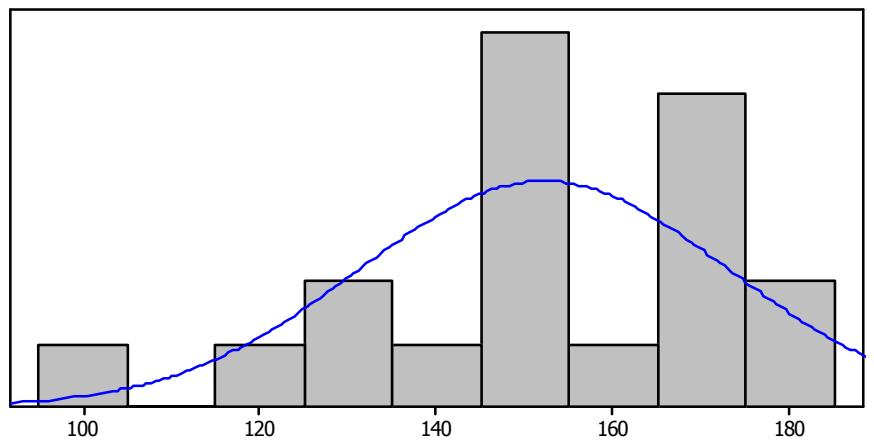

\begin{tabular}{lr} 
Anderson-Darling & Normality Test \\
A-Squared & 0,52 \\
P-Value & 0,158 \\
\hline Mean & 152,14 \\
StDev & 21,01 \\
Variance & 441,56 \\
Skewness & $-0,834626$ \\
Kurtosis & 0,027698 \\
N & 19 \\
\hline Minimum & 104,17 \\
1st Quartile & 143,37 \\
Median & 154,22 \\
3rd Quartile & 170,77 \\
Maximum & 178,15 \\
\hline
\end{tabular}

95\% Confidence Interval for Mean

$$
142,01 \quad 162,27
$$

95\% Confidence Interval for Median

$144,92 \quad 169,66$

95\% Confidence Interval for StDev $15,88 \quad 31,08$

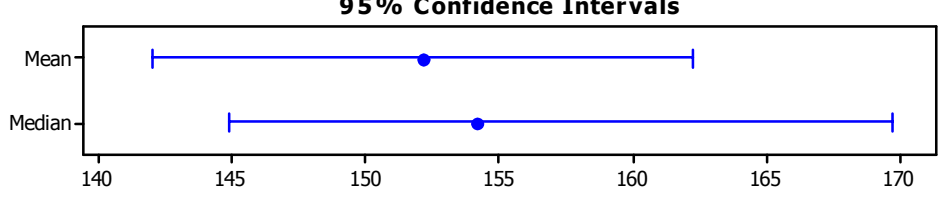




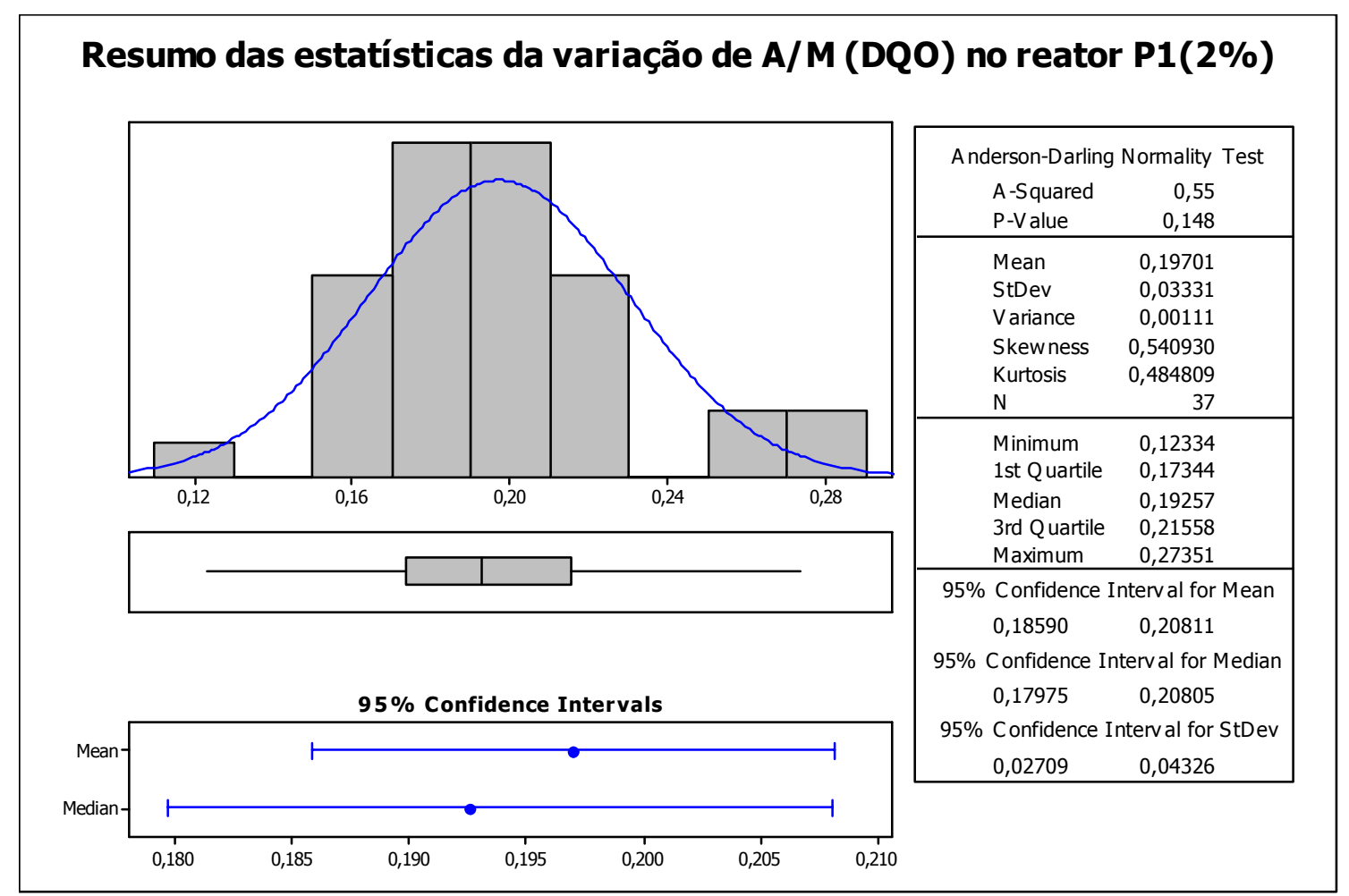

\section{Resumo das estatísticas da variação de A/M (DQO) no reator P2(0\%)}
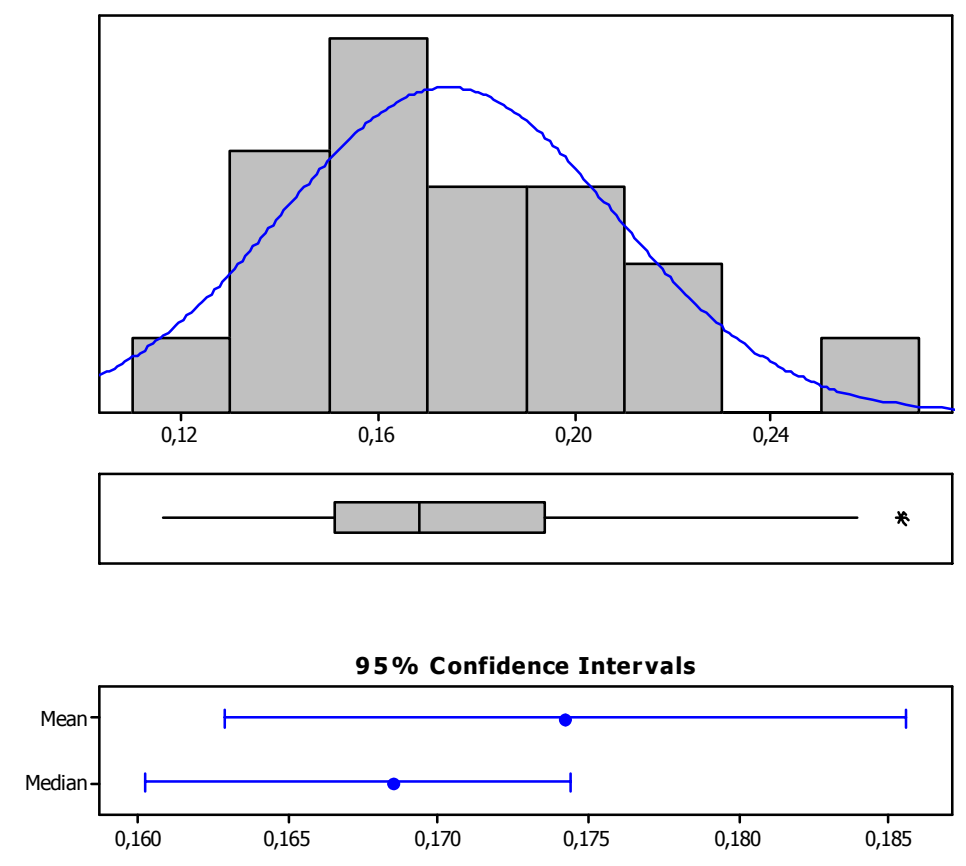

\begin{tabular}{|lr|}
\hline A nderson-Darling & Normality Test \\
A-Squared & 0,62 \\
P-Value & 0,100 \\
\hline Mean & 0,17424 \\
StDev & 0,03400 \\
Variance & 0,00116 \\
Skewness & 0,769788 \\
Kurtosis & 0,821800 \\
N & 37 \\
\hline Minimum & 0,11626 \\
1st Q uartile & 0,15115 \\
Median & 0,16848 \\
3rd Quartile & 0,19386 \\
Maximum & 0,26620 \\
\hline
\end{tabular}

95\% Confidence Interval for Mean $0,16291 \quad 0,18558$

95\% Confidence Interval for Median $0,16023 \quad 0,17442$

95\% Confidence Interval for StDev $0,02765 \quad 0,04417$ 